\author{
J osé Carlos Paliari
}

\title{
METODOLOGIA PARA A COLETA E ANÁUSE DE INFORMAÇÕES SOBRE CONSUMOS E PERDAS DE MATERIAIS E COMPONENTES NOS CANTEIROS DE OBRAS DE EDIF́CIOS
}

Dissertação apresentada à Escola Politécnica da Universidade de São Paulo para obtenção do título de Mestre em Engenharia

SÃO PAULO 
ESCOLA POLITÉCNICA DA UNIVERSIDADE DE SÃO PAULO DEPARTAMENTO DE ENGENHARIA DE CONSTRUÇÃO CIVIL Área de Concentração: Engenharia de Construção Civil e Urbana

J osé Carlos Paliari

\section{MEIODOLOG IA PARA A COLETA E ANÁUSE DE INFORMAÇÕES SOBRE CONSUMOS E PERDAS DE MATERIAIS E COMPONENTES NOS CANTEIROS DE OBRAS DE EDIŔCIOS}

Dissertação apresentada à Escola Politécnica da Universidade de São Paulo para a obtenção do título de Mestre em Engenharia

Área de Concentração: Engenharia Civil

Orientador: Prof. Dr. Ubiraci E. L. de Souza 


\section{FICHA CATALOGRÁFICA}

Paliari, José Carlos

Metodologia para a coleta e análise de informações sobre consumos e perdas de materiais e componentes nos canteiros de obras de edifícios. São Paulo, 1999.

473p.

Dissertação (Mestrado) - Escola Politécnica da Universidade de São Paulo. Departamento de Engenharia de Construção Civil.

1. Perdas de materiais 2. Desperdício de materiais 3. Canteiro de obras I. Universida de de São Paulo. Escola Politécnica. Departamento de Engenharia de Construção Civil. II. $\mathrm{t}$ 
Aos meus pais, Nelson e Iraci, por terem sido a base fundamental de toda a minha formação pessoal e por proporcionarem a viabilização desta etapa profissional da minha vida.

Aos meus irmãos, Luciano e Paulo, e minha irmã Sandra, pela compreensão e pelo incentivo nos momentos mais difíceis deste trabalho. 


\section{AGRADECIMENTOS}

Muito mais do que a satisfação em terminar mais uma etapa da minha vida acadêmica e profissional é a satisfação em ter feito, nestes anos de pósgraduação, inúmeros amigos que, de uma forma ou de outra, contribuíram significativamente para a conclusão deste trabalho.

Inicialmente gostaria de agradecer ao Prof. Dr. Ubiraci Espinelli Lemes de Souza, pela orientação segura na condução deste trabalho, pelas críticas construtivas, aliadas ao bom senso na elaboração do mesmo e, principalmente, pela amizade demonstrada no decorrer da elaboração desta dissertação.

Ao Prof. Dr. Vahan Agopyan, pela oportunidade e pela confiança em minha capacidade em conduzir um trabalho de tal importância.

Ao Prof. Dr. loshiaqui Shimbo, pela eterna orientação nos caminhos da minha vida profissional e pelo educador que é.

Ao Prof. Dr. Luís Sérgio Franco, pelas valiosas contribuições na apresentação do meu Exame de Qualificação.

Ao arquiteto Tarcísio de Paula Pinto, pelo empenho na articulação com os principais pesquisadores sobre o assunto no país, o que me proporcionou um aprendizado muito rico.

Aos professores Dr. Carlos Torres Formoso e M. Eng. Margaret Schmidt Jobim, pelo auxílio, principalmente no que se refere à estruturação das ferramentas de coleta e principais conceitos discutidos no início do trabalho. 
Aos amigos de pós-graduação, especialmente ao pessoal da sala Planeta e à Eloisa, pelo excelente convívio nestes anos.

À amiga Artemária, que ao iniciar as atividades na pós -graduação sobre este tema, injetou qualidade na condução de nosso trabalho.

À amiga Fanny, pela dedicação e competência em assumir parte da responsabilidade da coleta, processamento e análise dos resultados no decorrer da pesquisa e pela coerência e capacidade demonstrada na resolução de situações adversas.

Aos meus auxiliares de pesquisa, em especial à Bruna, Roney e Sheila, pelo empenho e dedicação na elaboração dos instrumentos de coleta e finalização dos trabalhos.

A todos os professores de outras instituições, pelas valiosas contribuições no decorrer da elaboração deste trabalho: M.Eng. Antônio Neves de Carvalho Jr., M.Eng. Cristóvão C. Carneiro Cordeiro, Dr. Emerson de Andrade M. Ferreira, Dr. José Guimarães Duque Filho e M.Eng. Maria Aridenise Macena Maia.

Ao Prof. Dr. Almir Sales, pelo apoio e por assumir parte das minhas atividades junto à Universidade Federal de São Carlos para o término desta dissertação.

Da mesma forma, meus agradecimentos ao Prof. Dr. Celso Carlos Novaes por assumir também parte das minhas atividades junto à UFSCar. 
Ao Departamento de Engenharia Civil da Universidade Federal de São Carlos, pela viabilização da minha estada em São Paulo para a realização deste trabalho.

Às empresas construtoras da cidade de São Paulo, Alves Dinis, Blokos, ERG, Fortenge, JBianchi, Noroeste e Tecnum \& Corporate, por terem aberto seus canteiros de obras para a realização da pesquisa e por terem acreditado que tal pesquisa poderia induzir a uma melhoria quanto à economia de materiais nos canteiros de obras.

Ao $C N P q$, pelo financiamento de parte de meus estudos junto à pós -graduação na realização deste trabalho.

À FINEP, pelo financiamento da pesquisa "Alternativas para a redução do desperdício de materiais nos canteiros de obras", que motivou a elaboração desta dissertação.

Ao ITQC, pelo apoio e articulação da pesquisa nacional supracitada junto aos principais centros de pesquisa instalados no país.

Ao SENAI-BA, por viabilizar a participação de um número considerável de pesquisadores e universidades da Região Nordeste, contribuindo assim, para o enriquecimento das discussões sobre o tema junto ao grupo de pesquisadores e universidades inicialmente constituído.

Aos amigos Bura, Bacana, Cristo, Xóxa, Mário, Rubens e Kleber, que o destino fez com que nos encontrássemos novamente, fazendo com que me sentisse em minha cidade natal. 
Ao amigo Rogério, pelo auxílio nas questões relativas à informática, sem o qual a finalização deste trabalho não teria sido tão simplificada.

À amiga Gislene, pela cuidadosa revisão deste texto.

À Fátima, pela cuidadosa revisão na montagem das referências bibliográficas.

A DEUS, pela família e amigos que tenho. 


\section{SUMÁRIO}

Lista de Figuras

Lista de Tabelas vi vi vis

RESUMO X xiii

"ABSTRACT" $\quad$ xiv

1 INTRODUÇÃO

$\begin{array}{ll}1.1 \text { Justificativa } & 1\end{array}$

$\begin{array}{ll}1.2 \text { Contexto do trabalho } & 11\end{array}$

$\begin{array}{ll}1.3 \text { Objetivos } & 12\end{array}$

$\begin{array}{ll}1.4 \text { Metodologia } & 15\end{array}$

$\begin{array}{ll}\text { 1.5 Materiais/componentes e serviços estudados } & 18\end{array}$

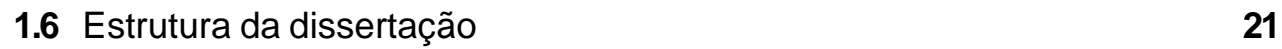

2 PERDAS NA CONSTRUÇÃO CIVIL: PRINCIPAIS CONCEITOS E 25 CLASSIFICAÇÕES

2.1 Subsídios para a avaliação das perdas na construção civil 25

2.1.1 Visão ampla das perdas na Construção Civil 26

2.1.1.1 A abrangência da avaliação das perdas 28 segundo as etapas do processo de construção civil

2.1.1.2 A abrangência da avaliação das perdas e consumo segundo o tipo de recurso analisado

2.1 .2 Perdas: um conceito relativo 
2.2 Conceito de perdas aplicado ao canteiro de obras

2.2.1 Conceito amplo

2.2.2 Restrito aos materiais

2.2.2.1 Consumo de material efetivamente realizado

2.2.2.2 Consumo de referência

48

2.3 Classificação das perdas

50

2.3.1 Enfoque amplo

50

2.3.1.1 Segundo sua natureza

50

2.3.1.2 Segundo seu momento de incidência 55

2.3.1.3 Segundo sua origem 56

2.3.1.4 Segundo seu controle

58

2.3.2 Enfoque restrito aos materiais

59

2.3.2.1 Segundo sua natureza

61

2.3.2.2 Segundo seu momento de incidência

64

2.3.2.3 Segundo sua origem

66

3 PRINCIPAIS PESQUISAS SOBRE PERDAS DE MATERIAIS:

68 APRESENTAÇÃO E ANÁLISE

3.1 SKOYLES (1976); SKOYLES (1878); SKOYLES \& SKOYLES (1987)

3.1.1 Metodologia

3.1.1.1 Cálculo da perda direta de materiais 71

3.1.1.2 Cálculo da perda indireta de materiais 
3.3 PICCHI (1993) 84

3.3.1 Metodologia

3.3.2 Principais resultados

3.3.3 Principais conclusões

3.4 SOIBELMAN (1993)

3.4.1 Metodologia

3.4.2 Principais resultados 91

3.4.3 Principais conclusões 95

3.5 HONG KONG POLYTECHNIC (1993) 
$\begin{array}{ll}3.7 \text { ENSHASSI (1996) } & 107\end{array}$

$\begin{array}{lr}3.8 \operatorname{LIRA}(1997) & 108\end{array}$

$\begin{array}{ll}\text { 3.8.1 Metodologia } & 109\end{array}$

$\begin{array}{ll}\text { 3.8.2 Resultados e conclusões } & 110\end{array}$

3.9 BOGADO (1998) 112

$\begin{array}{ll}\text { 3.9.1 Metodologia } & 113\end{array}$

$\begin{array}{ll}\text { 3.9.2 Principais resultados e conclusões } & 115\end{array}$

3.10 MCDONALD \& SMITHERS (1998) 119

$\begin{array}{ll}\text { 3.10.1 Metodologia } & 120\end{array}$

$\begin{array}{ll}\text { 3.10.2 Principais resultados e conclusões } & 121\end{array}$

$\begin{array}{ll}3.11 & \text { Análise das principais pesquisas apresentadas } \\ \end{array}$

$\begin{array}{ll}\text { 3.11.1 Comparações gerais } & 125\end{array}$

3.11.2 As principais lacunas identificadas 132

3.11.2.1 Procedimentos específicos de coleta, $\quad 132$ processamento e análise dos resultados

3.11.2.2 Estruturação dos indicadores de perdas 133

3.11.2.3 Visão analítica do referencial teórico $\quad 134$

3.11.2.4 Estabelecimento de indicadores de consumo 135

3.11.2.5 Caracterização tecnológica e gerencial dos $\quad \mathbf{1 3 6}$ serviços e especificação detalhada dos materiais 


\section{IDENTIFICANDO AS PERDAS E CONSUMOS FÍSICOS DE MATERIAIS NOS CANTEIROS DE OBRAS}

4.1 A investigação das perdas físicas de materiais nos canteiros de obras

4.2 O fluxograma dos processos como instrumento de investigação das perdas físicas de materiais nos canteiros de obras

4.3 As perdas físicas de materiais ao longo do fluxograma dos processos

4.3.1 As perdas na etapa de recebimento 146

4.3.2 As perdas na etapa de estocagem 152

4.3.2.1 Agregados: areia, pedra; adições: saibro 154

4.3.2.2 Aglomerantes: cimento, cal, gesso 156

4.3.2.3 Blocos/tijolos e placas cerâmicas

4.3.2.4 Tintas

160

4.3.3 As perdas na etapa de processamento intermediário

161

4.3.3.1 Argamassa e concreto produzidos em obra e 161 seus constituintes

4.3.3.2 Aço, eletrodutos, condutores, tubos para 165 instalações hidráulicas e sanitárias

4.3.3.3 Tintas 169

4.3.4 As perdas na etapa de aplicação (processamento final) 
4.3.4.1 Argamassa produzida em obra e seus constituintes ou argamassa parcial ou totalmente produzida fora do canteiro de obras nos serviços de revestimentos interno e externo

4.3.4.2 Argamassa produzida em obra e seus constituintes ou argamassa parcial ou totalmente produzida fora do canteiro de obras no serviço de alvenaria

4.3.4.3 Concreto usinado e produzido em obra para a 179 execução de estruturas de concreto armado

4.3.4.5 Eletrodutos, condutores elétricos e tubulações hidráulicas e sanitárias

4.3.4.6 Blocos e tijolos

4.3.4.7 Placas cerâmicas

4.3.4.8 Gesso

185

4.3.4.9 Tinta NOS CANTEIROS DE OBRAS

5.1 Importância da medição do desempenho nas organizações 
5.2.2.1 Indicadores de desempenho e de capacitação

5.2.2.2 Indicadores de qualidade e de produtividade

199

5.2.2.3 Abrangência ou nível de agregação de dados

200 utilizados para a sua elaboração

5.3 Unidades de medidas

5.4 Elaboração de um sistema de indicadores

203

5.4.1 A definição da estratégia competitiva da organização

205

5.4.2 Geração dos indicadores

206

5.4.3 Elaboração dos procedimentos de coleta,

209 processamento e análise

5.4.4 Pré-teste

5.4.5 Implantação

5.5 Sistema de indicadores de perdas e consumos de materiais nos canteiros de obras

5.5.1 Conceito de indicadores de perdas e de consumos

5.5.2 Estrutura do Sistema de Indicadores de perdas e 213 consumos de materiais nos canteiros de obras

5.5.2.1 Indicadores globais e parciais 215

5.5.2.2 Relação geral de indicadores de perdas e 222 consumos de materiais nos canteiros de obras 


\section{METODOLOGIA PARA COLETA E ANÁLISE DE INFORMAÇÕES SOBRE CONSUMO E PERDAS DE MATERIAIS NOS CANTEIROS DE OBRAS}

6.1 Apresentação sucinta da metodologia

6.2 Fundamentos da me todologia

6.3 Instrumentos de coleta de dados

256

6.3.1 Planilhas de coleta de dados

257

6.3.1.1 SÉRIE 1 - Dados relativos à empresa e à obra

6.3.1.2 SÉRIE 2 - Medição dos estoques de materiais

260

6.3.1.3 SÉRIE 3 - Medição da quantidade de serviço

261 (QS)

6.3.1.4 SÉRIE 4 - Quantidade de material recebida e/ou transferida da obra

6.3.1.5 SÉRIE 5 - Caracterização tecnológica e

265 gerencial das etapas de recebimento e estocagem dos materiais

6.3.1.6 SÉRIE 6 - Caracterização tecnológica e gerencial das etapas de processamento intermediário, transporte e aplicação dos materiais

6.3.1.7 SÉRIE 7 - Determinação de indicadores globais e parciais de perdas e/ou consumos de materiais 
6.4.1 Caracterização da empresa e da obra

6.4.2 Indicadores globais

282

6.4.2.1 Consumo real

282

6.4.2.2 Consumo de referência

292

6.4.3 Indicadores parciais

318

6.4.4 Caracterização das etapas do fluxograma dos processos

6.4.5 Estrutura de códigos: especificação dos materiais e 325 caracterização dos serviços

6.5 Processamento dos dados

6.5.1 No âmbito do canteiro de obras

330

6.5.1.1 Indicadores globais

331

6.5.1.2 Indicadores parciais

340

6.5.2 No âmbito da amostra de obras

341

6.6 Análise dos resultados

345

6.6.1 No âmbito do canteiro de obras

346

6.6.2 No âmbito da amostra de obras

351

6.7 Planejamento da Pesquisa

353

6.7.1 Recursos humanos

6.7.2 Periodicidade de visitas às obras e número de 356 estagiários 
6.7.4 Comprometimento da empresa e da obra para com a pesquisa

6.7.5 Escolha das datas VI e VF

6.7.6 Período de coleta de dados em canteiro

359

6.7.7 Planejamento das atividades a serem realizadas antes da data VI

\section{CONSIDERAÇÕES FINAIS}

362

7.1 Cumprimento dos objetivos

364

7.2 Avanços em relação aos trabalhos anteriormente realizados

7.3 Sugestões para a melhoria da metodologia desenvolvida

7.4 Sugestões para trabalhos futuros

369

7.5 Considerações complementares

371

ANEXO A - Exemplo de projeto de contrapiso para a definição das

374 espessuras teóricas

377

ANEXO B - Resumo dos prin cipais resultados e conclusões obtidos através da aplicação da metodologia proposta neste trabalho

ANEXO C - Natureza das perdas de materiais, suas origens e causas;

405 indicadores

ANEXO D - Exemplo de planilhas e procedimentos elaborados

419

ANEXO E - Exemplo de estrutura de código de especificação de material/componente - AÇO

ANEXO F - Exemplo de estrutura de código de caracterização dos serviços - ESTRUTURA DE CONCRETO ARMADO

ANEXO G - Exemplo de cálculo de CMB/MC 


\section{USTA DE RGURAS}

Figura2.1 O processo de construção - simplificado por este autor (MESEGUER, 1991)

Figura 2.2

Figura 2.3

Figura 2.4

Figura 2.5

Figura 3.1

Figura 3.2

Figura 3.3

Figura 3.4

Figura 4.1

Comparação entre a situação real e a de referência - perda de cimento (material básico) na alvenaria

Figura 4.2

Símbolos adotada na elaboração do fluxograma dos processos (MUTLER, 1978)

Figura 4.3

Exemplo de perda de material relacionada à etapa de concepção

Processo de produção do revestimento de gesso

44

Situações vigentes para a determinação dos valores de 49 referência - (a) existência de especificações claras; (b) inexistência de especificações claras.)

As perdas segundo seu momento de incidência e origem 57 (SANTOS et al., 1996)

Fluxograma de aplicação da metodologia (SKOYLES, 70 1978)

Consumo de cimento $/ \mathrm{m}^{3}$ de concreto produzido para estrutura de concreto armado - BOGADO (1998)

116

Consumo de areia $/ \mathrm{m}^{3}$ de concreto produzido para estrutura 117 de concreto armado - BOGADO (1998)

Consumo de pedra $/ \mathrm{m}^{3}$ de concreto produzido para 117 estrutura de concreto armado - BOGADO (1998)

Exemplo de um fluxograma dos processos - blocos no 143 serviço de alvenaria (GUEDERT, 1995) 
Figura 4.4

Figura 4.5

Figura 4.6

Figura 4.7

Figura 4.8

Figura 4.9

Figura 4.10

Figura 4.11

Figura 4.12

Figura 4.13

Figura 4.14

Figura 4.15

Figura 5.1
Exemplo de perda de cimento durante a etapa de recebimento: material perdido devido ao rasgamento do saco no descarregamento (Foto cedida por Antonio Neves de Carvalho Jr.)

Exemplo de uma situação geradora de perda de blocos e 158 tijolos na etapa de estocagem (Foto cedida por Antonio Neves de Carvalho Jr.)

Exemplo de uma situação geradora de perda de placas 160 cerâmicas na etapa de estocagem

"Layout" da central de produção - (MACIEL, 1997) - (a) não 164 otimizado; (b) otimizado

Desenho esquemático do comprimento das barras da 167 armadura longitudinal de um pilar genérico

Perdas de aço na etapa de processamento intermediário: 169 sobras devido ao corte não otimizado

Entulho gerado durante a execução do revestimento de 176 fachada

Exemplo de paginação da alvenaria

Geração de entulho durante a execução de rasgos nas 184 paredes para embutir instalações elétricas, hidráulicas e sanitárias

Exemplos de perdas de gesso durante a aplicação: (a) 187 durante a aplicação; (b) após a aplicação

Exemplo de transporte inadequado de blocos 190 Exemplo de equipamento adequado de transporte de 192 blocos (FRANCO, 1992) 
Figura 5.2

Figura 5.3

Figura 5.4

Figura 6.1

Figura 6.2

Figura 6.3

Figura 6.4

Figura 6.5

Figura 6.6

Figura 6.7

Figura 6.8

Figura 6.9

Figura 6.10

Figura 6.11
Principais etapas a serem seguidas na elaboração de um Sistema de Indicadores

Classificação dos indicadores de perdas e consumos de materiais segundo a sua abrangência

Exemplo sobre a obtenção do indicador parcial de perda de 220 forma indireta

Síntese da metodologia

252

Aplicação das séries de planilhas ao longo do fluxograma 259 genérico dos processos

Modelo de uma planilha da série 2- Medição dos estoques de blocos/tijolos nas datas VI e VF

Modelo de estrutura de uma planilha da série 3 - 263 Quantificação dos serviços

Modelo de estrutura de planilha da série 4- Recebimento /

265 transferência de materiais

Modelo de estrutura de planilha da série 5: dados relativos ao recebimento e estocagem dos materiais

Exemplo de uma planilha da série 7 - Espessura do contrapiso

Exemplo de procedimento de mensuração dos estoques: blocos e tijolos

Artifício utilizado para a contabilização do estoque de 285 eletrodutos

Modelo de procedimento das planilhas da série 4 295 Fluxograma de decisão - Quantidade de serviço (QS) 
Figura 6.12 Exemplo de procedimentos para quantificação dos serviços

(eletrodutos no serviço de instalações elétricas)

Figura 6.13 Transformação da quantidade de serviço de alvenaria-

300 argamassa: área para metros de juntas argamassadas

Figura 6.14 Fluxograma de decisão - Consumo de material por unidade 303 de serviço $(C M / Q S)$

Figura 6.15 Cálculo do CM/QS - blocos e tijolos 306

Figura 6.16

Largura das juntas de argamassa: (a) argamassa 308 preenchendo toda a largura do bloco; (b) argamassa aplicada na forma de dois filetes laterais

Figura 6.16 (a) CM/QS pa ra juntas horizontais - largura do bloco $\quad 309$

Figura 6.16 (b) CM/QS para juntas horizontais - filetes $\quad 309$

Figura 6.16(c) CM/QS para juntas verticais $\quad 310$

Figura 6.17 Modelo de procedimento de coleta de dados - Indicador parcial

Figura 6.18 Medição da espessura da laje - forma indireta

Figura 6.19 Estrutura do código para a especificação dos materiais

Figura 6.20

Estrutura do código para a caracterização dos serviços

328

Figura6.21 Fluxograma para o processamento dos dados para a obtenção das estatísticas relativas ao indicador global de perdas de material/componente por obra e por serviço

Figura6.22 Fluxograma para o processamento dos dados para a obtenção das estatísticas relativas ao indicador global de perdas de material/componente por serviço e por serviço pós-estocagem: comparações entre estatísticas de serviços e materiais com características diferentes 
Figura 6.23

Formulário de análise dos resultados

Figura 6.24

Distribuição amostral dos resultados de perdas: blocos e

353 tijolos (AGOPYAN et al., 1998c) 


\section{USTA DE TABELAS}

Tabela 1.1 Materiais e serviços objetos de estudo para a elaboração

20 da metodologia em questão

Tabela 2.1 Exemplo de cálculo do consumo de recursos financeiros em função da variação do custo unitário do material e da variação do consumo do recurso físico por unidade de serviço executado

Tabela 2.2 Classificação das perdas indiretas (SKOYLES \& $\mathbf{5 2}$ SKOYLES, 1987)

Tabela 2.3 Classificação das perdas segundo à sua natureza (SANTOS et al., 1996)

Tabela 2.4 Exemplos de perdas de acordo com o momento de 56 incidência

Tabela 2.5 Principais fontes geradoras de entulho (HONG KONG POLYTECHNIC, 1993)

Tabela 2.6 Classificação das perdas de materiais segundo o seu momento de incidência

Tabela 2.7 Natureza, momento de incidência, causas e origens das perdas de materiais

Tabela 3.1 Perdas diretas de materiais, baseadas em 114 canteiros de 77 obras (SKOYLES, 1976)

Tabela 3.2 Índices de perdas de material (PINTO, 1989)

Tabela 3.3 Dados relativos ao entulho gerado (PICCHI, 1993) 
Tabela 3.5

Tabela 3.6

Tabela 3.7

Tabela 3.8

Tabela 3.9

Tabela 3.10

Tabela 3.11

Tabela 3.12

Tabela 3.13

$$
\begin{aligned}
& \text { Índices de perdas: } \\
& \text { (ENSHASSI, 1996) }
\end{aligned}
$$

Tabela 3.14 Levantamento quanto às situações vigentes nas obras baseado em LIRA (1997)

Tabela 3.15 Consumo de materiais - Estrutura de concreto armado (BOGADO, 1998)
Tabela 3.16 Índices de perdas de materiais - Estrutura de concreto armado (BOGADO, 1998)

92

93

94

99

101

102

103

106

108

110

116

118 
Tabela 3.17 Índices de entulho - Complexo de edifícios Dandenong MCDONALD; SMITHERS (1998)

Tabela 3.18 Comparação entre os dados de entulho gerado nos dois canteiros analisados - MCDONALD; SMITHERS (1998)

Tabela 3.19

Principais diferenças detectadas entre as pesquisas 126 realizadas

Tabela 3.20 Diferenças no cálculo do indicador de perdas

Tabela 3.21 Fontes de consulta utilizadas nas pesquisas realizadas

130

Tabela 3.22 Parcela de serviço avaliado nas pesquisas apresentadas

Tabela 3.23 Exemplo sobre a necessidade do estabelecimento de 136 indicadores de consumo para os materiais básicos

Tabela 4.1 As possibilidades de ocorrência de perdas de materiais de 145 acordo com o fluxograma dos processos

Tabela 4.2 Variação dimensional de blocos e tijolos detectada

Tabela 4.3 Acréscimo de consumo de blocos/tijolos estimado por este autor em função da variação dimensional dos mesmos citadas por outros autores

Tabela 4.4 Altura de pilha de blocos/tijolos recomendada por diversos 159 autores e normas técnicas

Tabela 4.5 Estimativa das perdas de aço devido ao não 169 reaproveitamento das sobras de corte

Tabela 4.6

Camadas constituintes do revestimento em argamassa 173 (NBR 13530; ABNT, 1995)

Tabela 4.7 Perdas devido às sobrespessuras de revestimentos 
Tabela 4.8

Tabela 4.9

Tabela 4.10

Tabela 4.11

Tabela 4.12

Tabela 5.1

Tabela 5.2

Tabela 5.3

Tabela 5.4

Tabela 5.5

Tabela 5.6

Tabela 5.7

Tabela 5.8
Perdas devido à sobrespessura de juntas de argamassa no serviço de alvenaria

Estimativa de perda de argamassa no serviço de alvenaria 178 (parcela de material incorporado)

Parcela de perda relativa ao material incorporado: variação 180 das dimensões dos elementos estruturais

Tempo útil para a utilização da pasta de gesso (ANTUNES 186 et al., 1998)

Classificação do sistema de transporte - (LICHTENSTEIN, 189 1987)

Procedimentos para a geração de indicadores de qualidade 208 e produtividade (SOUZA et al., 1995)

Exemplo de geração de indicadores de qualidade e 209 produtividade relacionados à questão das perdas e/ou consumo de materiais

Unidades de expressão dos indicadores de perdas e 213 consumo de materiais e componentes

Indicadores de perdas e consumos de materiais e 223 componentes - Areia

Indicadores de perdas e consumos de materiais e 225 componentes - Cimento

Indicadores de perdas e consumos de materiais e 228 componentes - Pedra

Indicadores de perdas e consumos de materiais e 229 componentes - Concreto produzido em obra Indicadores de perdas e consumos de materiais e 230 
componentes - Concreto usinado

Tabela 5.9 Indicadores de perdas e consumos de materiais e 231 componentes - Aço

Tabela 5.10 Indicadores de perdas e consumos de materiais e 232 componentes - Blocos e tijolos

Tabela 5.11 Indicadores de perdas e consumos de materiais e 233 componentes - Cal

Tabela 5.12 Indicadores de perdas e consumos de materiais e 235 componentes - Argamassa pré-misturada

Tabela 5.13 Indicadores de perdas e consumos de materiais e 237 componentes - Argamassa industrializada

Tabela 5.14 Indicadores de perdas e consumos de materiais e 241 componentes- Eletrodutos

Tabela 5.15 Indicadores de perdas e consumos de materiais e $\mathbf{2 4 2}$ componentes- Condutores

Tabela 5.16 Indicadores de perdas e consumos de materiais e $\mathbf{2 4 3}$ componentes - Tubos

Tabela 5.17 Indicadores de perdas e consumos de materiais e $\mathbf{2 4 4}$ componentes - Telhas

Tabela 5.18 Indicadores de perdas e consumos de materiais e $\mathbf{2 4 5}$ componentes- Placas cerâmicas

Tabela 5.19 Indicadores de perdas e consumos de materiais e 246 componentes - Revestimento têxtil

Tabela 5.20 Indicadores de perdas e consumos de materiais e 247 componentes - Tintas 
Tabela 5.21

Indicadores de perdas e consumos de materiais e componentes - Gesso

Tabela 5.22 Indicadores de perdas e consumos de materiais e componentes - Saibro

Tabela 6.1

Relação de planilhas quantitativas

Tabela 6.2

Tabela 6.3

Tabela 6.4

Tabela 6.4 (a) Relação de planilhas desenvolvidas - informações qualitativas

Unidades de medida dos serviços

Relação de serviços e seus respectivos $C M / Q S$
248

249 274 279 296 302 304 revestimentos em argamassa

Tabela 6.4 (b) Valores de referência padrão para $C M / Q S$ - tintas 304

Tabela 6.4 (c) Valores de referência para a espessura de juntas - blocos e tijolos

Tabela 6.4 (d) Valores de referência para a espessura de juntas - placas cerâmicas parede

Tabela 6.4 (e) Valores de referência para a espessura de juntas - placas 305 cerâmicas piso

Tabela 6.5

Relações para a transformação do traço

312

Fórmulas para o cálculo do consumo de materiais básicos 314 por material composto $C M B / M C$ (argamassas)

Tabela 6.7 Valores da umidade da areia (h) e da massa específica das argamassas a serem utilizados na falta de valor tecnicamente confiável para a obra em estudo 
Tabela 6.8 $\quad$ Parâmetros para a transformação do traço e cálculo do consumo de materiais básicos por material composto

Tabela 6.9 Traços padrão de argamassas

Tabela 6.10 Exemplo do cômputo do consumo de referência

332

Tabela 6.11 Exemplo do cômputo do consumo real

Tabela 6.12(a) Exemplo do cômputo do consumo real - serviço pósestocagem: mapeamento das quantidades que saíram do estoque

Tabela 6.12(b) Exemplo de cômputo do consumo real - serviço pósestocagem: totalização para os vários serviços que fizeram uso dos materiais básicos

Tabela 6.13 Indicador global de perda/consumo de materiais - serviço pós-estocagem

Tabela 6.14 Indicador global de perda de material - por serviço

Tabela 6.15 Indicador global de perdas de material - obra

Tabela 6.16 Registro do arquivo - Indicador global de perda por obra

Tabela 6.17 Registro do arquivo - Indicador global de perda por serviço e por serviço pós-estocagem

Tabela 6.18 Comparação entre estatísticas: tipo de material constituinte e equipamento de transporte de blocos (AGOPYAN et al., 1998d)

Tabela 6.19 Exemplo para o cálculo da explicação do indicador global uso de concreto usinado na estrutura de concreto armado 


\section{METODOLOGIA PARA COLETA E ANÁLISE DE INFORMAÇÕES SOBRE CONSUMOS E PERDAS DE MATERIAIS E COMPONENTES NOS CANTEIROS DE OBRAS DE EDIFÍCIOS}

\section{RESUMO}

O trabalho desenvolvido propõe uma metodologia para coleta e análise de informações sobre o uso de materiais/componentes nos canteiros de obras.

Tal metodologia envolve o levantamento de indicadores globais (envolvem todas as etapas do processo de produção: recebimento, estocagem, processamento intermediário, transporte e aplicação final) e parciais (dizem respeito a uma das etapas do processo) sobre consumos e/ou perdas de materiais/componentes. O correlacionamento de tais avaliações numéricas com as situações vigentes no canteiro, serve de subsídio quanto à geração futura de alternativas para a redução destes índices.

A metodologia contempla 19 materiais; sua operacionalização é baseada num conjunto de 7 séries de planilhas contendo procedimentos específicos para a coleta de informações e cálculo dos índices. São definidas também diretrizes para a análise dos resultados. Tais instrumentos garantem a padronização da coleta, do processamento e da análise das informações e, conseqüentemente, permite a comparação entre índices levantados em obras diferentes de quaisquer partes do país. 


\section{METHODOLOGY FOR COLLECTION AND ANALYSIS OF INFORMATION ON MATERIALS/COMPONENTS CONSUMPTION AND WASTE IN THE BUILDING CONSTRUCTION SITES}

\section{ABSTRACT}

This work proposes a meticulous methodology for data collection and analysis on materials/components consumption and waste in building construction sites.

Such a methodology involves the calculation of global and partial indexes on materials/components consumption and/or waste. While the global ones represent the stages roamed by materials until their final destiny (receiving, storage, processing, transport and application) altogether, the partial ones evaluate each stage performance separately. The correlation of these numeric evaluations with the effective work conditions in the construction sites, may provide important figures to help detecting alternatives for the reduction of materials waste.

The methodology contemplates 19 materials; its operation is based on a group of seven sheets series contending specific procedures for the information collection and indexes calculation. It also defines guidelines for the results analysis. Such instruments warrant the standardization of the collection, processing, analysis of the information and, consequently, it allows the comparison among indexes representing different construction sites, located in any part of the country. 


\section{CAṔ́TIO 1}

\section{INTRODUÇÃO}

\subsection{Justificativa}

Nos últimos anos, as questões referentes a políticas da qualidade têm ocupado espaço significativo nas discussões do meio profissional da construção civil e tem tido presença constante nestas discussões a ocorrência de perdas em todo o processo de produção da edificação, sejam elas de materiais, mão-de-obra, equipamentos etc (FORMOSO, 1996).

Tal fato é decorrente da impossibilidade de se conviver, nos dias atuais, num mercado extremamente competitivo ${ }^{1}$, com índices de perdas consideráveis, relatados nas raras pesquisas existentes sobre o assunto.

Segundo PICCHI (1993), "empresas que durante anos sobreviveram utilizando a cultura do repasse de custos, ou seja, transferindo suas ineficiências operacionais ao invés de diminui-las, estão sendo expulsas do mercado".

\footnotetext{
${ }^{1}$ VARGAS (1993) discorre sobre alguns fatores que estão provocando mudanças na tradição do modelo empresarial e econômico do setor. Entre tais fatores, o autor cita a tendência de integração internacional entre os países, o que pode significar a competição com empresas internacionais que dispõem de um arsenal tecnológico e gerencial de várias gerações, a falência do Estado e o conseqüente impacto na tradicional fonte de oferta de obras, a recente política industrial, que privilegia 0 aumento da competitividade, a abertura do mercado e a integração econômica latino-americana (MERCOSUL), o novo Código de Defesa do Consumidor, entre outros.
} 
Para SCARDOELLI (1995), a atual conjuntura econômica do país e a conseqüente competição instaurada ${ }^{2}$ não permitem que empresas componham o preço do produto final através da soma dos custos de produção e os lucros previamente arbitrados, e sim, que o preço do produto final seja determinado pelo mercado, resultando em redução significativa da margem de lucro $^{3}$ e obrigando as empresas a reduzirem seus custos de produção.

Neste contexto, as empresas devem procurar reduzir os custos de seus produtos e, entre as várias possibilidades de atuações neste sentido, destacase a redução dos custos de produção. Uma das formas de se alcançar esta redução consiste na otimização do uso dos recursos físicos utilizados ao longo do processo produtivo.

Neste sentido, a redução das perdas de materiais configura-se em uma das metas a ser atingidas, visto que, segundo PINTO (1989), a participação deste recurso no custo final da edificação pode chegar até $70 \%$.

Acrescente-se a esta necessidade o fato de que, além do custo devido às perdas de material em si, há que se contabilizar também o aumento dos custos de transporte interno (tanto de materiais quanto do entulho gerado), assim como os custos advindos da redução da produtividade da mão-de-obra ${ }^{4}$.

\footnotetext{
${ }^{2}$ Uma pesquisa realizada no $1^{\circ}$ semestre/97 pelo SINDUSCON revela que a concorrência do mercado é a principal preocupação dos empresários do setor (SINDUSCON, 1997).

${ }^{3}$ Notícia veiculada no caderno Dinheiro do Jornal Folha de São Paulo do dia 01/11/98 tem como principal manchete a redução dos lucros das empresas neste final de ano e para o ano seguinte, lucro este que pode cair até $70 \%$, face à crise econômica atual que desencadeou a elaboração do pacote fiscal proposto pelo governo.

${ }^{4}$ Note que, por exemplo, a produtividade de um operário para executar $1 \mathrm{~m}^{2}$ de emboço será pior à medida que, ao invés de executá-lo com $2 \mathrm{~cm}$ de espessura, conforme especificado em projeto, tenha que executá-lo em média com $3 \mathrm{~cm}$ de espessura, para corrigir eventuais problemas de esquadro e desaprumo das alvenarias.
} 
Em que pese a importância dos índices de perdas de materiais, poucas foram as pesquisas realizadas no país até o momento. Tais pesquisas, embora sob óticas um pouco diferentes (físicas ou financeiras), com objetos de estudo não exatamente iguais (material isoladamente ou mão-de-obra agregada), com abrangências distintas (o canteiro isoladamente ou o empreendimento desde a concepção) e com universos de pesquisa variáveis (de um a vários estudos de casos reais), procuraram levantar índices de perdas consistentes e as causas da ocorrência das mesmas (SOUZA et al., 1998b).

Entre elas, destacam-se as pesquisas realizadas por RNTO (1989), pelo pioneirismo; por PICCHI (1993), pela análise e estimativa das perdas financeiras na construção de edificações; por SOIBELMAN (1993), pelo número de casos estudados e pelo efetivo acompanhamento do processo de produção na quantificação das perdas; por SANTOS (1995), pelo caráter próativo quanto à detecção e quanto às ações para a redução das perdas de materiais e, mais recentemente, por BOGADO (1998).

No exterior, destacam -se os trabalhos realizados por SKOYLES $(1976,1978)$ e SKOYLES \& SKOYLES (1987) no Reino Unido, iniciados na década de 60, que serviram de base para os principais trabalhos realizados no Brasil e no exterior. E, mais recentemente, tem-se o trabalho realizado por ENSHASSI (1996) ${ }^{5}$.

\footnotetext{
${ }^{5}$ De acordo com a revisão bibliográfica realizada, pôde-se identificar trabalhos com abordagens diferentes no que diz respeito à questão das perdas de materiais. Enquanto uns tiveram como tema central esta questão [(SKOYLES (1976, 1978); SKOYLES \& SKOYLES (1987); (PINTO, 1989); (SOIBELMAN, 1993); (ENSHASSI, 1996); (LIRA, 1997)], outros a estudaram como forma de complemento a outros temas centrais [(PICCHI, 1993), (SANTOS, 1995), (BOGADO, 1998)]. Outros trabalhos procuram abordar a questão do entulho de construção civil, seja durante a fase de construção de novas edificações ou na fase de demolições das mesmas [(HONG KONG POLYTECHNIC, 1993); MCDONALD \& SMITHERS (1998)].
} 
Apesar de um número reduzido de pesquisas, algumas conclusões importantes são extraídas das mesmas. A primeira delas consiste no fato de que existe uma parcela considerável das perdas detectadas passível de redução, visto que, para um mesmo material, obtiveram-se variações de empresa para empresa e, até mesmo, entre canteiros de obras de uma mesma empresa [(SKOYLES \& SKOYLES (1987); SOIBELMAN (1993)].

Além deste potencial de redução detectado, verificou-se também que os índices de perdas, de uma forma geral, se apresentaram superiores aos comumente adotados em literaturas técnicas de orçamentação. Enquanto, por exemplo, adotam-se expectativas de perdas que variam entre 1 a $20 \%$, ou até mesmo nula $(\text { TCPO } 10,1996)^{6}$, as pesquisas apontam índices de até $152 \%$ para determinados materiais.

Este fato evidencia que, atualmente, muitas empresas baseiam-se em índices errôneos de consumo (perdas) de materiais e que não refletem a realidade do desempenho da empresa, pois não levam em consideração as características gerenciais e tecnológicas da empresa/obra/serviço, não permitindo, assim, a elaboração de propostas competitivas em concorrências públicas ou outros processos de licitações.

Se, por um lado, a ocorrência das perdas de materiais/componentes tem uma expressão significativa no que se refere à possibilidade de redução dos custos de produção, por outro, as implicações de tal ocorrência extrapolam o âmbito

\footnotetext{
${ }^{6}$ No caso, o TCPO 10 (1996) não atribui uma estimativa de perdas para o caso dos eletrodutos. O maior valor encontrado referese à estimativa de perda para o cimento e areia no serviço de chapisco convencional.
} 
dos canteiros de obras pois, ao se desperdiçar materiais/componentes, estarse-á incorrendo em desperdício de recursos naturais.

De acordo com SILVEIRA (1993), “apesar de a evolução da espécie humana só ser possível pela absorção dos recursos naturais, aos quais o homem se entrelaça dentro de uma complexa teia de existência, as relações com o meio ambiente não se desenrolam equilibradamente nos dias de hoje, colocando em risco a própria sobrevivência do globo terrestre".

Em que pese este fato, ainda segundo o autor, "muitas mudanças do pensamento humano já começam a produzir forte conscientização, de tal forma que qualquer relação produtiva atual só pode ser pensada considerando, conjuntamente, o capital naturale o capital econômico".

Porém, na opinião de FILHO et al. (1997), apesar da importância do setor da Construção Civil sob o ponto de vista econômico, as considerações dos aspectos ambientais na produção dos materiais, fabricação e utilização dos produtos ainda está numa fase incipiente.

Para estes autores, apesar de ser difícil avaliar os impactos das atividades envolvidas sobre o meio ambiente, estes se manifestam sob a forma da extração de recursos renováveis e não renováveis ${ }^{7}$, contaminação do ar e da água para a produção dos materiais ou na fabricação dos produtos, consumo de energia tanto para a produção como para a manutenção da infra-estrutura

\footnotetext{
${ }^{7}$ Em notícia veiculada no Jornal Nacional do dia 02/10/98 pôde-se verificar as conseqüências da extração da matéria-prima para a produção do gesso de construção civil. A reportagem abordou as péssimas condições de trabalho dos operários, cujo trabalho era realizado sem equipamento de proteção (máscara anti-pó, por exemplo), assim como a degradação das reservas minerais e das florestas locais, que servem como fonte de energia durante o processo de produção.
} 
produtiva, alteração de ecossistema e geração de resíduos recicláveis e não recicláveis.

Apesar desta dificuldade, segundo FRIEDMAN \& CAMMALLERI (1995), o impacto ambiental de um produto de construção pode ser avaliado examinando como os recursos (incluindo a energia demandada), assim como os desperdícios, são utilizados e gerados, respectivamente, nas várias fases do ciclo de vida destes recursos ${ }^{8}$.

Para estes autores, a quantidade de energia incorporada ao material/componente é um indicador útil para avaliar o impacto ambiental e, segundo eles, a seleção de materiais/componentes para uma edificação deve ser feita através da maximização do uso de materiais/componentes recicláveis ou reciclados e do uso de materiais/componentes cuja extração da matériaprima utilizada em sua fabricação não comprometa significativamente o meio ambiente. Neste sentido, deve-se priorizar o uso de materiais cujas matérias primas possam ser renováveis e que incorporem o mínimo de energia durante todo o ciclo de vida destes recursos.

\footnotetext{
${ }^{8}$ Segundo o SETAC (1993) apud (FILHO et. al., 1997) ${ }^{8 a}$, "a análise do ciclo de vida - ACV é um processo objetivo no qual se avaliam as cargas ambientais (quantidade de contaminantes que chegam ao meio ambiente ou a quantidade de recursos extraídos do mesmo) associadas a uma atividade, processo ou produto, através da identificação e quantificação de todos os impactos no meio ambiente (consumo de energia e de recursos renováveis e não renováveis, emissões à atmosfera, contaminação da água, geração de resíduos etc).” Segundo (MILLER, 1998), o ciclo de vida de um material/componente de construção começa com a extração das matérias-primas utilizadas na fabricação do mesmo e termina com a sua disposição após a demolição do edifício e a reutilização ou reciclagem, incluindo também as fases de industrialização do material/componente, construção da edificação, manutenção e, inclusive, a fase de transporte.
}

8a SETAC (1993). A Conceptual Framework for Life-Cycle Impacts Assessment - Guidelines for Life-Cycle Assessment: a "Code of Practice”. Soc. De Quím. Y Toxic. Medioamb, Bruselas. 
Note, portanto, a preocupação em se otimizar o uso dos recursos, não só na sua extração/produção/utilização, mas também no que se refere ao destino dos rejeitos ou desperdícios gerados.

$\mathrm{E}$, neste sentido, não menos importante do que a preocupação com a escassez de recursos naturais, um outro aspecto relacionado especificamente a uma das parcelas de perdas físicas de materiais, o entulho de construção civil, é alvo de discussões em praticamente todas as cidades (ESTEVES, 1997).

Para este autor, o entulho tem causado grandes transtornos no meio urbano, alterando as características físicas e dinâmicas do mesmo, envolvendo as pessoas e o meio natural.

Para PINTO (1992), a "irracionalidade" da construção, no que diz respeito à geração de entulho, se transforma em custos sociais, parte mensuráveis e parte não mensuráveis. Como exemplo dos custos sociais não mensuráveis, cita a redução da eficiência do transporte urbano e drenagem, por obstrução de pistas e seções de córregos e redes de águas pluviais.

As estimativas do entulho da construção civil, que pode ser gerado durante 0 processo de produção das edificações ou, ainda, ser oriundo de demolições de edificações, manutenção corretiva e preventiva das mesmas, são variáveis, diferindo de cidade para cidade e, até mesmo, entre países. No Brasil, segundo PINTO (1992), mais especificamente na cidade de São Paulo, os valores alcançam a cifra de 2.000 t/dia, o que equivale a 500 viagens/dia retiradas da obra por pequenos transportadores e depositadas indiscriminadamente no tecido urbano. 
Para PINTO (1995b), a percepção nos vários países de que a construção civil precisa mudar "acontece não só por causa do elevado desperdício de materiais e do indesejado impacto nos custos finais, mas também porque as áreas urbanas disponíveis para a disposição de resíduos estão se exaurindo".

Este fato tem motivado vários estudos no sentido de estimar o volume ou massa de entulho gerado. No exterior, um estudo realizado pela Escola Politécnica de Hong Kong ,no ano de 1992, apontou um coeficiente de volume de entulho por área construída, oriundo do processo de produção, da ordem de $0,10 \mathrm{~m}^{3} / \mathrm{m}^{2}$. Utilizando este coeficiente e a média anual de área de construção na cidade de Hong Kong, nos anos de 1992 e 1993, os autores chegaram aos valores de $1.740 \mathrm{~m}^{3} / \mathrm{dia}$ ou $635.000 \mathrm{~m}^{3} /$ ano.

O entulho de construção civil tem também uma participação significativa no montante de resíduos sólidos de aterros sanitários. Na Holanda, Austrália, Estados Unidos, Alemanha e Finlândia, esta participação, considerando tanto o entulho gerado na construção da edificação quanto o originado em demolições, em termos de massa, chega a 26,20 a 30,20 a 29,19 e 13 a $15 \%$, respectivamente (BOSSINCK; BROUWERS, 1996). Para FERGUSON et al. (1995), o entulho de construção civil (independentemente da fase em que foi gerado) pode representar mais do que $50 \%$ do total de resíduos presentes em aterros sanitários. 
Por todos estes aspectos apresentados, torna-se essencial a elaboração de políticas $^{9}$ voltadas para a redução das perdas de materiais e componentes, sejam elas no âmbito de toda a cadeia produtiva ou apenas no âmbito do canteiro de obras. E, como parte integrante de tais políticas, há a necessidade de uma metodologia de coleta e análise de informações sobre perdas/consumos de materiais que subsidie, através de dados confiáveis e representativos, a proposição de alternativas para a redução das mesmas a patamares aceitáveis.

Tal necessidade é reforçada pelo fato de que, nos trabalhos realizados até o momento, verificou-se uma preocupação maior com os resultados do que com a sistematização e detalhamento das metodologias empregadas, uma preocupação já reinante na época dos primeiros trabalhos realizados no país, onde SILVA (1993) afirmara que "o debate provocado pela questão da ocorrência de perdas na construção civil tem se mostrado estéril, em face à inexistência de trabalhos de medição sistemática e de abordagem científica, que assegurem a representatividade dos dados levantados e possibilitem um diagnóstico confiável”.

\footnotetext{
${ }^{9}$ Observe que, em função da necessidade da melhoria da qualidade e produtividade na Construção Civil e, conseqüentemente, de redução das perdas, vários programas direcionados neste sentido foram e vêm sendo articulados entre o setor produtivo, entidades, sindicatos, universidades, como por exemplo, - Programa da Qualidade e da Produtividade na Construção Civil do Rio Grande do Sul, Clube da Qualidade da Construção do Rio de Janeiro e Sistema de Gestão para Empresas Construtoras do SINDUSCON de São Paulo. Em 1996 foi lançado o Qualihab (Programa da Qualidade da Construção Habitacional do Estado de São Paulo), que tem como objetivo a certificação da qualidade dos materiais e componentes e empresas construtoras e fornecedoras de serviços e produtos para a participação dos processos de licitação da CDHU (Companhia de Desenvolvimento Habitacional e Urbano do Estado de São Paulo). Recentemente (em novembro de 1997), foi lançado o Programa Brasileiro da Qualidade e Produtividade da Construção Nacional - PBQP-CH - que conta, entre outros, com a participação direta do Departamento de Engenharia de Construção Civil da Escola Politécnica da Universidade de São Paulo - PCC-EPUSP.
} 
Em complemento, tal necessidade foi apontada no Seminário "Desperdícios no Brasil: causas e soluções", realizado em Brasília em 1993, onde estabeleceuse, como uma das ações no combate aos desperdícios, o desenvolvimento de metodologias para a mensuração das perdas na construção civil como caminho para a conscientização e envolvimento de todos os interessados nesta questão: Subprograma Setorial da Qualidade e Produtividade - Indústria da Construção Civil do Programa Brasileiro de Qualidade e Produtividade (PBQP), Câmara Setorial da Construção Civil, Associação Brasileira de Cimento Portland (ABCP), Associação Brasileira de Normas Técnicas (ABNT), Universidades e outras entidades de classe do setor (DESPERDíCIOS, 1993).

Neste contexto, pesquisadores de 16 universidades brasileiras uniram esforços para estudar a questão das perdas de materiais no âmbito do canteiro de obras. Para tal, a elaboração de uma metodologia que assegure a padronização, tanto da coleta quanto do processamento e análise dos resultados, torna-se imperativo.

Justifica-se assim, principalmente num trabalho de âmbito nacional, a geração de uma metodologia que contemple as várias lacunas deixadas nos trabalhos anteriores. Entre estas lacunas ou pontos não elucidados, destacam-se a necessidade de um planejamento global e específico para a coleta de dados sobre perdas de materiais, levando-se em conta as peculiaridades do uso de cada material nos seus respectivos serviços, ferramentas e procedimentos simples e claros de coleta de dados e, principalmente, a adequação dos atuais 
conceitos de perdas às situações particulares encontradas nos canteiros quanto ao uso dos materiais.

Diante da grande variabilidade dos processos produtivos inerente ao setor de edificações, a proposta de metodologia deverá apresentar, de forma clara e objetiva, os conceitos envolvidos, critérios de medição, as imprecisões e, principalmente, a forma de apresentação dos resultados.

Ainda, ao se falar em perdas de materiais, há a necessidade de se estabelecer um referencial teórico adequado, ou seja, uma base de comparação respaldada tecnicamente pois, dependendo do referencial adotado, são agregadas perdas de diferentes naturezas a esses índices.

Por fim, a adoção desta metodologia por vários centros de pesquisa ao longo do Brasil proporcionará a constituição de padrões de referência (benchmarks) nacionais e das próprias empresas quanto ao consumo real dos materiais nas obras.

\subsection{Contexto do trabalho}

Este trabalho se insere no âmbito de uma ampla discussão nacional sobre o tema, que resultou na articulação de uma pesquisa financiada pela FINEP Financiadora de Estudos e Projetos do Ministério da Ciência e Tecnologia, intitulada "Alternativas para a redução do desperdício de materiais nos canteiros de obras", envolvendo o ITQC - Instituto Brasileiro de Tecnologia e Qualidade na Construção Civil e pesquisadores de mais 16 universidades nacionais, sob a coordenação do Departamento de Engenharia de Construção 
Civil da EPUSP, cujos objetivos principais foram: levantar índices de perdas de materiais/componentes nos canteiros de obras, identificar suas causas e, com base nos resultados obtidos, subsidiar alternativas para a redução das mesmas.

Iniciada no final de 1996, tal pesquisa envolveu mais de 80 canteiros de obras, contando ainda com o apoio dos SINDUSCON (ou SINDICON), dos SECOVI (ou ADEMI), dos SEBRAE, dos SENAI (com destaque para o SENAI-NE), assim como de inúmeras construtoras preocupadas com a questão.

No âmbito do Departamento de Engenharia de Construção Civil da Escola Politécnica da Universidade de São Paulo, este trabalho está inserido no Grupo de Ensino e Pesquisa em Tecnologia e Gestão da Produção de Edifícios (TGP), no qual o autor desenvolve suas atividades de pós-graduação. No âmbito do TGP, integra-se a um conjunto de trabalhos de pós-graduação que possuem a preocupação comum de contribuir para a gestão dos recursos físicos da construção civil.

\subsection{Objetivos}

Diante da necessidade de se levantar números confiáveis e representativos sobre o uso dos materiais/componentes nos canteiros de obras, este trabalho tem como objetivo principal a elaboração de uma proposta de metodologia padronizada e sistematizada para coleta e análise de informações sobre consumos e/ou perdas de materiais/componentes nos canteiros de obras. 
Como parte integrante desta metodologia, destacase a definição e elaboração de instrumentos de coleta de informações que possibilitem:

- o levantamento de índices globais (por obra, por serviço e por serviço pós estocagem) e parciais sobre consumos e/ou perdas de materiais/ componentes;

- a identificação de qual(is) etapa(s), percorrida(s) pelos materiais/ componentes no canteiro de obras, desde a de recebimento até a de aplicação final, a incidência de perdas é mais significativa;

- a geração de mecanismos para a identificação das causas imediatas das perdas de materiais/componentes;

- a caracterização da empresa/obra/serviço, de forma sistematizada, no que diz respeito aos itens considerados relevantes quanto à ocorrência de perdas de materiais/componentes nos canteiros de obras, como forma de subsidiar a discussão quanto a possíveis alternativas para a redução dos índices a patamares aceitáveis.

Tais instrumentos, por sua vez, deverão ter caráter prático, fazendo parte dos mesmos procedimentos claros e objetivos sobre como proceder a coleta de dados nos canteiros de obras.

Além do foco centralizado na coleta de dados, têm-se ainda, como parte integrante desta metodologia: 
- a proposição de uma sistemática para o processamento dos dados coletados em campo;

- a elaboração de diretrizes básicas para a análise dos resultados obtidos, levando-se em consideração as principais características dos materiais/componentes e dos serviços nos quais os mesmos são utilizados;

Este conjunto de ações e/ou produtos garantem a padronização da aplicação da metodologia em todas as suas fases.

Por sua vez, pode-se detalhar como objetivos secundários:

- o levantamento dos principais trabalhos realizados sobre o assunto, como forma de nortear a elaboração da metodologia;

- a realização de uma análise crítica destes trabalhos, onde procura-se identificar os principais pontos positivos e as principais lacunas a ser contempladas nesta metodologia;

- a discussão dos principais conceitos relacionados ao tema, seja sob um enfoque amplo ou restrito às perdas de materiais.

Ressalta-se ainda que a explicitação minuciosa da metodologia pode torná-la um instrumento útil para a contínua coleta e análise de informações sobre consumos/perdas de materiais/componentes, que subsidie uma integração nacional quanto a esforços, buscando a melhoria da Construção Civil. 


\subsection{Metodologia}

Os caminhos trilhados para a elaboração deste trabalho podem ser resumidos da seguinte forma:

- revisão bibliográfica sobre perdas de materiais na construção civil, assim como de temas complementares como: tecnologia, qualidade e orçamentação;

- contato com o setor produtivo com o intuito de complementar o conhecimento adquirido através da revisão bibliográfica;

- elaboração e experimentação dos instrumentos de coleta de dados;

- coleta de dados nos canteiros de obras;

- processamento dos dados e análise dos resultados;

- elaboração do texto final.

Com relação à revisão bibliográfica, inicialmente se realizou uma extensa busca nas principais bases de dados disponíveis na Biblioteca da Engenharia Civil e da Engenharia de Produção da EPUSP, assim como no acervo das bibliotecas das Universidades Federais do Rio Grande do Sul e de Santa Catarina, via internet, além de uma pesquisa na base de dados disponível no Instituto de Pesquisa Tecnológica - IPT.

Além da pesquisa bibliográfica centrada especificamente na questão das perdas de materiais, a mesma foi estendida também aos temas de qualidade, 
tecnologia e orçamentação, pelo fato de complementarem o objeto de estudo deste trabalho.

Concomitante aos conhecimentos adquiridos através da consulta da bibliografia levantada, iniciou-se também um maior contato com os profissionais do setor produtivo, como engenheiros, mestres de obras e operários, através de visitas periódicas a 8 canteiros de obras, de 7 empresas, localizados na cidade de São Paulo e cidades vizinhas. A discussão do tema junto a estes profissionais permitiu a consolidação dos conhecimentos adquiridos até então e proporcionou idéias sobre como deve ser realizada a avaliação das perdas de materiais nos canteiros de obras.

Após este embasamento teórico e prático, partiu-se para a elaboração dos instrumentos de coleta de dados e sua aplicação, em caráter experimental, em alguns canteiros de obras da cidade de São Paulo e em canteiros de obras distribuídos pelo país por intermédio dos pesquisadores de diversas universidades.

Além das experiências locais vividas ao longo da coleta de dados na cidade de São Paulo, a possibilidade de contatos com os principais pesquisadores sobre o assunto, através do estabelecimento de uma rede nacional de pesquisa, foi de grande importância para a definição de conceitos, planejamento da pesquisa e estruturação e elaboração dos instrumentos de coleta de informações nos canteiros de obras.

Este contato deu-se através da realização de diversas reuniões entre os pesquisadores, onde se discutia, além dos aspectos estratégicos da condução 
da pesquisa, aspectos específicos sobre a metodologia desenvolvida. As trocas de experiências entre pesquisadores também foi intensificada através do uso de correio eletrônico, o que permitiu maior integração entre os centros de pesquisa participantes. Assim, pôde-se receber contribuições e críticas e, principalmente, realizar discussões sobre a viabilidade da aplicação dos instrumentos de coleta de dados, os quais, aliás, totalizam mais de 200 planilhas auto-explicativas, além de manuais específicos de coleta.

Esta experimentação viabilizou os atuais instrumentos de coleta, apresentados em AGOPYAN et. al. (1998b) ${ }^{10}$, e também disponíveis na rede mundial de computadores (Internet) no endereço http://www.pcc.usp.br/Pesquisa/Perdas.

Ao término desta fase de experimentação (fase inicial do contato com as empresas avaliadas),passou-se a realizar a coleta de dados no âmbito da pesquisa, anteriormente citada, financiada pela FINEP e outras fontes, a qual teve a duração de aproximadamente 8 meses.

A consolidação desta rede de pesquisadores permitiu que a metodologia desenvolvida pudesse ser aplicada na prática em quase uma centena de canteiros de obras distribuídos pelo país.

Toda esta experiência adquirida foi extremamente útil para a redação final desta dissertação.

\footnotetext{
${ }^{10}$ Trata-se do relatório final encaminhado à FINEP, órgão financiador da pesquisa. É constituído por 5 volumes, a saber: Volume 1: Apresentação geral; Volume 2: Metodologia; Volumes 3, 4 e 5: Resultados e análises. Os instrumentos de coleta encontram-se no Volume 2.
} 


\subsection{Materiais/componentes e serviços estudados}

A construção civil envolve um número considerável de materiais/componentes ${ }^{11}$ e serviços, cada um com suas peculiaridades e características próprias e, face a esta dimensão, torna-se necessário estabelecer critérios no sentido de se delimitar o estudo quanto ao número de materiais/componentes e serviços a ser estudados.

Entre tais critérios, cita-se a representatividade do custo de cada material/componente no montante total da obra como um dos principais para a delimitação de tal estudo, combinado à maior ou menor probabilidade de ocorrência de perdas nos canteiros de obras.

Além desta combinação, outros critérios podem ser levados em consideração como, por exemplo, a particpação de cada um em termos de volume ou massa, o número de serviços nos quais são utilizados, entre outros.

Nesta proposta de metodologia, embora se reconheça a importância dos critérios citados anteriormente, tendo os mesmos sido levados em consideração, procurou-se ampliar a gama de materiais/componentes a ser estudados, valendo-se, principalmente, da oportunidade de se avaliar a questão das perdas em diversos canteiros distribuídos pelo país.

11 De acordo com o INTERNATIONAL COUNCIL FOR BUILDING RESEARCH, STUDIES AND DOCUMENTATION (CIB) (1974), o material pode ser definido como sendo um produto cuja correspondência com funções específicas é determinada apenas na ocasião de sua aplicação na edificação (exemplo: areia, cimento etc), enquanto que o componente pode ser definido como sendo o produto manufaturado ou industrializado como unidade distinta para servir uma função ou funções específicas (ex.: blocos, torneira, interruptor etc). Embora haja esta distinção, adotar-s e-á no decorrer deste texto a designação "materiais" quando se fizer referência aos materiais e componentes em conjunto. 
Outro aspecto importante, levado em consideração nesta escolha, consiste na possibilidade de se estudar as perdas de materiais/componentes em cada serviço, uma vez que, no caso de um material/componente que é usado em vários serviços, a perda no âmbito da obra não mostra em qual(is) serviço(s) há eventuais problemas ou virtudes.

Note que esta ênfase no estudo das perdas por serviço proporciona um desafio maior, principalmente no que diz respeito aos materiais básicos ${ }^{12}$ (cimento e cal, principalmente), uma vez que podem ser utilizados de forma simultânea em diversos serviços.

Neste sentido, procurando reunir estes anseios, somados aos critérios adotados pelos vários autores, apresenta-se na Tabela 1.1 a relação de materiais/componentes e serviços contemplados neste trabalho, onde pode-se perceber a complexidade e o desafio quando se enfatiza o estudo das perdas e lou consumos por serviço.

E este desafio e complexidade tornam-se maiores ainda uma vez que, ao se procurar relacionar as especificações dos materiais/componentes (abatimento do tronco de cone, fck, por exemplo no caso do concreto) e as características de cada serviço (equipamento de transporte, de aplicação, existência de projeto específico entre outros), onde cada combinação pode se configurar num tipo de material/componente e serviço, respectivamente, os números de

\footnotetext{
12 Para o desenvolvimento da metodologia, os materiais e componentes foram classificados em básicos, simples e compostos. Os básicos são representados por aqueles materiais que precisam ser previamente dosados e misturados a outros materiais básicos (Ex. cimento, cal, areia, pedra, saibro) para gerar os materiais compostos (argamassa e concretos produzidos em obra), enquanto que os materiais e componentes simples, são aqueles que podem ser utilizados diretamente nos serviços a ser executados, não havendo a necessidade de ser dosados e misturados a outros materiais.
} 
combinações de materiais/componentes e serviços envolvidos nesta proposta são seguramente muitíssimo maiores do que os apresentados nesta Tabela.

\section{Tabela 1.1 Materiais/componentes e serviços objetos de estudo para a elaboração da metodologia em questão}

\begin{tabular}{|c|c|c|}
\hline Serviços & Materiais/componentes & Materiais básicos \\
\hline \multirow[t]{2}{*}{ Estrutura de concreto } & Concreto usinado & - \\
\hline & Concreto produzido em obra & $\begin{array}{l}\text { Cimento, pedra, areia, } \\
\text { saibro }\end{array}$ \\
\hline \multirow[t]{2}{*}{ Armação } & Aço em vergalhões & - \\
\hline & Aço pré-cortado e dobrado & - \\
\hline \multirow[t]{3}{*}{ Alvenaria } & Blocos e tijolos & - \\
\hline & $\begin{array}{l}\text { Argamassa parcial ou totalmente } \\
\text { produzida fora do canteiro }^{13}\end{array}$ & Cimento $^{14}$ \\
\hline & argamassa produzida em obra & $\begin{array}{l}\text { Cimento, cal, areia, } \\
\text { saibro }\end{array}$ \\
\hline \multirow[t]{2}{*}{ Contrapiso } & $\begin{array}{l}\text { Argamassa parcial ou totalmente } \\
\text { produzida fora do canteiro }\end{array}$ & - \\
\hline & argamassa produzida em obra & Cimento, areia \\
\hline \multirow[t]{2}{*}{ Chapisco interno } & $\begin{array}{l}\text { Argamassa parcial ou totalmente } \\
\text { produzida fora do canteiro }\end{array}$ & - \\
\hline & argamassa produzida em obra & Cimento, areia \\
\hline \multirow[t]{3}{*}{ Chapisco externo } & $\begin{array}{l}\text { Argamassa parcial ou totalmente } \\
\text { produzida fora do canteiro }\end{array}$ & - \\
\hline & argamassa produzida em obra & Cimento, areia \\
\hline & Argamassa produzida em obra & $\begin{array}{l}\text { Cimento, cal, areia, } \\
\text { saibro }\end{array}$ \\
\hline
\end{tabular}

${ }^{13}$ Engloba a argamassa industrializada e a pré-misturada, de acordo com a definição da NBR B281 (1995).

${ }^{14}$ No caso da argamassa de cal pré-misturada, há a necessidade de se adicionar cimento, o que é feito no canteiro de obras. 
Tabela 1.1 Materiais/componentes e serviços objetos de estudo para a elaboração da metodologia em questão (continuação)

\begin{tabular}{|c|c|c|}
\hline Serviços & Materiais/componentes & Materiais básicos \\
\hline Emboço ou massa única interno & $\begin{array}{l}\text { Argamassa parcial ou totalmente } \\
\text { produzida fora do canteiro }\end{array}$ & Cimento \\
\hline \multirow[t]{2}{*}{ Emboço ou massa única externo } & $\begin{array}{l}\text { Argamassa parcial ou totalmente } \\
\text { produzida fora do canteiro }\end{array}$ & Cimento \\
\hline & argamassa produzida em obra & $\begin{array}{l}\text { Cimento, cal, areia, } \\
\text { saibro }\end{array}$ \\
\hline Revestimento cerâmico paredes (interno) & Placas cerâmicas & - \\
\hline Revestimento cerâmico paredes (externo) & Placas cerâmicas & - \\
\hline Revestimento cerâmico piso & Placas cerâmicas & - \\
\hline Instalações elétricas & Eletrodutos & - \\
\hline Instalações elétricas & Condutores (fios) & - \\
\hline Instalações hidráulicas e sanitárias & Tubos de PVC & - \\
\hline Pintura interna & $\begin{array}{l}\text { Tintas látex PVA e acrílica, } \\
\text { texturas }\end{array}$ & - \\
\hline Pintura externa & $\begin{array}{l}\text { Tintas látex PVA e acrílica, } \\
\text { texturas }\end{array}$ & - \\
\hline Revestimento têxtil & Revestimento têxtil & - \\
\hline Revestimento em gesso & Gesso & - \\
\hline Cobertura ${ }^{15}$ & $\begin{array}{l}\text { Telhas de fibrocimento e } \\
\text { cerâmica }\end{array}$ & - \\
\hline
\end{tabular}

\subsection{Estrutura da dissertação}

A dissertação é composta por 7 capítulos, sendo este o da introdução, e o último destinado às considerações finais.

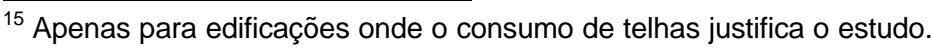


No Capítulo 2 são apresentados os principais conceitos que norteiam a discussão das perdas na Construção Civil. Com o objetivo de tornar daro o âmbito da proposição desta metodologia, assim como respaldar o entendimento dos resultados a ser obtidos, explora -se os diferentes conceitos de perdas possíveis, passando-se, inclusive, pelo estabelecimento de critérios para a determinação dos valores de referência, para o caso de a perda ser definida como o distanciamento em relação à uma meta preestabelecida. Além destes assuntos, destaca-se também a ênfase na questão das perdas físicas de materiais/componentes, onde se discorre sobre a perda incorporada e o entulho de construção civil. A classificação das perdas segundo vários autores é apresentada também neste capítulo.

As experiências e resultados das principais pesquisas sobre o assunto, realizadas no país e no exterior, são abordados no Capítulo 3. Para cada pesquisa, discorre-se sobre a metodologia empregada, os principais resultados e análises efetuadas, objetivando um maior embasamento para a elaboração da metodologia proposta.

O Capítulo 4 é dedicado à identificação das perdas e/ou consumos de materiais/componentes nos canteiros de obras. Neste Capítulo, cita-se a introdução do conceito de fluxograma dos processos e discorre-se sobre as possibilidades de ocorrência de perdas ao longo de todas as etapas deste fluxograma.

No Capítulo 5 é feita a apresentação dos principais conceitos e ferramentas relacionados à medição de desempenho, sendo os mesmos aplicados ao caso 
da mensuração das perdas e consumos de materiais/componentes nos canteiros de obras. Neste capítulo ainda, é proposta uma classificação dos indicadores de perdas e consumos de acordo com as peculiaridades de cada material/componente e do serviço estudado. Da mesma forma, apresenta-se uma extensa relação de indicadores levando-se em consideração a classificação proposta.

Embora a metodologia já venha sendo delineada no decorrer dos capítulos anteriores, mais especificamente nos Capítulos 2, 4 e 5, é no Capítulo 6 que são apresentados os aspectos relevantes da mesma quanto à coleta e análise de informações sobre perdas e/ou consumos de materiais/componentes nos canteiros de obras. Entre os vários aspectos abordados, destaca-se a apresentação do conjunto de ferramentas de coleta de dados nos canteiros de obras, os passos a serem seguidos em cada fase da aplicação da metodologia e, finalmente, as diretrizes básicas para a análise dos resultados a ser obtidos com a aplicação da metodologia.

O Capítulo 7é reservado para as considerações finais e para sugestões de futuras pesquisas.

Além destes capítulos, destaca-se também o conteúdo dos anexos presentes nesta dissertação, que têm por objetivo exemplificar algum conceito apresentado ao longo do desenvolvimento dos capítulos. No anexo $A$ exemplificase a complexidade em se definir os valores de referência para o cálculo do consumo de referência. 
Já no anexo $B$ são apresentados os principais resultados e conclusões obtidos no âmbito da aplicação da metodologia proposta neste trabalho.

O anexo $C$ traz uma relação das possíveis ocorrências de perdas de materiais nos canteiros de obras, relacionando-as as suas causas, origens e, principalmente, aos indicadores de perdas utilizáveis para avaliar tais ocorrências.

Um exemplo das planilhas e procedimentos de coleta de dados é apresentado no anexo $D$, enquanto que as estruturas de especificação dos materiais e caracterização dos serviços onde os mesmos são consumidos são apresentadas, respectivamente, nos anexos $E$ e $F$.

Finalmente, no anexo G, é apresentado um exemplo de cálculo da quantidade de material básico (cimento, cal, areia, saibro, brita) consumido por material composto (argamassas e concretos produzidos em obra). 


\section{CAṔ́TULO 2}

\section{PERDAS NA CONSTRUÇÃO CIVIL: PRINCIPAIS CONCETOSE CLASSIFCAÇÕES}

As controvérsias geradas a partir das raras pesquisas realizadas no país e no exterior sobre a questão das perdas na construção civil se devem, em grande parte, ao desconhecimento do escopo de tais pesquisas por parte dos leitores de seus resultados e, principalmente, à falta de conhecimento dos principais conceitos envolvidos neste assunto.

Com o intuito de se contribuir para o enriquecimento da discussão quanto à importância deste assunto para o Setor da Construção Civil e delimitar claramente o escopo deste trabalho, o presente capítulo traz uma revisão bibliográfica sobre a conceituação de perdas, envolvendo as principais definições e classificações.

\subsection{Subsídios para a avaliação das perdas na construção civil}

Segundo PICCHI (1995), a polêmica que se dá em torno dos números que caracterizam as perdas na Construção civil, deve-se aos diferentes conceitos e metodologias utilizados na sua mensuração. 
Tal opinião é compartilhada por CEOTTO (1995) ao afirmar que, ao se discutir esta questão, devem -se ter claramente definidos o referencial a partir do qual se considera o consumo excedente de recursos como sendo perdas e as unidades utilizadas na expressão dos resultados.

Para PICCHI (1995), cada conceito tem seu objetivo e aplicabilidade, no entanto, é necessário que fique claro o que está sendo medido e, neste sentido, defende a busca de uma terminologia que caracterize as bases utilizadas na obtenção dos números relativos às perdas, com o objetivo de se buscar a evolução da construção civil no país.

Neste contexto, nos itens subseqüentes, pretende-se apresentar uma série de questões relacionadas às preocupações até aqui apresentadas, no sentido de se contribuir para o pleno entendimento das perdas na construção civil, assim como tornar claro o real escopo e as limitações deste trabalho.

\subsubsection{Visão ampla das perdas na construção civil}

A Indústria de Construção Civil, quando comparada a outros segmentos do setor produtivo, é caracterizada pela heterogeneidade das etapas e dos agentes intervenientes que atuam no processo de construção. Esta heterogeneidade, aliada à complexidade do inter-relacionamento entre as etapas deste processo, favorece a ocorrência de falhas que repercutem em consumos adicionais de recursos em relação aos previstos. 
Estes consumos adicionais são denominados perdas e podem ocorrer de diversas formas: através do excesso de consumo de materiais, de mão-deobra, dos custos de reparos em produtos já entregues aos clientes, entre outras.

Neste sentido, o estudo das perdas e consumos de recursos na Indústria da Construção Civil pode assumir o mesmo grau de complexidade que a caracteriza e esta complexidade, por sua vez, é função do tipo de recurso a ser analisado e do número de etapas envolvidas no processo de construção.

Desta forma, o estudo sobre as perdas na construção civil passa, inicialmente, pela percepção de que estas podem ser avaliadas em cada etapa que compõe o processo de construção civil ou, ainda, no âmbito do conjunto destas etapas. Da mesma forma, há que se atentar também para o fato de que estas perdas/consumos podem estar relacionados aos vários recursos utilizados na elaboração de um empreendimento e que sua avaliação pode ser feita de forma individual, ou seja, considerando apenas um recurso isoladamente, ou de forma conjunta (envolvendo todos ao mesmo tempo).

Finalmente, insere-se a questão de que as perdas podem estar relacionadas às várias situações de referência, assumindo, portanto, valores distintos. $\mathrm{Na}$ opinião de SOUZA et al. (1998a), este fato configura-se numa dificuldade em se comparar os diferentes números citados nas bibliografias sobre o assunto.

Discutem-se, a seguir, mais detalhadamente, as diferentes perdas que podem ocorrer associadas às diferentes etapas que compõem o processo de 
construção civil. Finalmente, faz-se uma citação das diferentes perdas associadas aos diversos recursos participantes deste processo.

\subsubsection{A abrangência da avaliação das perdas segundo as etapas do processo de construção civil}

O processo de construção civil envolve todas as etapas relacionadas ao desenvolvimento de um empreendimento, assim como todos os intervenientes atuantes neste processo. Uma das formas de representação deste processo é apresentada por MESEGUER (1991). De acordo com sua representação, o processo de construção civil envolve 5 etapas principais: Planejamento, Projeto, Materiais, Execução e Uso-manutenção (Figura 2.1).

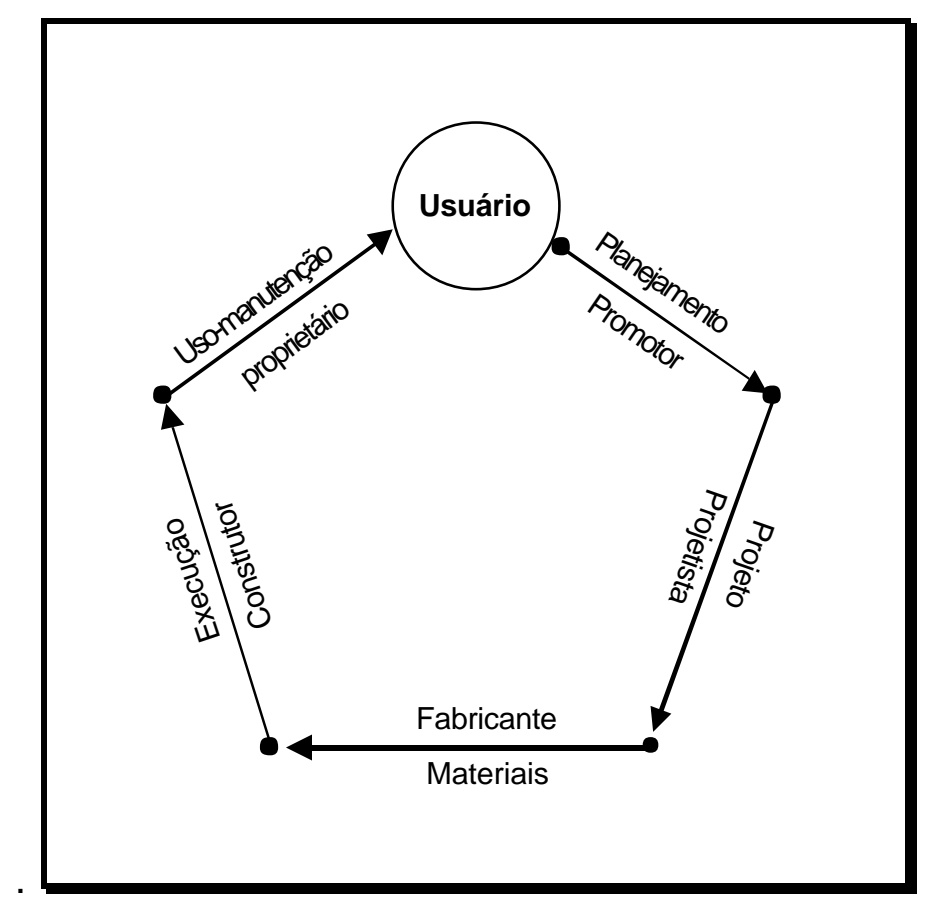

Figura 2.1 O processo de construção - simplificado por este autor (MESEGUER, 1991) 
O processo se inicia com a identificação das necessidades dos clientes (usuários), passa por etapas intermediárias envolvendo outros agentes e se encerra com o próprio usuário que recebe o produto final, fechando, assim, o ciclo.

As etapas de Planejamento e Projeto se referem à concepção do empreendimento. Enquanto a etapa de Planejamento diz respeito ao delineamento do escopo das alternativas em estudo e à elaboração de estimativas preliminares de custos, prazos, utilização de recursos, de forma a permitir a verificação da viabilidade de cada alternativa existente (ASSUMPÇÃO, 1988), a etapa de Projeto consiste no "instrumento que viabiliza a produção do empreendimento, concretizando a edificação" (GALVÃO \& SALGADO, 1997).

Já a etapa de Materiais diz respeito à fabricação dos materiais a ser utilizados na elaboração da obra, de acordo com as especificações definidas nas etapas de Planejamento e Projeto.

Por sua vez, a etapa de Execução diz respeito às atividades necessárias à materialização da obra. A partir da observação do que foi estabelecido nos projetos e planejamento, inicia-se a construção propriamente dita do produto idealizado (MACIEL \& MELHADO, 1995).

Finalmente, após o término do produto e da aquisição do mesmo pelo cliente, inicia-se a etapa de Uso-manutenção, que consiste em o usuário desfrutar do produto adquirido. Além destas etapas, outras podem ser agregadas a este 
ciclo, envolvendo um número maior de intervenie ntes ${ }^{16}$. Por exemplo, pode-se acrescentar a etapa de Suprimentos, que corresponde à interface entre o segmento de produção dos materiais e o segmento de produção do empreendimento.

As perdas podem estar presentes em todas as etapas deste processo [(CUNHA (1987); PICCHI (1995); SOUZA et al. (1995); FREITAS (1995); OLIVEIRA et al. (1998); SOUZA et al. (1998a), entre outros] e, conseqüentemente, podem ser abordadas de diversas formas, principalmente com relação ao tipo de recurso em questão e ao número de etapas envolvidas.

Isso significa dizer que as perdas podem ser avaliadas de forma global (envolvendo as perdas em mais de uma ou em todas as etapas do processo de construção) ou de forma específica (envolvendo as perdas em uma única etapa do processo de construção).

A definição da abordagem a ser realizada está vinculada ao usuário da informação. Assim, enquanto ao construtor interessa, por exemplo, a avaliação das perdas que ocorrem apenas durante a etapa de Execução, ao Setor da Construção Civil ou entidades relacionadas à proteção do Meio Ambiente interessa a avaliação das perdas dos recursos naturais (matéria-prima), desde a produção dos materiais até o fim da sua vida útil ${ }^{17}$.

\footnotetext{
${ }^{16}$ Um exemplo mais detalhado do ciclo do processo de construção, comumente denominado por Ciclo da Qualidade, pode ser visto em PICCHI (1993).

${ }^{17}$ A vida útil corresponde ao período ao qual as propriedades do material permanecem acima dos limites mínimos estabelecidos (LICHTEINSTEIN, 1985).
} 
Neste último caso, as perdas de recursos naturais seriam representadas pelas perdas ao longo do processo de fabricação dos materiais, pelas perdas decorrentes da deficiência da especificação dos materiais fabricados a partir destes recursos naturais em quantidade superior à necessária na etapa de Concepção $^{18}$, pelas perdas devido ao mau uso dos materiais durante a etapa de execução e, finalmente, pelas perdas ocorridas em função de problemas patológicos ${ }^{19}$ durante a etapa de Uso-manutenção.

No âmbito da etapa de Execução, os trabalhos são voltados para o estudo das perdas e da produtividade dos recursos físicos: mão-de-obra e materiais. No que diz respeito à avaliação da produtividade da mão-de-obra, embora realizados sob óticas um pouco diferentes, destacam-se os trabalhos realizados por SANTOS (1995), de um lado, e por SOUZA (1996b) e CARRARO $(1998)^{20}$, de outro.

Enquanto os trabalhos com enfoque semelhante ao do primeiro autor preocupam-se com a avaliação da porcentagem do tempo total realmente utilizado na execução dos serviços propriamente ditos, os trabalhos com abordagem coerente com a dada pelos dois outros autores buscam detectar as relações entre o esforço do operário (medido em homens-hora) e a quantidade de serviço realizada. Em ambos os casos, a comparação de situações

\footnotetext{
${ }^{18}$ Para simplificar o raciocínio, a Concepção envolve a etapa de Planejamento e Projeto.

19 Problema patológico é definido como sendo a "situação, em determinado instante da vida útil do edifício, em que este, ou uma de suas partes, não apresente um desempenho satisfatório" (LICHTEINSTEIN, 1985).

${ }^{20}$ Note que não é objetivo deste trabalho aprofundar nas questões relativas às perdas de outros recursos além das perdas de materiais e, portanto, limita-se em apenas citá-las, sem o devido grau de aprofundamento.
} 
mensuradas em obra com um valor de referência permite o cálculo das perdas de mão-de-obra.

No que diz respeito ao estudo das perdas de materiais, há que se destacar os trabalhos realizados por PINTO (1989), SOIBELMAN (1993) e, mais recentemente, a pesquisa intitulada "Alternativas para a redução das perdas de materiais nos canteiros de obras", que motivou o desenvolvimento deste trabalho ${ }^{21}$.

No âmbito da etapa de Uso-manutenção, as perdas estão relacionadas à incidência de problemas patológicos nas edificações que, para a empresa, representam dispêndio de recursos para a sua correção. Dentre os trabalhos realizados sobre a incidência de problemas patológicos nas edificações, podese citar o apresentado por IOSHIMOTO (1988) que, baseado em um levantamento realizado pelo IPT em 36 conjuntos habitacionais do Estado de São Paulo, levantou o índice CPU - Coeficiente de Problemas por Unidade ${ }^{22}$. Este autor chegou a valores de CPU da ordem de 4,5 a 6,0 para casas térreas e de 1,7 a 3,1 para apartamentos.

Uma outra questão importante, que também gera custos de manutenção para a empres a construtora, diz respeito às não-conformidades ${ }^{23}$ apresentadas pelo produto entregue ao cliente em relação ao projeto ou padrões

\footnotetext{
${ }^{21}$ Ressaltase que estas pesquisas, assim como as demais, serão apresentadas, com maiores detalhes, no capítulo 3 do presente trabalho.

${ }^{22}$ CPU consiste na relação entre o número de problemas detectados em cada conjunto habitacional e o número de unidades.

${ }^{23}$ De acordo com a NBR/ISO 8402 (1994), a não-conformidade consiste no "não atendimento de um requisito especificado".
} 
preestabelecidos. A correlação de tais problemas pode gerar um consumo de recursos maior que um valor esperado, constituindo-se em perdas.

Em recente pesquisa realizada pelo SECOVI-SP (1998) em 52 obras de 8 empresas de Construção civil, verificou-se que as não-conformidades, num período de 5 anos de vida da edificação, correspondem a 2,87\% do custo total da obra, equivalendo em custos, a edificação de $827 \mathrm{~m}^{2}$ de área construída, que correspondem a aproximadamente 4 apartamentos com área total de 206 $\mathrm{m}^{2}$ cada $u \mathrm{~m}^{24}$.

Seja qual for o tipo de recurso e a etapa na qual o mesmo é perdido, na opinião de LICHTENSTEIN (1985), PICCHI (1993), SOUZA et al. (1995), SECOVI (1998) e ressaltada na NBR/ISO 8402 (1994), a maior parcela de perda, talvez não quantificável, consiste na perda de imagem da empresa construtora perante o mercado consumidor, principalmente, em se tratando das ocorrências verificadas na etapa de Uso-manutenção, sentidas diretamente pelos usuários.

Com um enfoque um pouco diferente, as perdas ao longo do processo de construção civil podem ser tratadas, ainda, sob o ponto de vista dos custos da qualidade, mais especificamente sob o ponto de vista dos custos de falhas, que se dividem em custos de falhas internas e externas ${ }^{25}$.

\footnotetext{
${ }^{24}$ Neste estudo, foi calculado um índice de 212 defeitos por mil $\mathrm{m}^{2}$ de área construída e um índice de custo de correção dos defeitos detectados de $\mathrm{R} \$ 15,84$ por $\mathrm{m}^{2}$ de área construída. Em termos percentuais, as instalações hidráulicas responderam por $39,51 \%$ do total de defeitos; as paredes 17,46\%; impermeabilização 8,1\%; as esquadrias de alumínio 6,95\%; esquadrias de madeira 7,37\%; instalações elétricas 5,4\%; placas cerâmicas de parede 4,18\% e placas cerâmicas de piso 3,43\%.

25 De acordo com a NBR/ISO 9004 (1994), os custos da qualidade correspondem aos custos para prevenir ou compensar as falhas. Por sua vez, os custos da qualidade, segundo esta mesma norma, são divididos em custos de prevenção ("custos de esforços para a prevenção de falhas"), custos de
} 
A esse respeito, HAMMARLUND \& JOSEPHSON (1992) apresentam os custos de falhas internas e externas avaliadas em um grupo de 8 empresas na Suécia. Segundo estes autores, as falhas internas correspondem a $6 \%$ dos custos de produção, sendo que praticamente $1 / 3$ dos custos destas falhas foram atribuídas a falhas de gerenciamento. Por sua vez, os custos de falhas externas representam $4 \%$ dos custos de produção, sendo a maior parte destes custos atribuída ao projeto.

Embora se reconheça a existência de perdas em todas as etapas do processo de construção e que a preocupação com a minimização das perdas está presente em todos os trabalhos citados, sendo que alguns deles evidenciam o fato de que ações para a sua minimização devam estar embasadas em dados representativos do setor, obtidos mediante uma metodologia padronizada, $\mathbf{0}$ presente trabalho está centrado no estudo das perdas no âmbito da etapa de Execução.

avaliação ("custos de testes, inspeção e exames para verificar se a qualidade especificada está sendo mantida"), e custos de falhas, que podem ser decorrentes de fal has internas e externas. Os custos das falhas internas são os "custos resultantes de falhas dos requisitos da qualidade de um produto ou serviço antes da entrega (por exemplo: retrabalho, reprocessamento etc), enquanto que os custos das falhas externas "são resultantes de falhas de qualidade de um produto ou serviço após a entrega (por exemplo: garantias de devolução, consertos, custos de responsabilidade civil, entre outros). 


\subsubsection{A abrangência da avaliação das perdas e consumo segundo o tipo de recurso analisado}

Na elaboração de um produto comparecem, além dos materiais, vários outros recursos, como mão-de-obra, energia e equipamentos, além das quantidades monetárias necessárias para a sua obtenção.

Neste sentido, identificam-se duas possibilidades quanto à ocorrência de perdas na elaboração deste produto e, conseqüentemente, metodologias distintas para a sua avaliação. A primeira delas, mais restrita - porém não menos importante - consiste no estudo das perdas e/ou consumos dos recursos físicos (quantidade de materiais, mão-de-obra, energia, equipamentos) utilizados no processo produtivo. A outra possibilidade, mais ampla, consiste na avaliação das perdas e/ou consumos dos recursos financeiros (custos das perdas dos materiais, mão-de-obra, energia, equipamentos e custos relacionados a perdas de outra natureza).

A avaliação das perdas e/ou consumo em termos de recursos financeiros é desejável, uma vez que os resultados podem ser expressos numa única unidade, permitindo, assim, comparações entre os mesmos. Desta forma, pode-se priorizar as ações preventivas e corretivas para aquelas perdas que se mostrarem mais significativas em termos financeiros (BORNIA, 1995).

A este respeito, SOUZA (1998) apresenta uma equação matemática envolvendo as relações entre os consumos de recursos físicos e os consumos de recursos financeiros: 


$$
\frac{R \$}{Q S}=\left[\frac{R \$}{Q M O} x \frac{Q M O}{Q S}\right]+\left[\frac{R \$}{Q M A T} x \frac{Q M A T}{Q S}\right]+\left[\frac{R \$}{Q E Q U} x \frac{Q E Q U}{Q S}\right]
$$

onde:

$$
\begin{array}{ll}
R \$ & =\text { custo expresso em valores monetários; } \\
Q S & =\quad \text { quantidade de serviço expressa em unidades de medição física; } \\
Q M O & =\text { quantidade de mão-de-obra expressa em homens-hora; } \\
Q M A T & \text { quantidade de materiais expressa em massa, peso ou unidades; } \\
Q E Q U & =\text { quantidade de equipamentos expressa em horas necessárias. }
\end{array}
$$

De acordo com esta expressão, o consumo total de recursos financeiros consiste no somatório das parcelas de consumos financeiros relacionadas a cada tipo de recurso analisado. Por sua vez, cada parcela de consumo financeiro é dada pela combinação entre o consumo de recurso físico (quantidade de recurso/unidade de serviço executada) e o custo unitário do recurso. Fazendo-se a diferença entre os consumos de recursos realizados e os consumos de recursos previstos pode-se chegar ao valor da perda financeira global.

A análise mais acurada desta equação permite a identificação de que o desempenho global, quanto à ocorrência de perdas financeiras (ou quanto ao consumo de recursos financeiros), está condicionado aos desempenhos específicos quanto ao uso dos recursos físicos e quanto à aquisição ou contratação de tais recursos. Em outras palavras, o sucesso global, quanto ao 
desempenho no uso dos recursos financeiros, é fruto de uma combinação positiva de desempenhos parciais (SOUZA, 1998).

Isto permite vislumbrar a existência de perdas de caráter estritamente financeiro, isto é, aquelas que acontecem mesmo quando as perdas físicas são nulas. Neste caso, em particular, são decorrentes da ineficiência da empresa em adquirir ou contratar os recursos físicos, muitas vezes condicionada aos aspectos relacionados ao mercado (oferta do recurso, inflação, custo de oportunidade etc).

Como forma de ilustrar esta distinção, a Tabela 2.1 traz uma simulação de avaliação do desempenho do serviço de contrapiso quanto ao uso do cimento, a partir de uma situação de referência pré-definida. Observe que, apesar de os desempenhos globais das situações A e B serem idênticos, os fatores que motivaram esta igualdade são distintos. Enquanto a variação do desempenho na situação $A$ deveu-se à variação do consumo do recurso físico, na situação $\mathrm{B}$, a variação do desempenho foi motivada pela variação do custo unitário do recurso analisado.

Tabela 2.1 Exemplo de cálculo do consumo de recursos financeiros em função da variação do custo unitário do material e da variação do consumo do recurso físico por unidade de serviço executado

\begin{tabular}{|c|c|c|c|c|c|c|c|}
\hline \multirow[t]{2}{*}{ Tipo de recurso } & \multirow{2}{*}{$\begin{array}{c}\text { Consumos } \\
\text { de } \\
\text { referência }\end{array}$} & \multicolumn{2}{|c|}{ SITUAÇÃO A } & \multicolumn{2}{|c|}{ SITUAÇÃO B } & \multicolumn{2}{|c|}{ SITUAÇÃO C } \\
\hline & & $\begin{array}{c}\text { Consumos } \\
\text { reais }\end{array}$ & Perda (\%) & $\begin{array}{c}\text { Consumos } \\
\text { reais }\end{array}$ & Perda (\%) & $\begin{array}{c}\text { Consumos } \\
\text { reais }\end{array}$ & Perda (\%) \\
\hline $\begin{array}{l}\text { Recurso físico } \\
\left(\mathrm{kg} / \mathrm{m}^{2}\right)\end{array}$ & 7,5 & 10,0 & 33,3 & 7,5 & 0 & 9,0 & 20,0 \\
\hline $\begin{array}{l}\text { Custo unitário } \\
(\mathrm{R} \$ / \mathrm{kg})\end{array}$ & 0,16 & 0,16 & 0 & 0,21 & 56,3 & 0,20 & 25,0 \\
\hline $\begin{array}{l}\text { Recurso financeiro } \\
\left(\mathrm{R} \$ / \mathrm{m}^{2}\right)\end{array}$ & 1,2 & 1,6 & 33,3 & 1,56 & 33,3 & 1,8 & 50,0 \\
\hline
\end{tabular}


No que diz respeito ainda à ocorrência de perdas de natureza estritamente financeira, há que se ressaltar que as mesmas não estão relacionadas somente à ineficiência na aquisição ou contratação dos recursos físicos e sim, podem decorrer também do emprego de um capital para a formação de estoque de materiais que não serão utilizados num curto prazo, quando tal capital poderia estar sendo aplicado em investimentos financeiros [(BÓRNIA (1995); OLIVEIRA et al., 1998)]. Da mesma forma, pode-se citar também a perda financeira devido à substituição de um material de menor valor por outro de maior valor, em razão da inexistência do primeiro no local de trabalho.

A percepção de que as perdas podem ser estritamente financeiras ou decorrentes da ineficiência do uso dos recursos físicos, leva à necessidade de se desvincular o estudo das perdas e/ou consumo de recursos físicos do estudo das perdas e/ou consumo de recursos financeiros, ainda que, em última instância, os recursos físicos possam ser expressos em unidades financeiras.

Para SOUZA (1998), a decisão de se obter resultados em termos financeiros ou em termos físicos depende do nível hierárquico, dentro da empresa, para o qual a informação se destina. Assim, a informação sobre o consumo global de recursos financeiros seria desejável à direção geral do empreendimento, enquanto que a informação quanto ao consumo de recursos físicos seria mais útil ao pessoal da produção e a informação da relação entre o número de reais demandados para a aquisição de cada unidade de material empregada seria interessante ao responsável pela aquisição do mesmo. 
Embora se reconheça a importância da avaliação das perdas de recursos financeiros, este trabalho preocupa-se com o estudo das perdas e consumos dos recursos físicos utilizados na produção de uma edificação, especificamente no que diz respeito ao uso dos materiais no âmbito da etapa de Execução.

\subsubsection{Perdas: um conceito relativo}

Um dos aspectos mais importantes a ser considerado num estudo sobre perdas, seja qual for o tipo de recurso analisado, consiste na necessidade de se estabelecer e tornar clara a situação de referência a partir da qual todo o consumo excedente de recurso seja considerado como sendo perda, pois, dependendo da situação adotada, as perdas podem assumir valores distintos.

A este respeito, algumas definições de perdas apresentadas por diversos autores apontam para esta necessidade, ainda que sob o ponto de vista genérico. Como exemplo, MELINGHENDLER (1976) define perda como sendo "todo o diferencial que separa a obra realizada da obra perfeita". Para PICCHI (1995), o desperdício ${ }^{26}$ é definido como sendo "tudo aquilo que é despendido além do necessário em uma situação ideal'. Neste mesmo caminho, a perda, segundo CONWAY QUALITY (1998), consiste na "diferença entre a forma como as coisas são feitas agora e a forma como elas poderiam ser feitas, se tudo fosse perfeito".

\footnotetext{
${ }^{26}$ A distinção entre a conceituação de perdas e desperdício será feita no item 2.3.4. Para efeito de apresentação das considerações das citações dos autores, optou-se em manter o mesmo termo utilizado pelos mesmos, ainda que possa não estar em conformidade com a distinção feita no item supracitado.
} 
No entanto, as perdas não necessariamente precisam ser calculadas em relação a uma situação ideal ou perfeita e sim, o seu cálculo deve ser feito de acordo com a finalidade da informação a ser obtida. No que diz respeito ao estudo das perdas de materiais, por exemplo, estas poderiam ser calculadas tomando-se como referência os valores de consumo médio do setor (à medida que a empresa deseja se posicionar em relação ao mesmo), ou os valores de cons umo presentes no orçamento realizado a partir dos projetos (à medida que a empresa deseja se posicionar em relação ao orçamento inicial realizado) ou, ainda, os valores de consumo mínimo detectados no mercado (à medida que a empresa deseja se posicionar em relação à melhor empresa concorrente) (CEOTTO, 1995). Além destas possibilidades, pode-se citar também os valores de consumos estabelecidos em normas técnicas, entre outras.

No caso específico dos materiais, a definição da situação de referência tornase um pouco mais complexa na medida em que se considera as particularidades do uso de cada um no seu respectivo serviço e à medida que se deseja restringir a obtenção de valores de perdas apenas no âmbito das atividades desenvolvidas no canteiro de obras.

Com relação às particularidades relacionadas a cada material, podem-se exemplificálas para o caso da definição da espessura do revestimento horizontal (contrapiso), uma das informações necessárias para o cálculo do consumo de referência ${ }^{27}$. Ao contrário do que acontece com o serviço de revestimento interno (emboço) onde, geralmente, adota-se uma única

\footnotetext{
${ }^{27} \mathrm{O}$ cálculo do consumo de referência será melhor detalhado no item 2.2.2.2.
} 
espessura para a execução do revestimento como um todo, em se tratando do serviço de contrapiso, esta espessura é variável em função dos desníveis necessários entre ambientes e do tipo de acabamento decorativo de cada $u \mathrm{~m}^{28}$.

Ainda com relação à adoção da situação de referência, o fato de se objetivar a detecção de perdas no âmbito do canteiro de obras impossibilita a adoção de uma referência única, pois tal medida agregaria perdas relacionadas à outra etapa do processo de construção, no caso, a de concepção, representada pelas alterações de projeto impostas pelo executor, em função deste detectar especificações incorretas ou incompatíveis (à medida que o processo de elaboração do projeto não se deu de forma coordenada), entre outras.

Como exemplo, pode-se citar a diferença apresentada entre a espessura definida na etapa de concepção e a espessura adotada durante a execução pelos seus responsáveis, com o intuito de se compatibilizar a largura da alvenaria de vedação e a largura dos elementos estruturais (Figura 2.2), que não pode ser agregada à parcela de perdas decorrentes da ineficiência no uso deste material no canteiro de obras.

${ }^{28}$ No anexo A apresenta-se um caso prático onde pode-se verificar as diferenças entre as espessuras dos diferentes ambientes. Note que, neste caso, a não consideração desta particularidade significaria uma diferença de aproximadamente $45 \%$. 


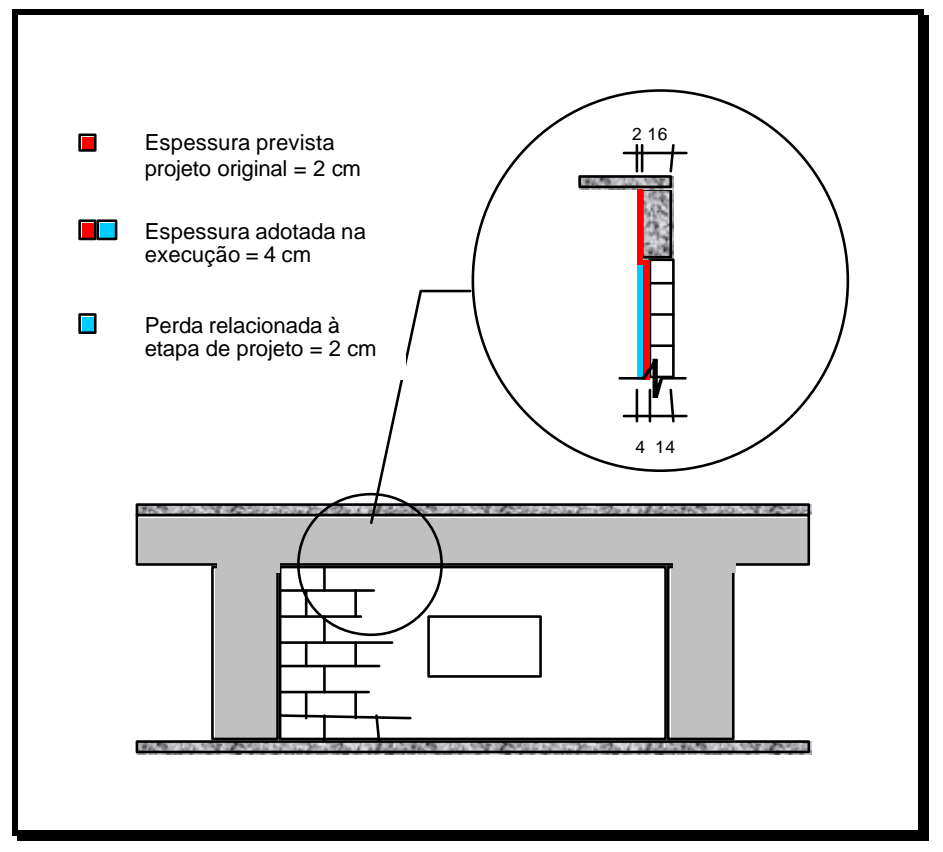

Figura 2.2 Exemplo de perda de material relacionada à etapa de concepção

Assim, a adoção da situação de referência neste trabalho deve ser feita através de procedimentos e critérios que convirjam para o estabelecimento de indicadores de perdas de materiais exclusivamente relacionados à ineficiência no uso dos mesmos nos canteiros de obras, respeitando-se as particularidades relacionadas a cada material.

\subsection{Conceito de perdas aplicado ao canteiro de obras}

Muito embora os conceitos apresentados neste item valham para todas as etapas do pro cesso de construção civil, faz-se aqui a sua interpretação quanto a situações vigentes nos canteiros de obras, objeto de estudo deste trabalho. 


\subsubsection{Conceito amplo}

Segundo (SANTOS et al., 1996), as perdas devem ser entendidas como sendo "qualquer ineficiência que reflita no uso de equipamentos, materiais e mão-deobra em quantidades superiores àquelas necessárias à produção da edificação".

Sob este mesmo enfoque amplo, VARGAS et al. (1997) define perdas como sendo "qualquer recurso que se gasta na execução de um produto ou prestação de serviços além do estritamente necessário (mão-de-obra, material etc)".

Assim, tomando-se como exemplo o processo de produção de um revestimento em gesso ilustrado na Figura 2.3 e partindo-se das definições anteriores, as perdas seriam representadas pela diferença entre o consumo real de recursos envolvidos neste processo e a previsão de consumo preestabelecido, ou seja: homens-hora previstos $\mathrm{x}$ homens-hora utilizados; consumo de materiais previsto $\mathrm{x}$ consumo de material realizado; consumo de energia previsto $\mathrm{x}$ consumo de energia realizado etc.

No entanto, ainda com relação ao conceito de perdas sob o ponto de vista amplo, insere-se, também, além da idéia de se comparar o consumo previsto e o consumo efetivamente realizado de rec ursos, a idéia de se avaliar o consumo 
de recurso efetivamente realizado sob a ótica da agregação de valor ao processo e, conseqüentemente, ao produto ${ }^{29}$.

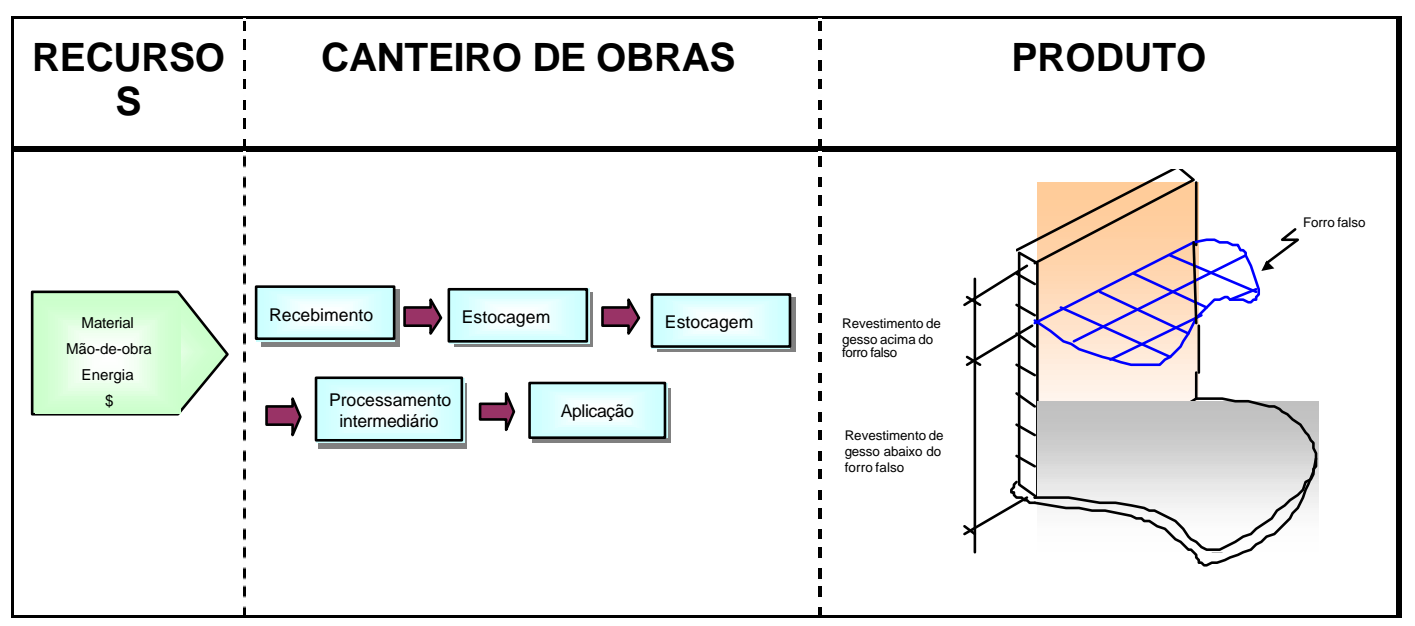

Figura 2.3 Processo de produção do revestimento de gesso

Assim, sob esta ótica, as perdas podem ser definidas como sendo todo o recurso que se gasta para elaborar um produto sem agregar valor ao mesmo [(CUNHA, 1987); FREITAS (1995)].

Valendo-se do mesmo exemplo apresentado na Figura 2.3, o consumo de mate rial (gesso) representado pela área revestida, localizada acima da altura do forro falso, consiste numa perda sob o ponto de vista da agregação de valor, enquanto que, sob o ponto de vista da comparação entre o consumo efetivamente realizado e o consumo teoricamente previsto, o consumo deste

\footnotetext{
${ }^{29}$ Agregar valor significa desenvolver atividades que aumentam o valor do produto sob a ótica do consumidor. Geralmente compreendem as atividades de transformação, ou seja, que transformam fisicamente o produto ao longo do processo de produção. Por conseguinte, a não agregação de valor é expressa pelas atividades de suporte às atividades que agregam valor. Cita-se, como exemplo, o transporte de insumos, inspeção etc. Em outras palavras, significa a redução de custos do produto sem alterar a qualidade ou funcionalidade através da Análise do Valor. Esta metodologia foi desenvolvida em 1947 por LAWRENCE DELLOS MILLES, na época engenheiro da General Electric americana (BASSO, 1991).
} 
material representado pela área acima do forro falso não seria considerado como sendo perdas desde que previsto no projeto executivo.

Note ainda, que tal conceito não se restringe apenas ao produto (no caso, a parede revestida com gesso) e sim, estende-se também para o âmbito das atividades desenvolvidas nos canteiros de obras para compor este produto.

Neste contexto, o conceito de perdas é entendido como sendo toda a atividade realizada que não agrega valor ao produto final (KOSKELA, 1992). Segundo este autor, entendendo a produção como sendo um fluxo de materiais e/ou informações, desde o recebimento da matéria-prima até a entrega do produto final, sendo que, neste fluxo, os materiais são processados, inspecionados, movimentados ou estão em espera, identificam-se dois tipos de atividades relacionadas ao mesmo:

(a) atividades de conversão: consiste no processamento dos materiais em produtos acabados e intermediários e agregam valor aos mesmos;

(b) atividades de fluxo: relacionam-se às tarefas de inspeção, movimento e espera dos materiais e não agregam valor ao produto;

Neste sentido, o conceito de perdas preconizado por este autor não está somente relacionado às atividades de conversão e sim também às atividades de fluxo, onde se procura reduzi-las ou até mesmo eliminá-las.

Tomando-se novamente a Figura 2.3, além da otimização das atividades de conversão (processamento intermediário, aplicação), deve-se eliminar as 
atividades relacionadas ao transporte excessivo e à estocagem intermediária do material, consideradas atividades de fluxo.

Há que se ressaltar, no entanto, que nem todas as atividades de conversão resultam em agregação de valor ao produto como, por exemplo, a necessidade de retrabalho (SANTOS et al., 1996). Assim é que, tendo-se refeito o revestimento mostrado na Figura 2.3 em função de o mesmo não apresentar desempenho superficial requerido, o material e as horas de trabalho adicionais são considerados perdas, ainda que o operário tenha atuado com disposição nesta tarefa.

Finalmente, o conceito amplo de perdas está relacionado também à qualidade do produto percebida pelo cliente. Neste sentido, SUZAKI ${ }^{30}$ apud SOUZA et al. (1995) definem desperdício como sendo "tudo o que impeça alcançar o máximo de qualidade, o mínimo preço e uma rápida entrega aos clientes". Para OLIVEIRA et al. (1998), a noção de perdas se refere a "toda a falta de aproveitamento dos recursos para atingir custos menores e maior satisfação do cliente".

Neste sentido, mesmo que os operários envolvidos na execução do revestimento de gesso, que ilustra este capítulo, tenham trabalhado com produtividade e utilizado a quantidade teoricamente necessária de material, terá havido perda se os mesmos começaram o trabalho tardiamente em relação ao cronograma de obras previsto, ocasionando um atraso na entrega da obra e, conseqüentemente, uma penalidade aos futuros moradores. 


\subsubsection{Restrito aos materiais}

Os trabalhos realizados com a intenção de avaliar as perdas de materiais nos canteiros de obras partem da idéia de se comparar a quantidade de materiais efetivamente empregada, na execução da edificação ou de partes da mesma, e a quantidade teoricamente prevista para tal, sendo considerada perda a diferença observada desta comparação.

Desta forma, para um período delimita do por duas datas (início e fim de coleta de dados), define-se perda de materiais como sendo a diferença percentual entre um consumo efetivamente realizado (consumo real) e um consumo de referência preestabelecido.

\subsubsection{Consumo de material efetivamente realizado}

O consumo de material efetivamente realizado durante um certo período corresponde à diferença entre a quantidades de material estocadas nas datas de início e fim de coleta de dados (estoque na data final - estoque na data inicial), acrescida da quantidade de material recebida no canteiro de obras entre estas datas.

Matematicamente, este consumo pode ser calculado de acordo com a seguinte expressão:

$$
\text { Consumo }_{\text {real }}=E_{\text {st }}\left(\text { data }_{\text {inicial }}\right)+\operatorname{Re} c\left(\text { data }_{\text {inicial }}, \text { data }_{\text {final }}\right)-E S T\left(\text { data }_{\text {final }}\right)
$$

\footnotetext{
${ }^{30}$ SUZAKI, K. Competitividad en fabricacióm en la década de los 90: técnicas para mejoria contínua TGP Tecnologias de Gerencia y Produción. Madri, 1987.
} 
onde,

$\begin{array}{ll}\operatorname{Est}\left(\text { data }_{\text {inicial }}\right) & \text { estoque de material na data inicial de coleta de dados } \\ \operatorname{Re} c\left(\text { data }_{\text {inicial }}, \text { data }_{\text {final }}\right) & = \\ & \text { quantidade de material recebida entre as datas inicial e } \\ & \text { final da coleta de dados } \\ \text { Est }\left(\text { data }_{\text {final }}\right) & =\end{array}$

\subsubsection{Consumo de referência}

O consumo de referência é obtido através da multiplicação de 3 variáveis, a saber:

- (QS): corresponde à quantidade de serviço executado no período concernente à coleta de dados no canteiro de obras (Exemplo: $400 \mathrm{~m}^{2}$ de revestimento em argamassa para emboço);

- $(C M / Q S)$ : corresponde ao consumo de material por unidade de serviço executado (Exemplo: $2 \mathrm{~m}^{3}$ de argamassa por $\mathrm{m}^{2}$ de revestimento);

- $(C M B / M C)$ : corresponde ao consumo dos materiais básicos (kg de cimento e de cal, volume de areia, de brita, de saibro) por unidade de material composto (Exemplo: $150 \mathrm{~kg}$ de cimento por $\mathrm{m}^{3}$ de argamassa).

A coleta destas informações é feita preliminarmente, utilizando-se o projeto como referência. No entanto, nem sempre estes dados estão claramente definidos nos projetos ou, ainda, no caso extremo, pode-se deparar com a inexistência de projetos específicos para tal fim. 
Neste contexto, na Figura 2.4 são representados dois caminhos para a definição das variáveis envolvidas no cálculo do consumo de referência, sempre priorizando a obtenção das perdas de materiais relacionadas às atividades desenvolvidas no âmbito do canteiro de obras.

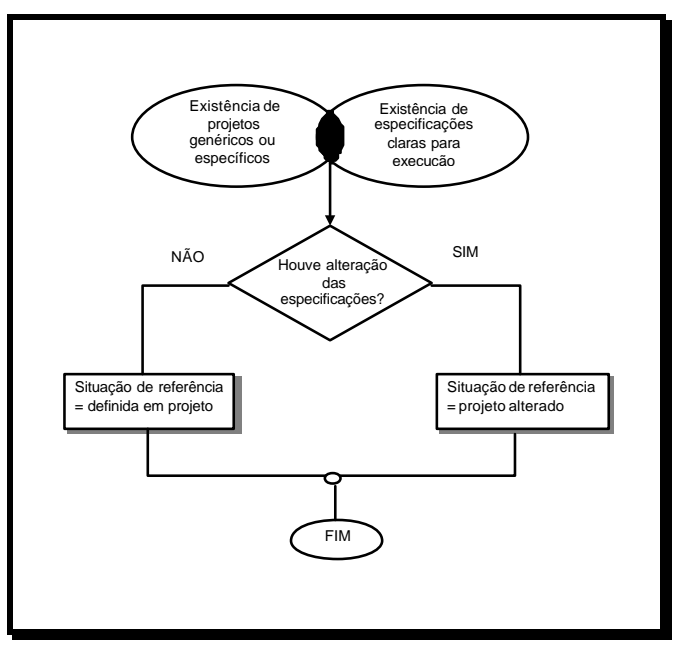

(a)

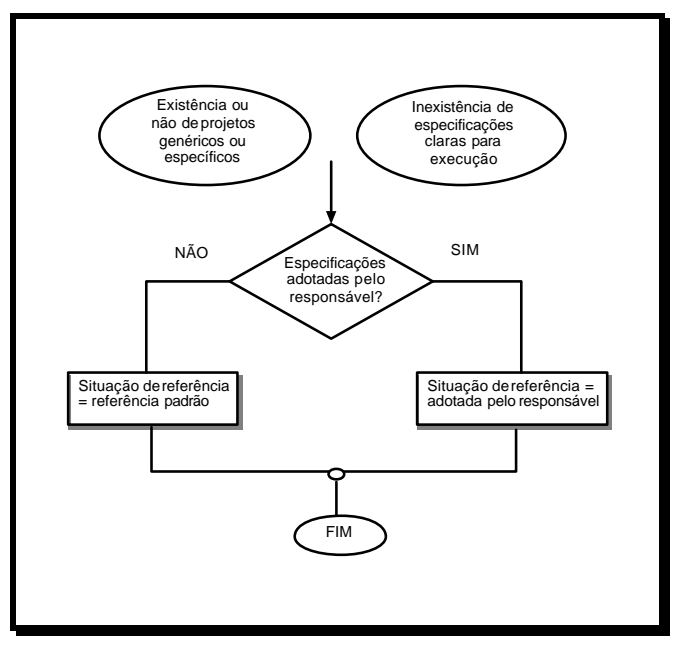

(b)

Figura 2.4 Situações vigentes para a determinação dos valores de referência - (a) existência de especificações claras; (b) inexistência de especificações claras

Matematicamente, o consumo de referência é calculado de acordo com a expressão [2.3], cuja composição com a equação [2.2] resulta na expressão do cálculo da perda de material no canteiro de obras (expressão [2.4]).

$$
\begin{aligned}
& \text { Consumo }_{\text {referência }}=Q S\left(\text { data }_{\text {nicial }}, \text { data }_{\text {final }}\right) \times \frac{C M}{Q S} \times \frac{C M B}{M C} \\
& \operatorname{Perda}(\%)=\left[\frac{\left.{\text { Est }\left(\text { data }_{\text {inicial }}+\operatorname{Re} c\left(\text { data }_{\text {inicial }}, \text { data }_{\text {final }}\right)-\text { Est }\left(\text { data }_{\text {final }}\right)\right.}_{Q S\left(\text { data }_{\text {inicial }}, \text { data }_{\text {final }}\right)}\right)}{Q S \frac{C M}{Q S} \times \frac{C M B}{M C}}-1\right] x 100
\end{aligned}
$$


Finalmente, vale lembrar que $Q S$ deve corresponder à quantidade "líquida" de serviços realizada durante o período de análise, ou seja, deve corresponder à área, volume etc, onde efetivamente se utilizou o material. Da mesma forma, os valores de $C M / Q S$ e $C M B / M C$ devem ser isentos de qualquer embutimento estimativa de perdas.

Em resumo, tal valor decorrente da multiplicação destas 3 variáveis, deve corresponder a um valor de referência considerado de perda nula (SOUZA et al., 1998a).

\subsection{Classificação das perdas}

\subsubsection{Enfoque amplo}

Os caminhos para a redução das perdas na Construção civil passam, necessariamente, pelo entendimento de como, onde, quando elas ocorrem e quem são os responsáveis pela sua ocorrência.

Com este objetivo, SKOYLES (1976), SKOYLES \& SKOYLES (1987) e SANTOS et al. (1996) classificaram as perdas segundo a sua natureza, seu momento de incidência, sua origem e seu controle.

\subsubsection{Segundo sua natureza}

Entende-se aqui como sendo natureza das perdas, a forma através da qual as mesmas ocorrem. A primeira classificação foi proposta por SKOYLES (1976) e melhor detalhada por SKOYLES \& SKOYLES (1987). 
Analisando as perdas de materiais nos canteiros de obras no Reino Unido, estes autores identificaram duas formas de ocorrência de perdas. A primeira, de forma visível, é representada pelos materiais danificados e, conseqüentemente, inutilizados para a execução do serviço a que foram destinados. A esta parcela de perdas, representada pelo entulho gerado pela má utilização do material durante a execução de um determinado serviço, denomina-se perda direta (SKOYLES \& SKOYLES, 1987).

No entanto, estes autores identificaram que as perdas de materiais não se manifestavam no canteiro de obras apenas sob a forma de entulho, mas sim, que as perdas de materiais poderiam ser caracterizadas pela diferença entre o custo dos materiais que deveriam ser aplicados e o custo dos materiais efetivamente aplicados. Esta diferença, segundo os autores, é representada não só pela utilização de um material de valor maior do que o especificado, assim como é representada também pela utilização de quantidades superiores às especificadas. A esta parcela de perdas, considerada como sendo perdas financeiras, denomina-se perdas indiretas, que podem ser classificadas em: perdas por substituição, por produção, operacional, por negligência e, finalmente, por conseqüência, de acordo com a Tabela 2.2 (SKOYLES \& SKOYLES, 1987).

Recentemente, SANTOS et al. (1996), associando os conceitos preconizados por KOSKELA (1992), juntamente com os critérios adaptados do estudo de SHINGO (1981) ${ }^{31}$ e SKOYLES \& SKOYLES (1987), classificaram as perdas na

31 SHINGO, S. A study of Toyota production system from an industrial engineering viewpoint. Tokyo, Japan Management Association, 1981. 
construção civil brasileira, segundo a sua natureza em: por superprodução, por substituição, por espera, por transporte, no processamento em si, nos estoques, no movimento, pela elaboração de produtos defeituosos, por roubo e vandalismo e outras, conforme apresentado na Tabela 2.3.

\section{Tabela 2.2 Classificação das perdas indiretas segundo SKOYLES \& SKOYLES (1987)}

\begin{tabular}{|c|c|c|}
\hline Classific ação & Definição & Exemplo \\
\hline Por substituição & $\begin{array}{l}\text { Diferença entre o custo do material especificado } \\
\text { e o custo do material realmente utilizado }\end{array}$ & $\begin{array}{l}\text { Utilização de tijolos à vista em } \\
\text { substituição aos tijolos comuns } \\
\text { durante a execução de uma } \\
\text { alvenaria a ser revestida } \\
\text { posteriormente }\end{array}$ \\
\hline Por produção & $\begin{array}{l}\text { Custo relativo ao excesso de material utilizado } \\
\text { na execução de um serviço devido à } \\
\text { incompatibilidade entre as especificações de } \\
\text { projeto e os equipamentos utilizados durante a } \\
\text { execução }\end{array}$ & $\begin{array}{l}\text { Utilização de um equipamento para a } \\
\text { abertura de uma vala de fundação, } \\
\text { cuja largura da "caçamba" é superior } \\
\text { à largura prescrita em projeto para a } \\
\text { fundação }\end{array}$ \\
\hline Operacional & $\begin{array}{l}\text { Custo de materiais utilizados para a execução } \\
\text { de instalações provisórias nos canteiros de } \\
\text { obras ou de auxílio à produção, não previstos } \\
\text { em projeto }\end{array}$ & $\begin{array}{l}\text { Construção de almoxarifado, } \\
\text { passarelas em concreto para o } \\
\text { tráfego de carrinhos, entre outros }\end{array}$ \\
\hline Por negligência & $\begin{array}{l}\text { Custos relativos ao uso de quantidade de } \\
\text { materiais superior à especificada devido a erros } \\
\text { do executor do serviço }\end{array}$ & $\begin{array}{l}\text { Sobrespessura de revestimentos; } \\
\text { solicitação de quantidade de } \\
\text { materiais superior à necessária etc }\end{array}$ \\
\hline Por conseqüência & Custos devido à ocorrência de outras perdas & $\begin{array}{l}\text { Limpeza e remoção do entulho } \\
\text { gerado; atrasos na execução dos } \\
\text { serviços devido à falta de material, } \\
\text { pelo fato de o mesmo ser utilizado } \\
\text { em outros locais além do previsto etc }\end{array}$ \\
\hline
\end{tabular}


Tabela 2.3 Classificação das perdas segundo a sua natureza (SANTOS et al., 1996)

\begin{tabular}{|c|c|c|}
\hline NATUREZA & DESCRIÇÃO & EXEMPLO \\
\hline Por superprodução & $\begin{array}{l}\text { Perdas devido à produção em quantidades superiores às } \\
\text { necessárias }\end{array}$ & $\begin{array}{l}\text { Produção de argamassa em quantidade superior à necessária } \\
\text { para execução do revestimento }\end{array}$ \\
\hline Por substituição & $\begin{array}{l}\text { Perda de capital devido à utilização de um material de } \\
\text { características de desempenho superiores ao especificado }\end{array}$ & Uso de concreto usinado com fck superior ao es pecificado \\
\hline Por espera & $\begin{array}{l}\text { Relacionadas com a sincronização e o nivelamento dos fluxos de } \\
\text { materiais e as atividades dos trabalhadores, envolvendo perdas de } \\
\text { mão-de-obra e equipamentos }\end{array}$ & $\begin{array}{l}\text { Paradas nos serviços originadas pela falta de disponibilidade de } \\
\text { materiais ou equipamentos }\end{array}$ \\
\hline Perdas por transporte & $\begin{array}{l}\text { Devido ao manuseio excessivo dos materiais e componentes em } \\
\text { função da má programação das atividades ou de um layout } \\
\text { ineficiente }\end{array}$ & $\begin{array}{l}\text { Tempo excessivo despendido em transporte de materiais devido } \\
\text { às grandes distâncias entre o local de estocagem e o elevador de } \\
\text { obras ou, ainda, quebra de blocos em função de duplo manuseio } \\
\text { ou equipamento de transporte inadequado }\end{array}$ \\
\hline No processamento em si & $\begin{array}{l}\text { tem origem na própria natureza das atividades do processo ou na } \\
\text { execução inadequada dos mesmos }\end{array}$ & $\begin{array}{l}\text { Quebra de paredes já emboçadas para viabilizar a execução de } \\
\text { instalações, quebra manual de blocos }\end{array}$ \\
\hline
\end{tabular}


Tabela 2.3 Classificação das perdas segundo a sua natureza (SANTOS et al., 1996) (continuação)

\begin{tabular}{|c|c|c|}
\hline NATUREZA & DESCRIÇÃO & EXEMPLO \\
\hline Perdas nos estoques & $\begin{array}{l}\text { Existência de estoques excessivos em função de programação } \\
\text { inadequada na entrega dos materiais ou erros na orçamentação, } \\
\text { gerando tanto perdas de material quanto de capital; também } \\
\text { decorrem da falta de cuidados no armazenamento dos materiais }\end{array}$ & $\begin{array}{l}\text { Mau acondicionamento dos sacos de cimento, acarretando a sua } \\
\text { hidratação }\end{array}$ \\
\hline No movimento & $\begin{array}{l}\text { Estão relacionadas com a realização de movimentos desnecessários } \\
\text { por parte dos trabalhadores durante a execução de suas atividades } \\
\text { e podem ser geradas por frentes de trabalho afastadas e de difíc il } \\
\text { acesso, falta de estudo de layout do canteiro e do posto de trabalho, } \\
\text { falta de equipamentos adequados }\end{array}$ & $\begin{array}{l}\text { Ausência de uma seqüência adequada de atividades devido à } \\
\text { falta de programação }\end{array}$ \\
\hline $\begin{array}{l}\text { Pela elaboração de } \\
\text { produtos defeituosos }\end{array}$ & $\begin{array}{l}\text { Ocorrem quando são fabricados podutos que não atendem aos } \\
\text { requisitos de qualidade especificados, resultando retrabalhos e } \\
\text { deficiência do desempenho do produto final; geralmente originam-se } \\
\text { na ausência de integração entre projeto e execução, nas deficiências } \\
\text { do planejamento e controle do processo produtivo }\end{array}$ & $\begin{array}{l}\text { Falhas na impermeabilização e pintura, descolamento de placas } \\
\text { cerâmicas etc }\end{array}$ \\
\hline Outras & Referem-se às perdas de natureza diferente das anteriores & Roubo, vandalismo, acidentes etc \\
\hline
\end{tabular}




\subsubsection{Segundo seu momento de incidência}

FRANCHI et al. (1993) e SOIBELMAN (1993) apresentam uma classificação das perdas segundo o seu momento de incidência. Segundo estes autores, as perdas podem ser subdivididas em 3 grupos:

- grupo A: perdas ocorridas durante o transporte, manuseio e armazenagem do material, ou seja, em etapas anteriores à execução final do produto;

- grupo B: perdas ocorridas na produção (execução) propriamente dita;

- grupo C: perdas ocorridas em qualquer das etapas do processo, em função de fatores externos (roubo, vandalismo, acidentes etc).

Embora tal classificação subsidie o entendimento de onde as perdas podem acontecer, percebe-se que a mesma apresenta deficiências em se tratando da abordagem ampla do estudo das perdas na construção civil.

Uma linha de raciocínio coerente para esta classificação consiste em relacionar o momento de incidência às etapas do processo de construção civil, conforme ressaltado no item 2.1.1.1, ou seja: Concepção, Suprimentos, Execução, e Uso-manutenção. A Tabela 2.4 reúne esta classificação, assim como apresenta alguns exemplos de perdas associados à etapa do processo de construção civil e ao recurso diretamente perdido. 
Tabela 2.4 Exemplos de perdas de acordo com o momento de incidência

\begin{tabular}{|c|c|c|}
\hline $\begin{array}{l}\text { Etapas do processo de } \\
\text { construção }\end{array}$ & $\begin{array}{l}\text { Recurso perdido } \\
\text { diretamente }\end{array}$ & Exemplo \\
\hline \multirow[t]{2}{*}{ Conc epção } & Material & Superdimensionamento da estrutura \\
\hline & Financeiro & $\begin{array}{l}\text { Especificação de um material de preço maior do que } \\
\text { outro que possui o mesmo desempenho }\end{array}$ \\
\hline Suprimentos & Financeiro & $\begin{array}{l}\text { Compra de material a um preço maior do que o } \\
\text { especificado (orçado) }\end{array}$ \\
\hline \multirow[t]{4}{*}{ Execução } & Material & Sobrelargura das vigas \\
\hline & Mão-de-obra & $\begin{array}{l}\text { Transporte excessivo de materiais nos canteiros de } \\
\text { obras (duplo manuseio) }\end{array}$ \\
\hline & Financeiro & $\begin{array}{l}\text { Substituição de materiais devido à inexistência do } \\
\text { material especificado no local de execução }\end{array}$ \\
\hline & Equipamento & $\begin{array}{l}\text { Utilização de grua para o transporte desnecessário } \\
\text { de materiais }\end{array}$ \\
\hline \multirow[t]{2}{*}{ Uso-manutenção } & Material & Necessidade de manutenção antes do previsto \\
\hline & Financeiro & $\begin{array}{l}\text { Gastos com locação de imóvel para a realização de } \\
\text { manutenção no apartamento já entregue pela } \\
\text { construtora }\end{array}$ \\
\hline
\end{tabular}

\subsubsection{Segundo sua origem}

A ocorrência de perdas de materiais numa determinada etapa do processo de construção é conseqüência de uma série de fatores, ações ou decisões relacionados às várias etapas deste processo [(SKOYLES \& SKOYLES, 1987); ENSHASSI (1996)]. A investigação das principais causas das perdas permite concluir que as mesmas podem ocorrer devido a falhas originadas em uma ou 
em um conjunto de etapas que antecedem a etapa onde se verifica tal ocorrência.

A este respeito, SANTOS et al. (1996) acrescenta que embora as perdas possam ser identificadas durante a etapa de execução, sua origem pode estar na própria etapa de execução quanto nas etapas antecessoras, como planejamento, projeto, fabricação de materiais, suprimentos e preparação dos recursos humanos (Figura 2.5).

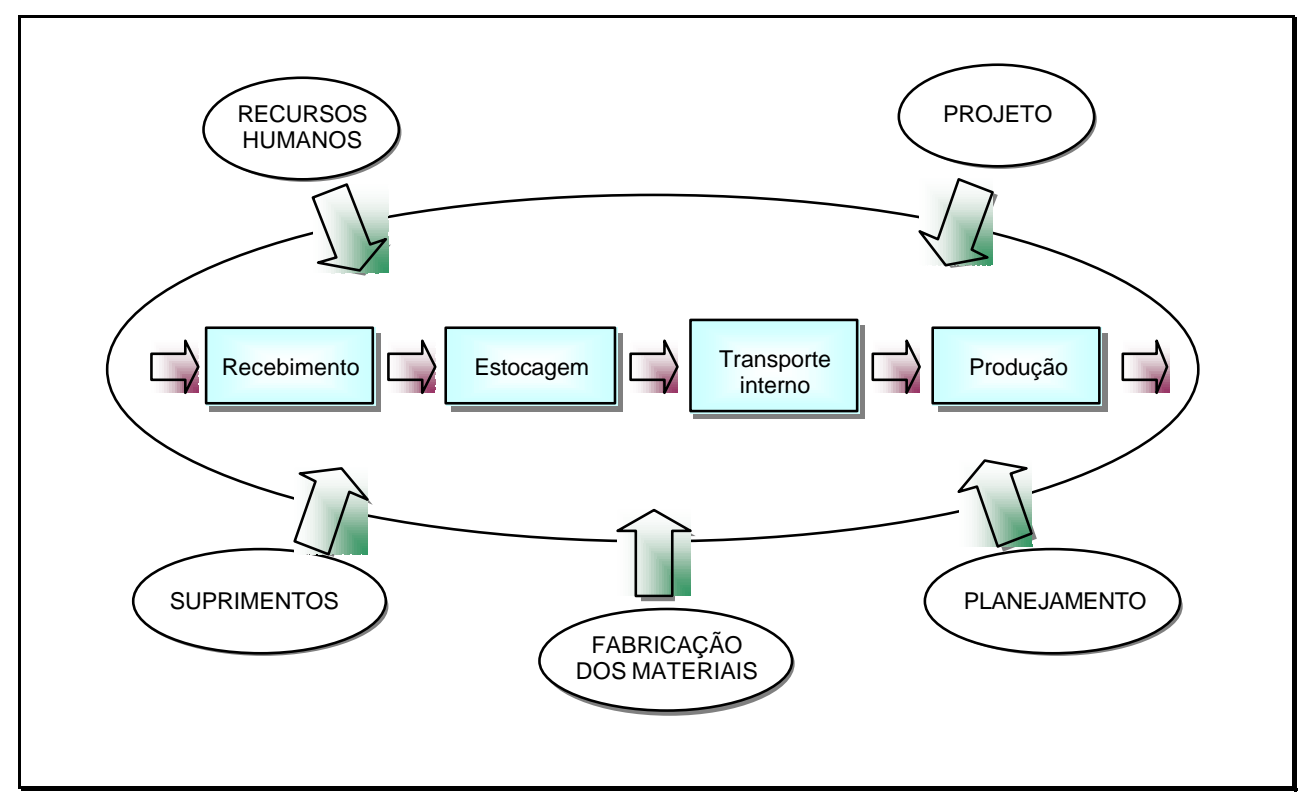

Figura 2.5 As perdas segundo seu momento de incidência e origem (SANTOS et al., 1996)

No que diz respeito as perdas originárias na etapa de projeto, ENSHASSI (1996) as relacionam à inexistência de informações suficientes ou adequadas nos projetos, gerando confusões durante a etapa de execução. SOIBELMAN (1993) e SKOYLES \& SKOYLES (1987) acrescentam, ainda, que este fato é 
agravado pela falta de integração entre os projetistas e os executores durante o processo de elaboração do projeto.

Para ANDRADE et al. (1997), muitas obras são iniciadas sem os projetos definitivos, acarretando grandes perdas devido a modificações durante a etapa de execução.

Com relação as perdas originárias na etapa de fabricação de materiais, SKOYLES \& SKOYLES (1987) apontam a incompatibilidade das dimensões e a qualidade dos materiais produzidos como as principais causas das perdas ocorridas durante a etapa de execução.

As perdas originárias na etapa de execução são decorrentes da própria característica da obra e ausência de procedimentos de execução e controle, enquanto que as perdas originárias na etapa de uso-manutenção se devem a utilização incorreta da edificação.

\subsubsection{Segundo seu controle}

Todo investimento ou ações voltadas para a redução das perdas de recursos e a conseqüente melhoria da qualidade e produtividade, têm como princípio a relação custo-benefício. É neste contexto que se insere a classificação das perdas, segundo o seu controle, em: perdas inevitáveis (ou perda natural) e perdas evitáveis.

As perdas inevitáveis correspondem a um nível aceitável de perdas, onde os investimentos necessários para combatê-las são maiores do que a economia 
gerada. Por sua vez, as perdas evitáveis correspondem à parcela em que os custos são substancialmente maiores que os custos de prevenção (SANTOS et al., 1996).

Para SKOYLES \& SKOYLES (1987) o nível aceitável de perdas depende do custo da solução apresentada, e isso depende, entre outros aspectos, do nível de organização ou desenvolvimento de ações de controle já preexistentes.

Sendo assim, este nível varia de empresa para empresa e mesmo de obra para obra de uma mesma empresa, dependendo do patamar de desenvolvimento da mesma (SANTOS et al. 1996).

Para SKOYLES \& SKOYLES (1987), em muitas situações, o alto nível de perda envolve menores custos para prevenilas, enquanto que esta relação se inverte para situações onde o nível de perdas é consideravelmente baixo.

É neste contexto que se faz a distinção entre o conceito de perdas e de desperdício. Enquanto o conceito de perdas envolve tanto a parcela de perdas evitável quanto a inevitável, o desperdício refere-se apenas à parcela de perdas evitável (SOIBELMAN, 1993).

\subsubsection{Enfoque restrito aos materiais}

Todas as classificações das perdas abordadas sob o enfoque amplo são adequadas ao se estudar as perdas físicas de materiais nos canteiros de obras. 
No entanto, pode-se aprofundar um pouco mais estas classificações, tornandoas ainda mais adequadas para o pleno entendimento da sua ocorrência nos canteiros de obras.

Como parte integrante deste aprofundamento, o primeiro aspecto que surge diz respeito à necessidade de se fazer uma classificação prévia das perdas com relação ao tipo de recurso analisado, fazendo-se distinção entre os recursos financeiros e os recursos físicos, considerando as suas particularidades.

Embora se reconheça a distinção entre perdas físicas e financeiras nos trabalhos que tratam deste assunto, dentre os quais citam-se os realizados por SKOYLES \& SKOYLES (1987), SOIBELMAN (1993) e SANTOS et al. (1996), a mesma não acontece ao nível das perdas financeiras, no que diz respeito ao fato de as mesmas ser de natureza estritamente financeira ou decorrente das perdas físicas $^{32}$.

Assim, de acordo com este critério, as perdas podem ser classificadas em físicas e financeiras. As perdas financeiras, podem ainda ser divididas em perdas estritamente financeiras e decorrentes das perdas físicas dos recursos empregados na elaboração de um produto, ou seja, mão-de-obra, equipamentos e materiais.

\footnotetext{
32 SKOYLES \& SKOYLES (1987) consideram as perdas indiretas como sendo perdas financeiras, sem no entanto considerar que estas perdas financeiras podem ser decorrentes das perdas físicas ou podem ocorrer sem que haja perda de recursos físicos. Como conseqüência, os principais números de sua pesquisa dizem respeito apenas a uma das parcelas de perdas físicas de materiais (o entulho), omitindo a outra parcela existente (incorporação de material em excesso na edificação).
} 
A partir desta classificação inicial, onde são identificadas claramente as perdas físicas de materiais, pode-se, então, classificá-las em função dos outros critérios já apresentados anteriormente.

\subsubsection{Segundo sua natureza}

Em se tratando especificamente das perdas de materiais, há que se fazer, ainda, uma distinção entre as parcelas de perdas detectadas. Partindo-se do conceito de perdas físicas de materiais apresentado no item 2.2.2, duas parcelas podem ser identificadas: a representada pelo material incorporado em excessona edificação e a representada pelo entulho gerado ${ }^{33}$.

\section{(a) Parcela de material incorporado em excesso}

Basicamente, a identificação da incorporação dos materiais é feita comparando-se o produto realizado e o produto idealizado ou previsto, definidos pelas 3 variáveis descritas no item 2.2.2.2. Assim, as perdas de materiais representadas por esta parcela que fica incorporada na edificação, podem, por exemplo, acontecer:

- por alteração na quantidade de serviço (QS): execução de área de revestimento interno maior do que a originalmente prevista, devido ao desconhecimento por parte do executor do projeto original;

- por alteração na quantidade de material por quantidade de serviço (CM/QS): aumento no consumo de blocos por $\mathrm{m}^{2}$ de alvenaria executada 
em função da redução das espessuras de juntas verticais e horizontais argamassadas; sobrespessura da laje de concreto armado devido à falta de planicidade das fôrmas etc;

- por alteração na quantidade de material básico por material composto $(C M B / M C)$ : erros de dosagem dos materiais básicos na produção de argamassa para a execução do serviço de emboçamento das faces das paredes internas.

\section{(b) Parcela de material não incorporada: o entulho}

O entulho de construção civil é um tipo de resíduo sólido e pode ser caracterizado como sendo constituído por "subprodutos gerados e removidos de construções, reformas e demolições de edificações ou obras de arte de engenharia civil" (HONG KONG POLYTECHNIC, 1993).

De acordo com esta definição, percebe-se que o estudo do entulho pode ser feito sob um enfoque amplo (considerando todas as fontes geradores de entulho conjuntamente: execução de obras novas, reformas ou demolições de edificações) ou um enfoque mais restrito, considerando cada uma destas origens separadamente.

Com relação ao primeiro tipo de abordagem, PINTO (1996) apresenta, em seu trabalho, um resumo da participação dos resíduos sólidos de construção no montante total de resíduos sólidos urbanos de alguns casos nacionais e

\footnotetext{
${ }^{33}$ A rigor, além destas parcelas, pode-se incluir uma outra representada, por exemplo, pelos materiais roubados dos canteiros de obras.
} 
internacionais. A análise dos dados resumidos por este autor permite verificar que a participação do entulho de construção civil é de aproximadamente 2/3 do montante total gerado.

Em recente pesquisa realizada pelo Departamento do Meio Ambiente de Hong Kong (Environmental Protection Department, 1991), o entulho total existente na cidade era proveniente, basicamente, de 5 fontes, conforme ilustra a Tabela 2.5 (HONG KONG POLYTECHNIC, 1993).

Tabela 2.5 Principais fontes geradoras de entulho (HONG KONG POLYTECNIC, 1993)

\begin{tabular}{l|c}
\hline Fontes & (\%) em massa \\
\hline Obras rodoviárias & 7 \\
\hline Escavações & 15 \\
\hline Demolições prediais & 38 \\
\hline Novas construções & 11 \\
\hline Limpeza de terrenos & 29 \\
\hline
\end{tabular}

A análise desta Tabela permite concluir que o percentual de entulho gerado durante a execução de obras novas é praticamente inferior aos percentuais das outras fontes de entulho, no entanto, não se pode negligenciar a importância da redução do mesmo.

Com relação à composição deste entulho, percebe-se que a mesma é variável, dependendo do tipo de obra analisada. Como exemplos de constituintes do 
entulho, podem ser citados: as sobras de argamassa produzidas em excesso e não utilizadas ao final do dia de trabalho ou, ainda, as argamassas que caem no pavimento durante a execução de serviços de revestimentos ou elevação de alvenaria e não são reaproveitadas; sobras de cortes de tubos para instalações hidráulicas e sanitárias, barras de aço, eletrodutos, entre outros; cacos provenientes de quebra de blocos/tijolos, placas cerâmicas; madeira proveniente dos sistemas de fôrmas etc.

PINTO (1995a), num levantamento realizado na cidade de São Carlos em 1989 chegou a valores percentuais da ordem de 64\% de argamassa, $30 \%$ de componentes de vedação e $6 \%$ de outros materiais (concreto, pedra, areia, metais, plásticos etc).

\subsubsection{Segundo seu momento de incidência}

Adota-se a mesma classificação apresentada no item 2.3.1.2, porém, pode-se ainda subdividir a etapa de execução em etapas menores, que correspondem àquelas percorridas pelos materiais no canteiro de obras, desde o seu recebimento até a sua aplicação final (Tabela 2.6). 
Tabela 2.6 Classificação das perdas de materiais segundo o seu momento de incidência

\begin{tabular}{|c|c|c|c|}
\hline Definição de perda & $\begin{array}{l}\text { Etapas do processo de } \\
\text { construção }\end{array}$ & Subetapas & Exemplo \\
\hline $\begin{array}{l}\text { Diferença entre a quantidade de recursos } \\
\text { previstos, segundo um projeto otimizado, e } \\
\text { a quantidade de recursos realmente } \\
\text { necessários de acordo com o projeto } \\
\text { idealizado }\end{array}$ & Concepção & - & $\begin{array}{l}\text { - especificação de um traço de argamassa com consumo } \\
\text { demasiadamente elevado de cimento para a execução de } \\
\text { um determinado serviço; } \\
\text { - traçado de instalações não otimizado, levando a um } \\
\text { consumo elevado de tubulações e eletrodutos. }\end{array}$ \\
\hline \multirow{5}{*}{$\begin{array}{l}\text { Diferença entre a quantidade de recurso } \\
\text { prevista no projeto idealizado e a } \\
\text { quantidade de recurso efetivamente } \\
\text { utilizada durante a execução }\end{array}$} & \multirow[t]{5}{*}{ Execução } & Recebimento & $\begin{array}{l}\text { - Perda de conteúdo dos sacos de cimento devido aos } \\
\text { mesmos estarem rasgados. }\end{array}$ \\
\hline & & Estocagem & - Entulho gerado pela quebra de placas cerâmicas. \\
\hline & & Processamento intermediário & $\begin{array}{l}\text { - Consumo excessivo de cal durante a produção de } \\
\text { argamassa. }\end{array}$ \\
\hline & & Aplicação & - Sobrespessura de revestimento (emboço). \\
\hline & & Transporte & $\begin{array}{l}\text { - Entulho gerado pela quebra de blocos/tijolos durante o } \\
\text { transp orte dos mesmos. }\end{array}$ \\
\hline $\begin{array}{l}\text { Diferença entre a quantidade de recursos } \\
\text { prevista para manutenção e a quantidade } \\
\text { de recursos efetivamente consumida num } \\
\text { certo período }\end{array}$ & Uso-manutenção & - & $\begin{array}{l}\text { - } \quad \text { repintura de uma fachada precocemente; } \\
\text { necessidade de reparos em tubulações hidrossanitárias } \\
\text { devido a vazamentos, acarretando, por exemplo, o consumo } \\
\text { de placas de gesso do forro falso. }\end{array}$ \\
\hline
\end{tabular}




\subsubsection{Segundo sua origem}

Para o caso dos materiais, adota-se a mesma classificação apresentada no item 2.3.1.3. ANDRADE (1999) ilustra muito bem tal classificação ao examinar as causas da quebra excessiva de blocos durante a etapa de execução. Segundo a autora, tal ocorrência pode estar relacionada à ausência de modulação entre a estrutura e a alvenaria (origem na etapa de concepção), na não previsão de recebimento dos blocos necessários para a execução da alvenaria antes da saída do equipamento adequado de transporte, ocasionando o transporte dos mesmos em equipamentos inadequados (origem na etapa do planejamento operacional), na baixa qualidade dos componentes (origem na etapa de aquisição ou, preliminarmente, na etapa de fabricação), ou ainda, no uso de procedimentos de manuseio inadequado (origem na etapa de execução).

Finalmente, em face das classificações apresentadas para o caso dos materiais, pode-se reuni-las em uma única Tabela, onde podese verificar a complexidade da ocorrência de perdas de materiais, principalmente no que diz respeito às causas, haja vista que, para uma mesma ocorrência, pode-se enumerar diversas causas e conseqüentemente, várias origens (Tabela 2.7). 
Tabela 2.7 Natureza, momento de incidência, causas e origens das perdas de materiais

\begin{tabular}{|c|c|c|c|c|c|}
\hline \multicolumn{2}{|c|}{ NATUREZA } & \multicolumn{2}{|c|}{ MOMENTO DE INCIDÊNCIA } & \multirow{2}{*}{\begin{tabular}{|l} 
EXEMPLOS/CAUSAS \\
- $\quad$ superdimensionamento da estrutura \\
- $\quad$ traçados não otimizados das instalações
\end{tabular}} & \multirow{2}{*}{\begin{tabular}{|l} 
ORIGEM \\
Concepção
\end{tabular}} \\
\hline \multirow{13}{*}{$\begin{array}{l}\text { PERDAS FíSICAS } \\
\text { DE MATERIAIS }\end{array}$} & \multirow[t]{6}{*}{$\begin{array}{l}\text { Material incorporado } \\
\text { em excesso }\end{array}$} & Concepção & - & & \\
\hline & & Execução & \multirow[t]{2}{*}{ Processamento intermediário } & $\begin{array}{l}\text { - especificação de um traço de argamassa com } \\
\text { consumo demasiadamente elevado de cimento para a } \\
\text { execução de um determinado serviço }\end{array}$ & Concepção \\
\hline & & & & - comprimento de traspasse superior ao especificado & Execução \\
\hline & & & \multirow[t]{2}{*}{ Aplicação } & $\begin{array}{l}\text { especificação incorreta da espessura de revestimento, } \\
\text { ocasionando um consumo excessivo de argamassa e } \\
\text { seus constituintes }\end{array}$ & Concepção \\
\hline & & & & $\begin{array}{l}\text { - espessura da laje superior à especificada, devido à } \\
\text { falta de planeza dos moldes }\end{array}$ & $\begin{array}{l}\text { Fabricação dos materiais, } \\
\text { Concepção, Execução }\end{array}$ \\
\hline & & Uso-manutenção & - & - repintura de uma fachada precocemente & $\begin{array}{l}\text { Fabricação dos materiais, } \\
\text { Concepção, Execução }\end{array}$ \\
\hline & \multirow[t]{6}{*}{ Entulho } & \multirow[t]{5}{*}{ Execução } & Recebimento & - quebra de blocos durante o recebimento & $\begin{array}{l}\text { Fabricação dos materiais, } \\
\text { Concepção, Suprimento, } \\
\text { Planejamento operacional, } \\
\text { Execução }\end{array}$ \\
\hline & & & Estocagem & - quebra de telhas na estocagem & $\begin{array}{l}\text { Fabricação dos materiais, } \\
\text { Concepção, Suprimento, } \\
\text { Planejamento operacional, } \\
\text { Execução }\end{array}$ \\
\hline & & & Processamento intermediário & 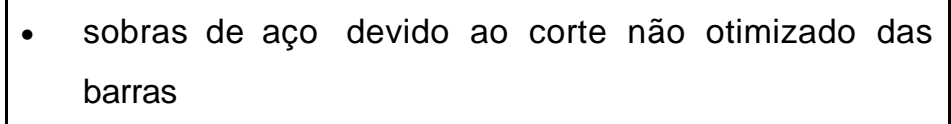 & Concepção, Execução \\
\hline & & & Aplicação & $\begin{array}{l}\text { - execução de rasgos na alvenaria gerando cacos de } \\
\text { blocos }\end{array}$ & Concepção, Execução \\
\hline & & & Transporte & - derramamento de concreto & Planejamento operacional \\
\hline & & Uso-manutenção & - & - vazamento de água nas tubulações & $\begin{array}{l}\text { Fabricação de materiais, } \\
\text { Concepção, Suprimentos, Execução }\end{array}$ \\
\hline & Outros & - & - & - roubo & - \\
\hline
\end{tabular}




\section{CAṔ́tULO 3}

\section{PRINCIPAIS PESQUISAS SOBRE PERDAS DE MATERIAIS: APRESENTAÇÃO E ANÁUSE}

Além de estar embasada nos principais conceitos e terminologias pertinentes ao assunto, o desenvolvimento da metodologia proposta demanda um prévio conhecimento das principais pesquisas na área realizadas até o momento. Com o intuito de nortear o delineamento desta metodologia no que se refere, principalmente, às idéias, resultados e experiências vivenciadas pelos diversos autores, este capítulo é dedicado à apresentação das principais pesquisas realizadas no país e no exterior sobre o assunto. Na apresentação de cada uma, enfatiza-se a metodologia empregada, os principais resultados e as principais conclusões. Este conhecimento, aliado à experiência acumulada em visitas feitas a inúmeros canteiros de obras e através de discussões com o setor produtivo, são considerados pilares básicos para a elaboração da metodologia proposta.

Após a apresentação sucinta destas pesquisas, discorre-se sobre as principais diferenças detectadas, assim como realiza-se uma análise crítica de alguns pontos considerados relevantes para a elaboração da proposta de metodologia contida neste trabalho. 


\subsection{SKOYLES (1976); SKOYLES (1978); SKOYLES \& SKOYLES (1987)}

Estes autores realizaram uma série de estudos relativos às perdas de materiais no Reino Unido, através do Building Research Establishment (BRE) e com a cooperação do Chartered Institute of Building (CIOB). Os primeiros estudos realizados pelo BRE, sobre esta questão, datam do ano de 1963 e foram concentrados nos principais materiais utilizados na construção de edificações tradicionais.

A detecção de uma significativa diferença entre os índices normalmente assumidos no processo de orçamentação e os realmente levantados por estes estudos iniciais, alavancou um amplo estudo posterior em 183 canteiros de obras distribuídos pelo Reino Unido, cujos objetivos eram, além de estabelecer índices de perdas, entender a razão pela qual canteiros com características similares apresentavam índices de perdas diferentes. Este novo estudo compreendeu uma amostra considerável de canteiros de obras, possibilitando, assim, considerar as particularidades da Indústria de Construção Civil. Em 1980, com a cooperação do CIOB, os autores estudaram mais 27 canteiros de obras na cidade de Londres e cidades vizinhas. ${ }^{34}$

\footnotetext{
${ }^{34}$ Apesar de existir a citação de um número superior de obras estudadas, os resultados de perdas apresentados dizem respeito a um total de 114 canteiros de obras.
} 


\subsubsection{Metodologia}

Toda a metodologia desenvolvida está baseada na classificação de perdas proposta pelos autores: perdas diretas (geração de entulho) e indiretas (correspondem às perdas financeiras ${ }^{35}$ ). De acordo com esta metodologia, a avaliação das perdas é feita através do levantamento de algumas informações, resumidas no fluxograma da Figura 3.1.

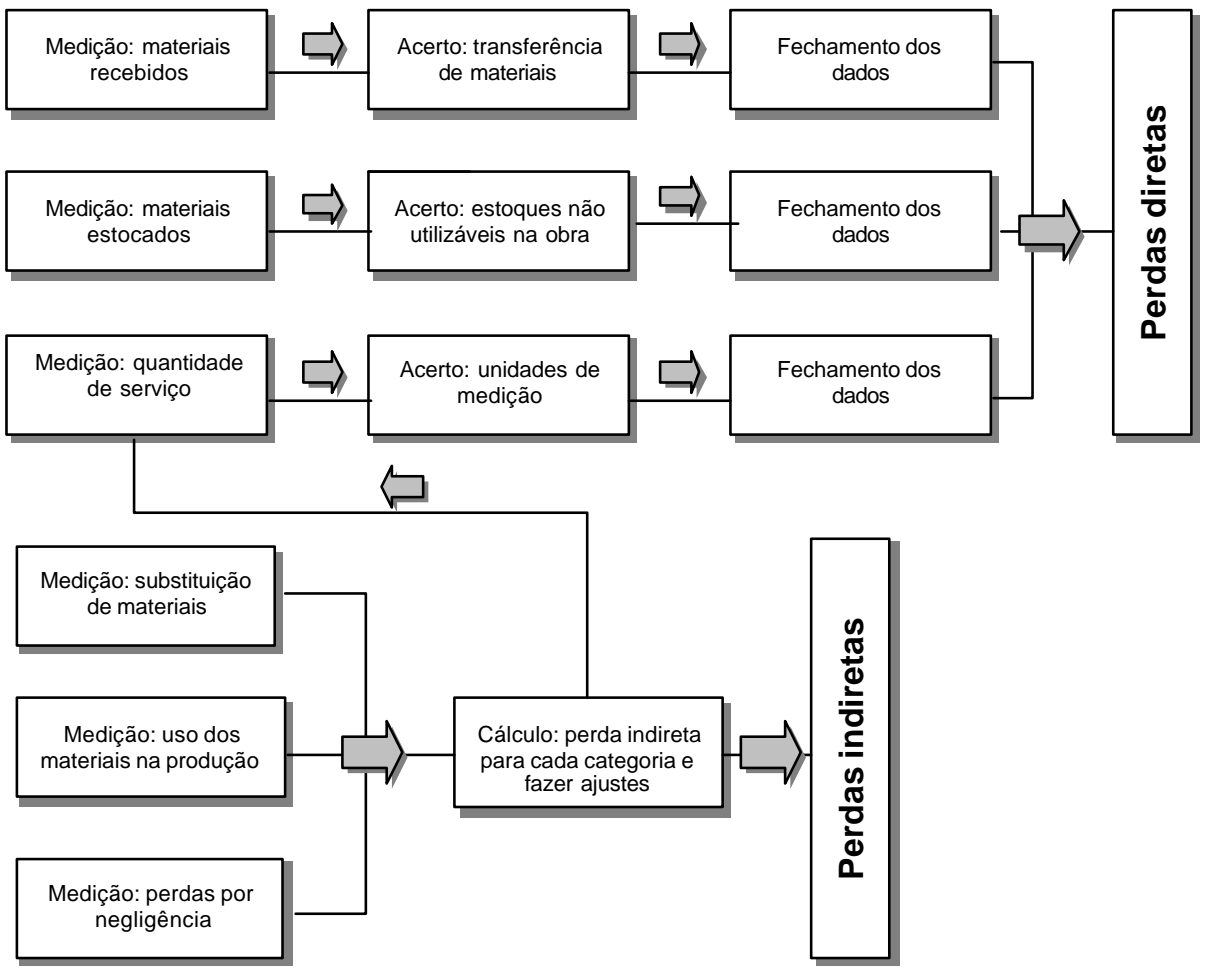

Figura 3.1 Fluxograma de aplicação da metodologia (SKOYLES, 1978)

Nesta figura, a principal informação obtida diz respeito à perda direta de material; entretanto, a identificação e mensuração da perda indireta é

\footnotetext{
${ }^{35} \mathrm{Na}$ nomenclatura aqui adotada as perdas financeiras citadas por SKOYLES (1978) englobam tanto as perdas estritamente financeiras quanto as decorrentes de perdas físicas.
} 
necessária no decorrer da execução da edificação, especificamente ao se medir a quantidade de serviço executada.

\subsubsection{Cálculo da perda direta de materiais}

Segundo SKOYLES (1978), para o cálculo das perdas diretas há a necessidade de se levantar 3 informações básicas:

(a) quantidade de material recebida no canteiro: toda entrega de material a ser estudado no canteiro deve ser computada. Para isso, o responsável pela coleta destes dados deve ter em mãos uma relação contendo a especificação completa dos materiais. Além das quantidades normalmente entregues no canteiro, o responsável deve computar também as quantidades adicionais, entregues no canteiro pelos fornecedores, motivadas pela existência de materiais danificados durante o transporte dos mesmos até o canteiro de obras;

(b) medição dos estoques de materiais: deve ser feita na data de fechamento dos dados. Nesta data, deve-se ter a garantia de que todos os materiais estocados sejam computados. Para isso, o autor sugere que seja feito um croqui contendo a localização dos estoques dos materiais, pois isto aumenta a confiabilidade na contagem. Para materiais estocados de forma irregular (pilhas de tijolos incompletas, por exemplo), apresenta medidas alternativas ou indiretas para esta contabilização ${ }^{36}$;

\footnotetext{
${ }^{36}$ Note que os autores não fazem menção à medição dos estoques na data de início da pesquisa de campo, porém, indicam que os trabalhos de apropriação devam ser realizados antes do início da execução do serviço a ser avaliado, o que significaria estoque nulo nesta data.
} 
(c) medição da quantidade de serviços: a medição dos serviços pode ser feita segundo vários critérios, cada qual com o nível de precisão compatível com a finalidade da informação. No que diz respeito ao levantamento dos índices de perdas diretas, SKOYLES (1978) ressalta que as quantidades de serviço extraídas do orçamento não refletem as executadas na prática, impossibilitando, assim, a utilização desta fonte de informação como base para a medição do serviço. Em lugar destas, aponta que as quantidades de serviços obtidas mediante medições realizadas para fins de pagamento de sub-contratados representam uma boa aproximação para o cálculo das perdas diretas, porém, enfatiza a necessidade da coincidência da data destas medições com a data de fechamento dos dados.

Os acertos que o autor cita na Figura 3.1 dizem respeito a:

(a) estoques não utilizáveis : é comum em canteiros a presença de materiais estocados que não serão utilizados na obra em questão e, portanto, não foram computados como recebidos para efeito de estimativa das perdas. Caso estes materiais estejam estocados na obra quando do fechamento dos dados, há que se fazer a subtração das quantidades dos mesmos;

(b) transferência de materiais: toda transferência de materiais, entre canteiros por exemplo, deve ser computada, somando-se as entradas ou subtraindo-se as saídas;

(c) unidades de medida: dependendo da unidade em que o material é computado na entrega no canteiro e da que serve para mensurar o uso do mesmo, tem-se que fazer a compatibilização entre as mesmas através de 
um fator de conversão. Como exemplo típico cita a medição da quantidade recebida e estocada de blocos em unidades (número de blocos) e a medição da quantidade de serviço em unidades de área. Sendo assim, a compatibilização é feita multiplicando-se a quantidade de serviço medido $\left(\mathrm{m}^{2}\right)$ pelo consumo deste material por unidade deárea $\left(\right.$ blocos $\left./ \mathrm{m}^{2}\right)$.

Note que, além destes acertos, há a necessidade de se fazer as correções nas quantidades de materiais realmente utilizadas, uma vez que os autores sugerem a utilização das quantidades de serviço levantadas para efeito de pagamento de sub-contratados, o que não inclui, na maioria das vezes, consumos extras de materiais (conforme explicado a seguir), cujos custos decorrentes destes consumos configuram-se em perdas indiretas, segundo 0 autor.

Os procedimentos para estas correções variam de acordo com o tipo de perda indireta detectada:

- por substituição: deve-se fazer a averiguação quanto à substituição de materiais num pavimento que seja representativo, estabelecendo a área correspondente a cada material utilizado. Interpretando a descrição da metodologia, em se detectando a substituição do tipo de placa cerâmica numa parcela do revestimento cerâmico no pavimento, a área substituída seria subtraída da área medida para efeito de pagamento do serviço, com o intuito de se chegar à área onde realmente se utilizou a placa cerâmica cuja perda esteja sendo estudada; 
- na produção: o autor dá este nome aos consumos de materiais em serviços não previstos, tipicamente de apoio à obra, como por exemplo, a confecção de uma base temporária para constituir o piso dos estoques. Embora não explicite a forma através da qual gera um fator de correção da quantidade de serviços, imagina-se que, a partir da quantidade de material estimada para tais usos, se calcule uma quantidade de serviço equivalente.

- perdas por negligência: da mesma forma que o item anterior, estabelece-se um fator de correção para o acerto da quantidade de serviço para o caso de se ter negligência. Como exemplo, para o caso de se ter estipulado no projeto a execução de $200 \mathrm{~m}^{2}$ de revestimento argamassado com espessura de $2 \mathrm{~cm}$ e se ter executado o mesmo com uma espessura de 3 $\mathrm{cm}$, deve-se corrigir a quantidade de serviço fazendo-se a multiplicação da área $\left(200 \mathrm{~m}^{2}\right)$ pelo fator $1,5 \mathrm{~cm}(3 \mathrm{~cm} / 2 \mathrm{~cm})$, que consiste na razão entre a espessura realmente executada e a espessura prevista originalmente.

Deve-se ressaltar, também, que a percentagem da perda direta obtida é calculada em relação à quantidade recebida, e não em relação à quantidade teoricamente prevista.

Para a obtenção destes dados, o autor enumera uma série de modelos de planilhas, cada qual para a realização de coletas específicas. Após a totalização dos dados, procede-se o cálculo da perda direta de acordo com a seguinte expressão simplificada: 
Perda direta $=Q_{\text {recebida }}-\left[\left(Q S_{\text {real }}+Q S_{\left.\text {equivalente( } \text { perdas }_{\text {indiretas }}\right)}\right) x \frac{Q \text { mat }}{\text { Unid }_{\text {serviço }}}+Q_{\text {estoque }}\right]$

onde:

$$
\begin{aligned}
& Q_{\text {recebida }}=\text { quantidade de material recebida durante } \circ \\
& \text { período de análise } \\
& Q S_{\text {real }}=\text { quantidade de serviço executada durante } \circ \\
& \text { período de análise } \\
& \left.Q S_{\text {equivalente( }} \text { perdas } \text { indiretas }\right)=\text { quantidade de serviço equivalente relacionada } \\
& \text { às perdas indiretas } \\
& \frac{\text { Qmat }}{\text { Unid }_{\text {serviço }}}=\begin{array}{l}
\text { consumo teórico de material por unidade de } \\
\text { serviço }
\end{array} \\
& \text { Q } Q_{\text {estoque }}=\text { quantidade de material estocada na data de } \\
& \text { fechamento dos dados }
\end{aligned}
$$

\subsubsection{Cálculo da perda indireta de materiais}

O cálculo da perda indireta consiste em computar os custos decorrentes das seguintes categorias:

(a) substituição: a perda consiste na diferença entre o custo do material substituído e o custo do material utilizado;

(b) negligência e usos adicionais no auxílio à produção: somam-se os custos decorrentes do consumo extra de materiais incorporados na edificação, por exemplo, na forma de sobrespessura de revestimentos e lajes e de materiais utilizados para a execução de construções auxiliares (almoxarifado, base de concreto para transporte de materiais, entre outros).

37 Embora tal expressão não esteja claramente definida nos textos originais, ela representa 0 entendimento do autor desta dissertação para que a metodologia de SKOYLES fique coerente. 


\subsubsection{Periodicidade de fechamento dos dados}

Apesar de a metodologia proposta ser aplicável a qualquer etapa da edificação, os autores sugerem que o fechamento seja feito mensalmente, podendo estender este prazo para até 3 meses como medida de acompanhamento, caso os índices levantados apontem perdas consideradas aceitáveis para os padrões da empresa.

\subsubsection{Principais resultados}

Os resultados relativos à perda direta de material levantados em 114 canteiros de obras no Reino Unido são apresentados na Tabela 3.1.

O autor também enfatiza que foram analisadas as perdas de materiais relacionadas às instalações elétricas, hidráulicas e sanitárias e à pintura, porém, os índices observados foram insignificantes. 
Tabela 3.1 Perdas diretas de materiais, baseadas no estudo em 114 canteiros de obras (SKOYLES, 1976)

\begin{tabular}{|c|c|c|c|c|}
\hline \multirow[t]{2}{*}{ Material } & \multirow{2}{*}{$\begin{array}{c}\mathrm{N}^{\circ} \text {. de } \\
\text { canteiros }\end{array}$} & \multirow{2}{*}{$\begin{array}{l}\text { Amplitude dos } \\
\text { resultados (\%) }\end{array}$} & \multicolumn{2}{|c|}{$\begin{array}{l}\text { Índice de perdas } \\
\text { diretas (\%) }\end{array}$} \\
\hline & & & Real & Usual $^{38}$ \\
\hline Concreto em infra-estrutura & 12 & $3-18$ & 8 & 2.5 \\
\hline Concreto em superestrutura & 3 & - & 2 & 2.5 \\
\hline Aço & 1 & - & 5 & 2.5 \\
\hline Tijolos comuns & 68 & $1-20$ & 8 & 4.0 \\
\hline Tijolos à vista & 62 & $1-22$ & 12 & 5.0 \\
\hline Tijolos estruturais vazados & 2 & - & 5 & 2.5 \\
\hline Tijolos estruturais maciços & 3 & $9-11$ & 10 & 2.5 \\
\hline Blocos leves & 22 & $1-22$ & 9 & 5.0 \\
\hline Blocos de concreto & 1 & - & 7 & 5.0 \\
\hline Telhas (inclusive de cumeeira) & 1 & - & 10 & 2.5 \\
\hline Madeira - tábuas & 3 & $12-22$ & 15 & 5.0 \\
\hline Madeira - compensados & 2 & - & 15 & 5.0 \\
\hline Rev. Argamassados -paredes & 4 & $2-7$ & 5 & 5.0 \\
\hline Rev. Argamassados tetos & 4 & $1-4$ & 3 & 5.0 \\
\hline Rev. Cerâmicos - paredes & 1 & - & 3 & 2.5 \\
\hline Rev. Cerâmicos - pisos & 1 & - & 3 & 2.5 \\
\hline Tubos cobre & 9 & - & 7 & 2.5 \\
\hline Tubos PVC & 1 & - & 3 & 2.5 \\
\hline Conexões de cobre & 7 & - & 3 & - \\
\hline Vidro - chapas & 3 & - & 9 & 5 \\
\hline Janelas pré-envidraçadas & 2 & - & 16 & - \\
\hline
\end{tabular}

${ }^{38}$ Em orçamentação. 


\subsubsection{Principais conclusões}

Embora os principais resultados da série de estudos realizados por estes autores sejam apresentados num artigo datado de 1976, as principais considerações e discussões gerais quanto à ocorrência de perdas de materiais e componentes são apresentadas em SKOYLES \& SKOYLES (1987), conforme indicado a seguir:

- os dados mostraram que a quantidade de material desperdiçado é maior do que a Indústria assume em suas estimativas, sendo, em geral, o dobro destas previsões orçamentárias;

- verificou-se também uma grande dispersão dos dados, indicando que existe uma considerável parcela de perda a ser combatida e reduzida;

- há uma tendência de os valores de perdas detectados ser maiores para residências privadas do que para o setor público ou outros setores;

- apesar da importância de se combater o nível de perdas detectadas, a Indústria não atua no sentido de prevenção, quando muito, apresenta iniciativas relacionadas ao controle das mesmas;

- as perdas de materiais são causadas por todos os envolvidos no processo da construção da edificação, embora nem todos contribuam com a mesma intensidade; 
- muitas das perdas têm origem fora do canteiro de obras propriamente dito, como, por exemplo, na elaboração do projeto e na aquisição dos materiais, entre outros;

- 20 a $30 \%$ da totalidade das perdas (direta e indireta) podem ter origem fora do canteiro de obras; no entanto, estas porcentagens podem ainda ser maiores uma vez que muitas das causas não são detectadas;

- para estes autores, o gerenciamento é o fator principal que interfere nos níveis de perdas existentes nos canteiros de obras.

\subsection{PINTO (1989)}

Os primeiros resultados sobre perdas de materiais levantados no âmbito do canteiro de obras no país são deste autor. Sua pesquisa consistiu na análise das perdas de materiais em um único edifício (Flat Hotel), com $3.658 \mathrm{~m}^{2}$ de área construída e distribuída em 18 pavimentos, localizado na cidade de São Paulo. Como características do edifício cita a estrutura em concreto usinado, a vedação em blocos de concreto celular autoclavado, o revestimento interno em gesso e o revestimento externo argamassado (massa única).

\subsubsection{Metodologia}

Inicialmente, há que se ressaltar que o autor empreendeu seu estudo em um edifício semi-acabado, isto é, coletou suas informações de campo num período de tempo restrito, não acompanhando a obra durante todo o seu desenvolvimento. Além deste aspecto, este estudo foi centrado naqueles 
serviços executados pela própria construtora, pelo fato de existirem, para os mesmos, documentos suficientemente detalhados. No âmbito destes serviços, o autor concentrou seus esforços nos materiais considerados, por ele, como potencialmente geradores de perdas, ou seja, concreto, aço, componentes de vedação, cimento, cal hidratada, areia, argamassa colante e placas cerâmicas. Para a obtenção dos índices, procedeu da seguinte forma:

- quantificação dos serviços a partir da verificação do conjunto de projetos;

- utilização de indicadores para o cálculo dos materiais teoricamente necessários para a execução de tais serviços (para isso, realizou-se a dedução das parcelas de perdas embutidas nas Composições Unitárias de Custo que foram utilizadas no orçamento);

- análise de todos os doc umentos fiscais (relativos às entradas de materiais) concernentes ao período de execução estudado, visando a quantificação dos materiais utilizados;

- realização de vistorias para definição das alterações realizadas no transcorrer da execução;

- aferição das dimensões reais executadas, como por exemplo, a espessura dos revestimentos de parede acabados, para subsidiar a análise das perdas. 


\subsubsection{Principais resultados}

Na Tabela 3.2 são apresentados os resultados desta pesquisa, onde os valores das perdas correspondem à diferença percentual entre as quantidades de materiais compradas e as quantidades teoricamente necessárias. Estas últimas foram calculadas a partir da quantificação dos serviços onde os materiais foram utilizados e posterior multiplicação pelos indicadores de consumo de materiais anteriormente citados. Tais perdas incluem, portanto, tanto a parcela de materiais que fica incorporada na edificação, quanto aquela descartada na forma de entulho.

Tabela 3.2 Índices de perdas de material (PINTO, 1989)

\begin{tabular}{|c|c|c|}
\hline Materiais & $\begin{array}{c}\text { Acréscimo } \\
\text { Verificado (\%) }\end{array}$ & $\begin{array}{c}\text { Expectativa usual } \\
\text { de perda (\%) }\end{array}$ \\
\hline Madeiras em geral & 47,5 & 15 \\
\hline Concreto usinado & 1,5 & 5 \\
\hline Aço CA 50/60 & 26,0 & 20 \\
\hline Componentes de vedação & 13,0 & 5 \\
\hline Cimento CP 32 & 33,0 & 15 \\
\hline Cal Hidratada & 102,0 & 15 \\
\hline Areia lavada & 39,0 & 15 \\
\hline Argamassa colante & 86,5 & 10 \\
\hline Placas cerâmicas-parede & 9,5 & 10 \\
\hline Placas cerâmicas - piso & 7,5 & 10 \\
\hline
\end{tabular}




\subsubsection{Principais conclusões}

Com relação aos índices apresentados na Tabela 3.2, o autor apresenta os seguintes comentários:

- o baixo índice obtido para o concreto usinado é justificado pelo fato de as concretagens ser realizadas por bombeamento;

- o elevado consumo de chapas de madeira ${ }^{39}$ justifica-se pelos desenhos curvos dos pilares, acarretando maiores consumos devido à dificuldade de execução das fôrmas para os mesmos e pela redução no número de reutilizações previsto originalmente; soma-se a estes fatos a má execução do serviço de fôrmas, segundo depoimento do responsável técnico da obra;

- quanto ao aço, o índice detectado é explicado pelo desbitolamento das barras e pelo não-reaproveitamento das pontas geradas no corte das mesmas;

- explica-se o baixo índice obtido para as placas cerâmicas em relação aos demais materiais analisados, pela razoável especialização da mão-de-obra responsável pelo assentamento das mesmas;

- com relação aos aglomerantes e à areia, o autor atribui ao mau acondicionamento destes materiais e à parcela de argamassa incorporada como as principais explicações dos índices detectados.

\footnotetext{
${ }^{39}$ Note que o número apresentado na Tabela 3.2 não diz respeito somente às chapas de madeira compensada, incluindo também a madeira serrada.
} 
Sabendo que uma das parcelas de perdas de aglomerante e agregado estaria representada pela perda de argamassa durante a sua aplicação, o autor as investigou no serviço de embutimento das instalações e nos de revestimentos. O autor concluiu que a perda de material no serviço de embutimento das instalações é insignificante, sendo mais expressivo o consumo de mão-de-obra para a sua execução. Quanto ao consumo/perda de argamassa nos serviços de revestimentos (paredes, tetos), chegou às seguintes conclusões:

- revestimentos de panos pequenos apresentaram espessuras inferiores às especificadas, com exceção dos panos contendo esquadrias (falta de coordenação modular);

- nos pavimentos de subsolo e térreo, a espessura dos revestimentos foi superior à ocorrida nas faces dos pavimentos-tipo;

- a má execução das fôrmas gerou grandes desnivelamentos nos panos da laje, acarretando acréscimo de espessura de argamassas tanto no emboço do teto quanto na regularização do piso;

- em função também da má execução das fôrmas, o revestimento argamassado das fachadas apresentou sobrespessura em relação à projetada da ordem de até $200 \%$, enquanto que o revestimento vertical argamassado de faces internas apresentou espessuras/consumos inferiores ao especificados, porém, no cômputo geral, a perda de argamassa foi de $80 \%$. 
Além dos percentuais de perdas calculados, o autor realizou também uma análise das perdas tomando como base a massa da edificação. Segundo ele, a perda total de material ocorrida numa obra é obtida pela relação entre o peso da totalidade do material comprado (incorporado ou não à edificação) e o peso do material que deveria ser incorporado conforme parâmetros técnicos recomendados (traços, dimensões, taxas de consumos etc).

Levando-se em consideração esta unidade de medida, o autor detectou uma perda de $18 \%$, pois o projeto previa a massa do edifício na ordem de $3.110 \mathrm{t}$ $\left(0,85 \mathrm{t} / \mathrm{m}^{2}\right)$, enquanto que o levantamento de notas fiscais apontou a utilização de $3.678 \mathrm{t}\left(1,0 \mathrm{t} / \mathrm{m}^{2}\right)$.

Em termos financeiros, segundo o autor, as perdas detectadas implicaram em um acréscimo de $10 \%$ sobre a expectativa de custo final da obra ${ }^{40}$, indicando a importância da necessidade de se reduzir estas perdas. Considerando somente os custos envolvidos nos serviços analisados (execução da estrutura, vedação e revestimentos), o impacto financeiro foi de $24 \%$.

\subsection{PICCHI (1993)}

Este autor realizou um estudo em 3 obras durante os anos de 1986 e 1987. Todas as obras eram de edifícios residenciais, executados em estrutura convencional e tendo tijolos cerâmicos furados como componentes de vedação. 


\subsubsection{Metodologia}

Avaliou o entulho gerado e retirado dos canteiros de obras, desconsiderando as primeiras viagens, identificadas como sendo compostas só por terra. Para isso, fez o levantamento dos documentos fiscais das empresas que realizaram a remoção e documentos da própria empresa para aqueles casos onde a remoção foi feita com caminhões próprios (caçambas estacionárias de $3,5 \mathrm{~m}^{3}$ cada).

O autor também analisou as sobrespessuras de revestimentos argamassados (comparação entre as espessuras reais executadas e as comumente utilizadas no mercado), consideradas, pelo autor, como sendo uma das principais fontes de perdas.

Além de estudar as perdas de materiais e componentes, no que diz respeito à parcela dos mesmos que fica incorporada ao edifício e à parcela que se transforma em entulho, as quais foram expressas em termos de massa e volume, o autor, baseado em algumas hipóteses, estimou as perdas em termos de percentagem do custo da obra. Nesta estimativa, contemplou as perdas de diversas naturezas, como as relativas a atrasos, reparos em obras entregues a clientes etc.

\footnotetext{
${ }^{40}$ Inclui c ustos de material, mão-de-obra, empreitada, serviços e verbas.
} 


\subsubsection{Principais resultados}

Os dados relativos ao entulho retirado das obras encontram-se na Tabela 3.3.

Tabela 3.3 Dados relativos ao entulho gerado (PICCHI, 1993)

\begin{tabular}{c|c|c|c|c|c}
\hline Obra & $\begin{array}{c}\text { Área } \\
\text { Construída } \\
\left(\mathbf{m}^{2}\right)\end{array}$ & $\begin{array}{c}\text { Qdade total } \\
\text { de entulho } \\
\left(\mathbf{m}^{3}\right)\end{array}$ & $\begin{array}{c}\text { Espessura } \\
\text { média } \\
\text { equivalente de } \\
\text { entulho }(\mathbf{c m})\end{array}$ & $\begin{array}{c}\text { Massa do entulho } \\
\left(\mathbf{t} / \mathbf{m}^{2}\right)(\mathbf{a})\end{array}$ & $\begin{array}{c}\text { Entulho/massa final } \\
\text { projetada do edifício } \\
(\%)(\mathbf{b})\end{array}$ \\
\hline A & 7.619 & 606,5 & 7,9 & 0,095 & 11,2 \\
\hline B & 7.982 & 707,7 & 8,9 & 0,107 & 12,6 \\
\hline C & 13.581 & $1.645,0$ & 12,1 & 0,145 & 17,1 \\
\hline
\end{tabular}

Observações:

(a) adotou-se a massa específica do entulho de $1,2 \mathrm{t} / \mathrm{m}^{3}$

(b) Adotou-se a massa final do edifício igual a $0,85 \mathrm{t} / \mathrm{m}^{2}$

No que diz respeito ao levantamento das perdas incorporadas de argamassas (não inclui o entulho considerado na Tabela 3.3), o autor chegou aos seguintes valores:

- comparando-se o volume de argamassa realizado com o projetado, a diferença detectada corresponde a $81,3 \%$; tal diferença é devida à sobrespessura dos revestimentos avaliados (contrapiso e revestimentos de tetos, paredes internas e externas);

- adotando-se o valor da massa específica média de $1.800 \mathrm{~kg} / \mathrm{m}^{3}$, os valores de perdas detectados em função da sobrespessura dos revestimentos, em 
termos de massa, corresponde a $146,4 \mathrm{~kg} / \mathrm{m}^{2}{ }^{41}$;

- este acréscimo de massa calculado em relação ao valor de referência da massa projetada do edifício adotada pelo autor $\left(0,85 \mathrm{t} / \mathrm{m}^{2}\right)$, corresponde a um acréscimo percentual da ordem de $17,2 \%{ }^{42}$.

Com relação à estimativa das perdas expressas em custo, o autor estimou uma representatividade de $30 \%$ em relação ao custo total da obra, sendo que as parcelas que compõem tal valor estão discriminadas na Tabela 3.4. Note que, nesta estimativa, o autor inclui outros custos além daqueles relativos à perda de material propriamente dita.

Tabela 3.4 Estimativa das perdas em termos de custos (PICCHI,1993)

\begin{tabular}{l|c}
\hline Origens das perdas & $\begin{array}{c}\text { Perdas estimadas (\%) sobre } \\
\text { o custo da obra }\end{array}$ \\
\hline Entulho gerado & 5,0 \\
\hline Espessuras adicionais de argamassa & 5,0 \\
\hline Dosagens de argamassa e concreto não otimizadas & 2,0 \\
\hline Reparos e retrabalhos não computados no entulho & 2,0 \\
\hline Projetos não otimizados & 6,0 \\
\hline Perdas de produtividade devido a problemas de qualidade & 3,5 \\
\hline Custos devido a atrasos & 1,5 \\
\hline Reparos em obras entregues a clientes & 5,0 \\
\hline Total & $\mathbf{3 0 , 0}$ \\
\hline
\end{tabular}

${ }^{41} \mathrm{O}$ autor chegou a este valor fazendo a multiplicação entre o volume adicional de argamassa empregado, devido à sobrespessura $\left(81,3 \mathrm{l} / \mathrm{m}^{2}\right)$, e a referida massa específica.

$42 \%$ massa $=\left[\frac{(0,1464+0,85)}{0,85}-1\right] x 100$ 


\subsubsection{Principais conclusões}

Como conclusões do seu estudo, PICCHI (1993) faz as seguintes colocações:

- ao acumular-se todo o volume de entulho gerado na obra, durante toda a sua construção, e dividi-lo pela área total construída, ter-se-ia uma espessura média de entulho na ordem de 8 a $12 \mathrm{~cm}$;

- a massa do entulho variou entre 0,095 a $0,145 \mathrm{t} / \mathrm{m}^{2}$, o que representa 11 a $17 \%$ da massa final do edifício, para a massa específica adotada.

\subsection{SOIBELMAN (1993)}

Este autor, em conjunto com um grupo de pesquisadores do Núcleo Orientado à Inovação das Edificações (NORIE), realizou um estudo sobre perdas de materiais em 5 canteiros de obras localizados na cidade de Porto Alegre. Os objetivos traçados pela equipe consistiam em levantar a incidência de perdas de materiais nos canteiros de obras, analisar as principais causas e propor diretrizes para a implementação de sistemas de controle de desperdício em empresas de construção. A pesquisa foi realizada durante o ano de 1992, tendo-se estudado os seguintes materiais: aço, concreto usinado, cimento, areia, cal, argamassa regular ${ }^{43}$ e tijolos. Inicialmente, estava previsto também 0

43 Argamassa regular corresponde à argamassa de cal e areia, também chamada de argamassa intermediária (se for adicionado cimento após o descanso) ou argamassa de cal (se for aplicada na seqüência). 
estudo do desperdício de madeira, placas cerâmicas, tintas, eletrodutos, condutores elétricos e tubos para instalações hidráulicas, porém, tal estudo adicional foi descartado em função das dificuldades de reunir documentações necessárias a sua realização, devido à contratação de terceiros para a execução do serviço e também à inexistência, nas obras estudadas durante o período de coleta, de serviços que fizessem o uso destes materiais. Ressaltase ainda que, na escolha destes materiais, o autor fez uma análise da curva ABC dos insumos utilizados nos projetos de padrão normal, de quatro, oito e doze pavimentos, da NBR 12721 (ABNT, 1992) ${ }^{44}$, sendo que os materiais estudados representam aproximadamente $20 \%$ do custo total das obras.

\subsubsection{Metodologia}

Ao contrário de PINTO (1989), este estudo foi caracterizado pelo efetivo acompanhamento dos materiais nos canteiros de obras durante todo o período do estudo. A coleta de dados foi delimitada por duas datas estratégicas, denominadas VI (vistoria inicial) e VF (vistoria final). Nestas datas, contabilizavam-se os estoques de materiais e a quantidade de serviço executada até as mesmas. Entre as mesmas, contabilizava-se a quantidade de material paga e realizavam-se observações de caráter qualitativo e quantitativo no canteiro de obras acerca das ocorrências das perdas de materiais. Foram elaboradas diversas planilhas de coleta de dados, estruturadas conforme o tipo de informações a ser coletadas. Os índices de perdas foram calculados para 3

\footnotetext{
${ }^{44}$ ASSOCIAÇÃO BRASILEIRA DE NORMAS TÉCNICAS. Avaliação de custos unitários e preparo de orçamento de construção para incorporação de edifício em condomínio; procedimento - NBR 12721. Rio de Janeiro, 1992.
} 
períodos distintos: do início da obra até a data VI; entre as datas VI e VF; e entre o início da obra e VF. Fez-se o uso das seguintes expressões:

(a) até a data (VI):

$$
\operatorname{Perda}(\%)=\frac{\text { Mreal }- \text { Est }(V I)}{\text { Mteo }}
$$

onde:

$$
\begin{array}{ll}
\operatorname{Perda}(\%)= & \begin{array}{l}
\text { indice total de perda do material, considerando as parcelas de } \\
\text { natureza direta e indireta }
\end{array} \\
\text { Mreal } & =\text { quantidade de material adquirida até a data }(\mathrm{VI}) \\
\operatorname{Est}(\mathrm{VI}) & =\text { quantidade de material existente no estoque na data }(\mathrm{VI}) \\
\text { Mteo } & =\begin{array}{l}
\text { quantidade de material teoricamente necessária para a execução } \\
\text { dos serviços até a data (VI) }
\end{array}
\end{array}
$$

(b) entre as datas (VI) e (VF)

$$
\operatorname{Perda}(\%)=\frac{\text { Mreal }+E s t(V I)-E s t(V F)}{M t e o}
$$

onde:

$$
\begin{aligned}
& \operatorname{Perda}(\%)=\text { índice total de perda do material, considerando as parcelas de } \\
& \text { natureza direta e indireta } \\
& \text { Mreal = quantidade de material adquirida entre as datas (VI) e (VF) } \\
& \operatorname{Est}(V I) \quad=\quad \text { quantidade de material existente no estoque na data (VI) } \\
& \operatorname{Est}(V F)=\text { quantidade de material existente no estoque na data (VF) } \\
& \text { Mteo = quantidade de material teoricamente necessária para a execução } \\
& \text { dos serviços entre as datas (VI) e (VF) }
\end{aligned}
$$

(c) até a data (VF) 


$$
\operatorname{Perda}(\%)=\frac{\text { Mreal }- \text { Est }(V F)}{\text { Mteo }}
$$

onde:

$$
\begin{array}{ll}
\operatorname{Perda}(\%)= & \begin{array}{l}
\text { indice total de perda do material, considerando as parcelas de } \\
\text { natureza direta e indireta }
\end{array} \\
\text { Mreal } & =\text { quantidade de material adquirida até a data (VF) } \\
\text { Est }(V F) & =\text { quantidade de material existente no estoque na data (VF) } \\
\text { Mteo } & =\begin{array}{l}
\text { quantidade de material teoricamente necessária para a execução } \\
\text { dos serviços até a data (VF) }
\end{array}
\end{array}
$$

Para o cálculo da quantidade de material teoricamente necessário, a equipe de coleta realizou o levantamento das quantidades de serviços através de consultas em projetos, utilizando as composições de custos fornecidas pela PINI $(1992)^{45}$ e pela REGIONAL SUL ORÇAMENTOS E CUSTOS $(1990)^{46}$, descontando-se as parcelas de perdas embutidas nas mesmas.

\subsubsection{Principais resultados}

Na Tabela 3.5 são apresentados os índices de perdas calculados pelo autor e sua equipe. Apesar da obtenção de 3 índices de perdas, considerando-se períodos distintos, serão apresentados aqui somente aqueles compreendidos entre as datas VI e VF, por ser este o período onde foram realizadas as verificações durante o processo produtivo.

\footnotetext{
45 PINI: Tabelas de composição de preços para orçamentos . $9^{a}$ edição. São Paulo, PINI, 1992.

46 Regional Sul Oçamentos e Custos. Listagem discriminada de composições e serviços. Porto Alegre, maio 1990.
} 
Tabela 3.5 Índices de perdas verificados entre as datas VI e VF (SOIBELMAN, 1993)

\begin{tabular}{l|c|c|c|c|c|c}
\hline \multirow{2}{*}{ Material } & \multicolumn{5}{c|}{ Obras } & \multirow{2}{*}{ Média } \\
\cline { 2 - 6 } & A & B & C & D & E & \\
\hline Aço 47 & 18,8 & 27,3 & 23,0 & 7,9 & 18,3 & 19,0 \\
\hline Cimento & 86,1 & 45,2 & 36,5 & 109,8 & 135,4 & 82,6 \\
Concreto & 5,7 & 17,2 & - & 15,9 & - & 12,9 \\
\hline Areia & 24,6 & 29,7 & - & 133,3 & 43,8 & 44,4 \\
\hline Argamassa & 103,0 & 87,5 & 40,4 & 152,1 & 85,0 & 93,6 \\
\hline Tijolo Furado & - & 8,2 & 93,3 & 33,6 & 107,3 & 50,0 \\
\hline Tijolo Maciço & 43,5 & 15,2 & - & 47,2 & 109,9 & 54,0 \\
\hline
\end{tabular}

Além destes resultados, o autor, através de verificações qualitativas e quantitativas, apontou uma série de causas e explicações para os índices de perdas detectados, as quais são reunidas sucintamente na Tabela 3.6.

Um outro resultado interessante apresentado pelo autor diz respeito ao custo das perdas de materiais detectadas. Para isso, utilizou a curva $A B C$ da NBR 12721 (ABNT, 1992) adaptada aos materiais utilizados nas obras pesquisadas. A Tabela 3.7 traz a representatividade das perdas em termos de 
custos, assim como o acréscimo verificado em função das perdas detectadas

para cada material em cada obra analisada. Ressalta-se que o custo dos

materiais estudados representam $20 \%$ do custo total da obra e, portanto, têm-

se os acréscimos de custos indicados sendo gerados apenas por esta fração

de custos da obra.

\section{Tabela 3.6 Principais causas das perdas verificadas nos canteiros de obras baseadas em SOIBELMAN (1993)}

\begin{tabular}{|c|c|}
\hline Material & Principais causas/explicações \\
\hline Concreto usinado & $\begin{array}{l}\text { - apesar das dificuldades em se avaliar o volume recebido, detectou-se } \\
\text { a variação entre a quantidade entregue e a solicitada em alguns } \\
\text { casos; } \\
\text { - constatou-se a utilização de equipamentos de transporte } \\
\text { inadequados, além de percursos favoráveis à ocorrência de perdas e } \\
\text { duplo manuseio do material; } \\
\text { - detectourse também erros de cubagem do material, acarretando } \\
\text { sobras ao final da concretagem; } \\
\text { - quanto à aplicação do material, verificações das dimensões das } \\
\text { peças estruturais apresentaram diferenças significativas entre a } \\
\text { teórica e a real, sendo a variação da espessura da laje a mais } \\
\text { significativa; }\end{array}$ \\
\hline Argamassa & $\begin{array}{l}\text { - o desaprumo e as irregularidades na estrutura e a falta de } \\
\text { coordenação entre o projeto arquitetônic o e estrutural foram as } \\
\text { principais causas das perdas detectadas para este material, que } \\
\text { ocorreram sob a forma de sobrespessura de revestimento, chegando } \\
\text { ao valor médio de } 89 \% \text { acima das espessuras de referênciais; } \\
\text { - era comum a sobra de argamassa ao final do dia; }\end{array}$ \\
\hline Tijolos furados & $\begin{array}{l}\text { - a má condição de estocagem deste material, assim como a falta de } \\
\text { controle quantitativo no recebimento, são apontados como } \\
\text { explicações dos índices; } \\
\text { quanto à aplicação do material, a falta de modulação, obrigando a } \\
\text { execução de cortes excessivos, também foi uma das causas das } \\
\text { perdas detectadas, principalmente no que diz respeito aos tijolos } \\
\text { furados; }\end{array}$ \\
\hline
\end{tabular}

${ }^{47}$ Considerado o índice do período compreendido entre o início da obra e a data VF por falta de dados para o cálculo do mesmo para o período compreendido entre VI e VF.

${ }^{48}$ Adotou-se como espessura padrão $1,5 \mathrm{~cm}$ para os revestimentos de paredes internas e forros e $2,0 \mathrm{~cm}$ para o revestimento de paredes externas, de acordo com a NBR 7200 (ABNT, 1982). Esta norma foi atualizada e publicada em 1998. 
Tabela 3.6 Principais causas das perdas verificadas nos canteiros de obras baseadas em SOIBELMAN (1993) - continuação

\begin{tabular}{|c|c|}
\hline Material & Principais causas/explicações \\
\hline Cimento & $\begin{array}{l}\text { - valem as mesmas observações feitas para a argamassa no que diz } \\
\text { respeito à variação das espessuras dos revestimentos; } \\
\text { - quanto ao recebimento do material, verificourse a ocorrência do } \\
\text { rasgamento dos sacos, ocasionando perda do mesmo; } \\
\text { - quanto à estocagem, não se verificou boa prática para o } \\
\text { acondicionamento dos sacos; }\end{array}$ \\
\hline Areia & $\begin{array}{l}\text { - a principal questão levantada nesta pesquisa diz respeito à } \\
\text { inexistência de contenções laterais e o duplo manuseio deste material } \\
\text { até o seu uso na produção de argamassa. }\end{array}$ \\
\hline
\end{tabular}

Tabela 3.7 Estimativa de custo das perdas dos materiais avaliados, considerando os demais custos (SOIBELMAN, 1993)

\begin{tabular}{l|c|c|c|c|c|c}
\hline \multirow{2}{*}{ Insumo } & \multirow{2}{*}{$\begin{array}{c}\text { Custo } \\
\text { Teórico (\%) }\end{array}$} & \multicolumn{4}{|c}{ Custo dos materiais = Custo teórico x [1 + perdas(\%)] } \\
\cline { 4 - 7 } & & A & B & C & D & E \\
\hline Aço & 4,31 & 5,12 & 5,49 & 5,30 & 4,65 & 5,10 \\
\hline Cimento & 5,24 & 9,25 & 7,61 & 7,04 & 13,19 & 11,15 \\
\hline Concreto & 5,38 & 5,96 & 6,01 & 6,32 & 5,42 & 6,73 \\
\hline Areia & 0,94 & 1,19 & 1,22 & 1,13 & 1,97 & 1,34 \\
\hline Argamassa & 0,69 & 1,40 & 0,69 & 0,97 & 1,24 & 1,20 \\
\hline Tijolos furados & 2,25 & 3,15 & 3,15 & 3,06 & 2,85 & 4,65 \\
\hline Tijolos maciços & 0,27 & 0,39 & 0,31 & 0,32 & 0,34 & 0,52 \\
\hline $\begin{array}{l}\text { Demais materiais }+ \\
\text { mão-de-obra }\end{array}$ & 80,92 & 80,92 & 80,92 & 80,92 & 80,92 & 80,92 \\
\hline TOTAL & 100,00 & 107,38 & 105,40 & 105,06 & 110,58 & 111,62 \\
\hline Custo das perdas & - & 7,38 & 5,40 & 5,06 & 10,58 & 11,62 \\
\hline
\end{tabular}




\subsubsection{Principais conclusões}

O autor confirmou a hipótese, traçada no início da pesquisa, de que as perdas de materiais na construção civil são maiores do que as normalmente aceitas, apresentando índices com um grande intervalo de variação (de 0,85 a 8 vezes as perdas usuais admitidas), dependendo do material em análise. Da mesma forma, a existência de índices variáveis para um mesmo material em diferentes obras, alerta para a existência de uma parcela considerável de perdas evitáveis, que podem ser minimizadas com medidas simples e elementares nas etapas de recebimento e estocagem, no manuseio e utilização do material.

Sob o ponto de vista das causas, o autor enfatiza que as perdas ocorreram mais por uma combinação de fatores do que por um fator isolado em uma operação, apontando, assim, a falta de gerenciamento do canteiro como a causa fundamental para os altos índices levantados.

Traduzindo os valores das perdas físicas de materiais para o âmbito financeiro, o autor concluiu que estes correspondem a um aumento de 5,06\% a $11,62 \%$ dos custos orçados das obras estudadas, tendo-se trabalhado com a parcela de custos da obra de apenas $20 \%$.

Por fim, evidenciou-se também a falta de interesse em se controlar os materiais, uma vez que todos os gerentes das obras tinham o conhecimento das perdas mas pouco fizeram para evitá-las. 


\subsection{HONG KONG POLYTECHNIC (1993)}

A pesquisa realizada pela Hong Kong Polytechnic para a Hong Kong Construction Association (HKCA), conforme acordo firmado entre as partes em maio de 1992, tem um enfoque voltado para a questão da geração e manipulação do entulho de construção civil. Este estudo foi motivado, entre outras razões, pela carência de espaço físico, naquela cidade, para a deposição do entulho gerado.

Iniciada em meados de 1992 e com duração de 9 meses, a pesquisa abrangeu 32 canteiros de obras e tinha como objetivos estudar os possíveis métodos, e formas economicamente viáveis, para reduzir a geração do entulho na própria fonte e estudar métodos alternativos para o tratamento do entulho, como forma de reduzir o volume final depositado. A consecução destes objetivos passava, necessariamente, pela quantificação e identificação da natureza dos vários tipos de entulhos de construção civil e identificação das principais causas da ocorrência dos mesmos.

Além de focar o entulho produzido ao longo da construção das edificações (obras novas), os autores também abordam a questão da geração do entulho devido às demolições das edificações, que também geram um considerável montante. Esta última abordagem não é detalhada nesta dissertação. 


\subsubsection{Metodologia}

Como colocado anteriormente, a pesquisa está focada na questão do entulho de construção civil. No que diz respeito à parcela deste entulho gerada nos canteiros de obras, proveniente do processo de construção de edificações, inicialmente foi realizado um estudo piloto em dois canteiros de obras para averiguar a aplicabilidade das planilhas de coleta de dados e da metodologia em si.

Após este estudo piloto, formaram-se equipes de coleta compostas por estudantes, divididos em grupos, os quais eram responsáveis por dois ou mais canteiros de obras, dependendo da dimensão, localização e complexidade dos mesmos.

Basicamente, a coleta de dados a ser efetuada tinha como objetivos:

- quantificar e identificar a natureza dos vários tipos de entulho de construção civil;

- identificar as principais causas dageração deste entulho.

A idéia central da metodologia consistia na comparação das quantidades de materiais entregues nos canteiros e as quantidades de materiais previstos ou teoricamente necessários, tomando-se como base o orçamento da obra, obtendo-se, assim, a percentagem ou a quantificação (expressa em massa ou volume) de material perdido, considerado pelos autores como sendo entulho ${ }^{49}$.

\footnotetext{
${ }^{49}$ Tal consideração apresenta incoerências, conforme se mostrará adiante.
} 
Aplicou-se a idéia de comparação entre estas quantidades apenas para o caso do estudo do concreto usinado, pois não se conseguiu estudar os outros materiais, inicialmente previstos, em função da ausência de documentos confiáveis acerca das quantidades de serviços executadas e das quantidades de materiais presentes no canteiro ${ }^{50}$.

Apesar da impossibilidade da avaliação do índice de entulho nos outros serviços considerados potencialmente geradores do mesmo, a partir de suas experiências, os autores chegaram a estimar a percentagem deste entulho para estes serviços.

Para isso, dividiram o entulho gerado durante o processo de construção em 5 categorias e, para cada uma, estabeleceram uma formulação para quantificar o volume de entulho gerado (Tabela 3.8).

Com o objetivo de testar o modelo proposto, principalmente no que se refere aos índices de entulho estabelecidos, o mesmo foi aplicado em um canteiro de obras. O teste consistia na comparação entre os volumes de entulho, calculados nos moldes da Tabela 3.8, e os retirados da obra no período concernente ${ }^{51}$.

\footnotetext{
${ }^{50}$ Aço, gesso e cimento, blocos e tijolos, placas cerâmicas e madeira.

51 Anotou-se o número de viagens feitas por caminhões basculantes de $9 \mathrm{~m}^{3}$; identificando-se percentualmente o material constituinte deste entulho.
} 


\section{Tabela 3.8 Modelo para estimação do entulho de canteiro de obras (HONG KONG POLYTECHNIC, 1993)}

\begin{tabular}{|c|c|c|}
\hline Categoria & $\begin{array}{l}\text { Índice de } \\
\text { entulho (\%) }\end{array}$ & Volume de entulho $\left(\mathrm{m}^{3}\right)$ \\
\hline $\begin{array}{l}\text { Granular inerte oriundo de } \\
\text { atividades de concretagem }\end{array}$ & 11 & QServiço $\left(m^{3}\right) x$ Índice entulho $(\%)$ \\
\hline $\begin{array}{l}\text { Granular inerte oriundo de } \\
\text { materiais cerâmicos }\end{array}$ & 15 & QServiç( $\left(m^{2}\right) x$ Espessur(m)xÍndic $\left.\varepsilon_{n t u l h} \phi \%\right)$ \\
\hline $\begin{array}{l}\text { Restos de madeira, oriundos da } \\
\text { produção de fôrmas ou } \\
\text { atividades temporárias }\end{array}$ & 100 & 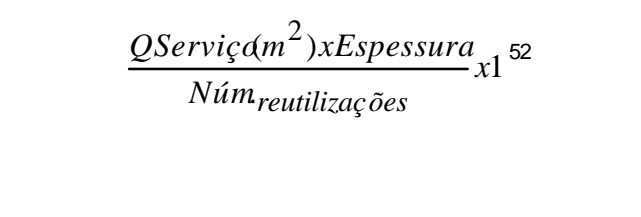 \\
\hline Materiais acondicionados & 5 & Volume $_{\text {materiais }}\left(\mathrm{m}^{3}\right)$ xÍndice $(\%)$ \\
\hline Outros entulhos & Desprezível & - \\
\hline
\end{tabular}

Os volumes determinados pelo modelo diferiam do valor real em $13,3 \%$. $O$ autor cita que tal discrepância é ainda menor, já que havia uma quantidade de entulho ainda presente na obra que foi gerada durante o período de coleta.

Feita esta averiguação, o modelo proposto foi aplicado a um conjunto de obras participantes da pesquisa, o que possibilitou a estimação do volume e massa anuais de entulho na cidade de Hong Kong.

Com relação ao segundo objetivo previsto para o levantamento de dados, as equipes de coleta obtiveram resultados qualitativos quanto às causas imediatas

\footnotetext{
52 O autor utiliza o número médio igual a 9 reutilizações do jogo de fôrmas, apesar de reconhecer que este número pode ser muito superior, podendo chegar até a 20 vezes.
} 
da geração do entulho nos canteiros de obras, mostrados em termos percentuais no item subseqüente.

\subsubsection{Principais resultados}

No que diz respeito ao levantamento quantitativo do entulho de construção civil, para o caso do concreto usinado, os autores chegaram ao valor médio de $10,92 \%^{53}$, sendo o valores máximo e mínimo obtidos iguais a $26,5 \%$ e $2,4 \%$, respectivamente, para uma amostra de 14 canteiros de obras. Os valores utilizados no estudo, para a averiguação do modelo proposto, são apresentados na Tabela 3.9.

Comparando-se o volume de entulho obtido pelo modelo $\left(1.496 \mathrm{~m}^{3}\right)$ com o volume real de entulho retirado da obra $\left(1.301 \mathrm{~m}^{3}\right)$, tem-se a diferença de 13,3\%. A aplicação deste modelo a um conjunto de 13 canteiros de obras levou ao coeficiente de $0,10 \mathrm{~m}^{3} / \mathrm{m}^{2}$ de área construída. Os valores utilizados para a determinação deste coeficiente estão reunidos na Tabela 3.10.

${ }^{53}$ Foi esta constatação que gerou o índice de entulho apresentado na Tabela 3.8. 
Tabela 3.9 Averiguação do modelo proposto para a quantificação do entulho de construção civil com base em dados provenientes de canteiro de obras (HONG KONG POLYTECHNIC, 1993) $)^{54}$

\begin{tabular}{|c|c|c|c|c|c|c|c|c|c|}
\hline \multirow[t]{2}{*}{ Serviço } & \multirow[t]{2}{*}{$\begin{array}{l}\text { Qdade } \\
\text { orçada }\end{array}$} & \multirow[t]{2}{*}{$\begin{array}{c}\% \\
\text { exec. }\end{array}$} & \multirow[t]{2}{*}{$\begin{array}{l}\text { Esp. } \\
(\mathrm{mm})\end{array}$} & \multicolumn{2}{|c|}{$\begin{array}{c}\text { Materiais } \\
\text { necessários }\left(m^{3}\right)\end{array}$} & \multirow[t]{2}{*}{$\begin{array}{l}(\%) \text { de } \\
\text { entulho }\end{array}$} & \multicolumn{3}{|c|}{$\begin{array}{l}\text { Total de entulho produzido } \\
\qquad\left(\mathrm{m}^{3}\right)\end{array}$} \\
\hline & & & & Granular & Madeira & & Granular & Acondic. & Madeira \\
\hline \multicolumn{10}{|l|}{ Infra-estrutura } \\
\hline Concreto & 1.511 & 100 & - & 1.511 & & 11 & 166 & - & - \\
\hline Fôrmas & 2.314 & 100 & 25 & & 6 & & - & - & 6 \\
\hline \multicolumn{10}{|l|}{ Superestrutura } \\
\hline Concreto & 7.186 & 87 & - & 6252 & - & 11 & 688 & - & - \\
\hline Fôrmas & 115.351 & 85 & 25 & & 272 & - & - & - & 272 \\
\hline Alvenaria & 6.841 & 77 & 210 & 1.106 & - & 11 & 122 & 55 & - \\
\hline Marco de porta & 7.731 & 77 & - & - & - & - & - & - & - \\
\hline \multicolumn{10}{|l|}{ Acab. interno } \\
\hline Chapisco & 31.572 & 84 & - & - & - & 3 & - & - & - \\
\hline Pisos cimentados & 15.248 & 13 & 25 & 50 & - & 15 & 7 & 2 & - \\
\hline Pisos cerâmicos & 2.969 & 19 & 10 & 6 & - & 15 & 1 & 0 & - \\
\hline Emb./reb. paredes & 13.068 & 76 & 25 & 248 & - & 15 & 37 & 12 & - \\
\hline Rev. Cerâmico & 14.451 & 66 & 10 & 95 & - & 15 & 14 & 5 & - \\
\hline Emb./reb. forros & 8.676 & 73 & 25 & 158 & - & 15 & 24 & 8 & - \\
\hline \multicolumn{10}{|l|}{ Acab. externo } \\
\hline Chapisco & 15.961 & 84 & - & - & - & 5 & - & - & - \\
\hline Emb./reb. paredes & 12.744 & 76 & 25 & 242 & - & 15 & 36 & 12 & - \\
\hline Rev. Cerâmico & 12.750 & 67 & 10 & 77 & - & 15 & 11 & 4 & - \\
\hline Emb./reb. forros & 2.135 & 60 & 25 & 41 & - & 15 & 6 & 2 & - \\
\hline Cobertura & 2.135 & 60 & 10 & 13 & - & 15 & 2 & 1 & - \\
\hline \multirow[t]{3}{*}{ Contrapiso } & 1.943 & 0 & 25 & 0 & - & 15 & 0 & 0 & - \\
\hline & & & & & & \multirow{2}{*}{ Totais } & 1.115 & 102 & 279 \\
\hline & & & & & & & \multicolumn{3}{|c|}{1.496} \\
\hline
\end{tabular}

${ }^{54}$ Esta Tabela foi extraída da referência sem alterações; nota-se uma provável omissão de dados que deveriam estar completando as informações apresentadas na mesma. 
Tabela 3.10 Volume de entulho através da aplicação do modelo proposto (HONG KONG POLYTECHNIC, 1993)

\begin{tabular}{|c|c|c|c|c|c|c|c|}
\hline \multicolumn{2}{|c|}{ Dados dos empreendimentos } & \multicolumn{6}{|c|}{ Estimativa do entulho $\left(\mathrm{m}^{3}\right)$} \\
\hline \multirow[t]{2}{*}{ Tipo de edificação } & \multirow{2}{*}{$\begin{array}{c}\text { Área } \\
\text { construída }\left(m^{2}\right)\end{array}$} & \multicolumn{2}{|c|}{ Granular } & \multirow[t]{2}{*}{ Ensacado } & \multirow[t]{2}{*}{ Madeira } & \multirow[t]{2}{*}{ Total } & \multirow[t]{2}{*}{$\mathrm{m}^{3} / \mathrm{m}^{2}$} \\
\hline & & Concreto. & Outros & & & & \\
\hline Casa & 55.817 & 3.838 & 602 & 231 & 596 & 5.267 & 0,09 \\
\hline Casa & 4.300 & 188 & 54 & 23 & 31 & 297 & 0,07 \\
\hline Casa & 3.162 & 198 & 72 & 31 & 45 & 346 & 0,11 \\
\hline $\mathrm{C}_{(39)}$ & 12.574 & 957 & 408 & 176 & 327 & 1.867 & 0,15 \\
\hline Escritório & 3.302 & 193 & 30 & 12 & 42 & 279 & 0,08 \\
\hline Escritório & 2.814 & 159 & 25 & 9 & 39 & 232 & 0,08 \\
\hline Escritório & 109.415 & 5.225 & 994 & 386 & 949 & 7.554 & 0,07 \\
\hline Prédio & 87.360 & 4.588 & 1572 & 702 & 0 & 6.861 & 0,08 \\
\hline Prédio & 86.497 & 4.709 & 1.390 & 615 & 531 & 7.244 & 0,08 \\
\hline Prédio & 5.250 & 291 & 164 & 80 & 49 & 583 & 0,11 \\
\hline Prédio & 102.780 & 9.272 & 3.179 & 1.302 & 1549 & 15.302 & 0,15 \\
\hline Escola & 8.390 & 497 & 96 & 40 & 79 & 712 & 0,08 \\
\hline Outro & 2.870 & 178 & 71 & 32 & 84 & 365 & 0,13 \\
\hline TOTAL & 484.531 & 30.293 & 8.657 & 3.639 & 4231 & 46.909 & 0,10 \\
\hline
\end{tabular}

Com relação às causas da geração do entulho para os materiais estudados, as mesmas foram relacionadas, em termos percentuais, em função das verificações qualitativas realizadas nos canteiros. Estão reunidas na Tabela 3.11. 
Tabela 3.11 Principais causas levantadas quanto à ocorrência de geração de entulho nas obras, baseadas em HONG KONG POLYTECHNIC (1993)

\begin{tabular}{|c|c|c|c|c|c|}
\hline Causas & $\begin{array}{c}\text { Concreto } \\
\text { usinado (\%) }\end{array}$ & Aço (\%) & $\begin{array}{c}\text { gesso/ } \\
\text { cimento (\%) }\end{array}$ & $\begin{array}{c}\text { Blocos/ } \\
\text { tijolos (\%) }\end{array}$ & $\begin{array}{c}\text { Placas } \\
\text { cerâmicas (\%) }\end{array}$ \\
\hline Pedido em excesso & 51,2 & - & - & 14,6 & 10,7 \\
\hline Perdas durante a concretagem & 22,0 & - & - & - & \\
\hline Quebra das fôrmas & 8,4 & - & - & - & - \\
\hline Trabalhos temporários & 7,8 & - & - & - & - \\
\hline Retrabalho & 5,2 & 3,5 & - & - & - \\
\hline Perdas no corte & - & 87,1 & - & 39,6 & 40,0 \\
\hline Perdas na estocagem & - & 4,4 & - & 11,1 & 29,3 \\
\hline Corrosão & - & 4,1 & - & - & - \\
\hline Produção excessiva & - & - & 58,8 & - & - \\
\hline Perdas durante a aplicação & - & - & 19,4 & - & - \\
\hline Armazenagem & - & - & 11,2 & - & - \\
\hline Perdas durante o assentamento & - & - & - & 18,9 & - \\
\hline Perdas durante o transporte & - & - & - & 15,8 & - \\
\hline Alteração de projeto & - & - & - & - & 12,9 \\
\hline Outros & 5,4 & 0,9 & 10,6 & - & 7,1 \\
\hline TOTAL & 100,0 & 100,0 & 100,0 & 100,0 & 100,0 \\
\hline
\end{tabular}

\subsubsection{Principais conclusões}

Entre as principais conclusões da pesquisa, pode-se citar a necessidade de se avaliar de forma sistemática e precisa o montante de entulho gerado nas obras de construção civil, durante o processo de execução, e aquele advindo de demolições e manutenções de edificações já existentes. Os autores avaliam o 
montante de material a ser retirado da obra como sendo da ordem de 2.902.510 toneladas, advindos de $6.350 .000 \mathrm{~m}^{2}$ de novas edificações e 5.488.700 $\mathrm{m}^{2}$ de edificações demolidas na cidade de Hong Kong. Desta massa, estimam que $12 \%$ venha de solos provenientes de escavação, $41 \%$ de entulho originado da construção de novas edificações e $47 \%$ advindos de demolições das edificações existentes. Ao se somar a manutenção e execução de obras de arte, execução de instalações provisórias de canteiro de obras, entre outros, este montante pode chegar a 8.164.000 toneladas de entulho por ano, exigindo um espaço considerável para deposição.

Como formas de minimizar esta necessidade, os autores citam o combate ao desperdício na fonte e a reciclagem dos materiais para posterior utilização na própria obra. Além da reciclagem, citam também a necessidade de se incorporar novas tecnologias no ambiente de construção. Mas, para isso, são necessários esforços de todas as partes envolvidas, engenheiros e arquitetos, clientes, usuários, contando-se com o apoio governamental.

\subsection{SANTOS (1995)}

Embora o enfoque principal do trabalho realizado pelo autor seja a intervenção no canteiro de obras atuando no sistema de movimentação e armazenamento dos materiais, como parte integrante do método desenvolvido, avaliou as perdas de materiais dos serviços de alvenaria, chapisco e emboço (cimento, areia, tijolos maciços e de 6 furos). 
Inicialmente, o estudo estava previsto apenas para o serviço de alvenaria, porém, dada a dificuldade de se conhecer as quantidades de cimento e areia destinadas a cada serviço (além do assentamento de alvenaria, tinha-se chapisco e emboço, que já haviam sido iniciados em algumas partes da obra), o autor teve de incluir todos no escopo da pesquisa.

A obra estudada era composta por 3 blocos de edifícios residenciais, construídos no sistema tradicional, com tijolos e blocos cerâmicos para vedação e estrutura de concreto convencional.

\subsubsection{Metodologia e principais resultados}

A metodologia empregada para o cálculo dos índices de perdas foi a mesma desenvolvida por SOIBELMAN (1993). Acrescenta-se a elaboração de uma extensa lista de verificação para avaliar o posicionamento dos elementos de canteiro quanto a terem uma influência positiva ou negativa em relação à ocorrência de perdas de materiais e ganho de produtividade. $\mathrm{O}$ autor, além de estabelecer os índices físicos contábeis (\%), também expressou a perda em termos financeiros, sendo os resultados apresentados na Tabela 3.12.

Com o objetivo de avaliar o entulho advindo da produção da alvenaria, o autor mediu o entulho gerado por uma equipe de 2 pedreiros em dois apartamentos, cujo volume $\left(1,26 \mathrm{~m}^{3}\right)$, dividido pela área de alvenaria executada $\left(300 \mathrm{~m}^{2}\right)$, resulta num índice de $0,0042 \mathrm{~m} 3 \mathrm{~m}^{2}$. Fazendo uma projeção em função da área de alvenaria executada durante o período de coleta $\left(17.420 \mathrm{~m}^{2}\right)$, o autor estimou um volume de entulho da ordem de $73 \mathrm{~m}^{3}$. 
Tabela 3.12 Perdas contabilizadas: estudo de caso (SANTOS, 1995)

\begin{tabular}{l|c|c|c|c}
\hline Material & Perda (\%) & Quantidade & U\$/un & Custo (U\$) \\
\hline Cimento & 79,6 & 3.163 sacos & 5,67 & 17.934 \\
\hline Areia & 42,5 & $325 \mathrm{~m}^{3}$ & 10,19 & 3.312 \\
\hline Tijolo 6 furos & 5,4 & $27.500 \mathrm{un}$ & 0,11 & 3.025 \\
\hline Tijolo maciço & 25,5 & 40.468 un & 0,07 & 2.833 \\
\hline
\end{tabular}

Referências de consumo com perda nula:

- $\quad$ espessura emboço interno $=1,5 \mathrm{~cm}$;

- $\quad$ espessura emboço externo $=2,5 \mathrm{~cm}$;

- $\quad$ espessura de junta argamassada = 1,5 cm;

- $\quad$ utilizado o traço de argamassa da empresa;

\subsubsection{Principais conclusões}

O autor apresenta, para os materiais, as principais causas e justificativas para a ocorrência dos índices de perda levantados. No caso do cimento, cita a falta de compatibilidade entre a alvenaria e a estrutura (vigas de $12 \mathrm{~cm}$ e blocos com largura de $9 \mathrm{~cm}$ ), o que originou uma sobrespessura do emboço da ordem de $80 \%$. Observou-se, também, o rasgamento dos sacos durante 0 recebimento, face ao descarregamento e transporte manual até o local de armazenamento.

A falta de compatibilidade entre a alvenaria e a estrutura também foi uma das principais causas do índice de perda para a areia, também associado à falta de 
proteção contra a ação das chuvas na armazenagem, além da falta de proteção lateral, o que possibilitava a "contaminação" com outros materiais.

No que diz respeito aos tijolos, notou-se que os meios de transporte deste material eram inadequados, ocasionando quebras, principalmente no local de descarregamento, em função de o mesmo ser feito manualmente, constituindose numa operação monótona que conduz ao descaso no manuseio do material. Com relação ao armazenamento, verificaram-se alguns desmoronamentos das pilhas em face da instabilidade das mesmas.

\subsection{ENSHASSI (1996)}

Este autor procedeu um estudo em 86 canteiros de obras, localizados na Faixa de Gaza, Israel, baseado nos conceitos sobre perdas de materiais preconizados por SKOYLES (1978) e, apesar de o trabalho escrito não apresentar detalhes, deduz se que este autor aplicou a mesma metodologia desenvolvida por SKOYLES.

As perdas de aço e tijolos foram avaliadas no decorrer do desenvolvimento dos serviços nos canteiros de obras e calculadas através da comparação entre os materiais entregues no mesmo e aqueles efetivamente utilizados nos serviços para os quais foram solicitados.

Seguindo a classificação proposta por SKOYLES (1978), o autor apresenta os resultados tanto para as perdas diretas quanto para as indiretas, conforme a Tabela 3.13. 
Tabela 3.13 Índices de perdas: estudo de 86 canteiros de obras (ENSHASSI, 1996) $^{55}$

\begin{tabular}{l|c|c|c|c}
\hline Material & $\begin{array}{c}\text { Perda direta } \\
(\%)\end{array}$ & $\begin{array}{c}\text { Perda indireta } \\
(\%)\end{array}$ & Total (\%) & $\begin{array}{c}\text { Expectativa } \\
(\%)\end{array}$ \\
\hline Tijolos comuns & 3.2 & 2.0 & 5.2 & 2 \\
\hline Tijolos à vista & 4.9 & 2.2 & 7.1 & 3 \\
\hline Barras de aço & 2.1 & 1.5 & 3.6 & 2 \\
\hline
\end{tabular}

O autor concluiu que os resultados apresentados demonstram que a parcela de perda direta é maior do que a indireta. Da mesma forma, verificou que o total de perdas obtido para estes materiais é superior às expectativas usuais.

\subsection{LIRA (1997)}

Este autor realizou um estudo qualitativo sobre perdas de materiais e componentes, utilizados no serviço de alvenaria, em 15 canteiros de obras de edifícios multi-familiares, localizados na Grande João Pessoa - PB, entre os meses de Novembro/95 e Março/96.

O enfoque do trabalho consistia em detectar as causas e as conseqüências das perdas de materiais neste serviço e não a quantificação de tais perdas de materiais.

${ }^{55} \mathrm{O}$ artigo não explicita se os valores em \% dizem respeito a comparações físicas ou fina nceiras, dentro do serviço específico ou com relação à obra em geral. No entanto, acredita-se que os mesmos se referem a comparações financeiras. 


\subsubsection{Metodologia}

O caminho delineado pelo autor consistiu, primeiramente, no estabelecimento do universo dentro do qual a pesquisa seria conduzida. Através de consultas junto ao Conselho Regional de Engenharia, Arquitetura e Agronomia - CREA e à Prefeitura Municipal de João Pessoa - PMJP, constatou a maior incidência de execução de edifícios multi-familiares de até 4 pavimentos.

Definidas as características das obras a ser estudadas, optou por aquelas mais facilmente acessíveis dentre as que possuíam serviço em quantidade expressiva prevista para o período de coleta.

Para a pesquisa de campo propriamente dita, o autor elaborou dois documentos distintos, sendo que o primeiro tratava-se de um questionário sobre informações relativas à empresa (caracterização, posturas quanto ao combate à ocorrência de perdas de materiais, entre outros aspectos), enquanto o segundo era constituído por um formulário que deveria ser preenchido pelo pesquisador no decorrer da execução do serviço.

De posse dos questionários preenchidos (o primeiro, através de entrevistam, e o segundo, através de observações feitas nos canteiros de obras), procedeu então a tabulação dos dados, cujos principais resultados e conclusões encontram-se na seqüência. 


\subsubsection{Resultados e conclusões}

Embora o autor tenha se proposto a estudar a alvenaria em três momentos distintos (início do serviço da alvenaria, durante o serviço de instalações prediais e durante a fase de revestimentos interno e externo), a apresentação dos resultados não contempla tal distinção.

Através dos resultados apresentados na Tabela 3.14, pode-se constatar o baixo nível de consciência dos empresários locais quanto às atitudes nos canteiros de obras, que poderiam minimizar a ocorrência de perdas.

\section{Tabela 3.14 Levantamento quanto às situações vigentes nas obras baseado em (LIRA, 1997)}

\begin{tabular}{|c|c|c|c|}
\hline Item observado & Alternativas & $\begin{array}{c}\text { No. } \\
\text { Absoluto }\end{array}$ & (\%) \\
\hline \multicolumn{4}{|c|}{ RECEBIMENTO } \\
\hline \multirow[t]{2}{*}{ Critério para compra de material } & Prazo/qualidade & 1 & 7 \\
\hline & Menor preço & 14 & 93 \\
\hline \multirow{2}{*}{$\begin{array}{l}\text { Existência de procedimentos/critérios para } \\
\text { aceitação dos materiais }\end{array}$} & Inspeção por amostragem & 8 & 53 \\
\hline & Sem inspeção & 7 & 47 \\
\hline \multirow[t]{2}{*}{ Aceitação de sacos de cimento rasgados } & Não aceitam & 6 & 40 \\
\hline & Aceitam & 9 & 60 \\
\hline \multirow{2}{*}{$\begin{array}{l}\text { Conferência entre a quantidade entregue e a } \\
\text { solicitada }\end{array}$} & Fazem conferência & 0 & 0 \\
\hline & Não fazem conferência & 15 & 100 \\
\hline \multirow[t]{2}{*}{ Forma de descarregamento dos materiais } & Manual & 15 & 100 \\
\hline & Outra (sem ser manual) & 0 & 0 \\
\hline \multirow{2}{*}{$\begin{array}{l}\text { Controle de entrada e saída do material do } \\
\text { estoque }\end{array}$} & Com controle & 0 & 0 \\
\hline & Sem controle & 15 & 100 \\
\hline
\end{tabular}


Tabela 3.14 Levantamento quanto às situações vigentes nas obras baseado em (LIRA, 1997) - continuação

\begin{tabular}{|c|c|c|c|}
\hline Item observado & Alternativas & $\begin{array}{c}\text { No. } \\
\text { Absoluto }\end{array}$ & (\%) \\
\hline \multicolumn{4}{|c|}{ ESTOCAGEM } \\
\hline \multirow[t]{2}{*}{ Estoque de tijolos a céu aberto } & Sim & 15 & 100 \\
\hline & Não & 0 & 0 \\
\hline \multirow{2}{*}{$\begin{array}{l}\text { Local de estocagem de cimento fechado e } \\
\text { protegido contra a umidade }\end{array}$} & Sim & 7 & 47 \\
\hline & Não & 8 & 53 \\
\hline \multirow[t]{2}{*}{ Areia estocada em local aberto } & Sim & 13 & 87 \\
\hline & Não & 2 & 13 \\
\hline \multicolumn{4}{|c|}{ PROCESSAMENTO INTERMEDIÁRIO } \\
\hline \multirow{2}{*}{$\begin{array}{l}\text { Definição do traço e propriedades da } \\
\text { argamassa }\end{array}$} & Empiricamente & 11 & 73 \\
\hline & Em laboratório & 4 & 27 \\
\hline \multirow[t]{2}{*}{ Dosagem em volume } & Sim & 15 & 100 \\
\hline & Não & 0 & 0 \\
\hline \multicolumn{4}{|c|}{ APLICAÇÃO } \\
\hline \multirow{2}{*}{$\begin{array}{l}\text { Definição da espessura das juntas } \\
\text { argamassadas }\end{array}$} & Com definição & 1 & 7 \\
\hline & Sob responsabilidade do pedreiro & 14 & 93 \\
\hline \multirow[t]{2}{*}{ Utilização de junta vertical argamassada } & Sim & 15 & 100 \\
\hline & não & 0 & 0 \\
\hline \multirow[t]{2}{*}{ Equipamento de aplicação da argamassa } & Colher de pedreiro & 15 & 100 \\
\hline & Outro & 0 & 0 \\
\hline
\end{tabular}

Em face dos resultados resumidos na Tabela 3.14, o autor tece alguns comentários e conclusões, obtidos através da realização desta pesquisa.

Embora seja de grande importância o andamento dos serviços nos canteiros de obras, principalmente no que diz respeito aos atrasos na entrega e entrega de materiais fora de padronização, as empresas não possuíam uma sistemática 
de controle, haja vista, por exemplo, que em nenhuma das empresas pesquisadas fez -se a conferência entre a quantidade entregue e a solicitada.

Esta inexistência de controle é corroborada pelo fato de que nenhuma das empresas havia feito qualquer estimativa de perdas em seus empreendimentos, não havendo, portanto, uma mínima noção de seus índices.

Da mesma forma, o autor aponta algumas incoerências detectadas ao se comparar as respostas dadas pelos gerentes e a realidade constatada nos canteiros de obras. Pode-se citar, por exemplo, o descaso com o recebimento e estocagem dos materiais, ausência de controle de qualidade no recebimento, a falta de treinamento do pessoal e o não-reaproveitamento dos materiais, detectados através das observações em canteiros, em contradição às respostas dadas pelos gerentes quanto a estes aspectos.

Estas conclusões, de uma forma geral, indicam que os empresários participantes da pesquisa não têm a real noção dos benefícios advindos a partir da redução das perdas de materiais, principalmente num mercado cada vez mais competitivo.

\subsection{BOGADO (1998)}

O trabalho realizado por este autor consistiu na análise da produtividade da mão-de-obra e das perdas de materiais num edifício destinado a famílias de baixa renda, constitu ído por 8 andares, possuindo 10 apartamentos por andar, totalizando uma área de $5.064 \mathrm{~m}^{2}$, localizado na cidade de Encarnación Paraguai. 
No que diz respeito especificamente aos materiais analisados, o autor estudou as perdas dos materiais básicos (cimento, areia, pedra) utilizados na produção de concreto para a estrutura de concreto armado e tijolos cerâmicos utilizados no serviço de alvenaria.

Estava previsto, no escopo inicial do trabalho, o estudo das perdas de aço. No entanto, este estudo foi descartado em função de o aço ter sido utilizado simultaneamente em outros locais, como a fundação de outro módulo da edificação, o que dificultou o seu controle.

O trabalho desenvolvido teve um cunho prático à medida que, uma vez detectada a ocorrência de perdas ou a baixa produtividade, realizava-se a intervenção, sem a indução da necessidade de mudanças significativas da tecnologia empregada, com o objetivo de melhorar o desempenho detectado.

Em função de ser um estudo de caso, o próprio autor alerta que os resultados obtidos não podem ser generalizados.

\subsubsection{Metodologia}

De uma forma geral, a condução da pesquisa deu-se em 2 etapas: a primeira foi destinada ao levantamento do desempenho quanto ao uso dos materiais e da mão-de-obra nos serviços de alvenaria e estrutura de concreto para, em seguida, realizar-se intervenções voltadas à melhoria do desempenho detectado; a segunda fase inicia-se após a implantação das soluções minimizadoras do desperdício e para o aumento da produtividade, onde realiza- 
se novamente a coleta de dados no sentido de se avaliar a melhoria do desempenho em função da intervenção realizada.

No que diz respeito à coleta de dados sobre as perdas de materiais propriamente dita, o autor utiliza os mesmos princípios propostos originalmente por SKOYLES (1978) e apresentados em maiores detalhes por SANTOS et al. (1996), onde o índice de perda é calculado de acordo com a seguinte expressão:

$$
\operatorname{Iperdas}(\%)=\left(\frac{\text { Creal }- \text { Cteor }}{\text { Cteor }}\right) \times 100
$$

onde,

$$
\begin{array}{ll}
\text { Creal }= & \text { Madq+Mest }(v i)-\operatorname{Mest}(v f) \\
\text { Madq }= & \text { quantidade de material adquirida entre as datas vi e vf, } \\
& \begin{array}{l}
\text { levantada através de notas fiscais referentes ao material } \\
\text { comprado no período }
\end{array} \\
\text { Mest }(v i)= & \text { quantidade de material existente no estoque na data vi } \\
\text { Mest }(v f)= & \text { quantidade de material existente no estoque na data } v f \\
\text { Cteor }= & C_{\text {unit }} x Q s e r v \\
C_{\text {unit }}= & \text { quantidade de material necessária para a execução de } \\
\text { Qserv } & \text { uma unidade de serviço } \\
& \text { quantidade de serviço executada }
\end{array}
$$


Os resultados sobre perdas de materiais e produtividade eram disponibilizados mensalmente para a empresa sendo que, além destes, eram contempladas também as sugestões para a melhoria do desempenho quanto ao uso dos materiais e produtividade da mão-de-obra. Além dos números em si, fazia-se também um registro fotográfico das situações prejudiciais ao melhor desempenho, que servia de grande utilidade na conscientização da necessidade da melhoria.

Além do cálculo dos índices, o autor elaborou uma lista de verificação, que abrange aspectos relacionados à segurança, organização da produção, armazenamento e movimentação de materiais, entre outros aspectos.

\subsubsection{Principais resultados e conclusões}

Apesar de o autor propor que as avaliações fossem feitas mensalmente, o mesmo apresenta periodicamente apenas os dados relativos aos materiais utilizados na estrutura de concreto armado, enquanto que, para o estudo do material tijolo cerâmico no serviço de alvenaria, apresenta apenas um único valor, provavelmente relativo ao período total de coleta de dados no canteiro de obras.

A Tabela 3.15 reúne os consumos dos materiais verificados na execução da estrutura de concreto. A partir deles, o autor traçou gráficos de desempenho indicando as principais melhorias implantadas no sentido de se reduzir estes consumos (Figuras 3.2, 3.3 e 3.4). 
Tabela 3.15 Consumo ocorrido de materiais - Estrutura de concreto armado (BOGADO, 1998)

\begin{tabular}{l|c|c|c|c|c|c|c|c|c}
\hline Laje/módulo56 & 1M1 & 2M1 & 3M1 & 1M2 & 4M1 & 2M2 & 5M1 & 3M2 & MÉDIA \\
\hline Concreto $\left(\mathrm{m}^{3}\right)$ & 51 & 51 & 51 & 45 & 51 & 45 & 51 & 45 & 49 \\
\hline $\begin{array}{l}\text { Cimento }\left(\mathrm{kg} / \mathrm{m}^{3} \text { de }\right. \\
\text { concreto })\end{array}$ & 345 & 334,5 & 332,5 & 342 & 318,5 & 331 & 312 & 309 & 328,1 \\
\hline $\begin{array}{l}\text { Areia }\left(\mathrm{m}^{3} / \mathrm{m}^{3} \text { de }\right. \\
\text { concreto })\end{array}$ & 0,69 & 0,69 & 0,73 & 0,82 & 0,78 & 0,83 & 0,69 & 0,68 & 0,74 \\
\hline $\begin{array}{l}\text { Pedra }\left(\mathrm{t} / \mathrm{m}^{3} \text { de }\right. \\
\text { concreto })\end{array}$ & 1,37 & 1,37 & 1,38 & 1,43 & 1,37 & 1,30 & 1,24 & 1,20 & 1,33 \\
\hline
\end{tabular}
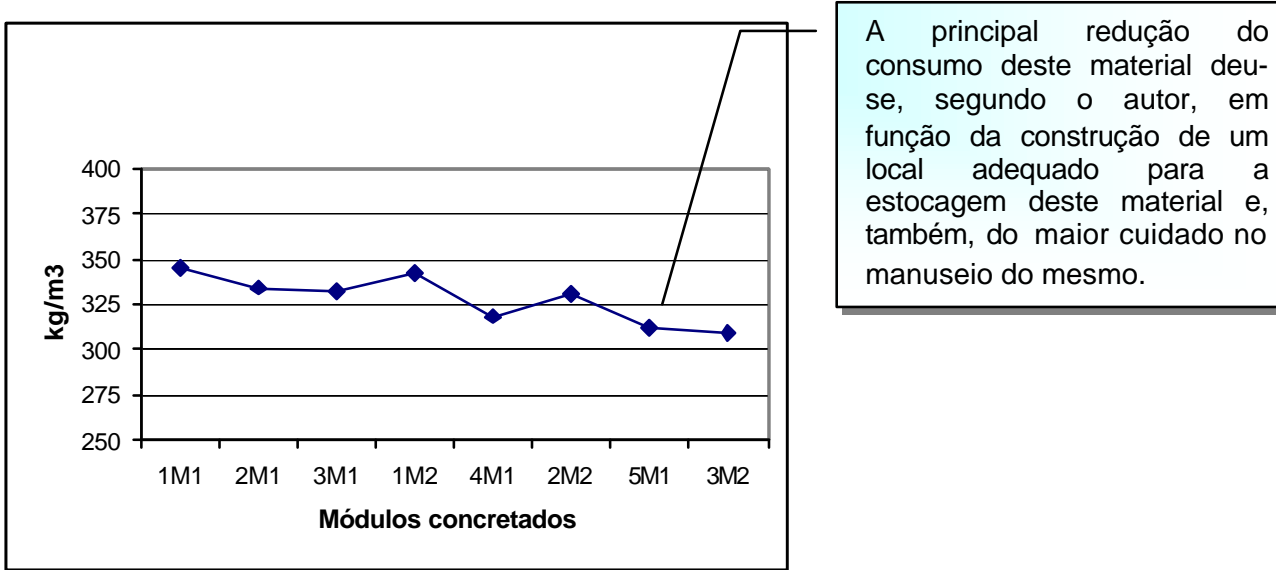
consumo deste material deuse, segundo o autor, em função da construção de um local adequado para a estocagem deste material $e$, também, do maior cuidado no manuseio do mesmo.

$\begin{array}{ll}\text { Figura } 3.2 & \text { Consumo de cimento } / \mathrm{m}^{3} \text { de concreto produzido para } \\ \text { estrutura de concreto armado - BOGADO (1998) }\end{array}$

${ }^{56} \mathrm{O}$ texto sugere que a laje de um mesmo pavimento possa ser considerada a soma de módulos (partes menores da mesma). 


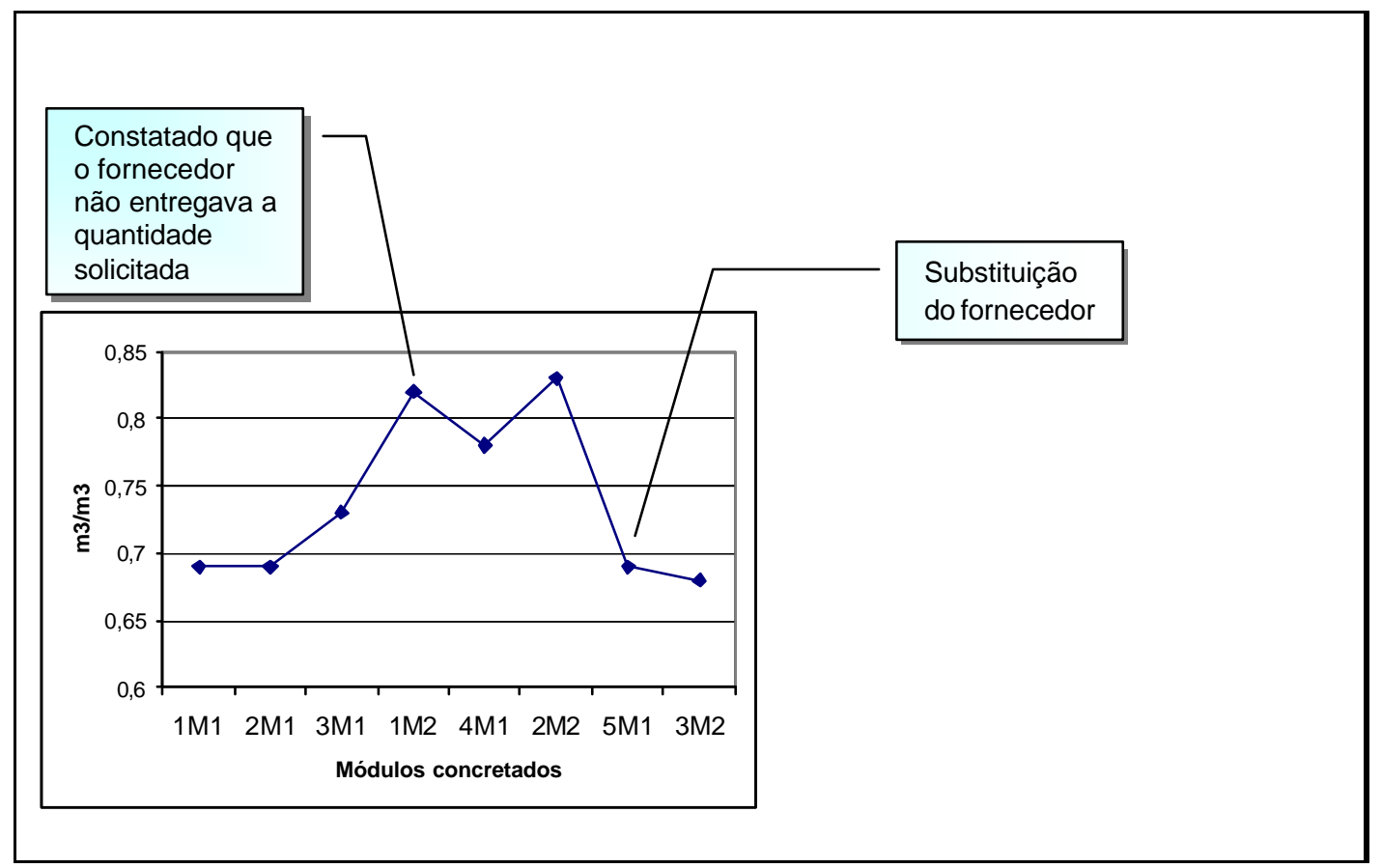

Figura 3.3 Consumo de areia $/ \mathrm{m}^{3}$ de concreto produzido para estrutura de concreto armado - BOGADO (1998)

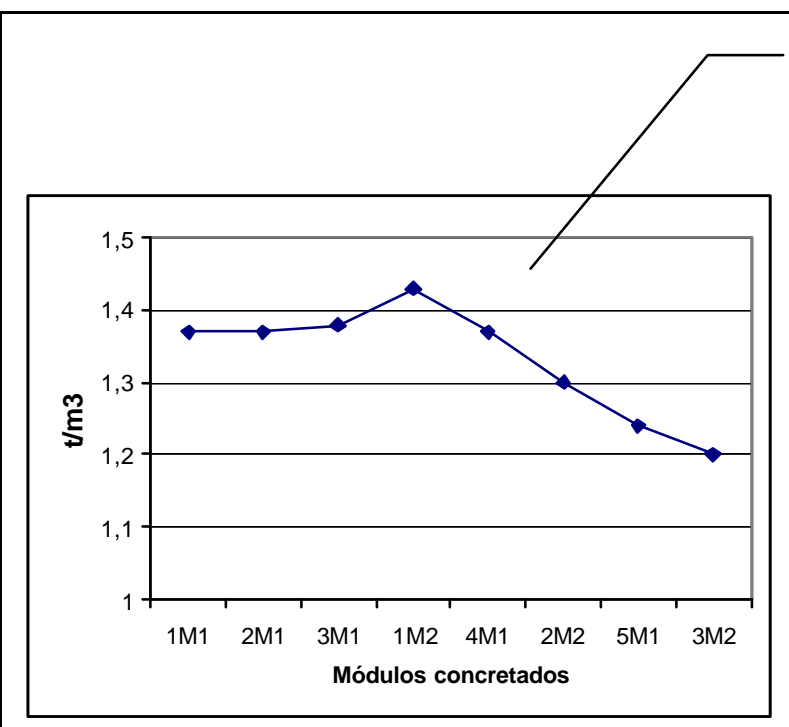

Descarregamento da brita num único local e solicitação de acordo

com a necessidade

Figura 3.4 Consumo de pedra/m3 de concreto produzido para estrutura de concreto armado - BOGADO (1998) 
Ao se comparar os consumos apresentados na Tabela 3.15 aos consumos teoricamente previstos, chega-se aos índices de perdas apresentados na Tabela 3.16.

\section{Tabela 3.16 Índices de perdas de materiais - Estrutura de concreto armado (BOGADO, 1998)}

\begin{tabular}{l|c|c|c|c|c|c|c|c|c}
\hline Laje/módulo & 1M1 & 2M1 & 3M1 & 1M2 & 4M1 & 2M2 & 5M1 & 3M2 & MÉDIA \\
\hline Cimento & 30 & 42 & 41 & 44 & 36 & 40 & 34 & 33 & 39 \\
\hline Pedra & 24 & 24 & 25 & 29 & 24 & 18 & 13 & 10 & 21 \\
\hline
\end{tabular}

Observação:

$$
\begin{aligned}
\text { Consumos de referência }^{57}: & \text { cimento }=255 \mathrm{~kg} / \mathrm{m}^{3} \\
\text { Pedra } & =1,08 \mathrm{t} / \mathrm{m}^{3}
\end{aligned}
$$

No que diz respeito aos resultados para os tijolos cerâmicos, a perda detectada foi de $13 \%$ (2.753 unidades).

Segundo o autor, a perda deste material poderia ser maior se não fosse o fato de a intervenção ter sido realizada no início da coleta de dados, independentemente de se ter números preliminares, conforme ocorreu para a estrutura de concreto. Como principais caminhos no sentido de minimizar estas perdas, o autor cita a introdução do meio tijolo, no sentido de evitar os cortes dos inteiros no acerto da modulação, e melhoria no sistema de transporte com a introdução de carrinhos adequados ao mesmo.

\footnotetext{
57 Já descontada a parcela de perdas embutida no orçamento: cimento $=15 \%$ e brita $=10 \%$
} 


\subsection{MCDONALD \& SMITHERS (1998)}

Estes autores realizaram um estudo sobre a geração de entulho nos canteiros de obras de dois conjuntos de edifícios construídos na cidade de Melbourne Austrália, destinados aos Sistemas Judiciário e Policial, constituídos por 2 pavimentos e mais 1 subsolo.

Embora não relatem a tipologia construtiva adotada, segundo os autores, os edifícios são similares, diferindo apenas quanto à área de construção, a qual totalizava $10.600 \mathrm{~m}^{2}$ em um dos conjuntos e alcançava um valor $28 \%$ inferior no outro.

Tal estudo foi motivado pela necessidade imposta pela legislação local de se reduzir em $50 \%$ a oferta de resíduos sólidos para os aterros sanitários até o ano 2.000. Sendo o entulho de construção civil um dos constituintes destes resíduos sólidos, a divisão australiana de uma Companhia Multinacional de Construção Civil, apoiada pelo Victorian Recycling and Resource Recovery Council, resolveu introduzir um programa de gerenciamento do entulho gerado nestes canteiros de obras, sob sua responsabilidade. $O$ intuito era 0 de minimizar a geração de entulho na origem, assim como maximizar a reciclagem do mesmo e a reutilização dos materiais reciclados, contribuindo, assim, para a redução do entulho destinado aos aterros sanitários.

A abordagem do assunto, no entanto, difere quanto aos dois canteiros de obras. Enquanto, em um deles, procurou-se implantar este programa de gerenciamento, visando alcançar os objetivos já descritos, no outro, realizou-se 
apenas a quantificação do entulho total gerado. Assim, pôde-se perceber os benefícios advindos deste programa de gerenciamento ao se comparar os desempenhos entre os dois canteiros de obras analisados.

\subsubsection{Metodologia}

Partindo-se da definição de que o entulho de construção civil envolve "todos os subprodutos gerados e removidos durante a fase de construção de novas construções, manutenção e demolição de edificações" (HONG KONG POLYTECHNIC, 1993) apud MCDONALD \& SMITHERS (1998), os autores traçaram uma estratégia no sentido de reduzir a geração de entulho e maximizar sua reciclagem, no âmbito apenas do canteiro de obras, ou seja, durante o desenvolvimento das atividades de execução de novas construções.

Para isso, inicialmente realizou-se um levantamento sobre as possibilidades de geração de entulho através da análise dos projetos, assim como o potencial de reciclagem e reutilização do material reciclado, com base em experiências de empreendimentos anteriormente realizados e na disponibilidade local de usinas de reciclagem.

Após este levantamento, partiu-se para a identificação das possibilidades de melhorias a ser efetuadas no canteiro de obras, no sentido de minimizar a ocorrência de entulho.

O passo seguinte consistiu na avaliação dos custos de remoção do entulho junto às empresas que prestam este tipo de serviço. Através deste conjunto de ações foi possível a quantificação de todo o volume de entulho gerado em um 
dos canteiros de obras. Tal valor pôde ser discriminado por tipo de material, bem como estimou-se a percentagem destinada à reciclagem e a enviada ao aterro sanitário local. Para isso foram instalados contêineres específicos para a destinação deste entulho gerado. No outro canteiro de obras similar, conforme ressaltado anteriormente, realizou-se apenas o levantamento do entulho total gerado, não havendo, portanto, a preocupação em se implementar todo este conjunto de ações.

\subsubsection{Principais resulta dos e conclusões}

A Tabela 3.17 reúne os resultados obtidos para o canteiro onde se efetuou o programa de gerenciamento do entulho. Segundo os autores, de acordo com esta Tabela, os painéis de gesso acartonado, a madeira, as embalagens (papel e papelão) e o entulho em geral, foram os materiais mais representativos em termos de volume gerado. Destes materiais mais representativos, a grande geração de entulho de painéis de gesso acartonado deve-se à falta de modulação entre as dimensões dos painéis e as dimensões dos vãos onde foram empregados tais painéis, ocasionando a necessidade de cortes adicionais e, conseqüentemente, a geração de sobras. No que diz respeito à madeira, a maior parte foi originária do sistema de fôrmas, o qual foi descartado ao final da estrutura. Destes materiais mais representativos, as embalagens foram as que tiveram maior percentagem de reciclagem em relação aos outros materiais. Isso deve-se ao fato de as usinas locais não estarem equipadas para a reciclagem da madeira e dos painéis de gesso 
acartonados. Quanto a este último material, o produto reciclado foi destinado à agricultura.

Tabela 3.17 Índices de entulho - Complexo de edifícios Dandenong MCDONALD \& SMITHERS (1998)

\begin{tabular}{|c|c|c|c|c|}
\hline \multirow[t]{2}{*}{ Material } & \multicolumn{2}{|c|}{ Destino } & \multirow[t]{2}{*}{ Total $\left(\mathrm{m}^{3}\right)$} & \multirow{2}{*}{$\begin{array}{c}\% \text { quanto ao } \\
\text { total de } \\
\text { entulho }\end{array}$} \\
\hline & $\begin{array}{c}\text { Reciclado } \\
\left(\mathrm{m}^{3}\right)\end{array}$ & $\begin{array}{c}\text { Aterro } \\
\text { sanitário }\left(\mathrm{m}^{3}\right)\end{array}$ & & \\
\hline Aço & 75,7 & - & 75,7 & 8,5 \\
\hline Outros metais & 8,8 & - & 8,8 & 1,0 \\
\hline Vidro & 3,5 & - & 3,5 & 0,4 \\
\hline Papel & 11,0 & - & 11,0 & 1,2 \\
\hline Concreto & 48,0 & 11,6 & 59,6 & 6,7 \\
\hline Jornal e papelão & 118,5 & 31,6 & 150,1 & 17,0 \\
\hline Painéis de gesso acartonado & 12,0 & 161,4 & 173,4 & 19,6 \\
\hline Plásticos & 5,0 & 55,7 & 60,7 & 6,9 \\
\hline Isolante térmico & 8,0 & 18,7 & 26,7 & 3,0 \\
\hline Madeira & 21,5 & 101,6 & 123,1 & 13,8 \\
\hline Entulho em geral & - & 134,9 & 134,9 & 15,2 \\
\hline Revestimento têxtil & - & 59,5 & 59,5 & 6,7 \\
\hline Total $\left(\mathrm{m}^{3}\right)$ & 311,9 & 575,0 & 887,0 & 100,0 \\
\hline Total (\%) & 35,2 & 64.8 & 100,0 & - \\
\hline
\end{tabular}

Além desta análise pormenorizada, os autores compararam o montante de entulho gerado na obra monitorada (Complexo de Edifícios de Dandenong) com a outra obra similar, onde se avaliou apenas o montante total de entulho gerado (Complexo de Edifícios Frankston). 
Desta comparação, os autores chegaram a uma diferença de $12,5 \%$ entre os volumes gerados por área de construção, como pode ser visto na Tabela 3.18. Note que, apesar de o volume total de entulho gerado no canteiro do Complexo de Edifícios de Dandenong ser maior do que o gerado no canteiro do Complexo de Edifícios de Frankston, ao se considerar o volume gerado por área de construção, a situação se inverte, o que comprova o sucesso da implantação do programa de gerenciamento do entulho.

Outra diferença significativa diz respeito à percentagem de materiais reciclados, que mostrou-se bem superior para o canteiro de obras onde se implantou o programa de gerenciamento de entulho, conforme esta mesma Tabela.

Tabela 3.18 Comparação entre os dados de entulho gerado nos dois canteiros analisados - MCDONALD \& SMITHERS (1998)

\begin{tabular}{l|c|c}
\hline Descrição & Dandenong & Frankston \\
\hline Área de construção $\left(\mathrm{m}^{2}\right)$ & 10600 & 8271 \\
\hline Total de entulho gerado $\left(\mathrm{m}^{3}\right)$ & 887 & 788 \\
\hline Entulho destinado aos aterros sanitários $\left(\mathrm{m}^{3}\right)$ & 575 & 786 \\
\hline Entulho destinado à reciclagem $(\%)$ & 35,0 & 1,5 \\
\hline Entulho gerado por área de construção $\left(\mathrm{m}^{3} / \mathrm{m}^{2}\right)$ & 0,084 & 0,096 \\
\hline
\end{tabular}

Ao se fazer comparações com trabalhos da mesma natureza, os autores observaram que as taxas de entulho por área de construção $\left(\mathrm{m}^{3} / \mathrm{m}^{2}\right)$ obtidas para os dois edifícios em questão mostraram-se próximas da obtida no estudo 
realizado pela HONG KONG POLYTECHNIC (1993), que variou entre 0,07 $\mathrm{m}^{3} / \mathrm{m}^{2}$ a $0,15 \mathrm{~m}^{3} / \mathrm{m}^{2}$, com média de $0,10 \mathrm{~m}^{3} / \mathrm{m}^{2}$.

Apesar de não relatarem as melhorias implementadas com a finalidade de redução do entulho, os autores indicaram que medidas simples, sem uma mudança radical nas atuais práticas de construção, contribuíram significativamente para esta redução.

Da mesma forma, os autores citam o grau de integração com as usinas de reciclagem como um aspecto importante para o sucesso da implementação deste programa de gerenciamento de entulho. Além disso, os autores atribuem a economia gerada pela implantação deste programa a alguns fatores favoráveis como, por exemplo, o menor custo de remoção do entulho destinado às usinas em comparação aos custos de remoção para os aterros sanitários, visto que as usinas localizavam-se mais próximas dos canteiros de obras do que os aterros sanitários (os autores apontam uma redução de $20 \%$ nos custos de transporte). Citam ainda, que as taxas cobradas pelos gerenciadores dos aterros sanitários, para a deposição do entulho, eram maiores que as cobradas pelas usinas de reciclagem.

\subsection{Análise das principais pesquisas apresentadas}

Procurou-se, até o momento, apresentar de forma sucinta as principais pesquisas realizadas no país e no exterior, com o intuito de se balizar o desenvolvimento da metodologia proposta. 
Como forma de enriquecer o conteúdo até então apresentado, torna-se importante apontar as principais diferenças entre cada pesquisa realizada, assim como avaliar alguns aspectos considerados de extrema importância e que, conseqüentemente, devem estar contemplados na metodologia proposta.

\subsubsection{Comparações gerais}

A análise comparativa entre as pesquisas realizadas permite identificar um contexto diferenciado quanto a alguns aspectos, embora tenha havido um objetivo comum: a mensuração das perdas e a identificação das suas causas e origens.

Esta diferenciação surge na gama de materiais e obras estudados, a qual parcela de perdas físicas de materiais o estudo se refere (incorporada e entulho ou apenas uma isoladamente), à estratégia de atuação (avaliação ou avaliação/intervenção), entre outros aspectos. Some-se a estas diferenças o fato de que, dentre estes trabalhos, alguns tiveram a questão das perdas de materiais como tema central, enquanto outros a abordaram apenas como complemento de outro assunto. A Tabela 3.19 reúne as principais diferenças que, de uma forma ou de outra, refletem o grau de profundidade e diversidade com que o assunto foi tratado pelos autores. 
Tabela 3.19 Principais diferenças detectadas entre as pesquisas realizadas

\begin{tabular}{|c|c|c|c|c|c|c|}
\hline Pesquisas & $\begin{array}{l}\text { No. de } \\
\text { obras }\end{array}$ & $\begin{array}{c}\text { No. de } \\
\text { materiais }\end{array}$ & $\begin{array}{l}\text { Parcela de perdas } \\
\text { físicas estudada }\end{array}$ & Tipo de abordagem & Tipo de avaliação & $\begin{array}{c}\text { Tema central = perdas } \\
\text { de materiais }\end{array}$ \\
\hline SKOYLES; SKOYLES (década de 60) & 114 & 22 & Entulho & Avaliação & Quantitativa & SIM \\
\hline PINTO (1989) & 1 & 10 & Incorporada e entulho & Avaliação & Quantitativa & SIM \\
\hline HONG KONG POLYTECHNIC (1993) & 13 & 8 & Entulho & Avaliação & Quantitativa & SIM \\
\hline SOIBELMAN (1993) & 5 & 7 & Incorporada e entulho & Avaliação & Quantitativa & SIM \\
\hline PICCHI (1993) & 3 & - & Incorporada e entulho & Avaliação & Quantitativa & NÃO \\
\hline SANTOS (1995) & 1 & 4 & Incorporada e entulho & Avaliação/intervenção & Quantitativa & NÃO \\
\hline ENSHASSI (1996) & 86 & 4 & Incorporada e entulho & Avaliação & Quantitativa & SIM \\
\hline LIRA (1997) & 15 & - & - & Avaliação & Qualitativa & SIM \\
\hline BOGADO (1998) & 1 & 4 & Incorporada e entulho & Avaliação/intervenção & Quantitativa & NÃO \\
\hline MCDONALD; SMITHERS (1998) & 2 & 8 & Entulho & Avaliação/intervenção & Quantitativa & SIM \\
\hline
\end{tabular}


Embora esta análise preliminar indique estas diferenças, pode-se identificar também a consolidação de uma idéia comum para a quantificação das perdas de materiais nos canteiros de obras: a comparação entre a quantidade de material efetivamente utilizada no canteiro de obras e a quantidade de material teoricamente necessária, isenta de parcelas de perdas já embutidas, inicialmente preconizada por SKOYLES (1976) e melhor detalhada por PINTO (1989) e SOIBELMAN (1993).

E, partindo-se desta definição, no que diz respeito às perdas físicas de materiais, identificam-se também duas parcelas de perdas: uma referente aos materiais que ficam incorporados no local de aplicação e outra referente aos materiais que se transformam em entulho, conforme já discutido no capítulo 2.

No entanto, embora se reconheça esta classificação, em alguns trabalhos realizados verificou-se a não distinção da parcela de perdas representada pela incorporação do material na edificação. Enquadram-se nesta situação os trabalhos realizados pela HONG KONG POLYTECHNIC (1993) e por BOGADO (1998).

No primeiro destes trabalhos, os autores assumem a diferença entre a quantidade adquirida e a quantidade teoricamente necessária ou prevista no projeto como sendo totalmente relativa ao entulho. Da mesma forma, assumem índices de entulho para os demais materiais presentes no escopo da pesquisa, baseados em suas experiências pessoais, face à dificuldade em se obtê-los para estes materiais da mesma forma que para o concreto pois, ao contrário 
deste, a execução dos serviços que os utilizam é feita simultaneamente em vários pavimentos, exigindo um controle mais efetivo ${ }^{58}$.

Note, no entanto, que apesar desta incoerência, os números levantados por estes autores encontram-se próximos dos levantados por PICCHI (1993) no Brasil e por MCDONALD; SMITHERS (1998) na Austrália.

Quanto ao segundo trabalho citado, o autor concentra boa parte das suas discussões nas perdas ocorridas nas etapas de recebimento e estocagem dos materiais, omitindo, no caso do concreto, as perdas oriundas da variação dimensional dos elementos estruturais (pilares, vigas e, principalmente, lajes). Este fato é ressaltado pelo tipo de intervenções propostas e realizadas pelo autor, claramente focadas nas duas etapas supracitadas.

Ainda com relação a estas duas parcelas de perdas, há que se ressaltar também que, apesar de não negligenciar a parcela de material que fica incorporada na edificação no desenvolvimento do raciocínio relativo à conceituação de perdas de materiais, SKOYLES (1976) divulga apenas os resultados relativos ao entulho gerado. Portanto, um cuidado adicional deve ser tomado ao se comparar os resultados divulgados por este autor com os apresentados, por exemplo, por PINTO (1989) e por SOIBELMAN (1993).

Um outro aspecto importante a ser observado refere -se à forma através da qual os indicadores de perda foram calculados. A este respeito, pode-se identificar uma diferença significativa, que consiste no valor utilizado no denominador das

\footnotetext{
${ }^{58}$ Note que o estudo das perdas de concreto usinado na estrutura é facilitada pelo fato de se ter um ciclo de produção bem definido e pelo fato de o material ser direcionado apenas para este serviço, o que não acontece com o estudo da argamassa no serviço de alvenaria, por exemplo.
} 
equações de cálculo. Enquanto SKOYLES (1976) e ENSHASSI (1996) utilizam a quantidade de material adquirido no denominador, PINTO (1989) e SOIBELMAN (1993) consideram a quantidade teoricamente necessária. A título de ilustração, considere o exemplo de um estudo de perdas de blocos no serviço de alvenaria, onde a quantidade de material efetivamente utilizada, ou seja, a quantidade adquirida $(Q A)$, foi de 150 unidades, enquanto que a quantidade teoricamente necessária $($ QTM ) era de 100 unidades. Os resultados do cálculo do indicador de perda (IP), considerando os dois procedimentos, são apresentados na Tabela 3.20.

Tabela 3.20 Diferenças no cálculo do indicador de perdas

\begin{tabular}{c|c}
\hline SKOYLES (1978); ENSHASSI (1996) & PINTO (1989); SOIBELMAN (1993) \\
\hline$I P=\left[\frac{Q A-Q T P}{Q A}\right] x 100$ & $I P=\left[\frac{Q A-Q T P}{Q T P}\right] x 100$ \\
$I P=\left[\frac{150-100}{150}\right] x 100$ & $I P=\left[\frac{150-100}{100}\right] x 100$ \\
\hline$I P=33,3 \%$ & $I P=50,0 \%$ \\
\hline
\end{tabular}

De acordo com este exemplo, verifica-se que o procedimento adotado por SKOYLES (1976) e por ENSHASSI (1996) é mais conservador do que o utilizado por PINTO (1989) e por SOIBELMAN (1993).

Não menos importante do que todos estes aspectos colocados até o momento, inserem-se também a discussão quanto às fontes de consulta utilizadas na adoção do referencial teórico que, conforme descrito no capítulo 2, podem ser 
diversas. Dentre os trabalhos que se valeram desta idéia (comparação entre uma situação real e uma de referência), identificam-se diferentes fontes, conforme a Tabela 3.21.

\section{Tabela 3.21 Fontes de consulta utilizadas nas pesquisas realizadas}

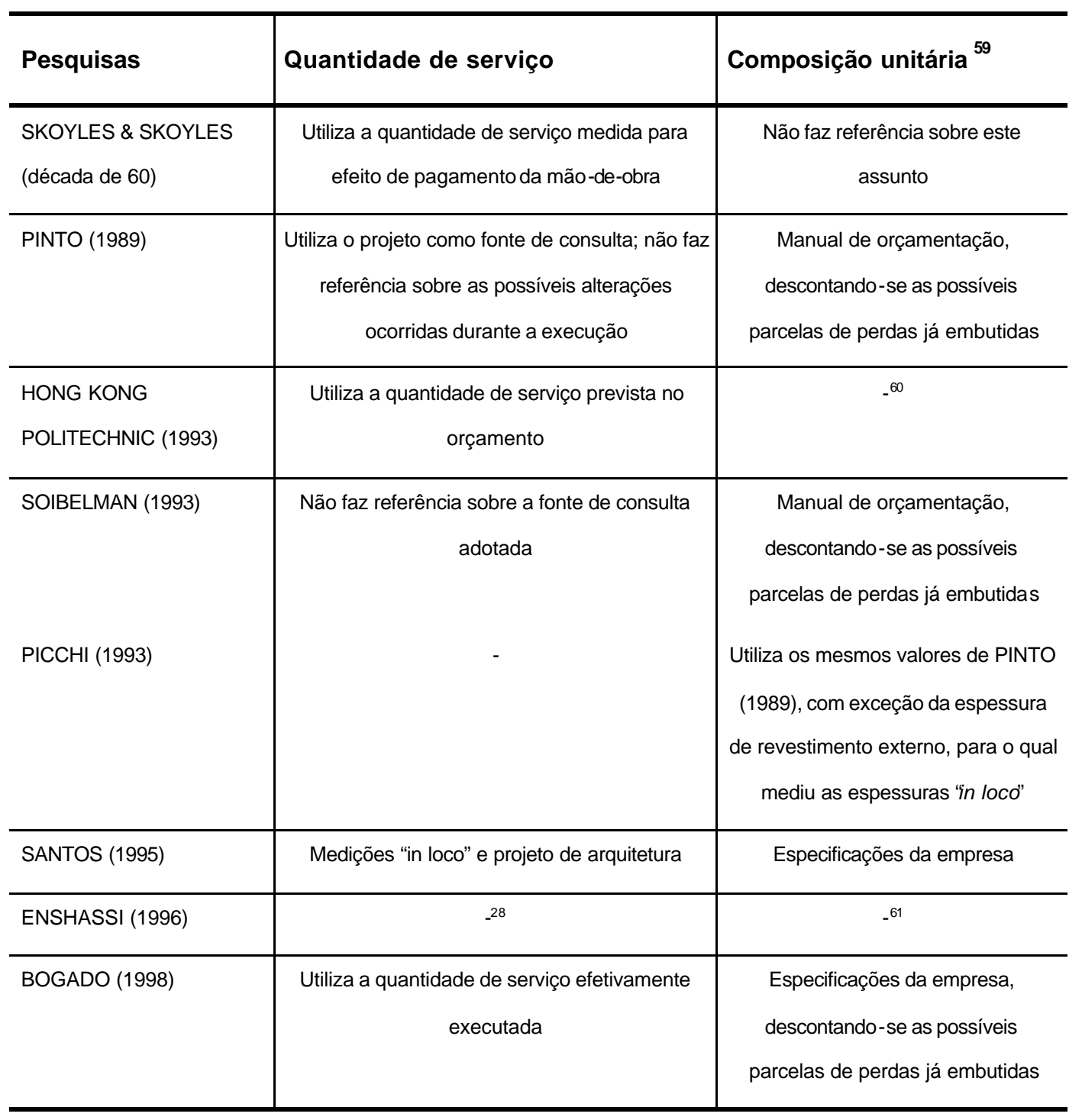

${ }^{59}$ A composição unitária diz respeito ao consumo de material por unidade de serviço.

${ }^{60}$ Quanto a este aspecto, só estudou o concreto usinado, para o qual a composição unitária é $1 \mathrm{~m}^{3} / \mathrm{m}^{3}$.

${ }^{61}$ Acredita-se ter usado as mesmas definições de SKOYLES \& SKOYLES (1987). 
No que diz respeito à avaliação das perdas físicas de materiais nos canteiros de obras, torna-se interessante utilizar a quantidade efetivamente recebida. No entanto, naqueles trabalhos cujo detalhamento permite a identificação deste aspecto, verificou-se a utilização da quantidade de material paga. De acordo com esta postura, assume-se que a quantidade paga equivale à quantidade recebida, o que na prática pode não ser verdade, principalmente naqueles casos onde o fornecedor não é idôneo.

Por fim, pode-se ainda estabelecer as diferenças no que diz respeito à abrangência do estudo de cada serviço. Enquanto alguns procederam a análise das perdas na obra ou serviço como um todo, outros as avaliaram em apenas uma fração do período de tempo relativo à execução do serviço, conforme indicado na Tabela 3.22.

Tabela 3.22 Parcela de serviço avaliado nas pe squisas apresentadas

\begin{tabular}{l|c}
\hline Pesquisas & Parcela de serviço avaliado \\
\hline SKOYLES \& SKOYLES (década de 60) & Totalidade \\
\hline PINTO (1989) & Totalidade \\
\hline HONG KONG POLYTECHNIC (1993) & Fração \\
SOIBELMAN (1993) & Fração \\
\hline SANTOS (1995) & Fração \\
\hline ENSHASSI (1996) & Totalidade ${ }^{\complement 2}$ \\
\hline BOGADO (1998) & Fração \\
\hline
\end{tabular}

62 Embora não esteja explicitamente descrito no artigo de referência, acredita-se ter usado as mesmas definições de SKOYLES \& SKOYLES (1987). 


\subsubsection{As principais lacunas identificadas}

Da mesma forma que pode-se identificar as principais diferenças entre as pesquisas apresentadas, pode-se identificar também alguns aspectos que não foram suficientemente detalhados ou apresentados pelos autores, considerados de extrema importância para a garantia da padronização na aplicação da metodologia proposta, no que diz respeito às etapas de coleta, processamento e análise dos resultados.

Sendo assim, com o propósito de se alcançar os objetivos propostos neste trabalho, são enumeradas as principais lacunas verificadas, as quais serão apresentadas na seqüência e que deverão fazer parte da metodologia proposta no capítulo 6 .

\subsubsection{Procedimentos específicos de coleta, processamento e análise dos resultados}

Para a obtenção dos índices de perdas de materiais, há a necessidade de se levantar uma série de informações como, por exemplo, a quantidade de material estocado, a quantidade de material entregue num determinado período e a quantidade de serviço executada neste período. Para cada uma destas informações, como forma de se garantir a padronização da coleta, a existência de procedimentos detalhados específicos contendo critérios de medição, tornase um aspecto indispensável. Dentre os trabalhos apresentados, detectou-se procedimentos de coleta de dados apenas no desenvolvido por SKOYLES (1978). Quanto ao processamento, os procedimentos resumiram-se apenas na apresentação da expressão para o cálculo das perdas. No que diz respeito à 
análise, não se detectou a existência explícita de diretrizes para a condução da mesma.

\subsubsection{Estruturação dos indicadores de perdas}

Nos trabalhos analisados, preponderou a ênfase no estabelecimento de indicadores que representam as perdas de materiais sob um enfoque não analítico, abrangendo conjuntamente todas as etapas percorridas pelo material. Isto aconteceu quanto à mensuração do entulho [HONG KONG POLYTECHNIC (1993); MCDONALD \& SMITHERS (1998)] e quanto às perdas totais [SKOYLES (1978), PINTO (1989), SOIBELMAN (1993), ENSHASSI (1996)]. Há, porém, a necessidade de se realizar um fracionamento destes indicadores globais em indicadores mais específicos, que representem as perdas de materiais em determinadas etapas (ou conjunto de etapas) que o material percorre até a sua aplicação final, possibilitando a identificação daquelas (ou daquela) onde a parcela de perda é mais significativa.

Poucos foram os trabalhos que abordaram esta questão no âmbito dos serviços, podendo-se citar o de BOGADO (1998) e o de LIRA (1997), sendo que este último, aborda a questão de forma qualitativa.

Um outro aspecto relativo à implantação de uma visão analítica das perdas diz respeito a se estudar um material dentro de um único serviço. SANTOS (1995) teve a intenção inicial de estudar as perdas de cimento e areia apenas no âmbito do serviço de alvenaria. No entanto, o autor teve que estender o escopo de seu trabalho também para outros serviços que estavam utilizando estes materiais simultaneamente. 
Sendo assim, em que pese as dificuldades a ser enfrentadas, justifica-se o estabelecimento de indicadores globais no âmbito dos serviços e não apenas no âmbito da obra, pelo fato de que, com esta abordagem, torna-se viável a comparação entre desempenhos de mesmos serviços realizados em obras diferentes, o que não é possível quando se estabelece apenas indicadores no âmbito da obra, principalmente em se tratando dos materiais básicos.

\subsubsection{Visão analítica do referencial teórico}

Conforme definido no capítulo 2, o conceito de perdas necessariamente deve estar associado a uma situação de referência e, portanto, a determinação desta referência deve se dar da forma mais transparente possível. Para isso, introduziu -se no capítulo 2 a idéia de se definir os valores de referência através de 3 variáveis a saber: $Q S, C M / Q S$ e $C M B / M C$.

Em nenhum dos trabalhos analisados verificou-se esta transparência na determinação dos valores de referência. Há que se ressaltar que foram utilizadas diversas fontes de consulta, como, por exemplo, manuais de orçamentação [PINTO (1989), SOIBELMAN (1993)], assim como valores adotados em normas técnicas [SANTOS (1995); BOGADO (1998)] ou ainda valores tomados da orçamentação ou da medição de serviços para efeito de pagamento (SKOYLES, 1976). Mas em nenhum destes casos, tem-se a possibilidade de fazer a referência refletir exatamente a especificação feita para cada obra em particular, fruto da tecnologia e gestão características do local em que está sendo executada. Isso torna-se extremamente crítico no caso de 
um estudo que queira analisar obras espalhadas por um território tão vasto, e com tantas diferenças regionais, quanto o Brasil.

Como exemplo, pode-se citar a diferença de especificação da espessura de revestimento em função da necessidade de se contemplar a resistência térmica necessária em determinadas regiões ou, ainda, a diferença de traços de argamassa para contrapiso.

Observe que, como será explicitado adiante, perda é um indicador que mostra o maior ou menor alcance de um objetivo pré-definido. Neste contexto, um cálculo de indicador de perdas só tem sentido se for definida como referência, a situação especificada para a obra em estudo.

\subsubsection{Estabelecimento de indicadores de consumo}

Em face das diversas possibilidades de referenciais teóricos a ser adotados que, em outras palavras, interferem nos resultados de perdas, torna-se interessante o estabelecimento de indicadores de consumo. Enquanto os de perdas medem o quanto o desempenho de um material se distanciou de uma situação de referência, conforme já citado, os de consumo medem o quanto se consumiu de material por unidade de serviço executada, representando um parâmetro de avaliação de produtividade no uso dos materiais.

Reforçando a necessidade do estabelecimento destes indicadores de consumo, tome como exemplo duas situações apresentadas na Tabela 3.23 para o caso da execução de certo revestimento em argamassa. 
Tabela 3.23 Exemplo sobre a necessidade do estabelecimento de indicadores de consumo para os materiais básicos

\begin{tabular}{c|c|c|c|c|c|c}
\hline Obra & $\begin{array}{c}\text { Espessura } \\
\text { especificada } \\
(\mathbf{c m})\end{array}$ & $\begin{array}{c}\text { Espessura } \\
\text { realizada } \\
(\mathbf{c m})\end{array}$ & $\begin{array}{c}\text { Consumo de } \\
\text { cimento (traço } \\
\text { especificado) } \\
\mathbf{( k g / \mathbf { m } ^ { 3 } )}\end{array}$ & $\begin{array}{c}\text { Consumo de } \\
\text { cimento (traço } \\
\text { realizado) } \\
\left(\mathbf{k g} / \mathbf{m}^{3}\right)\end{array}$ & Perda (\%) & $\begin{array}{c}\text { Consumo } \\
\mathbf{( k g / \mathbf { m } ^ { 2 } )}\end{array}$ \\
\hline A & 2 & 3 & 250 & 250 & 50,0 & 7,5 \\
\hline B & 3 & 4 & 280 & 280 & 33,3 & 11,2 \\
\hline
\end{tabular}

De acordo com esta Tabela, verifica-se que, apesar de a perda detectada no serviço realizado na obra $A$ ser maior do que a detectada no serviço realizado na obra B, o quadro inverte -se ao analisar-se os indicadores de consumo, indicando, portanto, a importância do estabelecimento dos mesmos.

Dentre os trabalhos apresentados, esta postura foi observada timidamente apenas no trabalho realizado por BOGADO (1998).

\subsubsection{Caracterização tecnológica e gerencial dos serviços e especificação detalhada dos materiais}

Mais do que levantar números sobre as perdas, é importante ter-se clareza quanto ao contexto em que elas ocorrem. SKOYLES \& SKOYLES (1987) já levantavam esta questão, à medida que afirmavam que nos manuais de orçamentação utilizados não havia o correlacionamento entre os indicadores de perdas e os aspectos tecnológicos e/ou especificações dos materiais.

Além de enriquecer a análise dos resultados, no que diz respeito à investigação de alternativas para a redução das perdas de materiais, a elaboração de uma 
forma estruturada desta caracterização contribuirá significativamente para a padronização da coleta, processamento e análise dos resultados.

No que diz respeito, portanto, a este aspecto, não se verificou em nenhum dos trabalhos apresentados esta sistematização. 


\section{CAṔ́TLL 4}

\section{IDENTIFCANDO AS PERDASE CONSUMOS FÍSICOS DE MATERIAIS NOS CANTEROS DE OBRAS}

Este capítulo é dedicado ao entendimento dos consumos e das perdas físicas dos materiais nos canteiros de obras. Para isso, discorre-se sobre as possibilidades de ocorrências das perdas de materiais no âmbito dos serviços onde os mesmos são consumidos, com base na consulta dos resultados das pesquisas até então desenvolvidas.

Além desta consulta, o presente capítulo está fortemente fundamentado na experiência com o setor produtivo, adquirida no transcorrer do desenvolvimento deste trabalho ${ }^{63}$, e nas principais normas nacionais e bibliografias que tratam das "práticas" de organização do canteiro de obras e de execução dos serviços propriamente dita.

\subsection{A investigação das perdas físicas de materiais nos canteiros de obras}

De acordo com o c apítulo 2, o conceito de perdas adotado neste trabalho está

${ }^{63}$ Embora tenha sido de grande importância esta experiência, não se estará incluindo neste capítulo, os principais resultados e conclusões obtidos no âmbito da Pesquisa realizada através da aplicação da metodologia proposta neste trabalho. Estes res ultados e conclusões estão reunidos no anexo B. 
associada à diferença entre a quantidade de material efetivamente utilizada num serviço (ou na obra) e a quantidade de material teoricamente necessária (ou especificada), definida pela multip licação entre 3 variáveis: quantidade de serviço (QS), consumo de material por unidade de serviço (CM/QS) e consumo de material básico por material composto $(C M B / M C)$. Relembre que esta última variável existe apenas para o caso dos materiais básicos, como o cimento, cal, areia, saibro e pedra.

A diferença entre o consumo real e o teoricamente necessário compreende duas parcelas: uma na forma de material incorporado e outra na forma de entulho. Quanto à parcela de perda incorporada, a investigação sobre a ocorrência de perdas de materiais nos canteiros de obras pode ser feita de uma forma global, envolvendo as variáveis $Q S, C M / Q S$ e $C M B / M C$ ou, ainda, de uma forma específica, ou seja, considerando cada uma isoladamente.

Para exemplificar a dinâmica deste raciocńio, tome como exemplo o estudo das perdas do cimento, um dos constituintes da argamassa utilizada no serviço de assentamento de alvenaria. A Figura 4.1 traz uma representação, tanto da situação de referência quanto da situação na qual a alvenaria foi reamente executada, onde identificam-se as possibilidades de ocorrência do sobreconsumo da argamassa e, conseqüentemente, do cimento, através da comparação entre estas duas situações.

No que diz respeito às perdas devido à variação da quantidade de serviço (QS), estas podem ser traduzidas pelos metros de juntas adicionais gerados pela área de alvenaria executada em quantidade superior à especificada, em 
função dos erros de locação da primeira fiada, incompatibilidade entre a alvenaria e as dimensões dos caixihos, entre outros aspectos.

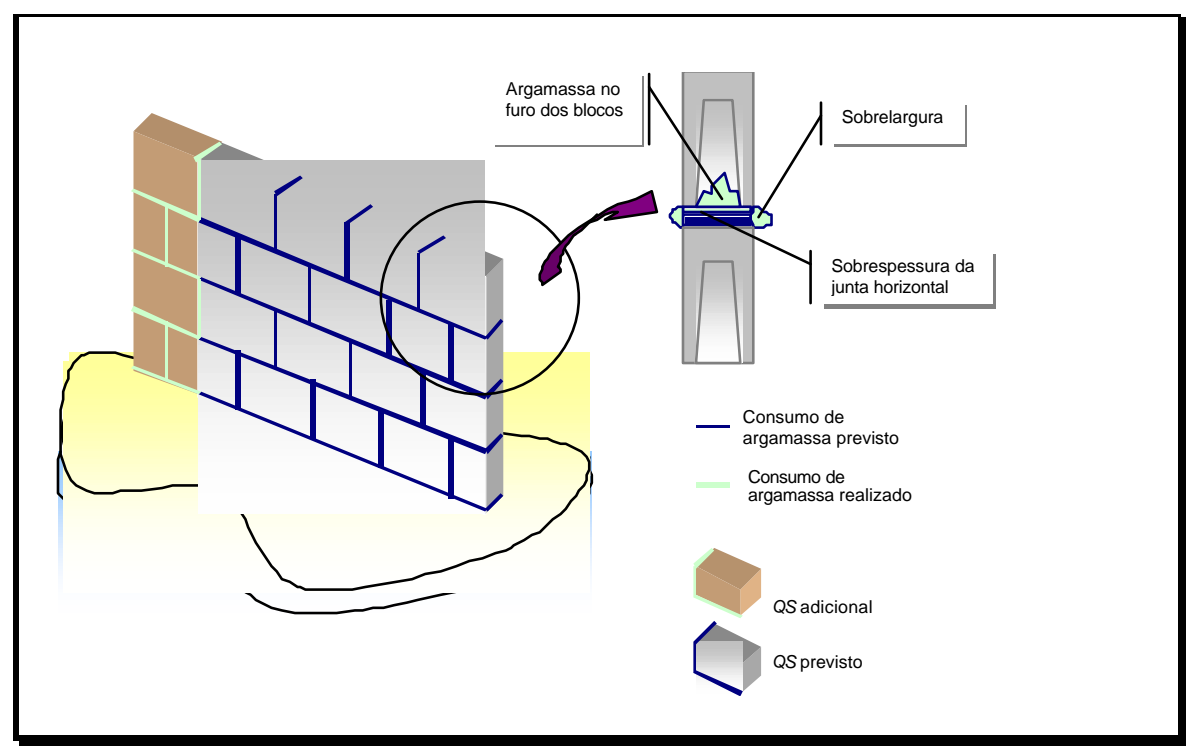

Figura 4.1 Comparação entre a situação real e a de referência-perda de cimento (material básico) na alvenaria

Com relação às perdas devido à variação do $C M / Q S$, estas podem ser representadas pela sobrelargura e/ou sobrespessura das juntas de assentamento horizontais e/ou verticais, ou pela argamassa presente nos furos dos blocos.

Resta discorrer, então, sobre as perdas relacionadas à variação do $C M B / M C$, que podem ser caracterizadas pelo maior consumo de cimento por $\mathrm{m}^{3}$ de argamassa produzida, em função da inexistência, por exemplo, da dosagem racional dos materiais (equipamentos de dosagem pré-definidos e perfeitamente identificados, existência de tabelas de traços, entre outros aspectos). 
Quanto à parcela das perdas representadas pelo entulho, esta pode ser gerada de diversas formas, como por exemplo, quebras de componentes, retrabalhos, sobras de material ao final da jornada diária, entre outros.

Ressalta-se ainda que, além dos materiais que se transformaram em produto final ou entulho, pode ainda haver uma perda relativa a se ter recebido uma quantidade de material inferior a que teoricamente deveria ter chegado ao canteiro.

Percebe-se, então, que as perdas de materiais não estão totalmente relacionadas à aplicação final dos mesmos. Isso significa dizer que a simples comparação entre a situação idealizada e a situação real não reflete a totalidade das perdas nos canteiros de obras, havendo, portanto, a necessidade de se estender a análise para além da etapa de aplicação final dos materiais.

Para se perceber mais claramente aonde as perdas ou sobreconsumos podem estar ocorrendo, utiliza-se um instrumento comumente empregado na Engenharia de Produção, denominado fluxograma dos processos.

\subsection{O fluxograma dos processos como instrumento de investigação das perdas físicas de materiais nos canteiros de obras}

No âmbito da atividade produtiva, ANTUNES JÚNIOR (1994), baseado no Sistema Toyota de Produção proposto por SHIGEO SHINGO, entende a produção, seja ela de produtos ou serviços, como sendo uma rede de processos e operações. Enquanto as operações dizem respeito ao fluxo do 
sujeito do trabalho (pessoas, equipamentos e ferramentas), os processos se referem ao fluxo do objeto do trabalho (materiais).

Assim, de acordo com SHINGO (1981) apud ANTUNES JÚNIOR (1994), os processos podem ser definidos como sendo "fluxo de materiais para os produtos, que modifica-se de acordo com o curso simultâneo do tempo e do espaço".

Analisando o fluxo dos materiais nos canteiros de obras, percebe-se que os mesmos passam por diversas etapas até chegarem ao destino final, ou seja, são recebidos e inspecionados, estocados, processados e, por fim, aplicados, sendo que entre cada etapa os mesmos são transportados.

Ao levantamento de todas estas etapas de um serviço em estudo, além da representação do relacionamento entre elas, denomina-se fluxograma dos processos, o qual constitui-se numa ferramenta importante para o entendimento e análise das perdas de materiais nos canteiros de obras (SOUZA, 1997).

A representação do fluxograma segue um conjunto de símbolos próprio, originalmente desenvolvida por FRANK e LILLIAN GILBRETH e, posteriormente, modificada por duas comissões da AMERICAN SOCIETY OF MECHANICAL ENGINEERS - ASME (MUTLER, 1978). Estes símbolos estão ilustrados na Figura 4.2, enquanto que um exemplo de aplicação é apresentado na Figura 4.3. 


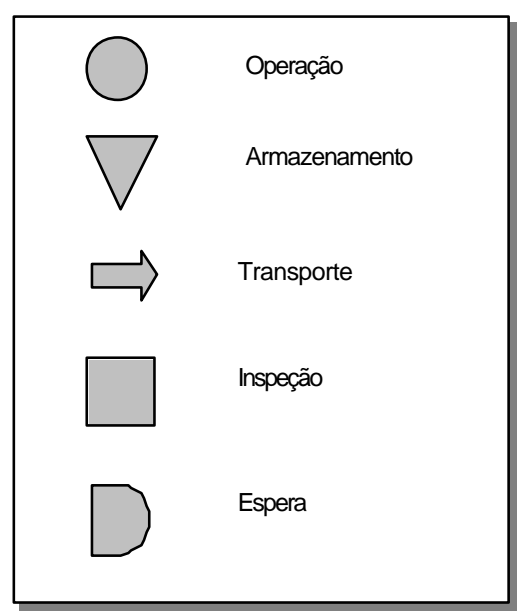

Figura 4.2 Símbolos adotados na elaboração do fluxograma dos processos (MUTLER, 1978)

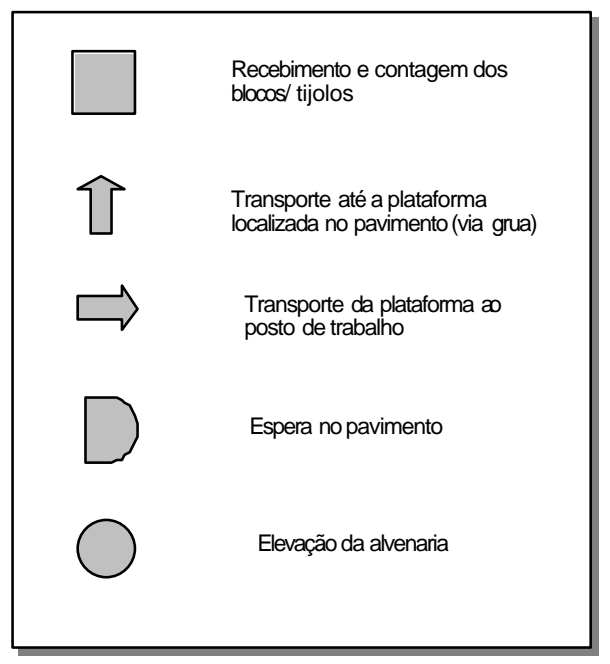

Figura 4.3 Exemplo de um fluxograma dos processos - blocos no serviço de alvenaria (GUEDERT, 1993)

Assim, voltando ao estudo do cimento no serviço de alvenaria, detecta-se que podem ocorrer perdas na etapa de recebimento (traduzida, por exemplo, pela diferença entre a quantidade solicitada e a entregue); na etapa de estocagem, sob a forma de cimento descartado em razão de o processo de hidratação já iniciado pela ação da umidade; na etapa de processamento intermediário, na 
forma de consumo superior ao especificado em função da variação do traço; na etapa de transporte, na forma de argamassa derramada ao longo do trajeto e, finalmente, na etapa de aplicação final do material, conforme já discutido anteriormente.

Note ainda que, dependendo do material analisado, algumas destas etapas podem ser suprimidas, como é o caso do aço comprado, cortado e dobrado. Neste caso, há a eliminação da etapa de processamento intermediário (corte e dobra), que é feito pelo próprio fornecedor.

Por outro lado, o aumento do número de etapas também pode ocorrer como, por exemplo, no caso da inserção de mais uma etapa de estocagem e transporte devido à estocagem inicial não ser feita no local definitivo quando da entrega de agregado, em função da inexistência da previsão de acesso do equipamento de transporte externo ao canteiro de obras.

\subsection{As perdas físicas de materiais ao longo do fluxograma dos processos}

Conhecidas as etapas nas quais as perdas de materiais podem ocorrer, tornase interessante discorrer sobre como as mesmas acontecem ao longo destas etapas e, neste sentido, para cada material num determinado serviço procurouse abordar as possibilidades de ocorrência de perdas. Para uma mesma etapa genérica do fluxograma dos processos, as perdas podem ser mais ou menos significativas, em função do tipo de material em estudo. Como exemplo, podese citar o fato de que é praticamente nula a ocorrência de perdas de 
eletrodutos na etapa de transporte quando comparada à ocorrência de perdas de argamassas nesta etapa.

Neste sentido, com o intuito de delimitar a análise, a Tabela 4.1 traz, para cada material num determinado serviço, a indicação das etapas do fluxograma dos processos há uma maior possibilidade de ocorrência de perdas ${ }^{64}$.

\section{Tabela 4.1 As possibilidades de ocorrência de perdas de materiais de} acordo com o fluxograma dos processos

\begin{tabular}{|c|c|c|c|c|c|}
\hline Material & Recebimento & Estocagem & $\begin{array}{c}\text { Processamento } \\
\text { intermediário }\end{array}$ & Aplicação & Transporte \\
\hline Areia & & & & - & - \\
\hline Pedra & & & & - & - \\
\hline Cimento & & & & - & - \\
\hline Cal & & & & - & \\
\hline Argamassa obra & - & - & & & $\square$ \\
\hline Concreto obra & - & - & & & $\Rightarrow$ \\
\hline Concreto usinado & & & & & \\
\hline Aço & & & & & $\Rightarrow$ \\
\hline Blocos/tijolos & & & & & $\square$ \\
\hline Placas cerâmicas & & & & & $\square$ \\
\hline Eletrodutos & & & & & $\square$ \\
\hline
\end{tabular}

${ }^{64}$ Evidentemente, para a confecção desta Tabela não foi considerada a ocorrência de perdas por roubo ou vandalismo, e sim, procurourse abordar questões relativas à produção da edificação. 
Tabela 4.1 As possibilidades de ocorrência de perdas de materiais de acordo com o fluxograma dos processos (continuação)

\begin{tabular}{|c|c|c|c|c|c|}
\hline Material & Recebimento & Estocagem & $\begin{array}{c}\text { Processamento } \\
\text { intermediário }\end{array}$ & Aplicação & Transporte \\
\hline Condutores & & & & & $\Rightarrow$ \\
\hline Tubos & & & & & $\square$ \\
\hline Tintas & & & & & $\Rightarrow$ \\
\hline Gesso & & & & & $\Rightarrow$ \\
\hline
\end{tabular}

Legenda: símbolos hachurados indicam a probabilidade de ocorrência de perdas enquanto os não hachurados indicam o contrário. $O$ traço indica que o material em análise não passa pela respectiva etapa do fluxograma dos processos.

Observação: alguns materiais (eletrodutos, por exemplo), podem passar pela etapa de processamento intermediário (produção de kit, por exemplo), ou ser utilizados sem a necessidade deste processamento intermediário

\subsubsection{As perdas na etapa de recebimento}

É na etapa de recebimento dos materiais que é feita a comparação entre o que foi especificado e o que foi entregue.

Tanto as especificações, quanto os procedimentos e critérios para a aceitação dos materiais nos canteiros de obras, podem ser regulamentados pelas normas da Associação Brasileira de Normas Técnicas - ABNT, especificamente as do tipo EB (Especificação Brasileira) ou por outras normas, por exemplo, nascidas internamente à empresa. 
A não observância destes procedimentos e critérios estabelecidos pelas normas técnicas pode acarretar problemas durante a execução ou até mesmo na etapa de uso e manutenção, através da modificação do consumo do material ou da manifestação de problemas patológicos. Como exemplos, podem-se citar o maior consumo de cimento por $\mathrm{m}^{3}$ de argamassa produzida, devido ao fato de a areia recebida estar com granulometria distinta da preconizada, e o aparecimento de fissuras no revestimentos devido à hidratação retardada do óxido de magnésio presente na cal utilizada para tal finalidade $^{65}$ (CINCOTTO, 1989). No caso deste último exemplo, tal problema patológico pode gerar um acréscimo de consumo de material ao se ter, eventualmente, que trocar o revestimento.

Se não bastasse esta indução de perdas ao longo da execução da edificação, ou até mesmo após a sua conclusão, no que diz respeito especificamente às perdas ocorridas na etapa de recebimento, estas são representadas pela diferença entre a quantidade solicitada e a quantidade, em condições de uso, efetivamente recebida no canteiro de obras.

As causas para esta ocorrência podem ser diversas, envolvendo desde a idoneidade do fornecedor, a qualidade intrínseca do material, até mesmo as condições de transporte externo.

É comum, por exemplo, verificar em cidades de relevo íngreme, concreto usinado caído no leito das ruas. Da mesma forma, para aqueles materiais

${ }^{65}$ A NBR 7175 (ABNT, 1992) impõe o limite de 10\% para o teor de óxidos não-hidratados (CaO e MgO) para o caso da cal $\mathrm{CH}$ I e $15 \%$ para o caso da cal $\mathrm{CH}$ III; note, ainda, que este problema poderia ser eliminado caso se procedesse a produção da argamassa intermediária para, posteriormente, passar à produção da argamassa definitiva, após um período de "descanso" para que as reações de hidratação dos óxidos pudessem ocorrer. 
frágeis, como blocos, placas cerâmicas ou ainda telhas, o acondicionamento inadequado deste materiais nos equipamentos de transporte, associado às condições de trajeto desfavoráveis, podem ocasionar a quebra dos mesmos que, se não for detectada no ato do recebimento, pode constituir-se numa perda para a empresa construtora.

Note ainda que, em se tratando dos materiais ensacados, como é o caso do cimento, cal e gesso, por exemplo, além da possibilidade de perdas em função do transporte e manuseio incorretos na etapa de recebimento (Figura 4.4), há ainda a possibilidade de que a massa real dos sacos não esteja de acordo com a nominal. A esse respeito, as normas da $A B N T^{66}$ estabelecem um limite de $2 \%$ para esta variação, tanto para mais quanto para menos.

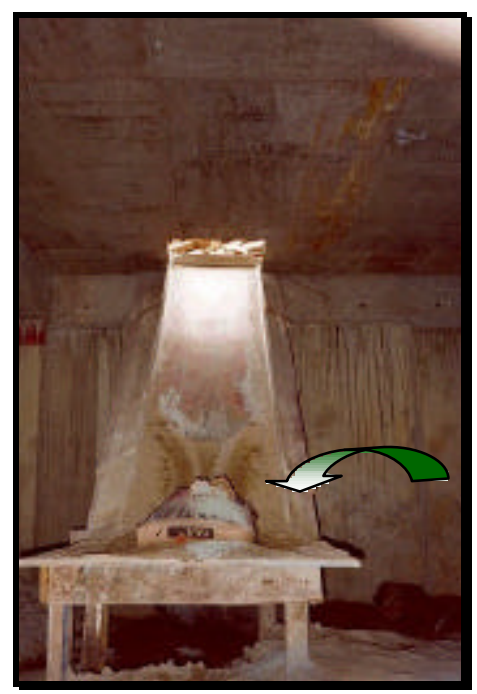

Figura 4.4 Exemplo de perda de cimento durante a etapa de recebimento: material perdido devido ao rasgamento do saco no descarregamento (Foto cedida por Antonio Neves. de Carvalho Jr.)

${ }^{66}$ Maiores detalhes podem ser vistos nas seguintes normas: NBR 13207 (ABNT, 1994) para o gesso; NBR 13281 (ABNT, 1995) para a argamassa industrializada; NBR 7175 (ABNT, 1992) para a cal hidratada; em se tratando do cimento, este assunto é tratado nas várias normas existentes de acordo com o tipo de cada um. 
Uma outra questão particular quanto à ocorrência de perdas no recebimento está relacionada ao aço pois, enquanto a utilização do mesmo envolve

medidas lineares, a compra é feita em massa, podendo haver maior cons umo de aço devido ao comumente denominado "desbitolamento", ou seja, a massa linear das barras pode ser maior do que a nominal, acarretando, assim, menor comprimento para uma mesma massa.

A NBR 7480 (ABNT, 1996) que trata deste assunto, tem como limites para esta variação os valores de $\pm 6 \%$ (para diâmetro nominal igual ou superior a $10 \mathrm{~mm}$ ) e $\pm 10 \%$ (para diâmetro nominal inferior a $10 \mathrm{~mm}$ ). Isto significa dizer que, caso a massa linear do aço adquirido esteja próxima ao patamar superior prescrito nesta norma, a empresa poderá estar assumindo uma perda na ordem de 6 ou $10 \%$ sem que este material tenha sido efetivamente consumido na edificação.

Embora este "desbitolamento" seja mencionado como uma das causas da perda de aço [PINTO (1989), SOIBELMAN (1993)], em nenhuma das pesquisas realizadas foram apresentados números relativos a esta ocorrência.

Um outro aspecto, porém agora relacionado aos blocos e tijolos, diz respeito às possíveis variações dimensionais dos mesmos, o que, além de comprometer a modulação da alvenaria, pode ocasionar maior consumo de argamassa de assentamento ou revestimento ou, até mesmo, do próprio material, dependendo da magnitude desta variação dimensional.

DIAS (1995), avaliando, entre outros aspectos, a padronização dimensional dos blocos cerâmicos , constatou que 100\% dos componentes da amostra tinha, pelo menos, uma das dimensões fora da tolerância admitida pela NBR 7171 
(ABNT, 1992), enquanto que 63\% possuíam 2 dimensões fora dos padrões. Da mesma forma, $82 \%$ dos casos amostrados não atendiam às especificações no que diz respeito à planeza das faces, enquanto que $100 \%$ não atendiam ao quesito esquadro.

Para NEVES (1994), a falta de padronização das dimensões dos blocos cerâmicos pode levar a um acréscimo de $12 \%$ de argamassa de assentamento e $33 \%$ de argamassa de revestimento. A autora, avaliando as características físicas dos blocos cerâmicos da cidade de Salvador-BA, detectou diferenças significativas nas dimensões dos mesmos, assim como no esquadro e planeza das faces.

Com relação a estes obis últimos aspectos, enquanto a NBR 7171 (ABNT, 1992) estabelece uma tolerância de $3 \mathrm{~mm}$ de desvio em relação ao esquadro e à planeza das faces, o autor detectou valores máximos de 12,1 e 9,1 mm, respectivamente. Fazendo-se a média aritmética dos valores encontrados pela autora para a verificação da planeza das faces, chega-se a 5,6 mm e, tomando-se este valor como referência e adotando-se uma espessura prevista de revestimento de $15 \mathrm{~mm}$, chega-se aproximadamente ao valor apresentado pela autora com relação à perda de argamassa de revestimento.

Atentando para este aspecto, SOIBELMAN (1993) realizou esta verificação para os tijolos maciços e furados em seu estudo, encontrando variações significativas, tanto para mais quanto para menos. Estes valores, assim como os das demais avaliações sobre este assunto apresentadas neste item, estão reunidos na Tabela 4.2, onde são inseridos também os resultados obtidos por MERGULHÃO (1995) no Estado da Paraíba. 
Tabela 4.2 Variação dimensional de blocos e tijolos detectada

\begin{tabular}{|c|c|c|c|c|c|c|c|c|c|c|}
\hline \multirow[t]{2}{*}{ Autores } & \multirow[t]{2}{*}{ Componente } & \multicolumn{3}{|c|}{$\begin{array}{c}\text { Dimensões } \\
\text { nominais (cm) }\end{array}$} & \multicolumn{3}{|c|}{$\begin{array}{l}\text { Dimensões reais } \\
\qquad(\mathrm{cm})\end{array}$} & \multicolumn{3}{|c|}{ Diferença (\%) } \\
\hline & & C & $\mathbf{L}$ & H & c & $\mathbf{L}$ & H & C & $\mathbf{L}$ & H \\
\hline \multirow[t]{2}{*}{ SOIBELMAN (1993) } & Tijolo furado & 190 & 135 & 90 & 186,5 & 138,9 & 91,7 & $(1,9)$ & 2,9 & 1,9 \\
\hline & Tijolo maciço & 200 & 100 & 50 & 201,0 & 95,7 & 47,7 & 0,5 & $(4,3)$ & $(4,6)$ \\
\hline NEVES (1994) & Blocos ce râmicos & 190 & 90 & 190 & 188,0 & 86,6 & 152,8 & $(1,1)$ & $(3,8)$ & $(19,6)$ \\
\hline MERGULHÃO (1995) & Blocos cerâmicos & 190 & 90 & 190 & 181,8 & 88,2 & 171,0 & $(4,7)$ & $(2,0)$ & $(10,0)$ \\
\hline
\end{tabular}

Note ainda que, além da indução da perda de argamassa de revestimento, o fato de os blocos apresentarem menores dimensões do que as nominais acarreta, desde que não compensadas por um sobrespessamento da argamassa de assentamento, um consumo adicional de blocos para a execução da alvenaria. Este acréscimo pode ser significativo, conforme verificado na Tabela 4.3, sendo que, em alguns casos, os valores superam a expectativa de perda apresentada no TCPO $10(1996)^{67}$, sem que os componentes sejam propriamente utilizados para a execução da alvenaria. 
Tabela 4.3 Acréscimo de consumo de blocos/tijolos estimado por este autor em função da variação dimensional dos mesmos citada por outros autores

\begin{tabular}{c|l|c|c|c|c}
\hline \multicolumn{1}{c|}{ Autores } & Componente & $\begin{array}{c}\text { Dimensões } \\
\text { nominais } \\
{[\mathbf{C} \times \mathbf{~} \mathbf{x ~ H}](\mathbf{m m})}\end{array}$ & $\begin{array}{c}\text { Consumo } \\
\text { teórico }\left(\mathbf{u n} / \mathbf{m}^{2}\right)\end{array}$ & $\begin{array}{c}\text { Consumo } \\
\text { real }\left(\mathbf{u n} / \mathbf{m}^{2}\right)\end{array}$ & $\begin{array}{c}\text { Diferença } \\
(\%)\end{array}$ \\
\hline \multirow{2}{*}{ SOIBELMAN (1993) } & Tijolo furado & $190 \times 135 \times 90$ & 50,0 & 50.0 & 0,0 \\
\cline { 2 - 6 } & Tijolo maciço & $200 \times 100 \times 50$ & 79,4 & 82,1 & 3,4 \\
\hline NEVES (1994) & Blocos cerâmicos & $190 \times 90 \times 190$ & 25,0 & 31,0 & 24,0 \\
\hline MERGULHÃO (1995) & Blocos cerâmicos & $190 \times 90 \times 190$ & 25,0 & 28,8 & 15,2 \\
\hline
\end{tabular}

Além desta questão, não se pode negligenciar também a possibilidade de os blocos ser quebrados ao longo do transporte externo, sendo que este raciocínio pode ser também aplicado às placas cerâmicas e telhas.

Embora seja real a ocorrência de perdas nesta etapa, LIRA (1997) verificou em sua pesquisa que a preocupação com a quantidade e qualidade dos materiais entregues nos canteiros de obras locais (João Pessoa) ainda é incipiente, visto que, as 15 obras estudadas, em nenhuma se conferiu a quantidade entregue nos canteiros de obras, embora aproximadamente $50 \%$ destas empresas realizassem o controle qualitativo destes materiais. Tais constatações também foram citadas por SOIBELMAN (1993).

\subsubsection{As perdas na etapa de estocagem}

Não menos importante do que a etapa de recebimento dos materiais, a etapa de estocagem pode responder por uma significativa parcela das perdas totais

${ }^{67}$ O TCPO 10 (1996) traz uma expectativa, para os blocos e tijolos, entre 3 e 10\%. 
nos canteiros de obras, principalmente se não forem observadas algumas condições mínimas preconizadas por diversas bibliografias.

Para ENSHASSI (1996), a estocagem inadequada dos materiais nos canteiros de obras é uma das principais razões para a ocorrência das perdas de materiais.

Embora seja uma etapa potencialmente geradora de entulho, observa-se, em muitas obras um descaso quanto a mesma. Os construtores raramente estão atentos para as vantagens de se ter locais de estocagem adequados, organizados e previamente planejados (ENSHASSI, 1996). Para este autor, a estocagem dos materiais tem que estar relacionada com a seqüência de construção para garantir o mínimo de manuseio possível.

Da mesma forma, segundo SCARDOELLI et al. (1994), embora existam inúmeras recomendações presentes em normas técnicas e bibliografias específicas, e muitas destas recomendações sejam de baixo custo e dependam muito mais do bom senso dos profissionais envolvidos, as mesmas não são aplicadas na prática.

Ainda segundo estes autores, estas recomendações, além de proporcionar a redução das perdas de materiais, têm também efeito na melhoria do aspecto visual do canteiro de obras, assim como na redução do risco de acidentes de trabalho.

Sob esta ótica, a Norma Reguladora 18 da Secretaria de Segurança e Saúde no Trabalho do Ministério do Trabalho - NR 18 (1995), além de estabelecer diretrizes de ordem administrativa, de planejamento e de organização visando 
a segurança nos processos, tem diretrizes que contribuem para a redução das possibilidades de ocorrência de perdas de materiais nos canteiros de obras durante a estocagem dos mesmos.

Segundo esta norma, os materiais devem ser armazenados e estocados de forma que "não prejudiquem o trânsito de pessoas e de trabalhadores, a circulação de materiais, o acesso ao equipamentos de combate a incêndio (...)".

Da mesma forma, ainda segundo esta norma regulamentadora, esta estocagem deve ser feita de modo a propiciar a retirada dos materiais na seqüência de utilização planejada, sem prejudicar a estabilidade das pilhas. Alerta ainda para o fato de não se fazer o empilhamento dos materiais diretamente sobre piso instável, úmido ou desnivelado.

Além destas recomendações gerais, podem-se citar outras, de caráter mais específico quanto ao tipo de material envolvido, as quais são descritas na seqüência, para aqueles insumos sujeitos à perda nesta etapa.

\subsubsection{Agregados: areia, pedra; adições: saibro}

As perdas destes materiais nesta etapa podem dar-se, por exemplo, pela mistura dos mesmos entre si ou com o solo, impossibilitando a utilização ou interferindo no desempenho das argamassas e concretos produzidos. Além desta possibilidade, citam-se também as perdas decorrentes do carreamento destes materiais pela ação da água das chuvas, desde que não sejam 
respeitados alguns cuidados mínimos, como contenção lateral, cobertura, sistema de drenagem etc.

No sentido de se evitar tais ocorrências e, ao mesmo tempo, impor uma melhor organização da estocagem destes materiais nos canteiros de obras, a NBR 7200 (ABNT, 1998) prescreve que os agregados devem ser estocados em compartimentos separados, de acordo com a natureza e classificação granulométrica.

Da mesma forma, ainda segundo este projeto de norma, estes compartimentos (ou baias) devem conter um fundo inclinado e com possibilidades de drenagem, evitando também o contato dos materiais com o solo. As mesmas recomendações podem ser aplicadas também para as adições, sendo que as de natureza argilosa devem ser protegidas da chuva.

SOUZA et al. (1996) alertam ainda para a necessidade de se cobrir a areia em época de chuvas torrenciais, além de se planejar com antecedência o local destinado à estocagem dos agregados, evitando que a mesma ocorra em calçadas públicas ou em áreas que interfiram com o andamento dos outros serviços na obra.

A este respeito, SOUZA et al. (1997) apontam que a área de estocagem dos agregados deve ser diretamente acessível, quando possível, ao basculamento do caminhão. Recomendam ainda que a altura máxima do estoque seja ch ordem de 1,5 m, além de não aconselhar que o mesmo seja feito sobre as lajes. 
No que diz respeito aos trabalhos realizados, SOIBELMAN (1993) e LIRA (1997) detectaram condições favoráveis à ocorrência de perdas em função do desrespeito às boas práticas de estocagem de agregados. SOIBELMAN (1993), inclusive, relatou a ocorrência de perda de areia em função de a mesma ser carreada pela ação das chuvas.

\subsubsection{Aglomerantes: cimento, cal, gesso}

O principal cuidado com relação ao armazenamento do cimento diz respeito à hidratação precoce deste material, induzida pela presença de umidade. No sentido de se evitar a ação desta umidade, várias medidas devem ser tomadas como, por exemplo, a limitação da altura das pilhas deste material e a utilização do mesmo dentro do prazo de validade. Com relação a estes aspectos, a NBR 12655 (ABNT, 1996) prescreve que o cimento deve ser armazenado em pilhas de, no máximo, 15 sacos, durante período de armazenamento não superior a 15 dias, ou na altura de, no máximo, 10 sacos, quando for utilizado dentro de um período superior a este.

Além da preocupação em limitar a altura da pilha, que está relacionada à pressão exercida sobre os sacos localizados na porção inferior da mesma, induzindo à hidratação do cimento, a mesma norma recomenda que os sacos devam estar apoiados sobre estrado de madeira, a fim de se evitar que os mesmos entrem em contato direto como o piso, situação em que a umidade ascendente pode iniciar o processo de hidratação do cimento (SOUZA et al. 1996). Raciocínio semelhante induziria um afastamento com relação às paredes laterais do ambiente onde os sacos estão estocados. 
Além da umidade advinda do solo, SOUZA et al. (1996) alertam para possíveis goteiras e vazamentos não notados na cobertura. Ainda segundo os autores, em se tratando de obras localizadas em regiões litorâneas, recomenda-se uma proteção adicional contra a umidade através do uso de uma lona plástica.

Uma outra medida direcionada a evitar o processo de hidratação e a conseqüente inutilização do cimento, diz respeito à organização do estoque de tal forma que os sacos "mais velhos" sejam utilizados antes dos sacos recémentregues, dentro da política do PEPS (primeiro que entra, primeiro que sai).

Com relação à cal hidratada, são válidas as mesmas recomendações quanto à proteção contra a umidade, sendo que SOUZA et al. (1996) recomendam ainda que as pilhas deste material sejam, no máximo, de 20 sacos e que o prazo de estocagem não exceda a 6 meses.

Com relação ao gesso, a NBR 13207 (ABNT, 1994) recomenda que o mesmo deva ser estocado em locais secos e protegidos. Segundo ainda esta mesma norma, as pilhas de sacos devem ser colocadas sobre estrados e não devem conter mais do que 20 unidades superpostas.

\subsubsection{Blocos/tijolos e placas cerâmicas}

A preocupação maior com estes componentes está relacionada à possibilidade de quebra dos mesmos em função das más condições de estocagem, que podem ser traduzidas pela instabilidade das pilhas devido à altura excessiva, locais de estocagem inclinados, estocagem fora do canteiro de obras; neste 
último caso, os componentes estão ainda sujeição à ação de vandalismo e roubo.

Um exemplo de situação geradora de perdas é ilustrado na Figura 4.5, onde se pode perceber o descaso com a estocagem destes componentes.

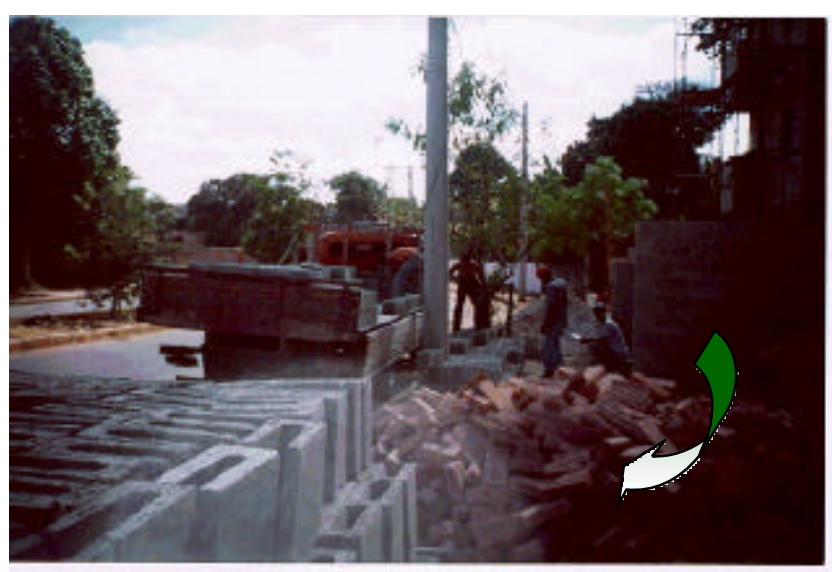

Figura 4.5 Exemplo de uma situação geradora de perda de blocos e tijolos na etapa de estocagem (Foto cedida por Antonio Neves de Carvalho Jr.)

Com relação à altura das pilhas dos blocos e tijolos, verificam-se recomendações um pouco diferentes, dependendo do tipo de bloco/tijolo, conforme ilustra a Tabela 4.4 .

Quanto ao local de estocagem, SOUZA et al. (1996) recomendam que seja feito um planejamento adequado no sentido de evitar que estes componentes sejam colocados fora do canteiro de obras e de dar preferência à estocagem junto ao equipamento de transporte vertical ${ }^{68}$.

68 Evidentemente, tal recomendação aplica-se ao sistema de transporte constituído por elevador de cargas e não por grua; no caso desta última, basta que o eventual estoque esteja dentro do raio de ação da lança. 
Tabela 4.4 Altura de pilha de blocos/tijolos recomendada por diversos autores e normas técnicas

\begin{tabular}{l|l|c}
\hline Fonte & Componente & $\begin{array}{c}\text { Altura } \\
\text { recomendada (m) }\end{array}$ \\
\hline NBR 8798 (ABNT, 1985) & $\begin{array}{l}\text { Bloco de concreto vazado simples para } \\
\text { alvenaria estrutural }\end{array}$ & $\leq 2,0$ \\
\hline SKOYLES; SKOYLES (1987) & Tijolos & 1,5 a 2,0 \\
SANTOS (1995) & - & $\leq 1,8$ \\
\hline SOUZA et al. (1996) & Blocos cerâmicos para alvenaria de vedação & $\leq 2,0$ \\
\cline { 2 - 3 } & Blocos de concreto para alvenaria de vedação & $\leq 1,5$ \\
\hline
\end{tabular}

Uma outra preocupação diz respeito à umidade, a qual é mais contundente nos casos de blocos de concreto do que nos cerâmicos. A este respeito, SOUZA et al. (1996) recomendam que os blocos de concreto sejam cobertos para evitar a ação da chuva.

Quanto às caixas de placas cerâmicas, uma vez recebidas na obra, de acordo com o CPqDCC-EPUSP, devem ser protegidas de intempéries e, de preferência, estocadas em local de difícil acesso, sendo liberadas para o uso somente no momento de utilização. Este procedimento evita que tais caixas sejam danificadas, o que implicaria em um transporte de placas a granel (USP, 1990). 
Ainda segundo CPqDCC-EPUSP, a altura das pilhas deve ser limitada a 2,0 metros, a fim de se evitar possíveis quedas que venham danificar os componentes. Um exemplo de uma situação geradora de perdas na etapa de estocagem das placas cerâmicas é ilustrado na Figura 4.6.

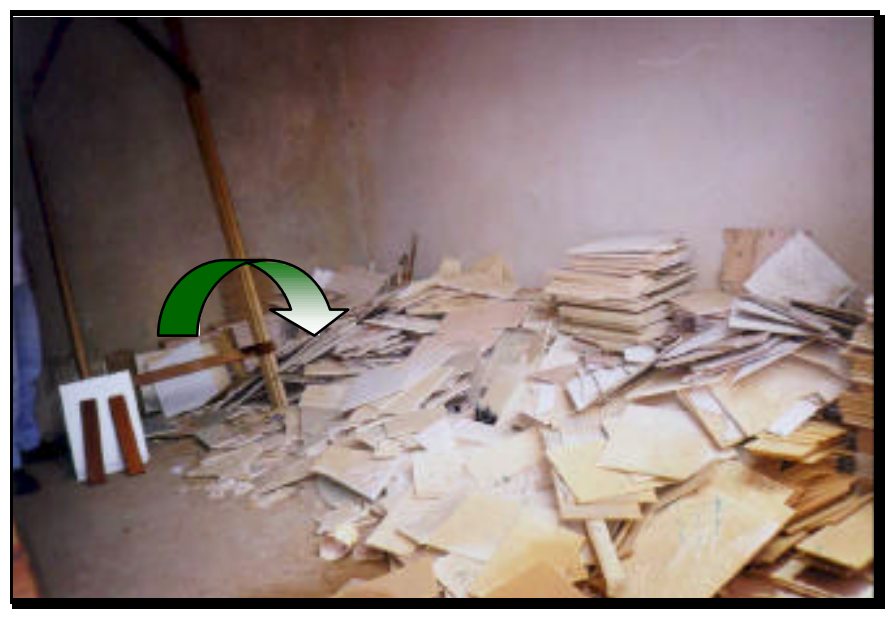

Figura 4.6 Exemplo de uma situação geradora de perda de placas cerâmicas na etapa de estocagem

\subsubsection{Tintas}

O principal problema relacionado com a estocagem das tintas diz respeito ao vencimento da validade das mesmas. De acordo com . Manuais de pintura, a estocagem prolongada das tintas sob calor ou frio intenso pode provocar reações químicas que levam à inutilização das mesmas, através do surgimento dos seguintes problemas:

- $\quad$ separação dos sólidos do veículo;

- quebra de dispersão (pigmentos se separam do veículo, sem sedimentação); 
- gelatinização (solidificação da tinta);

- formação de grumos ou arenosidade.

\subsubsection{As perdas na etapa de processamento intermediário}

Alguns materiais não podem ser aplicados diretamente na confecção final do produto desejado sem que haja um processamento intermediário. Pode-se distinguir dois grandes grupos de materiais que passam por tal etapa do fluxograma dos processos: o dos materiais básicos e o dos componentes demandando acertos geométricos.

Quanto ao primeiro grupo, pode-se citar o caso do uso de materiais básicos (cimento, cal areia, entre outros) que, antes de virarem produtos finais (revestimentos de argamassa, estrutura de concreto etc) têm de ser transformados em materiais compostos.

Quanto ao segundo grupo, tem-se, por exemplo, o caso do aço comprado em barras, onde há a necessidade de se cortá-las nos comprimentos especificados no projeto estrutural. Este mesmo procedimento é aplicado aos eletrodutos, fios e tubos para instalações hidráulicas e sanitárias.

Seja qual for o tipo de processamento necessário, observa-se a ocorrência de perdas de materiais, seja pela incorporação adicional de materiais básicos ou pelas sobras de cortes de c omponentes, perdas estas discutidas na seqüência.

\subsubsection{Argamassa e concreto produzidos em obra e seus constituintes}


A NBR 13530 (ABNT, 1995) define argamassa preparada (produzida) em obra como sendo "argamassa simples ou mista, cujos materiais constituintes são medidos em volume ou massa e misturados na própria obra".

Partindo-se desta definição e extrapolando-a para o concreto produzido em obra, a produção destes materiais compostos compreende as atividades de transporte até o equipamento de mistura, de dosagem (proporcionamento dos constituintes) e colocação dos materiais neste equipamento, segundo uma determinada seqüência e, por fim, a mistura destes materiais básicos.

No que diz respeito à produção de argamassa mista (cimento e cal hidratada), esta pode-se dar através de procedimentos envolvendo dois ou um processamento intermediário. No primeiro caso, inicialmente procede-se a produção de uma argamassa composta pela cal e areia, denominada argamassa "intermediária", a qual permanecerá em repouso para que, entre outros aspectos, ocorra a completa hidratação dos possíveis óxidos de cálcio e magnésio livres presentes na cal, evitando-se assim, que esta ocorra no revestimento já executado, ocasionando fissuras ${ }^{69}$. Em seguida, procede-se a produção da argamassa definitiva através da dosagem e mistura com cimento. No segundo caso, a dosagem e mistura dos aglomerantes e agregados são feitas num único processamento intermediário.

Em se tratando das perdas propriamente ditas, estas podem ocorrer sob a forma de erros de dosagem, seja pela inexperiência do responsável ou pela

\footnotetext{
${ }^{69}$ Note que pode ocorrer o fornecimento de argamassa de cal em caminhão betoneira, já misturada, restando, portanto, a complementação desta argamassa com cimento no canteiro de obras.
} 
inexistência de um controle efetivo do traço a ser produzido (perda de materiais básicos).

Com relação à dosagem, esta pode ser feita em massa ou volume, sendo que a primeira opção está associada uma menor probabilidade de perdas, devido à suposta maior precisão na dosagem. Cabe ressaltar que, sendo feita com os devidos cuidados, a dosagem em volume pode ser supostamente precisa.

SCARDOELLI et al. (1994) identificam algumas medidas para melhorar o controle da produção das argamassas, conforme segue:

- exposição dos traços nas obras em quadros didáticos (utilização de desenhos e cores, por exemplo);

- confecção de caixas (padiolas) para agregados e aglomerantes em cores diferentes, de acordo as especificadas, por exemplo, no quadro de traços; dentro deste mesmo espírito, deve-se priorizar o uso de recipientes de volume conhecido para se fazer a dosagem, em lugar do uso de medidas imprecisas, tais como um certo número de "pás" de material

- todas as colocações feitas para a argamassa podem ser perfeitamente estendidas para o concreto,.

Além dos aspectos relacionados diretamente à dosagem dos materiais, SOUZA et al. (1997) recomendam que a central de produção de argamassa seja localizada nas proximidades do estoque de areia e do equipamento de transporte vertical, de preferência que a mesma seja coberta, no sentido de se viabilizar o trabalho mesmo em dias chuvosos, além da previsão de um tablado 
para o estoque de sacos de aglomerantes necessários para um dia de serviço. Com relação à produção da argamassa intermediária, deve-se prever também um local adequado para o armazenamento da mesma. A Figura 4.7 ilustra duas situações distintas de centrais de argamassa quanto à disposição do equipamento de mistura, estoques de materiais e distância em relação ao equipamento de transporte verificadas por MACIEL (1997) em seu trabalho.

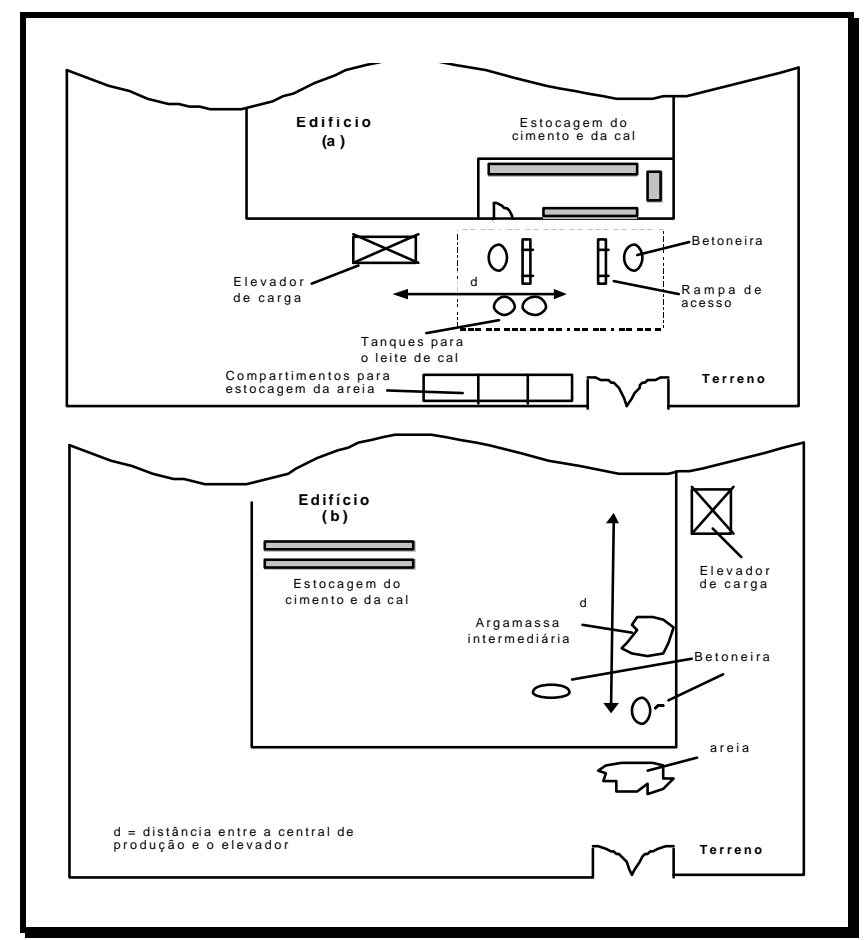

Figura 4.7 Layout da central de produção - (MACIEL, 1997) - (a) não otimizado; (b) otimizado

É de se esperar que, quanto maior a distância entre o equipamento de transporte vertical e o local de produção, e quanto piores as condições da base do trajeto, maior a probabilidade de incidência de perdas da argamassa e concreto produzidos. Note que os últimos comentários feitos associam à etapa 
de processamento algumas atividades que dizem respeito ao transporte e à própria estocagem dos materiais.

Além da perda representada pela incorporação adicional dos materiais básicos durante a produção, destacase também a geração de entulho devido à produção em excesso de argamassa e/ou concreto. Para minimizar tal ocorrência, várias medidas podem ser tomadas. Uma delas, que além de evitar esta perda contribui também para o monitoramento do consumo dos materiais, consiste na adoção de um sistema de fichas coloridas. De acordo com este sistema, as fichas são entregues ao responsável pela produção da argamassa ou concreto, de acordo com a necessidade do posto de trabalho. (SCARDOELLI et al., 1994).

\subsubsection{Aço, eletrodutos, condutores, tubos para instalações hidráulicas e sanitárias}

As perdas destes materiais nesta etapa estão relacionadas à geração de entulho, representado pelas sobras das barras cortadas. Como forma de minimizar tal ocorrência, pode-se citar:

- estabelecimento de um plano de corte das barras e tubos;

- previsão de um local onde a estocagem das sobras seja feita de forma organizada e identificada, facilitando, assim, o reaproveitamento destas sobras provenientes do corte;

- o estabelecimento de kits configura-se numa alternativa para a otimização do corte e reaproveitamento das sobras provenientes do mesmo; a 
confecção de kits de montagem em bancadas permite, além de absorver mão-de-obra menos qualificada, a redução das perdas destes materiais, o aumento da produtividade e qualidade na união entre os tubos e entre os fios (PINTO \& PINTO, 1995).

Com relação aos tubos para as instalações hidráulicas e sanitárias, fica patente a inserção da análise financeira quanto à definição do que é perda, pois o reaproveitamento destas sobras requer também a utilização de conexões para a realização das emendas, e estas têm um custo relativamente superior aos tubos. SKOYLES \& SKOYLES (1987) detectaram valores de perdas para tubos de cobre variando entre $0 \%$ a 5,4\%, tendo como média $1,9 \%$ e, para tubos de PVC, os autores apresentam valores não desprezíveis. Além destes números, os autores verificaram que as perdas mostravam-se superiores para os tubos de diâmetros maiores do que para os menores.

No que diz respeito à detecção das perdas de aço, SKOYLES \& SKOYLES (1987) consideram o corte das barras de aço como sendo o gerador da maior parcela de perdas detectadas nos canteiros de obras, sendo que apresentam números de perda, devido ao corte, variando entre $2,4 \%$ a $4,8 \%$.

Muito mais ainda do que procurar reaproveitar as sobras destes materiais, há que se centrar esforços no sentido de reduzi-las e, para isso, o projeto configura-se numa etapa importante. No que diz respeito especificamente ao aço, os projetistas estruturais poderiam preocupar-se, além dos aspectos relacionados à segurança estrutural, com os aspectos relacionados à produção das armaduras, especificamente no sentido de otimizar o corte das barras 
através do estabelecimento de um plano de corte, pelo menos para aqueles diâmetros de uso restrito na edificação, geralmente associados aos pilares.

A potencialidade de otimização no corte pode ser averiguada através do dimensionamento do comprimento da armadura longitudinal de um pilar genérico (Figura 4.8), conforme a NBR 6118 (ABNT, 1980).

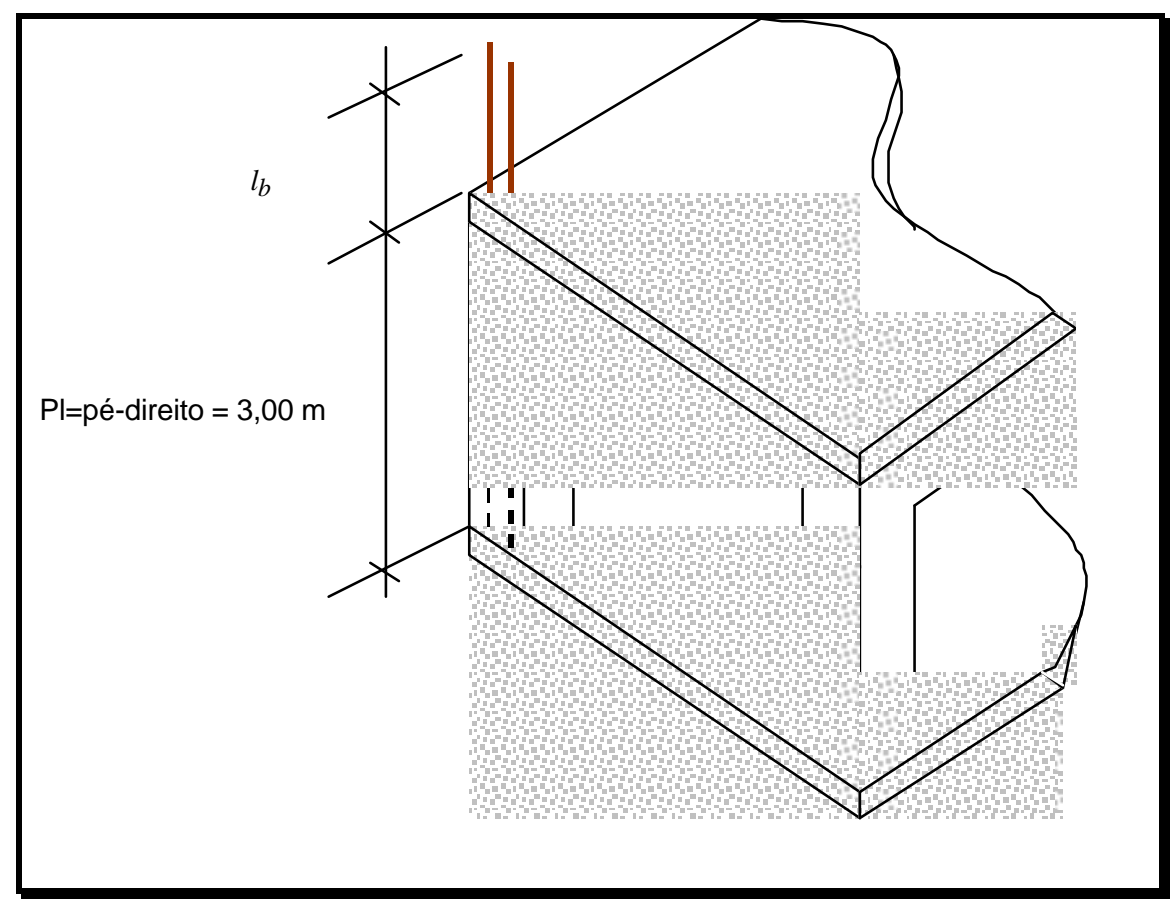

\section{Figura 4.8 Desenho esquemático do comprimento das barras da armadura longitudinal de um pilar genérico}

Nesta figura percebe-se que o comprimento total da armadura longitudinal será dado pelo somatório da altura do pavimento com o comprimento de ancoragem.

O cálculo do comprimento de ancoragem necessário para aderência das peças comprimidas (que é o caso dos pilares) pode ser feito utilizando-se a mesma 
fórmula para as barras tracionadas, respeitando-se, no entanto, os seguintes limites:

$l_{b}=\frac{\phi}{4} x \frac{f_{y d}}{\tau_{b u}} x \frac{A_{\text {scalculo }}}{A_{\text {se }}} \geq \quad\left(\begin{array}{l}10 \phi \\ 0,6 l_{b 1} \\ 15 \mathrm{~cm}\end{array}\right.$

onde,

$$
\begin{aligned}
& \frac{A_{\text {scalculo }}}{A_{s e}}=1 \\
& \tau_{b u}=0,42 \sqrt[3]{{f_{c d}}^{2}} \text {, para } \eta_{b} \geq 1,5 \text { (situação de boa aderência) }
\end{aligned}
$$

Supondo $f_{c k}=25 M P a$ :

$$
\begin{aligned}
& \tau_{b u}=0,42 \sqrt[3]{\left(\frac{25}{1,4}\right)^{2}}=2,87 M P a ; \text { portanto: } \\
& l_{b}=1 x \frac{500}{1,15} \times \frac{1}{2,87} \times \frac{\phi}{4}=37,9 \phi
\end{aligned}
$$

Calculando-se o comprimento de ancoragem e o comprimento total da peça a ser empregada no pilar em questão, chega-se à estimativa de perdas conforme a Tabela 4.5, considerando que as barras são entregues nos canteiros de obras com 11 metros de comprimento, conforme NBR 7480 (ABNT, 1996), e que as sobras provenientes do corte não serão reaproveitadas. 
De acordo com esta Tabela, justificam-se medidas no sentido de se minimizar as pontas geradas, principalmente daquelas bitolas de uso quase que exclusivo em alguns elementos estruturais. Uma não preocupação pode levar uma obra a se deparar com situações idênticas à apresentada na Figura 4.9.

Tabela 4.5 Estimativa das perdas de aço devido ao não reaproveitamento das sobras de corte

\begin{tabular}{c|c|c|c|c|c|c}
\hline Aço CA 50 & $\begin{array}{c}\text { Pé-direito } \\
(\mathbf{m})\end{array}$ & $\begin{array}{c}l_{b}=39 \phi \\
(\mathbf{m})\end{array}$ & $\begin{array}{c}\text { Comprimento } \\
\text { da peça (m) (a) }\end{array}$ & $\begin{array}{c}\text { Número de } \\
\text { peças inteiras } \\
\mathbf{( b )}\end{array}$ & $\begin{array}{c}\text { Sobra do } \\
\text { corte (11- (a) } \mathbf{x} \\
\mathbf{( b )}(\mathbf{m})\end{array}$ & Sobra (\%) \\
\hline 16 & 3,0 & 0,61 & 3,61 & 3 & 0,17 & 1,56 \\
\hline 20 & 3,0 & 0,76 & 3,76 & 2 & 3,48 & 31,6 \\
\hline 25 & 3,0 & 0,95 & 3,95 & 2 & 3,10 & 28,0 \\
\hline
\end{tabular}

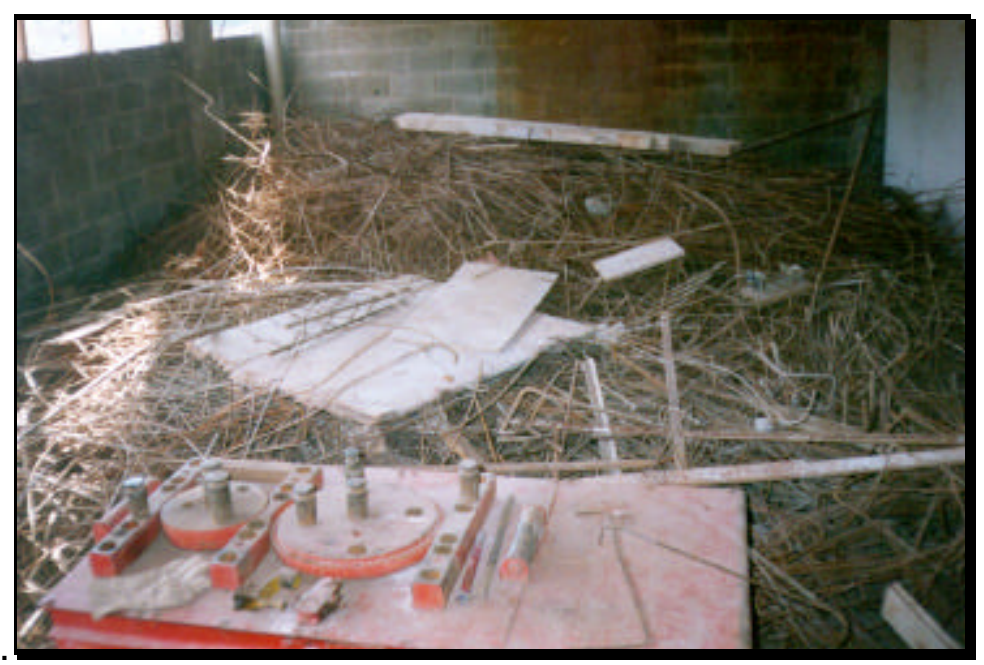

Figura 4.9 Perdas de aço na etapa de processamento intermediário: sobras devido ao corte não otimizado

\subsubsection{Tintas}

Segundo a NBR 12554 (ABNT, 1991), as tintas "são produtos compostos de veículo, pigmentos, aditivos e solventes que, quando aplicados sobre um 
substrato, se convertem em película sólida, dada a evaporação do solvente e/ou reação química, com a finalidade de decoração, proteção e outras".

O veículo consiste na fração líquida da tinta, constituída basicamente por resina e solvente, cuja finalidade é converter-se em película sólida (filme). Em geral, as tintas recebem o nome de suas resinas e, neste trabalho, a análise é sobre as tintas látex acrílica e látex PVA, embora o que será descrito aqui possa se aplicar perfeitamente às outras modalidades de tintas.

Antes da utilização das tintas, as mesmas passam por um processamento intermediário, que consiste, em se tratando dos látex, na diluição destas em água. A proporção entre a quantidade de tinta e o diluente depende do tipo de substrato a receber a pintura, se o mesmo está selado ou não, do tipo de tinta, do número de demãos previstas, das ferramentas de aplicação, das condições ambientais, entre outros aspectos.

Analisando Manuais de pintura, verifica-se que o percentual de diluição pode variar entre 10 a 20\% de água. A diluição incorreta da tinta pode ocasionar problemas estéticos e de durabilidade como, por exemplo, a cobertura insuficiente ou escorrimento da tinta no substrato (diluição excessiva) ou dificuldades da aplicação à medida em que a tinta não foi suficientemente diluída.

Erros na diluição das tintas podem ter reflexos danosos na sua utilização, induzindo, por vezes, a maiores consumos.

\subsubsection{As perdas na etapa de aplicação (processamento final)}


Da mesma forma que para as etapas antecedentes à de aplicação final destes materiais, para esta etapa existem diversas recomendações quanto às "boas práticas" de execução dos serviços, que visam, além do uso racional dos materiais, também a minimização de ocorrência de problemas patológicos.

A este respeito, merecem destaque os trabalhos desenvolvidos no âmbito do Departamento de Engenharia de Construção Civil da EPUSP (PCC-USP), mais especificamente desenvolvidos pelo Grupo de Ensino e Pesquisa voltado para a Tecnologia e Gestão da Produção - TGP.

Dentre os trabalhos realizados nesta linha, pode-se citar o desenvolvido por BARROS (1991), que trata da execução do contrapiso, SOUZA (1996a), que discute a execução de lajes de concreto armado, MACIEL (1997), que fala da execução do revestimento de fachada em argamassa, entre outros.

Há que se ressaltar também que, além de discutirem tecnicamente a execução de cada serviço propriamente dito, inclusive tratando de aspectos relacionados ao processamento intermediário, discutem o enriquecimento das informações trazidas pelo projeto do produto, contemplando especificações técnicas dos materiais e equipamentos/ferramentas e, principalmente, valem-se da idéia da elaboração destes projetos voltados aos aspectos da produção da edificação propriamente dita, ou seja, do projeto para a produção.

Ainda com relação aos procedimentos adequados de execução dos serviços, há que se destacar também o trabalho desenvolvido por SOUZA et al. (1996), o qual reúne estes procedimentos para uma gama considerável de serviços, 
reunindo, inclusive, vários procedimentos desenvolvidos no âmbito do PCCUSP.

Embora estes procedimentos sejam de grande valia para a minimização das perdas e consumos de materiais, não haveria espaço suficiente para tratá-los com profundidade nesta dissertação. No entanto, os mesmos são contemplados nos instrumentos de coleta de dados elaborados, apresentados e discutidos no capítulo 6. Aqui, discutir-se-ão apenas as possibilidades de ocorrência de perdas destes materiais no ato de sua aplicação, levando-se em consideração as experiências e resultados obtidos nas pesquisas já realizadas e também as experiências adquiridas, junto ao setor produtivo, ao longo da execução deste trabalho.

\subsubsection{Argamassa produzida em obra e seus constituintes, ou argamassa parcial ou totalmente produzida fora do canteiro de obras, nos serviços de revestimentos interno e externo}

Antes de entrar especificamente na questão das perdas de argamassa no serviço de revestimento, convém apresentar a classificação do mesmo quanto às camadas que o constitui (Tabela 4.6), de acordo com a NBR 13530 (ABNT, 1995).

Embora, em nenhuma das pesquisas citadas tenha-se contabilizado de forma distinta as duas parcelas de perdas (incorporada e entulho), as sobrespessuras de revestimentos vêm sendo apontadas como a parcela de perdas mais significativa das argamassas e, conseqüentemente, dos seus constituintes (aglomerantes e agregados) nestes serviços. 
Tabela 4.6 Camadas constituintes do revestimento em argamassa (NBR 13530; ABNT, 1995)

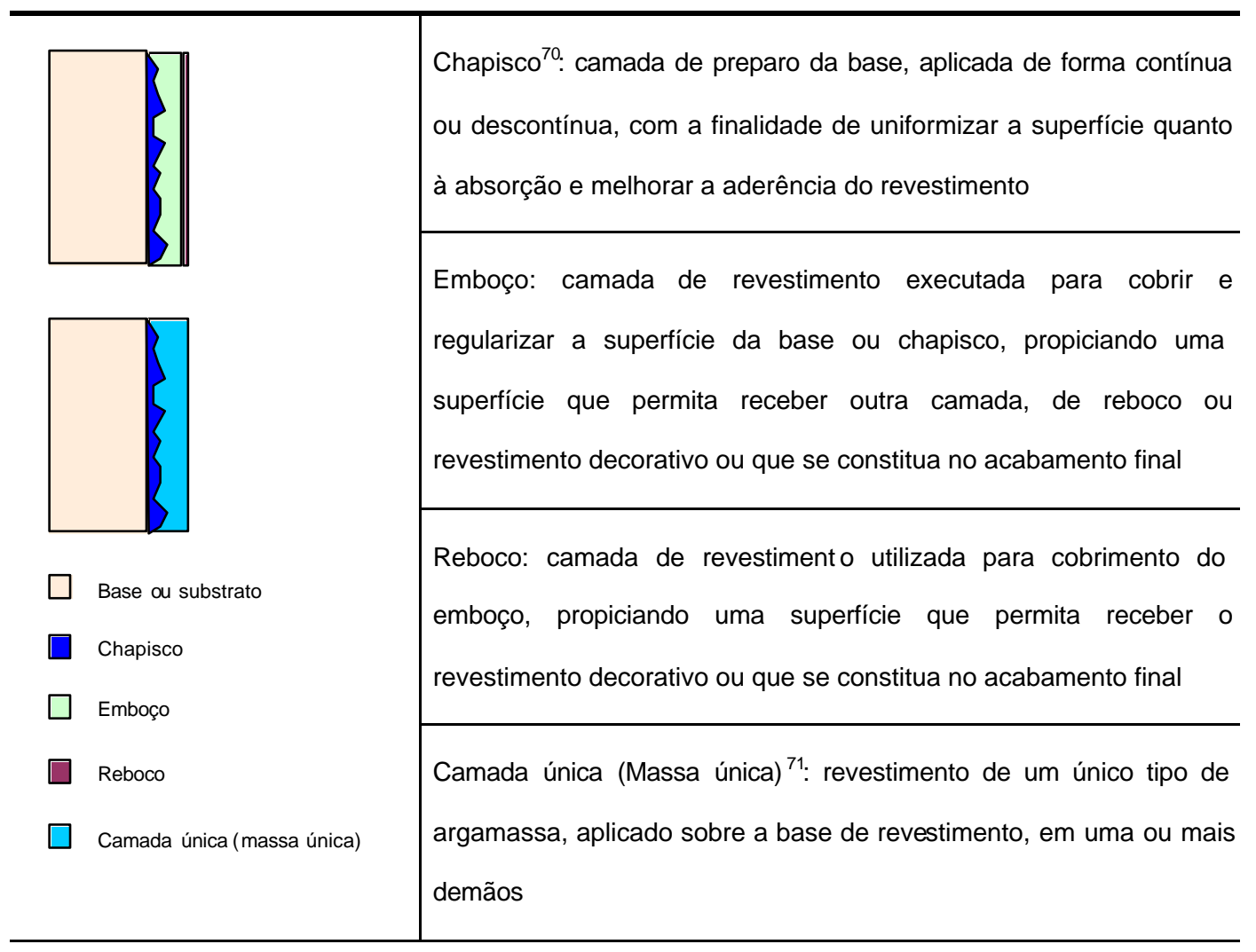

Calculando a diferença entre o volume projetado (espessura projetada $\mathrm{x}$ área de revestimento) e o volume utilizado na execução dos revestimentos em argamassa (contrapiso, tetos, paredes internas e externas), PINTO (1989) chegou ao valor de $80 \%$ de perdas devido à sobrespessura detectada. Resultado semelhante foi verificado por PICCHI (1993) na avaliação dos mesmos serviços estudados por PINTO (1989). Recentemente, pode-se citar também o trabalho realizado por SOUZA et al. (1998c) em Belém do Pará, onde foram analisadas as perdas de argamassa por sobrespessura em 7

\footnotetext{
70 Note que, de acordo com esta norma, a camada de chapisco configura-se como uma camada de preparação da base e não de revestimento propriamente dito.

71 O revestimento de camada única deve cumprir as funções desempenhadas tanto pela camada de emboço quanto pela de reboco.
} 
canteiros de obras distribuídos pela cidade. A Tabela 4.7 reúne os valores médios levantados por estes autores e por SOIBELMAN (1993) em suas pesquisas.

Tabela 4.7 Pe rdas devido às sobrespessuras de revestimentos

\begin{tabular}{|c|c|c|c|c|}
\hline Pesquisa & Local & $\begin{array}{l}\text { Espessura de } \\
\text { referência } \\
(\mathrm{cm})\end{array}$ & $\begin{array}{c}\text { Espessura } \\
\text { detectada }(\mathrm{cm})\end{array}$ & $\begin{array}{c}\text { Perda } \\
\text { incorporada(\%) }\end{array}$ \\
\hline \multirow[t]{4}{*}{ PINTO (1989) } & Paredes internas & 2,0 & 1,2 & (39) \\
\hline & Fachada & 2,0 & 6,0 & 200 \\
\hline & Teto & 2,0 & 3,8 & 90 \\
\hline & Contrapiso & 3,0 & 5,7 & 90 \\
\hline \multirow[t]{3}{*}{ SOIBELMAN (1993) } & Paredes internas & 1,5 & 2,6 & 76 \\
\hline & Fachada & 2,0 & 3,9 & 93 \\
\hline & Teto & 1,5 & 1,8 & 18 \\
\hline \multirow[t]{4}{*}{ PICCHI (1993) } & Paredes internas & 2,0 & 3,0 & 50 \\
\hline & Fachada & 3,0 & 6,5 & 117 \\
\hline & Teto & 2,0 & 4,0 & 100 \\
\hline & Contrapiso & 3,0 & 6,0 & 100 \\
\hline SOUZA et al. (1998c) & Emboço & 1,5 & 2 & 33 \\
\hline
\end{tabular}

De acordo com os valores desta Tabela, verificam-se que as perdas devido à sobrespessura dos revestimentos chegam quase a $100 \%$ e que as mesmas são mais acentuadas para os revestimentos de fachada do que para os de paredes internas. Observe que os valores de referência adotados para a espessura dos revestimentos interno e externo não são muito discrepantes; PINTO (1989), por exemplo, adotou valores idênticos. 
Como causas destas sobrespessuras, são identificadas basicamente duas: a falta de qualidade na execução dos serviços que antecedem o revestimento, como a alvenaria e a estrutura, que são traduzidas pelo desaprumo das alvenarias e estrutura, falta de planeza e nível das lajes, entre outros; falta de coordenação entre os projetos, principalmente entre o de arquitetura e o de estrutura, o que acarreta a necessidade de se aumentar a espessura dos revestimentos.

Além desta falta de coordenação entre tais projetos, a execução de revestimentos com espessuras superiores à especificada em projeto deve-se, também, à incompatibilidade, não detectada previamente, entre a largura dos componentes de vedação e a posição dos contramarcos das aberturas (janelas e portas).

Com relação aos desaprumos da estrutura, CAZET et al. (1996) apresentaram um estudo de caso de uma obra de edifício residencial de 6 pavimentos, onde levantaram valores do desaprumo, tomados em 21 pilares, da ordem de $4 \mathrm{~mm}$, em duas direções perpendiculares " $x$ " e "y". Tomando-se como premissa que nesta obra será respeitado o valor mínimo da espessura especificada no ponto mais desfavorável, caso este tenha ocorrido na estrutura, o revestimento a ser realizado terá uma sobrespessura da ordem da metade do desaprumo levantado pelos autores. Assim, tomando-se como exemplo a especificação de $1,5 \mathrm{~cm}$ de revestimento das paredes internas, esta sobrespessura corresponderia a uma perda de 13,3\%.

Além da perda representada pela sobrespessura dos revestimentos, há que se considerar também a geração de entulho durante a execução dos mesmos, o 
qual é visível para o caso da execução dos revestimentos de fachada, conforme ilustrado na Figura 4.10.

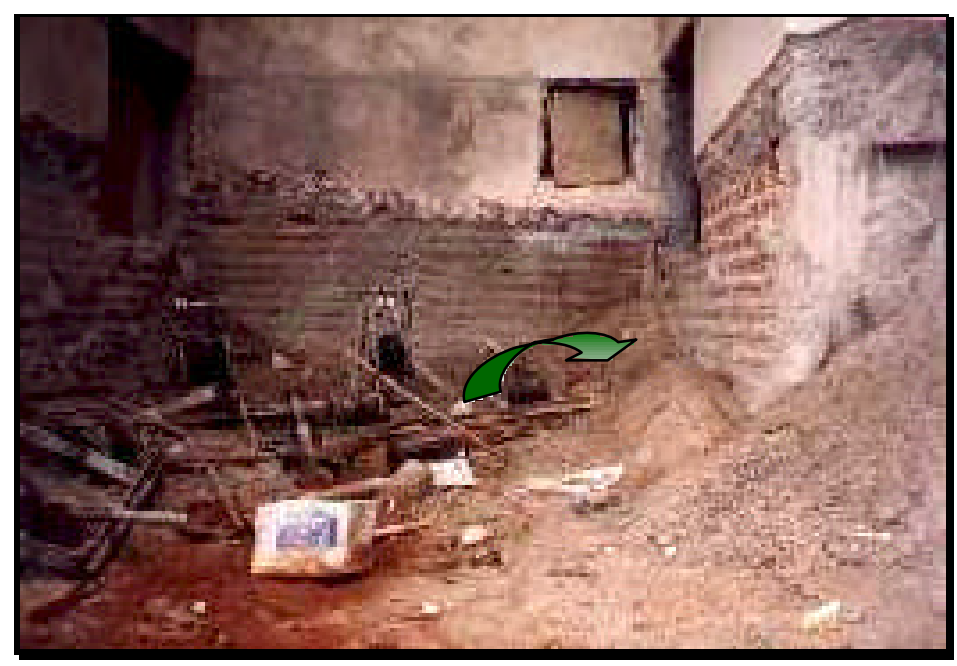

Figura 4.10 Entulho gerado durante a execução do revestimento de fachada

\subsubsection{Argamassa produzida em obra e seus constituintes ou argamassa parcial ou totalmente produzida fora do canteiro de obras no serviço de alvenaria}

As perdas de argamassa no assentamento dos blocos/tijolos podem ser genericamente associadas à sobrespessura e à sobrelargura das juntas verticais e horizontais, à argamassa que fica incorporada nos furos dos blocos e, por fim, ao entulho gerado pela argamassa que cai no piso e não é reaproveitada.

Destas possibilidades de perdas, apenas as sobrespessuras das juntas foram objeto de estudo da pesquisa realizada por SOIBELMAN (1993), cujos resultados estão reunidos na Tabela 4.8. Fazendo-se a média aritmética destes resultados, chega-se a uma perda de $27,5 \%$. Os resultados apontam ainda 
para uma perda maior no que diz respeito às juntas horizontais em relação às verticais.

Tabela 4.8 Perdas devido à sobrespessura de juntas de argamassa no serviço de alvenaria

\begin{tabular}{l|l|c|c|c}
\hline \multicolumn{1}{c|}{ Componente } & Tipo de junta & $\begin{array}{c}\text { Espessura de } \\
\text { referência (cm) }\end{array}$ & $\begin{array}{c}\text { Espessura } \\
\text { detectada (cm) }\end{array}$ & $\begin{array}{c}\text { Perda } \\
\text { incorporada(\%) }\end{array}$ \\
\hline \multirow{2}{*}{ Tijolo furado } & Horizontal & 1,5 & 2,09 & $\mathbf{3 9 , 3}$ \\
\cline { 2 - 5 } & Vertical & 1,5 & 1,72 & $\mathbf{1 4 , 7}$ \\
\hline \multirow{2}{*}{ Tijolo maciço } & Horizontal & 1,5 & 2,09 & $\mathbf{3 9 , 3}$ \\
\cline { 2 - 5 } & Vertical & 1,5 & 1,75 & $\mathbf{1 6 , 7}$ \\
\hline
\end{tabular}

Esta avaliação é pertinente em se tratando de tijolos maciços. No entanto, não é suficiente em se tratando dos blocos furados, pois, conforme ressaltado anteriormente, não se pode negligenciar a argamassa que fica incorporada nos furos dos mesmos.

A título de exemplo, tomando-se o bloco de concreto de dimensões nominais 9 x 19 x $39 \mathrm{~cm}$ com dois furos, assentado com bisnaga, pode-se fazer uma estimativa de perda de argamassa conforme a Tabela 4.9. Desta estimativa, verifica-se que o material incorporado nos furos pode equivaler ao consumo, devido à sobrespessura das juntas horizontais argamassadas.

Observe ainda que, se para este tipo de bloco o assentamento da argamassa for feito com colher de pedreiro, seguramente a perda de argamassa presente nos blocos será bem s uperior à apresentada nesta Tabela. 
Tabela 4.9 Estimativa de perda de argamassa no serviço de alvenaria (parcela de material incorporado)

\begin{tabular}{|c|c|c|c|}
\hline Parcela de perda & Considerações & $\begin{array}{l}\text { Volume } \\
\text { (litros/m) }\end{array}$ & $\begin{array}{c}\text { Perda } \\
\text { incorporada } \\
\text { (\%) }\end{array}$ \\
\hline $\begin{array}{l}\text { Sobrespessura (junta } \\
\text { horizontal) }\end{array}$ & Sobrespessura de $1 \mathrm{~cm}$ & 0,117 & 100,0 \\
\hline $\begin{array}{l}\text { Argamassa incorporada } \\
\text { nos furos dos blocos }\end{array}$ & $\begin{array}{l}\text { Considerando o acúmulo de } 0,5 \mathrm{~cm} \text { de } \\
\text { argamassa numa área total de } 2,38 \mathrm{dm}^{2} \\
(2 \times 0,7 \times 1,7) \text { relativa aos } 2 \text { furos }\end{array}$ & 0,119 & 101,7 \\
\hline $\begin{array}{l}\text { Sobrelargura das juntas } \\
\text { horizontais }\end{array}$ & $\begin{array}{l}1 \mathrm{~cm} \text { de sobrelargura em apenas } 1 \text { dos } \\
\text { lados de cada filete }\end{array}$ & 0,156 & 133,4 \\
\hline Total & - & 0,392 & 335,1 \\
\hline Situação de referência & $\begin{array}{l}2 \text { filetes de argamassa (espessura de } 1 \\
\mathrm{~cm} \text {, largura de } 1,5 \mathrm{~cm} \text { ) (volume }= \\
2 \times(3,9 \times, 15 \times 0,1)=0,117 \mathrm{l} / \mathrm{m}\end{array}$ & 0,117 & 0 \\
\hline
\end{tabular}

Uma outra forma de se abordar a questão da avaliação do desempenho quanto ao uso dos materiais básicos no serviço de alvenaria ( e nos demais serviços), consiste em estabelecer o consumo destes materiais por unidade de serviço executada.

Com relação a esta abordagem, LEÃO (1997) apresenta um estudo realizado na cidade de Recife (PE), em duas obras de edifícios de uma mesma empresa. A autora determinou o consumo de cimento por unidade de área de alvenaria executada por um período de 6 meses. 
Como resultados, a autora chegou a um valor médio de $2,52 \mathrm{~kg} / \mathrm{m}^{2}$ para uma obra e $1,81 \mathrm{~kg} / \mathrm{m}^{2}$ para a outra, o que representa uma perda de $40 \%$ e $0,6 \%$, respectivamente, em relação a um consumo planejado de $1,8 \mathrm{~kg} / \mathrm{m}^{2}$.

Como causas para a significativa variação, em se tratando da primeira obra, a autora relaciona algumas possíveis causas, quais sejam, o uso de colher por parte de alguns pedreiros em detrimento à bisnaga, conforme estabelecido nos procedimentos da empresa, as irregularidades na altura dos blocos, o que exige maior espessura de juntas horizontais argamassadas, e a ausência de controle dos traços utilizados.

\subsubsection{Concreto usinado e produzido em obra para a execução de estruturas de concreto armado}

As perdas de concreto geralmente estão associadas à variação dimensional dos elementos estruturais, muitas vezes induzidas pela má qualidade do sistema de fôrmas utilizado, qualidade esta resultante do seu mau dimensionamento ou, ainda, do desgaste dos moldes ao longo da evolução dos pavimentos.

Note ainda que, dentre os elementos estruturais, a laje configura-se como a mais representativa quanto a este tipo de perdas, em função, principalmente, do volume de concreto envolvido e por se constituir, também, no elemento mais susceptível à deformação em relação aos outros elementos estruturais. Ressalta-se, ainda, que as lajes possuem a dimensão mais susceptível a erros (a espessura), muito menos que suas duas outras dimensões (comprimento e 
largura) o que, matematicamente, faz como que pequenas sobrespessuras representem variações volumétricas significativas.

Da mesma forma, é de se esperar também que aqueles elementos da fundação como, por exemplo, as cortinas, apresentem uma perda maior, uma vez que em uma das faces é comum utilizar-se o próprio solo como fôrma, sendo este totalmente irregular.

A Tabela 4.10 reúne as perdas detectadas em função da variação das dimensões dos elementos estruturais.

Tabela 4.10 Parcela de perda relativa ao material incorporado: variação das dimensões dos elementos estruturais

\begin{tabular}{l|l|c}
\hline \multicolumn{1}{c|}{ Pesquisa } & \multicolumn{1}{|c|}{ Elemento estrutural } & Perda incorporada $^{\left({ }^{*}\right)}(\%)$ \\
\hline SOIBELMAN (1993) & Viga & 2,1 \\
\cline { 2 - 3 } & Laje & 4,9 \\
\hline \multirow{2}{*}{ CAZET et al. (1996) } & Pilares & 12,3 \\
\cline { 2 - 3 } & Vigas e lajes & 4,9 \\
\hline
\end{tabular}

(*) expressa em termos da variação volumétrica relativa ao elemento em estudo, e não à estrutura como um todo

Observe que, de acordo com os resultados apresentados nesta Tabela, não se pode negligenciar as perdas de concreto devido à variação das dimensões da seção dos pilares ${ }^{72}$, embora os dados apresentados por CAZET et al. (1996) digam respeito apenas a uma única obra, ao contrário dos apresentados por SOIBELMAN (1993), que dizem respeito a 5 obras.

\footnotetext{
${ }^{72}$ Relembre que, como atenuante, tem-se a constatação de que, usualmente, enc ontram-se estruturas com volume dos pilares bem inferiores aos volumes das vigas e lajes.
} 
Além da perda representada por esta variação dimensional, podem ser citadas também as sobras ao final da concretagem que, uma vez não prevista sua utilização em outros elementos estruturais, configuram-se como perdas.

Note ainda que estas sobras podem ser decorrentes de solicitação de quantidades superiores às necessárias ou, ainda, em se tratando de concreto bombeado, as mesmas podem ser representadas pelo material que fica na tubulação da bomba ao final da concretagem.

Sendo assim, de acordo com o exposto até o momento, as seguintes hipóteses quanto à ocorrência de perdas deste material podem ser feitas, as quais seguramente devem ser levadas em consideração na análise dos resultados:

- elementos de fundação apresentam maior parcela de perdas incorporadas do que os elementos estruturais da superestrutura;

- no que diz respeito à superestrutura, é de se esperar que as perdas por material incorporado sejam maiores nos últimos pavimentos do que nos primeiros, devido ao desgaste dos moldes do sistema de fôrmas;

\subsubsection{Aço}

Com relação à ocorrência de perdas na aplicação deste material, identificase basicamente a parcela de material incorporado na estrutura. Esta incorporação pode se dar através da diferença entre o comprimento de traspasse previsto e o executado, diminuição entre os espaçamentos das barras e substituição de bitolas. Em todas as pesquisas apresentadas, não foi detectada nenhuma avaliação detalhada quanto a esta parcela de perda. 


\subsubsection{Eletrodutos, condutores elétricos e tubulações hidráulicas e sanitárias}

Da mesma forma que o aço, as perdas destes materiais na aplicação são representadas pela parcela que fica incorporada na edificação. A principal causa para a ocorrência destas perdas consiste na negligência, por parte da mão-de-obra, à medida que realiza-se alteração de projeto sem o conhecimento e autorização do responsável técnico e o retrabalho devido a algum dano causado aos eletrodutos/tubulações durante a execução de outro serviço, como por exemplo, o esmagamento de eletrodutos na laje durante a concretagem.

Estas perdas podem ser representadas também pelas sobras de cortes destes materiais no próprio local de aplicação.

\subsubsection{Blocos e tijolos}

De uma forma geral, as perdas de blocos na etapa de aplicação estão relacionadas à incompatibilidade das dimensões dos mesmos com relação aos vãos da estrutura (altura e comprimento). Esta incompatibilidade acarreta a necessidade de cortes que, dependendo da qualidade do material e do equipamento utilizado para tal, podem gerar maior ou menor quantidade de entulho.

Como forma de minimizar tal ocorrência, podem ser citados três procedimentos. O primeiro deles consiste em se utilizar componentes flexíveis quanto à modulação, como, por exemplo, blocos secionáveis ou de concreto celular. 
O outro procedimento consiste em elaborar o projeto específico de alvenaria após o projeto de estrutura já estar concebido. Neste caso, a modulação é feita utilizando-se um número maior de componentes, inclusive de dimensões diferentes.

Mesmo tendo prevista, na fase de concepção, uma modulação adequada, fazendo uso de componentes específicos, uma não previsão de todos os componentes necessários a cada posto de trabalho pode gerar entulho à medida que o pedreiro, na falta do componente especificado, utiliza o que está disponível, diminuindo, consideravelmente, a eficácia do projeto.

Por fim, pode-se destacar também a elaboração de projeto específico de alvenaria de vedação em coordenação com os outros projetos (arquitetura, estrutura, instalações etc), suficientemente detalhado a ponto de contemplar a paginação de cada alvenaria a ser executada no edifício, identificando, inclusive, as interferências com outros subsistemas, como o de instalações elétricas, por exemplo (Figura 4.11). Neste caso, a paginação da alvenaria poderá ser feita, de forma geral, com a utilização de um número menor de tipos de componente. Por exemplo, é possível realizar-se a modulação usando apenas o componente inteiro e o meio-componente.

Com relação à geração de entulho, note que o mesmo não é gerado somente durante a etapa de execução da alvenaria, e sim, pode ser gerado também durante o serviço de instalações elétricas e hidráulicas e sanitárias, através da execução de rasgos nas paredes para se embutir tais instalações, conforme ilustrado na Figura 4.12. 


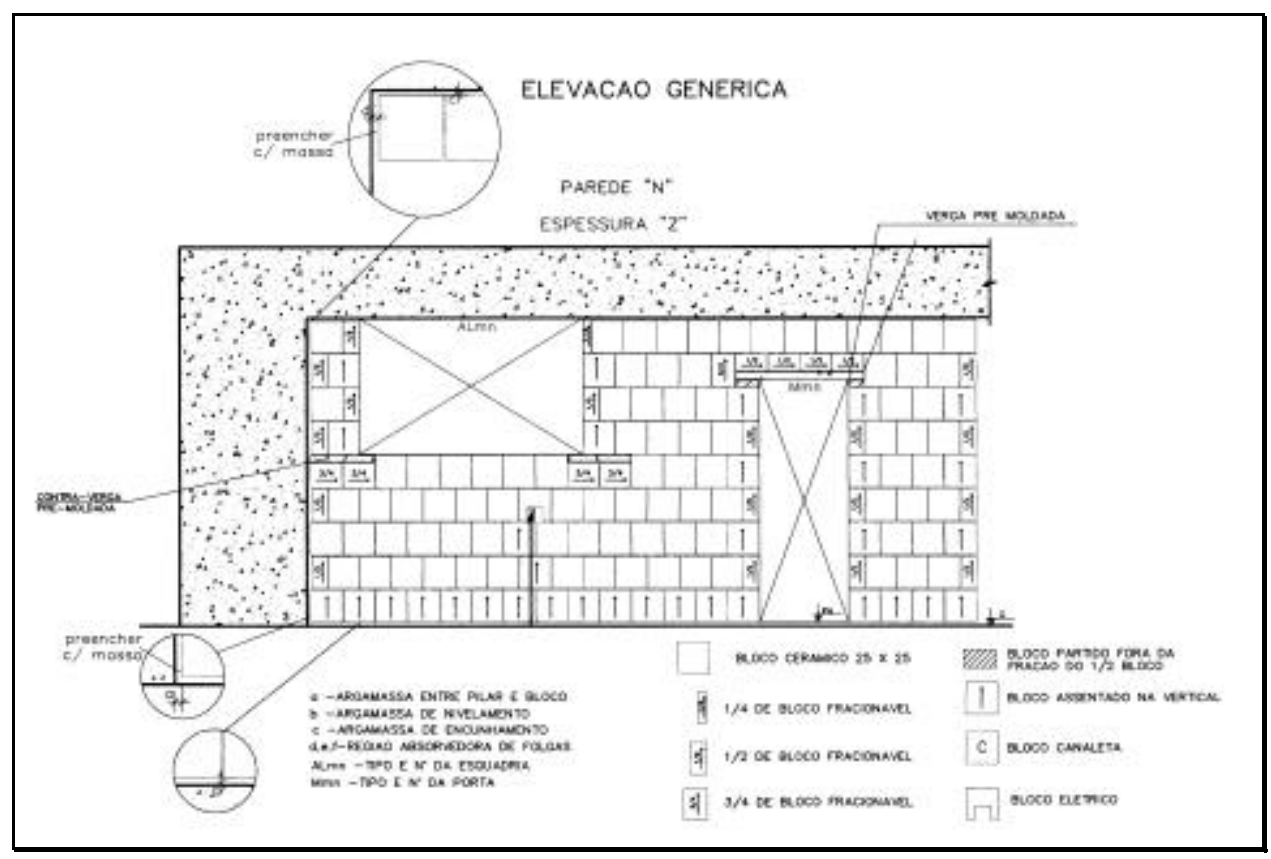

Figura 4.11 Exemplo de paginação da alvenaria

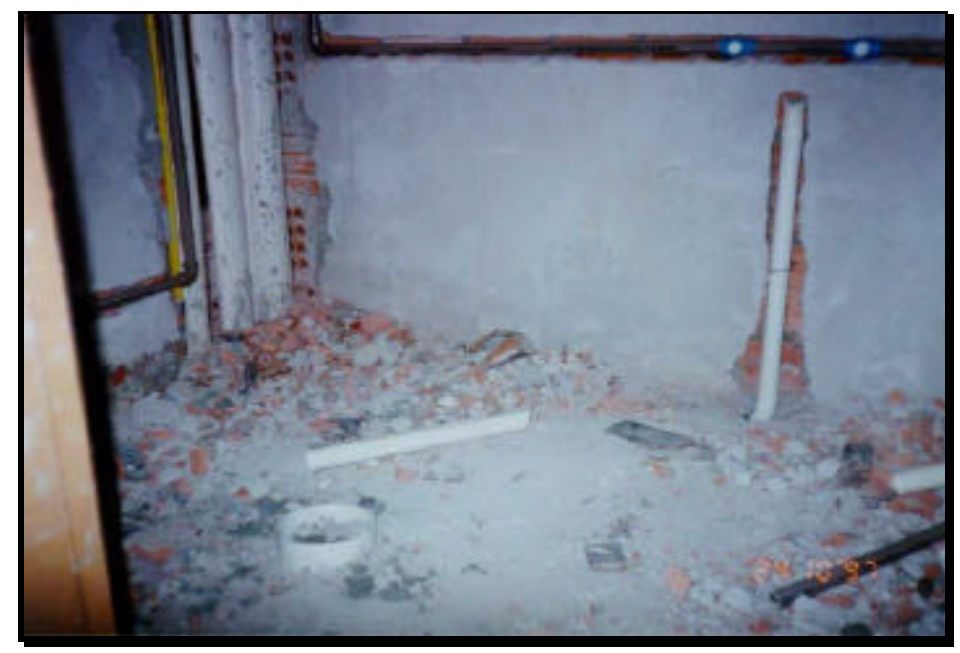

Figura 4.12 Geração de entulho durante a execução de rasgos nas paredes para se embutir as instalações elétricas, hidráulicas e sanitárias 


\subsubsection{Placas cerâmicas}

Similarmente aos blocos e tijolos, as perdas de placas cerâmicas na etapa de aplicação estão relacionadas ao corte das mesmas para a adequação às dimensões dos ambientes em que são aplicadas.

As perdas podem ser devido às quebras de componentes durante o corte, muitas vezes como fruto de uso de equipamento inadequado e podem, também, no caso de não haver tal quebra significativa no processo de corte (por exemplo, ao se fazer uso de equipamento adequado tal como a máquina de corte), ter-se uma perda significativa por não se pla nejar o reaproveitamento das "sobras".

Embora alguns construtores acreditem, sem fundamentação experimental definida, que as perdas de placas cerâmicas sejam desprezíveis, a Tabela de Composição Orçamentária (TCPO 10, 1996) traz uma estimativa variando entre 5 e $10 \%$.

Num estudo realizado por ARAÚJO \& MEIRA (1996), com o objetivo de avaliar a influência da existência de procedimentos de execução para revestimentos cerâmicos, obtiveram-se valores de perdas de $5 \%$ antes da inserção de tais procedimentos e $1 \%$ após a utilização dos mesmos.

\subsubsection{Gesso}

As perdas de gesso manifestam -se em revestimento, assim como no caso das argamassas, através de sobrespessuras e geração de entulho. Porém, no que 
diz respeito ao entulho gerado, este é mais significativo para o caso da aplicação do gesso. Tal fato decorre da própria natureza do material, que possui um tempo muito curto para a sua aplicação após a mistura do aglomerante com a água, gerando sobras endurecidas mais facilmente, as quais não são reaproveitadas.

Este fato pode ser exemplificado através do trabalho realizado por ANTUNES et al. (1999), que avaliaram o tempo útil para a aplicação de pastas de gesso na cidade de São Paulo (Tabela 4.11). De acordo com os dados desta Tabela, percebe-se o pouco tempo que o gesseiro tem para aplicar a pasta, ocasionando uma geração significativa de entulho, conforme constatado visualmente pelos autores. Um exemplo de tal situação é mostrado na Figura 4.13.

Tabela 4.11 Tempo útil para a utilização da pasta de gesso (ANTUNES et al., 1999)

\begin{tabular}{c|c|cc}
\hline $\begin{array}{c}\text { Código das } \\
\text { pastas }\end{array}$ & $\begin{array}{c}\Delta \text { t para se tornar } \\
\text { utilizável após } \\
\text { mistura }\end{array}$ & $\begin{array}{c}\Delta \text { t até torna-se } \\
\text { não mais } \\
\text { utilizável }\end{array}$ & Tempo Útil \\
\hline $\left.\mathrm{A} 1[0,66]^{*}\right)$ & 20,0 & 54,75 & 34.8 \\
\hline $\mathrm{B} 2[0,85]$ & 20,92 & 54,42 & 35.5 \\
\hline $\mathrm{C} 3[0,68]$ & 19,50 & 51,00 & 31.5 \\
\hline $\mathrm{C} 4[0,78]$ & 21,32 & 51,50 & 30.2 \\
\hline $\mathrm{C} 5[0,76]$ & 25,82 & 56,33 & 30.5 \\
\hline $\mathrm{C} 6[0,86]$ & 29,15 & 52,97 & 23.8 \\
\hline $\mathrm{D} 7[0,70]$ & 25,50 & 49,83 & 24.3 \\
$\mathrm{D} 8[0,73]$ & 23,00 & 57,05 & 34.1 \\
\hline
\end{tabular}

(*) o número entre colchetes representam a relação água/gesso, em massa, das pastas estudadas 


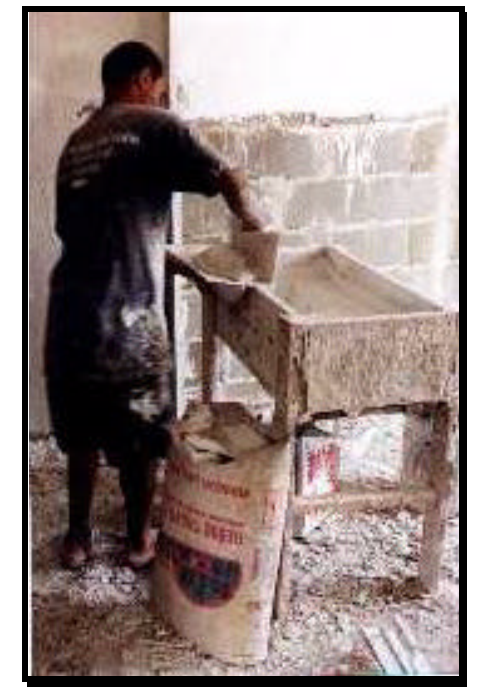

(a)

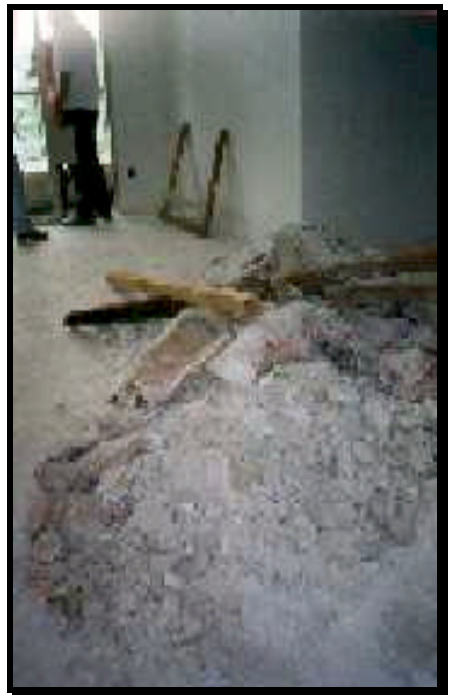

(b)

Figura 4.13 Exemplos de perdas de gesso durante a aplicação: (a) durante a aplicação; (b) após a aplicação

\subsubsection{Tinta}

As perdas das tintas látex PVA e/ou acrílica nesta etapa são representadas pelo número de demãos aplicadas ao substrato (perda incorporada) superior ao preconizado e pelas sobras não reaproveitadas deste material nas latas.

A necessidade de um número de demãos superior ao especificado pode-se dar em função da cobertura insuficiente da tinta, muitas vezes decorrente da má qualidade do material. Outros erros de execução, tais como, homogeneização insuficiente ou, ainda, aplicação sobre substratos muito absorventes não devidamente selados, podem também contribuir para uma elevação das perdas. SKOYLES \& SKOYLES (1987) declaram que os valores detectados em suas pesquisas mostraram-se condizentes com suas expectativas. Definem, 
como principal causa das perdas deste material, a necessidade de retrabalho devido às paredes e tetos ser danificados ou sujos durante serviços realizados posteriormente à pintura dos mesmos.

\subsubsection{As perdas na etapa de transporte}

As perdas durante o transporte estão limitadas àqueles materiais que são susceptíveis a quebras ou a ser derramados durante o trajeto. Dentre a gama de materiais envolvidos, enquadram-se nesta situação as argamassas e concretos, os blocos e tijolos, telhas e placas cerâmicas.

A combinação de um correto planejamento do transporte destes materiais, através da previsão de caminhos específicos e de equipamento adequado de transporte, consiste numa medida eficaz para o combate à ocorrência das perdas.

Diversos equipamentos podem ser adotados para fazer o transporte dos materiais, conforme ilustrado na Tabela 4.12.

No que referem-se às perdas de materiais, uma compatibilização entre o específico material e o equipamento usado nesta movimentação é essencial. Como exemplos de incompatibilização, pode-se citar o transporte de blocos com jericas, uma vez que os mesmos têm a forma de paralelepípedos, ou seja, possuem arestas, enquanto a jerica tem a forma arredondada ${ }^{73}$; o transporte de concreto ou argamassa (material fluido) através de carrinhos de mão, susceptível a derramamentos, já que estes carrinhos, além de rasos, são

${ }^{73}$ Caso semelhante ocorre com o transporte destes blocos com carrinhos de mão (Figura 4.14). 
instáveis; o transporte de telhas (materiais frágeis e que requerem um empilhamento ordenado) realizado com carrinhos de mão ou, ainda, na mão gerando estoques que favorecem a quebra, entre outros.

Tabela 4.12 Classificação do sistema de transporte- LICHTENSTEIN (1987)

\begin{tabular}{|c|c|c|c|c|}
\hline \multirow{4}{*}{\multicolumn{2}{|c|}{ 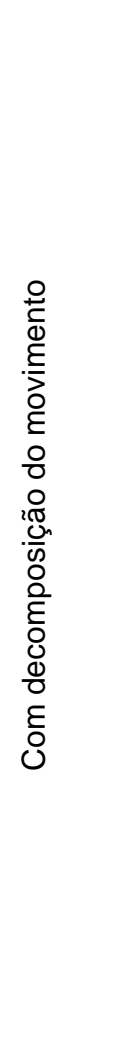 }} & \multirow[t]{2}{*}{$\begin{array}{l}\text { Com movimento } \\
\text { horizontal }\end{array}$} & Equipamentos manuais & $\begin{array}{l}\text { - } \quad \text { padiola; } \\
\text { - } \quad \text { carrinho de mão; } \\
\text { - jerica; } \\
\text { - carrinho porta -pálete }\end{array}$ \\
\hline & & & Equipamentos motorizados & $\begin{array}{l}\text { - jerica motorizada; } \\
\text { - dumper. }\end{array}$ \\
\hline & & \multirow[t]{2}{*}{ Movimento vertical } & Equipamentos manuais & $\begin{array}{l}\text { - } \quad \text { talha; } \\
\text { - } \quad \text { sarilho; } \\
\text { - guincho manual. }\end{array}$ \\
\hline & & & Equipamentos motorizados & $\begin{array}{l}\text { - } \quad \text { guincho de coluna; } \\
\text { - } \quad \text { elevador de carga. }\end{array}$ \\
\hline \multirow{2}{*}{ 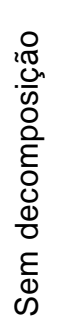 } & \multirow[b]{2}{*}{ 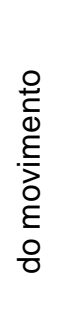 } & \multicolumn{2}{|c|}{ Sistema com movimento descontínuo } & - guindaste \\
\hline & & \multicolumn{2}{|c|}{ Sistema com movimento contínuo } & $\begin{array}{l}\text { - } \text { bomba de concreto } \\
\text { - } \text { bomba de } \\
\text { argamassa }\end{array}$ \\
\hline
\end{tabular}




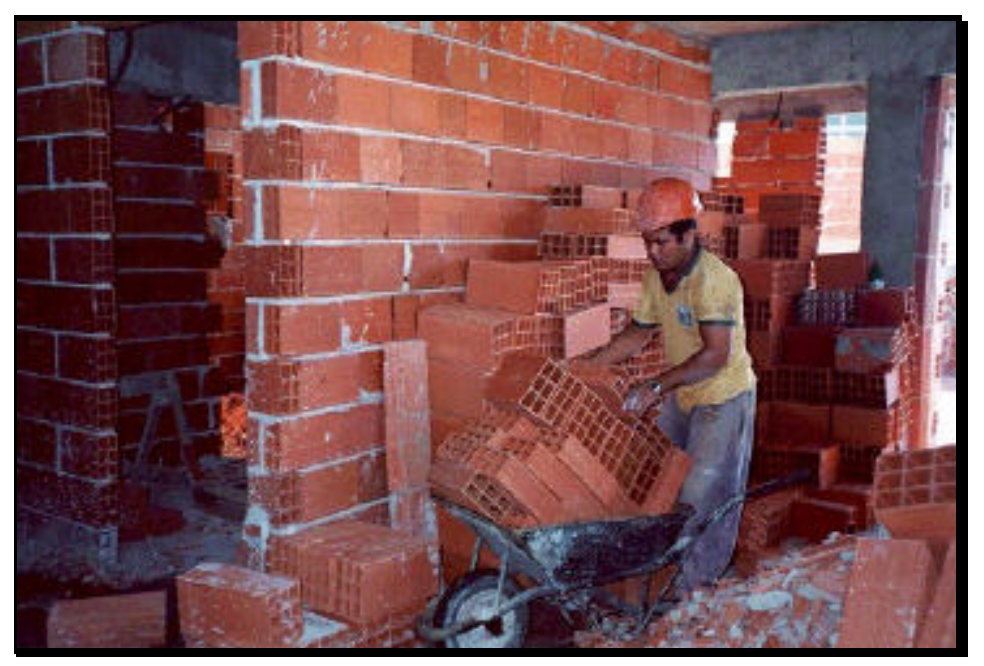

\section{Figura 4.14 Exemplo de transporte inadequado de blocos}

Ainda que hajam diferentes escolhas compatíveis, pode haver expectativa de perdas distintas para cada sistema de transporte adotado. Por exemplo, para o caso do concreto usinado, sistemas de transportes compatíveis poderiam ser compostos por jericas e elevador de cargas, caçamba e grua ou, ainda, por bomba.

A princípio pode parecer lógico que as perdas sejam mais acentuadas para o sistema composto por jericas-elevador de cargas do que para o sistema composto por bomba, em função de haver uma maior expectativa quanto ao transbordamento do material durante o trajeto a ser vencido.

Tal perda pode ser minimizada se forem previstos trajetos adequados, sem rampas acentuadas, em terreno regular (sem buracos ou saliências). Em contrapartida, caso não se faça a previsão de utilização das sobras de concreto usinado decorrentes da limpeza da tubulação do sistema de transporte 
composto por bomba, as perdas podem ser muito significativas para este sistema $^{74}$.

Ações voltadas para a redução das perdas de materiais e a otimização do sistema de transporte, em muitos casos, dependem de avanços relacionados à forma na qual os materiais são embalados ou entregues nos canteiros de obras, isto é, dependem também da participação dos fornecedores.

Um avanço significativo observado nos últimos anos diz respeito aos blocos e tijolos. Hoje em dia é comum os mesmos ser entregues na obra paletizados e protegidos. Ao pessoal da obra, dependendo do tipo de sistema de transporte adotado, cabe apenas o transporte destes páletes ao local de utilização. Isto pode ser feito através de gruas ou, ainda, através de carrinhos porta-páletes.

Um exemplo de equipamento de transporte idealizado para este objetivo é ilustrado na Figura 4.15. Pode-se identificar a praticidade na sua utilização, tanto no que se refere à contribuição para a redução das perdas de materiais, como na amenização do esforço dos operários.

Por fim, cabe ressaltar que esta evolução não tem sentido se o canteiro de obras não estiver preparado para a mesma, ou seja, de nada adianta, por exemplo, os blocos ser paletizados, se no canteiro de obras não existir um equipamento adequado para o seu transporte interno.

\footnotetext{
${ }^{74}$ Note que, não ocorrendo o reaproveitamento das sobras de concreto bombeado contidas na tubulação das bombas, quanto maior o comprimento desta tubulação, maior a percentagem de perdas.
} 


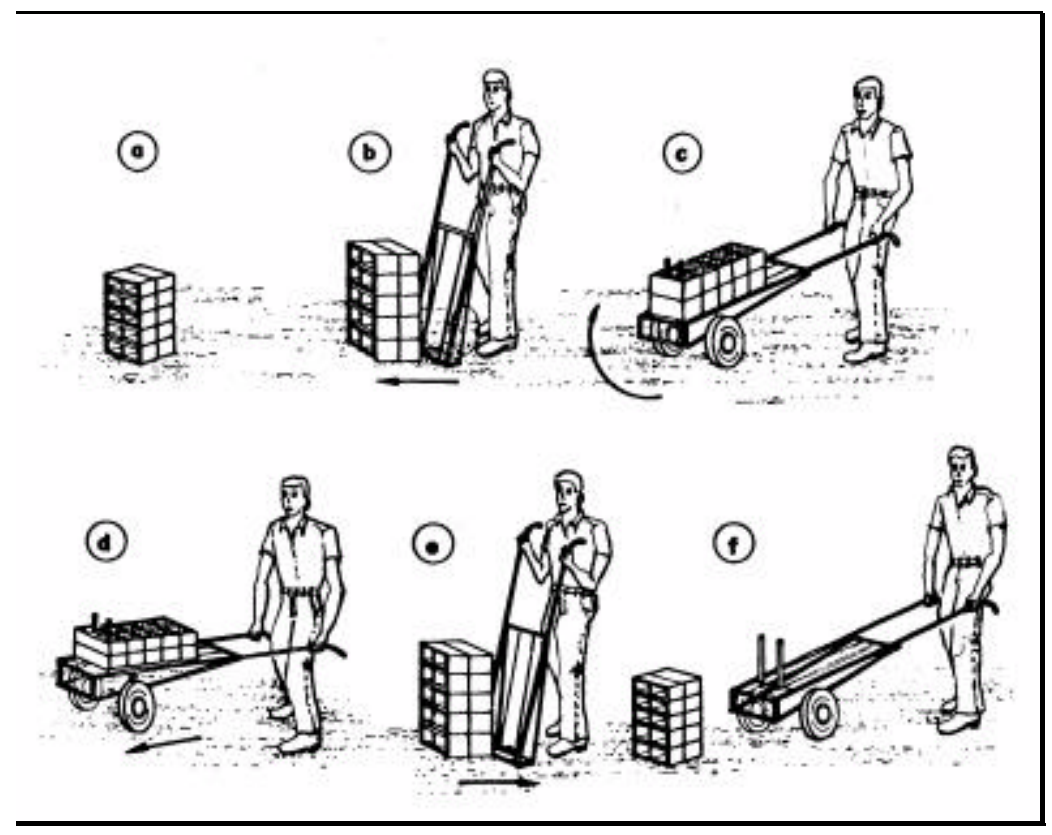

Figura 4.15 Exemplo de equipamento adequado de transporte de blocos (FRANCO 1992) 


\section{CAṔ́TULO 5}

\section{MENSURANDO AS PERDAS E CONSUMOS FíSICOS DE MATERIAIS NOS CANIEIROS DE OBRAS}

Neste capítulo discorre-se sobre os principais conceitos relacionados à medição do desempenho nas organizações, dentre os quais, destacam-se o conceito de indicador e sua classificação, a seqüência das etapas inerentes à implantação de um Sistema de Indicadores, entre outros.

Tais conceitos e classificações são aplicados ao estudo das perdas e consumos de materiais nos canteiros de obras, resultando em um Sistema de Indicadores, estruturado de tal forma a atingir os objetivos propostos neste trabalho.

\subsection{Importância da medição do desempenho nas organizações ${ }^{75}$}

Hoje em da, a sociedade em geral convive, em maior intensidade, com a presença de diversos indicadores, sejam eles econômicos, sociais, culturais, entre outros. Através da análise de tais indicadores, as pessoas tomam decisões, por exemplo, quanto à melhor aplicação financeira a realizar, ao

\footnotetext{
75 Segundo a NBR ISO 8402 (1994), o termo organização pode ser entendido como sendo uma "companhia, corporação, firma, empresa ou instituição, ou partes destas, pública ou privada, sociedade anônima, limitada ou com outra forma estatutária que têm funções e estruturas administrativas próprias.
} 
melhor curso universitário a freqüentar, ao melhor filme ou peça de teatro a assistir etc.

Da mesma forma, os gerentes, sejam eles de administrações públicas ou privadas, baseiam-se em indicadores para a tomada de decisões e ações perante determinados assuntos. Como exemplo, pode-se citar o esforço do Governo Federal em estabelecer um conjunto de indicadores voltados para a avaliação da qualidade e produtividade do serviço público (PROGRAMA BRASILEIRO DA QUALIDADE E PRODUTIVIDADE, 1991). Através de indicadores relacionados à saúde como, por exemplo, o tempo de espera entre a marcação de consulta e o atendimento, tempo médio de internação hospitalar, entre outros, o Governo pode tomar decisões quanto às ações a ser tomadas no sentido de melhorar os resultados apontados por tais indicadores.

Neste contexto, verifica-se que o indicador se configura num importante instrumento para a tomada de decisão, principalmente no que diz respeito à melhoria de uma situação vigente.

Em se tratando de um cenário de competição instalado no país e no mundo, os indicadores assumem o papel de posicionar a organização quanto ao seu desempenho em relação ao desempenho de seus concorrentes imediatos. Da mesma forma, a organização poderá também verificar o retorno de uma possível melhoria implementada na mesma.

Os indicadores também podem ser úteis para o planejamento e para o controle

dos processos das organizações. Segundo TAKASHINA \& FLORES (1996), os indicadores são essenciais ao planejamento "porque possibilitam o 
estabelecimento de metas quantificadas e o seu desdobramento na organização" e essenciais ao controle "porque os resultados apresentados através dos indicadores são ferramentas para a análise crítica do desempenho da organização, para a tomada de decisão e para o replanejamento".

Neste contexto, LANTELME (1994), reunindo os conceitos apresentados por SINK \& TUTTLE (1993) e BURBANK (1992) ${ }^{76}$, classifica as medições, segundo a finalidade à qual as mesmas se destinam, em: para a visibilidade, para o controle, para a melhoria e para a motivação.

Segundo a autora, a medição para a visibilidade tem por objetivo identificar pontos fortes e fracos em uma situação vigente, sendo que a finalidade principal é a de conscientizar a gerência para a melhoria e mostrar o desempenho atual. Como o próprio nome enfatiza, a medição para o controle visa controlar a variação de desempenho de uma situação vigente em relação a padrões previamente estabelecidos. Já a medição para a melhoria tem como finalidade verificar o impacto dos planos de ações aplicados para a melhoria sobre o desempenho do processo ou da organização, enquanto que a medição para a motivação se destina à motivação das pessoas envolvidas no processo de melhoria contínua ${ }^{77}$.

No âmbito da qualidade e produtividade, para a implantação de um Sistema de

\footnotetext{
${ }^{76}$ BURBANK, J.R. Design performance measures for productivity and customer satisfaction. In: ANNAUL QUALITY CONGRESS, 46., 1992, Nashiville. Transations. Milwaukee: American Society for Quality Control, 1992, p. 57-63.

77 A medição do desempenho do processo no qual as pessoas estão inseridas, objetivando o pagamento de prêmios em função deste desempenho, constituise num exemplo de medição para a motivação.
} 
Gestão da Qualidade há a necessidade de se medir a eficácia dos processos e resultados e, como instrumentos para suprir esta necessidade, insere-se o estabelecimento de indicadores (SOUZA et al., 1995).

Em outras palavras, definir indicadores de mensuração da qualidade consiste em viabilizar "a própria noção de qualidade, possibilitando o seu gerenciamento de forma concreta, sistematizada e científica", de tal forma que, "SEM INDICADORES NÃO HÁ GESTÃO E, SEM GESTÃO, NÃO HÁ QUALIDADE" (PROGRAMA BRASILEIRO DA QUALIDADE E PRODUTIVIDADE, 1991).

Para TIRONI et al. (1991), definir indicadores de qualidade é, basicamente, "construir conceitos que permitam a sua mensuração, providência indispensável para a avaliação dos resultados alcançados com esforços aplicados na melhoria da qualidade, ou para traçarem-se comparações entre produtos ou serviços a partir da qualidade".

É neste cenário que se insere a importância do estabelecimento de indicadores de perdas e consumos de materiais nos canteiros de obras.

Uma vez que a empresa tenha como estratégia competitiva a redução do custo dos seus produtos, através da otimização do uso dos materiais no âmbito do canteiro de obras, o ponto de partida consiste em se conhecer os reais níveis de perdas praticados em seus canteiros. O caminho para alcançar este objetivo consiste no estabelecimento de um Sistema de Indicadores ${ }^{78}$ que forneça

\footnotetext{
${ }^{78}$ Entende-se como Sistema de Indicadores, o conjunto de indicadores elaborados de forma estruturada e integrada, cujos resultados apontados pelos mesmos visam cumprir a finalidade para a qual foram elaborados.
} 
informações suficientemente claras e confiáveis de quais são os pontos a ser atacados.

Além desta importância, segundo SOUZA (1997), os indicadores de perdas podem ser utilizados de diversas maneiras: para a comparação relativa entre situações semelhantes em obras diferentes, para avaliação e como subsídio para a correção de indicadores para orçamentação, para comparação entre diferentes "tecnologias" etc.

Reforçando a importância de se desenvolver indicadores de perdas e consumos, destaca-se o fato de existirem poucas bibliografias que abordem este assunto. Se não bastasse esta escassez, os índices apontados nestas escassas bibliografias encontram-se demasiadamente subestimados para uma grande maioria de materiais, além de não os relacionarem, em muitos casos, com as características dos materiais e dos serviços onde os mesmos são consumidos.

Por fim, à medida que as ações voltadas à otimização destes recursos nos canteiros de obras dependem de uma avaliação custo/benefício, o estabelecimento de indicadores de perdas e/ou consumos físicos de materiais configura-se num passo importante em direção a este caminho.

\subsection{Principais conceitos}

\subsubsection{Conceito de indicador}

De acordo com LANTELME (1994), “a medição é um processo que envolve a decisão quanto ao que medir, como coletar, processar e avaliar dados e, 
através de sua incorporação às atividades da empresa, é que se obtém os dados e fatos necessários para a tomada de decisão".

Em outras palavras, a medição consiste no estabelecimento de indicadores, sendo que, para isso, deve-se seguir as etapas de definição de quais indicadores se medir, de como processar as informações coletadas e necessárias ao cálculo dos mesmos e, finalmente, de como avaliar os resultados advindos deste processamento.

Neste contexto, na essência da palavra, o indicador pode ser definido como sendo "um dispositivo, um medidor, mostrador, registrador ou apontador, que mede ou registra e fornece indicações visíveis" (SINK \& TUTTLE, 1993).

Para SOUZA et al. (1995), o indicador consiste na "expressão quantitativa que representa uma informação gerada, a partir da medição e avaliação de uma estrutura de produção, dos processos que a compõem e/ou produtos resultantes".

Definição semelhante é apresentada por TAKASHINA \& FLORES (1996). Para estes autores, o indicador consiste em "formas de representação quantificáveis das características de produtos ou processos e são utilizados pelas organizações para controlar e melhorar a qualidade e o desempenho de seus produtos e processos ao longo do tempo".

\subsubsection{Classificação dos indicadores}

Os indicadores podem ser classificados de diversas formas. As classificações existentes visam subsidiar o perfeito entendimento dos mesmos e, 
conseqüentemente, a perfeita implantação de um Sistema de Medição em uma organização.

\subsubsection{Indicadores de desempenho e de capacitação}

Segundo SOUZA et al. (1995), dentro de um processo produtivo, os indicadores podem ser divididos em duas categorias: indicadores de capacitação e indicadores de desempenho.

Para estes autores, os indicadores de capacitação expressam informações sobre uma determinada estrutura de produção, enquanto que os indicadores de desempenho estão relacionados ao comportamento do processo ou produtos em relação a determinadas variáveis.

\subsubsection{Indicadores de qualidade e de produtividade}

Embora, sob a luz do conceito amplo de qualidade, não se possa fazer uma dis tinção clara entre produtividade e qualidade, uma vez que produzir com economia, ou seja, com aumento de produtividade, possa ser entendido como produzir com qualidade, vários autores fazem uma distinção entre indicadores de qualidade e indicadores de produtividade [LANTELME (1994), SOUZA et al. (1995)].

Para LANTELME (1994), o indicador de qualidade está relacionado à medição da eficácia da empresa em atender às necessidades do cliente; em outras palavras, está relacionado à medição das não-conformidades nos resultados de um processo. 
Esta definição é compartilhada por TAKASHINA \& FLORES (1996) ao afirmarem que os indicadores de qualidade estão associados às características da qualidade do produto julgadas pelo cliente.

Para TIRONI et al. (1991), o indicador de qualidade configura-se num instrumento de mensuração da qualidade, imprescindível ao seu gerenciamento, e consiste "na expressão quantificável da qualidade de um produto ou serviço".

Já o indicador de produtividade mede o "desempenho dos processos, através de relações elaboradas a partir dos recursos utilizados e os respectivos resultados" (SOUZA et al., 1995).

Em complemento a esta definição, LANTELME (1994) acrescenta que o indicador de produtividade representa a "ineficiência do processo na obtenção dos resultados esperados". Ainda segundo esta autora, este indicador pode ser entendido como sendo uma relação entre entradas e saídas de um processo.

\subsubsection{Abrangência ou nível de agregação de dados utilizados para a sua elaboração}

LANTELME (1994) e SOUZA et al. (1995) classificam os indicadores de desempenho, quanto à abrangência, em indicadores globais e indicadores específicos.

Para LANTELME (1994), a diferença entre indicadores de desempenho globais e específicos refere-se, essencialmente, aos usuários das informações. De uma forma geral, os indicadores de desempenho específicos são utilizados 
pelos gerentes e operários de uma empresa nos processos internos, enquanto que os globais fornecem uma visão mais agregada do desempenho da empresa ou do setor, sem a visão de suas particularidades.

Neste sentido, para SOUZA et al. (1995), os indicadores de desempenho globais estão relacionados mais ao planejamento estratégico da empresa e demonstram o grau de competitividade da mesma frente ao setor ou aos com petidores diretos.

Por sua vez, os indicadores de desempenho globais, segundo LANTELME (1994), podem se relacionar à empresa ou ao setor. Enquanto os relacionados à empresa "têm o papel de orientar políticas internas da empresa" ou, ainda, indicar a "sua capacidade de atender as necessidades dos consumidores frente a seus concorrentes diretos", os relacionados ao setor" são importantes para orientar políticas governamentais, principalmente em situações de competição por recursos e incentivos econômicos".

Os indicadores de desempenho específicos "fornecem informações sobre processos ou sobre estratégias e práticas gerenciais dos mesmos, de forma individualizada, orientando a tomada de decisões em termos operacionais (indicadores operacionais) ou gerenciais (indicadores gerenciais)" (SOUZA et al., 1995).

Enquanto os indicadores gerenciais estão associados diretamente à implantação de estratégias através de Planos de Ação ou Programas de Melhoria e apresentam-se desdobrados em vários níveis gerenciais dentro de 
uma empresa, os indicadores operacionais estão relacionados ao gerenciamento das tarefas rotineiras na empresa (LANTELME, 1994).

Como forma de proporcionar uma visão ampla das classificações aqui apresentadas, na Figura 5.1 são ilustradas tais classificações, assim como alguns exemplos de indicadores.

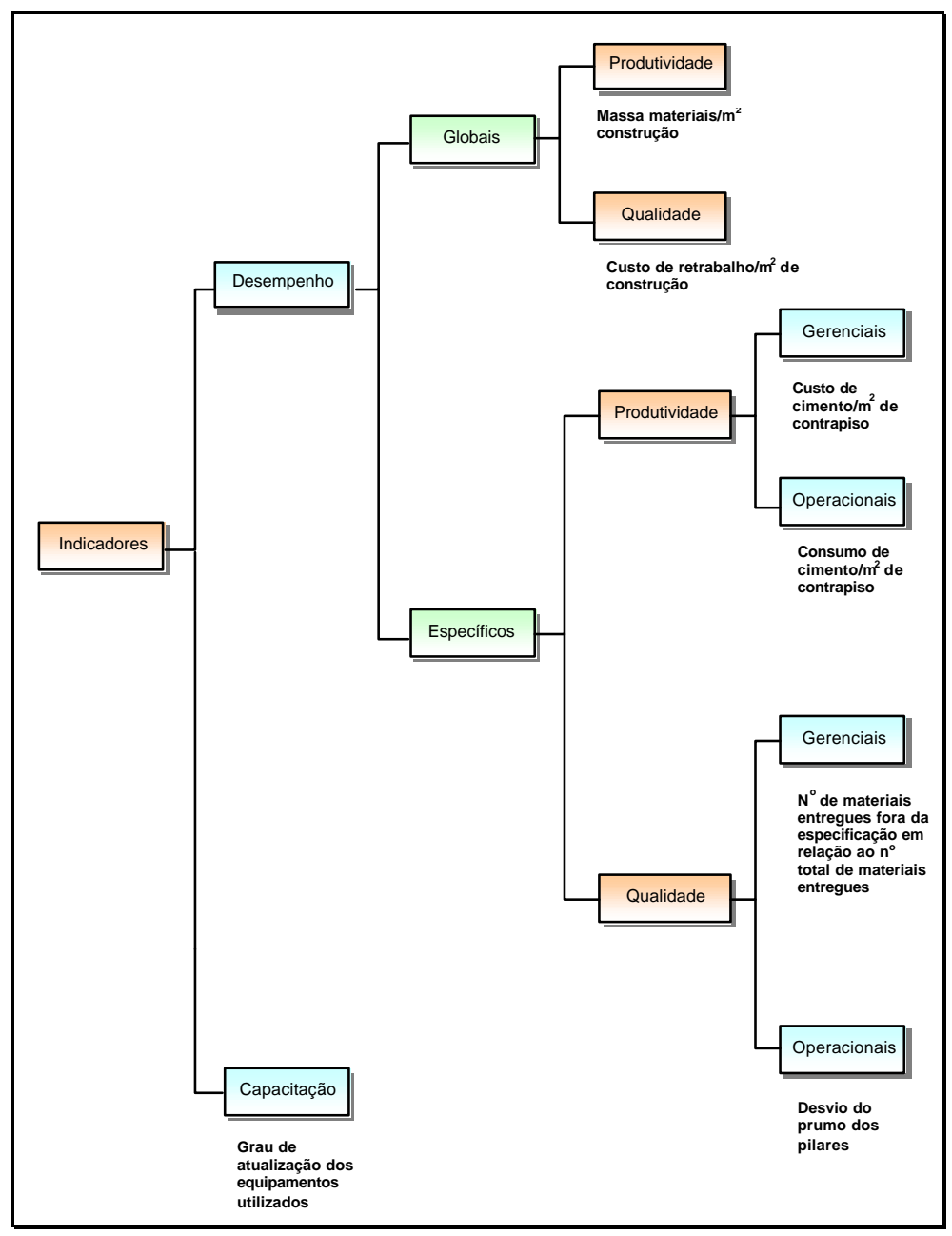

Figura 5.1 Classificação dos indicadores 


\subsection{Unidades de medidas}

Os indicadores podem ser expressos em diversas unidades. SOUZA et al. (1995) resumem bem estas unidades de acordo com a seguinte regra:

- quando o indicador refere-se a uma única variável, sua unidade de medida é um número absoluto ou uma relação com outra referência (tempo, por exemplo); enquadram-se nesta regra os seguintes indicadores: número de dias para a conclusão de um serviço, número de acidentes por mês, custo por $\mathrm{m}^{2}$ etc;

- quando o indicador é comparativo, o resultado do indicador pode se configurar num número absoluto ou numa porcentagem; enquadram-se nesta regra os seguintes indicadores: comparação entre número de dias restantes para a conclusão da obra segundo o cronograma real e de acordo com o cronograma original, consumo de material efetivamente realizado em relação ao previsto etc.

\subsection{Elaboração de um sistema de indicadores}

Feita a apresentação dos principais conceitos relacionados aos indicadores, parte-se, então, para os procedimentos/etapas para a elaboração de um Sistema de Indicadores.

No entanto, antes de se entrar especificamente nestes procedimentos/etapas, cabe ressaltar que a bibliografia consultada para o desenvolvimento deste tópico aborda esta questão, com o enfoque voltado para a implantação de um Sistema de Indicadores nas organizações. 
Embora este não seja o enfoque dado nesta dissertação, acredita-se que os procedimentos descritos em tais bibliografias são perfeitamente aplicáveis ou adaptáveis ao contexto ao qual a mesma se insere, uma vez que a metodologia de coleta e análise de informações sobre perdas e consumos de materiais, aqui desenvolvida, tem por objetivo servir de orientação ao estudo das perdas/consumos de materiais em quaisquer partes do país.

Sendo assim, o estudo das principais bibliografias sobre o assunto, dentre as quais pode-se citar SINK \& TUTTLE (1993), LANTELME (1994), SOUZA et al. (1995), TAKASHINA \& FLORES (1996) e FRANCISCHINI (1998), permite o estabelecimento dos seguintes procedimentos/etapas para a elaboração de um Sistema de Indicadores numa organização, conforme ilustrado na Figura 5.2.

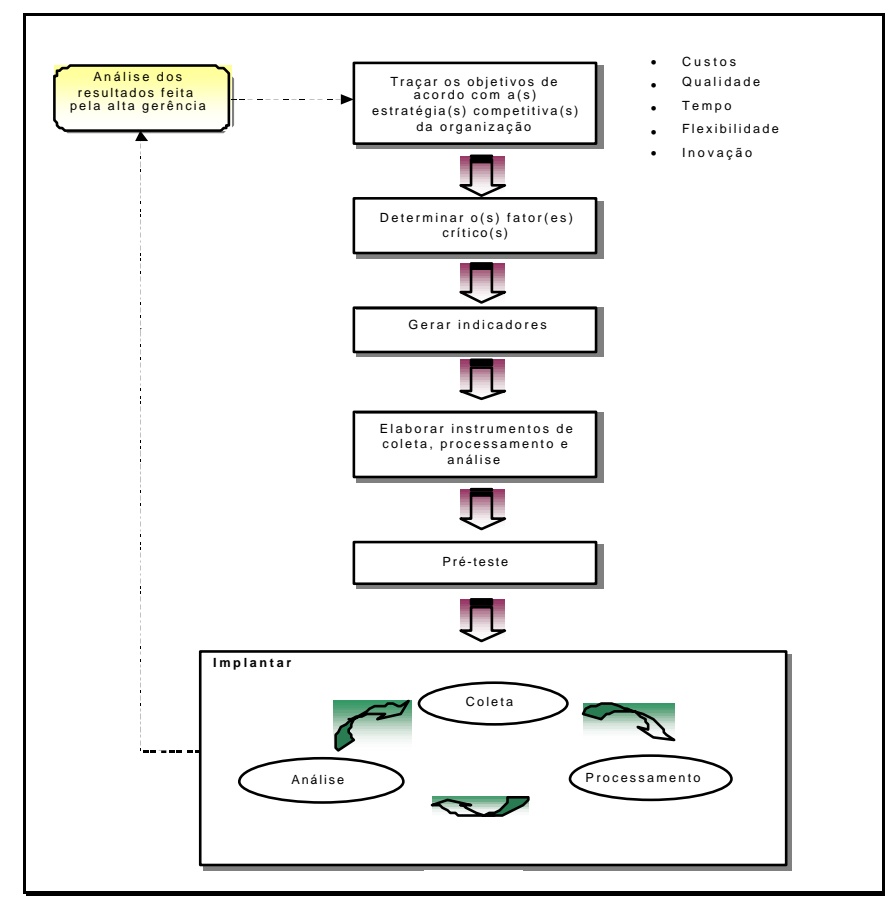

Figura 5.2 Principais etapas a serem seguidas na elaboração de um Sistema de Indicadores 


\subsubsection{A definição da estratégia competitiva da organização}

Segundo FRANCISCHINI (1998), a elaboração de um Sistema de Indicadores não deve ser feita de forma aleatória, mas sim, que tal Sistema deva ser elaborado de acordo com os objetivos estratégicos da empresa, os quais podem ser reunidos em 5 grandes categorias: custo, qualidade, tempo, flexibilidade e inovação.

De acordo com este autor, na estratégia baseada em custo, a empresa busca reduzilo na produção dos bens ou serviços; em qualidade, busca a elaboração de produtos melhores e adequados às necessidades dos clientes; em tempo, busca a entrega de seus produtos ou prestar seus serviços no menor tempo possível e no prazo estipulado; em flexibilidade, a empresa busca adequar-se rapidamente à demanda e, em inovação, busca ser próativa na colocação de novos produtos no mercado.

Seja qual for a estratégia competitiva adotada pela empresa, há que se centrar esforços nos pontos ou fatores considerados chaves ou críticos do processo em que se deseja intervir.

Estes fatores críticos, de acordo com FRANCISCHINI (1998), consistem nas variáveis quanto as quais a empresa deve, necessariamente, ter bom desempenho para que possa atingir as metas traçadas na formulação da sua estratégia competitiva. Em outras palavras, são os pontos importantes a ser monitorados pela empresa e, a identificação destes pontos passa, necessariamente, pela compreensão do processo em que se pretende atuar. 
Aplicando esta idéia ao estudo das perdas e consumos de materiais, fica evidente que as empresas participantes de um trabalho desta natureza, tem por estratégia competitiva, a redução dos custos de seus produtos e, dentre os fatores críticos considerados para tal, insere-se a questão da ocorrência de perdas de materiais nos canteiros de obras.

Definida a estratégia competitiva a ser adotada pela empresa e identificado(s) o(s) fator(es) crítico(s) a ser(em) monitorado(s), parte-se, então, para a etapa de elaboração do Sistema de Indicadores, sendo que o mesmo pode ser dividido em 4 subetapas: geração dos indicadores, elaboração dos instrumentos de coleta, processamento e análise, realização de um pré-teste e, finalmente, a implantação do Sistema.

\subsubsection{Geração dos indicadores}

Segundo FRANCISCHINI (1998), os indicadores, para ser úteis às empresas ou para atenderem à finalidade para a qual foram elaborados, devem ser necessariamente confiáveis. Para ele, os indicadores devem ser completos, isto é, devem abranger todos os aspectos importantes da situação que está sendo analisada.

Para TAKASHINA \& FLORES (1996), os indicadores devem ser gerados de forma criteriosa, de maneira a assegurar a disponibilidade de dados e resultados relevantes, no menor tempo possível e ao menor custo.

Neste sentido, TIRONI et al. (1991) relacionam alguns requisitos que devem ser levados em consideração na geração/seleção dos indicadores: 
- seletividade: na elaboração dos indicadores não se deve abranger todo o processo ou todas as características do produto mas sim, devem ser escolhidos aqueles aspectos que se mostram como fatores críticos para a capacitação ou desempenho da empresa;

- simplicidade: os indicadores a ser elaborados não devem exigir grandes dificuldades na obtenção dos dados, assim como não devem exigir também cálculos e processamentos complexos; em conseqüência, devem ser de fácil compreensão e aplicação nos diversos níveis da empresa;

- baixo custo: os indicadores devem ser obtidos a um custo relativamente baixo, ou seja, as despesas não devem ser superiores ao valor do benefício que se espera obter;

- estabilidade: os indicadores devem permanecer no período que o processo de obtenção se transforme numa rotina incorporada às atividades da empresa;

- rastreabilidade: o processo de elaboração dos indicadores deve ser detalhado e documentado o suficiente para que permita a reconstituição de etapas e resultados parciais.

Além destes requisitos, FRANCISCHINI (1998) relaciona o termo rastreabilidade ao fato de o indicador poder ser desagregado em parcelas menores, permitindo, assim, chegar ao foco do problema detectado pelo mesmo. 
TAKASHINA \& FLORES (1996) acrescentam a esta relação de requisitos, o requisito de comparabilidade, ou seja, os indicadores a ser elaborados devem ser compatíveis ou comparáveis a referenciais apropriados, tais como a média do mercado, o melhor concorrente etc.

Levando-se em consideração tais requisitos, parte-se ,então, para a geração dos indicadores e, a este respeito, SOUZA et al. (1995) resumem muito bem os procedimentos a serem seguidos para a sua geração (Tabela 5.1).

Tabela 5.1 Procedimentos para a geração de indicadores de qualidade e produtividade (SOUZA et al., 1995)

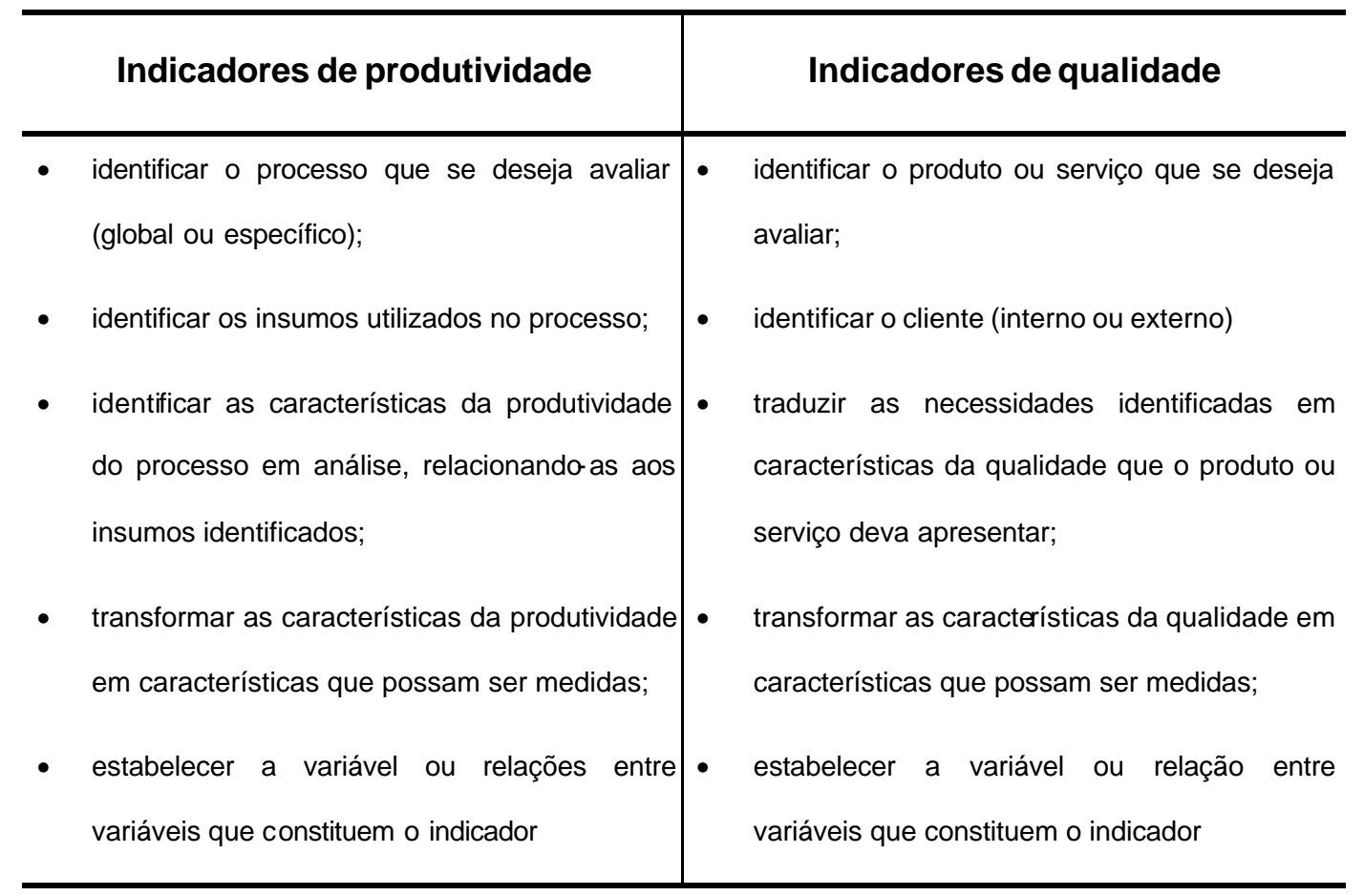

A aplicação destes procedimentos à geração de indicadores relacionados a perdas e consumos de materiais nos canteiros de obras permite 0 estabelecimento de tais indicadores, exemplificados de acordo com a Tabela 5.2. Ressalta-se que a relação completa dos indicadores relacionados à questão das perdas e consumos de materiais será apresentada no capítulo 6 . 


\section{Tabela 5.2 Exemplo de geração de indicadores de qualidade e produtividade relacionados à questão das perdas e/ou consumo de materiais}

\begin{tabular}{|c|c|c|c|c|}
\hline \multicolumn{5}{|c|}{ INDICADOR DE PRODUTIVIDADE } \\
\hline Processo & Insumos & $\begin{array}{c}\text { Característica da } \\
\text { produtividade }\end{array}$ & $\begin{array}{c}\text { Característica a ser } \\
\text { medida }\end{array}$ & Indicador \\
\hline $\begin{array}{l}\text { Execução da } \\
\text { alvenaria }\end{array}$ & Blocos & $\begin{array}{l}\text { Cumprimento do } \\
\text { consumo de blocos } \\
\text { previsto }\end{array}$ & $\begin{array}{l}\text { Consumo de blocos por } \\
\text { serviço de alvenaria } \\
\text { executado }\end{array}$ & $\begin{array}{l}\text { número de blocos por } \mathrm{m}^{2} \mathrm{de} \\
\text { alvenaria }\end{array}$ \\
\hline \multicolumn{5}{|c|}{ INDICADOR DE QUALIDADE } \\
\hline Cliente & Necessidades & $\begin{array}{c}\text { Característica da } \\
\text { qualidade }\end{array}$ & $\begin{array}{c}\text { Característica a ser } \\
\text { medida }\end{array}$ & Indicador \\
\hline $\begin{array}{l}\text { Assentadores } \\
\text { de alvenaria }\end{array}$ & $\begin{array}{l}\text { Padronização } \\
\text { das dimensões } \\
\text { dos componentes }\end{array}$ & $\begin{array}{l}\text { Cumprimento das } \\
\text { dimensões previstas } \\
\text { pelo fornecedor e } \\
\text { normas técnicas }\end{array}$ & $\begin{array}{l}\text { Dimensões dos } \\
\text { componentes entregues no } \\
\text { canteiro de obras }\end{array}$ & $\begin{array}{l}\text { Variação dimensional dos } \\
\text { componentes de alvenaria }\end{array}$ \\
\hline
\end{tabular}

\subsubsection{Elaboração dos procedimentos de coleta, processamento e análise}

Definidos os indicadores a ser coletados, passa-se, então, à elaboração dos procedimentos de coleta, ao processamento e à análise dos resultados.

Faz parte destes procedimentos a determinação de como os dados serão obtidos e armazenados, quem será o responsável pela coleta de tais dados, onde serão obtidos e qual a freqüência de coleta (SOUZA et al., 1995).

Um modelo de procedimento de coleta e processamento dos dados é apresentado por OLIVEIRA et al. (1993), o qual é dividido nos seguintes itens: identificação do indicador, objetivo a ser alcançado com o estabelecimento do mesmo, roteiro de cálculo contendo fórmulas, descrição das variáveis e 
critérios utilizados na coleta e processamento, periodicidade e momento da coleta de dados.

TAKASHINA \& FLORES (1996) apresentam um modelo de procedimento semelhante, acrescentando, entre outras, as seguintes informações: o responsável pela coleta e a metodologia de análise. Independentemente do modelo utilizado, o importante é que o procedimento contenha informações suficientemente detalhadas para que se possa realizar, na prática, a medição das informações.

No que diz respeito especificamente ao processamento dos dados, devem ser estabelecidos os aspectos relacionados a quais ferramentas serão utilizadas, à forma de apresentação dos indicadores, entre outros; enquanto que, em se tratando da análise, deve-se definir quais os critérios para a avaliação tanto nos casos positivos quanto nos casos negativos, além de como os resultados obtidos realimentarão o processo de elaboração dos indicadores (SOUZA et al., 1995).

\subsubsection{Pré-teste}

Uma etapa de extrema importância para o sucesso da implantação do Sistema de Indicadores consiste na realização de uma experimentação da coleta, processamento e análise dos resultados. Assim, pode-se prever e dirimir as principais dúvidas por parte dos responsáveis pela medição, assim como amenizar as dificuldades encontradas. 
Da mesma forma, caso alguns indicadores não se mostrem realmente importantes ao longo do tempo, devem ser alterados (OLIVEIRA et al., 1993).

Além destes aspectos, esta etapa torna-se importante uma vez que se realiza o treinamento das pessoas envolvidas no trabalho e se verifica se os indicadores propostos atendem aos requisitos apresentados no item 5.4.2. Nesta fase, com o intuito de se atender a estes requisitos, discute-se com a empresa as possíveis mudanças necessárias no processo original a ser avaliado, conforme será detalhado no capítulo 6 .

\subsubsection{Implantação}

Finalmente, após todos os procedimentos estarem adequados aos objetivos da medição e perfeitamente claros aos responsáveis pela coleta, procede-se, então, a implantação do Sistema de Indicadores.

\subsection{Sistema de indicadores de perdas e consumos de materiais nos canteiros de obras}

A associação dos conceitos relacionados à medição do desempenho nas organizações e às situações geradoras de perdas ou consumos de materiais nos canteiros de obras, permite o estabelecimento de um Sistema de Indicadores.

A implantação deste Sistema nos canteiros de obras permitirá não só o estabelecimento de indicadores de perdas e consumos de materiais nos canteiros de obras, como também a identificação das principais etapas onde a incidência de perdas ou consumos é mais significativa. 


\subsubsection{Conceito de indicadores de perdas e de consumos}

O indicador de consumo pode ser classificado como sendo um indicador de desempenho, mais especificamente, como sendo um indicador de produtividade, pois estabelece uma relação entre entradas e saídas de um processo, sendo a entrada representada pelos materiais e a saída pelos serviços ou a obra como um todo.

Desta forma, define-se indicador de consumo de materiais como sendo a relação entre a quantidade consumida destes e a quantidade de serviço executada com tais materiais.

Por sua vez, o indicador de perdas também pode ser classificado como sendo um indicador de desempenho. No entanto, ao contrário do indicador de consumo, este não pode ser classificado como indicador de produtividade, pois enquanto este consiste na relação entre os recursos (materiais, mão-de-obra, energia etc) utilizados na produção de um determinado produto (serviço, obra etc) e a quantidade de produto produzido com tais recursos, o indicador de perda consiste na relação percentual entre os recursos efetivamente utilizados na produção de um produto e os recursos de referência.

Neste sentido, define-se indicador de perdas como sendo a expressão do distanciamento do desempenho de um processo, quanto à utilização de um recurso, em relação a uma situação de referência. Desta forma, partindo-se do conceito de que atender e/ou produzir com economia é sinônimo de qualidade e atender e/ou produzir com economia é sinônimo de redução de perdas, o indicador de perdas pode ser classificado como indicador de qualidade . 
Note ainda que, partindo-se deste conceito, o indicador de perda de materiais pode ser definido também, como sendo a diferença entre o indicador de consumo real de materiais e o indicador de consumo de referência na execução de um determinado serviço e/ou obra.

No que diz respeito às unidades de expressão dos indicadores, os de perdas são normalmente expressos em percentagem, enquanto que, os de consumo, são expressos através da relação entre a unidade na qual o material é comprado ou analisado dentro do canteiro de obras e a unidade de medida do serviço na qual são consumidos. Na Tabela 5.3 são apresentados alguns exemplos de unidades de expressão dos indicadores de perdas e consumos de materiais.

Tabela 5.3 Unidades de expressão dos indicadores de perdas e consumo de materiais

\begin{tabular}{|c|c|c|c|c|c|}
\hline \multicolumn{2}{|c|}{ Serviços } & \multicolumn{2}{|c|}{ Materiais } & \multicolumn{2}{|c|}{$\begin{array}{c}\text { Indicadores (unidades de } \\
\text { expressão) }\end{array}$} \\
\hline Descrição & $\begin{array}{l}\text { Unidade de } \\
\text { medida }\end{array}$ & Descrição & $\begin{array}{l}\text { Unidade de } \\
\text { medida }\end{array}$ & Perdas & Consumo \\
\hline Alvenaria & $\mathrm{m}^{2}$ & Blocos & un & $\%$ & $\mathrm{un} / \mathrm{m}^{2}$ \\
\hline Contrapiso & $\mathrm{m}^{2}$ & Cimento & $\mathrm{kg}$ & $\%$ & $\mathrm{~kg} / \mathrm{m}^{2}$ \\
\hline Rev. Interno & $\mathrm{m}^{2}$ & Cal & $\mathrm{kg}$ & $\%$ & $\mathrm{~kg} / \mathrm{m}^{2}$ \\
\hline Rev. Interno & $m^{2}$ & Argamassa & $\mathrm{m}^{3}$ & $\%$ & $\mathrm{~m}^{3} / \mathrm{m}^{2}$ \\
\hline
\end{tabular}

\subsubsection{Estrutura do Sistema de Indicadores de perdas e consumos de materiais nos canteiros de obras}

O Sistema de Indicadores proposto deve ser estruturado de tal forma que permita o estabelecimento de números representativos sobre o processo que 
se esteja analisando e a identificação das etapas do fluxograma dos processos onde há a maior incidência de perdas de materiais.

Para atingir tais objetivos, o Sistema de Indicadores deverá atender, na medida do possível, aos requisitos apresentados no item 5.4 .2 deste capítulo. Desta forma, pode-se estabelecer as seguintes diretrizes quanto ao estabelecimento dos indicadores:

(a) as perdas ou consumos de materiais devem ser abordados de uma forma global (abrangendo todas ou algumas etapas do fluxograma dos processos) e de uma forma mais específica (abrangendo apenas uma etapa do fluxograma dos processos), atendendo-se, portanto, ao requisito de rastreabilidade;

(b) dentre as etapas do fluxograma dos processos, deve-se priorizar o estabelecimento de indicadores para aquelas consideradas potencialmente geradoras de perdas, atendendo-se, portanto, o requisito de seletividade;

(c) na medida do possível, deve-se priorizar o estabelecimento de indicadores que melhor atendam ao requisito de simplicidade; no entanto, tal requisito pode ser relegado a segundo plano desde que a informação a ser obtida seja de fundamental importância para o entendimento das perdas;

(d) em conseqüência, as perdas relacionadas àquelas etapas com menor probabilidade de ocorrência de perdas podem ser obtidas analiticamente, subtraindo-se do valor global (considerando todas as etapas do fluxograma dos processos) o valor relacionado às etapas potencialmente geradoras de perdas. 


\subsubsection{Indicadores globais e parciais}

A classificação dos indicadores de perdas e/ou consumo de materiais está relacionada à natureza do fluxograma dos processos que, por sua vez, é função do tipo de material.

Este aspecto fica evidenciado ao comparar-se, por exemplo, o estudo das perdas do cimento e do concreto usinado. Enquanto o fluxograma dos processos relativo ao segundo material contempla as etapas de recebimento, transporte e aplicação, o do primeiro contém, além destas etapas, a de estocagem e processamento intermediário para a produção de uma argamassa ou concreto produzidos em obra. Além deste fato, a argamassa, cujo cimento é um dos seus constituintes, pode ser utilizada simultaneamente em vários serviços.

Dentro deste contexto, podem ser estabelecidos indicadores abrangentes, denominados aqui de globais, ou específicos, denominados aqui de parciais. Por sua vez, os indicadores globais podem expressar os valores de perda de um determinado material na obra como um todo, apenas em um serviço ou, ainda, apenas nas etapas subseqüentes a sua estocagem. Tal abrangência depende da complexidade do fluxograma dos processos no qual o material está inserido, conforme exemplificado anteriormente e ilustrado na Figura 5.3. 


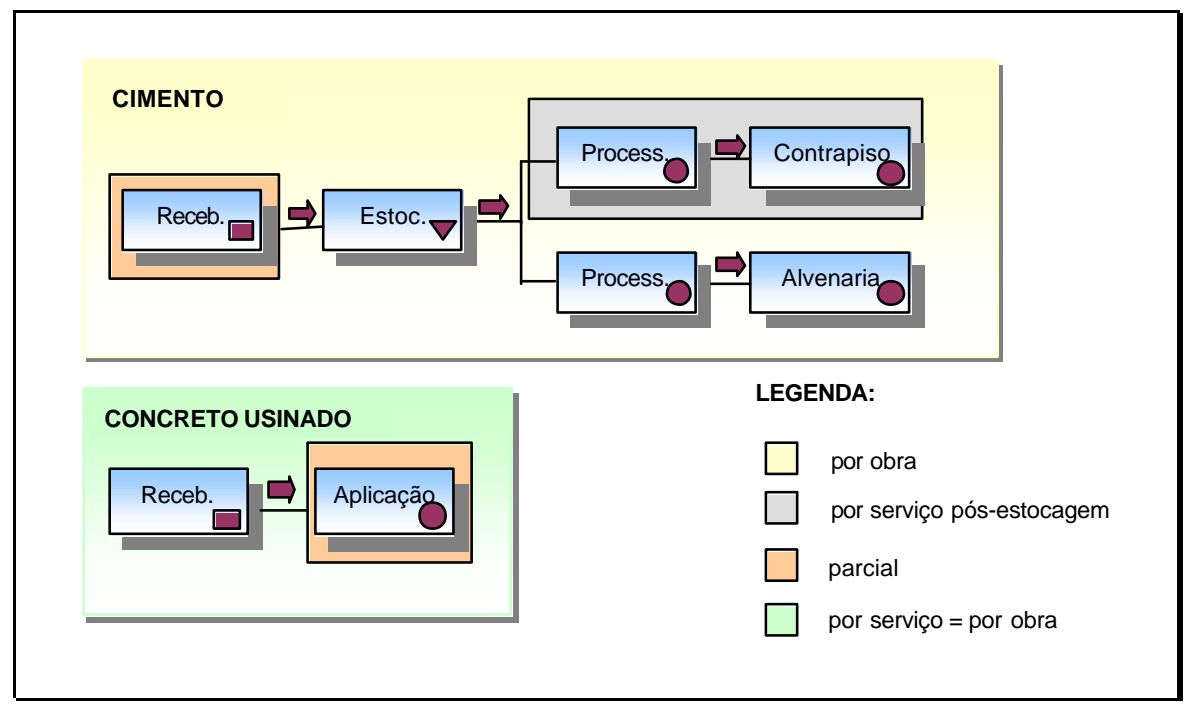

\section{Figura 5.3 Classificação dos indicadores de perdas e consumos de materiais segundo a sua abrangência}

Neste sentido, define-se aqui indicador parcial como sendo a expressão dos valores de consumos e/ou perdas de materiais associados apenas a uma etapa do fluxograma dos processos. À expressão dos valores das perdas e/ou consumos, associada a mais de uma etapa do fluxograma dos processos denomina-se indicador global. O indicador global pode, ainda, ser classificado em: indicador de perda de material por obra, indicador global de perda e consumo de material por serviço e indicador global de perda e consumo de material por serviço pós-estocagem. Tanto os indicadores globais quanto os indicadores parciais serão melhor detalhados na seqüência enquanto que os respectivos cálculos serão melhor detalhados no capítulo 6 . 


\section{(a) Indicador global de perda de material por obra ${ }^{79}$}

Como o próprio nome enfatiza, o indicador global de perdas de material por obra abrange todas as etapas do fluxograma dos processos percorridas pelo material, independentemente de o mesmo ser utilizado num único serviço ou não.

Em termos analíticos, para um determinado período, genericamente o indicador global é dado pela diferença percentual entre o consumo de referência e o consumo efetivamente ocorrido, conforme a expressão:

$$
I_{\text {global }, \text { obra }}=\left[\frac{\text { Consumo }_{\text {real }}}{\text { Consumq }_{\text {referencia }}}-1\right] x 100
$$

onde,

$$
\begin{aligned}
& \text { Consumgreal }=\begin{array}{l}
\text { quantidade total de material utilizada (consumida) nos diversos } \\
\text { serviços executados durante o período de coleta }
\end{array} \\
& \text { Consumo }_{\text {referência }=} \begin{array}{l}
\text { quantidade teoricamente necessária para a execução dos serviços } \\
\text { durante o período de coleta }
\end{array}
\end{aligned}
$$

\section{(b) Indicadores globais de consumo e perda de material por serviço}

Consistem na expressão do valor da perda e/ou consumo de material num único serviço, abrangendo desde a etapa de recebimento até a aplicação final. Para o cálculo do indicador de perda utilizase a mesma fórmula anterior, porém, para um único serviço. Para o caso de expressarem-se os valores em termos de consumo de materiais, substitui-se o denominador da expressão

\footnotetext{
${ }^{79}$ Note que não tem sentido calcular o indicador global de consumo na obra para aqueles casos onde as unidades de medida dos serviços nos quais o material é utilizado, são diferentes. Exemplo: cimento no serviço de chapisco $\left(\mathrm{m}^{2}\right)$ e cimento no serviço de alvenaria $(\mathrm{m})$.
} 
[5.1] pela quantidade de serviço executada durante o período correspondente, conforme expressão [5.2]:

$$
I_{\text {global }_{\text {consumo }}}=\left[\frac{\text { Consumo }_{\text {real }} \text { serviço }}{Q S}\right]
$$

onde,

$$
\begin{array}{ll}
\text { Consumo }_{\text {real }} \text { serviço }= & \begin{array}{l}
\text { quantidade total de material utilizada (consumida) no serviço } \\
\text { executado durante o período de coleta }
\end{array} \\
Q S \quad & \text { quantidade de serviço executada durante o período de coleta }
\end{array}
$$

\section{c) Indicadores globais de consumo e perda de material por serviço pós-estocagem}

De todos os indicadores globais, estes são o mais específicos, abrangendo somente as etapas subseqüentes à estocagem do material analisado. Aplicamse aos materiais básicos, ou seja, àqueles utilizados para a produção de outro material (material composto), como é o caso do cimento, da cal e, eventualmente, da argamassa pré-misturada. Para a coleta destes indic adores é necessário que se faça um controle de saída do material do estoque. Assim, é possível determinar as quantidades reais do material destinadas a cada serviço. Para o cálculo destes indicadores, são utilizadas as mesmas expressões apresentadas anteriormente, substituindo-se apenas o numerador das mesmas pela quantidade de material destinada a cada serviço. 


\section{(d) Indicadores parciais de consumos e perdas de materiais}

A análise das possibilidades de ocorrência de perdas de materiais ao longo do fluxograma dos processos permite o estabelecimento de um conjunto de indicadores mais específicos, cuja relação pode ser visualizada no anexo C. Neste anexo, além desta relação, procurou-se também associar a ocorrência das perdas de materiais as suas causas, assim como, a sua origem.

No entanto, a obtenção de todos estes indicadores citados no anexo torna-se inviável, principalmente para aqueles casos onde há a necessidade de se alterar o modo de organização da execução dos serviços ou, ainda, para aqueles casos onde há a necessidade de equipamentos de medição não disponíveis na obra ${ }^{80}$.

Embora, num primeiro momento, tal postura venha comprometer 0 entendimento das perdas de materiais nos canteiros de obras, a estrutura proposta adotada para o Sistema de Indicadores, permite o estabelecimento do valor destas perdas indiretamente.

Como exemplo, a Figura 5.4 traz o fluxograma dos processos para o estudo do cimento nos serviços de chapisco e emboço interno. Focando-se o estudo apenas no âmbito do serviço de emboço interno, consegue-se estabelecer o valor das perdas para as etapas subseqüentes à estocagem (indicador global por serviço pós-estocagem) e, especificamente, para as etapas de processamento intermediário (Diferença entre o consumo de cimento previsto e

\footnotetext{
${ }^{80}$ Como exemplo, pode-se citar a medição do entulho de aço gerado durante o corte. Além de ser necessária uma organização deste entulho, há a necessidade também de se ter uma balança compatível para a medição da massa do mesmo.
} 
o realmente ocorrido durante a produção da argamassa) e aplicação (Diferença entre a espessura real do emboço e a espessura prevista). Com estes valores, as perdas ocorridas durante o transporte podem ser obtidas indiretamente, com as devidas ressalvas quanto à precisão requerida, fazendo-se a diferença entre o valor do indicador global por serviço pós-estocagem e o somatório dos valores dos indicadores parciais coletados.

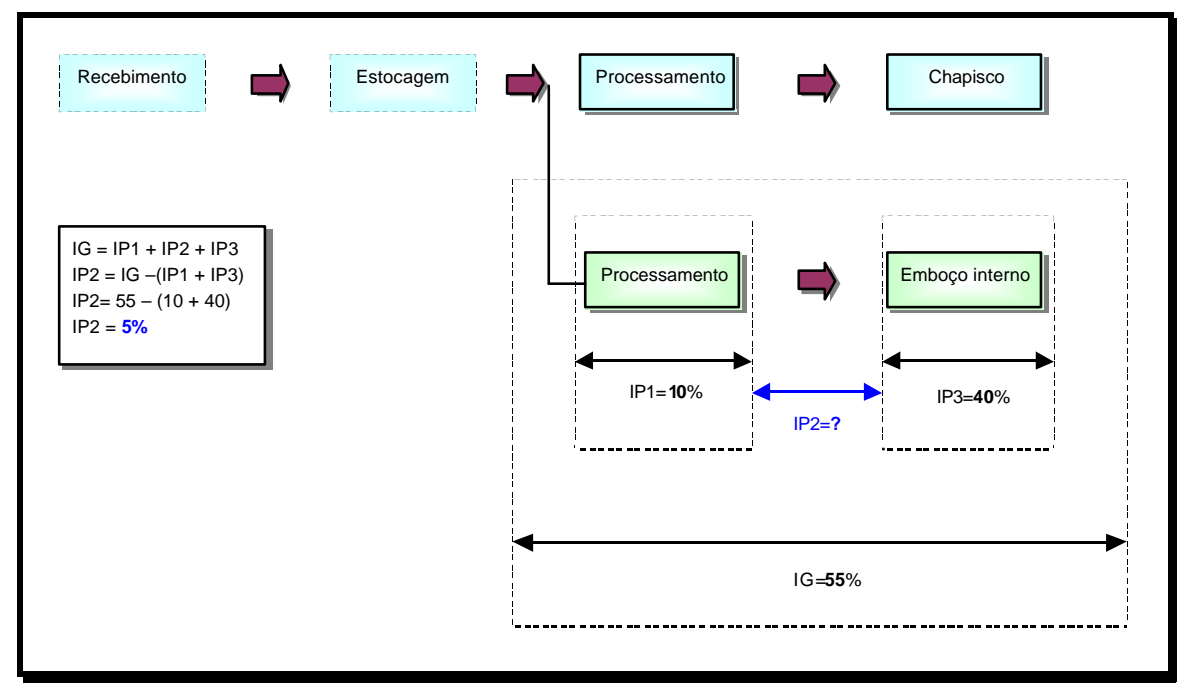

\section{Figura 5.4 Exemplo sobre a obtenção do indicador parcial de perda de forma indireta}

Note ainda que tal raciocínio pode ser aplicado no âmbito apenas dos indicadores parciais. Como exemplo, pode-se citar a estimativa do valor do entulho gerado durante a execução do emboço interno. Para isso, inicialmente mede-se o volume de um caixote de argamassa a ser aplicado numa determinada área. Em seguida, mede-se a área revestida, assim como a espessura do emboço executado ${ }^{81}$. Ao comparar-se o volume do caixote com o

\footnotetext{
${ }^{81}$ Note que a espessura do emboço é medida antes da execução do mesmo, a partir das taliscas já posicionadas.
} 
volume aplicado existente na parede (multiplicação entre a espessura média e a área de revestimento executada), obtém-se o valor do entulho gerado.

A aplicação deste raciocínio ao estudo dos outros materiais nos seus respectivos serviços, viabiliza o entendimento das perdas sem que seja necessária uma coleta muito onerosa, principalmente com relação à medição do entulho.

Da mesma maneira que é possível a obtenção de valores das perdas de materiais de forma indireta, há que se ressaltar também que os indicadores parciais de perdas não necessariamente representam diretamente as perdas ocorridas nos canteiros de obras. Em outras palavras, podem ser estabelecidos indicadores que indiquem a maior ou menor probabilidade de ocorrência de perdas. Como exemplo, pode-se citar o percentual de blocos cortados na parede, cujo resultado não diz respeito à perda deste material propriamente dita, e sim, à maior ou menor probabilidade de ocorrência de perdas deste componente devido ao corte do mesmo. Tal discussão é tanto mais direta quanto mais se detecte que há uma ocorrência significativa de quebras durante o corte ou que não se faça o reaproveitamento das partes originadas deste corte.

Assim, os indicadores parciais podem ser classificados, ainda, em indicadores parciais de perdas diretos e indicadores parciais de perdas indiretos. Enquanto os diretos representam uma parcela de perdas do indicador global, os indiretos inferem à maior ou menor probabilidade de ocorrência de perdas. 
5.5.2.2 Relação geral de indicadores de perdas e consumos de materiais nos canteiros de obras

Feitas as considerações quanto à definição dos indicadores de perdas e consumos de materiais e quanto à estrutura proposta para o Sistema de Indicadores, nas Tabelas 5.4 a 5.22 são apresentados os indicadores relacionados a perdas e consumos de materiais nos canteiros de obras que foram efetivamente adotados para tornar parte da metodologia proposta neste trabalho. 
Tabela 5.4 Indicadores de perdas e consumos de materiais e componentes - Areia

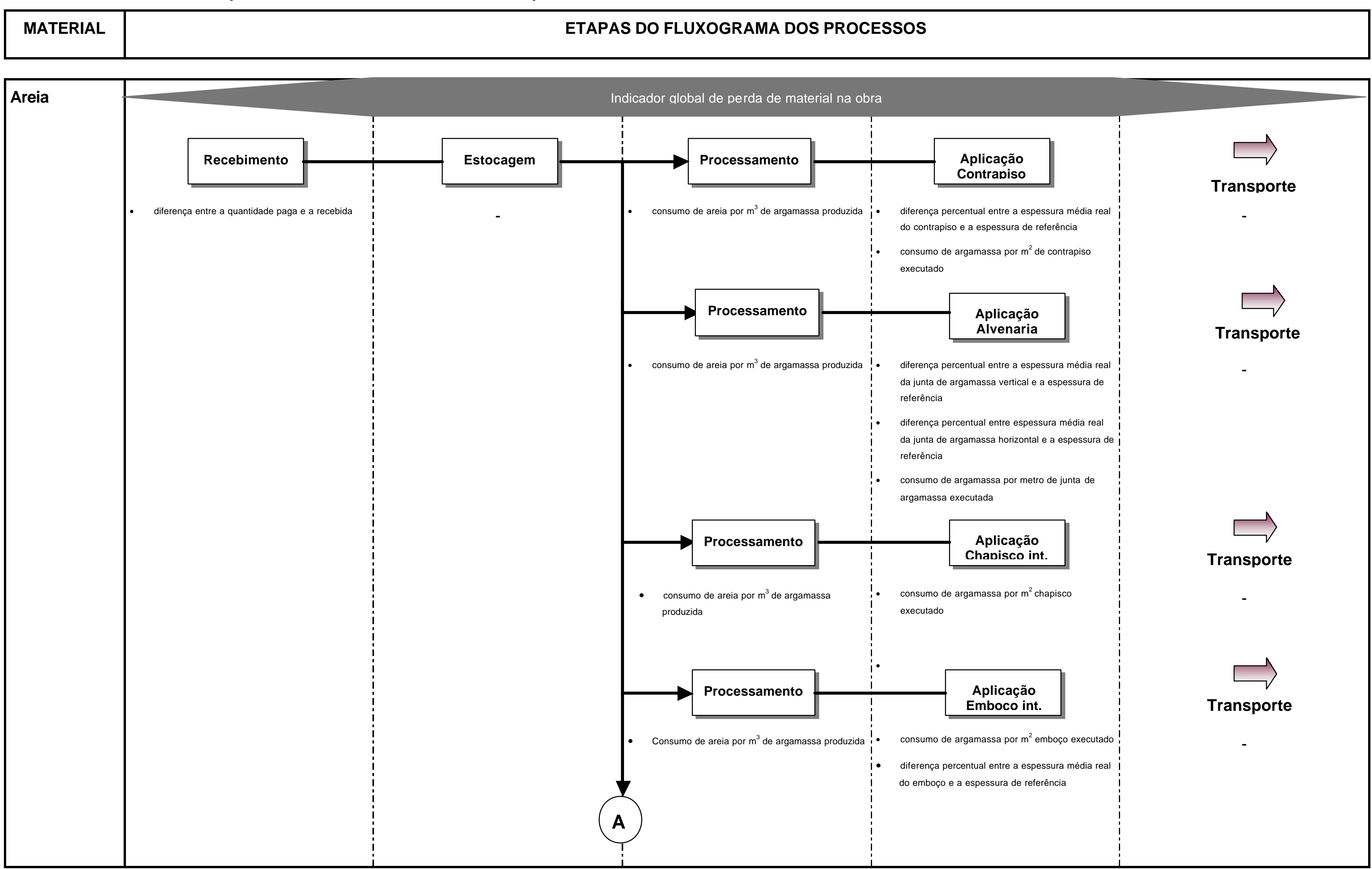


Tabela 5.4 Indicadores de perdas e consumos de materiais e componentes - Areia (continuação)

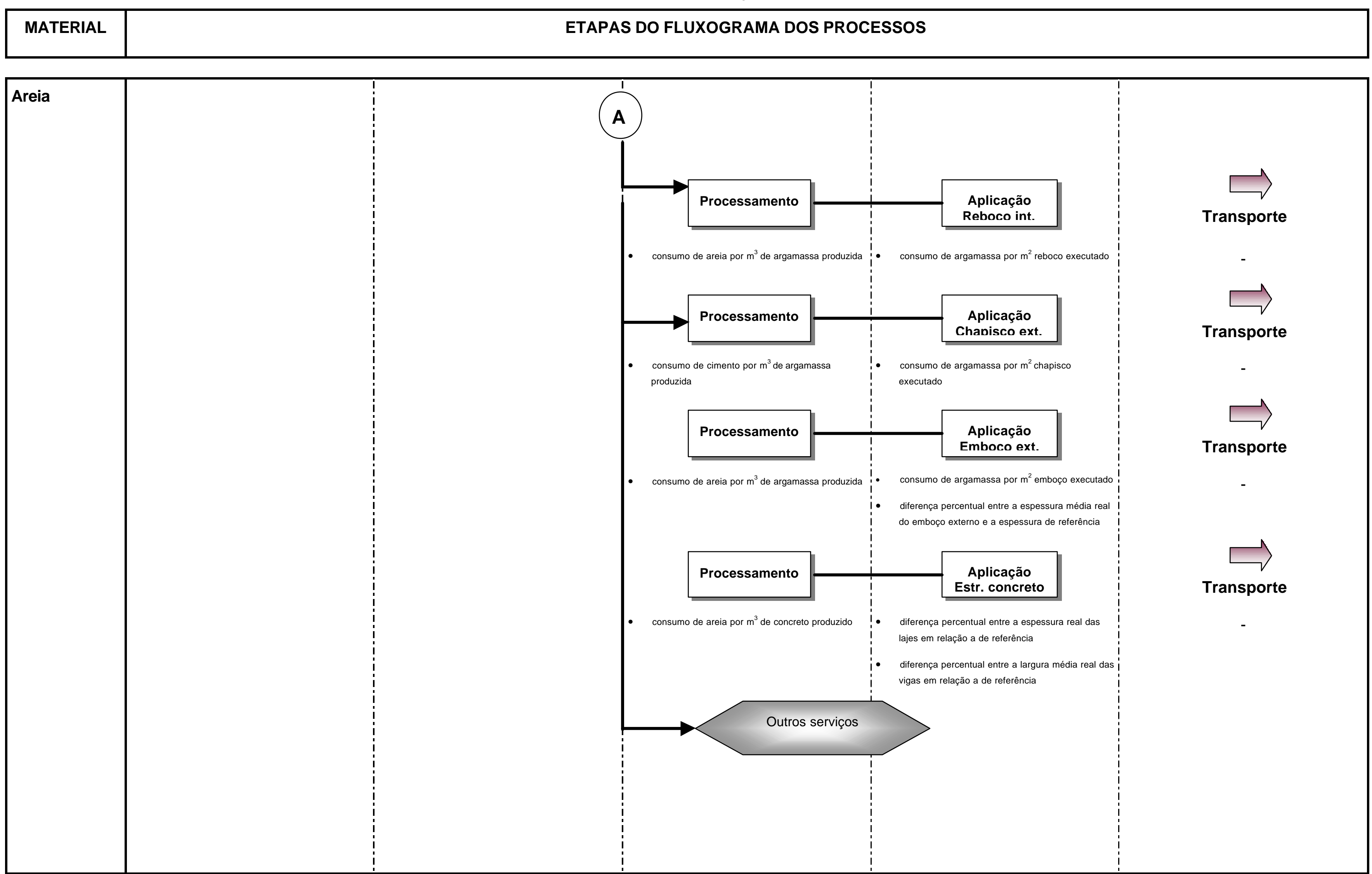


Tabela 5.5 Indicadores de perdas e consumos de materiais e componentes - Cimento

\begin{tabular}{l|ll} 
MATERIAL & ETAPAS DO FLUXOGRAMA DOS PROCESSOS
\end{tabular}

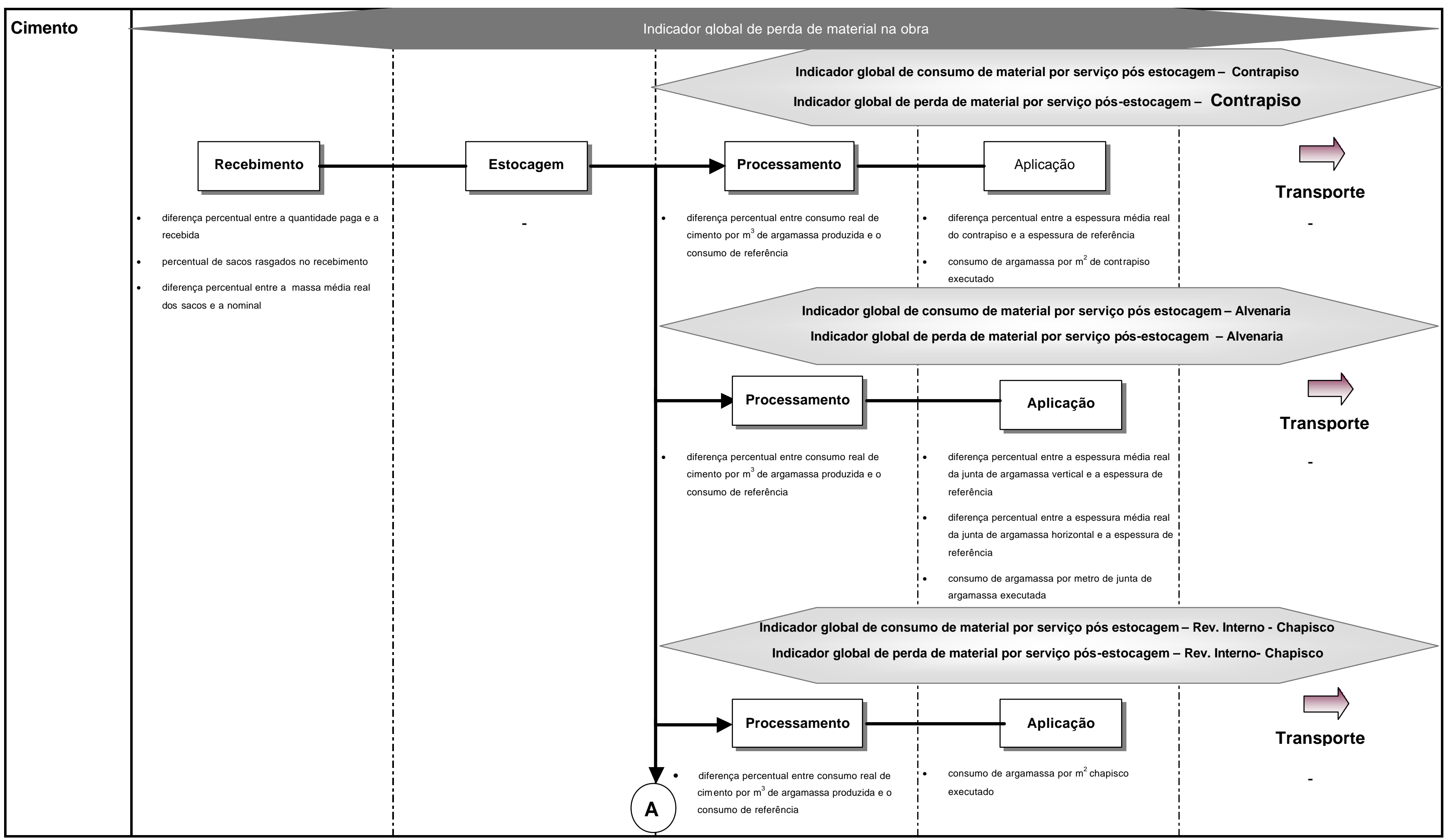


Tabela 5.5 Indicadores de perdas e consumos de materiais e componentes - Cimento (continuação)

\begin{tabular}{|l|ll} 
MATERIAL & ETAPAS DO FLUXOGRAMA DOS PROCESSOS \\
\hline
\end{tabular}

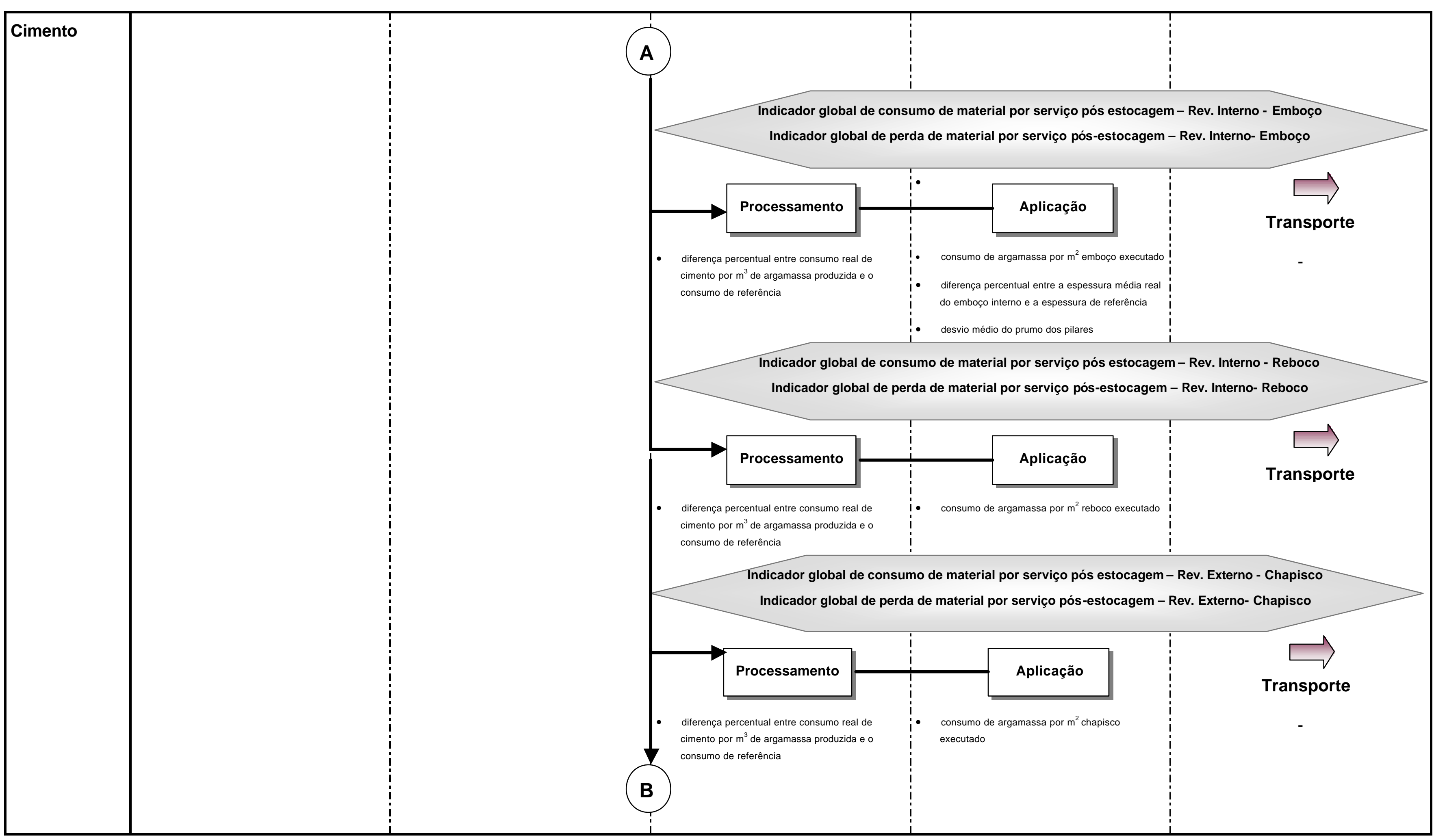


Tabela 5.5 Indicadores de perdas e consumos de materiais e componentes - Cimento (continuação)

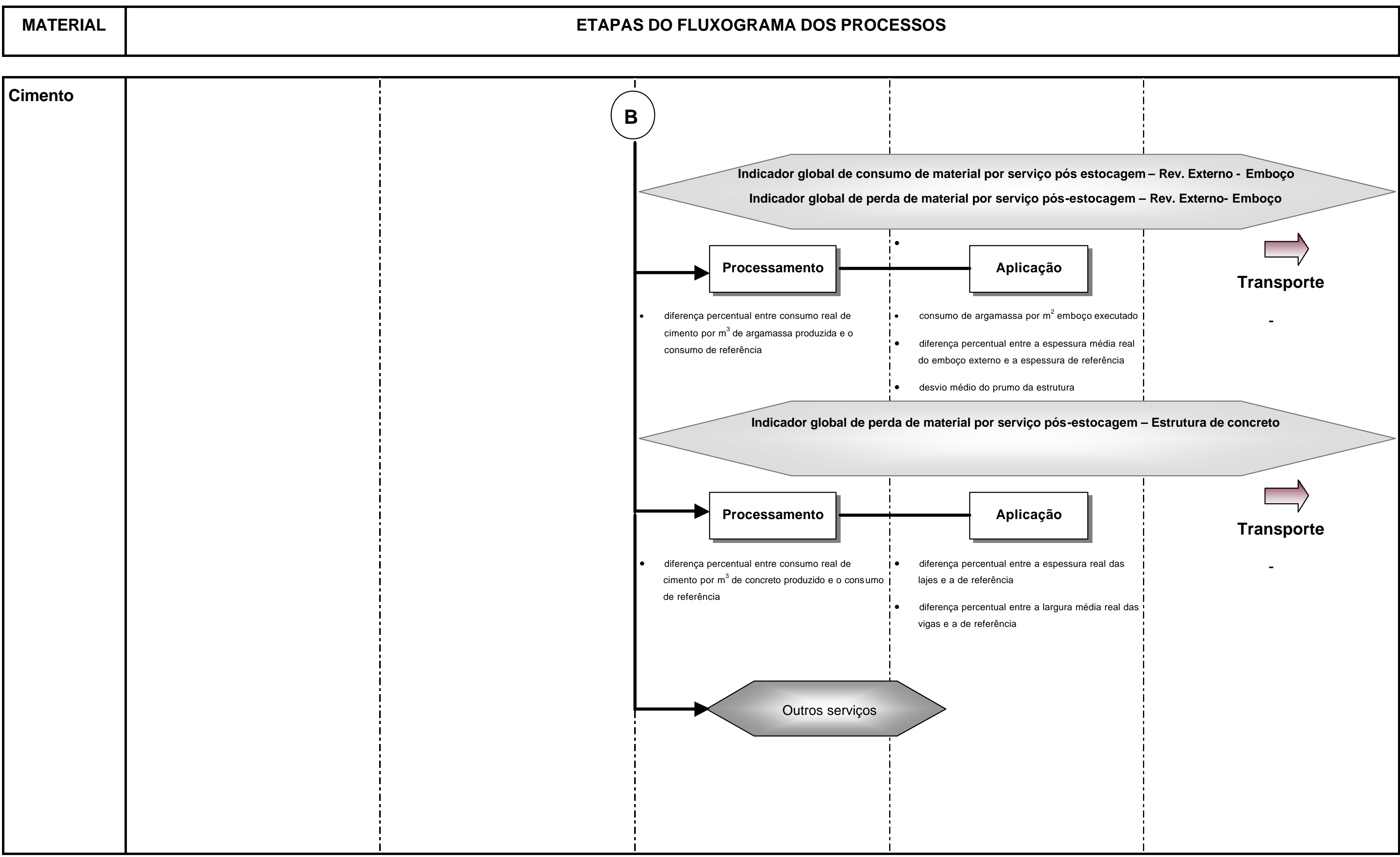


Tabela 5.6 Indicadores de perdas e consumos de materiais e componentes - Pedra

\begin{tabular}{|l|l|}
\hline MATERIAL & ETAPAS DO FLUXOGRAMA DOS PROCESSOS \\
\hline
\end{tabular}

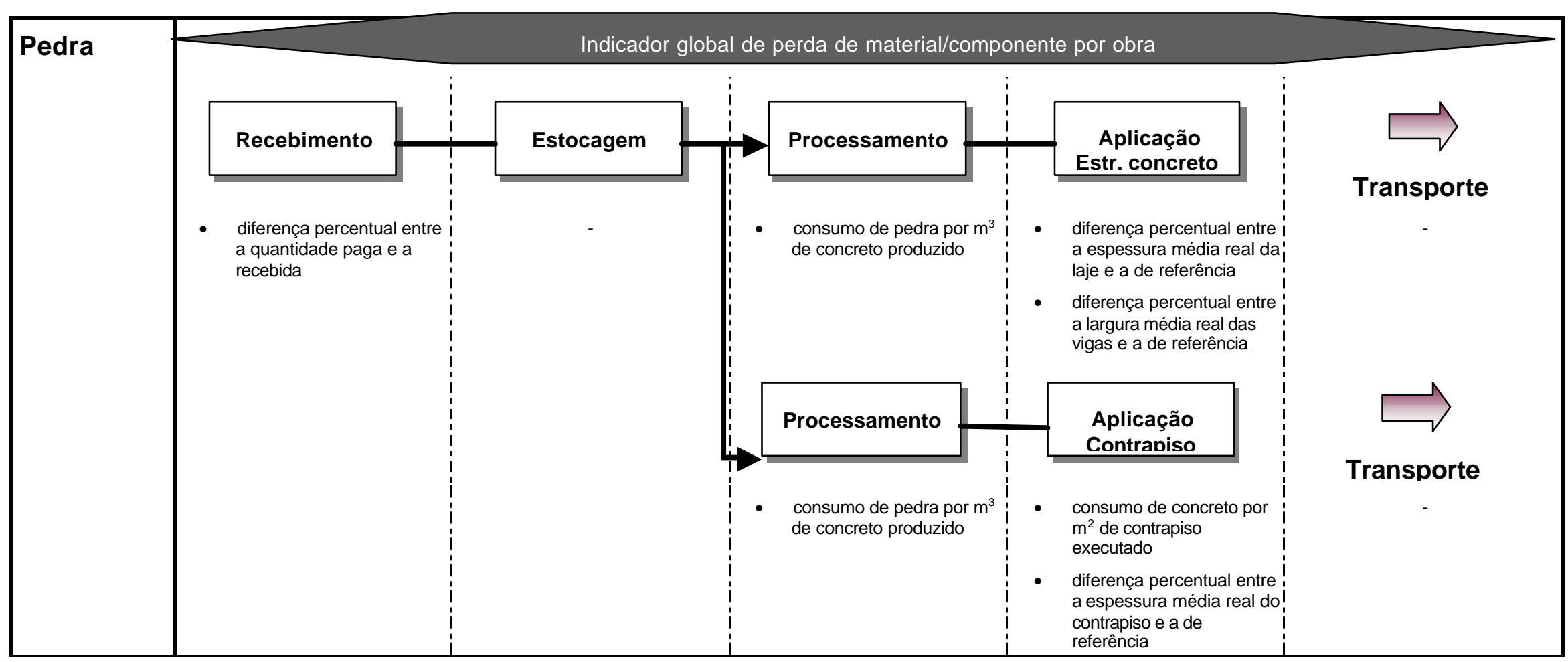


Tabela 5.7 Indicadores de perdas e consumos de materiais e componentes- Concreto produzido em obra

\begin{tabular}{|l|l|}
\hline MATERIAL & ETAPAS DO FLUXOGRAMA DOS PROCESSOS \\
\hline
\end{tabular}

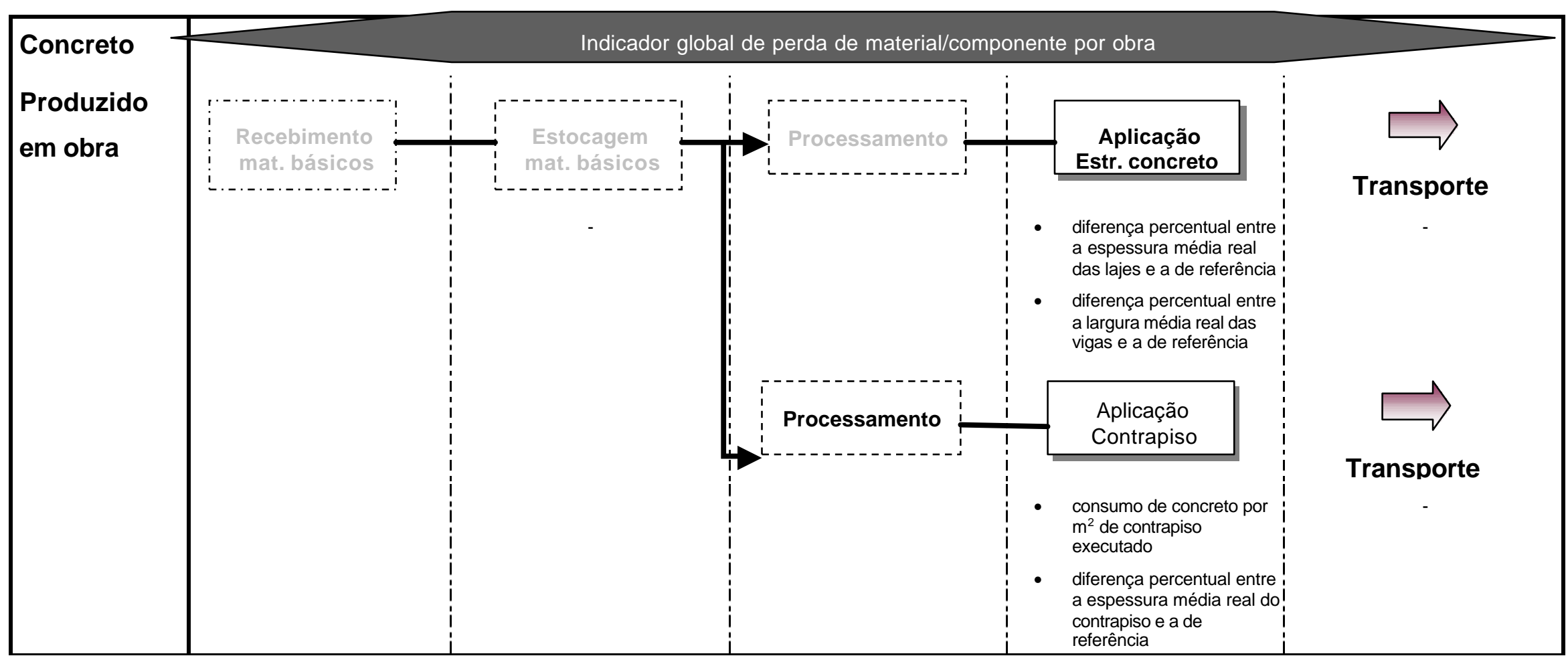

Tabela 5.8 Indicadores de perdas e consumos de materiais e componentes- Concreto usinado 
\begin{tabular}{|l|l}
\hline MATERIAL & ETAPAS DO FLUXOGRAMA DOS PROCESSOS \\
\hline
\end{tabular}

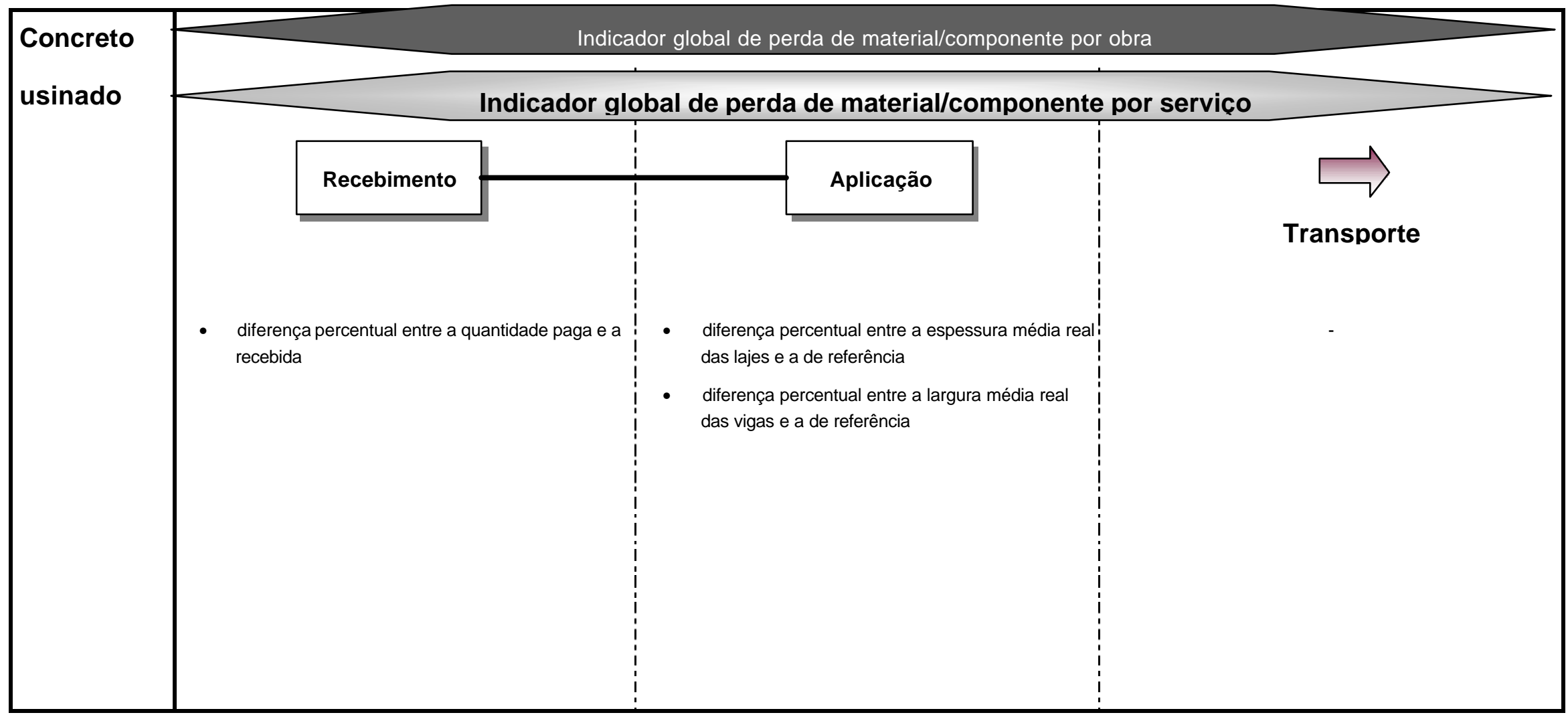


Tabela 5.9 Indicadores de perdas e consumos de materiais e componentes- Aço

\begin{tabular}{|l|l|l|l}
\hline MATERIAL & ETAPAS DO FLUXOGRAMA DOS PROCESSOS \\
\hline
\end{tabular}

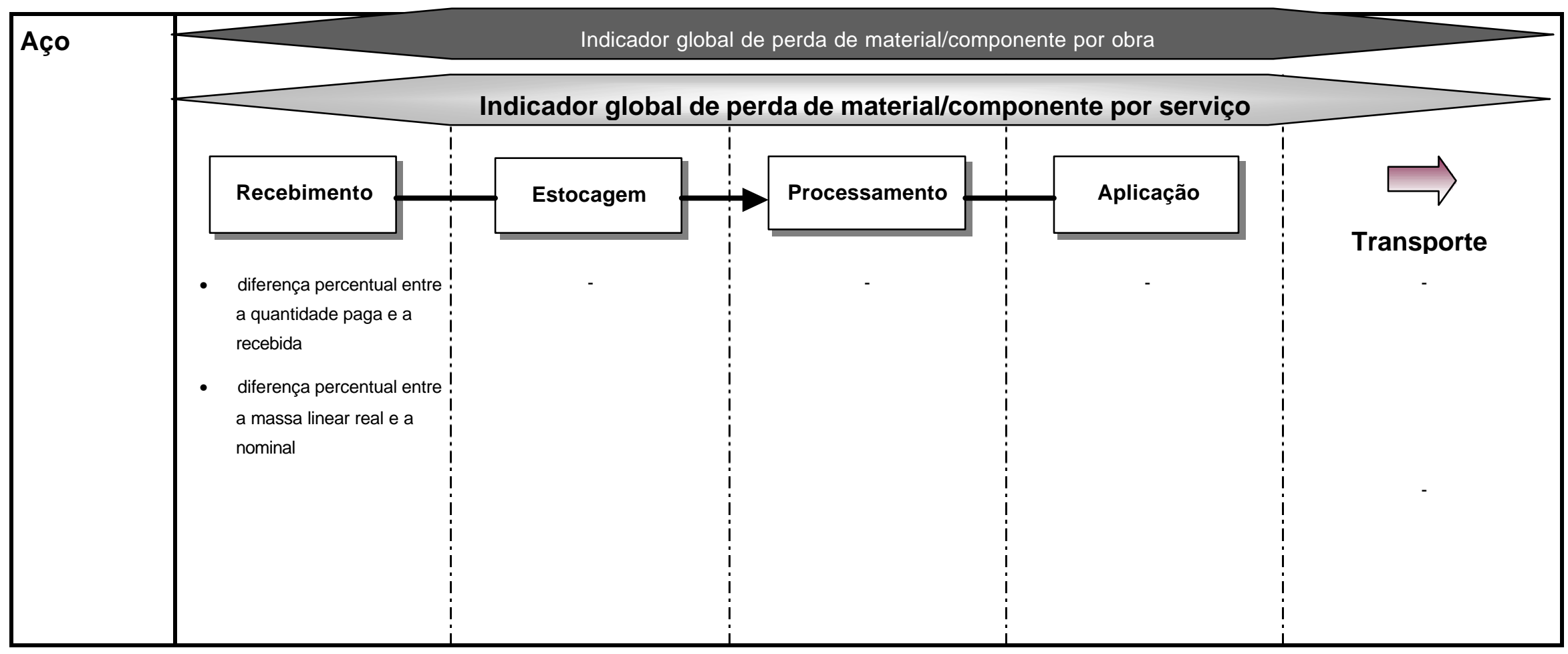


Tabela 5.10 Indicadores de perdas e consumos de materiais e componentes- Blocos e tijolos

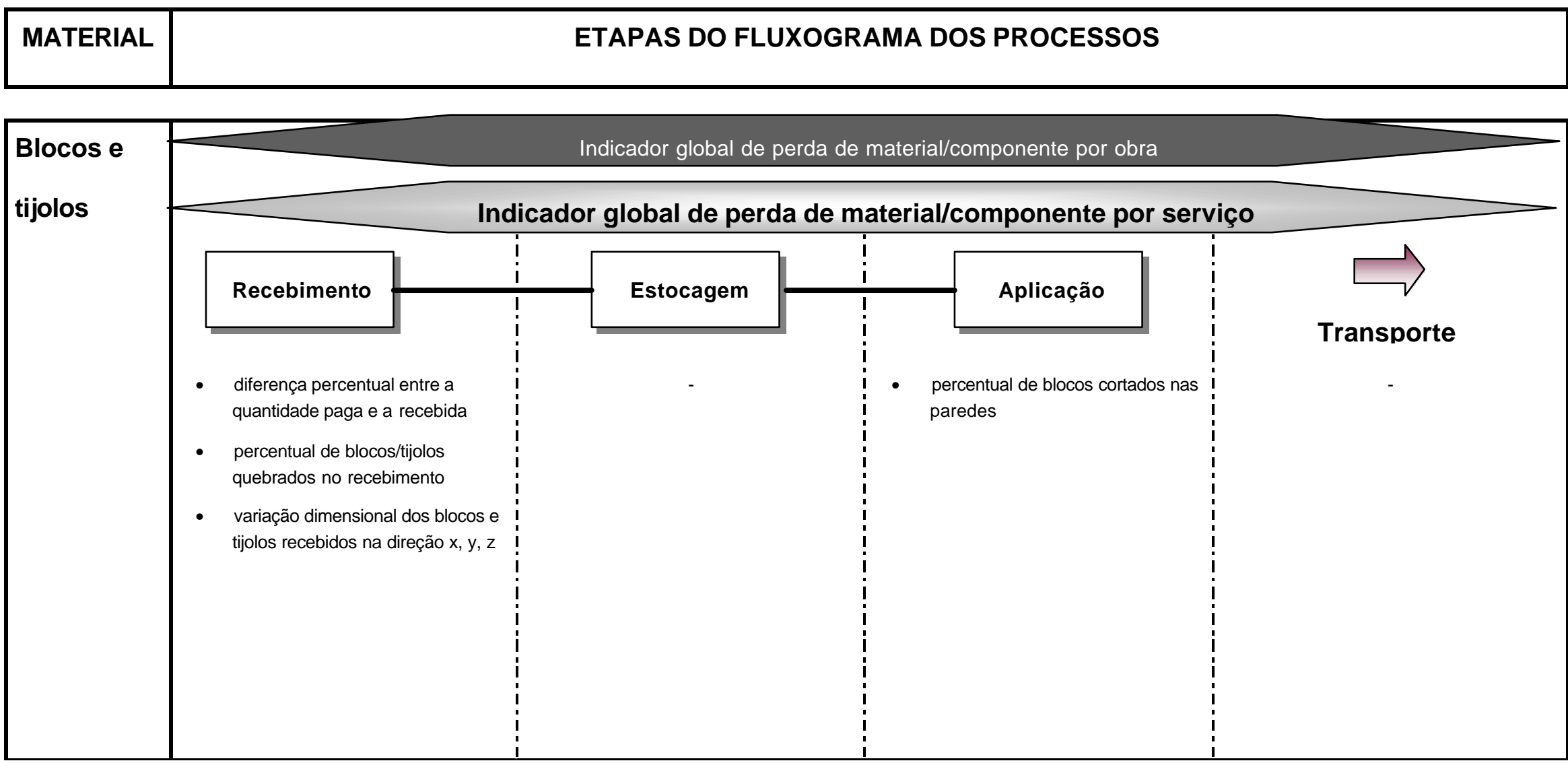


Tabela 5.11 Indicadores de perdas e consumos de materiais e componentes - Cal

\begin{tabular}{|l|ll}
\hline MATERIAL & ETAPAS DO FLUXOGRAMA DOS PROCESSOS
\end{tabular}

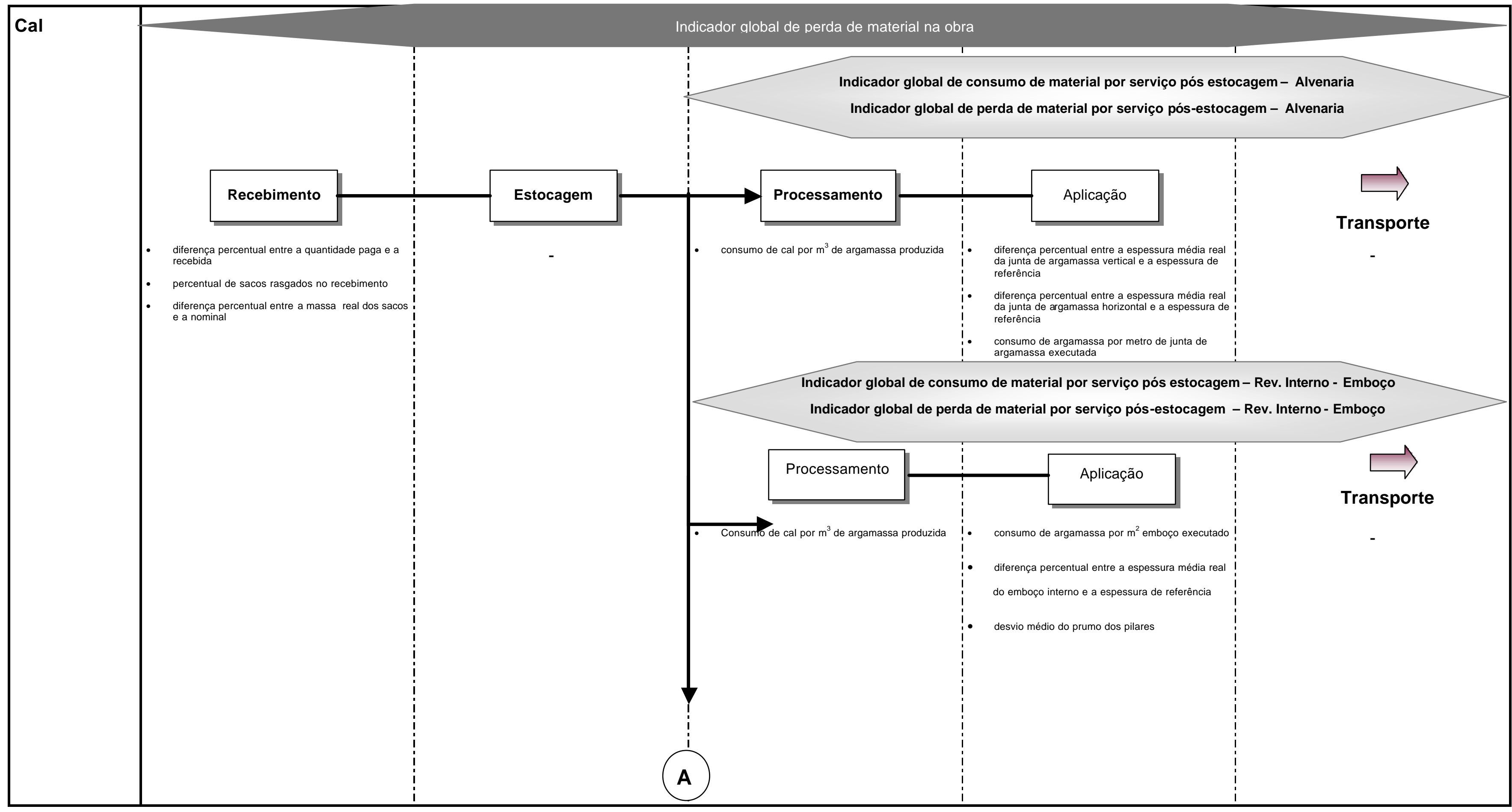


Tabela 5.11 Indicadores de perdas e consumos de materiais e componentes - Cal (continuação)

\begin{tabular}{|l|ll}
\hline MATERIAL & ETAPAS DO FLUXOGRAMA DOS PROCESSOS \\
\hline
\end{tabular}

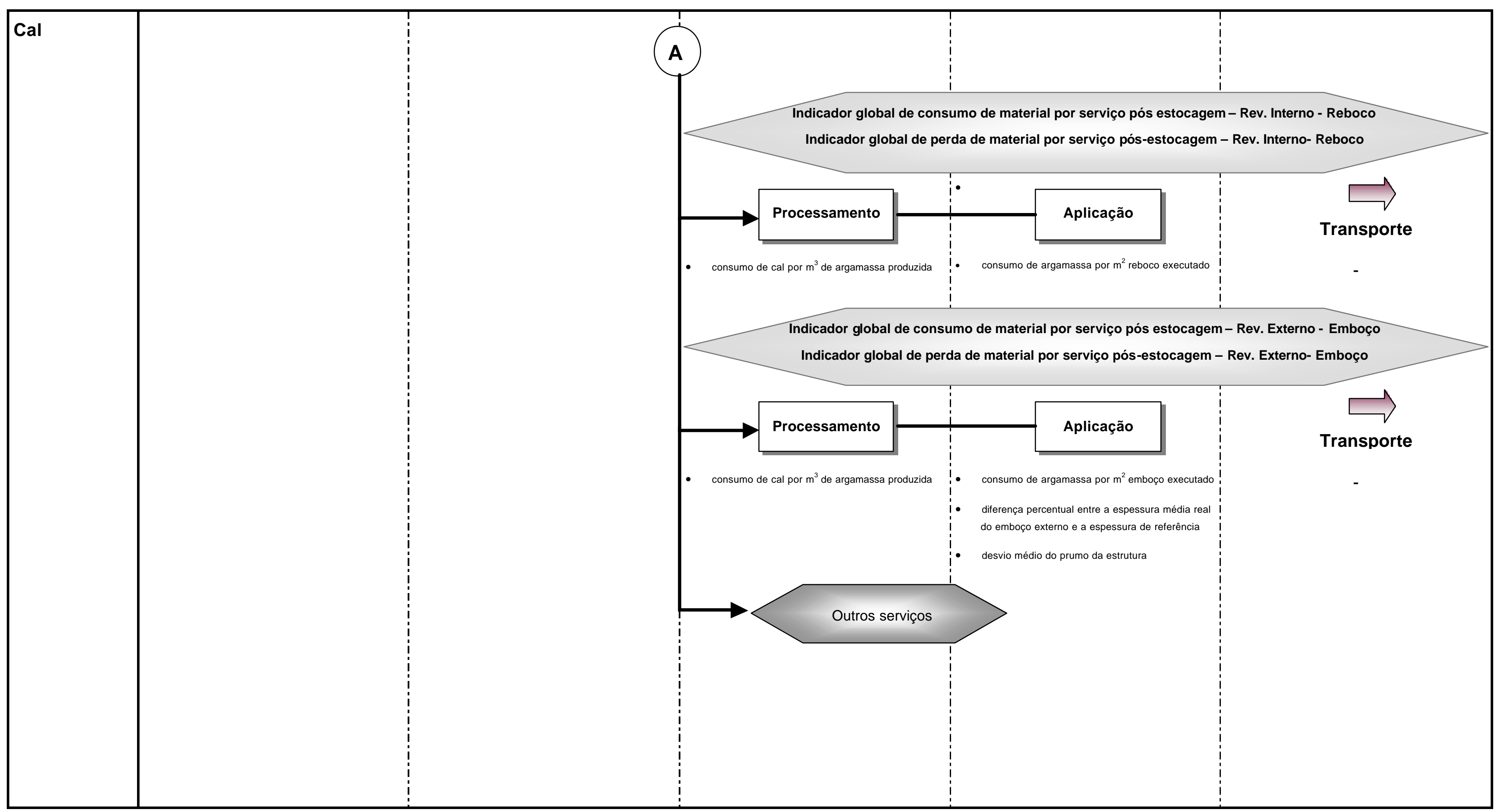


Tabela 5.12 Indicadores de perdas e consumos de materiais e componentes - Argamassa pré-misturada

\begin{tabular}{|l|ll}
\hline MATERIAL & ETAPAS DO FLUXOGRAMA DOS PROCESSOS
\end{tabular}

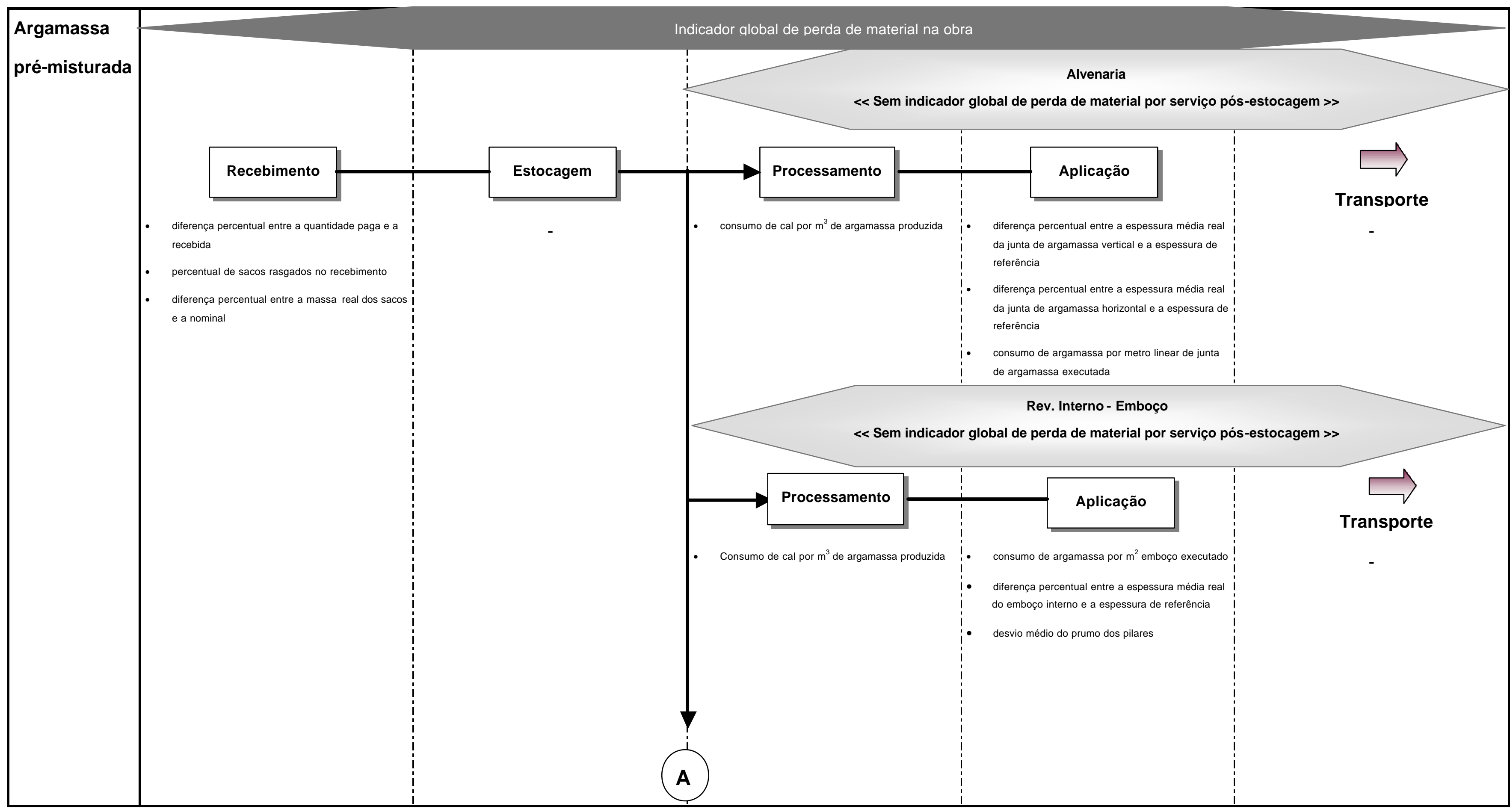


Tabela 5.12 Indicadores de perdas e consumos de materiais e componentes - Argamassa pré-misturada (continuação)

MATERIAL

ETAPAS DO FLUXOGRAMA DOS PROCESSOS

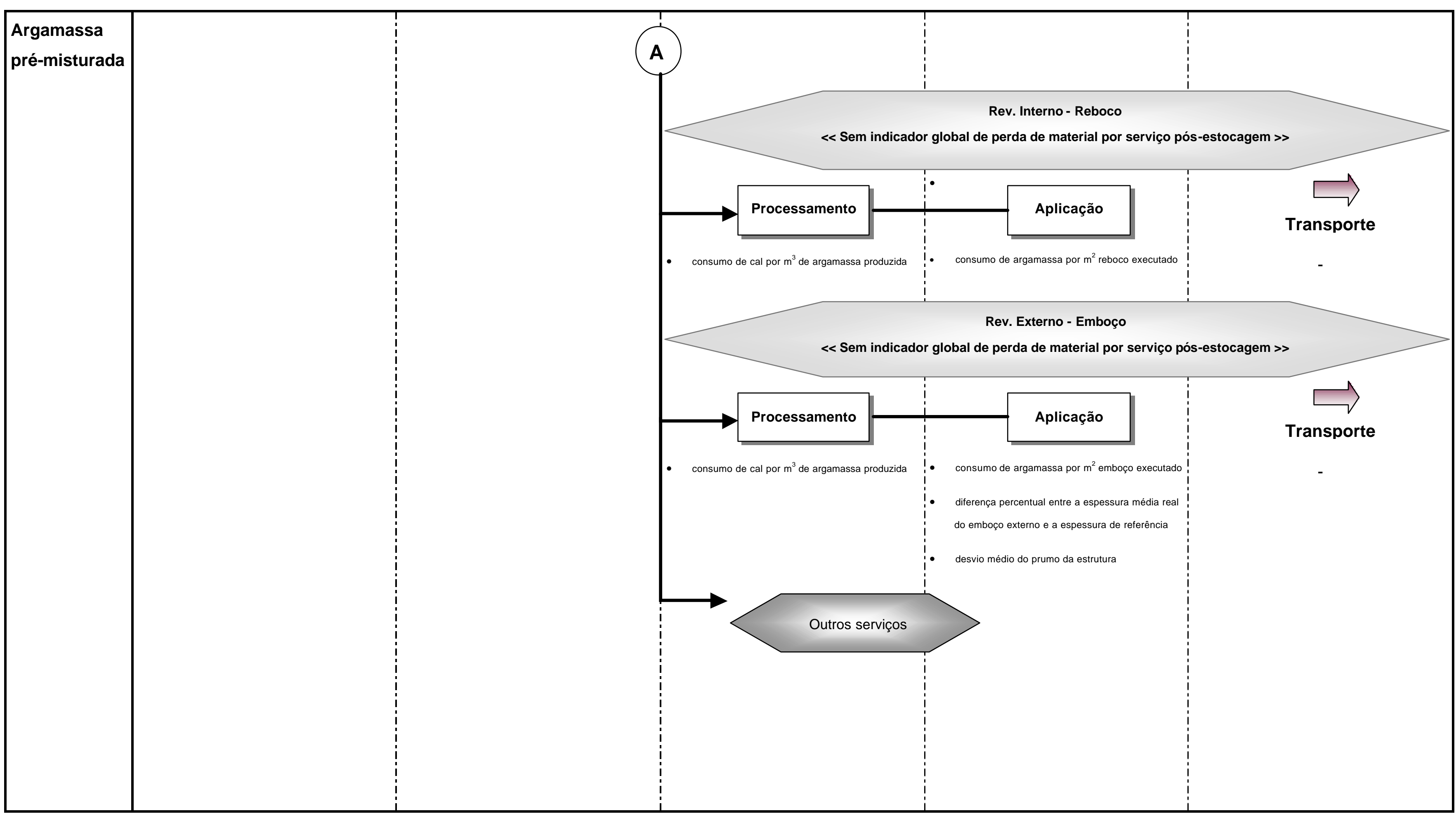


Tabela 5.13 Indicadores de perdas e consumos de materiais e componentes - Argamassa industrializada

\begin{tabular}{|l|ll} 
MATERIAL & ETAPAS DO FLUXOGRAMA DOS PROCESSOS
\end{tabular}

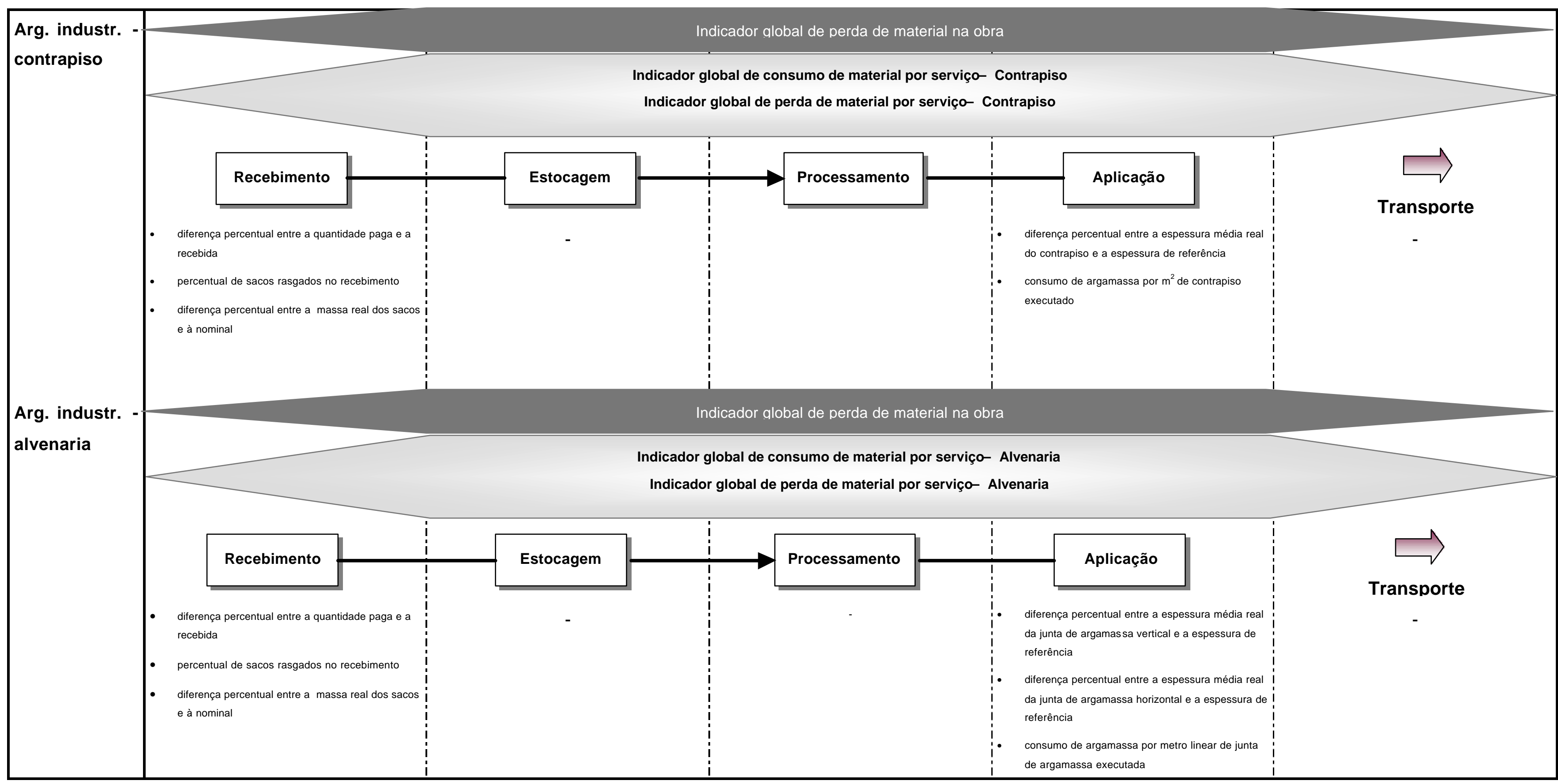


Tabela 5.13 Indicadores de perdas e consumos de materiais e componentes - Argamassa industrializada (continuação) \begin{tabular}{|l|l} 
MATERIAL & ETAPAS DO FLUXOGRAMA DOS PROCESSOS
\end{tabular}

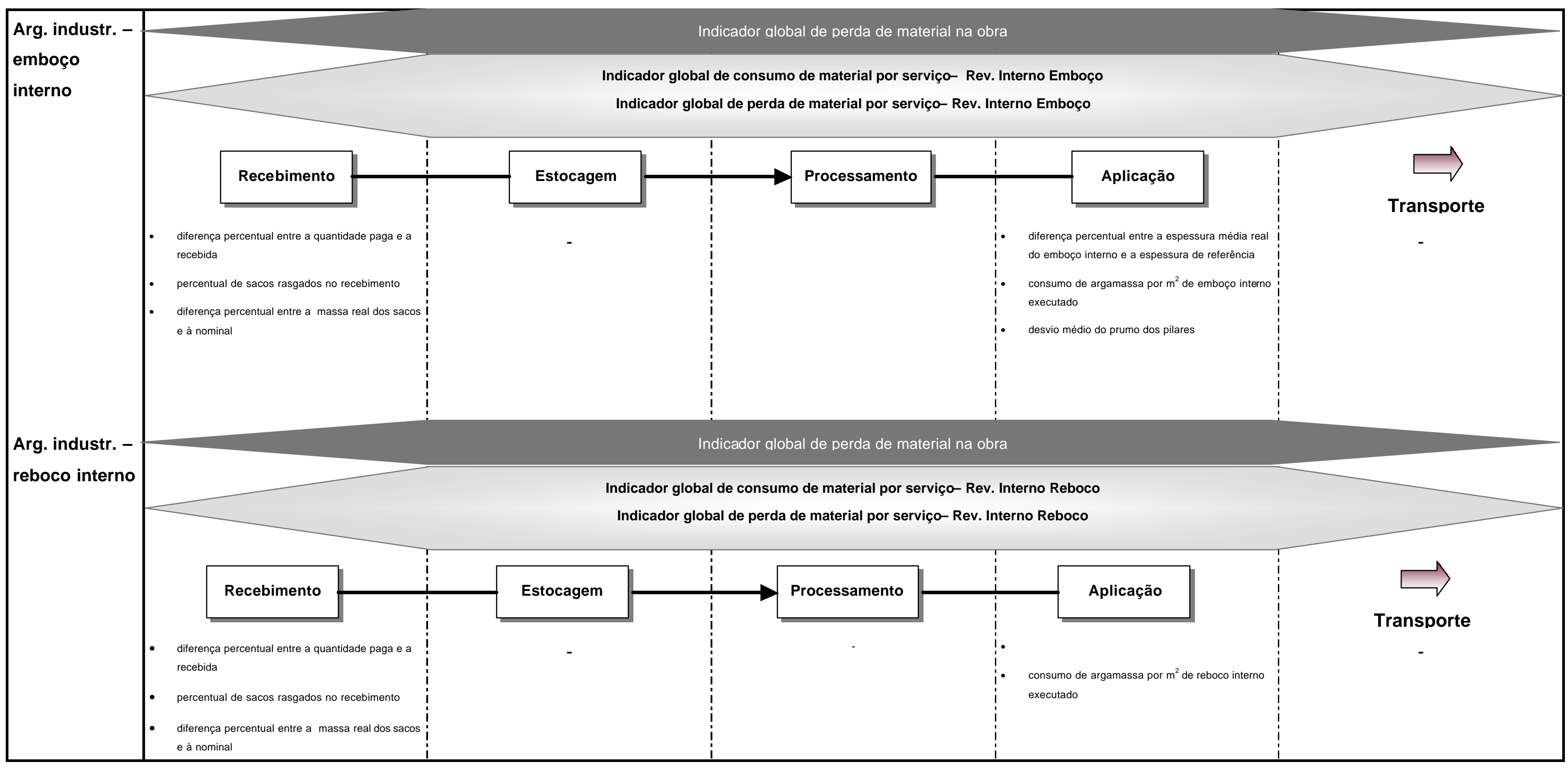


Tabela 5.13 Indicadores de perdas e consumos de materiais e componentes - Argamassa industrializada (continuação) \begin{tabular}{|l|ll} 
MATERIAL & ETAPAS DO FLUXOGRAMA DOS PROCESSOS
\end{tabular}

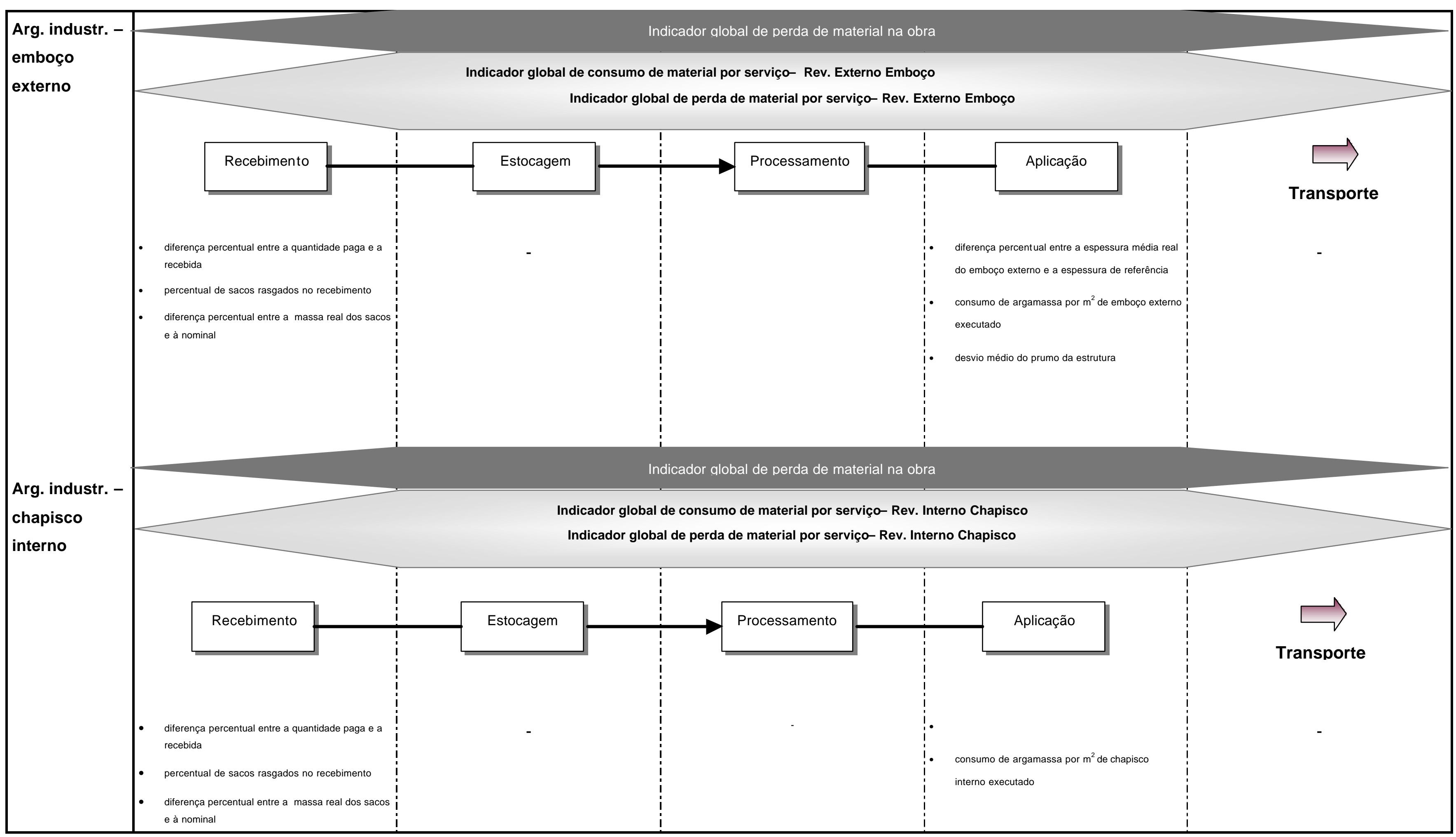


Tabela 5.13 Indicadores de perdas e consumos de materiais e componentes - Argamassa industrializada (continuação) MATERIAL ETAPAS DO FLUXOGRAMA DOS PROCESSOS

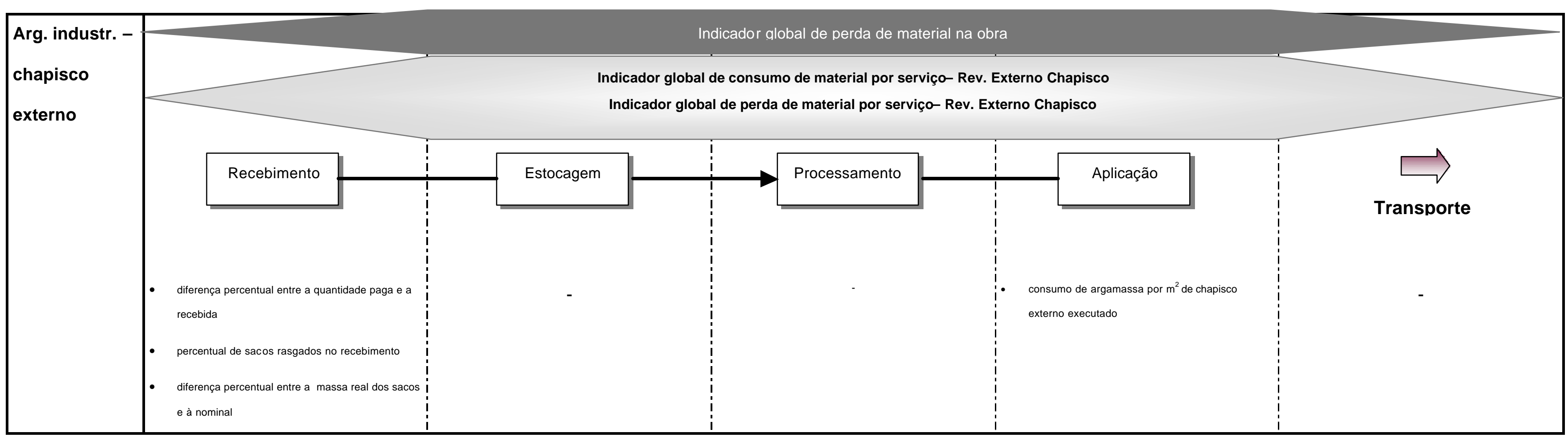


Tabela 5.14 Indicadores de perdas e consumos de materiais e componentes- Eletrodutos

\begin{tabular}{|c|c|c|c|c|c|}
\hline MATERIAL & \multicolumn{5}{|c|}{ ETAPAS DO FLUXOGRAMA DOS PROCESSOS } \\
\hline \multirow[t]{3}{*}{ Eletrodutos } & \multicolumn{5}{|c|}{ Indicador global de perda de material/componente por obra } \\
\hline & \multicolumn{5}{|c|}{ Indicador global de perda de material/componente por serviço } \\
\hline & $\begin{array}{l}\text { - diferença percentual entre } \\
\text { a quantidade paga e a } \\
\text { recebida }\end{array}$ & - & - & $\begin{array}{l}\text { - diferença percentual entre } \\
\text { o comprimento real do } \\
\text { trecho executado e o de } \\
\text { referência }\end{array}$ & - \\
\hline
\end{tabular}


Tabela 5.15 Indicadores de perdas e consumos de materiais e componentes-Condutores

\begin{tabular}{|l|l}
\hline MATERIAL & ETAPAS DO FLUXOGRAMA DOS PROCESSOS
\end{tabular}

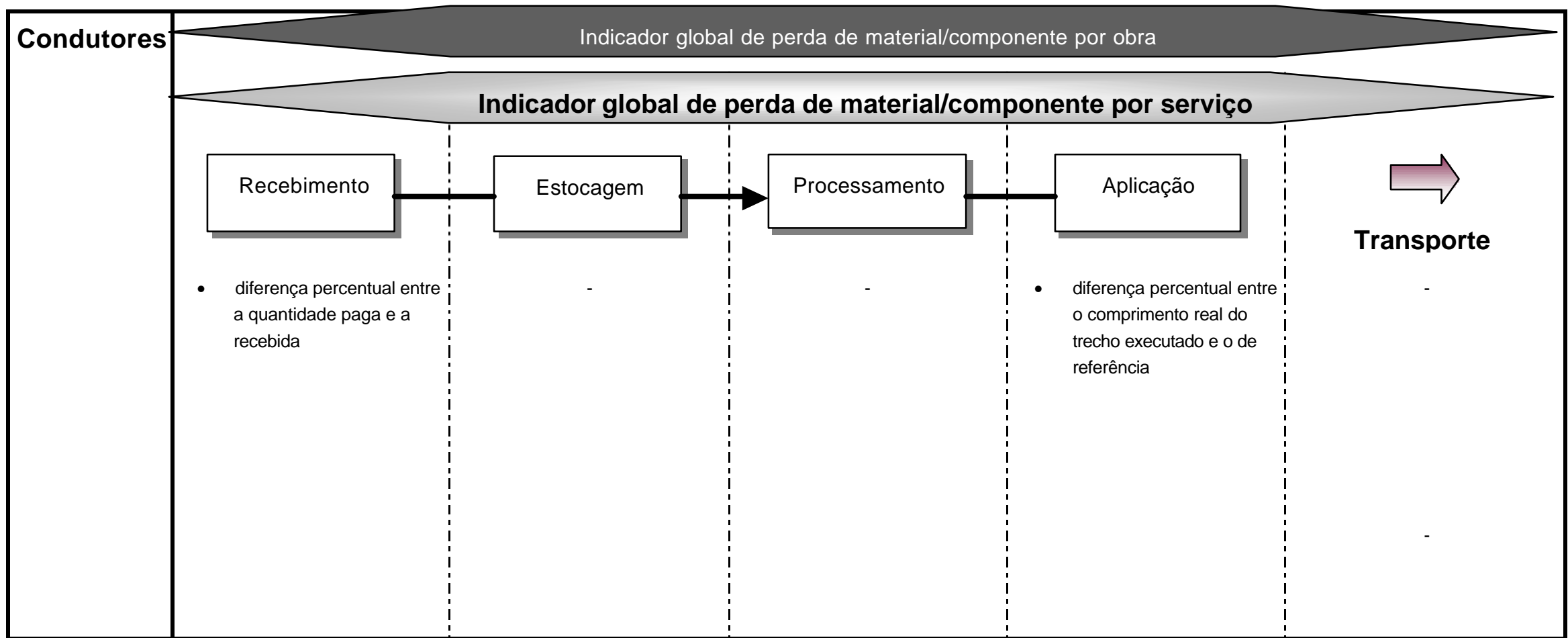


Tabela 5.16 Indicadores de perdas e consumos de materiais e componentes-Tubos

\begin{tabular}{|c|c|c|c|c|c|}
\hline MATERIAL & \multicolumn{5}{|c|}{ ETAPAS DO FLUXOGRAMA DOS PROCESSOS } \\
\hline \multirow[t]{3}{*}{ Tubos } & \multicolumn{5}{|c|}{ Indicador global de perda de material/componente por obra } \\
\hline & \multicolumn{5}{|c|}{ Indicador global de perda de material/componente por serviço } \\
\hline & $\begin{array}{l}\text { diferença percentual entre } \\
\text { a quantidade paga e a } \\
\text { recebida }\end{array}$ & - & - & - & - \\
\hline
\end{tabular}


Tabela 5.17 Indicadores de perdas e consumos de materiais e componentes-Telhas

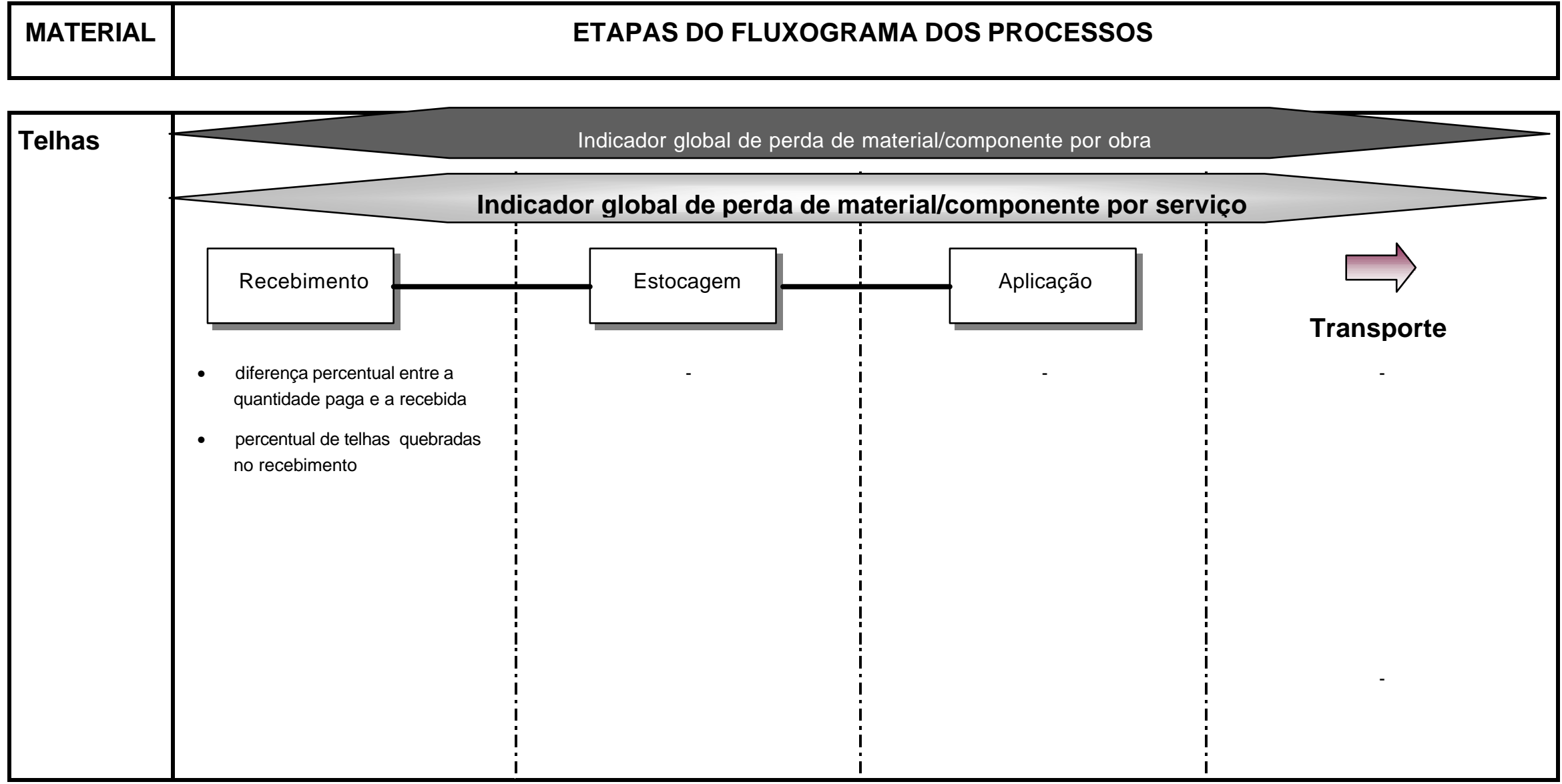


Tabela 5.18 Indicadores de perdas e consumos de materiais e componentes- Placas cerâmicas

\begin{tabular}{|l|l|}
\hline MATERIAL & ETAPAS DO FLUXOGRAMA DOS PROCESSOS \\
\hline
\end{tabular}

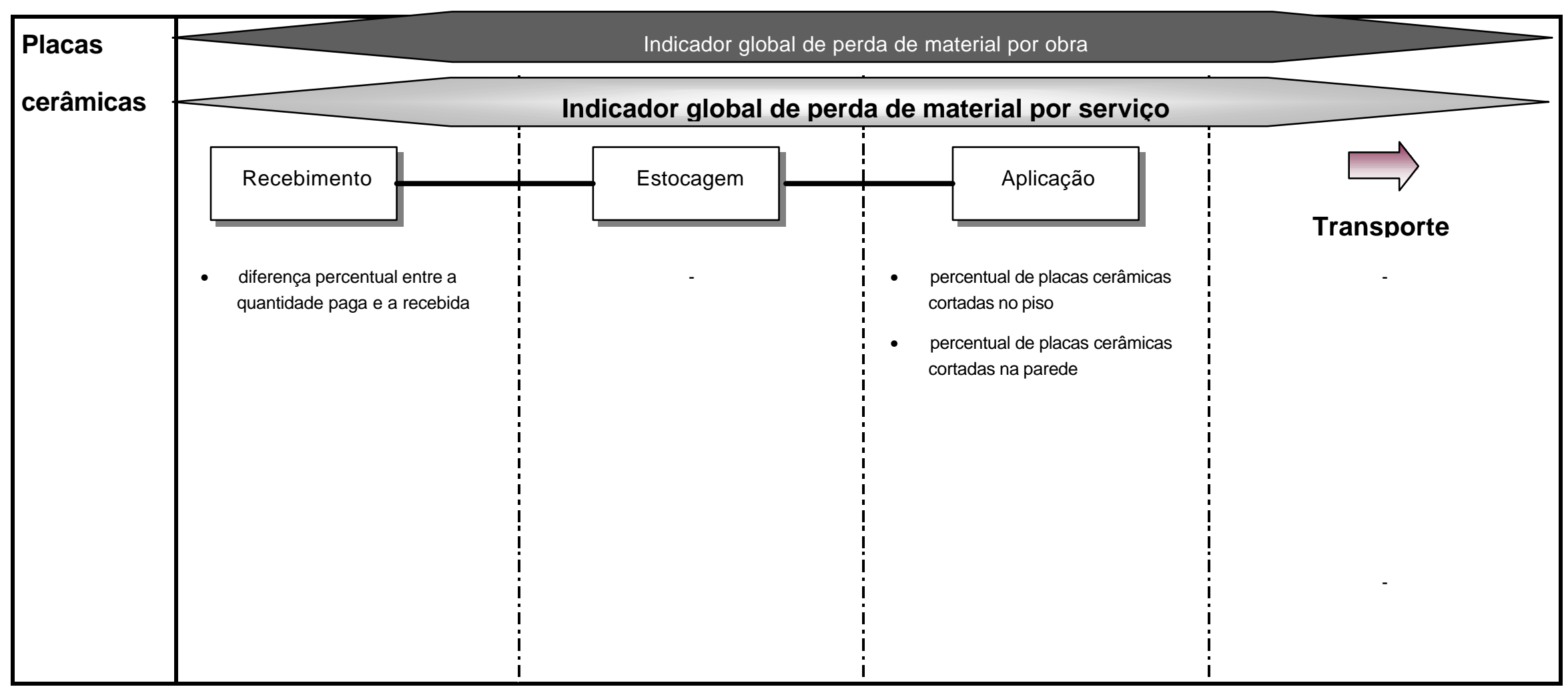


Tabela 5.19 Indicadores de perdas e consumos de materiais e componentes- Revestimento têxtil

\begin{tabular}{|l|l|}
\hline MATERIAL & ETAPAS DO FLUXOGRAMA DOS PROCESSOS \\
\hline
\end{tabular}

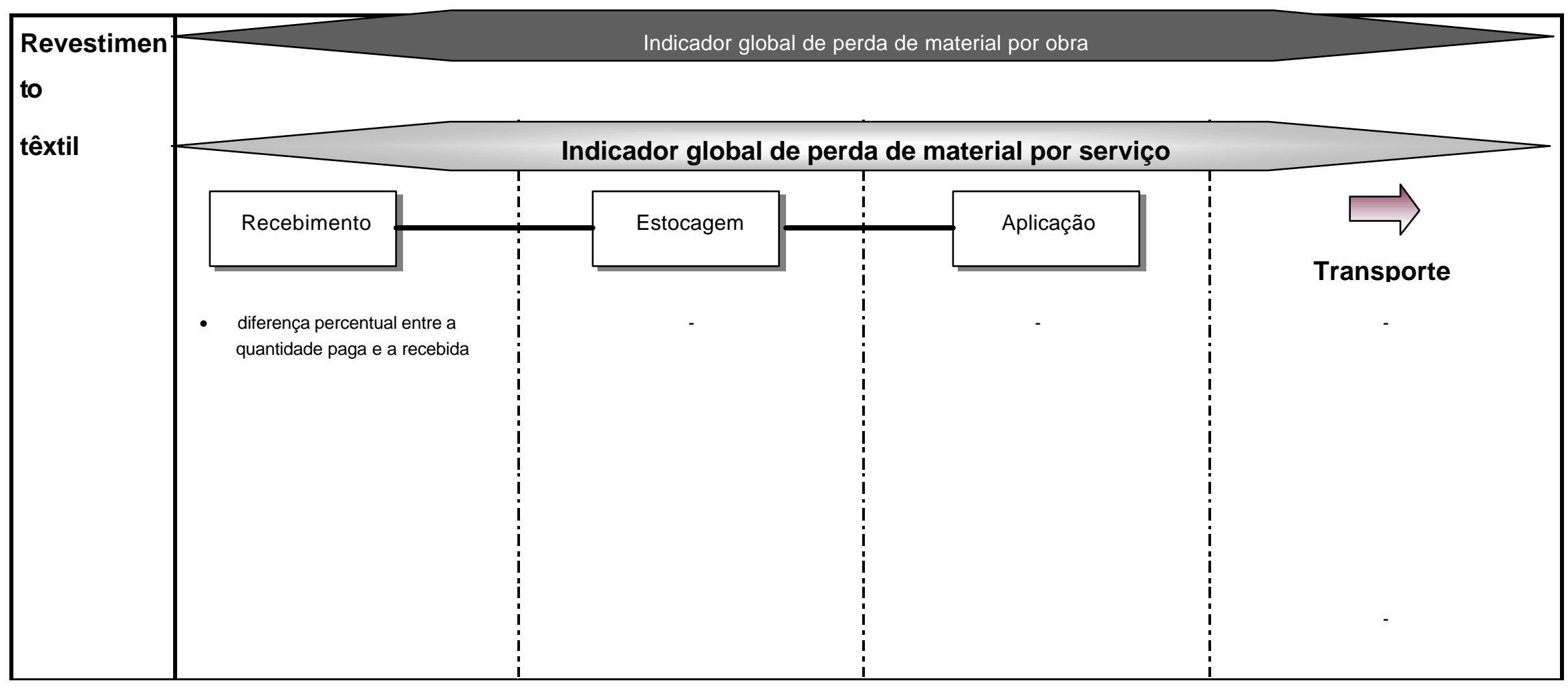


Tabela 5.20 Indicadores de perdas e consumos de materiais e componentes-Tintas

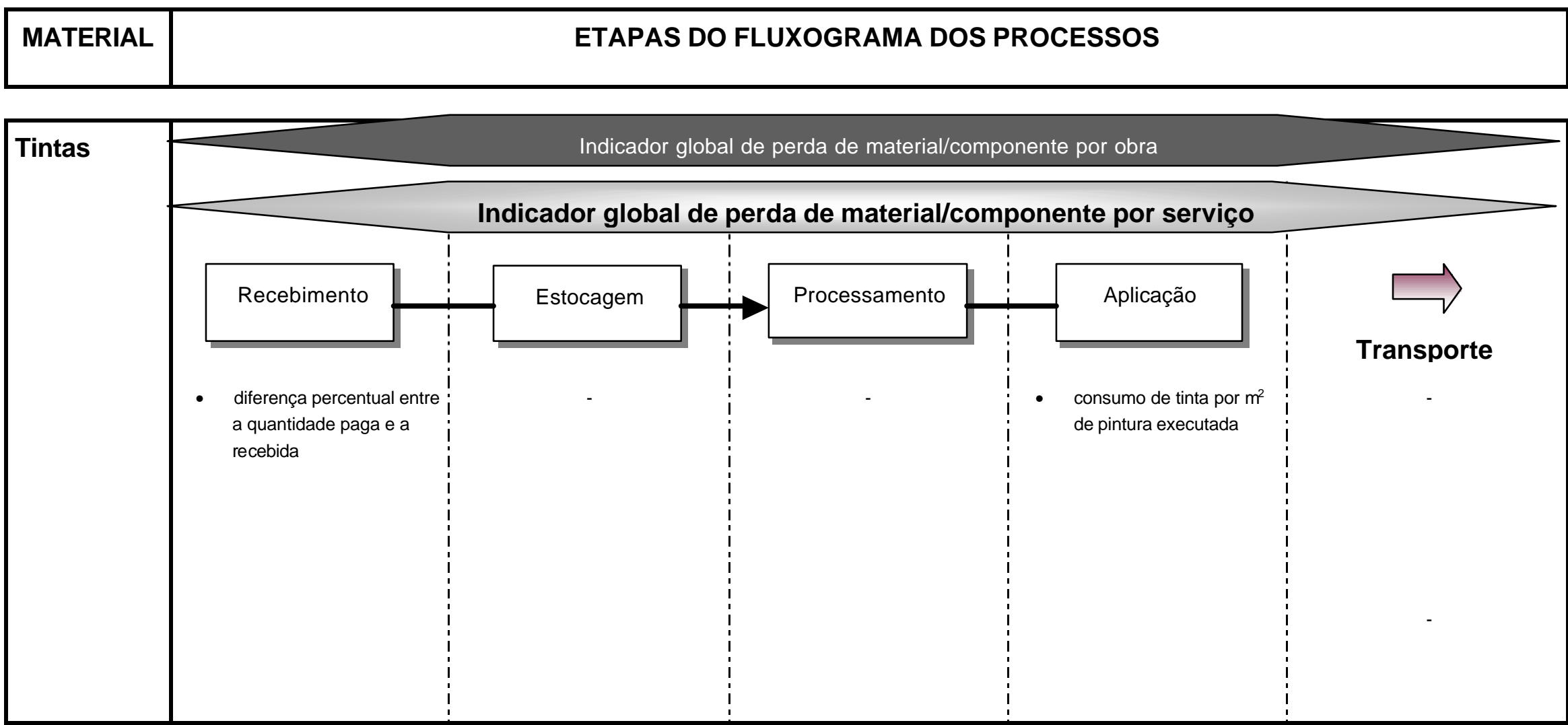


Tabela 5.21 Indicadores de perdas e consumos de materiais e componentes- Gesso

\begin{tabular}{|c|c|c|c|c|c|}
\hline MATERIAL & \multicolumn{5}{|c|}{ ETAPAS DO FLUXOGRAMA DOS PROCESSOS } \\
\hline \multirow[t]{3}{*}{ Gesso } & \multicolumn{5}{|c|}{ Indicador global de perda de material/componente por obra } \\
\hline & \multicolumn{5}{|c|}{ Indicador global de perda de material/componente por serviço } \\
\hline & $\begin{array}{l}\text { - diferença percentual entre } \\
\text { a quantidade paga e a } \\
\text { recebida } \\
\text { - diferença percentual entre } \\
\text { a massa real dos sacos e } \\
\text { a nominal } \\
\text { - percentual de sacos } \\
\text { rasgados no recebimento }\end{array}$ & - & - & $\begin{array}{l}\text { - consumo de gesso por } \mathrm{m}^{2} \\
\text { de revestimento } \\
\text { executado }\end{array}$ & - \\
\hline
\end{tabular}


Tabela 5.22 Indicadores de perdas e consumos de materiais e componentes - Saibro

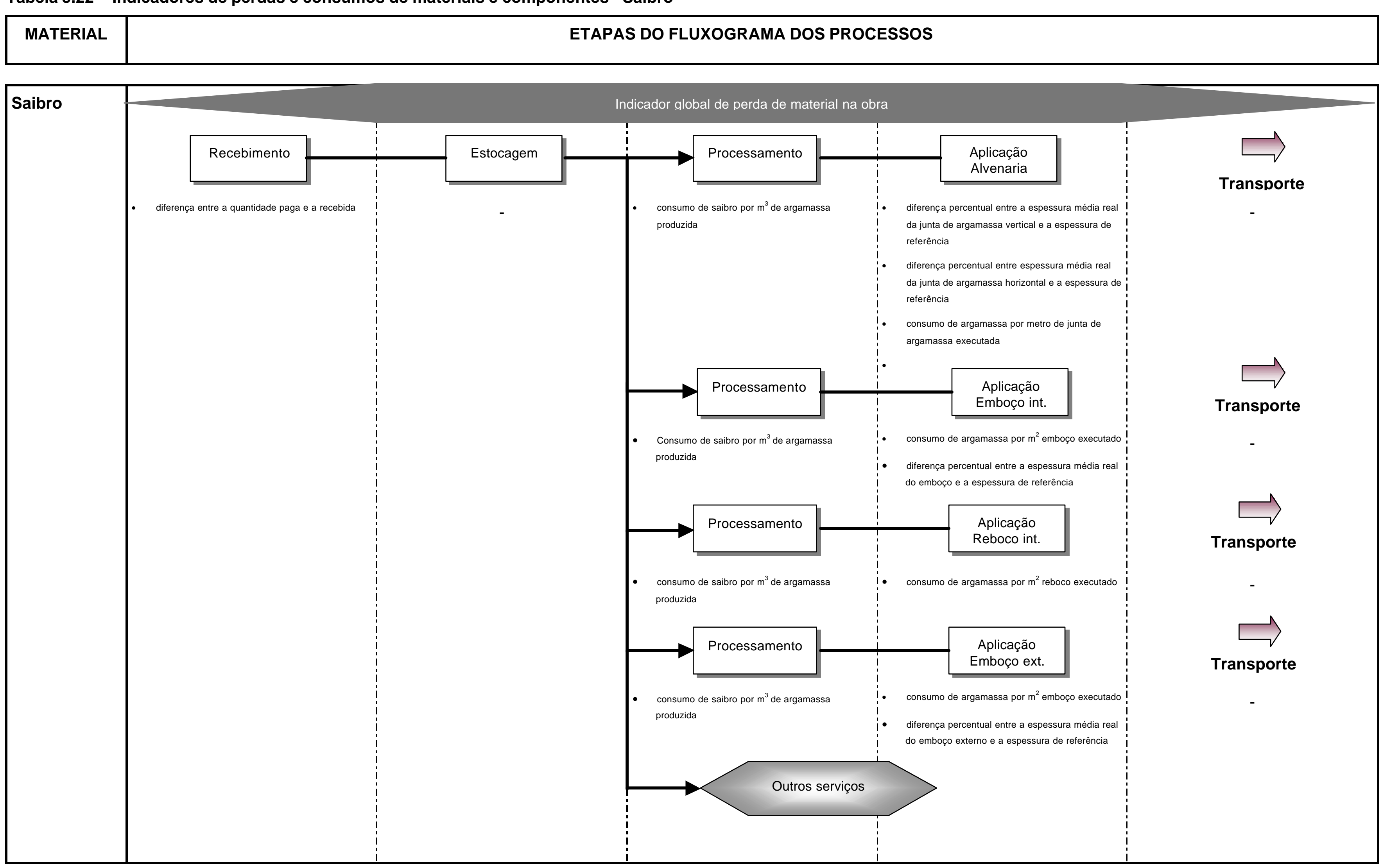




\section{CAṔ́TULO 6}

\section{MEIODOLOGIA PARA COLETA E ANÁUSE DE INFORMAÇÕES SOBRE CONSUMO E PERDAS DE MATERIAIS NOS CANTEIROS DE OBRAS}

Embora a metodologia já venha sendo desenvolvida ao longo dos capítulos anteriores, mais especificamente nos capítulos 2, 3, 4 e 5, é neste capítulo que é feita a apresentação completa da mesma, no que se refere a todos os seus aspectos relacionados à coleta e processamento dos dados e análise dos resultados.

Para isso, este capítulo se inicia com uma apresentação geral da metodologia e, em seguida, apresenta-se, de forma detalhada, todos os aspectos relacionados à operacionalização das várias fases para a obtenção das informações quantitativas (indicadores de perdas e consumos) e informações qualitativas (caracterização da empresa, obra, serviços, materiais).

Finalmente, tendo-se apresentadas todas as partes da metodologia, este capítulo se encerra com o planejamento da coleta de dados, considerado de suma importância para facilitar tanto a coleta, quanto o processamento e a análise dos resultados. 


\subsection{Apresentação sucinta da metodologia}

O princípio básico considerado na elaboração da metodologia, consiste na observação crítica do uso dos materiais ao longo das etapas percorridas pelos mesmos, nos canteiros de obras, até a sua aplicação final.

Tal observação implica no estabelecimento de indicadores de perdas divididos em duas categorias: a primeira, de âmbito maior (indicadores globais), que procura estabelecer números relativos a um conjunto de etapas percorridas pelos materiais no canteiro de obras e, a segunda, mais específica, que procura estabelecer números relativos a uma única etapa, cuja finalidade principal é a explicação parcial dos indicadores globais, permitindo identificar em quais etapas percorridas pelos materiais estas perdas são mais significativas.

Conforme anteriormente discutido, mais do que levantar indicadores de perdas/consumos de materiais, a metodologia enfatiza a caracterização do contexto (características tecnológica e gerencial das etapas do fluxograma dos processos) onde tais valores são calculados, com o intuito de permitir seu entendimento.

A avaliação conjunta das informações coletadas (análise quantitativa e qualitativa) permitirá a explicação das perdas e/ou consumos de materiais nos canteiros de obras e, mais ainda, balizará a geração futura de alternativas para a redução destas perdas/consumos a patamares aceitáveis.

Para a obtenção destas informações, elaborou-se um conjunto de instrumentos de coleta de dados e diretrizes para o processamento dos mesmos e análise 
dos resultados, garantindo, assim, a padronização do estudo no que diz respeito a todas as suas etapas.

Todas as ações necessárias para a aplicação da metodologia, assim como os principais instrumentos de coleta de dados, estão reunidos na Figura 6.1, de uma forma resumida.

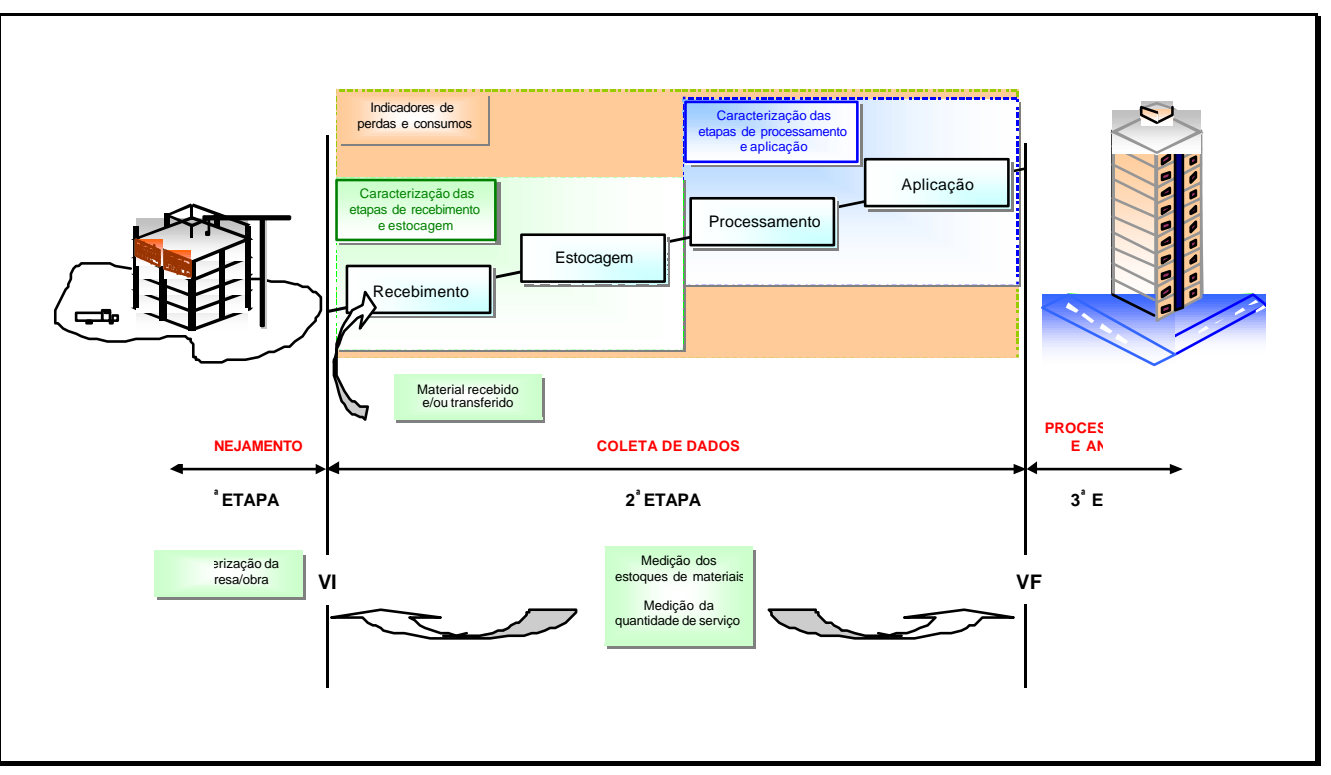

Figura 6.1 Síntese da metodologia

Nesta figura destacam-se 3 etapas da metodologia, relacionadas a duas datas

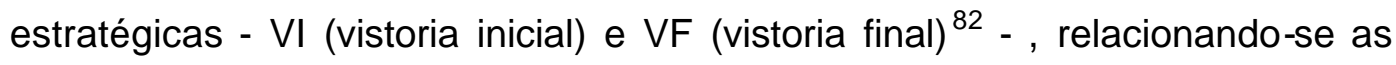
tarefas a ser realizadas durante as diferentes etapas e mesmo nas próprias datas estratégicas.

A primeira etapa da aplicação da metodologia consiste no planejamento da coleta e envolve, entre outras atividades, contato preliminar com a obra em

${ }^{82}$ Adotou-se a mesma nomenclatura utilizada por SOIBELMAN (1993) 
estudo, treinamento da equipe de coleta, envolvimento do pessoal da obra e da empresa, entendimento e quantificação dos serviços a ser estudados.

A segunda etapa consiste na coleta de dados no canteiro propriamente dito. Entre as datas VI e VF contabiliza-se a quantidade de material que entrou ou saiu da obra, realiza-se a coleta dos dados referentes à caracterização das etapas do fluxograma dos processos, no qual o material está inserido e, finalmente, faz-se a coleta de dados para o cálculo dos indicadores parciais sobre perdas e/ou consumo. Finalmente, a terceira etapa é dedicada ao processamento dos dados e à análise dos resultados.

Após o processamento dos dados, insere-se ainda uma subetapa que consiste em uma análise crítica dos resultados obtidos. Havendo incoerências ou pontos completamente não elucidados, torna-se necessário levantar ainda algumas informações adicionais, principalmente no que diz respeito às explicações das perdas e/ou consumos detectados, como subsídios para a análise final dos resultados. Nesta subetapa, a participação dos envolvidos na coleta de dados, assim como os responsáveis pela obra por parte da empresa, é de suma importância.

Nas datas VI e VF contabiliza-se a quantidade de material estocado, sendo que a diferença entre tais quantidades é depois somada à entrada líquida de materiais na obra para se calcular o consumo total. Da mesma forma, computase em tais datas a quantidade de serviço executada até as mesmas, cuja diferença representa a quantidade de serviço executada entre estas datas. Através deste procedimento consegue-se o estabelecimento de indicadores globais de perdas e consumos de apenas uma parte do serviço que se esteja 
analisando, não necessitando, portanto, que seja preciso avaliá-lo na sua totalidade, ou seja, desde seu início até seu fim.

\subsection{Fundamentos da metodologia}

Um dos fatores determinantes para o sucesso da aplicação da metodologia nos canteiros de obras consiste na padronização das ações a ser efetuadas durante a coleta, o processamento e a análise dos resultados, ainda que todas elas dependam, em parte, das situações particulares vivenciadas em cada canteiro de obras.

Além da elaboração de instrumentos de coleta de dados, e de diretrizes para o processamento e análise dos resultados, como forma de garantir esta padronização, outros aspectos considerados de extrema importância para o completo delineamento da metodologia merecem ser destacados:

(a) ainda que as perdas de materiais se originem em outras etapas da vida de um empreendimento, a mensuração destas perdas, no caso desta metodologia, está centrada apenas no âmbito da etapa de execução, ou seja, estimam-se as perdas/consumos decorrentes da ineficiência no uso dos materiais nos canteiros de obras;

(b) conseqüentemente, a definição de critérios para o estabelecimento dos valores de referência visam quantificar as perdas inerentes ao processo executivo e não as embutidas nas especificações impróprias;

(c) embora a quantificação das perdas de capital decorrentes das perdas de materiais seja desejável, a metodologia enfatiza o estabelecimento de 
índices físicos que, posteriormente, poderão ser transformados em perdas financeiras;

(d) muito mais do que estabelecer índices globais de perdas/consumos de materiais na obra, enfatiza-se a obtenção de tais índices no âmbito dos serviços, possibilitando, assim, comparações entre mesmos serviços de obras diferentes;

(e) em face do número de materiais envolvidos e da necessidade de garantir a padronização da coleta de informações, a metodologia contempla um sistema de códigos, que deverá ser utilizado para o processamento dos resultados, possibilitando, assim, comparações entre índices associados a materiais de diferentes especificações e entre serviços com diferentes características;

(f) apesar de os índices de perdas se constituírem na essência da pesquisa, os indicadores de consumos de materiais também assumem considerável importância na análise dos resultados, principalmente no que diz respeito aos materiais básicos (cimento, cal), devido à flexibilidade na adoção dos valores de referência.

Todos estes aspectos serão detalhados na seqüência da apresentação da metodologia. 


\subsection{Instrumentos de coleta de dados}

Se a coleta de dados não for realizada corretamente, corre-se o risco de se comprometer toda a análise dos resultados. Logo, a formulação dos instrumentos de coleta de dados deve estar em conformidade com as necessidades ou objetivos da medição.

Associando este aspecto aos objetivos delineados para esta metodologia, definiu-se uma série de recursos (planilhas, procedimentos de coleta, registros fotográficos a ser utilizados), seguindo-se as diretrizes:

(a) coleta rápida e dinâmica de informações pertinentes ao cálculo dos indicadores de perdas elou consumos e caracterização tecnológica e gerencial das etapas do fluxograma dos processos: deve-se priorizar ao máximo o preenchimento das planilhas no escritório, deixando para o canteiro de obras somente aquelas informações passíveis de ser obtidas apenas no âmbito do mesmo (Exemplo: para a medição dos serviços, procede-se previamente toda a estruturação da coleta no escritório, desde a codificação dos elementos a ser medidos até a elaboração de croquis relativos às medições a ser efetuadas);

(b) existência de procedimentos claros e objetivos: a obtenção de indicadores de perdas e/ou consumos envolve inúmeras medições, sendo, portanto, necessária a definição de critérios para a realização das mesmas. Estes procedimentos devem estar acessíveis aos coletores de dados no ato da medição; 
(c) estruturação dos instrumentos de coleta de dados: dividi-los de acordo com a medição ou informação a ser obtida, isto é, a cada objetivo de coleta associa-se um tipo de planilha.

A partir destas diretrizes, procedeu-se a elaboração de um conjunto de planilhas e procedimentos de coleta de dados, cuja estrutura e detalhamento estão apresentados na seqüência.

\subsubsection{Planilhas de coleta de dados}

As planilhas de coleta de dados foram estruturadas em 7 séries, divididas em duas categorias: as destinadas à obtenção de informações qualitativas (caracterização da empresa/obra e etapas do fluxograma dos processos) e as utilizadas para a obtenção de informações quantitativas (quantidade de materiais em estoque, serviços executados, transferência de materiais, dados subsidiando o cálculo de indicadores parciais de perdas e/ou consumos):

\section{(a) Informações qualitativas:}

- SÉRIE 1 - Dados relativos à empresa e à obra: destinada à caracterização da empresa e da obra;

- SÉRIE 5 - Dados relativos ao recebimento e à estocagem: a aplicação desta série de planilhas objetiva a caracterização do recebimento e estocagem dos materiais;

- SÉRIE 6 - Dados relativos ao processamento intermediário, ao transporte e à aplicação: esta série de planilhas visa a 
caracterização das etapas subseqüentes à estocagem dos materiais, abrangendo desde o processamento dos mesmos para gerar um outro material (no caso a argamassa ou concreto) até a aplicação final do mesmo;

\section{(a) Informações quantitativas:}

- SÉRIE 2 - Medição dos estoques de materiais;

- SÉRIE 3 - Medição da quantidade de serviço (QS);

- SÉRIE 4 - Controle de rec ebimento e estoque de materiais;

- SÉRIE 7 - Determinação de indicadores globais e parciais de perdas elou consumos de materiais.

A aplicação destas séries de planilhas ao longo do fluxograma dos processos e para um serviço genérico, é ilustrada na Figura 6.2, enquanto que o detalhamento de cada série é feito nos itens subseqüentes. Ressalta-se que o exemplo de uma planilha de cada série, bem como o seu respectivo procedimento de coleta, são apresentados no anexo $\mathrm{D}$, sendo que a totalidade das planilhas e procedimentos pode ser encontrada em AGOPYAN et al. (1998b), ou ainda na homepage específica da Pesquisa "Alternativas para a

redução do desperdício de materiais nos canteiros de obras", cuja URL ${ }^{83}$ é http://www.pcc.usp.br/Pesquisa/Perdas .

$\overline{{ }^{83} U R L=\text { Uniform Resource Location }}$ 


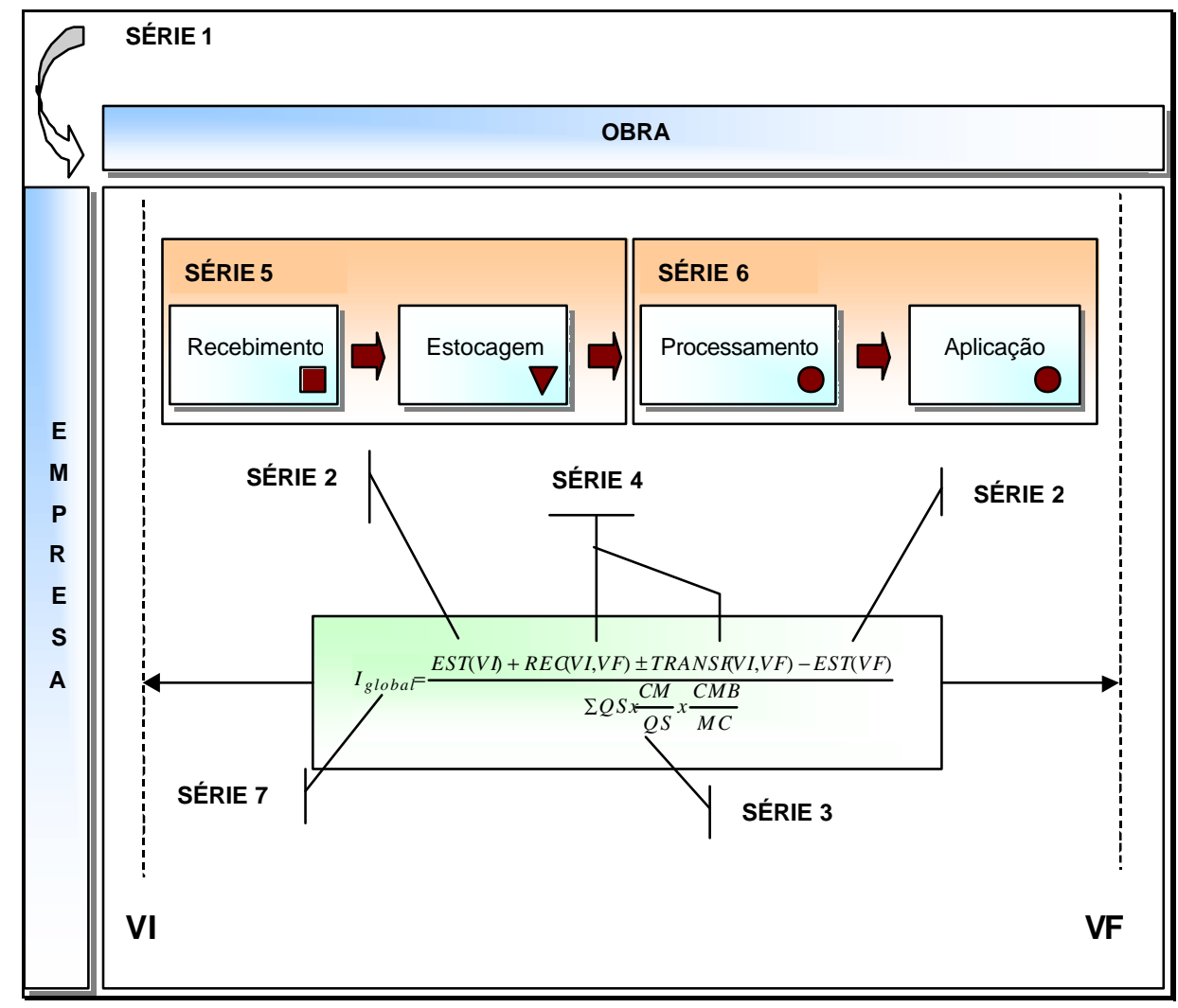

Figura 6.2 Aplicação das séries de planilhas ao longo do fluxograma genérico dos processos

\subsubsection{SÉRIE 1 - Dados relativos à empresa e à obra}

Esta série é composta por duas planilhas: 1.1 e 1.2. A planilha 1.1 diz respeito às informações sobre as características da empresa, sendo dividida em 3 itens: identificação (nome, endereço da empresa), características gerais, que dão idéia sobre o porte da empresa ( $\mathrm{n}^{\circ}$ de empregados registrados, faturamento médio da empresa por atividade nos últimos dois anos) e nível de mobilização 
para a qualidade (segurança do trabalho, programas de implantação da ISO 9000, entre outros).

A planilha 1.2 é destinada à caracterização da edificação (área construída, número de pavimentos), da estrutura, dos principais equipamentos utilizados na locação, transporte de materiais etc. Nesta planilha anotam-se, também, quais materiais e serviços serão estudados, mediante análise conjunta do cronograma de execução dos serviços pela equipe de coleta de dados e pelo responsável pela obra.

Também, neste momento, faz-se o registro das especificações dos materiais e serviços a ser estudados, que deverá seguir o sistema de código que será apresentado no item 6.4.5. Por fim, contempla-se nesta planilha, a elaboração de um croqui do canteiro de obras, contendo, entre outros, a discriminação dos locais de estocagem dos materiais e instalações provisórias, centrais de produção, fluxo de pessoas e materiais no canteiro.

\subsubsection{SÉRIE 2 - Medição dos estoques de materiais}

Como o próprio título enfatiza, nesta série de planilhas coletam-se informações relativas à quantidade de material estocado nas datas VI e VF. Embora a quantificação do estoque possa ser trabalhosa, o preenchimento da planilha é simples, bastando apenas, ao observador, anotar a quantidade de material estocado. Para cada material contemplado nesta metodologia foi elaborada uma planilha específica, de acordo com o modelo apresentada na Figura 6.3. 


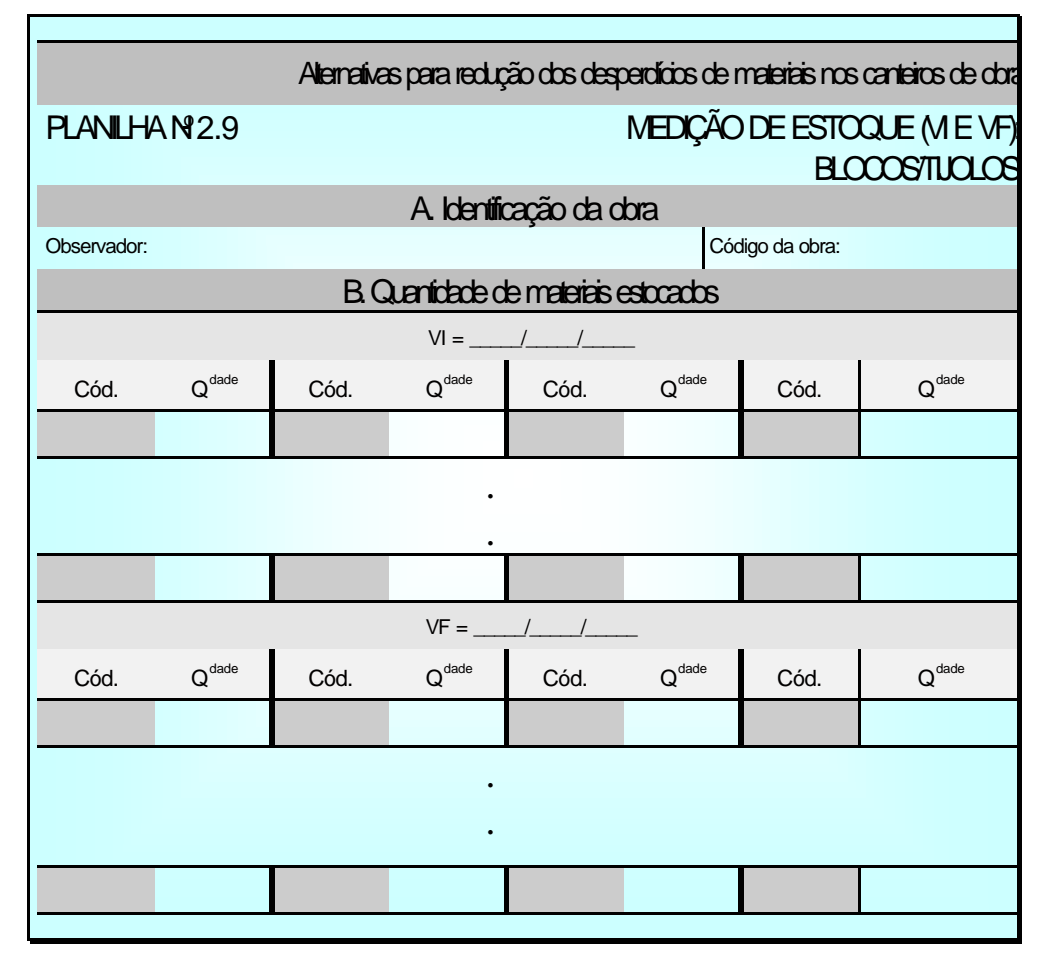

Figura 6.3 Modelo de uma planilha da série 2- Medição dos estoques de blocos/tijolos nas datas VI e VF

\subsubsection{SÉRIE 3 - Medição da quantidade de serviço (QS)}

Dentre as séries de planilhas elaboradas, esta se configura na mais complexa, por envolver a coleta de inúmeras informações para o cálculo do consumo de referência entre as datas VI e VF.

Basicamente, as planilhas desta série, além de conterem um campo reservado à identificação da obra e do serviço a ser medido, são divididas em mais 5 campos, a saber (Figura 6.4):

(a) campo A o observador deverá parcelar o serviço a ser medido em elementos, conforme croqui específico (exemplo: Parede 1B, Viga 200E, 
Face $1 \mathrm{~F}$ etc). As regras para este parcelamento estão descritas nos procedimentos referentes a esta série. Como regra geral, o observador deverá fazer esta divisão levando-se em consideração as especificações dos materiais e características do serviço (por exemplo, separa-se as partes da estrutura de concreto armado que sejam executadas com concretos de diferentes resistências), facilidade de mensuração da quantidade de serviço (por exemplo, define-se as características do contrapiso ambiente por ambiente da edificação) e, principalmente, a facilidade de acesso ao local de execução do mesmo para o preenchimento dos campos $C$ e $D$ (por exemplo, definindo a extensão de uma parede a partir do lado onde tem-se menos intersecções com outras paredes;

(b) campo B: é composto pelas dimensões a ser utilizadas no cálculo da quantidade de serviço $(Q S)^{84}$;

(c) campos $C$ e $D$. para cada elemento, devem-se anotar os percentuais de serviço executado até as datas VI e VF, respectivamente;

(d) campo $E$ A diferença entre os percentuais anotados nos campos $C$ e $D$ multiplicada pela quantidade de serviço (QS) calculada para cada parcelamento do mesmo, resultará na quantidade de serviço entre as datas VI e VF para tal parcela; tal valor, multiplicado pelos valores de referência adotados para as outras variáveis $(C M / Q S$ e $C M B / M C$, que são detalhadas no item 6.4.2.2), resultará no consumo de referência para a fração do serviço em estudo. 


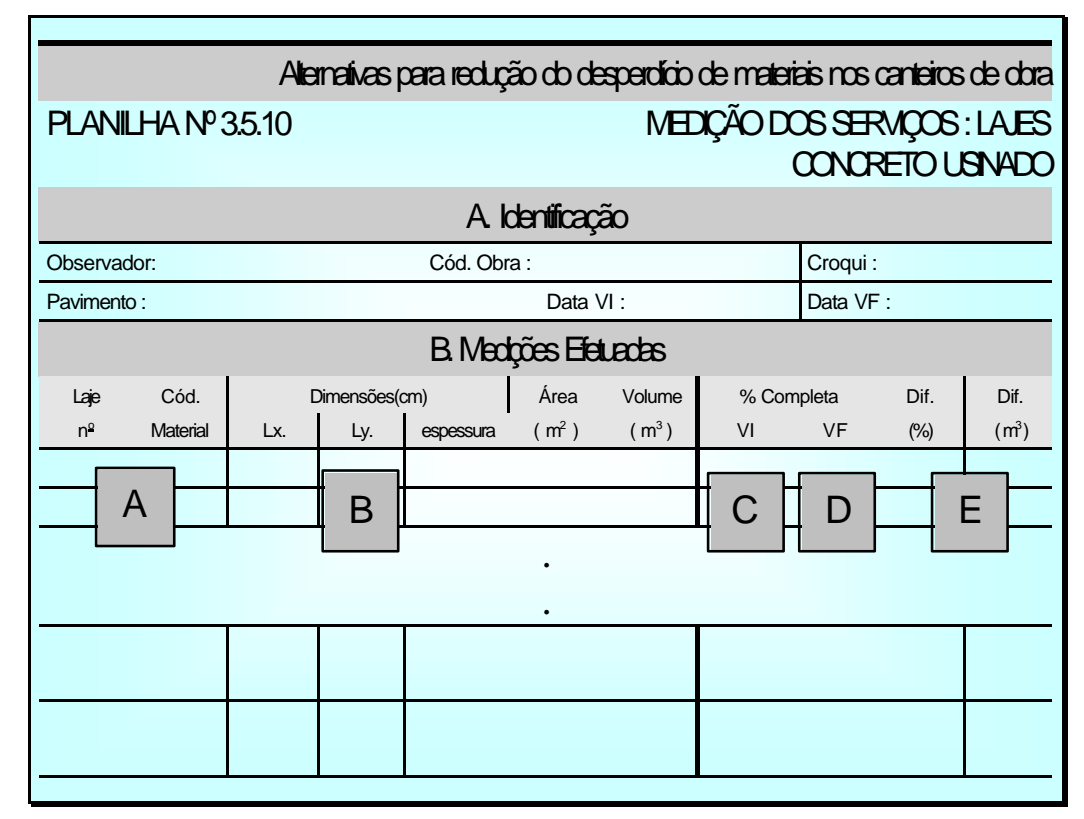

Figura 6.4 Modelo de estrutura de uma planilha da série 3Quantificação dos serviços

\subsubsection{SÉRIE 4 - Quantidade de material recebida e/ou transferido da obra}

As quantidades de materiais recebidas no canteiro de obras, assim como as quantidades de materiais transferidas entre canteiros, são anotadas nas planilhas desta série. Para cada material existe uma planilha específica, cuja estrutura é apresentada na Figura 6.5. Nesta figura, podem-se identificar 4 campos a ser preenchidos, além do campo reservado à identificação da obra:

(a) campo A: neste campo devem ser anotadas as quantidades solicitadas, as recebidas e as pagas, de materiais, entre as datas VI e VF;

\footnotetext{
${ }^{84}$ Por exemplo, para o cálculo da quantidade de serviço de estrutura de concreto, especificamente para o caso da laje em concreto armado, necessita-se das dimensões da mesma que definirão a sua área, assim como, a sua espessura.
} 
(b) Campo B: anotam-se, neste campo, informações para o cálculo dos indicadores parciais relativos à etapa de recebimento ${ }^{85}$,

(c) campo C: neste campo devem ser anotadas as possíveis quantidades transferidas entre canteiros;

(d) campo $D$ : este campo é reservado à anotação das quantidades de materiais destinadas aos respectivos serviços e deverá ser preenchido apenas para aqueles materiais cujo controle, de saída dos mesmos dos estoques, é necessário para o cálculo do indicador global de perda de material por serviço pós-estocagem ${ }^{86}$;

(e) campo E: este campo é reservado à caracterização do recebimento dos materiais nos canteiros de obras quanto aos procedimentos adotados pela empresa na ocorrência de possíveis diferenças entre as quantidades pagas, solicitadas e recebidas; de uma forma geral, é comum a empresa pagar apenas a quantidade que efetivamente recebeu.

\footnotetext{
${ }^{85}$ Como exemplo, citam-se o número de blocos e/ou tijolos quebrados, número de sacos de cimento e cal rasgados, entre outros; estas informações servirão para o cálculo dos respectivos indicadores de perdas no recebimento: percentual de tijolos/blocos quebrados no recebimento e percentual de sacos rasgados no recebimento.

${ }^{86}$ É o uso do cimento e cal, utilizados simultaneamente em vários serviços como contrapiso, elevação de alvenaria etc.
} 


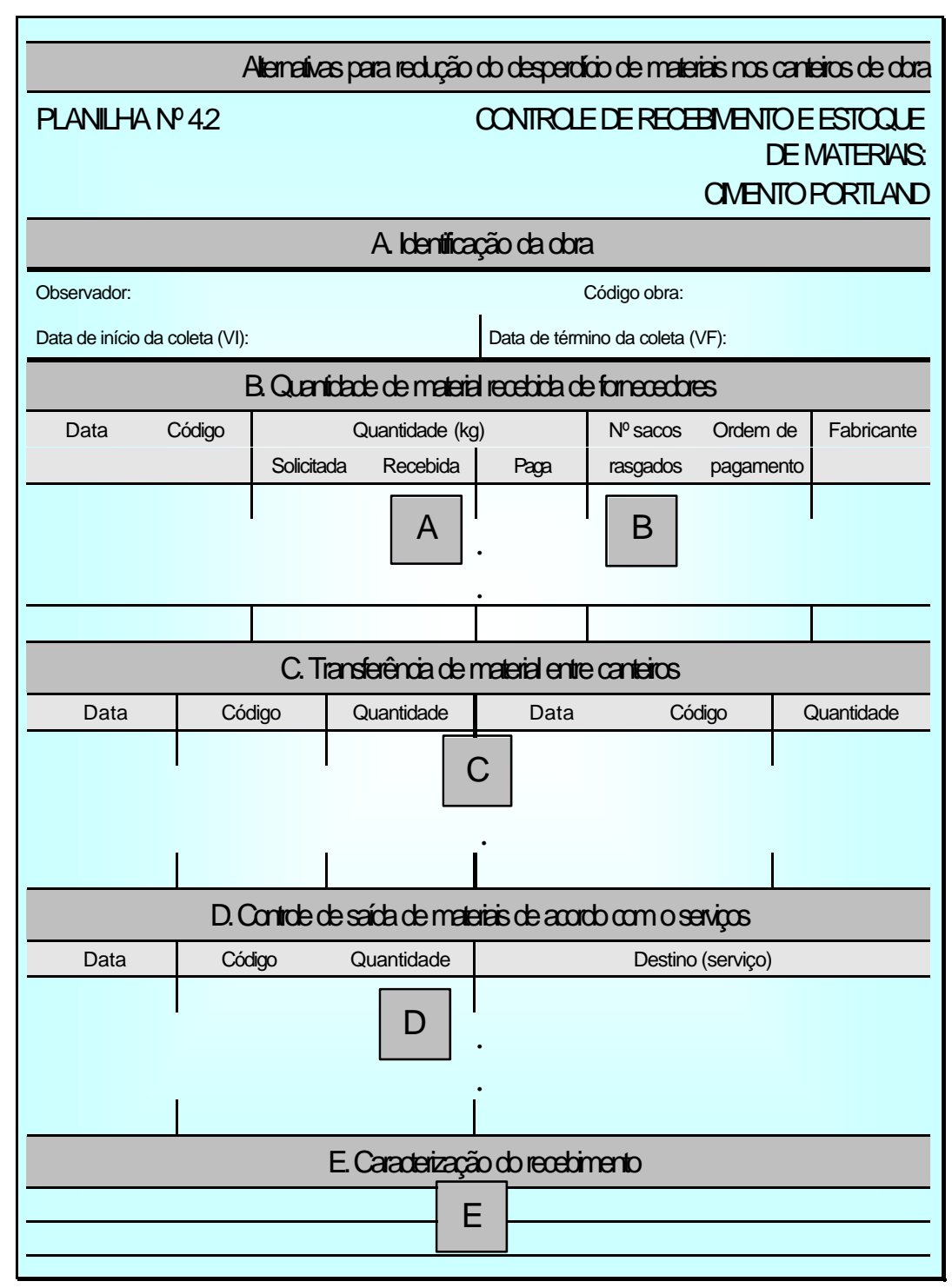

Figura 6.5 Modelo de estrutura de planilha da série 4-Recebimento / transferência de materiais

\subsubsection{SÉRIE 5 - Caracterização tecnológica e gerencial das etapas de recebimento e estocagem dos materiais}

A avaliação do contexto tecnológico e gerencial no qual os indicadores de perdas/consumos foram levantados, é de suma importância para o entendimento e explicação de tais indicadores. As planilhas desta série visam o 
estabelecimento deste contexto nas etapas de recebimento e estocagem dos materiais.

Basicamente, para cada material contemplado nesta metodologia, existe uma planilha correspondente, cujo modelo de estrutura é apresentado na Figura 6.6.

Com relação à estrutura das planilhas desta série, destaca-se o preenchimento de uma lista de verificação, que contém os principais pontos a ser observados quanto à possibilidade de ocorrência de perdas de materiais nestas etapas. Em outras palavras, enumeram-se fatores que poderão, de uma maneira direta ou indireta, influenciar na ocorrência das perdas de materiais.

Para a formulação desta lista de verificação, utilizou-se o conhecimento de diversas bibliografias e normas relativas ao assunto e de situações vivenciadas nos canteiros de obras visitados, conforme anteriormente descrito no capítulo 4. Valendo-se deste conhecimento, partiu-se para a elaboração de perguntas ou itens a ser verificados nas etapas de recebimento e estocagem. Estas perguntas, por sua vez, foram elaboradas de tal forma que toda a resposta positiva anotada pelo observador indicasse a existência de uma condição satisfatória para a não ocorrência de perdas. Além deste critério, procurou-se detalhar o conteúdo das perguntas, dando assim maior subsídio aos observadores de campo para a definição da resposta a ser assinalada. 


\begin{tabular}{|c|c|c|c|c|c|}
\hline \multicolumn{6}{|c|}{ Alemelivas para redução do desperdício de materiás nos canterios de dara } \\
\hline \multicolumn{3}{|c|}{ PLANILHA № 5.10} & \multicolumn{3}{|c|}{$\begin{array}{r}\text { DADOSREATMOSAOSMATERAL: } \\
\text { CALHDRATADA }\end{array}$} \\
\hline \multicolumn{6}{|c|}{ A ldentificação da dora } \\
\hline \multicolumn{2}{|c|}{ Observador: } & Data: & \multicolumn{3}{|c|}{ Código da obra: } \\
\hline \multicolumn{6}{|c|}{ B. Serviços nos quais o materia é utizado } \\
\hline \multicolumn{2}{|c|}{$\begin{array}{l}\text { Alvenaria } \\
\text { Revestimento interno argamassa } \\
\text { Contrapiso } \\
\end{array}$} & \multicolumn{4}{|c|}{\begin{tabular}{|ll} 
Revestimento externo argamassa \\
Outros: \\
\end{tabular}} \\
\hline \multicolumn{6}{|c|}{ C. Lista de verificação } \\
\hline \multicolumn{4}{|c|}{ Item } & Sim Não & $\begin{array}{c}\text { Não se } \\
\text { aplica }\end{array}$ \\
\hline \multicolumn{6}{|c|}{ Recebimento } \\
\hline \multicolumn{6}{|c|}{$\begin{array}{l}\text { 1. Existe procedimento sistematizado do controle da quantidade no } \\
\text { recebimento do material }\end{array}$} \\
\hline \multicolumn{6}{|c|}{$\begin{array}{l}\text { 5. Existe dispositivo para reduzir o esforço do operário no descarregamento? } \\
\text { Se sim, quais? } \\
\begin{array}{lll}\text { carrinhos } & \square_{\text {pallets }} & \square_{\text {outros: }}\end{array}\end{array}$} \\
\hline \multicolumn{6}{|c|}{ Estocagem } \\
\hline \multicolumn{6}{|c|}{$\begin{array}{l}\text { 6. O material está protegido de chuvas no local de estocagem } \\
\text { 12.. O local de estocagem é fechado e com acesso restrito (prevenção quantc } \\
\text { a roubos) }\end{array}$} \\
\hline \multicolumn{6}{|c|}{ D. Registros do cantrio de daras } \\
\hline \multirow{2}{*}{\multicolumn{4}{|c|}{$\begin{array}{l}\text { Local de descarregamento (se for diferente do local da estocagem) } \\
\text { Local de estocagem do material }\end{array}$}} & \multirow{2}{*}{\multicolumn{2}{|c|}{$\begin{array}{l}\text { Foto } \mathrm{n}^{0} 5.10 .1 \\
\text { Foto } \mathrm{n} \times 5.10 .4\end{array}$}} \\
\hline & & & & & \\
\hline \multicolumn{6}{|c|}{ E Registo de ocorêndas anomais } \\
\hline \multicolumn{6}{|c|}{$\begin{array}{l}\text { Descreva qualquer tipo de ocorrência relacionada à utilização inadequada dos materiais, como } \\
\text { acidentes, consumo em serviços não previstos. Faça uma estimativa aproximada da perda. Justifique } \\
\text { as respostas dos itens de verificação, assim como anote qualquer alteração ocorrida durante c } \\
\text { período de coleta de dados. }\end{array}$} \\
\hline Data & Observações & & & & \\
\hline
\end{tabular}

\section{Figura 6.6 Modelo de estrutura de planilha da série 5: dados relativos ao recebimento eestocagem dos materiais}

Cabe ao observador o preenchimento da coluna, correspondente à situação vivenciada no canteiro, para cada item de verificação, ou seja, assinalar a coluna "sim" caso as condições encontradas estejam de acordo com a pergunta e a coluna "não" para o caso contrário. Podem ainda existir casos 
onde o item de verificação não se aplica. Neste caso, o observador deverá fazer uma anotação, para o item correspondente, na coluna "Não se aplica".

Note que o preenchimento de tal lista é rápido, pois o observador deverá assinalar apenas a coluna correspondente à situação vivenciada no canteiro de obras. Entretanto, sabe-se que a construção de edificações possui muitas particularidades sendo que nem sempre, consegue-se ter uma resposta objetiva para uma pergunta objetiva e, às vezes, as situações vivenciadas nos canteiros não correspondem à totalidade dos requisitos contidos nas perguntas. Sendo assim, optou-se também por solicitar-se uma justificativa para cada item avaliado, como forma de respaldar a resposta assinalada no item de verificação. Por outro lado, a justificativa proporciona um melhor entendimento do uso dos materiais nestas etapas, principalmente para aquelas pessoas que não estiveram diretamente relacionadas à coleta de dados nos canteiros de obras.

Além desta lista de verificação, as planilhas desta série trazem em sua estrutura uma lista de registros fotográficos solicitados, onde procura-se ilustrar as condições verificadas, com relação ao uso dos materiais nestas etapas, quanto ao uso de equipamentos, condições de estocagem, ocorrência de perdas, entre outros aspectos. Este registro fotográfico, se por um lado serve para identificar as boas práticas relacionadas ao manuseio dos materiais quanto à ocorrência de perdas, possibilitando, assim, identificar alternativas para a redução das perdas nas etapas de recebimento e estocagem, por outro, serve também para ilustrar a ocorrência de perdas parciais, muitas vezes não quantificadas. 
Por fim, o último campo desta planilha é destinado à anotação de explicações adicionais quanto aos itens de verificação abordados e à anotação das eventuais ocorrências de perdas de materiais que, de uma forma ou de outra, não estejam contempladas na forma de indicadores de perdas, ou seja, as ocorrências anormais.

\subsubsection{SÉRIE 6 - Caracterização tecnológica e gerencial das etapas de processamento intermediário, transporte e aplicação dos materiais}

As planilhas desta série têm a mesma dinâmica apresentada nas planilhas da série anterior; porém, estão voltadas para as etapas do fluxograma dos processos subseqüentes à estocagem, ou seja, processamento, transporte e aplicação final dos materiais.

Podem-se identificar 4 grupos de informações ${ }^{87}$ a ser obtidas com a aplicação destas planilhas. O primeiro grupo de informações diz respeito à caracterização destas etapas quanto a alguns itens relacionados à tecnologia (equipamentos de transporte, de aplicação). O segundo grupo de informações a ser coletadas apresenta-se sob a forma de uma lista de verificação que, por sua vez, é mais extensa do que a apresentada nas planilhas da série 5, por conter um número maior de assuntos a ser verificados. Este segundo grupo encontra-se subdividido em 4 tipos de informações:

(a) dados relativos ao projeto: contém itens de verificação relacionados primeiramente, à existência ou não de projeto específico quanto ao serviço

\footnotetext{
${ }^{87}$ A visualização completa dos campos a preencher pode ser feita através da observação das planilhas contidas no Anexo D.
} 
em análise; em caso afirmativo, é feita uma descrição do conteúdo de tal projeto;

(b) planejamento e organização do canteiro: contém itens relacionados ao planejamento e organização durante a execução do serviço; abordam-se questões relacionadas à logística, organização do posto de trabalho e condições do trajeto onde se realiza o transporte de materiais;

(c) procedimentos de execução e controle: verifica-se a existência ou não de procedimentos de execução e de controle;

(d) processo de execução: são relacionados itens de verificação que dizem respeito ao processo de execução do serviço.

O terceiro grupo é composto por uma lista de registros fotográficos recomendados, cuja finalidade é a de ilustrar as principais características das etapas de processamento, transporte e aplicação do material, assim como ilustrar as possíveis ocorrências de perdas nestas etapas, cujas descrições deverão ser feitas no último campo da planilha.

No quarto grupo, além da descrição das ocorrências de perdas, o observador deverá também detalhar as respostas assinaladas nos principais itens de verificação.

\subsubsection{SÉRIE 7 - Determinação de indicadores globais e parciais de perdas e/ou consumos de materiais}

A série 7 diz respeito aos indicadores de perdas e consumos de materiais. No capítulo 5 definiu-se uma lista de indicadores parciais, de acordo com a análise 
do fluxograma dos processos dos serviços contemplados nesta metodologia e, para cada indicador parcial relacionado, elaborou-se planilha específica para a coleta e processamento das informações.

As únicas exceções dizem respeito às informações relativas aos indicadores parciais da etapa de recebimento como, por exemplo, o cálculo do percentual de blocos quebrados, variação dimensional dos blocos/tijolos, entre outros. Estas informações serão anotadas nas respectivas planilhas da série 4, conforme já ressaltado no item 6.3.1.4.

Cada planilha tem uma estrutura particular, pois as informações a ser levantadas em campo são variadas, dependendo do tipo de serviço e material que se esteja focando. A título de exemplo, a Figura 6.7 ilustra um modelo de planilha para a coleta de dados para o cálculo de um indicador parcial de perda.

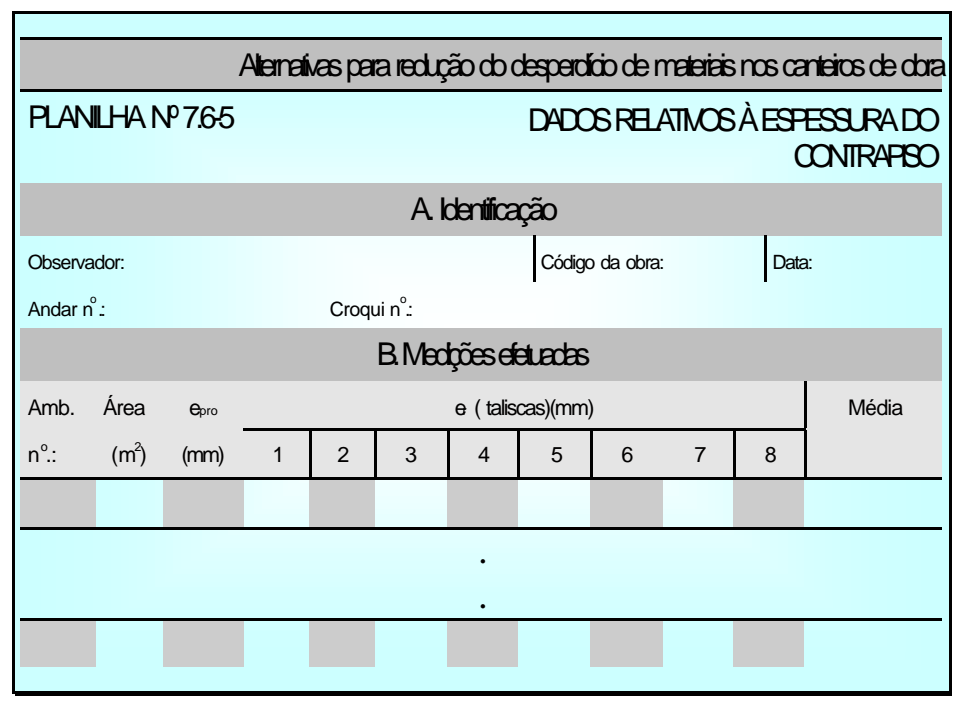

Figura 6.7 Exemplo de uma planilha da série 7 - Espessura do contrapiso 


\subsubsection{Procedimentos de coleta de dados}

Visando a padronização da coleta de dados, foram elaborados procedimentos específicos para as planilhas das séries 1, 2, 3, 4 e 7. Estes procedimentos serão descritos de forma resumida no item relativo à aplicação de cada série de planilhas, sendo que a leitura dos mesmos, no verso de cada planilha apresentada no anexo D, possibilitará uma melhor visão do conteúdo de cada um.

Com relação às séries de planilhas 5 e 6, não foram elaborados procedimentos específicos, visto que as próprias planilhas são auto-explicativas.

\subsubsection{Organização das planilhas e procedimentos}

Todas as planilhas foram numeradas e organizadas para que possibilitasse ao usuário sua fácil identificação (Tabelas 6.1 e 6.2). Na concepção adotada quanto à numeração das planilhas, o primeiro dígito diz respeito à série a qual a planilha pertence e o segundo dígito ao material que se deseja estudar.

Assim, por exemplo, caso o usuário queira proceder um estudo das perdas do concreto usinado, basta ele reunir todas as planilhas cujo segundo dígito for o correspondente ao concreto usinado (neste caso, o dígito 5). De acordo com tais Tabelas, o usuário deverá reunir, então, todas as planilhas pertencentes à linha reservada a este material (para o caso do concreto usinado em exemplificação). Este mesmo procedimento é aplicado para os materiais simples, como é o caso dos eletrodutos, condutores, placas cerâmicas, entre outros. Porém, no que diz respeito ao estudo dos mate riais básicos (cimento, 
por exemplo), além das planilhas relacionadas ao próprio material, ou seja, segundo dígito igual a 2, conforme as Tabelas citadas, são reunidas também as planilhas referentes aos materiais compostos (argamassa e concreto produzidos em obra) a partir deste material básico, já que o estudo do cimento, na etapa de aplicação, é feito indiretamente através do estudo destes materiais compostos.

Observe que, no caso de materiais compostos, os indicadores globais de perdas e consumos não são calculados para os mesmos, e sim, tais perdas e consumos são analisados através da determinação do indicador global de perda e consumo pós-estocagem dos materiais básicos que lhes deram origem.

Observe ainda que, o material de código 8 (chapas de madeira compensada) foi retirado destas Tabelas em função de as planilhas relativas ao mesmo carecerem de um futuro aprofundamento do estudo. 
Tabela 6.1 Relação de planilhas desenvolvidas - informações quantitativas

\begin{tabular}{|c|c|c|c|c|c|c|c|c|c|}
\hline \multirow{3}{*}{$\begin{array}{c}\text { Código principal } \\
\text { do material }\end{array}$} & \multirow{3}{*}{$\begin{array}{l}\text { Descrição do } \\
\text { material }\end{array}$} & \multirow[t]{3}{*}{ Série 2} & \multirow{3}{*}{\multicolumn{2}{|c|}{ Série 3}} & \multirow[t]{3}{*}{ Série 4} & \multicolumn{4}{|r|}{ Série 7} \\
\hline & & & & & & \multicolumn{2}{|c|}{ Indicadores globais } & \multirow{2}{*}{\multicolumn{2}{|c|}{ Indicadores parciais }} \\
\hline & & & & & & Obra/Serviço & $\begin{array}{c}\text { Por serviço pós - } \\
\text { estocagem }\end{array}$ & & \\
\hline 1 & Areia & 2.1 & & - & 4.1 & 7.1 & - & 7.1.1 & Diferença percentual entre a quantidade paga e a recebida \\
\hline 2 & Cimento Portland & 2.2 & & & 4.2 & 7.2 & $\begin{array}{c}\text { 7.2Alven } \\
\text { 7.2Contr } \\
\text { 7.2Revint } \\
\text { 7.2Revext } \\
\text { 7.2EstrConcr }\end{array}$ & $\begin{array}{l}7.2 .1 \\
7.2 .2 \\
7.2 .3\end{array}$ & $\begin{array}{l}\text { Diferença percentual entre a quantidade paga e a recebida } \\
\text { Diferença percentual entre a massa média real dos sacos e a nominal } \\
\text { Percentual de sacos rasgados no recebimento }\end{array}$ \\
\hline 3 & Pedra & 2.3 & & - & 4.3 & 7.3 & - & 7.3.1 & Diferença percentual entre a quantidade paga e a recebida \\
\hline 4 & Concreto obra & - & \begin{tabular}{l|}
3.4 .1 \\
\\
3.4 .2 \\
3.4 .3 \\
3.4 .4 \\
3.4 .5 \\
3.4 .6 \\
3.4 .7 \\
3.4 .8 \\
3.4 .9 \\
3.4 .10 \\
3.4 .11
\end{tabular} & $\begin{array}{l}\text { Fundações diretas } \\
\text { Fundações profundas } \\
\text { Cortinas } \\
\text { Blocos de fundação } \\
\text { Vigas baldrames } \\
\text { Caixas d' águas } \\
\text { Pilares } \\
\text { Escadas } \\
\text { Vigas } \\
\text { Lajes } \\
\text { Contrapiso }\end{array}$ & - & - & - & $\begin{array}{l}7.4 .1 \\
7.4 .2 \\
7.4 .3\end{array}$ & $\begin{array}{l}\text { Variação percentual entre o consumo real de cimento por } \mathrm{m}^{3} \text { de concreto produzido em relação ao } \\
\text { especificado } \\
\text { Diferença percentual entre a espessura média real das lajes e a de referência } \\
\text { Variação percentual entre a largura média real das vigas e a de referência }\end{array}$ \\
\hline
\end{tabular}


Tabela 6.1 Relação de planilhas desenvolvidas - informações quantitativas (continuação)

\begin{tabular}{|c|c|c|c|c|c|c|c|c|c|}
\hline \multirow{3}{*}{$\begin{array}{l}\text { Código principal } \\
\text { do material }\end{array}$} & \multirow{3}{*}{$\begin{array}{l}\text { Descrição do } \\
\text { material }\end{array}$} & \multirow[t]{3}{*}{ Série 2} & \multirow{3}{*}{\multicolumn{2}{|c|}{ Série 3}} & \multirow[t]{3}{*}{ Série 4} & \multicolumn{4}{|r|}{ Série 7} \\
\hline & & & & & & \multicolumn{2}{|c|}{ Indicadores globais } & \multirow{2}{*}{\multicolumn{2}{|c|}{ Indicadores parciais }} \\
\hline & & & & & & Obra/Serviço & $\begin{array}{l}\text { Por serviço pós - } \\
\text { estocagem }\end{array}$ & & \\
\hline 5 & Concreto usinado & - & $\begin{array}{l}3.5 .1 \\
3.5 .2 \\
3.5 .3 \\
3.5 .4 \\
3.5 .5 \\
3.5 .6 \\
3.5 .7 \\
3.5 .8 \\
3.5 .9 \\
3.5 .10 \\
3.5 .11\end{array}$ & $\begin{array}{l}\text { Fundações diretas } \\
\text { Fundaçōes profundas } \\
\text { Cortinas } \\
\text { Blocos de fundação } \\
\text { Vigas baldrames } \\
\text { Caixas d' águas } \\
\text { Pilares } \\
\text { Escadas } \\
\text { Vigas } \\
\text { Lajes } \\
\text { Contrapiso }\end{array}$ & 4.5 & 7.5 & - & $\begin{array}{l}7.5 .1 \\
7.5 .2 \\
7.5 .3\end{array}$ & $\begin{array}{l}\text { Diferença percentual entre a quantidade paga e a recebida } \\
\text { Diferença percentual entre a espessura média real das lajes e a de referência } \\
\text { Diferença percentual entre a largura média real das vigas e a de referência }\end{array}$ \\
\hline 6 & Argamassa obra & - & $\begin{array}{l}3.6 .1 \\
3.6 .2 \\
3.6 .3 \\
3.6 .4 \\
3.6 .5 \\
3.6 .6 \\
3.6 .7\end{array}$ & $\begin{array}{l}\text { Alvenaria } \\
\text { Rev. Interno - Chapisco } \\
\text { Rev. Interno - Emboço } \\
\text { Rev. Interno - Reboco } \\
\text { Rev. Externo - Chapisco } \\
\text { Rev. Externo - Emboço } \\
\text { Contrapiso }\end{array}$ & - & - & - & $\begin{array}{l}7.6 .1 \\
7.6 .2 \\
7.6 .3 \\
7.6 .4 \\
7.6 .5 \\
7.6 .6 \\
7.6 .7 \\
7.6 .8 \\
7.6 .9\end{array}$ & $\begin{array}{l}\text { Diferença percentual entre consumo real de cimento por } \mathrm{m}^{3} \text { de argamassa produzida e o consumo } \\
\text { de referência } \\
\text { Diferença percentual entre o consumo real de cal por } \mathrm{m}^{3} \text { de argamassa produzida e o consumo de } \\
\text { referência } \\
\text { Diferença percentual entre a espessura média real do revestimento interno e a de referência } \\
\text { Diferença percentual entre a espessura média real do revestimento externo e a de referência } \\
\text { Diferença percentual entre a espessura média real do contrapiso e a de referência } \\
\text { Desvio médio do prumo dos pilares } \\
\text { Desvio médio do prumo da estrutura } \\
\text { Consumo de argamassa por } \mathrm{m} \text { de junta argamassada (alvenaria) executada } \\
\text { Consumo de argamassa por } \mathrm{m}^{2} \text { de revestimento (contrapiso, rev. interno e externo) executado }\end{array}$ \\
\hline
\end{tabular}


Tabela 6.1 Relação de planilhas desenvolvidas - informações quantitativas (continuação)

\begin{tabular}{|c|c|c|c|c|c|c|c|c|c|}
\hline \multirow{3}{*}{$\begin{array}{l}\text { Código principal } \\
\text { do material }\end{array}$} & \multirow{3}{*}{$\begin{array}{l}\text { Descrição do } \\
\text { material }\end{array}$} & \multirow[t]{3}{*}{ Série 2} & & \multirow[t]{3}{*}{ Série 3} & \multirow[t]{3}{*}{ Série 4} & \multicolumn{4}{|r|}{ Série 7} \\
\hline & & & & & & \multicolumn{2}{|c|}{ Indicadores globais } & \multirow{2}{*}{\multicolumn{2}{|c|}{ Indicadores parciais }} \\
\hline & & & & & & Obra/Serviço & \begin{tabular}{|c} 
Por serviço pós- \\
estocagem
\end{tabular} & & \\
\hline 7 & Aço & 2.7 & $\begin{array}{l}3.7 .1 \\
3.7 .2 \\
3.7 .3 \\
3.7 .4 \\
3.7 .5 \\
3.7 .6 \\
3.7 .7 \\
3.7 .8 \\
3.7 .9 \\
3.7 .10\end{array}$ & $\begin{array}{l}\text { Fundações diretas } \\
\text { Fundações profundas } \\
\text { Cortinas } \\
\text { Blocos de fundação } \\
\text { Vigas baldrames } \\
\text { Caixas d' águas } \\
\text { Pilares } \\
\text { Escadas } \\
\text { Vigas } \\
\text { Lajes }\end{array}$ & 4.7 & 7.7 & - & $\begin{array}{l}7.7 .1 \\
7.7 .2\end{array}$ & $\begin{array}{l}\text { Diferença percentual entre a quantidade paga e a recebida } \\
\text { Diferença percentual entre a massa linear real e a nominal }\end{array}$ \\
\hline 9 & Blocos e tijolos & 2.9 & 3.9 .1 & Alvenaria & 4.9 & 7.9 & - & $\begin{array}{r}7.9 .1 \\
7.9 .2 \\
7.9 .3 \\
7.9 .4\end{array}$ & $\begin{array}{l}\text { Diferença percentual entre a quantidade paga e a recebida } \\
\text { Percentual de blocos/tijolos quebrados no recebimento } \\
\text { Variação dimensional dos blocos/tijolos nas direções } x, y, z \\
\text { Percentual de blocos cortados na parede }\end{array}$ \\
\hline 10 & Cal hidratada & 2.10 & & - & 4.10 & 7.10 & $\begin{array}{l}\text { 7.10Alven } \\
\text { 7.10Contr } \\
\text { 7.10Revint } \\
\text { 7.10Revext }\end{array}$ & $\begin{array}{l}7.10 .1 \\
7.10 .2 \\
7.10 .3\end{array}$ & $\begin{array}{l}\text { Diferença percentual entre a quantidade paga e a recebida } \\
\text { Diferença percentual entre a massa média real dos sacos e a nominal } \\
\text { Percentual de sacos rasgados no recebimento }\end{array}$ \\
\hline
\end{tabular}


Tabela 6.1 Relação de planilhas desenvolvidas - informações quantitativas (continuação)

\begin{tabular}{|c|c|c|c|c|c|c|c|c|c|}
\hline \multirow{3}{*}{$\begin{array}{l}\text { Código principal } \\
\text { do material }\end{array}$} & \multirow{3}{*}{$\begin{array}{l}\text { Descrição do } \\
\text { material }\end{array}$} & \multirow[t]{3}{*}{ Série 2} & \multirow{3}{*}{\multicolumn{2}{|c|}{ Série 3}} & \multirow[t]{3}{*}{ Série 4} & \multicolumn{4}{|r|}{ Série 7} \\
\hline & & & & & & \multicolumn{2}{|c|}{ Indicadores globais } & \multirow{2}{*}{\multicolumn{2}{|c|}{ Indicadores parciais }} \\
\hline & & & & & & Obra/Serviço & $\begin{array}{l}\text { Por serviço pós- } \\
\text { estocagem }\end{array}$ & & \\
\hline 11 & $\begin{array}{l}\text { Argamassa } \\
\text { parcial ou } \\
\text { totalmente } \\
\text { produzida Fora } \\
\text { do canteiro de } \\
\text { obras }\end{array}$ & 2.11 & $\begin{array}{l}3.11 .1 \\
3.11 .2 \\
3.11 .3 \\
3.11 .4 \\
\\
3.11 .5 \\
3.11 .6 \\
3.11 .7\end{array}$ & $\begin{array}{l}\text { Alvenaria } \\
\text { Rev. Interno - Chapisco } \\
\text { Rev. Interno - Emboço } \\
\text { Rev. Interno - Reboco } \\
\text { Rev. Externo - Chapisco } \\
\text { Rev. Externo - Emboço } \\
\text { Contrapiso }\end{array}$ & 4.11 & 7.11 & - & $\begin{array}{r}7.11 .1 \\
7.11 .2 \\
7.11 .3 \\
7.11 .4 \\
7.11 .5 \\
7.11 .6 \\
7.11 .7 \\
7.11 .8 \\
7.11 .9 \\
7.11 .10 \\
7.11 .11\end{array}$ & $\begin{array}{l}\text { Diferença percentual entre a quantidade paga e a recebida } \\
\text { Diferença percentual entre a massa média real dos sacos e a nominal } \\
\text { Percentual de sacos rasgados no recebimento } \\
\text { Diferença percentual entre consumo real de cimento por } \mathrm{m}^{3} \text { de argamassa produzida e o consumo } \\
\text { de referência } \\
\text { Diferença percentual entre a espessura média real do revestimento interno e a de referência } \\
\text { Diferença percentual entre a espessura média real do revestimento externo e a de referência } \\
\text { Diferença percentual entre a espessura média real do contrapiso e a de referência } \\
\text { Desvio médio do prumo dos pilares } \\
\text { Desvio médio do prumo da estrutura } \\
\text { Consumo de argamassa por } \mathrm{m} \text { de junta argamassada (alvenaria) executada } \\
\text { Consumo de argamassa por } \mathrm{m}^{2} \text { de revestimento (contrapiso, rev. interno e externo) executado }\end{array}$ \\
\hline 12 & Eletrodutos & 2.12 & $\begin{array}{l}3.12 . \\
3.12 . \\
3.12 . \\
3.12 .\end{array}$ & $\begin{array}{l}\text { Alimentação } \\
\text { Prumadas } \\
\text { Paredes } \\
\text { Lajes }\end{array}$ & 4.12 & 7.12 & - & $\begin{array}{l}7.12 .1 \\
7.12 .2\end{array}$ & $\begin{array}{l}\text { Diferença percentual entre a quantidade paga e a recebida } \\
\text { Diferença entre o comprimento real e o especificado }\end{array}$ \\
\hline 13 & Condutores & 2.13 & $\begin{array}{l}3.13 . \\
3.13 . \\
3.13 . \\
3.13 .\end{array}$ & $\begin{array}{l}\text { Alimentação } \\
\text { Prumadas } \\
\text { Paredes } \\
\text { Lajes }\end{array}$ & 4.13 & 7.13 & - & $\begin{array}{l}7.13 .1 \\
7.13 .2\end{array}$ & $\begin{array}{l}\text { Diferença percentual entre a quantidade paga e a recebida } \\
\text { Diferença percentual entre o comprimento real do trecho executado e o de referência }\end{array}$ \\
\hline
\end{tabular}


Tabela 6.1 Relação de planilhas desenvolvidas - informações quantitativas (continuação)

\begin{tabular}{|c|c|c|c|c|c|c|c|c|c|}
\hline \multirow{3}{*}{$\begin{array}{c}\text { Código principal } \\
\text { do material }\end{array}$} & \multirow{3}{*}{$\begin{array}{l}\text { Descrição do } \\
\text { material }\end{array}$} & \multirow[t]{3}{*}{ Série 2} & \multirow{3}{*}{\multicolumn{2}{|c|}{ Série 3}} & \multirow[t]{3}{*}{ Série 4} & \multicolumn{4}{|r|}{ Série 7} \\
\hline & & & & & & \multicolumn{2}{|c|}{ Indicadores globais } & \multirow{2}{*}{\multicolumn{2}{|c|}{ Indicadores parciais }} \\
\hline & & & & & & Obra/Serviço & \begin{tabular}{|c} 
Por serviço pós - \\
estocagem
\end{tabular} & & \\
\hline 14 & Tubos & 2.14 & $\begin{array}{l}3.14 .1 \\
3.14 .2 \\
3.14 .3 \\
3.14 .4 \\
3.14 .5\end{array}$ & $\begin{array}{l}\text { Ramais intemos A.F. } \\
\text { Ramais internos esgoto } \\
\text { Ramais internos A.P. } \\
\text { Prumadas A.F. } \\
\text { Tubos de queda etc }\end{array}$ & 4.14 & 7.14 & - & 7.14 .1 & Diferença percentual entre a quantidade paga e a recebida \\
\hline 15 & Telhas & 2.15 & 3.15 .1 & Cobertura & 4.15 & 7.15 & - & $\begin{array}{l}7.15 .1 \\
7.15 .2\end{array}$ & $\begin{array}{l}\text { Diferença percentual entre a quantidade paga e a recebida } \\
\text { Percentual de telhas quebradas no recebimento }\end{array}$ \\
\hline 16 & Placa cerâmica & 2.16 & $\begin{array}{l}3.16 .1 \\
3.16 .2 \\
3.16 .3\end{array}$ & $\begin{array}{l}\text { Rev. cerâmico - piso } \\
\text { Rev. cerâmico - parede } \\
\text { Rev. cerâmico - fachada }\end{array}$ & 4.16 & 7.16 & - & $\begin{array}{l}7.16 .1 \\
7.16 .2 \\
7.16 .3\end{array}$ & $\begin{array}{l}\text { Diferença percentual entre a quantidade paga e a recebida } \\
\text { Percentual de placas cerâmicas cortadas no piso } \\
\text { Percentual de placas cerâmicas cortadas na parede }\end{array}$ \\
\hline 17 & $\begin{array}{l}\text { Revestimento } \\
\text { têxtil }\end{array}$ & 2.17 & 3.17 & Rev. têxtil - piso & 4.17 & 7.17 & - & 7.17.1 & Diferença percentual entre a quantidade paga e a recebida \\
\hline 18 & Tinta & 2.18 & $\begin{array}{l}3.18 .1 \\
3.18 .2\end{array}$ & $\begin{array}{l}\text { Pintura interna } \\
\text { Pintura externa }\end{array}$ & 4.18 & 7.18 & - & $\begin{array}{l}7.18 .1 \\
7.18 .2\end{array}$ & $\begin{array}{l}\text { Diferença percentual entre a quantidade paga e a recebida } \\
\text { Consumo de tinta por } \mathrm{m}^{2} \text { de pintura executada }\end{array}$ \\
\hline 19 & Gesso & 2.19 & 3.19 .1 & Parede interna & 4.19 & 7.19 & - & $\begin{array}{l}7.19 .1 \\
7.19 .2 \\
7.19 .3 \\
7.19 .4\end{array}$ & $\begin{array}{l}\text { Diferença percentual entre a quantidade paga e a recebida } \\
\text { Diferença percentual entre a massa média real dos sacos e a nominal } \\
\text { Percentual de sacos rasgados no recebimento } \\
\text { Consumo de gesso por } \mathrm{m}^{2} \text { de revestimento executado }\end{array}$ \\
\hline 20 & Saibro & 2.20 & & - & 4.20 & 7.20 & - & 7.20 .1 & Diferença percentual entre a quantidade paga e a recebida \\
\hline
\end{tabular}


Tabela 6.2 Relação de planilhas desenvolvidas - informações qualitativas

\begin{tabular}{|c|c|c|c|c|c|}
\hline \multirow{2}{*}{$\begin{array}{c}\text { Código } \\
\text { Principal do } \\
\text { material } \\
\end{array}$} & \multirow{2}{*}{$\begin{array}{l}\text { Descrição do } \\
\text { material }\end{array}$} & \multirow{2}{*}{$\frac{\text { Série } 5}{\text { Recebimento - estocagem }}$} & \multicolumn{3}{|r|}{ Série 6} \\
\hline & & & Processamento intermediário & & Transporte - aplicação \\
\hline 1 & Areia & 5.1 & - & - & - \\
\hline 2 & Cimento Portland & 5.2 & - & - & - \\
\hline 3 & Pedra & 5.3 & - & - & - \\
\hline 4 & Concreto obra & - & 6.4 .1 & 6.4 .2 & Infra e superestrutura de concreto \\
\hline 5 & Concreto usinado & 5.5 & - & 6.5 & Infra e superestrutura de concreto \\
\hline 6 & Argamassa obra & - & 6.6 .1 & $\begin{array}{l}6.6 .2 \\
6.6 .3 \\
6.6 .4 \\
6.6 .5 \\
\end{array}$ & \begin{tabular}{|l} 
Alvenaria \\
Rev. interno \\
Rev. externo \\
Contrapiso \\
\end{tabular} \\
\hline 7 & Aço & 5.7 & Vide planilha 6.7 & 6.7 & Corte, montagem e colocação \\
\hline 9 & Blocos/tijolos & 5.9 & Vide planilha 6.9 & 6.9 & Alvenaria \\
\hline 10 & Cal & 5.10 & - & - & - \\
\hline 11 & $\begin{array}{l}\text { Argamassa parcial } \\
\text { ou total// prod. fora }\end{array}$ & 5.11 & 6.11 .1 & $\begin{array}{l}6.11 .2 \\
6.11 .3 \\
6.11 .4 \\
6.11 .5\end{array}$ & $\begin{array}{l}\text { Alvenaria } \\
\text { Rev. interno } \\
\text { Rev. externo } \\
\text { Contrapiso }\end{array}$ \\
\hline
\end{tabular}


Tabela 6.2 Relação de planilhas desenvolvidas - informações qualitativas (continuação)

\begin{tabular}{|c|c|c|c|c|c|}
\hline \multirow{2}{*}{$\begin{array}{l}\text { Código } \\
\text { Principal do } \\
\text { material }\end{array}$} & \multirow{2}{*}{$\begin{array}{l}\text { Descrição do } \\
\text { material }\end{array}$} & \multirow{2}{*}{$\frac{\text { Série } 5}{\text { Recebimento - estocagem }}$} & \multicolumn{3}{|c|}{ Série 6} \\
\hline & & & Processamento intermediário & & Transporte - aplicação \\
\hline 12 & Eletrodutos & Vide planilha 6.12 & - & 6.12 & Instalações elétricas \\
\hline 13 & Condutores & Vide planilha 6.13 & - & 6.13 & Instalações elétricas \\
\hline 14 & Tubos & Vide planilha 6.14 & - & 6.14 & Instalações hidrossanitárias \\
\hline 15 & Telhas & 5.15 & - & 6.15 & Cobertura \\
\hline 16 & Placas cerâmicas & 5.16 & - & $\begin{array}{l}6.16 .1 \\
6.16 .2 \\
6.16 .3 \\
\end{array}$ & $\begin{array}{l}\text { Revestimento cerâmico piso } \\
\text { Revestimento cerâmico parede } \\
\text { Revestimento cerâmico - fachada }\end{array}$ \\
\hline 17 & Rev. Têxtil & Vide planilha 6.17 & - & 6.17 & Revestimento têxtil \\
\hline 18 & Tinta & 5.18 & $\begin{array}{l}\text { Vide planilha } 6.18 .1 \\
\text { Vide planilha 6.18.2 }\end{array}$ & $\begin{array}{l}6.18 .1 \\
6.18 .2 \\
\end{array}$ & $\begin{array}{l}\text { Pintura interna } \\
\text { Pintura externa }\end{array}$ \\
\hline 19 & Gesso & 5.19 & Vide planilha 6.19 & 6.19 & Revestimento em gesso \\
\hline 20 & Saibro & - & - & - & - \\
\hline
\end{tabular}




\subsection{Coleta de dados}

A coleta de dados se procederá basicamente em 3 momentos distintos: antes da data de vistoria inicial (VI), nas datas da vistoria inicial e final (VI e VF) e entre estas datas. Caso seja necessário, pode haver também a coleta de informações adicionais após a data VF, especificamente após o processamento e análise crítica dos resultados. Na seqüência, apresentam-se os principais caminhos para a coleta das informações, que visam à:

(a) caracterização da obra e da empresa na qual se realizará o estudo;

(b) obtenção dos indicadores globais de perdas e/ou consumos;

(c) obtenção dos indicadores parciais;

(d) caracterização das etapas do fluxograma dos processos percorridas pelos materiais.

\subsubsection{Caracterização da empresa e da obra}

A coleta de dados relativos à empresa e à obra deverá ser feita através da aplicação das planilhas da série 1. A aconselha-se que a coleta seja efetuada antes da data da vistoria inicial (VI).

Uma atenção especial deverá ser dada à definição dos materiais e serviços a ser estudados. Esta definição dependerá, entre outros aspectos, do cronograma de execução da obra e, até mesmo, da possibilidade de realização de controles de saída dos materiais básicos (cimento, cal) do estoque. Neste 
momento também procede-se a codificação dos materiais e serviços, conforme estrutura que será apresentada no item 6.4.5.

Da mesma forma, como parte integrante da caracterização da obra, solicita-se a elaboração de um croqui contendo o arranjo físico do canteiro de obras, a partir das instruções que podem ser vistas na própria planilha 1.2.

\subsubsection{Indicadores globais}

Conforme destacado no capítulo 5, os indicadores globais são divididos em três categorias: por obra, por serviço e por serviço pós-estocagem. O cálculo destes indicadores é feito através da diferença percentual entre a quantidade efetivamente utilizada no canteiro de obras (consumo real) e a quantidade teoricamente necessária (consumo de referência) para a execução dos serviços compreendidos entre duas datas estratégicas, denominadas VI e VF.

\subsubsection{Consumo real}

O consumo real de materiais num determinado período delimitado pelas datas VI e VF é obtido, mediante a diferença entre as quantidades de materiais estocadas respectivamente nas datas VI e VF, somada às quantidades líquidas de materiais recebidas entre as mesmas.

\section{(a) medição dos estoques nas datas VI e VF (Série 2)}

A medição dos estoques deverá ser feita, necessariamente, nas datas VI e VF. Como regra geral, é importante que todos, inclusive o responsável pela obra, estejam cientes das necessidades: 
- de mensuração de toda a quantidade de material estocada, independentemente do local no qual o material esteja armazenado, seja nos subsolos ou no próprio local de aplicação;

- de que esta mensuração seja feita levando-se em consideração as especificações dos materiais, conforme estrutura de códigos a ser apresentada no item 6.4.5.

Muitas vezes, a contabilização dos estoques de materiais não se configura numa tarefa agradável e fácil de ser realizada, em função, principalmente, das condições de estocagem (pilhas mal feitas, local de difícil acesso, materiais de características diferentes estocados no mesmo local, inclusive misturados entre si etc).

Estas diversidades, que dependem muito mais da política da empresa, voltada ou não para a organização dos estoques de materiais, também estão associadas à forma pela qual o material é entregue na obra (ensacado, a granel, paletizados etc).

Como forma de amenizar tais problemas, aconselha-se que os estoques dos materiais sejam organizados previamente à contabilização dos mesmos.

Tratando-se desta contabilização, no verso de cada planilha existe um procedimento específico contendo os critérios a ser adotados no que diz respeito à mesma (ver anexo D). Na Figura 6.8 apresenta-se um exemplo de procedimento para a mensuração das quantidades de materiais estocados. 


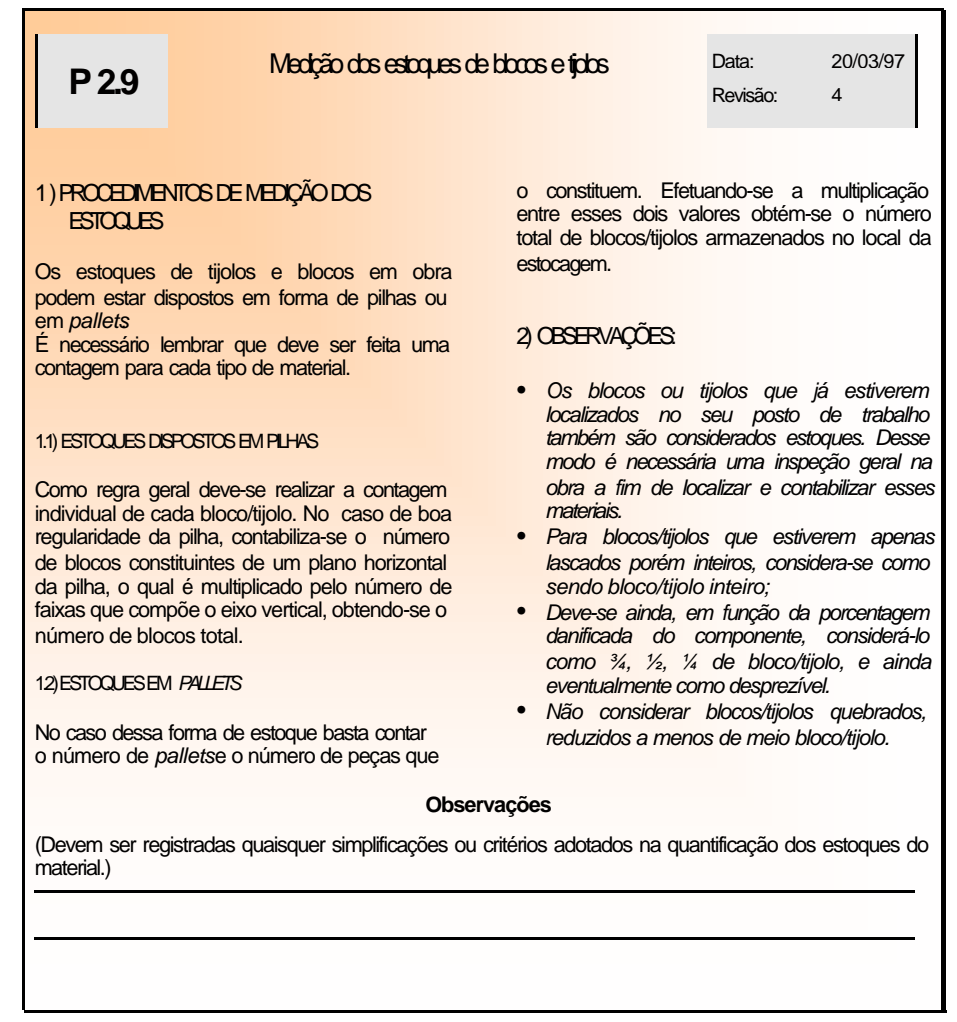

\section{Figura 6.8 Exemplo de procedimento de mensuração dos estoques: blocos e tijolos}

Não se tendo uma organização prévia, caberá ao observador avaliar a margem de erro cometida numa possível estimativa de material estocado e a definição de procedimentos alternativos que a minimize. A título de ilustração, na Figura 6.9 apresenta-se um artifício utilizado por uma equipe de coleta ao se contabiliz ar o estoque de eletrodutos rígidos. Observe que, dada a dificuldade de acesso e de iluminação do local de estocagem, esta equipe utilizou canudos plásticos coloridos para identificar cada eletroduto, sendo uma cor específica para cada especificação do material. Após a plena identificação (colocação dos tubos plásticos dentro dos eletrodutos), a equipe recolheu estes canudos plásticos e contou-os, levando-se em consideração as cores. 


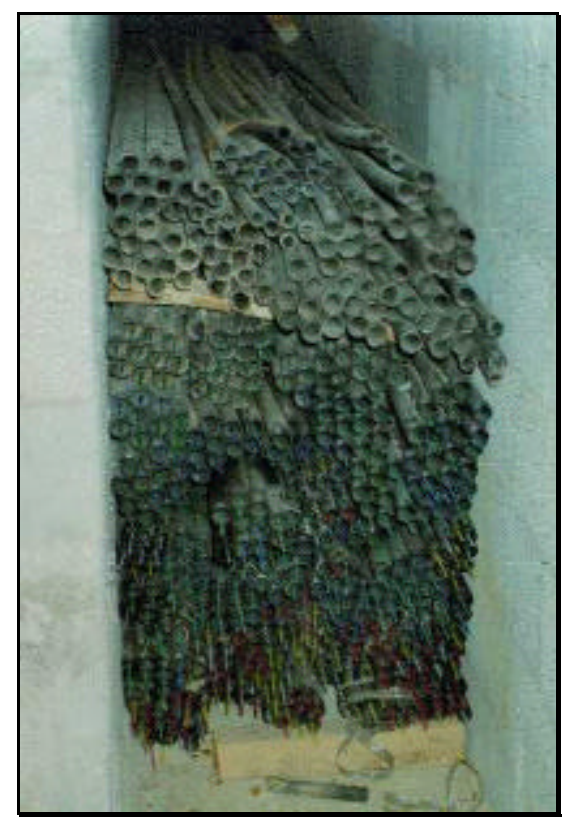

Figura 6.9 Artifício utilizado para a contabilização do estoque de eletrodutos

Este exemplo ilustra a seriedade que a equipe de coleta deve ter ao se realizar este procedimento, independentemente de eventuais condições adversas encontradas nos canteiros de obras.

(b) Contabilização da quantidade de material recebida no canteiro de obras

Como o enfoque do trabalho consiste no estabelecimento de indicadores de perdas e/ou consumos físicos de materiais, torna-se necessário levantar as quantidades de materiais recebidas nos canteiros de obras entre as datas VI e VF. Dentro do espírito de que o estudo das perdas/consumos seja feito por uma equipe de pesquisadores/profissionais não pertencentes à obra estudada, são apresentadas duas possibilidades quanto à mensuração de tais quantidades: 
(a) mensuração feita pela equipe de coleta de dados externa à obra: a concretização desta operação depende da possibilidade de a equipe de coleta estar no canteiro de obras durante a entrega do material;

(b) mensuração feita por um funcionário da empresa: esta opção foge ao alcance da equipe externa de coleta, pois está condicionada à disponibilidade de tal funcionário no quadro da empresa.

Dentre as duas opções levantadas, a segunda parece ser a menos onerosa, pois diversas empresas possuem a política de se fazer a conferência das quantidades de materiais entregues nos canteiros de obras; geralmente esta atividade é atribuída aos almoxarifes ou apontadores.

Entretanto, nem sempre se consegue realizar a mensuração das quantidades recebidas, ou por falta desta política na empresa em contabilizar tais recebimentos ou, também, por insuficiência de pessoal da entidade pesquisadora externa.

Neste caso, pode-se optar pela utilização das quantidades descritas nas notas fiscais como representativas da quantidade recebida; porém, ressalta-se que tal medida pode acarretar imprecisões, principalmente se o fornecedor não for idôneo.

Adotando-se esta opção, a equipe de coleta deverá criar um mecanismo para a obtenção de tais notas fiscais para a atualização freqüente das planilhas pois, senão, corre-se o risco de as mesmas ser extraviadas e, conseqüentemente, as informações necessárias para o cálculo do indicador global podem ser perdidas. Ainda quanto a esta segunda situação, recomenda-se que se faça, 
amostralmente, algumas verificações de recebimento, para se ter melhor confiabilidade quanto à hipótese de não se ter discrepâncias entre as quantidades pagas e recebidas.

Da mesma forma que os materiais comprados são entregues nos canteiros de obras pelos fornecedores, pode haver casos onde há a transferência destes entre canteiros de obras de uma mesma empresa, não se constituindo numa transação comercial atestada por notas fiscais. Nestes casos, estas quantidades devem ser computadas e, para isso, torna-se imprescindível a comunicação desta ocorrência à equipe de coleta de dados, que deverá anotar esta informação no local reservado à mesma nas planilhas da série 4 .

De posse destas informações (quantidade estocada, recebida e transferida), obtém-se o consumo real de material entre as datas VI e VF. Entretanto, o procedimento apresentado até o momento possibilita o estabelecimento do indicador global de perda de material, por serviço ou por obra, apenas para alguns materiais, como é o caso, por exemplo, do concreto usinado, dos blocos/tijolos, das placas cerâmicas, enfim, daqueles materiais utilizados em um único serviço. Para aqueles materiais utilizados em vários serviços simultaneamente, como é o caso do cimento e da cal, este procedimento não é suficiente quando se pretende obter indicador por serviço, havendo a necessidade de se proceder de forma diferente. Para estes materiais, há a necessidade de se fazer um controle de saída dos estoques, obtendo-se, assim, as respectivas quantidades destinadas à execução de serviços específicos, como contrapiso, elevação de alvenaria etc. 


\section{(c) Controle de saída dos materiais do estoque}

Além de proporcionar o estabelecimento de indicadores de perdas de materiais básicos por serviço pós-estocagem, tal controle tem também a finalidade de minorar os erros decorrentes da não contabilização de serviços ao longo da coleta de dados.

A pesquisa está centrada nos principais serviços para a construção de edificações. Dentre os serviços a ser executados, excluem-se do escopo, por exemplo, o chumbamento de caixilhos, enchimento de rasgos de instalações hidráulicas e sanitárias, entre outros que, geralmente, são executados simultaneamente aos serviços em estudo. O controle de saída de material do estoque elimina a necessidade da contabilização destes serviços, assim como do estabelecimento de valores de referência para os mesmos ${ }^{88}$.

Entretanto, a operacionalização deste controle não é tarefa fácil e depende de vários fatores. O primeiro deles, considerado o mais importante, está relacionado ao grau de comprometimento da empresa para com a obtenção destes índices. Este comprometimento é traduzido na disponibilidade de um funcionário para a realização do controle e na conscientização do engenheiro responsável pela obra quanto à importância do mesmo, ainda que acarrete

mudanças na forma de organização da produção das argamassas e concretos.

\footnotetext{
${ }^{88}$ Note que a não contabilização destes serviços, aliada à inexistência de controle de saída dos materiais do estoque, majorará o índice global de perda na obra. Como exemplo, caso a quantidade de cimento destinada ao serviço de enchimento dos rasgos da alvenaria para passagem de tubulações hidráulic as e sanitárias não seja mapeada e o serviço em questão não seja computado, esta quantidade será considerada como perda.
} 
O segundo ponto a destacar, reside na necessidade de se realizar um treinamento dos responsáveis pelo controle, além da realização de um préteste antes da coleta de dados propriamente dita. Através deste pré-teste, as possíveis dificuldades iniciais podem ser averiguadas e resolvidas com a participação de todos os envolvidos, desde a equipe de coleta e engenheiro responsável pela obra, até o almoxarife e o responsável pela produção de argamassas e concretos no canteiro de obras.

Várias são as formas de se realizar este controle, sendo que a definição daquela a ser adotada dependerá das situações particulares da obra quanto à disponibilidade de pessoal, localização dos estoques dos materiais em relação à central de produção, restrição ou não quanto ao acesso de pessoas ao estoque destes materiais etc.

Dentre as soluções possíveis, pode-se exemplificar:

- colocar os sacos vazios de aglomerantes em tambores ou cabides, identificados de acordo com a produção de argamassa e/ou concreto para os diversos serviços executados; ao final do dia, conta-se o número de sacos vazios destinados a cada serviço, registrando tal informação na planilha da série 4 correspondente ao material;

- elaborar um sistema de fichas coloridas e depositá-las numa urna à medida que se produz um traço; cada cor diz respeito a um serviço.

A adoção de uma destas soluções, ou de outra em comum acordo com os responsáveis pela obra, é viável desde que se produza argamassa de diferentes traços para diferentes serviços. Porém, muitas vezes há situações 
onde um mesmo traço é utilizado em vários serviços. Neste caso, deve-se adotar um sistema de controle integrado, envolvendo também as frentes de trabalho. Uma solução seria prover o responsável pelo transporte da argamassa ou concreto de fichas, as quais devem ser entregues ao responsável pela produção ou depositadas numa urna relativa ao serviço suprido à medida que o material é transportado pelo mesmo. Outras soluções poderão ser desenvolvidas de acordo com o sistema de produção presente no canteiro de obras. Porém, estas deverão ser estudadas e, principalmente, implantadas anteriormente à data VI.

Após a implantação deste controle, há a necessidade de se avaliar a precisão do mesmo através da identificação de falhas no mapeamento das quantidades destinadas aos serviços. Uma forma de se fazer esta avaliação consiste em confrontar, semanalmente ou na periodicidade mais conveniente para minimizar as incertezas, a variação da quantidade de material estocada neste perío do com a movimentação dos materiais apropriada através do procedimento de controle para o mesmo período. Para isso, deve-se utilizar a seguinte verificação de consistência:

$\operatorname{Est}\left(d_{i}\right)=\operatorname{Est}\left(d_{i-1}\right)+\operatorname{Re} c\left(d_{i-1}, d_{i}\right) \pm \operatorname{Transf}\left(d_{i-1}, d_{i}\right)-\sum_{j} \operatorname{Saida}_{E s t .}\left(d_{i-1}, d_{i}\right)[6.1$

onde,

$$
\begin{array}{ll}
E s t\left(d_{i}\right) & =\text { estoque de material na data do presente controle } \\
\operatorname{Est}\left(d_{i-1}\right) \quad \text { estoque de material na data onde se realizou o último } \\
\text { controle }
\end{array}
$$




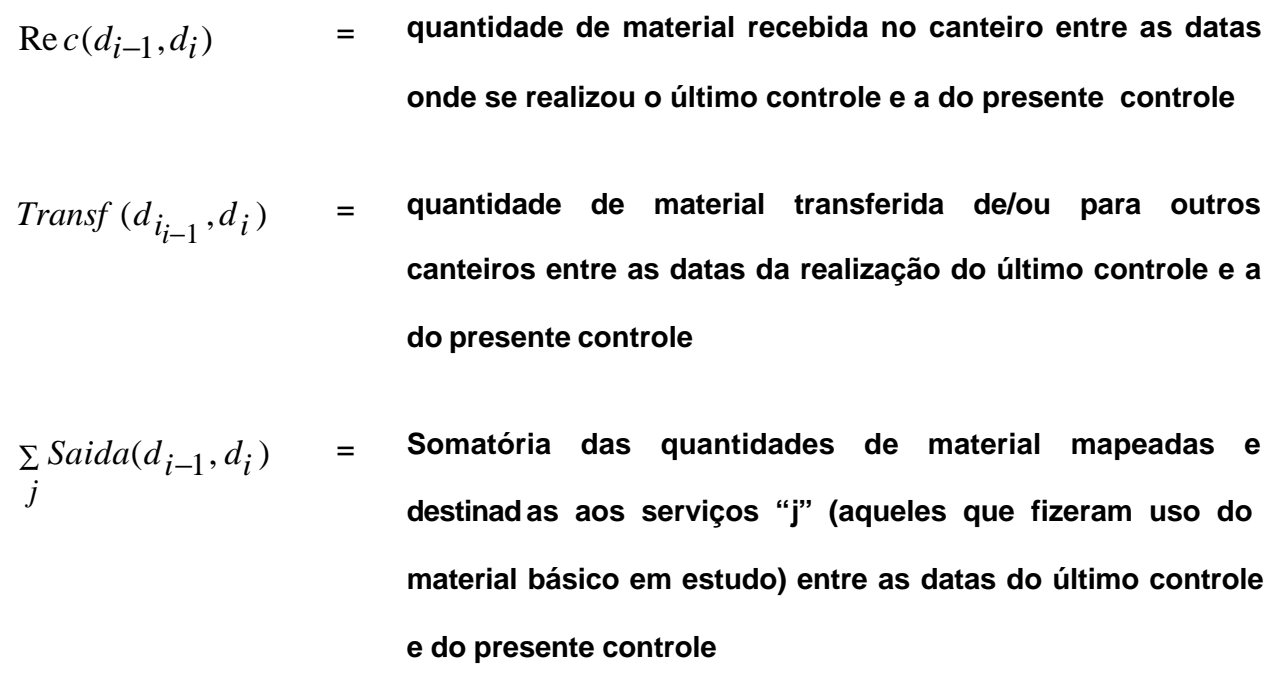

Esta equação deverá ser satisfeita; caso contrário, deve-se descobrir onde ocorreu a falha de apropriação no período correspondente.

Finalmente, em hipótese alguma esta consistência pode deixar de ser feita periodicamente, sob o risco de se perder todo o esforço de coleta dos indicadores globais por serviço pós-estocagem.

A título de exemplo, apresenta-se um modelo de procedimento da série 4 , onde estes aspectos abordados até aqui quanto à contabilização das quantidades recebidas e transferidas e à realização do mapeamento dos materiais básicos são verificados (Figura 6.10). 


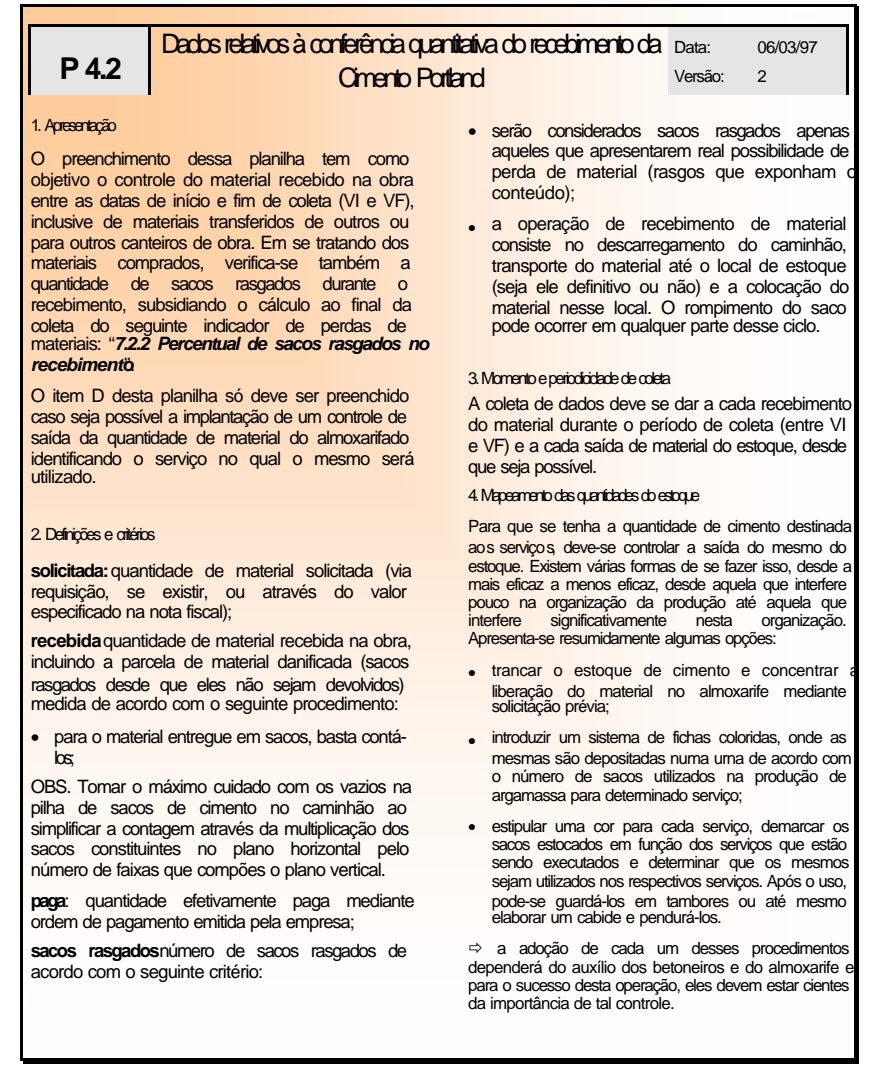

Figura 6.10 Modelo de procedimento das planilhas da série 4

\subsubsection{Consumo de referência}

Conforme ressaltado anteriormente, o cálculo do consumo de referência passa, necessariamente, pelo estabelecimento dos valores atribuídos a 3 variáveis: $Q S$ = quantidade de serviço, CM/QS = consumo de material por unidade de serviço, $C M B / M C=$ consumo de material básico por material composto.

Estas variáveis podem assumir diversos valores, dependendo da fonte de consulta, conforme discutido no capítulo 2 , onde se prioriza a flexibilidade da adoção de tais valores, sempre objetivando o estabelecimento das perdas e/ou consumos de materiais no âmbito do canteiro de obras. Para se 
atingir este objetivo, são descritos, na seqüência, os passos a serem seguidos para o estabelecimento destes valores.

\section{(a) cálculo da quantidade de serviço (QS)}

Antes de se entrar especificamente no cálculo da quantidade de serviço, tornase necessário estabelecer algumas diretrizes compatíveis com o propósito da pesquisa. A primeira delas reside na determinação da fonte de consulta adotada para al especificação, onde se prioriza o estabelecimento de índices de perda e/ou consumos de materiais decorrentes da ineficiência do uso dos mesmos no âmbito do canteiro de obras. Com este objetivo, elaborou-se um Fluxograma de decisão para a determinação dos valores de referência quanto à quantidade de serviço (Figura 6.11).

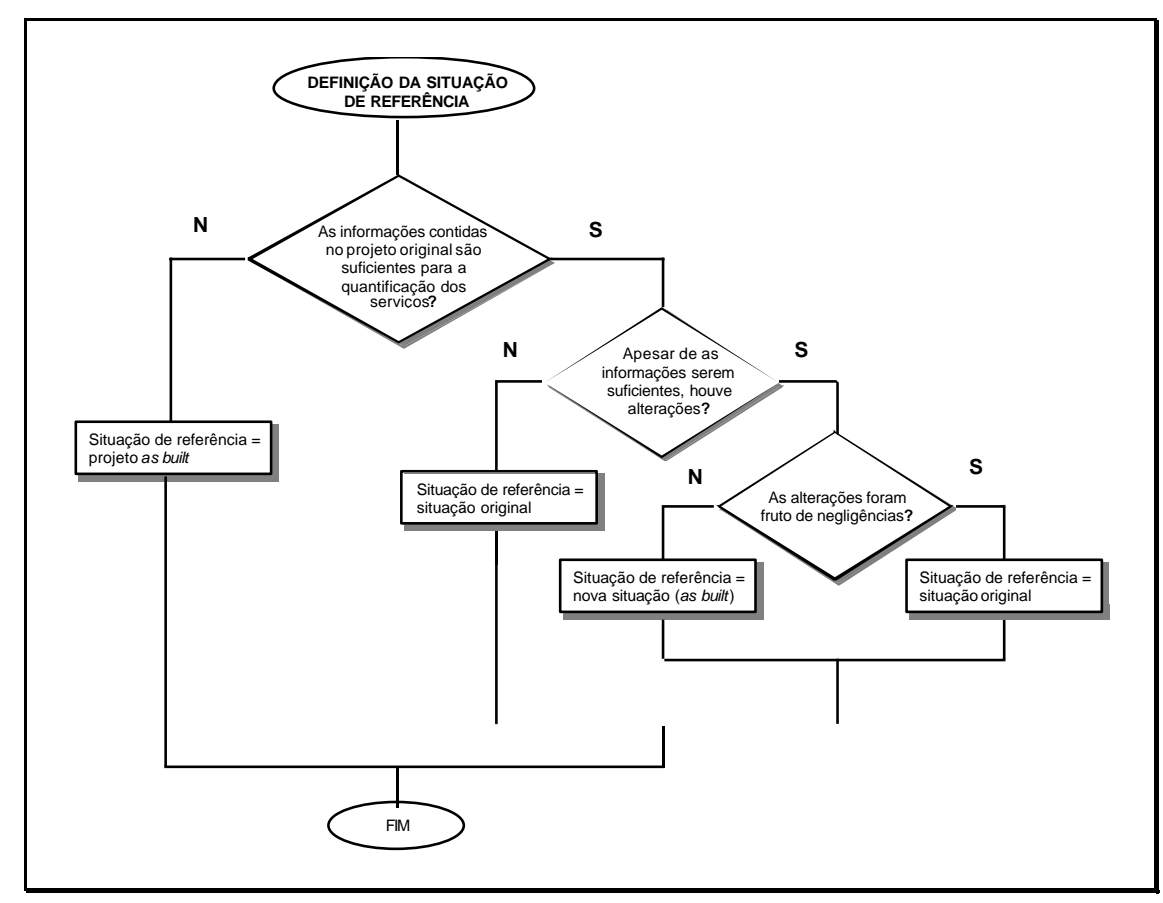

Figura 6.11 Fluxograma de decisão-Quantidade de serviço (QS) 
Um outro aspecto importante diz respeito à própria quantidade de serviço, que deverá corresponder à quantidade “líquida", ou seja, esta quantidade deverá corresponder àquela onde os materiais são efetivamente utilizados. Traduzindo esta regra em termos práticos, tomando-se o caso da alvenaria como exe mplo, a quantidade de serviço $\left(\mathrm{m}^{2}\right)$ será composta pela área efetiva de alvenaria, descontando-se todas as aberturas e áreas que não serão preenchidas com a argamassa de assentamento e o bloco, excluindo-se, inclusive, a camada de fixação (união entre a alvenaria e viga/laje).

Definidas estas diretrizes, o cálculo da quantidade de serviço executado entre as datas VI e VF é feito utilizando-se as planilhas da série 3, cujo preenchimento se dará em 3 momentos distintos: antes da data VI, na data VI e na data VF. Nas datas VI e VF, a equipe de coleta deverá verificar a percentagem de serviço executado até as mesmas e, para isso, toda a identificação dos elementos a ser medidos, inclusive as dimensões necessárias para o cálculo da quantidade de serviço para cada elemento, deverá estar pronta antes da data VI.

Portanto, uma grande parcela do trabalho para a quantificação dos serviços concentra-se na etapa antes da data VI. Nesta etapa, de posse dos projetos específicos ou genéricos dos serviços objetos de estudo, a equipe de coleta deverá seguir alguns passos para a realização da quantificação. Inicialmente, deve-se fazer um croqui, representativo do pavimento, contendo os elementos (ou partes) a ser medidos. Como exemplo, tomando-se o caso da alvenaria, a mesma deverá ser dividida em paredes dentro de um pavimento, que deverão ser identificadas como Parede 1, Parede 2 e assim sucessivamente. 
Esta regra deve ser aplicada aos outros serviços e, após a identificação de cada elemento (Face 1, Parede 1, Viga 2, Trecho 34 etc), procede-se a anotação das medidas correspondentes às dimensões dos elementos. No caso do emboço, por exemplo, serão necessários o comprimento e a altura de cada elemento, cuja composição resultará na quantidade de serviço deste elemento em metros quadrados. Tomando-se como exemplo o caso de uma viga, devese anotar a sua altura, largura e comprimento; a composição destas medidas resultará na quantidade de serviço a ser executada em metros cúbicos.

As unidades de medida da quantidade de serviço são diversificadas, expressando áreas, volumes e, até mesmo, comprimentos. Na Tabela 6.3 apresentam-se, para cada serviço, as unidades de medida, que correspondem, na maioria dos casos, às unidades comumente utilizadas em orçamentação, podendo haver algumas variações, como é o caso da alvenaria.

Somente após a elaboração dos croquis, e do preenchimento das colunas relativas às dimensões dos elementos a ser medidos no canteiro de obras, é que se procede a verificação das percentagens executadas de cada elemento na data VI. Nesta data, a equipe de coleta deverá percorrer toda a obra e, de acordo com o croqui, anotar para cada elemento a percentagem executada até esta data.

A coluna referente à data VF deverá ser preenchida somente nesta data, quando se anotará a percentagem executada de cada elemento discriminado de acordo com o croqui. A diferença entre as percentagens da quantidade de serviço executado entre as datas VI e VF, multiplicada pela quantidade total de 
serviço do elemento em questão, resultará na quantidade de serviço

efetivamente executada entre estas datas para o elemento em questão.

\section{Tabela 6.3 Unidades de medida dos serviços}

\begin{tabular}{|c|c|}
\hline Descrição do serviço & $\begin{array}{l}\text { Unidade } \\
\text { medida }\end{array}$ \\
\hline Armaduras - corte, montagem e colocação & $\mathrm{kg}$ \\
\hline Estrutura de concreto - concreto produzido em obra e concreto usinado & $\mathrm{m}^{3}$ \\
\hline Alvenaria - blocos/tijolos - $\mathrm{m}^{2}$ & $\mathrm{~m}^{2}$ \\
\hline Alvenaria - blocos/tijolos - un 89 & un \\
\hline $\begin{array}{l}\text { Alvenaria - juntas - argamassa produzida em obra ou parcial ou totalmente } \\
\text { produzida fora do canteiro }\end{array}$ & $\mathrm{m}$ \\
\hline $\begin{array}{l}\text { Contrapiso - argamassa produzida em obra ou parcial ou totalmente produzida fora } \\
\text { do canteiro }\end{array}$ & $\mathrm{m}^{2}$ \\
\hline $\begin{array}{l}\text { Revestimento - (chapisco, emboço, reboco) - argamassa produzida em obra e } \\
\text { parcial ou totalmente produzida fora do canteiro }\end{array}$ & $m^{2}$ \\
\hline $\begin{array}{l}\text { Revestimento externo - chapisco - emboço ou massa única - argamassa parcial ou } \\
\text { totalmente produzida fora do canteiro }\end{array}$ & $\mathrm{m}^{2}$ \\
\hline Revestimento interno - gesso & $m^{2}$ \\
\hline Revestimento cerâmico - paredes internas e externas; pisos interno e externo & $\mathrm{m}^{2}$ \\
\hline Revestimento têxtil & $\mathrm{m}^{2}$ \\
\hline Instalação elétrica - eletroduto (laje e parede) - corte, montagem e colocação & $\mathrm{m}$ \\
\hline Instalações elétrica - enfiação & $\mathrm{m}$ \\
\hline Instalação de água fria, esgoto e água pluvial - corte, montagem e colocação & $\mathrm{m}$ \\
\hline Cobertura & $\mathrm{m}^{2}$ \\
\hline Pintura interna e externa & $m^{2}$ \\
\hline
\end{tabular}

${ }^{89}$ Observe que, no caso dos blocos, há a possibilidade da adoção de duas unidades de medida: un e $\mathrm{m}^{2}$.

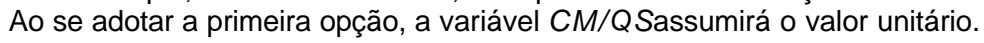


Assim, para o caso de uma viga, cujo volume previsto é de $2 \mathrm{~m}^{3}$, e nas datas VI e VF apresentava-se respectivamente $30 \%$ e $100 \%$ concretada, a quantidade de serviço efetivamente executado entre estas datas será 70\% (100\% - 30\%) de $2 \mathrm{~m}^{3}$, resultando $1,4 \mathrm{~m}^{3}$.

Os passos descritos até o momento estão contemplados no verso de cada planilha da série 3, na forma de procedimentos específicos, conforme 0 exemplo apresentado na Figura 6.12, para o caso de eletrodutos.

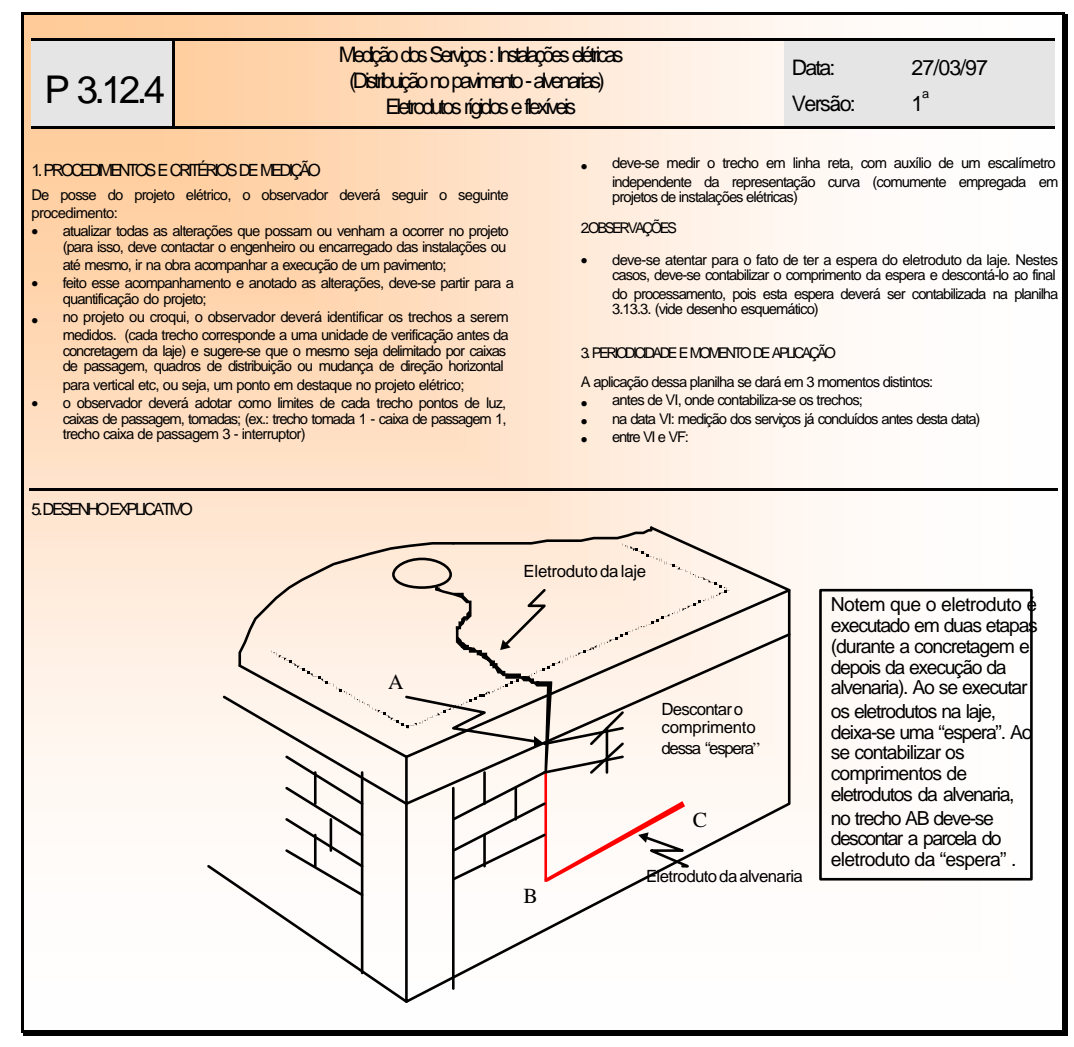

Figura 6.12 Exemplo de procedimentos para quantificação dos serviços (eletrodutos no serviço de instalações elétricas)

Dentre os serviços-materiais contemplados, os de alvenaria-blocos/tijolos, alvenaria-argamassa de assentamento, instalação elétrica-eletrodutos e 
instalação elétrica-condutores merecem destaque e, através do desenvolvimento do raciocínio para os mesmos, imagina-se conseguir explicitar as diretrizes para os outros.

\section{(a1) Medição do serviço de alvenaria - blocos/tijolos}

A medição da quantidade de blocos a ser utilizada no serviço de alvenaria é feita, geralmente, através da medição de área que, multiplicada pelo consumo de bloco por unidade de área, resulta no número de blocos. Este procedimento é perfeitamente aplicável em se tratando do uso de um único tipo de blocos num pano de alvenaria; porém, em se tratando do uso de mais de um tipo de bloco (inclui-se blocos de mesmo material, porém de dimensões diferentes), a medição da área torna-se mais complexa, devido à necessidade de dividir o pano de alvenaria em áreas correspondentes a cada tipo de bloco utilizado.

Como alternativa, não somente para o caso citado e sim como postura geral ${ }^{90}$, propõe-se a quantificação deste serviço em termos de unidades de blocos ao invés da área. Para isso, o observador deverá contar o número de blocos através de dois caminhos:

(a) tendo-se um projeto de alvenaria específico, o observador poderá utilizar este como fonte de consulta, devendo verificar em obra ou com o engenheiro responsável, possíveis alterações;

\footnotetext{
90 A contagem em unidades de blocos pode minimizar erros gerados por uma definição imprecisa de blocos por unidade de área, necessária no caso de se medir o serviço em $\mathrm{m}^{2}$. Por exemplo, uma eventual variação de espessura de junta de assentamento de $10 \mathrm{~mm}$ para $15 \mathrm{~mm}$, para o caso dos blocos de $25 \mathrm{~cm} \times 25 \mathrm{~cm}$ de face, resulta numa variação, de tal indicador, de 14,8 un/m² para 14,2 $\mathrm{un} / \mathrm{m}^{2}$, ou seja, aproximadamente $4 \%$.
} 
(b) tendo-se apenas o projeto de arquitetura, o observador deverá contar o número de blocos de cada parede num pavimento já executado e ainda não revestido e adotar esta contagem para os demais pavimentos.

Evidentemente, caberá à equipe de coleta avaliar as imprecisões decorrentes da adoção de tais caminhos e adotar aquele que gerar menores probabilidades de erro.

\section{(a2) Medição do serviço de alvenaria-argamassa de assentamento}

Da mesma forma que a medição do serviço de alvenaria para o caso dos blocos/tijolos, o consumo de argamassa de assentamento de alvenaria pode ser obtido através da medição da área de alvenaria. Porém, este procedimento tradicional não contempla, por exemplo, se as juntas verticais são argamassadas ou não, passando-se também pela mesma situação descrita em (a1) quanto à necessidade de se dividir esta área em função do tipo de bloco/tijolo utilizado ${ }^{91}$. Além do mais, o consumo de argamassa por unidade de área será determinado também pela espessura das juntas. Sendo assim, propõe-se, como forma de medição para o consumo deste material na alvenaria, o cômputo dos metros de juntas argamassadas ao invés da área de alvenaria.

Para isso, são apresentados dois procedimentos:

(a) tendo-se projeto específico (elevação da alvenaria), faz-se a medição dos metros lineares de juntas argamassadas a partir deste;

${ }_{91}$ Da mesma forma que as dimensões dos blocos determinam o seu consumo por unidade de serviço, determinam também o consumo de argamassa por unidade de serviço quando este é medido em área. 
(b) não se tendo o projeto específico de alvenaria, deve-se fazer a medição, in loco, numa alvenaria já executada em um dos pavimentos, e tomar o resultado obtido para a mesma alvenaria dos demais pavimentos.

Para aqueles casos onde se realizou a medição deste serviço em área de alvenaria, pode-se utilizar as expressões apresentadas na Figura 6.13 para a transformação desta área em metros de juntas argamassadas.

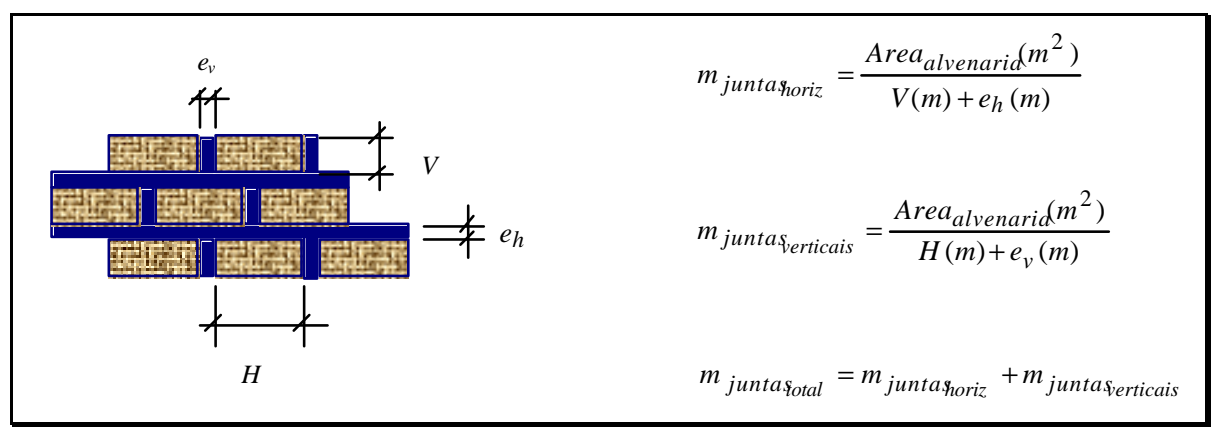

\section{Figura 6.13 Transformação da quantidade de serviço de alvenaria - argamassa: área para metros de juntas argamassadas}

Evidentemente, caberá à equipe de coleta avaliar as possíveis imprecisões quanto à adoção de cada procedimento.

\section{(a3) Medição do serviço de Instalações elétricas - eletrodutos e condutores elétricos}

A medição do consumo destes materiais possui uma particularidade em relação à medição dos outros serviços. Os traçados apresentados no projeto de instalações elétricas nem sempre correspondem àqueles efetivamente realizados durante a execução pois, no projeto, esta representação dá-se sob a forma curvilínea para o caso dos eletrodutos flexíveis embutidos nas lajes. 
Como solução, adotou-se o procedimento de se medir cada trecho em linha reta e, em seguida, através de medições específicas realizadas in loco, estabelecer-se um indicador parcial de perda, para este material, que corresponde à diferença entre as medidas efetuadas no projeto e as de campo.

Além desta particularidade, no que diz respeito à medição dos metros de condutores elétricos, uma outra questão importante deve ser ressaltada. Tratase da necessidade de se conduzir o estudo das perdas/consumos dos condutores elétricos em toda a sua totalidade, ou seja, o VI para este serviço deverá ser feito antes do início deste serviço na obra e, da mesma forma, o VF deverá ser feito após o término do mesmo. Tal necessidade está relacionada ao fato de não se poder estabelecer a quantidade de serviço após o mesmo já ter sido em parte realizado, pois os condutores, sendo embutidos, são de difícil visualização e, conseqüentemente, de difícil contabilização.

\section{(b) consumo de material por quantidade de serviço (CM/QS)}

Esta variável diz respeito à quantidade de material teoricamente gasto por unidade de medida dos serviços (Ex.: blocos $/ \mathrm{m}^{2}$ de alvenaria, $\mathrm{m}^{3}$ de $\operatorname{argamassa} / \mathrm{m}^{2}$ de contrapiso etc).

Note que a necessidade de se definir esta variável nasce devido à diferença entre a unidade de compra do material e a unidade de medida dos serviços. Assim, quando as mesmas fore m iguais, esta variável assume o valor unitário, como é o caso, por exemplo, do concreto usinado no serviço de estrutura de concreto $\left(1 \mathrm{~m}^{3} / \mathrm{m}^{3}\right)$. Na Tabela 6.4 são apresentadas as unidades de 
mensuração de CM/QS para os serviços nos quais os valores assumidos para esta variável sejam diferentes da unidade.

Da mesma forma que para a determinação da quantidade de serviço, o observador deverá seguir uma rotina de decisão para estabelecer o valor de CM/QS (Figura 6.14). Aconselha-se que a determinação de tais valores seja realizada após a definição dos materiais e serviços a ser estudados na obra (Planilhas da série 1), com a participação do engenheiro responsável e demais envolvidos na pesquisa pela empresa.

Tabela 6.4 Relação de serviços e seus respectivos CM/QS

\begin{tabular}{|c|c|c|c|c|c|}
\hline \multicolumn{2}{|c|}{ Serviço } & \multirow{2}{*}{$\begin{array}{c}\begin{array}{c}\text { Unidade de } \\
\text { serviço }\end{array} \\
\mathrm{m}^{2}\end{array}$} & \multirow{2}{*}{$\frac{\text { Material }}{\text { Blocos/tijolos }}$} & \multirow{2}{*}{$\begin{array}{c}\text { Unidade de compra } \\
\text { ou uso } \\
\text { un }\end{array}$} & \multirow{2}{*}{$\frac{\mathrm{CM} / \mathrm{QS}}{\mathrm{un} / \mathrm{m}^{2}}$} \\
\hline Alvenaria & Blocos/tijolos & & & & \\
\hline & juntas & m juntas & argamassa & $m^{392}$ & $\mathrm{~m}^{3} / \mathrm{m}$ \\
\hline \multicolumn{2}{|c|}{ Rev. interno - chapisco } & $\mathrm{m}^{2}$ & argamassa & $\mathrm{m}^{3}$ & $m^{3} / m^{293}$ \\
\hline \multicolumn{2}{|c|}{ Rev. interno emboço/m.única } & $\mathrm{m}^{2}$ & argamassa & $\mathrm{m}^{3}$ & $\mathrm{~m}^{3} / \mathrm{m}^{2}$ \\
\hline \multicolumn{2}{|c|}{ Rev. interno - reboco } & $\mathrm{m}^{2}$ & argamassa & $\mathrm{m}^{3}$ & $\mathrm{~m}^{3} / \mathrm{m}^{2}$ \\
\hline \multicolumn{2}{|c|}{ Rev. externo - chapisco } & $\mathrm{m}^{2}$ & argamassa & $\mathrm{m}^{3}$ & $\mathrm{~m}^{3} / \mathrm{m}^{2}$ \\
\hline \multicolumn{2}{|c|}{ Rev. externo emboço/m.única } & $\mathrm{m}^{2}$ & argamassa & $\mathrm{m}^{3}$ & $\mathrm{~m}^{3} / \mathrm{m}^{2}$ \\
\hline \multicolumn{2}{|l|}{ Contrapiso } & $\mathrm{m}^{2}$ & argamassa & $\mathrm{m}^{3}$ & $\mathrm{~m}^{3} / \mathrm{m}^{2}$ \\
\hline \multicolumn{2}{|c|}{ Rev. cerâmico - parede } & $\mathrm{m}^{2}$ & placas cerâmicas & un & $\mathrm{un} / \mathrm{m}^{2}$ \\
\hline \multicolumn{2}{|c|}{ Rev. cerâmico - piso } & $\mathrm{m}^{2}$ & placas cerâmicas & un & $\mathrm{un} / \mathrm{m}^{2}$ \\
\hline \multicolumn{2}{|c|}{ Rev. interno - pasta gesso } & $\mathrm{m}^{2}$ & Pasta de gesso & $\mathrm{m}^{3}$ & $\mathrm{~m}^{3} / \mathrm{m}^{2}$ \\
\hline \multicolumn{2}{|l|}{ Cobertura } & $\mathrm{m}^{2}$ & telhas & un & $\mathrm{un} / \mathrm{m}^{2}$ \\
\hline \multicolumn{2}{|c|}{ Pintura interna } & $\mathrm{m}^{2}$ & tinta & litros & litros $/ m^{2}$ \\
\hline \multicolumn{2}{|c|}{ Pintura externa } & $\mathrm{m}^{2}$ & tinta & litros & litros $/ \mathrm{m}^{2}$ \\
\hline
\end{tabular}

\footnotetext{
92 Note que em se tratando de argamassa industrializada, a unidade de compra pode ser o kg.

${ }^{93}$ Note que, para o caso dos revestimentos em argamassa e em gesso, o CM/QSreferese à espessura dos mesmos.
} 


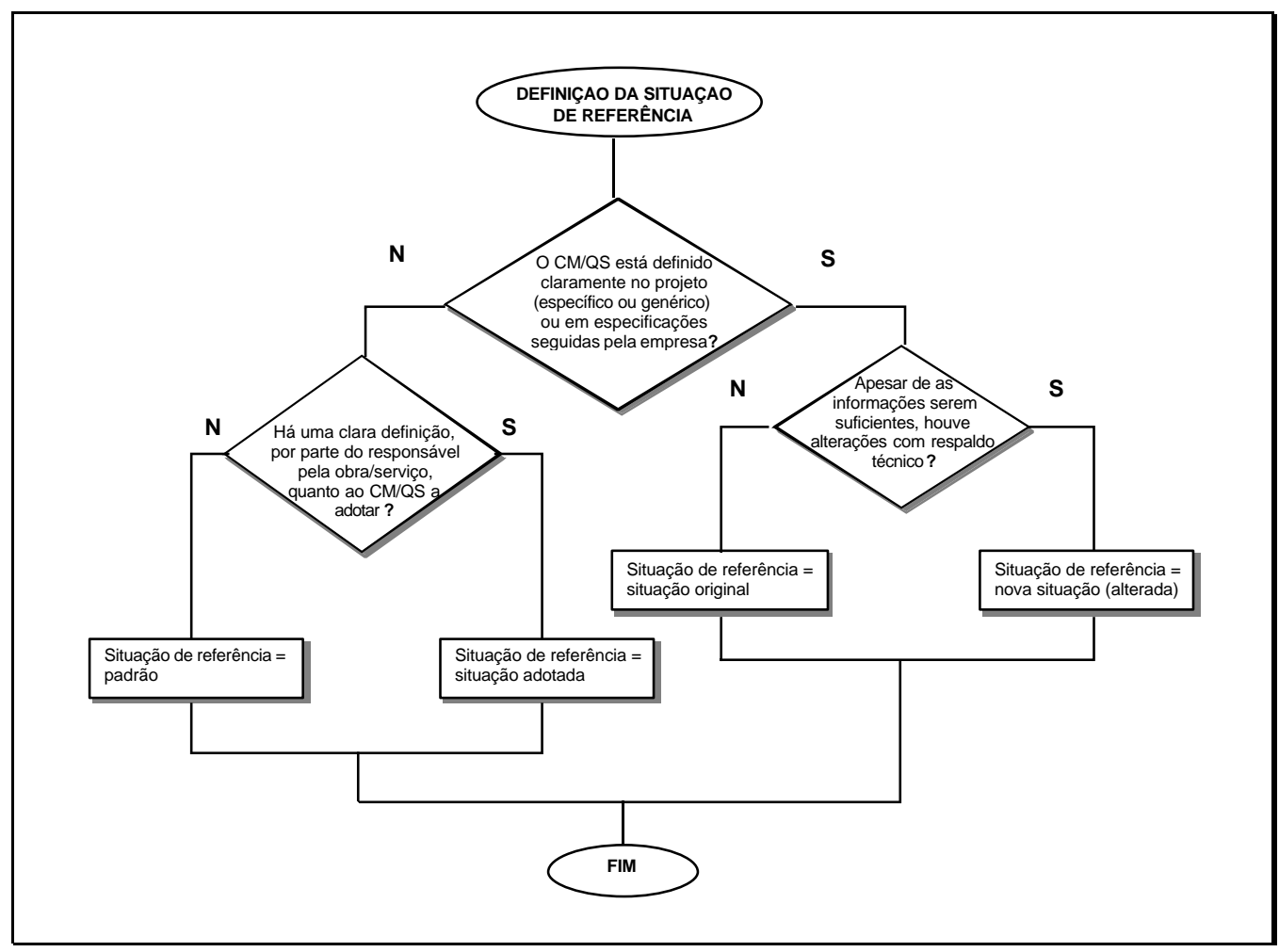

Figura 6.14 Fluxograma de decisão-Consumo de material por unidade de serviço (CM/QS)

Caso o CM/QS não tenha sido especificado no projeto ou pelo responsável técnico da obra/serviço, devem-se utilizar, conforme indicado na Figura 6.14, os valores padrão, que podem ser calculados direta ou indiretamente, a partir das definições mostradas nas Tabelas 6.4(a) a 6.4(e). 
Tabela 6.4 (a) Valores de referência padrão para CM/QS - espessura de revestimentos em argamassa

\begin{tabular}{l|c|c}
\hline Serviço & Valores $(\mathbf{m})$ & Unidade \\
\hline Revestimento interno - chapisco & 0,005 & $\mathrm{~m}^{3} / \mathrm{m}^{2}$ \\
\hline Revestimento interno- emboço/massa única & 0,010 & $\mathrm{~m}^{3} / \mathrm{m}^{2}$ \\
\hline Revestimento interno - reboco & 0,005 & $\mathrm{~m}^{3} / \mathrm{m}^{2}$ \\
\hline Revestimento externo - chapisco & 0,005 & $\mathrm{~m}^{3} / \mathrm{m}^{2}$ \\
\hline Revestimento externo emboço/massa única & 0,025 & $\mathrm{~m}^{3} / \mathrm{m}^{2}$ \\
\hline Contrapiso & 0,020 & $\mathrm{~m}^{3} / \mathrm{m}^{2}$ \\
\hline
\end{tabular}

Tabela 6.4 (b) Valores de referência padrão para CM/QS -tintas

\begin{tabular}{l|c|c}
\hline \multirow{2}{*}{ ipo de tinta } & \multicolumn{2}{|l}{ ipo de substrato } \\
\cline { 2 - 3 } & Argamassa & Massa corrida \\
\hline Látex PVA & $0,103 \mathrm{l} / \mathrm{m}^{2}$ & $0,080 \mathrm{l} / \mathrm{m}^{2}$ \\
\hline $300 \times 300$ Látex acrílico & $0,080 \mathrm{l} / \mathrm{m}^{2}$ & $0,066 \mathrm{l} / \mathrm{m}^{2}$ \\
\hline
\end{tabular}

Tabela 6.4 (c) Valores de referência para a espessura de juntas - blocos e tijolos

\begin{tabular}{l|c|c}
\hline Tipo de junta & $\begin{array}{c}\text { Juntas totalmente } \\
\text { preenchidas }\end{array}$ & $\begin{array}{c}\text { Juntas verticais } \\
\text { parcialmente } \\
\text { preenchidas }\end{array}$ \\
\hline Espessura de juntas horizontais & $10 \mathrm{~mm}$ & $10 \mathrm{~mm}$ \\
\hline Espessura de juntas verticais & $10 \mathrm{~mm}$ & $5 \mathrm{~mm}$ \\
\hline
\end{tabular}


Tabela 6.4 (d) Valores de referência para a espessura de juntas - placas cerâmicas parede

\begin{tabular}{c|c}
\hline Dimensões (mm x mm) & Espessura de junta (mm) \\
\hline $150 \times 150$ & 1,5 \\
\hline $150 \times 200$ ou $200 \times 200$ & 2,0 \\
\hline $200 \times 250$ & 2,5 \\
\hline
\end{tabular}

Tabela 6.4 (e) Valores de referência para a espessura de juntas - placas cerâmicas piso

\begin{tabular}{c|c|c}
\hline \multirow{2}{*}{ Dimensões (mm x mm) } & \multicolumn{2}{|c}{ Espessura de junta (mm) } \\
\cline { 2 - 3 } & Rev. Interno & Rev. externo \\
\hline $100 \times 100$ & 3 & 6 \\
\hline $100 \times 200$ & 4 & 6 \\
\hline $200 \times 200$ & 4 & 8 \\
\hline $200 \times 300$ & 5 & 10 \\
\hline $300 \times 300$ & 6 & 10 \\
\hline
\end{tabular}

Para o revestimento em gesso, no caso de não se ter uma definição clara da especificação da espessura, seja no projeto ou pelo responsável pela obra, adota-se o valor de 0,005 m. Como o gesso é comprado em $\mathrm{kg}$ e aplicado em volume, o CM/QS para este material será a multiplicação da espessura do 
revestimento pelo consumo de $889 \mathrm{~kg} / \mathrm{m}^{3}$ 94, resultando em 4,45 kg/m². Procedimento análogo é adotado no caso das argamassas industrializadas.

Dentre os serviços e materiais onde há a necessidade de se determinar o CM/QS, merecem destaque: alvenaria-blocos/tijolos e alvenaria-argamassa de assentamento, os quais são detalhados na seqüência.

\section{(b1) Alvenaria - blocos/tijolos}

De acordo com a Tabela 6.3, a quantificação do serviço de alvenaria pode ser feita de duas formas: medindo-se a área ou contando-se os blocos na parede. Adotando-se a segunda opção, descarta-se automaticamente a necessidade de se calcular o CM/QS, que assumirá o valor unitário (1 un/un). Porém, em se tratando da primeira opção este cálculo é necessário, utilizando-se a expressão apresentada na Figura 6.15.

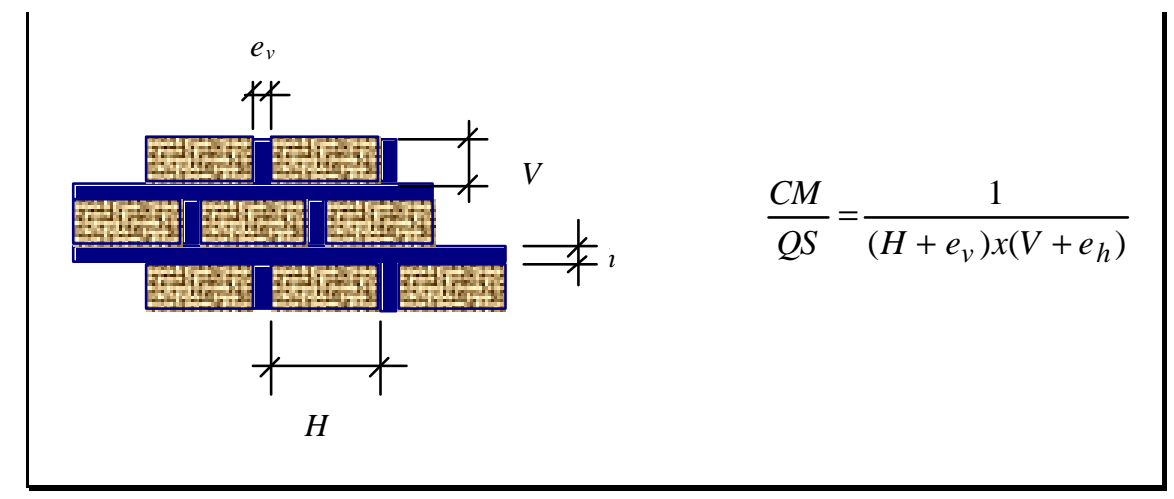

Figura 6.15 Cálculo do CM/QS - blocos e tijolos

\footnotetext{
${ }^{94}$ Este número advém da consideração de uma densidade da pasta de $1600 \mathrm{~kg} / \mathrm{m}^{3}$ e de uma relação água/gesso de 0,8 em massa.
} 
A definição dos valores de $e_{v}$ e $e_{h}$ deve ser feita seguindo-se as idéias apresentadas na Figura 6.14. No caso de se necessitar utilizar o valor padrão, este é obtido a partir da Tabela 6.4(c).

\section{(b2) Alvenaria - argamassa de assentamento}

O consumo de argamassa de assentamento por unidade de serviço ${ }^{95}$ está condicionado, entre outros aspectos, ao tipo de bloco/tijolo e ao tipo de equipamento utilizado na execução (bisnaga/desempenadeira estreita/meiacana, colher de pedreiro). Em função do equipamento e o tipo de bloco/tijolo, a argamassa pode ser espalhada por toda a largura do bloco/tijolo ou ser apenas espalhada nas laterais sob a forma de filetes, conforme ilustra a Figura 6.16.

Aplica-se o caso (a) para blocos/tijolos maciços ou perfurados/vazados sem furos passantes, quando se utiliza colher de pedreiro no assentamento. $O$ caso (b) aplica-se para os blocos/tijolos vazados/perfurados com furos passantes, ou maciços quando se utiliza bisnaga/desempenadeira estreita/meia-cana no assentamento. Sendo assim, para essas duas situações, tem-se os CM/QS para as juntas horizontais e verticais conforme mostrado nas Figuras 6.16(a), 6.16(b) e 6.16(c). Note que, apesar de se estar utilizando o decímetro como unidade de medida, resultando, em conseqüência, o volume em litros, deve-se realizar a transformação para $\mathrm{m}^{3}$ ao se aplicar a fórmula para o cálculo dos índices de perdas ou consumos.

\footnotetext{
${ }^{95}$ a unidade de medida do serviço deve ser o metro.
} 


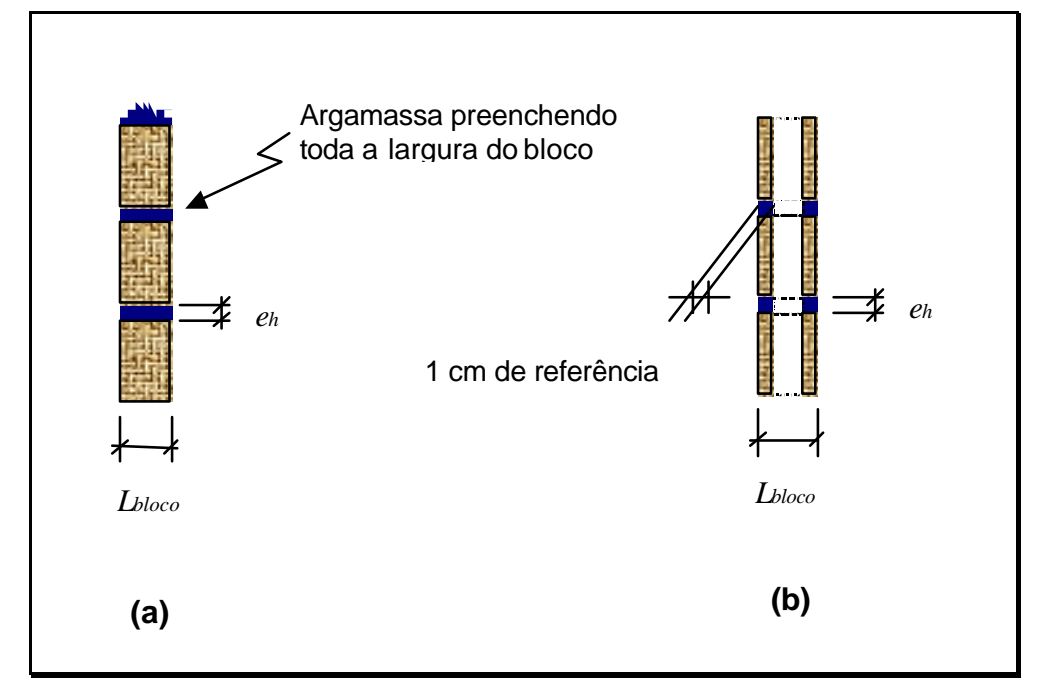

Figura 6.16 Largura das juntas de argamassa: (a) argamassa preenchendo toda a largura do bloco; (b) argamassa aplicada na forma de dois filetes laterais

Aplica-se o caso (a) para blocos/tijolos maciços ou perfurados/vazados sem furos passantes quando se utiliza colher de pedreiro no assentamento. $O$ caso (b) aplica-se para os blocos/tijolos vazados/perfurados com furos passantes ou maciços quando se utiliza bisnaga/desempenadeira estreita/meia-cana no assentamento. Sendo assim, para essas duas situações, tem-se os seguintes CM/QS para as juntas horizontais e verticais conforme mostrado nas Figuras 6.16(a), 6.16(b) e 6.16(c). Note que, apesar de se estar utilizando o decímetro como unidade de medida, resultando em conseqüência o volume em litros, deve-se realizar a transformação para $\mathrm{m}^{3}$ ao se aplicar a fórmula para o cálculo dos índices de perdas ou consumos. 


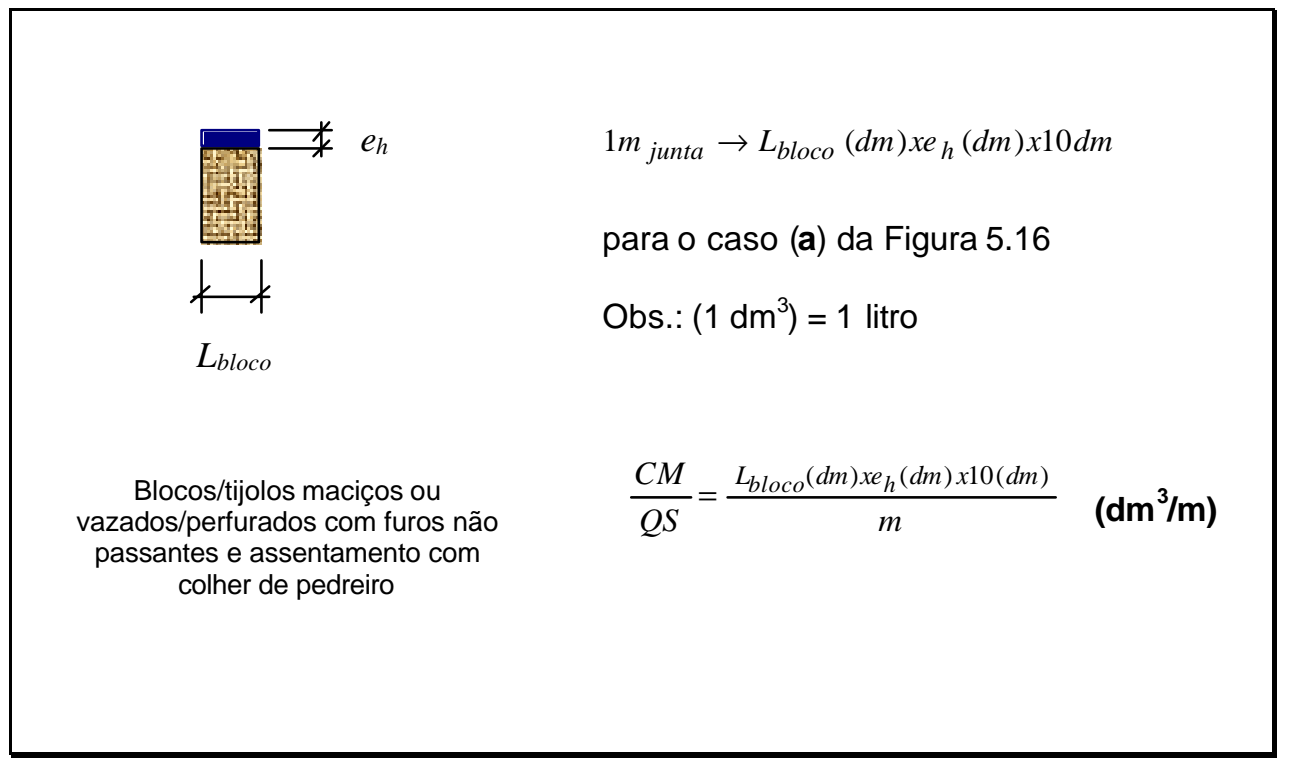

Figura 6.16 (a) CM/QS para juntas horizontais - largura do bloco

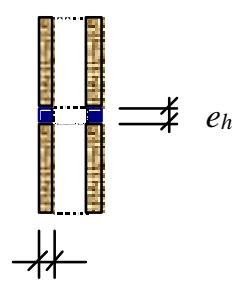

$$
\begin{aligned}
& 1 m_{\text {junta }}=2(\text { juntas }) x 0,1(\mathrm{dm}) x e_{h}(\mathrm{dm}) \times 10 \mathrm{dm} \\
& \text { para o caso (b) da Figura } 5.16 \\
& \text { Obs.: } 1 \mathrm{dm}^{3}=1 \text { litro } \\
& \frac{C M}{Q S}=\frac{2(\text { juntas }) x 0,1(\mathrm{dm}) x e_{h}(\mathrm{dm}) \times 10(\mathrm{dm})}{m}\left(\mathbf{d m}^{3} / \mathbf{m}\right)
\end{aligned}
$$$$
1 \mathrm{~cm}=0,1 \mathrm{dm} \text { (referência) }
$$

Blocos/tijolos

vazados/perfurados com

furos passantes ou

blocos/tijolos maciços ou

vazados (perfurados com

furos não passantes) e

assentamento com

bisnaga/meia-cana

Figura 6.16 (b) CM/QS para juntas horizontais- filetes 


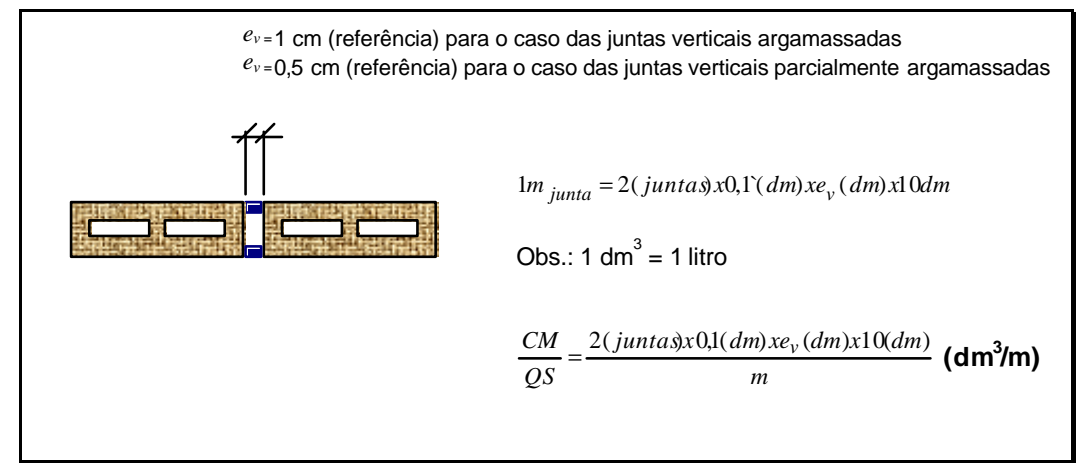

Figura 6.16 (c) CM/QS para juntas verticais

\section{(c) Consumo de material básico por material composto ( $C M B / M C)$}

Relembre, inicialmente, conforme já explicitado no capítulo 1, que a mistura de materiais básicos gera um material composto. Por exemplo, ao se misturar cal, cimento, areia (materiais básicos) e água, pode-se gerar uma argamassa (material composto) para revestimento de parede.

Note, portanto, que a necessidade desta variável está associada apenas ao cálculo de consumo e perdas dos materiais básicos, assumindo, assim, para os outros materiais, o valor unitário.

Para o cálculo destes valores, a equipe de coleta deve partir do traço de referência, obido conforme o procedimento ilustrado pelo fluxograma de decisão anteriormente apresentado na Figura 6.14. Definido o traço, utilizam-se as fórmulas de consumo descritas na seqüência, tomando-se o cuidado de utilizá-las nas unidades corretas.

O traço pode ser expresso em diversas unidades (massa, volume). Para efeito de cálc ulos de consumo, o traço será apresentado da seguinte forma: 
concreto:

$$
1: a^{96}: b, a / c
$$

argamassa sem o uso de argamassa intermediária:

1 : cal : a : sai : ent

argamassa definitiva com uso de argamassa intermediária

$$
\left(\text { cal : a) }+\left(1: a_{i}\right)\right.
$$

\begin{tabular}{|c|c|c|c|}
\hline 1 & $=$ & cimento & (kg) \\
\hline cal & $=$ & cal & (kg) \\
\hline a & $=$ & areia & (I, úmido) \\
\hline b & $=$ & brita & (I) \\
\hline sai & $=$ & saibro & (I) \\
\hline$a_{i}$ & $=$ & Arg. intermediária & (I, úmido) \\
\hline Ent & $=$ & entulho & (I, seco e sem estar moído) \\
\hline$a / c$ & $=$ & fator água/cimento & $(\mathrm{l} / \mathrm{kg})$ \\
\hline
\end{tabular}

onde,

Se a obra em estudo tiver indicações da dosagem (traço) em outros formatos, as relações apresentadas na Tabela 6.5 poderão ser usadas para transformar as quantidades expressas em outras unidades nas unidades acima solicitadas.

\footnotetext{
${ }^{96}$ Observe que, havendo mais de um tipo de areia (fina, média, grossa), os volumes de cada tipo deverão ser somados para se obter um único volume "a". O mesmo aplica-se às britas.
} 
Tabela 6.5 Relações para a transformação do traço

\begin{tabular}{|c|c|c|}
\hline Material & De $\Rightarrow$ para & Fórmula \\
\hline Cimento & Volume $\Rightarrow$ massa & $M_{\text {cim }}=$ Vol. ap $_{\text {cim. }} x M U_{\text {cim }}$. \\
\hline Cal & Volume $\Rightarrow$ massa & 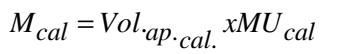 \\
\hline \multirow[t]{3}{*}{ Areia } & Volume seco $\Rightarrow$ volume úmido & $V_{\text {umido }}=V_{\sec o^{x}} x(1+i)$ \\
\hline & Massa seca $\Rightarrow$ volume úmido & $V_{\text {umido }_{a}}=\frac{M_{a}}{M U_{a}} x(1+i)$ \\
\hline & Massa úmida $\Rightarrow$ volume úmido & $V_{a p \cdot \sec o_{a}}=\frac{\frac{M_{\text {umida }}}{(1+h)}}{M U_{a}}$ \\
\hline Saibro & massa $\Rightarrow$ Volume & $V_{\text {ap. } \text { saibro }}=\frac{M_{\text {saibro }}}{M U_{\text {saibro }}}$ \\
\hline Material moído & $\mathrm{V}_{\text {moído }} \Rightarrow \mathrm{V}_{\text {antes de moer }}$ & $V_{\text {antes }_{\text {moer }}}=\frac{\text { Vmoido }}{(1-k)}$ \\
\hline
\end{tabular}

Onde,

$\begin{array}{ll}M_{\text {cim }} & =\text { massa de cimento } \\ M U_{\text {cim }} & =\text { massa unitária do cimento (ver item c3) } \\ V o l_{\text {ap } \cdot \text { cim }} & =\text { volume aparente de cimento } \\ M_{\text {cal }} & =\text { massa de cal } \\ M U_{\text {cal }} & =\text { massa unitária da cal (ver item } c 3 \text { ) } \\ V o l_{\text {ap } \cdot \text { cal }} & \text { Volume aparente da cal } \\ M_{a} & =\text { massa de areia }\end{array}$




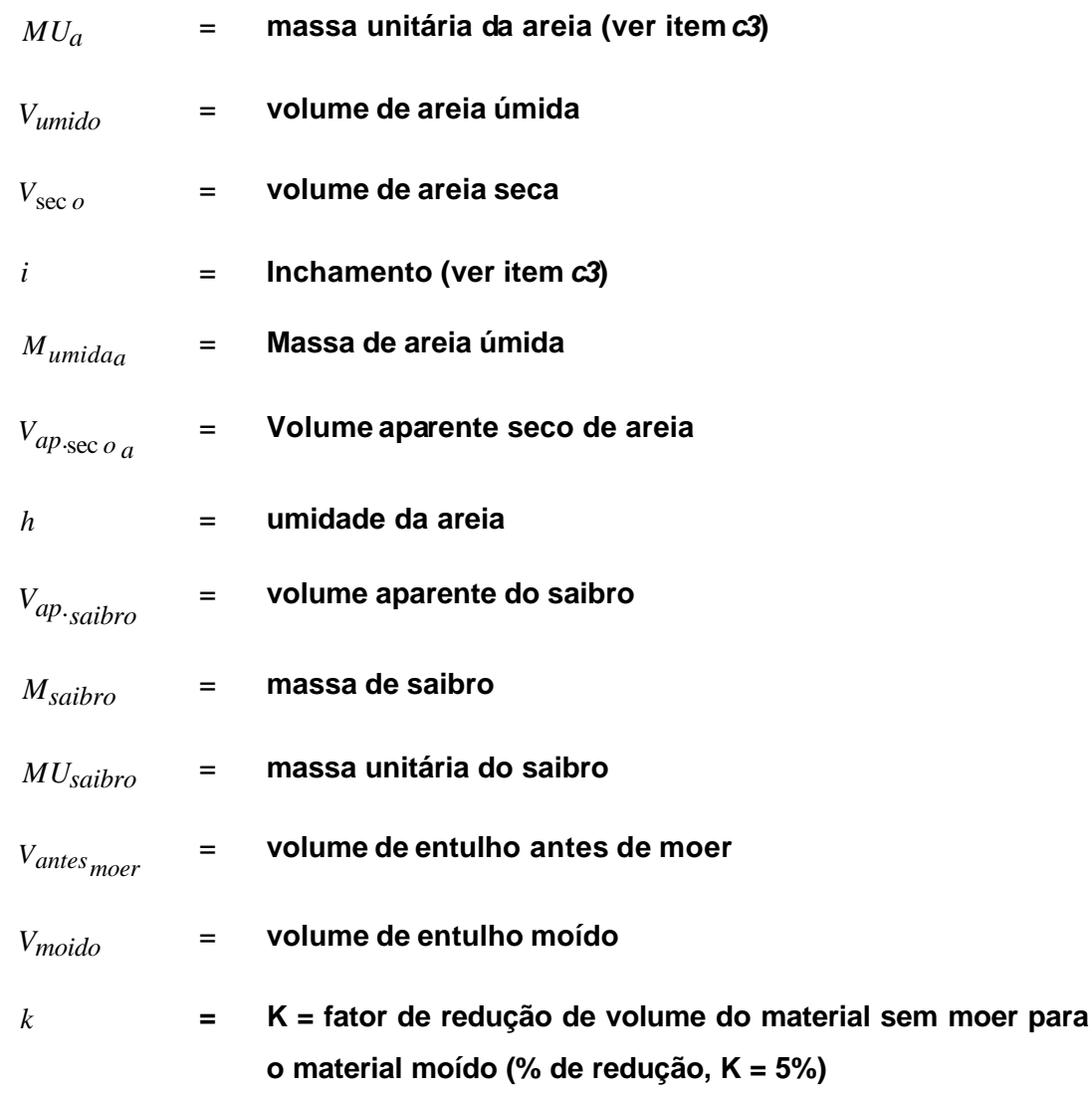

\section{(c1) consumo de materiais básicos em argamassas}

Com o traço nas unidades corretas, utilizam-se então as fórmulas de consumo apresentadas na Tabela 6.6, sendo que os valores das variáveis das mesmas são apresentados na Tabela 6.7 e no item c3. Note que houve a preocupação em expressar os resultados na mesma unidade de compra do material ${ }^{97}$.

\footnotetext{
${ }^{97}$ No anexo G apresenta-se um exemplo de cálculo de CMB/MC utilizando-se as fórmulas apresentadas na Tabela 6.6, a seguir.
} 
Tabela 6.6 Fórmulas para o cálculo do consumo de materiais básicos por material composto CMB/MC (argamassas)

\begin{tabular}{|c|c|c|c|c|c|c|c|}
\hline \multicolumn{3}{|c|}{ Identificação } & \multicolumn{5}{|c|}{ Fórmulas de consumo de material básico por material composto ( $C M B / M C)$} \\
\hline Tipo de argamassa & Serviço (s) & Formato do (Traço) & $C_{\text {cim }}\left(\mathrm{kg} / \mathrm{m}^{3}\right)$ & $C_{c a} l\left(\mathrm{~kg} / \mathrm{m}^{3}\right)$ & $C a_{\text {úmida }}\left(\mathrm{m}^{3} / \mathrm{m}^{3}\right)$ & $C_{\text {sai }}\left(m^{3} / m^{3}\right)$ & $C_{\text {ent }}\left(\mathrm{m}^{3} / \mathrm{m}^{3}\right)$ \\
\hline $\begin{array}{l}\text { Argamassa mista de cimento e } \\
\text { cal, sem uso de argamassa } \\
\text { intermediária }\end{array}$ & Diversos & $1: \mathrm{cal}: \mathrm{a}: 0: 0$ & $\frac{M E_{\arg \text { amassa }}}{(1+h) x\left(1+c a l+\frac{a}{1+i} x M U_{a}\right)}$ & calx $C_{\text {cim }}$ & $\frac{a x C_{c i m}}{1000}$ & - & - \\
\hline $\begin{array}{l}\text { Argamassa mista de cimento e } \\
\text { cal, com o uso de argamassa } \\
\text { intermediária }\end{array}$ & Diversos & $($ cal : a $)+\left(1: a_{i}\right)$ & $\frac{M E_{\arg \text { amassa }}}{(1+h) x\left(1+\frac{a_{i} x i}{a}+a_{i} x M U_{a}\right)}$ & $\frac{a_{i} x i}{a} x C_{c i m}$ & $\frac{\left(a_{i} x i\right) x C_{c i m}}{1000}$ & - & - \\
\hline Argamassa de cimento & $\begin{array}{c}\text { Chapisco convencional, } \\
\text { rolado e contrapiso }\end{array}$ & $1: 0: a: 0: 0$ & $\frac{M E_{\arg \text { amassa }}}{(1+h) x\left(1+\frac{a}{1+i} x M U_{a}\right)}$ & - & $\frac{a x C_{c i m}}{1000}$ & - & - \\
\hline $\begin{array}{l}\text { Argamassa de cimento e } \\
\text { saibro (arenoso) }\end{array}$ & Diversos & $1: 0: a:$ sai $: 0$ & $\frac{M E_{\text {arg } \text { amassa }}}{(1+h) x(1+\text { saixMU }}$ & - & $\frac{a x C_{c i m}}{1000}$ & $\frac{\operatorname{saix}_{\text {cim }}}{1000}$ & - \\
\hline $\begin{array}{l}\text { Argamassa de cimento e } \\
\text { entulho }\end{array}$ & Diversos & $1: 0: \mathrm{a}: 0:$ ent & $\frac{M E_{\text {arg amassa }}}{(1+h) x\left(1+e n t x M U_{\text {ent }}+\frac{a}{1+i} \times M U_{a}\right)}$ & - & $\frac{a x C_{c i m}}{1000}$ & - & $\frac{e_{\text {entx }} C_{\text {cim }}}{1000}$ \\
\hline
\end{tabular}


Tabela 6.7 Valores da umidade da areia (h) e da massa específica das argamassas a ser utilizados na falta de valor tecnicamente confiável para a obra em estudo

\begin{tabular}{|c|c|c|c|}
\hline Tipo de argamassa & Serviço (s) & $M E_{\text {argamassa }}\left(\mathrm{kg} / \mathrm{m}^{3}\right)$ & $h(\%)$ \\
\hline $\begin{array}{l}\text { Argamassa mista de cimento e } \\
\text { cal, sem uso de argamassa } \\
\text { intermediária }\end{array}$ & Diversos & 2000 & $\begin{array}{l}22 \% \text { para a } \leq 6 \\
25 \% \text { para } a>6\end{array}$ \\
\hline $\begin{array}{l}\text { Argamassa mista de cimento e } \\
\text { cal, com uso de argamassa } \\
\text { intermediária }\end{array}$ & Diversos & 2000 & $\begin{array}{l}22 \% \text { para } a_{i} \leq 6 \\
25 \% \text { para } a_{i}>6\end{array}$ \\
\hline Argamassa de cimento & Contrapiso & $\begin{array}{c}1900 \mathrm{~kg} / \mathrm{m} 3 \text {, para contrapisos mal } \\
\text { compactados } \\
2200 \mathrm{~kg} / \mathrm{m}^{3} \text {, para contrapisos bem } \\
\text { compactados (uso de soquetes) }\end{array}$ & $15 \%$ \\
\hline & $\begin{array}{l}\text { Chapisco } \\
\text { convencional }\end{array}$ & 1900 & $30 \%$ \\
\hline $\begin{array}{l}\text { Argamassa de cimento e saibro } \\
\text { (arenoso) }\end{array}$ & $\begin{array}{l}\text { Chapisco rolado } \\
\text { Diversos }\end{array}$ & $\begin{array}{l}1700 \\
2000\end{array}$ & $\begin{array}{c}50 \% \\
22 \% \text { para a } \leq 6 \\
25 \% \text { para } a>6\end{array}$ \\
\hline $\begin{array}{l}\text { Argamassa de cimento e } \\
\text { entulho }\end{array}$ & Diversos & 2000 & $\begin{array}{l}22 \% \text { para a } \leq 6 \\
25 \% \text { para } a>6\end{array}$ \\
\hline
\end{tabular}

(c2) consumo de materiais básicos em concretos 
Tendo-se o traço nas unidades requeridas, o cálculo do consumo de materiais básicos é feito mediante a aplicação das seguintes fórmulas de consumo para concretos sem aditivos:

$$
\begin{aligned}
& C_{\text {cim }}\left(k g / \mathrm{m}^{3}\right)=\frac{980}{\frac{1}{M E_{c i m}}+\frac{a x M U_{a}}{(1+i) x M E_{a}}+\frac{b}{M E_{b}} x M U_{b}+\frac{\frac{a}{c}}{1}} \\
& C_{b}\left(m^{3} / m^{3}\right)=\frac{b x C_{c i m}}{1000} \\
& C_{a_{u m i d a}\left(m^{3} / m_{3}\right)=\frac{a x C_{c i m}}{1000}}
\end{aligned}
$$

onde,

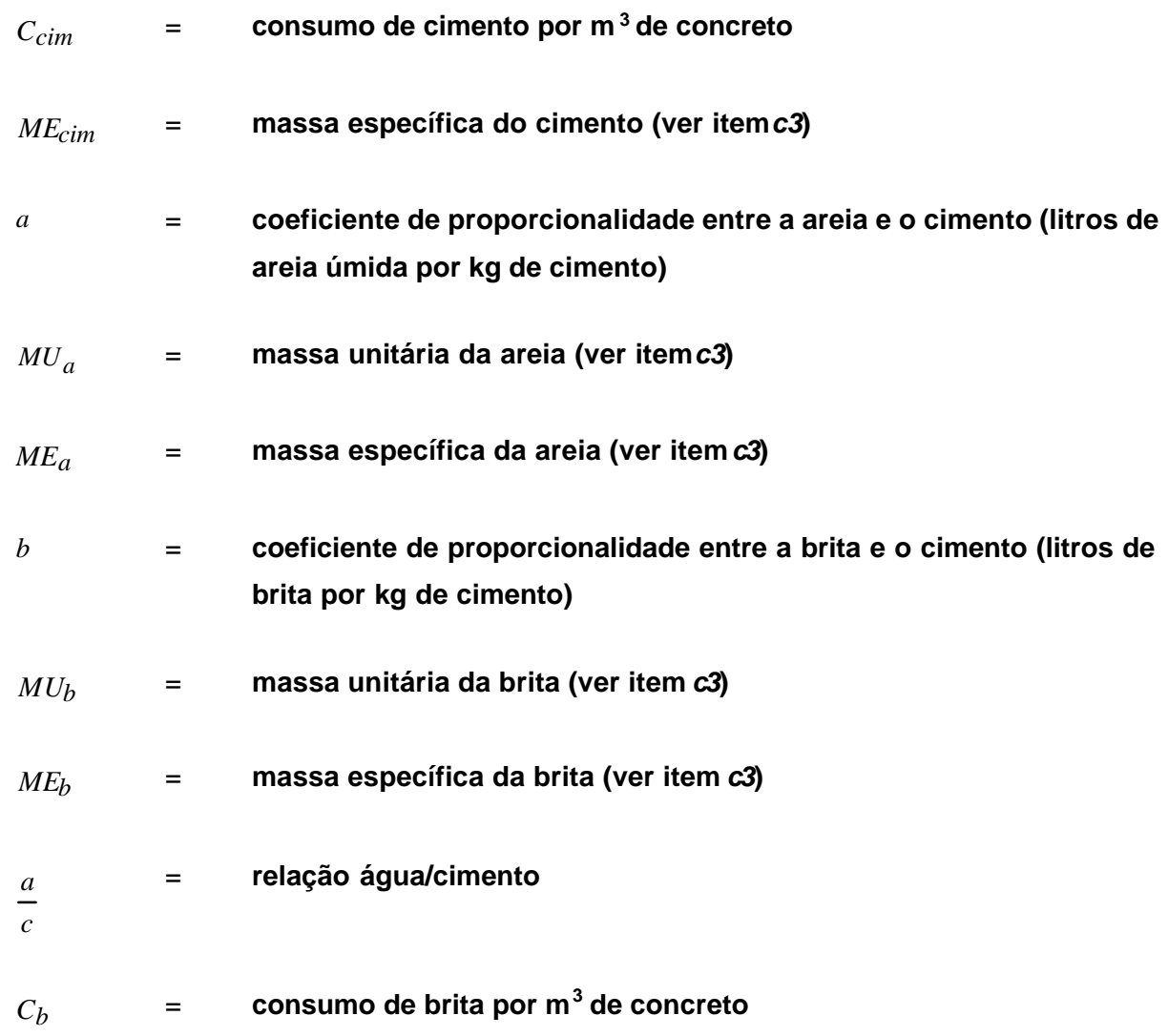




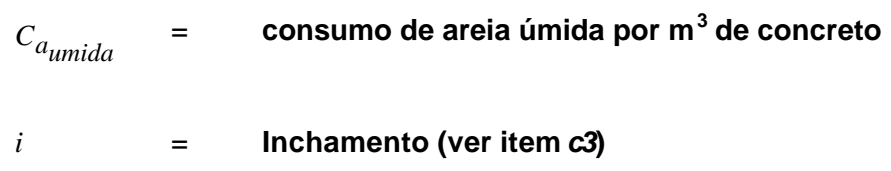

(c3) valores das massas unitária e específica e do inchamento (i)

Os valores de $M U$ e $M E$ deverão ser obtidos através dos seguintes caminhos, em ordem decrescente de precisão:

- medi-los para os materiais da obra em estudo;

- conseguir valores representativos para os materiais através de consulta a um laboratório especializado no assunto com experiência no material em uso pela obra;

- adotar os valores expressos na Tabela 6.8.

Tabela 6.8 Parâmetros para a transformação do traço e cálculo do consumo de materiais básicos por material composto

\begin{tabular}{lc|c|c}
\hline \multicolumn{1}{c|}{ Material } & $\begin{array}{c}\text { Massa específica } \\
\left(\mathbf{k g} / \mathbf{d m}^{3}\right)\end{array}$ & Massa unitária $\left(\mathbf{k g} / \mathbf{d m}^{3}\right)$ & \\
\hline Cimento & 3,15 & 1,15 & - \\
\hline Cal & 2,65 & $\mathrm{CH} \mathrm{I}=0,6 ; \mathrm{CH}$ III $=0,85^{98}$ & - \\
\hline Areia & 2,65 & 1,30 & - \\
Saibro (arenoso) & 2,65 & 1,60 & - \\
\hline Entulho & 2,65 & 1,30 & \\
\hline
\end{tabular}

Em não se tendo um traço definido na obra, pode-se adotar os seguintes traços apresentados na Tabela 6.9. 
Tabela 6.9 Traços padrão de argamassas

\begin{tabular}{l|l|l}
\hline Serviços & Traço $(\mathbf{1}: \mathbf{c a l}: \mathbf{a})$ & Observações \\
\hline Alvenaria & $1: 0,5: 8,8$ & Blocos de concreto e cerâmicos \\
\hline & $1: 0,8: 8,8$ & Blocos sílico-calcáreos \\
\hline Emboço & $1: 1: 8,8$ & Blocos de concreto celular \\
\hline & $1: 0,5: 8,8$ & Rev. interno - base para pintura \\
\hline & $1: 0,4: 6,5$ & Revestimento interno - cerâmica \\
\hline Chapisco & $1: 0,5: 7,6$ & Revestimento externo - base para pintura \\
\hline Massa única & $1: 0,4: 4,8,8$ & Revestimento externo - cerâmica \\
\hline & $1: 0,3: 5,4$ & Revestimento interno - base para pintura \\
\hline Contrapiso & $1: 0: 7,4$ & Revestimento externo - base para pintura \\
\hline & $1: 0,5: 6,5$ & - \\
\hline
\end{tabular}

\subsubsection{Indicadores parciais}

No período compreendido entre as datas VI e VF, além do estabelecimento dos indicadores globais, realiza-se a coleta de informações para o cálculo dos indicadores parciais sobre perdas e/ou consumos de materiais.

Para cada etapa percorrida pelo material na obra, estabeleceu-se um conjunto de indicadores parciais, cujo objetivo principal é o de explicar os indicadores globais detectados no período concernente. A relação destes indicadores foi preliminarmente apresentada no capítulo 5 e a sua elaboração foi feita com

\footnotetext{
${ }^{98}$ A designação quanto à classificação da cal em $\mathrm{CH}$ I, $\mathrm{CH}$ II e $\mathrm{CH}$ III vem impressa na embalagem.
} 
base nas possibilidades de ocorrência das perdas de materiais ao longo das etapas do fluxograma dos processos.

No que diz respeito à coleta de dados propriamente dita, além das planilhas para a anotação das medições de campo, foram elaborados, também, para o estabelecimento de cada indicador, procedimentos específicos contendo os principais caminhos e critérios a serem seguidos ao longo da coleta de dados. A estrutura de tais procedimentos foi baseada na adotada por OLIVEIRA et al., (1993) na elaboração de um manual sobre coleta de indicadores . Um modelo da estrutura de procedimento de coleta de dados para o cálculo dos indicadores parciais de perdas e consumos é apresentado na Figura 6.17, onde destacam-se:

- objetivo da medição: contém uma pequena introdução onde se explica a importância da medição de tal indicador, enfatizando-se o objetivo da mesma;

- roteiro para cálculo: neste item, além da apresentação da fórmula utilizada para o cálculo do indicador parcial, é apresentado, também, um detalhamento de todas as variáveis envolvidas e, principalmente, os procedimentos/critérios de como se medi-las; para alguns indicadores, contempla-se também um desenho esquemático, objetivando a melhor visualização da medição a ser realizada pelo observador; há que se destacar a proposta de se fazer a ponderação entre as medições efetuadas e a quantidade de serviço relacionada a esta medição. Por exemplo, no caso do cálculo da espessura do emboço, a média desta espessura é 
obtida ponderando-se a média das medições realizadas em cada face pela respectiva área.

- momento e periodicidade da coleta de dados: além de conter a definição do momento e periodicidade da coleta de dados, neste item alerta-se, também, para a necessidade de se ter representatividade e aleatoriedade nas medições; em se tratando de medições a ser efetuadas nos pavimentos, adotou-se como critérios a medição de pelo menos $1 / 3$ da quantidade de serviço executado entre as datas VI e VF (por exemplo, em $600 \mathrm{~m}^{2}$ de alvenaria e xecutada entre VI e VF, deve-se proceder a medição em paredes representando pelo menos $200 \mathrm{~m}^{2}$ ); com relação ao momento de coleta, destaca-se a necessidade de medição das informações antes que haja a ocultação do serviço executado (por exemplo, deve-se realizar a medição do número de blocos cortados na parede antes da execução do revestimento argamassado). 


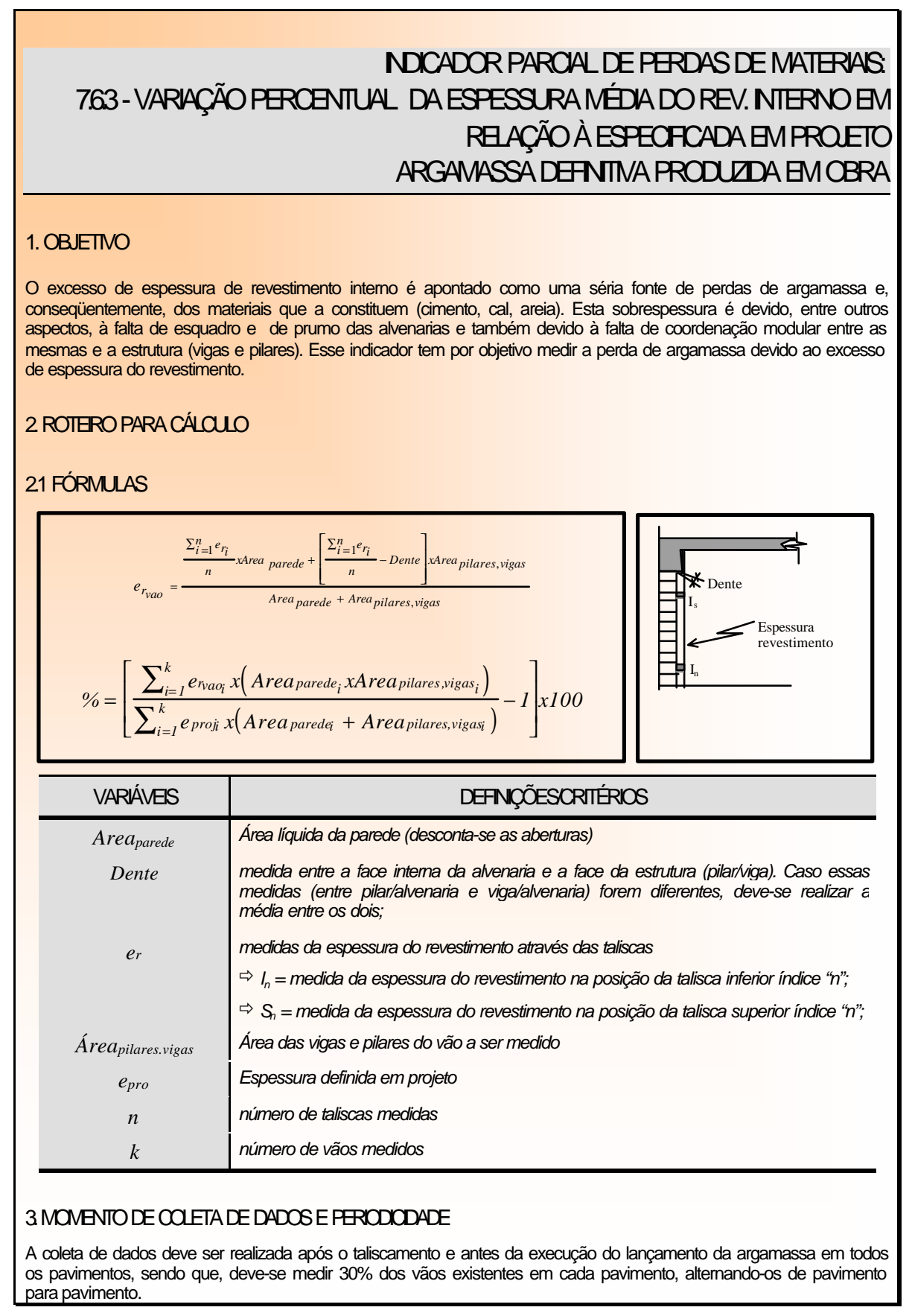
Figura 6.17 Modelo de procedimento de coleta de dados - Indicador parcial

Apesar de esta estrutura ser padronizada para todos os indicadores de perdas e consumos, existem algumas particularidades no conteúdo de cada item, que 
vão desde a disposição de procedimentos alternativos para a realização da medição até alguns cuidados adicionais a ser observados.

Como exemplo de necessidade de procedimentos alternativos, citam-se as duas possibilidades de se realizar a medição da espessura das lajes: a direta e a indireta. Para a obtenção da espessura pelo modo direto, faz-se uso de uma furadeira de impacto para furar a laje a ser medida. Após o furo, procede-se a medição com o auxílio de um paquímetro. A forma indireta consiste na obtenção da espessura da laje através de medições auxiliares, conforme se ilustra na Figura 6.18, sendo que a espessura da laje é dada por: $e_{\text {laje }}=A-(B+C)$, sendo "A" mensurado a partir das aberturas das janelas sucessivas posicionadas numa mesma vertical na fachada, e "B" e "C" mensurados da borda da janela às superfícies da laje, superior e inferior respectivamente.

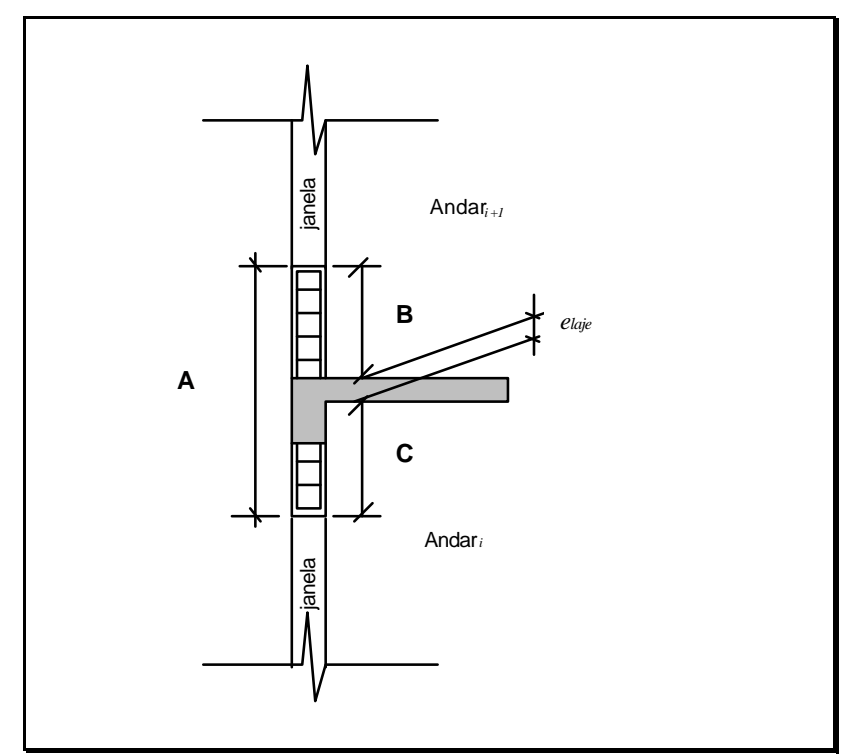

Figura 6.18 Medição da espessura da laje - forma indireta 
Com relação aos cuidados adicionais ao se proceder a coleta, podem ser citados, entre outros:

- precisão da medição: a equipe de coleta deverá ter o senso crítico quanto à medição dos dados, atentando para alguns cuidados quanto à perpendicularidade ou paralelismo do instrumento utilizado para a medição (por exemplo, na medição das taliscas do emboço, a trena deverá estar situada perpendicularmente à superfície da talisca; no caso da medição das espessuras das juntas em argamassa, no serviço de alvenaria, deve-se ter o completo discernimento entre a junta de argamassa e o bloco, principalmente em alvenarias de blocos de concreto, entre outros; recomenda-se, neste caso, que se raspe a região da interface junta-bloco para que a mesma auxiliar este discernimento;

- segurança do observador. devem ser utilizados, quando necessários, equipamentos de segurança (por exemplo, na medição da largura das vigas externas do pavimento $)^{99}$;

Um outro aspecto importante e comum à maioria dos procedimentos para a obtenção dos indicadores parciais relacionados à execução dos serviços nos pavimentos, diz respeito à elaboração de um croqui representativo do pavimento a ser medido, que poderá ser o mesmo utilizado para a quantificação dos serviços (Série 3). Através deste croqui, a equipe de coleta identificará os elementos a ser medidos (face, parede, viga, laje etc) e poderá conferir às medições a aleatoriedade e representatividade desejada, através da

\footnotetext{
${ }^{99}$ Neste exemplo citado, em se detectando que, mesmo fazendo-se uso de equipamentos de segurança, a mensuração pode ainda por em risco a pessoa que faz a coleta, sugere-se não utilizar tal indicador.
} 
alternância de elementos de andar para andar e da visão global dos elementos a ser medidos em cada pavimento.

\subsubsection{Caracterização das etapas do fluxograma dos processos}

Esta caracterização deverá ser feita entre as datas VI e VF e, para isso, utilizam-se as planilhas da série 5 para a caracterização das etapas de recebimento e estocagem e da série 6 para a caracterização das etapas de processamento intermediário (dosagem/mistura, corte), transporte e aplicação do material.

Conforme a estrutura destas planilhas apresentada nos itens 6.4.1.5 e 6.4.1.6, o principal item consiste numa lis ta de verificação de caráter pró-ativo com relação à minimização de ocorrência de perdas de materiais, contendo itens facilmente compreensíveis e auto-explicativos. As respostas positivas correspondem a condutas favoráveis à não ocorrência ou redução das perdas de materiais.

No entanto, muito mais do que assinalar a alternativa correspondente à situação encontrada, cabe à equipe de coleta investigar as evidências que conduziram a tal resposta, visando a uma caracterização mais detalhada das etapas analisadas.

Além do preenchimento desta lista de verificação, deve-se anotar também, nas planilhas destas séries, as principais ocorrências anormais geradoras de perdas como, por exemplo, sobras de concreto e argamassas, acidente com páletes de blocos etc. 


\subsubsection{Estrutura de códigos: especificação dos materiais e caracterização dos serviços}

O universo de materiais e serviços contemplados nesta metodologia é bastante amplo. No que se refere aos materiais, nota-se que os mesmos possuem diversas especificações ${ }^{100}$, sendo que algumas delas podem ser consideradas importantes quanto à ocorrência de perdas.

Procurando conciliar a possibilidade de análise dos indicadores de perdas levando-se em consideração tais especificações, assim como garantir a padronização da coleta de dados, elaborou-se um sistema de códigos, estruturado segundo a Figura 6.19.

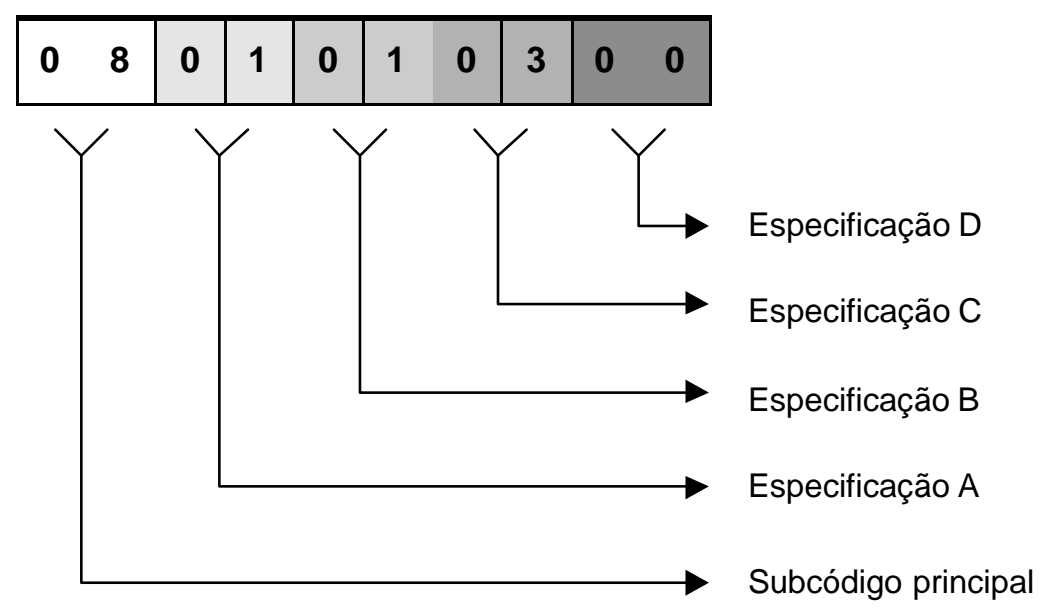

Figura 6.19 Estrutura do código para a especificação dos materiais

\footnotetext{
${ }^{100}$ Tomando-se, como exemplo, os blocos, pode-se citar: dimensões, material constituinte, classificação quanto à função estrutural, classificação quanto à presença de furos, entre ouros.
} 
De acordo com esta Figura, o código para a designação dos materiais é composto por 10 dígitos, dividido em subcódigos compostos por 2 dígitos. A separação entre os mesmos é feita por um ponto, e cada subcódigo representa uma especificação do material, sendo que o primeiro diz respeito à identificação do material propriamente dito. $\mathrm{Na}$ ausência de número de especificações correspondente ao número de subcódigos previstos na estrutura, atribui-se o valor "00" para os subcódigos não utilizados.

A aplicação desta estrutura, assim como a descrição completa para a especificação de todos os materiais, é apresentada no anexo E.

Além das especificações dos materiais, em se tratando do uso dos mesmos nos canteiros de obras, existem também características relacionadas aos serviços e suas interações que podem influenciar na ocorrência de perdas e/ou sobreconsumos.

A Indústria de Construção Civil tem como característica principal a heterogeneidade do seu processo produtivo. Esta heterogeneidade transparece tanto no âmbito da qualidade da mão-de-obra e da técnica empregada (ferramentas, equipamentos, procedimentos etc), quanto no que diz respeito aos aspectos relacionados à gerência da produção, entre outros.

É inegável que os vários fatores inerentes à hdústria de Construção Civil interferem na questão das perdas de materiais nos canteiros de obras e, c om o intuito de se detectar estes fatores considerados importantes quanto às perdas de materiais, a metodologia contempla uma série de informações, acerca desta caracterização, através da aplicação das planilhas das séries 1,5 e 6 . 
Esta caracterização dá-se em diferentes níveis. No âmbito da empresa pode-se citar, como exemplo, o porte da mesma (pequena, média, grande), segmento de atuação (obras comerciais, residenciais), existência de programas de políticas de qualidade ou treinamento, entre outros. No âmbito da obra, destaca-se o tipo de edificação (residencial, comercial), o sistema construtivo adotado, entre outros. No que diz respeito aos serviços, a existência de procedimentos de execução e controle, o tipo de equipamento de transporte (carrinhos porta-pálete, jericas) e aplicação dos materiais (bisnaga, colher de pedreiro) são exemplos de fatores que podem interferir significativamente nas perdas ou consumos de materiais.

Apesar de se levantar um universo de informações acerca desta caracterização, a busca das características a ser verificadas foi feita através da observação crítica de cada etapa do fluxograma dos processos e das interações entre os mesmos, onde foram elegidas aquelas consideradas relevantes.

Neste sentido, elaborou-se um sistema de códigos que, além de contribuir para a padronização da coleta, possibilita a obtenção de indicadores levando-se em consideração estas características (Figura 6.20), isto é, tendo-se um conjunto de valores de perdas obtidos para o mesmo tipo de serviço em dferentes obras, pode-se subdividir tal grupo em partes com características distintas, permitindo a comparação dos resultados de perdas entre si.

De acordo com esta estrutura, cada subcódigo representa uma característica, sendo que o subcódigo principal define o serviço (contrapiso, chapisco). Esta 
estrutura, assim como as características relacionadas aos serviços, pode ser vista no anexo $\mathrm{F}$.

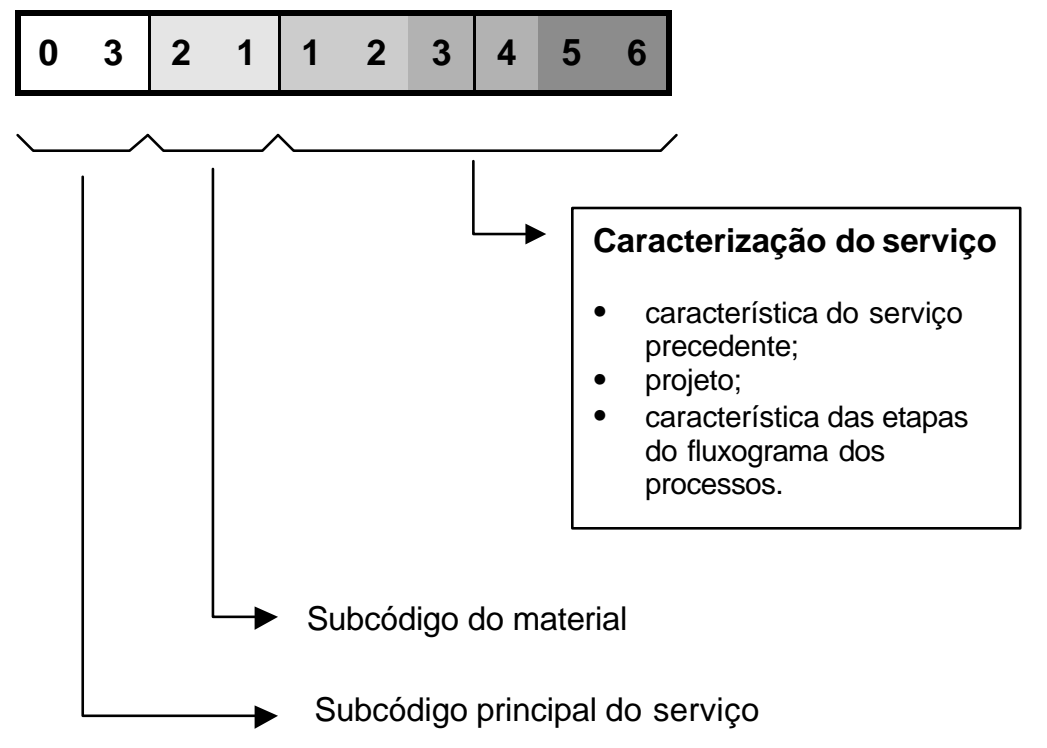

Figura 6.20 Estrutura do código para a caracterização dos serviços

A coleta de informações sobre a especificação dos materiais, assim como a da caracterização dos serviços, deverá ser feita antes do início da coleta de dados sobre perdas de materiais no canteiro de obras. Isto se deve ao fato de que todas as demais informações sobre a ocorrência de perdas de materiais deverá estar associada à codificação de materiais e serviços.

Note que tal sistema de códigos foi estruturado em consonância com a elaboração de um programa de banco de dados, conforme será discutido na seqüência. 


\subsection{Processamento dos dados}

Feita a coleta de dados, ou concomitantemente à mesma, procede-se o processamento dos dados coletados para a obtenção dos indicadores globais e parciais sobre perdas e consumos de materiais. No que diz respeito aos indicadores parciais, foram elaborados procedimentos específicos, os quais não serão discutidos com profundidade aqui, sendo que as especificidades podem ser visualizadas na homepage específica (http://www.pcc.usp.br/Pesquisa/perdas) ou ainda em AGOPYAN et al. (1998b).

Aqui, estar-se-á dando ênfase apenas ao cálculo dos indicadores globais, os quais envolvem uma série de informações coletadas através de diversas séries de planilhas.

O cálculo de tais indicadores pode ser abordado sob duas óticas: no âmbito do uso do material no canteiro de obras (intracanteiro) ou no âmbito de uma amostra de serviços ou obras (intercanteiros).

Com relação ao cálculo dos indicadores em canteiros específicos, o mesmo foi feito através de planilhas eletrônicas elaboradas no mesmo formato que as planilhas relativas ao cálculo deste indicador, ou seja, planilhas das séries 2, 3 e 4. Através deste procedimento, é feita a totalização das informações ao término da coleta de dados entre as datas VI e VF, cuja manipulação organizada, conforme apresentado no item 6.6.1, resulta nos indicadores globais nas suas diversas modalidades.

No que diz respeito à obtenção dos indicadores no âmbito da amostra de canteiros de obras, elaborou-se um programa de Banco de Dados, em Visual 
Basic, onde são reunidos, de forma organizada para cada obra e/ou serviço, os valores do consumo real e do consumo de referência. O processamento de tais informações permite o cálculo das estatísticas média, mediana, desvio padrão, valores máximo e mínimo, que serão utilizadas na análise final.

Como opções, o programa de Banco de Dados desenvolvido permite a determinação de estatísticas considerando as diversas características dos serviços e especificações dos materiais, através do sistema de códigos desenvolvido conforme item 6.4.5.

Os procedimentos a ser seguidos para a obtenção dos resultados decorrentes do levantamento de campo são apresentados, de forma resumida, na seqüência.

\subsubsection{No âmbito do canteiro de obras}

Esta fase se refere ao processamento dos dados coletados no canteiro de obras para a obtenção dos indicadores globais (em todas as suas modalidades) e parciais. Enquanto o cálculo dos indicadores globais passa, necessariamente, pela contabilização dos estoques e quantidades de serviços na data VF, o dos indicadores parciais não precisa, obrigatoriamente, ser iniciado após o término da coleta em canteiro, ou seja, após o VF, e sim, pode ocorrer simultaneamente à coleta de dados de campo, sendo possível sua finalização antes de VF, desde que se tenham medições condizentes com o montante mínimo estabelecido nos procedimentos específicos. 


\subsubsection{Indicadores globais}

O processamento dos dados para a obtenção dos indicadores globais passa, necessariamente, pelo cálculo dos consumos de referência e real. O cálculo do consumo de referência é calculado através da multiplicação da quantidade de serviço (QS) (obtida a partir da totalização dos dados das planilhas da série 3) pelo consumo de material por quantidade de serviço $(C M / Q S)$ e pelo consumo de material básico por material composto $(C M B / M C)$.

Uma listagem organizada (conforme ilustra a Tabela 6.10), confeccionada previamente, contendo descrição e código dos serviços e dos respectivos materiais envolvidos, além dos valores de $Q S, C M / Q S$ e $C M B / M C$, auxilia bastante o cálculo do consumo de referência. 
Tabela 6.10 Exemplo do cômputo do consumo de referência

\begin{tabular}{|c|c|c|c|c|c|c|c|c|c|c|c|c|}
\hline & \multicolumn{2}{|l|}{ SERVIÇOS } & \multicolumn{3}{|c|}{ MATERIAL COMPOSTO } & \multicolumn{3}{|c|}{ MATERIAL BÁSICO OU SIMPLES } & \multirow[b]{2}{*}{ QS } & \multirow[b]{2}{*}{ CM/QS } & \multirow[b]{2}{*}{$\mathrm{CMB} / \mathrm{MC}$} & \multirow[b]{2}{*}{ Cref. } \\
\hline Código & Descrição resumida & Un. & Código & Descrição & Un. & Código & Descrição resumida & Un. & & & & \\
\hline $05.07 \cdot 2 \cdot 1 \cdot 1 \cdot 0.0 .0$ & Armação & $\mathrm{kg}$ & - & - & - & 07.01.02.02.00 & Aço $6,3 \mathrm{~mm}$ & $\mathrm{~kg}$ & 10.420 & 1 & 1 & 10.420 \\
\hline $08 \cdot 05 \cdot 2 \cdot 1 \cdot 3 \cdot 2 \cdot 0 \cdot 2$ & Estrutura concreto usinado & $\mathrm{m} 3$ & - & - & - & 05.14.07.00.00 & Concreto Usinado & $\mathrm{m} 3$ & 620 & 1 & 1 & 620 \\
\hline 23.19.2.1.0.0.0.0 & Rev. Int. - gesso & m2 & - & - & - & 19.00.00.00.00 & Gesso & $\mathrm{kg}$ & 10.620 & 4 & 1 & 47.259 \\
\hline $26 \cdot 16 \cdot 1 \cdot 0 \cdot 0 \cdot 0 \cdot 0 \cdot 0$ & Rev. cerâmico. - par. internas & m2 & - & - & - & 16.01.00.00.00 & Placa cerâmica 15,43 × 15,43 & un. & 1.615 & 39 & 1 & 63.647 \\
\hline $37.13 \cdot 1 \cdot 1 \cdot 2 \cdot 0 \cdot 0.0$ & Inst. elétrica - enfiação & $\mathrm{m}$ & - & - & - & 13.01.02.02.01 & Condutor $1,5 \mathrm{~mm} 2$ & $\mathrm{~m}$ & 4.280 & 1 & 1 & 4.280 \\
\hline $39 \cdot 12 \cdot 1 \cdot 1 \cdot 2 \cdot 1 \cdot 0.0$ & Inst. elétrica - el etroduto & $\mathrm{m}$ & - & - & - & 12.01.01.02.03 & Eletroduto PVC $25 \mathrm{~mm}$ & $\mathrm{~m}$ & 4.400 & 1 & 1 & 4.400 \\
\hline \multirow[t]{3}{*}{ 11.06.1.1.2.1.1.0 } & \multirow[t]{3}{*}{ Alvenaria - juntas - arg. obra } & \multirow[t]{3}{*}{$\mathrm{m}$} & \multirow[t]{3}{*}{ 06.02.05.03.04 } & \multirow[t]{3}{*}{ Argamassa obra } & \multirow[t]{3}{*}{ m3 } & 01.02.00.00.00 & Areia média & m3 & \multirow{3}{*}{100.000} & \multirow{3}{*}{0,0002} & 1 & 25 \\
\hline & & & & & & 02.03.02.00.00 & Cimento Portland & $\mathrm{kg}$ & & & 296 & 5.920 \\
\hline & & & & & & 10.03.00.00.00 & $\mathrm{Cal} \mathrm{CHI}$ & $\mathrm{kg}$ & & & 170 & 3.400 \\
\hline \multirow[t]{3}{*}{ 19.06.2.0.0.0.0.0 } & \multirow[t]{3}{*}{ Rev. interno- emboço ou m. única } & \multirow[t]{3}{*}{ m2 } & \multirow[t]{3}{*}{ 06.02.09.03.04 } & \multirow[t]{3}{*}{ Argamassa obra } & \multirow[t]{3}{*}{ m3 } & 01.02.00.00.00 & Areia média & m3 & \multirow{3}{*}{630} & \multirow{3}{*}{0,0250} & 1 & 20 \\
\hline & & & & & & 02.03.02.00.00 & Cimento Portland & $\mathrm{kg}$ & & & 296 & 4.662 \\
\hline & & & & & & 10.03.00.00.00 & $\mathrm{Cal} \mathrm{CHI}$ & $\mathrm{kg}$ & & & 170 & 2.678 \\
\hline 34.18.1.2.2.2.2.0 & Pintura interna & m2 & - & - & - & 18.01.01.00.00 & Tinta látex PVA & I & 3.000 & 0,103 & 1 & 309 \\
\hline
\end{tabular}


Após o cálculo dos consumos de referência, procede-se o cálculo do consumo real dos materiais no canteiro de obras e nos respectivos serviços com base na totalização dos dados das planilhas das séries 2 e 4, que pode ser obtida de duas formas:

(a) somando-se toda a quantidade de material recebida e/ou transferida do canteiro de obras entre as datas VI e VF à diferença entre as quantidades do respectivo material estocadas nas datas VF e VI, para o caso daqueles materiais utilizados em serviços específicos durante o período de estudo (blocos, concreto usinado etc) (Tabela 6.11), ou;

(b) através das quantidades mapeadas quanto aos respectivos serviços que fazem uso do material (aplicado àqueles materiais básicos utilizados em vários serviços simultaneamente) [Tabelas 6.12(a) e 6.12(b)].

Tabela 6.11 Exemplo do cômputo do consumo real

\begin{tabular}{|c|c|c|c|c|c|c|}
\hline 07.01 .02 .02 .00 & Aço $6,3 \mathrm{~mm}$ & 0 & 14.000 & 200 & 2.000 & 12.200 \\
\hline 05.14 .07 .00 .00 & Concreto Usinado & 0 & 650 & 0 & 0 & 650 \\
\hline 16.01 .00 .00 .00 & Placa cerâmica 15,43 × 15,43 & 15.000 & 15.000 & 50.000 & 10.000 & 70.000 \\
\hline 13.01 .02 .02 .01 & Condutor $1,5 \mathrm{~mm} 2$ & 0 & 4.500 & 0 & 0 & 4.500 \\
\hline 12.01 .01 .02 .03 & Eletroduto $25 \mathrm{~mm}$ & 200 & 5.000 & 0 & 0 & 5.200 \\
\hline 10.03 .00 .00 .00 & $\mathrm{Cal} \mathrm{CH} \mathrm{I}$ & 2.000 & 10.990 & -2.000 & 2.000 & 8.990 \\
\hline 18.01 .01 .00 .00 & Tinta látex PVA & 0 & 400 & 0 & 0 & 400 \\
\hline
\end{tabular}

${ }^{101} \mathrm{O}$ sinal positivo indica entrada no estoque e o negativo diz respeito à saída do estoque (transferência desse para outra obra). 
Tabela 6.12(a) Exemplo do cômputo do consumo real - serviço pósestocagem: mapeamento das quantidades que saíram do estoque

\begin{tabular}{|c|c|c|c|c|c|}
\hline \multicolumn{2}{|c|}{ MATERIAL BÁSICO } & \multirow[t]{2}{*}{ Data } & \multicolumn{2}{|r|}{ SERVIÇOS } & \multirow{2}{*}{$\begin{array}{c}\text { Qdade } \\
\text { Kg }\end{array}$} \\
\hline Código & Descrição & & Código & Descrição & \\
\hline \multirow[t]{10}{*}{ 02.03.02.00.00 } & \multirow[t]{10}{*}{ Cimento Portland } & $10 / 01 / 99$ & 11.06.1.1.2.1.1.0 & Alvenaria - juntas - argamassa obra & 2.000 \\
\hline & & $10 / 01 / 99$ & 19.06.2.0.0.0.0.0 & Revestimento interno- emboço ou m. única & 1.000 \\
\hline & & $11 / 01 / 99$ & 11.06.1.1.2.1.1.0 & Alvenaria - juntas - argamassa obra & 1.950 \\
\hline & & $12 / 01 / 99$ & - & Outros & 2.500 \\
\hline & & $13 / 01 / 99$ & 11.06.1.1.2.1.1.0 & Alvenaria - juntas - argamassa obra & 2.050 \\
\hline & & $13 / 01 / 99$ & 11.06.1.1.2.1.1.0 & Alvenaria - juntas - argamassa obra & 2.000 \\
\hline & & $14 / 01 / 99$ & 19.06.2.0.0.0.0.0 & Revestimento interno- emboço ou m. única & 2.000 \\
\hline & & $13 / 01 / 99$ & 19.06.2.0.0.0.0.0 & Revestimento interno- emboço ou m. única & 750 \\
\hline & & $15 / 01 / 99$ & 19.06.2.0.0.0.0.0 & Revestimento interno- emboço ou m. única & 2.250 \\
\hline & & $16 / 01 / 99$ & - & Outros & 3.500 \\
\hline \multirow[t]{9}{*}{ 10.03.00.00.00 } & \multirow[t]{9}{*}{$\mathrm{Cal} \mathrm{CH} \mathrm{I}$} & $10 / 01 / 99$ & 11.06.1.1.2.1.1.0 & Alvenaria - juntas - argamassa obra & 1.000 \\
\hline & & $10 / 01 / 99$ & 19.06.2.0.0.0.0.0 & Revestimento interno- emboço ou m. única & 1.400 \\
\hline & & $11 / 01 / 99$ & 11.06.1.1.2.1.1.0 & Alvenaria - juntas - argamassa obra & 990 \\
\hline & & $12 / 01 / 99$ & - & Outros & 500 \\
\hline & & $13 / 01 / 99$ & 11.06.1.1.2.1.1.0 & Alvenaria - juntas - argamassa obra & 600 \\
\hline & & $13 / 01 / 99$ & 19.06.2.0.0.0.0.0 & Revestimento interno- emboço ou m. única & 1.500 \\
\hline & & $14 / 01 / 99$ & 11.06.1.1.2.1.1.0 & Alvenaria - juntas- argamassa obra & 2.000 \\
\hline & & $14 / 01 / 99$ & 19.06.2.0.0.0.0.0 & Revestimento interno- emboço ou m. única & 500 \\
\hline & & $14 / 01 / 99$ & - & Outros & 500 \\
\hline
\end{tabular}


Tabela 6.12(b) Exemplo de cômp uto do consumo real - serviço pósestocagem: totalização dos materiais básicos que foram utilizados por serviço

\begin{tabular}{|c|c|c|c|c|}
\hline \multicolumn{2}{|c|}{ MATERIAL BÁSICO } & \multicolumn{2}{|r|}{ SERVIÇO } & \multirow{2}{*}{$\begin{array}{l}\text { Qdade } \\
\qquad \mathrm{Kg}\end{array}$} \\
\hline Código & Descrição & Código & Descrição & \\
\hline \multirow[t]{4}{*}{ 02.03.02.00.00 } & \multirow[t]{4}{*}{ Cimento Portland } & 11.06.1.1.2.1.1.0 & Alvenaria-juntas - argamassa obra & 8.000 \\
\hline & & 19.06.2.0.0.0.0.0 & Revestimento interno- emboço ou m. única & 6.000 \\
\hline & & - & Outros & 6.000 \\
\hline & & & TOTAL & 20.000 \\
\hline \multirow[t]{4}{*}{ 10.03.00.00.00 } & \multirow[t]{4}{*}{ Cal CH I } & 11.06.1.1.2.1.1.0 & Alvenaria-juntas - argamassa obra & 4.590 \\
\hline & & $19.06 \cdot 2 \cdot 0 \cdot 0 \cdot 0 \cdot 0.0$ & Revestimento interno- emboço ou m. única & 3.400 \\
\hline & & - & Outros & 1.000 \\
\hline & & & TOTAL & 8990 \\
\hline
\end{tabular}

Note que, com relação aos materiais básicos, a quantidade dos mesmos, obtida pela primeira forma (Tabela 6.11), deve corresponder à somatória das quantidades dos mesmos destinadas aos diversos serviços onde foram utilizados [Tabela 6.12(b)], atestando ou não a precisão do mapeamento. No caso do cimento, por exemplo, tem-se $20.000 \mathrm{~kg}$ estimados em ambas as Tabelas citadas.

Note ainda que, nas Tabelas 6.12(a) e 6.12(b), discrimina-se o serviço "outros", que corresponde às quantidades do referido material destinadas àqueles serviços que não fazem parte do escopo da metodologia (por exemplo, chumbamento de tubulações, vergas e contravergas etc). 
De posse destes consumos, procede-se o cálculo dos indicadores globais, conforme expressões apresentadas no capítulo 5, detalhadas a seguir em função de cada uma das suas modalidades de cálculo.

\section{(a) Perda e/ou consumo de material por serviço pós-estocagem}

Para cada serviço onde se utilizou material básico, o cálculo do indicador de perda é feito utilizando-se a seguinte expressão:

$I_{\text {global,servico pos-estocagem }}=\left[\frac{\text { consumoreal }_{\text {rensumoferencia }}}{\text { consur }_{\text {refervico }}(V I, V F)}-1\right] x 100=\left[\frac{M A T_{\text {se }}}{Q S} \times \frac{C M B}{M C}-1\right] x 100$

onde,

$$
\begin{array}{ll}
M A T_{\text {serviço }}(V i, V F)= & \begin{array}{l}
\text { quantidade de material destinada (mapeada) para a execução do } \\
\text { serviço entre VI e VF }
\end{array} \\
Q S(V I, V F) & \text { quantidade de serviço executada entre VI e VF (serviço onde se } \\
& \text { utilizou o material estudado) } \\
\frac{C M}{Q S} & \text { consumo de material por unidade (quantidade) de serviço } \\
\frac{C M B}{M C} & =\text { consumo de material básico por unidade de material composto }
\end{array}
$$

Tratando-se, porém, do uso destes materiais, torna-se interessante o cálculo também dos indicadores de consumos, uma vez que, em face da flexibilidade da adoção dos valores de referência (espessura de revestimento, traços de argamassa), não necessariamente o menor indicador de perda está associado 
ao menor indicador de consumo, quando se comparam indicadores de um mesmo serviço entre diferentes obras.

O cálculo dos indicadores de consumo é feito dividindo-se as quantidades de material, destinadas ao serviço, pela quantidade de serviço executada, conforme a expressão:

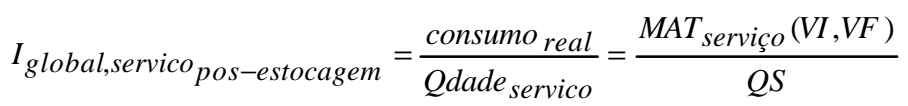

Aplicando-se este raciocínio aos valores apresentados nas Tabelas 6.10 e 6.12(b) chega-se, então, aos indicadores de perdas e/ou consumos de materiais por serviço pós -estocagem (Tabela 6.13).

Tabela 6.13 Indicador global de perda/consumo de materiais/ componentes - serviço pós-estocagem

\begin{tabular}{c|c|c|c|c|c}
\hline \multicolumn{2}{c|}{ MATERIAL } & \multicolumn{2}{c|}{ SERVIÇO } & \multirow{2}{*}{ Perda } & Consumo \\
\hline \multirow{2}{*}{ Código } & Descrição & Código & Descrição & (\%) & (kg/m2) \\
\hline \multirow{2}{*}{ 02.03.02.00.00 } & Cimento Portland & 11.06 .1 .1 .2 .1 .1 .0 & Alvenaria - juntas - argamassa obra & 35 & 0,080 \\
\cline { 3 - 6 } & & 19.06 .2 .0 .0 .0 .0 .0 & Rev. interno- emboço ou m. única & 29 & 9,520 \\
\hline \multirow{2}{*}{ 10.03.00.00.00 } & Cal CHI & 11.06 .1 .1 .2 .1 .1 .0 & Alvenaria - juntas - argamassa obra & 35 & 0,046 \\
\cline { 3 - 6 } & & 19.06 .2 .0 .0 .0 .0 .0 & Rev. interno- emboço ou m. única & 30 & 5,400 \\
\hline
\end{tabular}

Note que, para o caso do uso das argamassas mistas (cimento e cal), os índices de perdas para os dois materiais devem ser iguais. Caso não sejam, isto indica um erro no mapeamento das quantidades que saíram dos estoques ou a ocorrência de variação do traço durante a produção da argamassa. 


\section{(b) Perda de material por serviço}

Este indicador é obtido utilizando-se a seguinte expressão que, aplicada aos dados de consumo real (Tabela 6.11) e consumo de referência (Tabela 6.10), leva aos indicadores constantes da Tabela 6.14:

$I_{\text {global }}(\%)=\left[\frac{E s t(V I)+\operatorname{Re} c(V I, V F) \pm \operatorname{Transf}(V I, V F)-E s t(V F)}{Q S(V I, V F) \frac{C M}{Q S} x \frac{C M B}{M C}}-1\right] x 100$

onde,

$$
\begin{array}{ll}
\operatorname{Est}(V I) & =\text { estoque de material na data VI } \\
\operatorname{Re} c(V I, V F) & =\text { quantidade de material recebida entre as datas VI e VF } \\
\operatorname{Transf}(V I, V F) & =\begin{array}{l}
\text { quantidade de material transferida (de/para outros canteiros, por } \\
\text { exemplo) entre as datas VI e VF }
\end{array} \\
\operatorname{Est}(V F) & =\text { estoque de material na data VF }
\end{array}
$$

\begin{tabular}{|c|c|c|c|c|}
\hline \multicolumn{2}{|r|}{ MATERIAL } & \multirow[t]{2}{*}{ Creal } & \multirow[t]{2}{*}{ Cref. } & \multirow[t]{2}{*}{ Perda (\%) } \\
\hline Código & Descrição & & & \\
\hline 07.01 .02 .02 .00 & Aço 6,3 mm & 12.200 & 10.420 & 17 \\
\hline 05.14.07.00.00 & Concreto Usinado & 650 & 620 & 5 \\
\hline 19.00 .00 .00 .00 & Gesso & 56.000 & 47.259 & 18 \\
\hline 16.01.00.00.00 & Placa cerâmica 15,43 x 15,43 cm & 70.000 & 63.647 & 10 \\
\hline 13.01.02.02.01 & Condutor $1,5 \mathrm{~mm}^{2}$ & 4.500 & 4.280 & 5 \\
\hline 12.01 .01 .02 .03 & Eletroduto $25 \mathrm{~mm}$ & 5.200 & 4.400 & 18 \\
\hline 18.01 .01 .00 .00 & Tinta látex PVA & 400 & 309 & 29 \\
\hline
\end{tabular}

Tabela 6.14 Indicador global de perda de material - por serviço 


\section{(c) Perda de material na obra}

Ao contrário do indicador de perda de material por serviço, o global na obra não é calculado levando-se em consideração as especificações detalhadas dos materiais. Por exemplo, independentemente de se ter duas especificações para o concreto (abatimentos do tronco de cone diferentes), calcula-se apenas um indicador de perda, considerando estes concretos conjuntamente através da seguinte expressão:

$I_{\text {global,obra }}=\left[\frac{\text { consumo }_{\text {real }}}{\text { consumo }_{\text {referencia }}}-1\right] x 100=\left[\frac{E S T(V I) \pm R E C(V I, V F) \pm T R A N F(V I, V F)-E S T(V F)}{\Sigma_{1}^{n} Q S_{j} x \frac{C M}{Q S} j x \frac{C M B}{M C} j}-1\right] x 100$

onde,

$$
j=\begin{aligned}
& \text { número de serviços executados entre VI e VF, onde } \\
& \text { material/componente foi utilizado }
\end{aligned}
$$

Em se tratando, no entanto, do cálculo deste indicador para os materiais básicos, há a necessidade de se fazer uma pequena correção na fórmula anteriormente apresentada. Tal correção consiste em subtrair do numerador, as quantidades destes materiais destinadas a "outros serviços", não medidos durante o período de coleta e, portanto, não tendo as respectivas quantidades teóricas computadas no denominador. Matematicamente, tem -se:

$I_{\text {global }, \text { obra }}=\frac{\text { consumo }_{\text {real }}}{\text { consumo }_{\text {referencia }}}=\left[\frac{E S T(V I) \pm R E C(V I, V F) \pm T R A N F(V I, V F)-E S T(V F)-\text { Outros }_{\text {servicos }}}{\sum_{j=1}^{n} Q S_{j} x \frac{C M}{Q S} j x \frac{C M B}{M C} j}-1\right] x 100$

Utilizando-se os dados das Tabelas 6.10, 6.11 e 6.12(b) chega-se aos indicadores globais de perdas de materiais por obra (Tabela 6.15). 
Tabela 6.15 Indicador global de perdas de material - obra ${ }^{102}$

\begin{tabular}{c|l|c|c|c}
\hline Código & \multicolumn{1}{|c|}{ Material } & Creal & Cref. & (\%) \\
\hline 07 & Aço & 12.200 & 10420 & 17 \\
\hline 05 & Concreto Usinado & 650 & 620 & 5 \\
\hline 19 & Gesso & 56.000 & 47259 & 18 \\
\hline 16 & Placa cerâmica & 70.000 & 63647 & 10 \\
\hline 13 & Condutor & 4.500 & 4280 & 5 \\
\hline 12 & Eletroduto & 5.200 & 4400 & 18 \\
\hline 01 & Areia & 49 & 45 & 9 \\
\hline 02 & Cimento Portland & 12.000 & 10582 & 13 \\
\hline 10 & Cal & 7.000 & 6078 & 15 \\
\hline 18 & Tinta látex & 400 & 309 & 29 \\
\hline
\end{tabular}

\subsubsection{Indicadores parciais}

O cálculo dos indicadores parciais deverá ser feito de acordo com as fórmulas existentes nos respectivos procedimentos. Em linhas gerais, o cálculo consiste na comparação entre as médias ponderadas dos valores medidos e os seus respectivos valores de referência ${ }^{103}$. São exemplos deste tipo de cálculo a variação da espessura das lajes, largura das vigas, espessura do emboço,

\footnotetext{
102 Note que, tendo-se uma única especificação de material, o indicador global de perda por obra é igual ao indicador global por serviço.
} 
entre outros, em relação aos seus respectivos valores de referência. Uma outra modalidade indicador parcial, diz respeito àqueles que podem estar indiretamente associados à ocorrência de perdas. Como exemplos, citam-se: o percentual de blocos cortados na parede, que pode estar favorecendo o aumento da perda global de blocos, na medida em que ao se cortar os blocos, pode-se ter maiores quebras; percentual de sacos rasgados no recebimento, que podem estar gerando perda de material no manuseio, podendo ter reflexos nos valores de perdas determinados; entre outros.

\subsubsection{No âmbito da amostra de obras}

O processamento dos dados no âmbito da amostra de obras consiste em estabelecer estatísticas (média, mediana) dos indicadores globais de perdas e consumos de materiais, assim como em estabelecer medidas de dispersão, como o desvio padrão, a diferença entre quartis e valores máximo e mínimo.

Conforme ressaltado anteriormente, foi elaborado um programa de banco de dados contendo as principais informações para o cálculo de tais estatísticas, cuja estrutura e conteúdo serão apresentados de forma sim plificada.

Basicamente, a partir de registros específicos (Tabelas 6.16 e 6.17), procedese a entrada dos dados, já totalizados anteriormente para cada canteiro de obras, conforme citado no item 6.5.1.1.

\footnotetext{
${ }^{103}$ Por exemplo, uma sobrespessura de contrapiso de $50 \%$ num pano de $20 \mathrm{~m}^{2}$ é mais relevante que outra de $60 \%$ num pano de $10 \mathrm{~m}^{2}$.
} 
Tabela 6.16 Registro do arquivo - Indicador global de perda por obra

\begin{tabular}{c|l|c}
\hline Campo & Descrição & Exemplo \\
\hline Codobra & Código da obra & BR000 \\
\hline Codmat & Código do material & 05.01 .03 .00 .00 \\
\hline Estvi & Estoque na data VI & 0 \\
\hline Rec & Quantidade recebida & 500 \\
\hline Transf & Quantidade transferida & 0 \\
\hline Estvf & Estoque VF & 0 \\
\hline QS & Quantidade de serviço & 400 \\
\hline CM/QS & Consumo de material por unidade de serviço & 1 \\
\hline CMB/MC & Consumo de material básico por material composto & 1 \\
\hline
\end{tabular}

Tabela 6.17 Registro do arquivo - Indicador global de perda por serviço e por serviço pós-estocagem

\begin{tabular}{c|l|c}
\hline Campo & Descrição & Exemplo \\
\hline Codobra & Código da obra & BR001 \\
\hline Codmat & Código do material & 07.02 .03 .03 .00 \\
\hline Codserv & Código do serviço & 05.07 .2 .1 .2 .0 .0 .0 \\
\hline QS & Quantidade de serviço & 4.500 \\
\hline CM/QS & Consumo de material por unidade de serviço & 250 \\
\hline CMB/MC & Consumo de material básico por material composto & 0,02 \\
\hline Consreal & Consumo real & 25.000 \\
\hline
\end{tabular}


A partir da entrada destas informações, faz-se o processamento das mesmas, conforme os algoritmos simplificados apresentados na forma de fluxograma nas Figuras 6.21 e 6.22. O uso do algoritmo mostrado na Figura 6.21 permite a automatização do cálculo das perdas globais. Neste exemplo, as perdas seriam de $25 \%$ para o uso das informações contidas na Tabela 6.16 e de $11 \%$ para o caso dos dados contidos nada Tabela 6.17. Utilizando-se os dados do registro exemplificado na Tabela 6.16 obtém-se também o indicador global de consumo por serviço pós-estocagem. No caso exemplificado, o valor deste indicador seria 5,65 unidades do material/unidade de serviço.

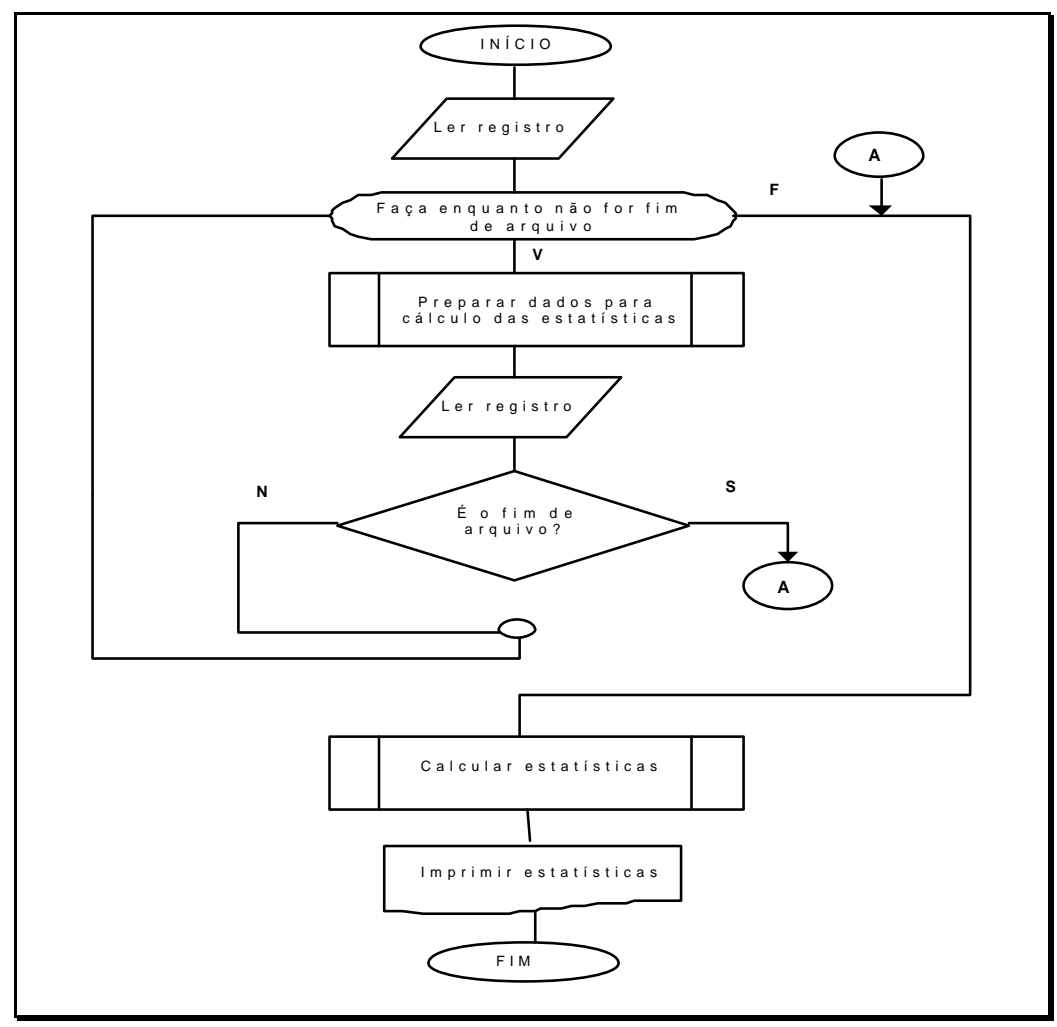

Figura 6.21 Fluxograma para o processamento dos dados para a obtenção das estatísticas relativas ao indicador global de perdas de material por obra e por serviço 


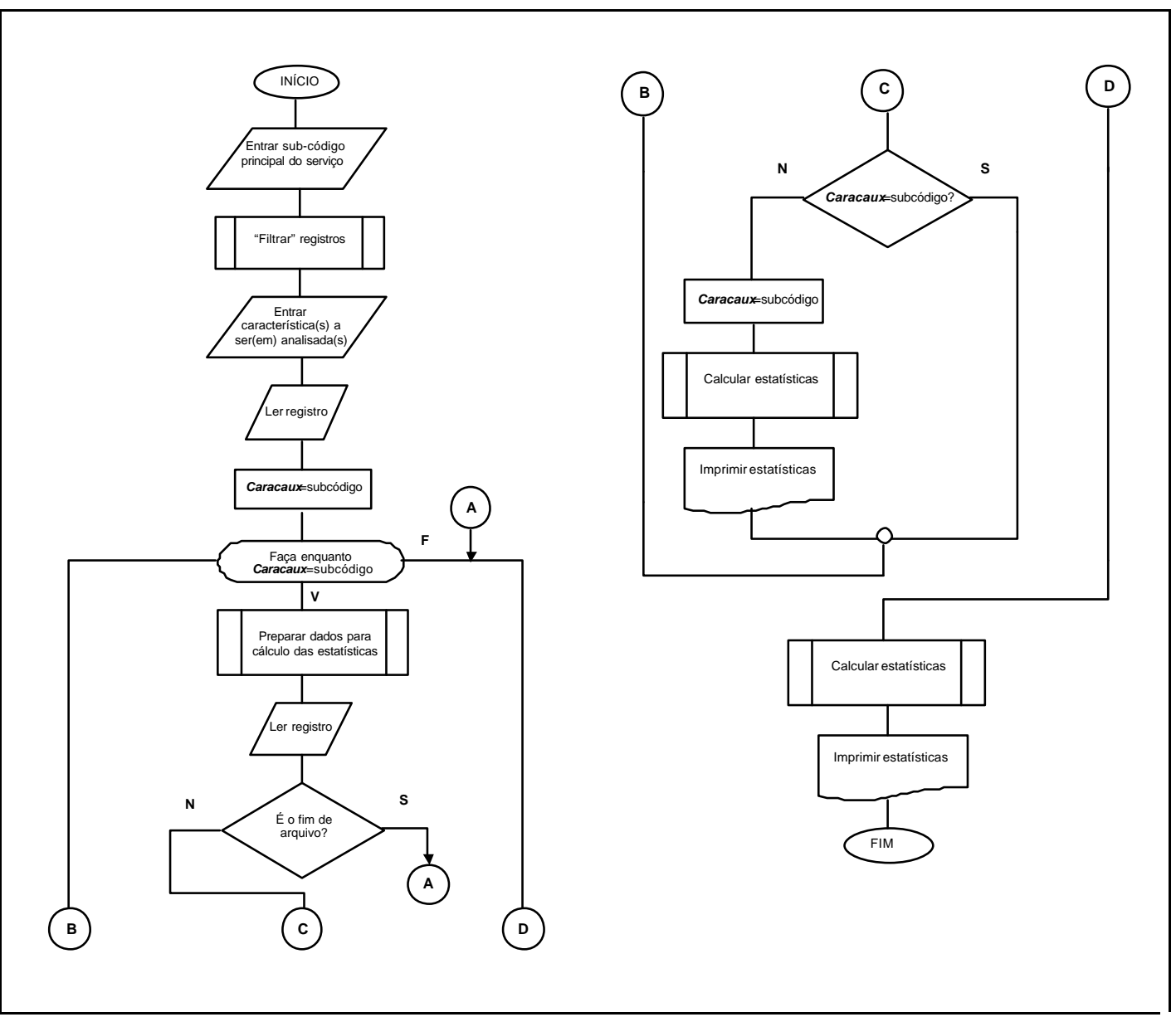

Figura 6.22 Fluxograma para o processamento dos dados para a obtenção das estatísticas relativas ao indicador global de perdas de material por serviço e por serviço pósestocagem: comparações entre estatísticas de serviços e materiais com características diferentes

Cabe ressaltar que o cálculo do indicador global de perda por obra é feito sem levar em consideração a especificação detalhada dos materiais, conforme algoritmo apresentado na Figura 6.21. Tratando-se, no entanto, do cálculo do indicador global de perda e/ou consumo de materiais por serviço ou por serviço pós-estocagem, este pode ser realizado considerando as especificações e características detalhadas dos materiais e serviços respectivamente, conforme algoritmo apresentado na Figura 6.22. 
Dentre as diversas possibilidades de resultados, são apresentados, a título de exemplo, as estatísticas comparativas obtidas através da experimentação desta metodologia no âmbito da pesquisa FINEP (Tabela 6.18).

Tabela 6.18 Comparação entre estatísticas: tipo de material constituinte e equipamento de transporte de blocos (AGOPYAN et al. 1998d)

\section{Resultados gerais (especificação abrangente)}

\begin{tabular}{c|c|cc|c|c|c}
\hline Média (\%) & $\begin{array}{c}\text { Mediana } \\
(\%)\end{array}$ & Desvio P. & $\begin{array}{c}\text { Dif. Quartis } \\
(\%)\end{array}$ & Mínimo (\%) & Máximo (\%) & $\mathrm{n}$ \\
\hline 17 & 13 & 12 & 11 & 3 & 48 & 37 \\
\hline
\end{tabular}

Tipo de material (subespecificação do material)

\begin{tabular}{lc|c|c|cc|c|c}
\hline Categorias & $\begin{array}{c}\text { Média } \\
(\%)\end{array}$ & $\begin{array}{c}\text { Mediana } \\
(\%)\end{array}$ & Desvio P. & $\begin{array}{c}\text { Dif. Quartis } \\
(\%)\end{array}$ & $\begin{array}{c}\text { Mínimo } \\
(\%)\end{array}$ & $\begin{array}{c}\text { Máximo } \\
(\%)\end{array}$ & $\mathrm{n}$ \\
\hline Bloco cerâmico & 18 & 14 & 12 & 11 & 5 & 48 & 21 \\
\hline Bloco de concreto & 10 & 11 & 5 & 6 & 3 & 20 & 9 \\
\hline Tijolo cerâmico & 21 & 15 & 14 & 15 & 10 & 48 & 7 \\
\hline
\end{tabular}

Tipo de equipamento de transporte (subespecificação do serviço)

\begin{tabular}{l|c|c|c|c|c|c|c}
\hline \multicolumn{1}{c|}{ Categorias } & Média (\%) & $\begin{array}{c}\text { Mediana } \\
(\%)\end{array}$ & $\begin{array}{c}\text { Desvio } \\
\mathrm{P} .\end{array}$ & $\begin{array}{c}\text { Dif. Quartis } \\
(\%)\end{array}$ & $\begin{array}{c}\text { Mínimo } \\
(\%)\end{array}$ & $\begin{array}{c}\text { Máximo } \\
(\%)\end{array}$ & $\mathrm{n}$ \\
\hline $\begin{array}{l}\text { Páletes/carrinho } \\
\text { específico }\end{array}$ & 16 & 12 & 11 & 11 & 3 & 48 & 18 \\
\hline Outros & 18 & 13 & 13 & 8 & 5 & 48 & 19 \\
\hline
\end{tabular}

\subsection{Análise dos resultados}

Como conseqüência das possibilidades de processamento dos dados coletados, a análise dos resultados pode se dar tanto no âmbito do canteiro de obras, mais especificamente nos serviços nos quais o uso dos materiais foi 
avaliado, e no âmbito da comparação entre resultados de mesmos serviços numa amostra de obras diferentes.

\subsubsection{No âmbito do canteiro de obras}

Ao se analisar o uso de materiais em cada serviço, tem-se um esclarecimento muito maior quanto aos consumos/perdas dos mesmos na obra como um todo. Por exemplo, constatar que uma obra tem perdas de $50 \%$ de cimento é muito menos importante que saber que existe uma perda de $10 \%$ do cimento no assentamento da alvenaria e $80 \%$ no revestimento de paredes.

Nesta etapa, procura-se explicar os índices de perdas/consumos detectados no período de coleta e, para isso, faz-se uso das classificações dos indicadores de perdas/consumos apresentadas até aqui. Em outras palavras, esta análise consiste em explicar os indicadores globais de perdas/consumos obtidos no âmbito dos serviços e, para isso, recorre-se aos indicadores parciais relacionados ao uso do material no referido serviço.

Entretanto, somente os valores dos indicadores parciais podem não explicar totalmente o indicador global. No período concernente, podem haver ocorrências anormais geradoras de perdas como, por exemplo, desabamento de paredes pela ação de vento, rejeição de caminhão de concreto por quebra do equipamento de transporte da obra, entre outros.

Portanto, resumidamente, a explicação destes indicadores deve-se dar pela "somatória" das perdas mensuradas através dos indicadores parciais e das perdas decorrentes de ocorrências anormais nos canteiros de obras. 
Com relação à primeira parcela de explicação, vale salientar que a relação entre os percentuais dos indicadores globais e parciais pode não ser direta. Como exemplo, a perda global do concreto usinado de $10 \%$ não é explicada totalmente pelo indicador parcial de variação da espessura de lajes, caso este seja por exemplo $10 \%$, pois esta parcela diz respeito apenas a um determinado volume de concreto usinado (volume das lajes, somente). Portanto, nestes casos, deve-se fazer a ponderação entre os índices parciais levantados e as respectivas quantidades de serviço. Assim, a titulo de exemplo, observe os dados apresentados na Tabela 6.19.

Tabela 6.19 Exemplo para o cálculo da explicação do indicador global uso de concreto usinado na estrutura de concreto armado

\begin{tabular}{l|c|c}
\hline Elemento & Volume especificado $\left(\mathbf{m}^{\mathbf{3}}\right)$ & Indicador global (\%) \\
\hline Lajes & 70 & $\mathbf{2}$ \\
\hline Vigas & 20 & \\
\hline Pilares + escadas & 10 & \\
Total especificado & 100 & \\
\hline Total utilizado & 123 & \\
\hline
\end{tabular}

Indicadores parciais

\begin{tabular}{l|c}
\hline Variação percentual da espessura da laje em relação à especificada & 20 \\
\hline Variação percentual da largura da viga em relação à especificada & 30 \\
\hline
\end{tabular}

De acordo com estes dados, verifica-se que, apesar de o indicador global de perda por sobrespessura indicar $20 \%$, esta não é a percentagem com que esta parcela de perda contribui para a explicação do indicador global de perda (no 
caso, $23 \%$ ), pois o cálculo da representatividade desta parcela de perda é feito de acordo com a seguinte expressão, para o caso específico deste exemplo:
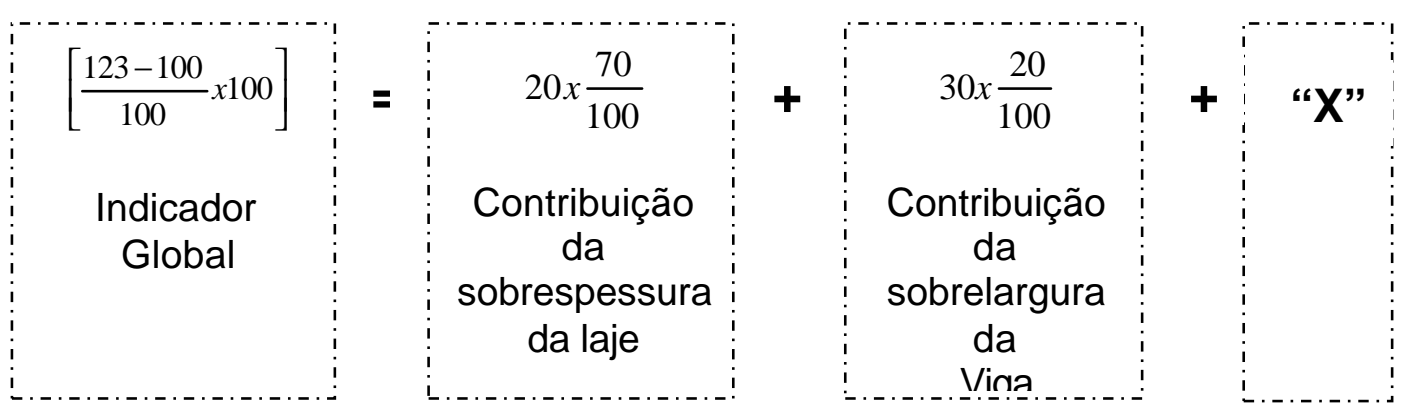

De acordo com estes resultados, $60,9 \%$ (14\% em $23 \%$ ) das perdas totais detectadas são relativas à sobrespessura das lajes enquanto que $26,1 \%$ (6\% em $23 \%$ )são relativas à sobrelargura das vigas. Conforme ilustra a fórmula, a incógnita "X" (parte ainda não explicada das perdas) corresponde a 3,3\% ou, percentualmente em relação ao indicador global, resta explicar 13\%. Pode-se incluir nesta parcela não explicada, o entulho gerado durante a aplicação do material e no transporte ou, pode-se ainda, considerar tal diferença atribuível a uma possível diferença entre a quantidade solicitada e a realmente entregue, assim como, a alguma ocorrência anormal verificada durante o período de coleta.

Note que, apesar de a variação percentual da largura das vigas ser maior do que a variação percentual da sobrespessura das lajes, esta não é a mais significativa parcela de perda, o que mostra a importância e o cuidado ao se analisar os resultados.

Há que se ressaltar também que alguns dos indicadores parciais não exprimem diretamente a perda, mas sim, indicam a maior probabilidade de ocorrência da 
perda, como é o caso, por exemplo, do percentual de blocos cortados na parede conforme citado anteriormente. Nestas situações, cabem, seguramente, avaliações especiais quanto à ocorrência do não reaproveitamento dos blocos cortados e da incidência da quebra total do mesmo no ato do corte.

Em se tratando do estudo das argamassas, a análise fica mais enriquecida quando se obtém indicadores parciais de consumo, além dos de perda. Por exemplo, no caso do uso da argamassa no serviço de alvenaria, a obtenção de indicadores de consumo pode identificar as parcelas de argamassa que ficam incorporadas nos furos dos blocos, uma vez que a variação da espessura das juntas já se constitui num outro indicador parcial.

Por fim, nesta etapa, a equipe de coleta deverá ter o senso crítico e o bom senso de levantar as hipóteses da ocorrência das perdas e, se for o caso, voltar ao canteiro de obras para a realização de medições complementares com a finalidade de comprovar as hipóteses levantadas. A própria criação de indicadores relevantes não contemplados na metodologia pode ser um bom procedimento.

Identificadas as principais explicações das perdas para um determinado material num determinado serviço, torna-se interessante reunir estas informações num formulário que contemple, além das explicações, as especificações do material e características do serviço, e, principalmente, os valores de referência adotados. Um modelo deste formulário é apresentado na Figura 6.23. Note o espaço reservado para a colocação dos resultados dos indicadores parciais relativos ao material e serviço em estudo. 


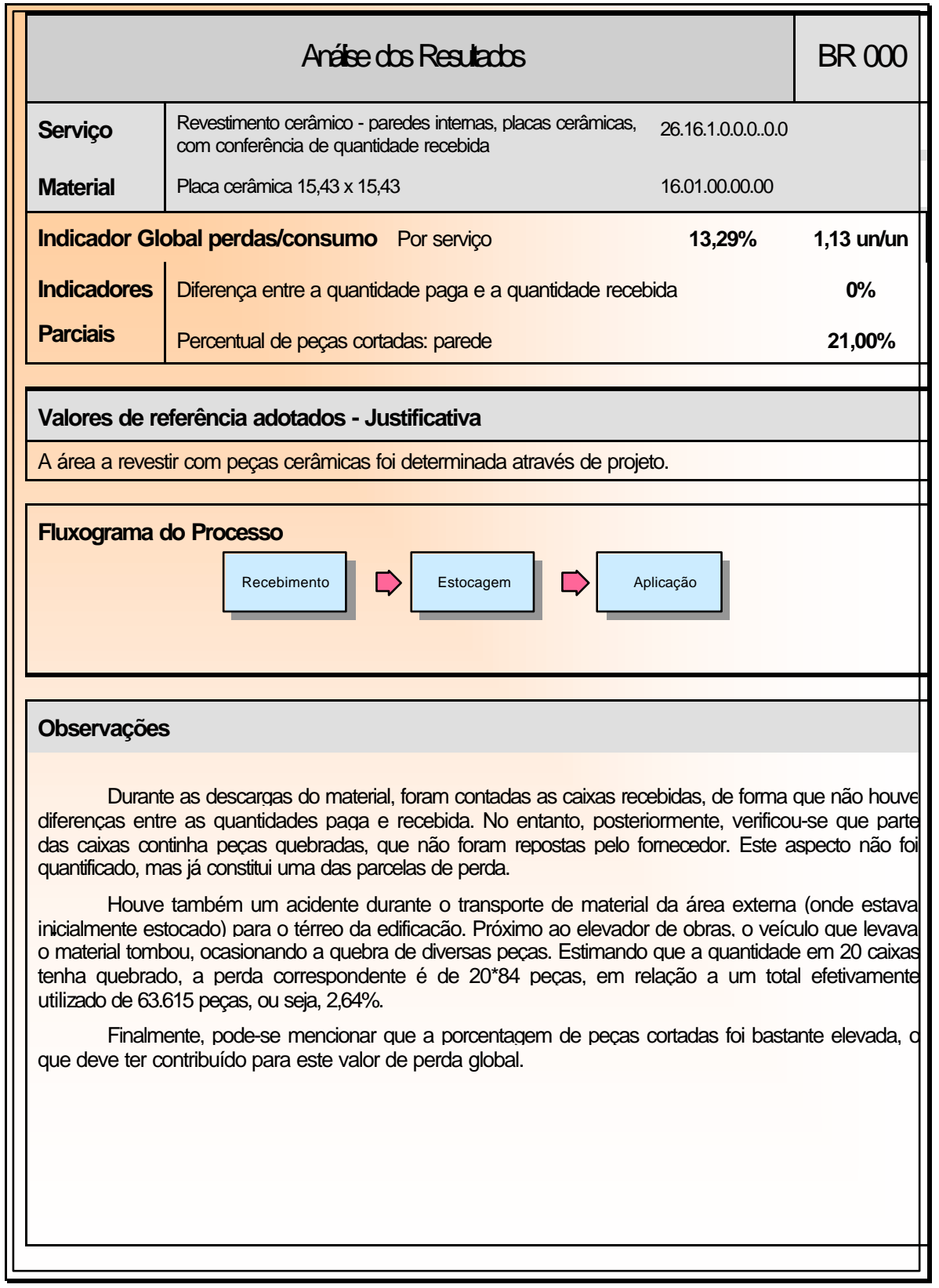

\section{Figura 6.23 Formulário de análise dos resultados (AGOPYAN et al.} 1998e) 


\subsubsection{No âmbito da amostra de obras}

Esta análise consiste na identificação dos pontos positivos ou fatores que contribuam para a redução dos índices de perdas do material, num determinado serviço e para balizar discussões quanto às alternativas para a redução dos índices de perdas a patamares aceitáveis.

Quanto a esta modalidade de análise, alguns pontos merecem ser destacados:

(a) deve-se considerar o tamanho da amostra para a realização de afirmações seguras quanto à significância de determinado fator na ocorrência de perdas;

(b) as perdas podem estar associadas não somente a um fator, mas sim, a um conjunto de fatores;

(c) diante da grande dispersão dos resultados, verificados nas principais pesquisas realizadas até o momento, deve-se levar em consideração não somente a média das perdas, mas sim, o desvio padrão, valores máximos e mínimos e, principalmente, dar preferência à mediana em detrimento da média, que não é distorcida quando se tem resultados muito discrepantes.

Tendo-se levado em consideração estes pontos, a análise dos resultados, considerando-se as especificações dos materiais e características dos serviços, é facilitada pelo sistema de códigos estabelecido nesta metodologia. Assim, as possibilidades de análise podem focar os seguintes fatores:

- tipo de equipamento e forma de transporte; 
- existência ou não de projeto específico;

- tipo de equipamento/ferramenta de aplicação do material;

- políticas de contabilização da quantidade recebida no canteiro;

- dosagem em massa ou com uso de equipamento dosador de materiais básicos;

- produção de kits, entre outros.

Da mesma forma, pode-se verificar a relação entre o indicador global e os indicadores parciais referentes ao serviço. São exemplos:

- representatividade da sobrespessura do revestimento quanto ao indicador global;

- relação entre percentual de placas cerâmicas cortadas e o indicador global, entre outros;

Além destes resultados, pode-se ainda estabelecer um diagrama de dispersão sob a forma de barras, cuja finalidade é a de identificar a faixa onde se concentra a maioria dos casos amostrados, conforme exemplo apresentado na Figura 6.24 . 


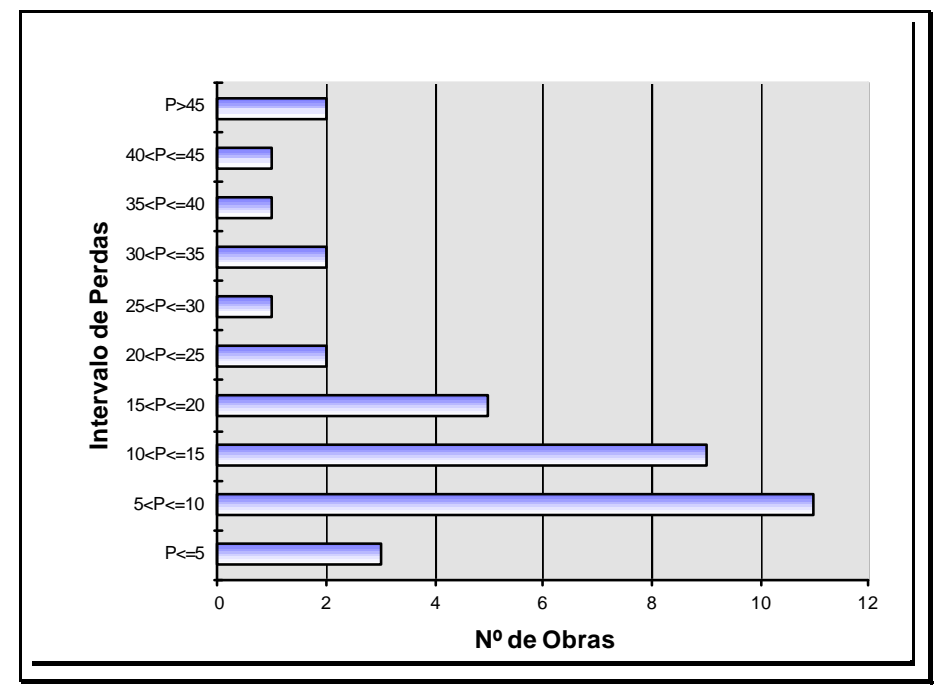

Figura 6.24 Distribuição amostral dos resultados de perdas: blocos e tijolos (AGOPY AN et al., 1998d)

\subsection{Planejamento da Pesquisa}

O sucesso de qualquer atividade a ser desenvolvida é conseqüência, entre outros aspectos, de um bom planejamento, e o sucesso da aplicabilidade desta metodologia, em qualquer localidade, está condicionado ao planejamento da pesquisa, principalmente por envolver um número amplo de materiais e serviços.

Além das diversidades inerentes ao próprio objeto de estudo, tem-se ainda o aspecto relacionado à capacidade da equipe de coleta em assimilar o conteúdo da metodologia e, principalmente, implantar as ações nos canteiros de obras, o que muitas vezes depende da cooperação e envolvimento da empresa e da obra em estudo. 
Em função das principais dificuldades encontradas na aplicação da metodologia pela equipe de coleta de dados da Universidade de São Paulo, discorre-se, a seguir, sobre o planejamento adequado da pesquisa para que estas dificuldades sejam amenizadas.

A discussão, a seguir, insere-se num contexto de continuidade de pesquisas desta natureza, sob a coordenação de, pelo menos, um pesquisador em cada Instituição responsável por um grupo de obras.

\subsubsection{Recursos humanos}

O pesquisador responsável pelo trabalho, que deve centralizar as responsabilidades quanto à condução geral dos trabalhos, deve organizar uma equipe de trabalho que permita a obtenção de resultados confiáveis.

A equipe de coleta de dados, para um grupo de 6 obras em estudo deve, obrigatoriamente, possuir uma pessoa com dedicação em tempo integral, de preferência com experiência em canteiros de obras e com formação relacionada à área. Esta pessoa tem a função de organizar a equipe de coleta de dados e, eventualmente, realizar tarefas que os demais integrantes estejam impossibilitados de realizar, por falta de tempo ou pela dificuldade inerente à tarefa.

A equipe de coleta deverá ser constituída, além do responsável pela equipe, denominado analista, por estagiários que, de preferência, poderão ser alunos de engenharia civil, arquitetura ou de tecnologia de edificações. De preferência, é interessante que os mesmos já tenham œnhecimentos de materiais e 
tecnologia de construção civil e que tenham disponibilidade de pelo menos 3 meios períodos por semana.

Estes recursos humanos podem advir da própria Instituição ou, até mesmo, da obra onde se está realizando o estudo, pois é comum a empresa querer envolver seu próprio estagiário na pesquisa. De certa forma, este perfil de estagiário (empresa) acarreta algumas facilidades à coleta de dados como, por exemplo, as advindas de um maior conhecimento dos projetos em estudo e do conhecimento da evolução dos serviços na obra.

Porém, alguns cuidados devem ser levados em consideração ao se utilizar estagiário da própria obra:

- este deverá estar fortemente integrado à a pesquisa; de forma alguma o mesmo pode considerar as tarefas da obra como sua única obrigação em detrimento às atribuições relativas à pesquisa. Experiências têm mostrado que entre as atividades do dia-a-dia da obra e a coleta de dados sobre perdas de materiais, esta última pode ficar relegada a segundo plano, se o responsável da obra não tiver consciência da importância do envolvimento de tal estagiário na pesquisa; ${ }^{104}$

- deve-se programar atividades semanais para o controle do andamento das atividades realizadas por este estagiário, principalmente se ele não for membro da Instituição que está realizando a pesquisa; de forma alguma

\footnotetext{
${ }^{104} E$ comum uma empolgação por parte do estagiário no início da pesquisa, pois estará realizando uma atividade diferente; porém, com o passar do tempo, ele começará a achar que sua remuneração é insuficiente em função do acúmulo das atividades em canteiro. Se não bastasse esta possível desmotivação, existem casos onde o engenheiro responsável, se sentindo avaliado pela pes quisa, força o estagiário a desempenhar primeiramente as atividades da obra, e não as relativas à coleta de dados.
} 
deve-se deixá-lo distanciar das discussões inerentes à pesquisa. Aconselha-se a reunião semanal ou quinzenal entre o mesmo e o analista.

Por fim, o pesquisador responsável pela pesquisa, juntamente com o analista ou demais pesquisadores, devem incentivar e motivar os estagiários no decorrer da coleta de dados, pois é normal o desânimo na realização de atividades, em muitos casos repetitivas e desestimulantes, enquanto não ocorrer a análise dos dados.

\subsubsection{Periodicidade de visitas às obras e número de estagiários}

A periodicidade de ida às obras depende do ritmo dos serviços e da disponibilidade de tempo dos estagiários. Experiências decorrentes da coleta de dados em São Paulo apontam o número de 2 estagiários por obra, indo pelo menos 3 meios períodos cada um na obra por semana. Aconselha-se também que os mesmos reservem um destes períodos para irem, ao mesmo tempo, na obra realizar tarefas comuns.

\subsubsection{Organização da equipe na coleta de dados}

Embora a equipe de coleta de dados, para o caso de uma obra, seja constituída em geral por dois estagiários, assessorados em parte por um analista, há certas ocasiões onde há a necessidade de uma força de trabalho

maior. É o caso, por exemplo, da contabilização dos estoques de materiais e de serviços nas datas VI e VF. Para a execução destas atividades aconselhase que, pelo menos, haja a participação de mais uma ou duas pessoas. Enquanto duas contabilizam os estoques, as outras duas encarregam-se da 
contabilização dos serviços ${ }^{105}$. Ao analista cabe a supervisão das medições e eventuais ajudas nas atividades que exigem maior esforço de coleta.

Uma outra atividade, que pode ter a participação maior de estagiários, referese à quantificação dos serviços antes da data $\mathrm{VI}$; os estagiários extras devem atuar sob a orientação do analista e dos estagiários responsáveis pela coleta de dados na obra em estudo.

\subsubsection{Comprometimento da empresa e da obra para com a pesquisa}

A elaboração de um excelente planejamento das atividades a ser realizadas não é condição suficiente para o sucesso da aplicação da metodologia. Muitas destas atividades dependem, essencialmente, da colaboração dos envolvidos, por parte da empresa e da obra.

Dentre estas atividades, pode-se citar:

- organização dos estoques de materiais para a realização das vistorias inicial e final;

- implantação de um mecanismo para o controle de saída dos materiais básicos dos estoques.

O sucesso deste comprometimento depende, entre outras coisas, da capacidade da equipe em saber "vender" a idéia aos responsáveis pela obra, através de palestras e reuniões para discussão dos mecanismos possíveis de ser implantados durante a coleta de dados e, principalmente, da participação

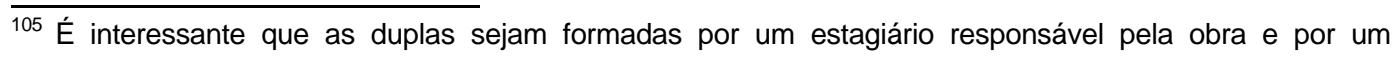


dos responsáveis pelas empresas em querer este sucesso, dando liberdade à implantação destes mecanismos de controle.

\subsubsection{Escolha das datas VI e VF}

Em face das atividades a ser desenvolvidas nestas datas, torna-se indispensável que as mesmas estejam associadas aos dias em que a obra esteja com os serviços paralisados, reduzindo, assim, erros de coleta de dados.

Além desta necessidade, pode-se ainda eleger outras situações que visem facilitar a coleta de dados nestas datas. Com relação aos estoques de materiais, torna-se interessante que as vistorias iniciais e finais coincidam com a baixa quantidade de material estocado no canteiro. Com relação ao andamento dos serviços, fica evidente que a programação destas vistorias anteriormente ao início do serviço a ser analisado e após o término da totalidade do mesmo, evita a contabilização de serviços incompletos nas datas VI e VF respectivamente, além de proporcionar maior representatividade.

Da mesma forma, para alguns materiais, em face da dificuldade de se mensurar os estoques dos mesmos ou de se quantificar o serviço executado nas datas $\mathrm{VI}$ e VF, a postura anterior, recomendável em geral, torna-se obrigatória, enquadrando-se neste perfil, os seguintes os seguintes serviços:

- instalações elétricas/condutores: a maior dificuldade reside na determinação das quantidades de serviço, quando parte do mesmo já tenha sido estagiário auxiliar. 
executado até a data $\mathrm{VI}$; como solução, o serviço de enfiação deverá ser estudado em sua totalidade, ou seja, a vistoria inicial (VI) deverá ocorrer antes do início do serviço e a vistoria final (VF), após o término do mesmo;

- pintura interna e externa/tinta: valem as mesmas considerações feitas no item anterior, pois a dificuldade reside na determinação do número de demãos já aplicadas;

- armação/aço: a dificuldade do estudo do aço reside na contabilização do estoque deste material e na possibilidade de as pontas geradas ao longo da execução da armação ser utilizadas no final da estrutura; para se evitar imprecisões, o estudo deste material no serviço de armação deverá estar compreendido entre um momento anterior ao iníci do serviço, o que elimina a necessidade de medir o estoque na data VI, e o fim da execução da estrutura (redução do estoque do material e aproveitamento das pontas geradas no decorrer da execução da estrutura já realizado).

Evidentemente, tais situações são desejáveis, porém, na prática, nem sempre ocorrem. Caberá à equipe de coleta avaliar as imprecisões decorrentes das soluções adotadas.

\subsubsection{Período de coleta de dados em canteiro}

A definição do período de coleta de dados dependerá de muitos fatores como, por exemplo, o ritmo de execução dos serviços, a representatividade das medições e também o escopo da pesquisa a ser realizada, principalmente no 
que diz respeito à dinâmica do ciclo medição-processamento-análiseintervenção-nova medição.

Além destes fatores, a equipe de coleta deverá avaliar também a precisão das medições efetuadas no canteiro, principalmente no que se refere aos estoques de materiais e de serviços. Quanto maior o período de coleta, maior a "diluição" de eventuais erros em tais levanta mentos.

Acredita-se que a coleta de dados num período entre 3 e 6 meses consiga equilibrar estes fatores.

\subsubsection{Planejamento das atividades a ser realizadas antes da data VI}

O completo conhecimento dos passos a serem seguidos para a obtenção das informações sobre consumos e/ou perdas de materiais é uma das condições essenciais para o sucesso da aplicação desta metodologia. Este conhecimento não deve ser resumido apenas ao âmbito dos procedimentos e dos critérios de medição, mas também, ao âmbito do momento e periodicidade da coleta destas informações.

Algumas tarefas têm o seu momento exato de execução pois, caso contrário, corre-se o risco de acumulá-las e, conseqüentemente, interferir-se na qualidade do andamento dos trabalhos.

Visando evitar os acúmulos de tarefas, listam-se, na seqüência, as principais a ser realizadas antes da data da vistoria inicial:

- obtenção e compreensão dos projetos dos serviços objetos de estudo; 
- levantamento do quantitativo dos serviços objetos de estudo;

- levantamento dos valores de referência para o cálculo dos consumos de referência;

- implantação do controle de saída dos materiais básicos dos estoques;

- organização dos estoques de materiais;

- treinamento/conscientização das pessoas da empresa de alguma maneira relacionadas com a pesquisa, entre outros. 


\section{CAṔ́tULO 7}

\section{CONSIDERAÇÕES RNAIS}

Embora seja de suma importância, em termos econômicos ou até mesmo em termos ambientais, a quantificação das perdas ou consumos de materiais nos canteiros de obras não é uma tarefa fácil e, principalmente, sua avaliação deve ser conduzida de forma séria, perfeitamente alicerçada nos principais conceitos relacionados ao tema, nas experiências adquiridas junto ao setor produtivo e através do estudo aprofundado das raras pesquisas existentes sobre o assunto.

A seriedade que deve ser embutida neste estudo justifica-se pelo fato de que a má interpretação dos resultados pode levar à descrença quanto à verdadeira situação dos canteiros, no que diz respeito à ocorrência de perdas de materiais, dificultando assim, a adoção de possíveis ações voltadas para a redução das mesmas. Isto seria bastante danoso, à medida que as perspectivas almejadas com trabalhos desta natureza são exatamente as de abrir discussões junto ao setor produtivo no sentido de viabilizar alternativas para a redução destas perdas. 
Neste sentido, muito mais do que levantar números para os agentes que podem e devem mudar o possível panorama de ocorrência de perdas, há que torná-los suficientemente transparentes, possibilitando, assim, o seu completo entendimento.

Tornar tais números transparentes significa mostrar a estes agentes quais foram os critérios adotados em todas as fases de seu levantamento, a abrangência de tais números quanto à parcela ou etapa da cadeia produtiva à qual os mesmos se referem, quais foram os instrumentos e caminhos utilizados para a obtenção dos mesmos e, principalmente, enfatizar o caráter relativo do conceito de perdas.

O caminho para atender a estes requisitos consiste na elaboração de uma metodologia criteriosa, esclarecedora e, principalmente, transparente quanto aos aspectos sugeridos anteriormente.

Neste contexto, acredita-se ter contemplado neste trabalho, se não todos estes aspectos, pelo menos os mais relevantes, dentre os quais podem-se citar a elaboração estruturada de procedimentos de coleta, a proposição de diretrizes para o processamento dos dados e análise dos resultados obtidos, entre outros.

A consideração de tais aspectos neste trabalho garantiu um princípio básico, pilar de toda a idéia presente no desenvolvimento desta metodologia, qual seja: a padronização das ações para a obtenção de informações relativas às perdas e/ou consumos de materiais nos canteiros de obras. 


\subsection{Cumprimento dos objetivos}

A avaliação do conteúdo apresentado, seja no que diz respeito aos aspectos conceituais envolvidos, seja no grau de detalhamento utilizado, permite concluir que o presente trabalho cumpriu, em sua plenitude, os objetivos propostos anteriormente.

No que diz respeito ao estudo dos principais trabalhos realizados, a revisão incluiu as principais discussões nacionais e internacionais, incluindo, nesta gama, trabalhos preocupados com o levantamento de apenas uma das parcelas das perdas físicas de materiais (entulho), assim como trabalhos que trataram o assunto observando a totalidade das perdas, ou seja, incluindo as duas parcelas (entulho e material incorporado em excesso na edificação).

No que diz respeito ao levantamento de informações quanto à ocorrência de perdas ou consumos de materiais, apresentou-se uma linha de raciocínio de forma estruturada, que permitiu o seu pleno entendimento. Através deste raciocínio, as perdas podem ser avaliadas no âmbito da obra como um todo, no âmbito dos serviços ou, ainda, no âmbito das etapas subseqüentes à estocagem dos materiais, para aqueles materiais utilizados em vários serviços simultaneamente. Além desta abordagem analítica, as perdas podem ser avaliadas também quanto a uma única etapa pertencente ao fluxograma dos processos. Esta estruturação de indicadores de perdas e/ou consumo, aliada às diretrizes definidas quanto à análise dos resultados, permitiu a identificação de qual etapa do fluxograma dos processos possuía incidência de perdas mais 
significativa. Esta postura pode alavancar ações para a minimização da incidência destas perdas ocorridas em uma etapa específica, o que, seguramente, reflete-se na minimização das perdas globais.

No que diz respeito às causas e origens destas ocorrências, acredita-se que o conteúdo apresentado nos capítulos 2 e 4 forneceu subsídios valiosos quanto à detecção das mesmas. Este conteúdo foi contemplado nas séries de planilhas 5 e 6 que, de certa forma, "ensinam" ao construtor e, inclusive, ao coletor de dados, as boas práticas de organização e execução dos serviços abordados neste trabalho.

Se não bastassem estes aspectos, pode-se ainda enumerar uma série de questões não verificadas nos trabalhos anteriormente apresentados e contempladas nesta metodologia. Tudo isso vem corroborar com o sentimento de ter-se atingida a plenitude dos objetivos.

\subsection{Avanços em relação aos trabalhos anteriormente realizados}

A atuação no âmbito da pesquisa "Alternativas para a redução do desperdício de materiais nos canteiros de obras", não somente enriqueceu o desenvolvimento da metodologia aqui apresentada, como representou por si só, um grande avanço em relação aos trabalhos anteriormente realizados no Brasil e no exterior. Enquanto há 10 anos PINTO (1989) realizava a primeira avaliação concisa sobre as perdas em um único edifício, hoje este número passa seguramente de 80 canteiros de obras. Se não bastasse esta diferença, a consolidação de uma rede nacional de pesquisa proporcionou esta avaliação 
em canteiros de obras de 12 Estados brasileiros, envolveu 90 pesquisadores de 16 universidades (professores, estudantes de graduação e pós-graduação), além de 52 empresas (AGOPYAN et al., 1998a).

Além deste contexto, que permitiu a discussão quanto ao desenvolvimento da metodologia, o estudo dos trabalhos anteriormente realizados permitiu a identificação de alguns aspectos, não ou precariamente, abordados. Tais lacunas foram preenchidas com este trabalho.

Em se tratando dos materiais, pela primeira vez foram desenvolvidos procedimentos de coleta, processamento e análise sobre consumo/perdas de tintas, revestimento têxtil, eletrodutos e condutores elétricos, tubos para instalações hidráulicas/sanitárias e telhas e, conseqüentemente, dos serviços nos quais os mesmos são utilizados.

Como produtos imediatos, destaca-se a elaboração de um conjunto estruturado de planilhas de coleta de dados e de procedimentos específicos de coleta que, "a priori", garantem a padronização da coleta de dados.

Outro avanço relevante configura-se na ênfase no cálculo de indicadores globais de consumo e/ou perdas de materiais por serviço e, em certos casos, por serviço pós-estocagem, e não apenas no âmbito da obra. Tal fato possibilita a comparação entre resultados de serviços de várias obras, inclusive daqueles materiais utilizados em vários serviços simultaneamente, como é o caso dos materiais bás icos. Ressalta-se que o estudo das perdas/consumos de materiais pós-estocagem é algo inédito, nacional e internacionalmente. 
Com relação às contribuições para o processo de orçamentação, destaca-se a definição analítica dos consumos de referência, ou seja, identificaram-se as variáveis que definem este consumo e estabeleceram-se procedimentos para a quantificação das mesmas. Em todos os trabalhos realizados, tais valores de referência não foram totalmente explicitados.

Com relação ao processamento dos dados, a elaboração de um programa de banco de dados que possibilite resultados, levando-se em consideração as características dos materiais e das etapas do fluxograma dos processos dos serviços, também foi um produto inédito.

Em termos de análise dos resultados, enfatizou-se a avaliação não somente dos indicadores de perdas e sim, em certos casos, a análise dos indicadores de consumo, sempre indicando em quais circunstâncias os mesmos foram obtidos. Tal postura contribui para a minimização de erros de interpretação de resultados, obtidos em coletas que sigam a mesma metodologia aqui apresentada.

Por fim, além de todos estes aspectos apontados anteriormente, não se poderia deixar de relatar, neste momento, a importância que tal metodologia e os resultados obtidos através da sua aplicação, têm para a formação dos futuros engenheiros do país. Acredita-se ter reunido uma série de informações relevantes, cujo estudo configura-se numa lição a ser levada para toda a vida profissional. Espera-se, assim, que esta nova força de trabalho possa contribuir para o crescimento econômico do setor e do país. 


\subsection{Sugestões para a melhoria da metodologia desenvolvida}

Embora tenha-se conseguido contemplar diversos avanços em relação aos trabalhos anteriormente realizados, existem ainda pontos a melhorar no que diz respeito ao trabalho desenvolvido.

O primeiro deles consiste no aprofundamento do estudo das perdas e consumos de alguns materiais abordados neste trabalho, como, por exemplo, 0 aço e o bloco/tijolo. Este aprofundamento pode ser entendido como sendo a elaboração de outros indicadores além dos considerados neste trabalho, que permitam o pleno entendimento da incidência de perdas destes materiais ao longo das etapas do fluxograma dos processos. No caso do aço há uma carência de indicadores que abordem a parcela de perdas que fica incorporada em excesso nos elementos estruturais (diferença entre o comprimento de traspasse real e o previsto, diferença entre o espaçamento das barras real e 0 previsto, por exemplo), enquanto que no caso dos blocos, esta carência é verificada quanto à mensuração da parcela representada pelo entulho.

Um outro aspecto a ser melhorado consiste na simplificação da coleta, na tentativa de minimizar esforços ao se realizar a mesma. No entanto, não se pode confundir simplificação com eliminação de atividades essenciais para o entendimento das perdas/consumos de materiais. Por exemplo, embora tenhase a consciência do esforço necessário para levantarem-se indicadores específicos (como, por exemplo, o de consumo pós-estocagem, que implica no mapeamento da saída de material básico do estoque), não se justifica uma 
postura de eliminação de tal indicador em função da importância que o mesmo desempenha no entendimento das perdas. Simplificar aqui significaria perda de precisão.

No que diz respeito ao processamento dos dados, sugere-se melhorar o programa de banco de dados desenvolvido, com o objetivo de facilitar, principalmente, a entrada dos dados. Como conseqüência, tem-se também uma maior agilidade no processamento e uma melhoria da análise dos resultados.

\subsection{Sugestões para trabalhos futuros}

A postura adotada no desenvolvimento desta metodologia foi a de possibilitar uma "radiografia" do setor, no tocante às perdas e consumos de materiais nos canteiros de obras e se todas as ações e procedimentos contidos na mesma estão em consonância com tal postura.

Portanto, a mesma não foi desenvolvida com o intuito de reverterem-se, de forma imediata, os resultados obtidos pelas empresas e, conseqüentemente, de possibilitar às mesmas a atuação imediata no sentido de minimizar as perdas detectadas ainda durante a execução de uma obra em estudo.

Este fato fica evidente, por exemplo, quando estabelece-se um período longo de coleta de dados (aproximadamente 6 meses) para, som ente em seguida, terem-se os resultados em mãos, quando muitas vezes o serviço analisado já havia se encerrado. Esta postura deve-se à idéia de "diluírem-se" possíveis 
erros de medições de estoques e serviços, tornando os números mais confiáveis.

Neste sentido, o desenvolvimento de trabalhos com a postura de intervenção no próprio processo em avaliação, que possibilitem respostas rápidas ao pesquisador e ao construtor, configura-se numa das possibilidades para estudos futuros. Ressalta-se que iniciativas neste sentido já vem sendo efetuadas no âmbito do TGP-PCC-EPUSP.

A metodologia desenvolvida foca claramente a questão das perdas físicas de materiais nos canteiros de obras. No entanto, dentre as parcelas de perdas físicas, o trabalho focou com maior intensidade a representada pelo material incorporado em excesso. Neste sentido, sugere-se estudos que abordem com maior profundidade a parcela de perdas relativa ao entulho gerado nos canteiros de obras.

Ainda com relação às parcelas de perdas, porém sob o ponto de vista mais amplo, sugere-se que o assunto possa ser tratado levando-se em consideração a questão financeira, abordando, inclusive, a avaliação integrada dos outros recursos físicos envolvidos como, por exemplo, custo de equipamentos de transporte de entulho, mão-de-obra etc. Através desta avaliação financeira, conseguem-se subsidiar discussões mais profundas quanto a possíveis alternativas para a redução destas perdas.

Neste sentido, insere-se também, como sugestão para futuros estudos, a proposição de alternativas para a redução dos consumos, subsidiadas através 
desta avaliação financeira, que facilita a definição de perda economicamente evitável e inevitável.

Nesta investigação quanto às alternativas existentes para a redução do desperdício, acredita-se que se deva fazer um estudo aprofundado sobre as informações coletadas através da aplicação das planilhas das séries 5 e 6, as quais não foram totalmente exploradas no âmbito desta pesquisa, onde a metodologia foi desenvolvida.

Embora o trabalho esteja centrado na avaliação do processo produtivo, em muitos casos verificaram-se alterações no projeto original, impostas por proprietários ou, ainda, definidas pelos responsáveis pela execução em face da inexistência de detalhamento ou especificação adequada. Neste sentido, justifica-se também um estudo aprofundado sobre as perdas decorrentes destas alterações ou especificações não suficientemente claras, tomando-se como referência o projeto original ou, ainda, as especificações tecnicamente recomendadas.

Por fim, pelo fato de a coleta de informações para a definição dos indicadores envolver diversos setores da empresa como, por exemplo, o de orçamentação e o de elaboração e/ou coordenação de projetos, além do próprio canteiro de obras, seria desejável, adequar estas informações às necessidades de cada setor da empresa. Sugere-se, portanto, um estudo focando a integração destes setores, o que permitirá a inexistência de trabalhos repetitivos na coleta e análise de informações dentro da empresa. 


\subsection{Considerações complementares}

Em que pese a importância do estudo sobre perdas e consumos de materiais, o mesmo torna-se incompleto se não houver um comprometimento por parte das empresas construtoras e, principalmente, das instituições ligadas ao setor, como SINDUSCON, SENAI, SECOVI, SEBRAE, entre outros.

Os resultados apresentados nas diversas pesquisas realizadas apontam que existe uma parcela de perdas de materiais passíveis de redução. Neste sentido, todos os agentes envolvidos devem procurar soluções para viabilizar tal redução em lugar de entender que estudos desta natureza venham apenas a denegrir a imagem da Indústria de Construção Civil.

A avaliação contínua do desempenho dos processos quanto ao uso dos materiais nos canteiros de obras permite não só vislumbrar ações visando esta redução, mas também, fornecer números confiáveis para o subsidiar orçamentos e participação em processos de licitações com propostas mais realistas.

Além destes aspectos, que são de interesse direto de empresas de construção civil, há que se destacar também a questão da geração de entulho, economia de energia, em pauta nos dias atuais através de discussões relativas ao desenvolvimento sustentável.

Encerrou-se em 1998 um dos mais sérios estudos sobre este assunto já realizado internacionalmente. Sem dúvida, ele contribuiu e contribuirá para o 
estabelecimento de metas para as empresas construtoras e para o próprio setor.

Mas cabe observar que as empresas, o setor e o próprio país, dentro do cenário de alta competição nacional e internacional, carecem de uma constante revisão dos parâmetros de referência. Isso implica na necessidade de uma permanente reavaliação dos números que a aplicação desta metodologia pode gerar.

No que diz respeito ao uso dos materiais em obras de construção civil, a aplicação contínua destas avaliações, através de uma metodologia padronizada, constitui-se num grande desafio nacional na busca do aumento da produtividade no uso dos recursos físicos e, conseqüentemente, financeiros, contribuindo, assim, para o crescimento do país como um todo.

A metodologia para este desafio, acredita-se, já está consolidada. 


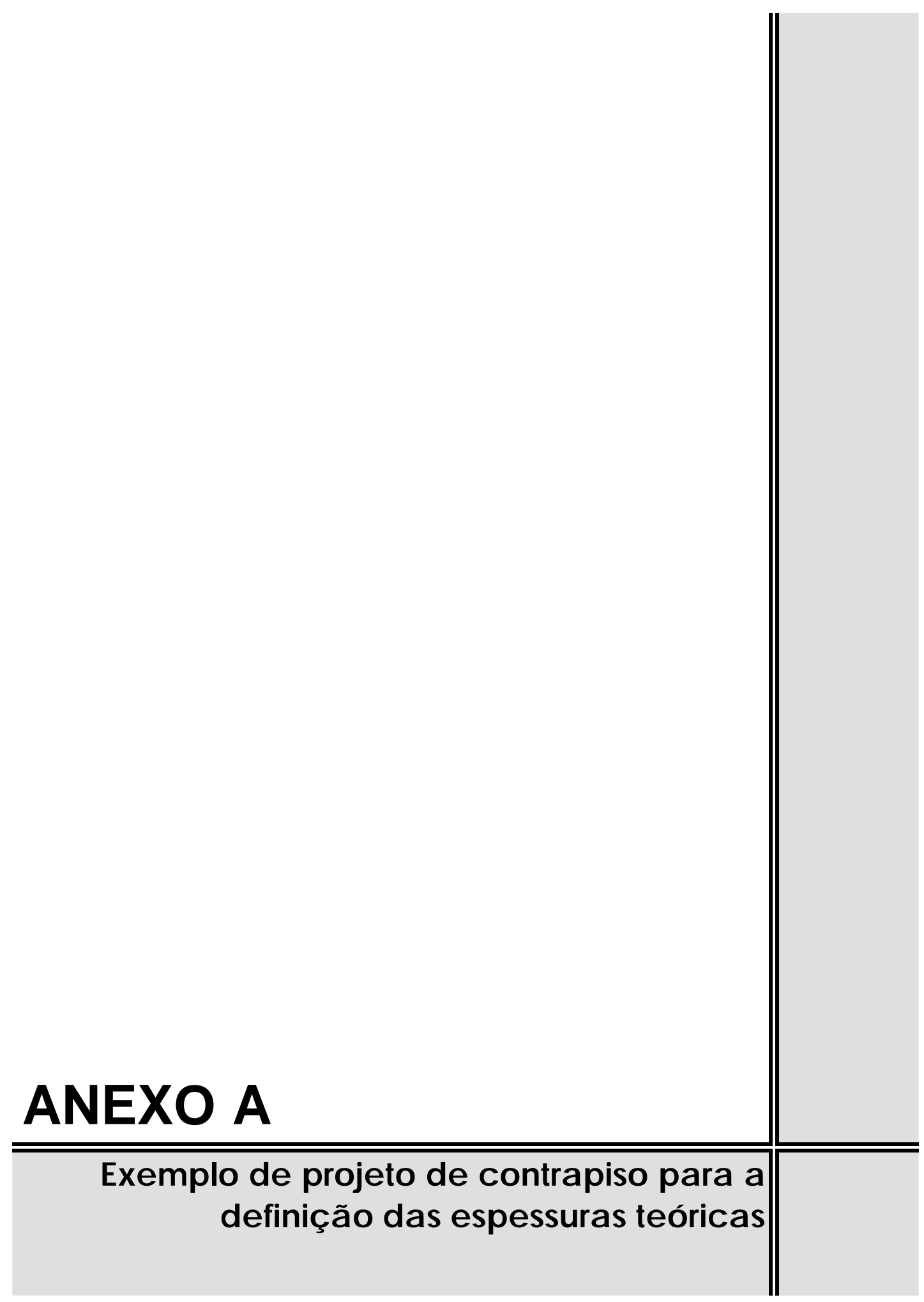


Tabela A1 Especificações do acabamento decorativo

\begin{tabular}{|c|c|c|c|c|c|c|}
\hline \multirow[t]{2}{*}{ Ambiente } & \multirow[t]{2}{*}{ Identificação } & \multicolumn{2}{|c|}{ Acabamento } & \multicolumn{2}{|c|}{ Fixação } & \multirow{2}{*}{$\begin{array}{l}\text { Espessura } \\
\text { total (mm) }\end{array}$} \\
\hline & & Tipo & $\begin{array}{c}\text { Espessura } \\
(\mathrm{mm})\end{array}$ & Tipo & $\begin{array}{c}\text { Espessura } \\
(\mathrm{mm})\end{array}$ & \\
\hline Hall & AMB A & Ardósia & 12 & Arg. adesiva & 6 & 18 \\
\hline Sala de Jantar & AMB B & Carpete & 6 & Cola & 1 & 7 \\
\hline Cozinha & AMB C & Cerâmico & 7 & Arg. adesiva & 3 & 10 \\
\hline Banheiro & AMB D & Cerâmico & 7 & Arg. adesiva & 3 & 10 \\
\hline Box & AMB E & Cerâmico & 7 & Arg. adesiva & 3 & 10 \\
\hline Dormitório & AMB F & Carpete & 6 & Cola & 1 & 7 \\
\hline
\end{tabular}

Tabela A2 Determinação das cotas e das espessuras do contrapiso por ambiente

\begin{tabular}{|c|c|c|c|c|}
\hline Ambiente & Identificação & $\begin{array}{c}\text { Cota do } \\
\text { contrapiso }(\mathrm{cm})\end{array}$ & $\begin{array}{l}\text { Cota do piso } \\
\text { acabado }(\mathrm{cm})\end{array}$ & $\begin{array}{l}\text { Espessura do } \\
\text { contrapiso }(\mathrm{mm})\end{array}$ \\
\hline Hall & AMB A & 102,7 & 104,5 & 27 \\
\hline Sala de Jantar & AMB B & 104,8 & 105,5 & 48 \\
\hline Cozinha & AMB C & 103,5 & 104,5 & 35 \\
\hline Banheiro & AMB D & 103,5 & 104,5 & 35 \\
\hline Box & AMB E & 102,5 & 103,5 & 25 \\
\hline Dormitório & AMB F & 104,8 & 105,5 & 48 \\
\hline \multicolumn{4}{|c|}{ ESPESSURA MÉDIA } & 36,3 \\
\hline & & \multicolumn{2}{|c|}{ ESPESSURA ESPECIFICADA } & 25,0 \\
\hline & & \multicolumn{2}{|l|}{ DIFERENÇA (\%) } & 45,2 \\
\hline
\end{tabular}




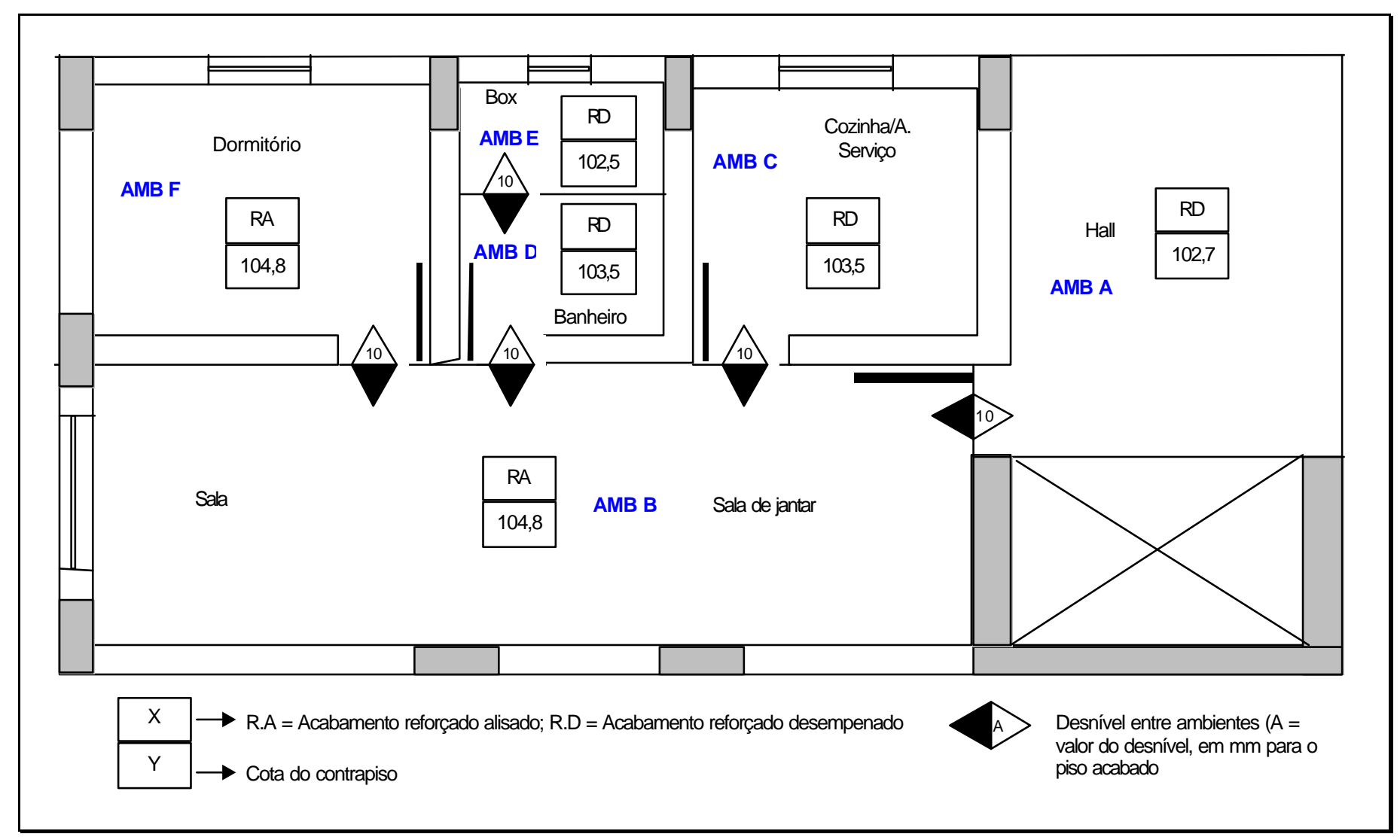

Figura A1 Exemplo de projeto de contrapiso para a determinação das espessuras do contrapiso em cada ambiente 


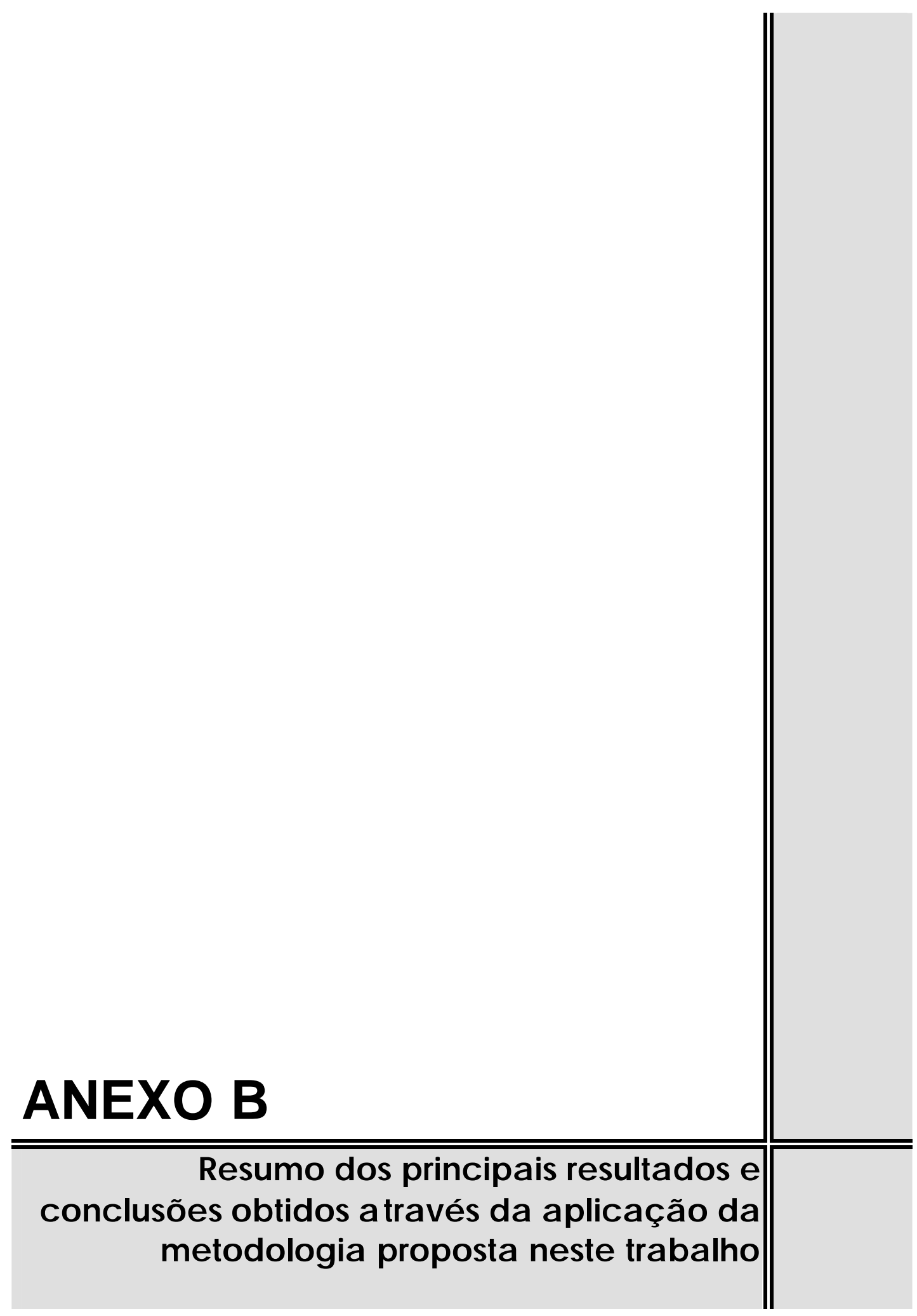


Os resultados e conclusões apresentados neste anexo foram extraídos de AGOPYAN et al. (1998b); AGOPYAN et al. (1998c); AGOPYAN et al. (1998d); AGOPYAN et al. (1998e). Tais resultados e conclusões foram frutos do trabalho de toda a equipe de trabalho constituída no Departamento de Engenharia de Construção Civil da EPUSP, no âmbito do curso de pós graduação, para a execução da pesquisa Alternativas para a redução do desperdício de materiais nos canteiros de obras.

\section{B.1 Estrutura de concreto armado}

\section{B.1.1 Concreto usinado}

A tabela B.1 reúne os valores representativos da amostra estudada, destacando-se as medidas de posição (mediana e média), as medidas de dispersão (diferença entre quartis, desvio padrão e valores mínimo e máximo) e o tamanho da amostra (n).

Tabela B.1 Estatísticas da amostra - concreto usinado

\begin{tabular}{ccccccc}
\hline Média (\%) & $\begin{array}{c}\text { Mediana } \\
(\%)\end{array}$ & Desvio P. & $\begin{array}{c}\text { Dif. Quartis } \\
(\%)\end{array}$ & Mínimo (\%) & Máximo (\%) & $\mathbf{n}$ \\
\hline 9 & 9 & 5 & 6 & 2 & 23 & 35 \\
\hline
\end{tabular}

O gráfico B.1 configura-se numa representação visual da distribuição dos valores de perdas para os casos amostrados. Nele, pode -se perceber a região de concentração preferencial e a forma de dispersão dos resultados.

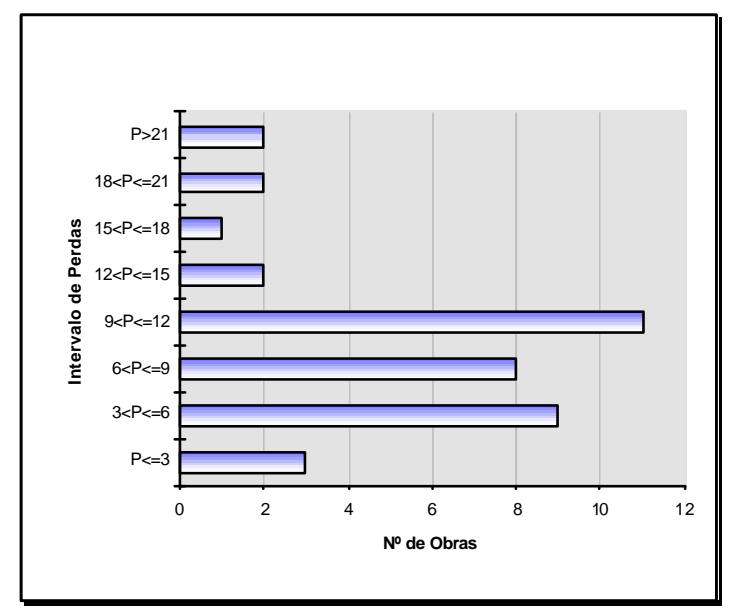

Gráfico B.1 Distribuição amostral dos resultados de perdas: concreto usinado 
Pode-se tecer alguns comentários adicionais quanto às perdas deste material:

(a) a comparação dos dados apresentados na Tabela B.2 parece indicar que uma preocupação maior com o sistema de fôrmas como um todo (molde e cimbramento de boa qualidade) podem reduzir as perdas. Esta tendência é válida não somente para os moldes de plástico ou metálicos, mas também para os de madeira bem projetados/concebidos. Deve-se frisar que se está baseando tal colocação não somente em uma amostragem muito pequena de moldes de plástico ou metálicos, mas também em observações qualitativas feitas quanto às obras estudadas;

Tabela B.2 Comparação entre estatísticas: tipo de molde das fôrmas

\begin{tabular}{l|ccccccc}
\hline Categorias & $\begin{array}{c}\text { Média } \\
(\%)\end{array}$ & $\begin{array}{c}\text { Mediana } \\
(\%)\end{array}$ & $\begin{array}{c}\text { Desvio } \\
\text { P. }\end{array}$ & $\begin{array}{c}\text { Dif. } \\
\text { Quartis } \\
(\%)\end{array}$ & $\begin{array}{c}\text { Mínimo } \\
(\%)\end{array}$ & $\begin{array}{c}\text { Máximo } \\
(\%)\end{array}$ & $\mathbf{n}$ \\
\hline Metálico/plástico & 4 & 4 & - & - & 4 & - & 1 \\
Outros & 10 & 9 & 5 & 6 & 2 & 23 & 37 \\
\hline
\end{tabular}

(b) as falhas quanto à obediência da geometria da estrutura prevista em projeto aparece como grande explicador de perdas para a maioria dos casos, conforme se detecta ao analisar a Tabela B.3, relativa às lajes, e a Tabela B.4, relativa às vigas. Entretanto há indícios de que a falta de controle no recebimento, de modo a garantir a compatibilidade entre a quantidade solicitada e a recebida tenha sido um fator importante para explicar as perdas em algumas obras com índices elevados. Às obras em que se mediu menores erros quanto à sobrespessura das lajes (e < $5 \%$ ) associa-se uma mediana das perdas significativamente menor que às obras onde tal erro foi superior (e $\geq 5 \%$ ). Fato análogo, embora não tão acentuado, detectou-se quanto à sobrelargura das vigas;

Tabela B.3 Comparação entre estatísticas: sobrespessura das lajes

\begin{tabular}{c|ccccccc}
\hline Categorias & $\begin{array}{c}\text { Média } \\
(\%)\end{array}$ & $\begin{array}{c}\text { Mediana } \\
(\%)\end{array}$ & $\begin{array}{c}\text { Desvio } \\
\text { P. }\end{array}$ & $\begin{array}{c}\text { Dif. } \\
\text { Quartis } \\
(\%)\end{array}$ & $\begin{array}{c}\text { Mínimo } \\
(\%)\end{array}$ & $\begin{array}{c}\text { Máximo } \\
(\%)\end{array}$ & $\mathbf{n}$ \\
\hline $\mathrm{e} \leq 5 \%$ & 8 & 6 & 6 & 7 & 2 & 22 & 15 \\
\hline $\mathrm{e}>5 \%$ & 12 & 11 & 5 & 7 & 4 & 23 & 14 \\
\hline
\end{tabular}


Tabela B.4 Comparação entre estatísticas: sobrelargura das vigas

\begin{tabular}{c|ccccccc}
\hline Categorias & $\begin{array}{c}\text { Média } \\
(\%)\end{array}$ & $\begin{array}{c}\text { Mediana } \\
(\%)\end{array}$ & Desvio P. & $\begin{array}{c}\text { Dif. } \\
\text { Quartis } \\
(\%)\end{array}$ & $\begin{array}{c}\text { Mínimo } \\
(\%)\end{array}$ & $\begin{array}{c}\text { Máximo } \\
(\%)\end{array}$ & $\mathbf{n}$ \\
\hline$e \leq 2,5 \%$ & 9 & 7 & 6 & 7 & 2 & 23 & 19 \\
$e>2,5 \%$ & 10 & 10 & 5 & 5 & 3 & 22 & 12 \\
\hline
\end{tabular}

(c) a importância da qualidade geométrica das lajes quanto ao nível de perdas levantado levou à avaliação dos equipamentos de nivelamento das mesmas quanto a constituírem-se ou não em indutores de desempenhos diferenciados. A Tabela B.5 confirma um valor de perdas menos acentuado para o conjunto de obras que fizeram uso de nível laser ou alemão para o nivelamento das lajes, embora se possa concluir também (em face das dispersões dos resultados) que a adoção do equipamento (sem a utilização correta dos mesmos) não leva por si só a melhores desempenhos. O gráfico B.2 ilustra a distribuição dos intervalos de perdas considerando as duas categorias analisadas;

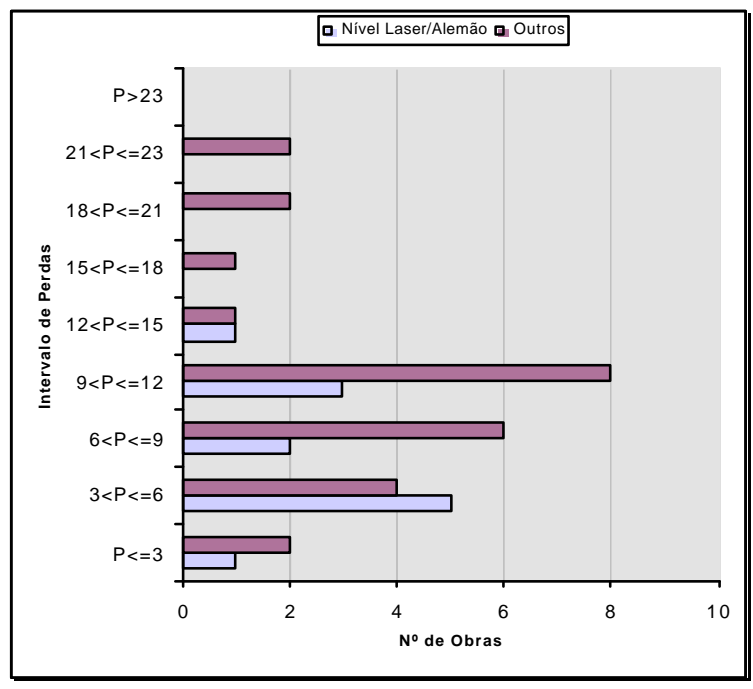

Gráfico B.2 Distribuição amostral dos resultados de perdas: equipamento de nivelamento da laje 
Tabela B.5 Comparação entre estatísticas: equipamento de nivelamento da laje

\begin{tabular}{c|ccccccc}
\hline Categorias & $\begin{array}{c}\text { Média } \\
(\%)\end{array}$ & $\begin{array}{c}\text { Mediana } \\
(\%)\end{array}$ & $\begin{array}{c}\text { Desvio } \\
\text { P. }\end{array}$ & $\begin{array}{c}\text { Dif. } \\
\text { Quartis } \\
(\%)\end{array}$ & $\begin{array}{c}\text { Mínimo } \\
(\%)\end{array}$ & $\begin{array}{c}\text { Máximo } \\
(\%)\end{array}$ & $\mathbf{n}$ \\
\hline Nível laser/alemão & 7 & 7 & 4 & 6 & 3 & 15 & 12 \\
Outros & 11 & 10 & 0.06 & 0.05 & 1 & 1.23 & 26 \\
\hline
\end{tabular}

(d) a observação da Tabela B.6 indica que o transporte por bombeamento pode ter uma associação com valores maiores de perdas, em função de, muitas vezes, terse detectado a não utilização das sobras representadas pelo concreto que fica nas tubulações e no recipiente de bombeamento. O gráfico B.3 ilustra a distribuição dos intervalos de perdas considerando as duas categorias analisadas;

Tabela B.6 Comparação entre estatísticas: equipamento/forma de transporte

\begin{tabular}{c|ccccccc}
\hline Categorias & $\begin{array}{c}\text { Média } \\
(\%)\end{array}$ & $\begin{array}{c}\text { Mediana } \\
(\%)\end{array}$ & $\begin{array}{c}\text { Desvio } \\
\text { P. }\end{array}$ & $\begin{array}{c}\text { Dif. } \\
\text { Quartis } \\
(\%)\end{array}$ & $\begin{array}{c}\text { Mínimo } \\
(\%)\end{array}$ & $\begin{array}{c}\text { Máximo } \\
(\%)\end{array}$ & $\mathbf{n}$ \\
\hline Bombeado & 10 & 9 & 6 & 6 & 3 & 23 & 20 \\
Grua/jerica & 9 & 8 & 5 & 6 & 2 & 22 & 18 \\
\hline
\end{tabular}

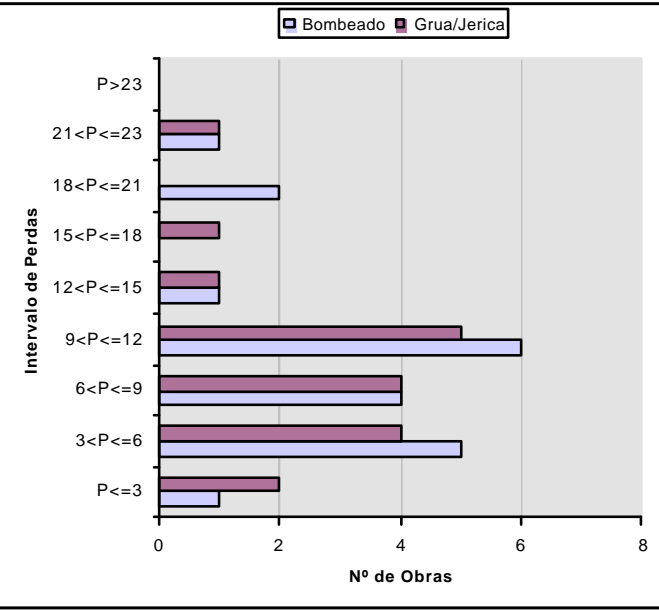

Grá fico B.3 Distribuição amostral dos resultados de perdas: equipamento/forma de transporte 
(e) os valores das estatísticas apresentados na Tabela B10-1 são superiores quando comparados aos valores usuais estipulados em composições orçamentárias. $O$ TCPO 10 (1996), por exemplo, aponta uma estimativa de perda de apenas $2 \%$, igual ao valor mínimo obtido nos casos amostrados nesta pesquisa.

\section{B.1.2 Aço}

A Tabela B.7 reúne os valores representativos da amostra estudada, destacando-se as medidas de posição (mediana e média), as medidas de dispersão (diferença entre quartis, desvio padrão e valores mínimo e máximo) e o tamanho da amostra (n).

Tabela B.7 Estatísticas da amostra-aço

\begin{tabular}{ccccccc}
\hline Média (\%) & $\begin{array}{c}\text { Mediana } \\
(\%)\end{array}$ & Desvio P. & $\begin{array}{c}\text { Dif. Quartis } \\
(\%)\end{array}$ & Mínimo (\%) & Máximo (\%) & n \\
\hline 10 & 11 & 4 & 6 & 4 & 16 & 12 \\
\hline
\end{tabular}

O gráfico B.4 configura-se numa representação visual da distribuição dos valores de perdas para os casos amostrados. Nele, pode-se perceber a região de concentração preferencial e a forma de dispersão dos resultados.

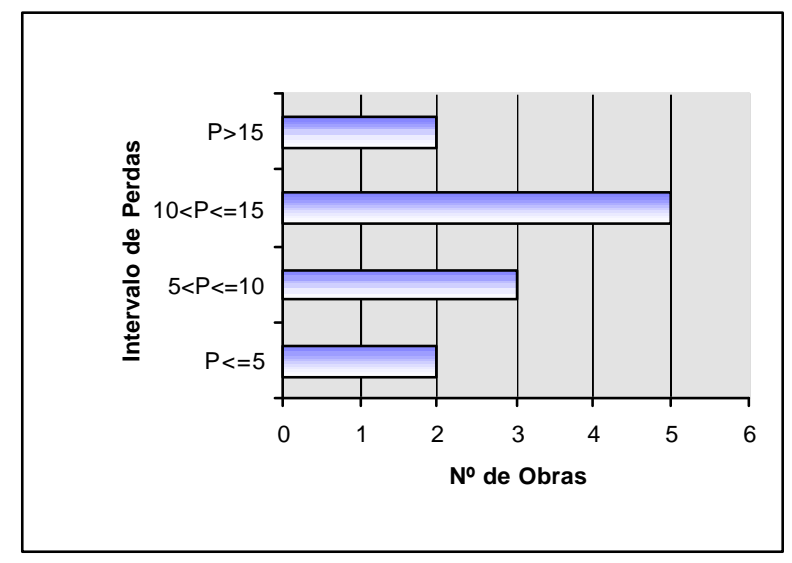

Gráfico B.4 Distribuição amostral d os resultados de perdas: aço

Pode-se tecer alguns comentários adicionais quanto às perdas deste material:

(a) o desbitolamento, tido há alguns anos como possível responsável por considerável parcela de perdas, não parede ser mais um problema quanto ao fornecimento de barras, conforme se nota na Tabela B.8; 
Tabela B.8 Estatísticas da amostra-desbitolamento - aço

\begin{tabular}{ccccccc}
\hline Média (\%) & $\begin{array}{c}\text { Mediana } \\
(\%)\end{array}$ & Desvio P. & $\begin{array}{c}\text { Dif. Quartis } \\
(\%)\end{array}$ & Mínimo (\%) & Máximo (\%) & n \\
\hline$(0.92)$ & $(0.90)$ & 4 & 5 & $(14.00)$ & 8.40 & 60 \\
\hline
\end{tabular}

(b) acredita-se que o mau planejamento do ørte dos vergalhões, com reduzido aproveitamento das pontas, possa ser um grande indutor de perdas. A comparação entre os dados da Tabela B.9 mostra uma ocorrência de perdas menor para diâmetros menores, para os quais se detecta uma presença de peças de amadura com comprimentos menores convivendo no projeto com peças de comprimentos maiores, o que naturalmente facilita um melhor aproveitamento das barras recebidas nas obras.

Tabela B.9 Comparação entre estatísticas: bitolas

\begin{tabular}{c|ccccccc}
\hline Categorias & $\begin{array}{c}\text { Média } \\
(\%)\end{array}$ & $\begin{array}{c}\text { Mediana } \\
(\%)\end{array}$ & $\begin{array}{c}\text { Desvio } \\
\text { P. }\end{array}$ & $\begin{array}{c}\text { Dif. } \\
\text { Quartis } \\
(\%)\end{array}$ & $\begin{array}{c}\text { Mínimo } \\
(\%)\end{array}$ & $\begin{array}{c}\text { Máximo } \\
(\%)\end{array}$ & $\mathbf{n}$ \\
\hline bitolas $\leq 10 \mathrm{~mm}$ & 8 & 6 & 13 & 10 & $(15)$ & 51 & 42 \\
bitolas $>10 \mathrm{~mm}$ & 17 & 11 & 25 & 20 & $(31)$ & 134 & 38 \\
\hline
\end{tabular}

(c) os valores das estatísticas apresentados na Tabela B.7 são inferiores quando comparados aos valores usuais estipulados em composições orçamentárias. $\mathrm{O}$ TCPO 10 (1996), por exemplo, aponta uma estimativa de perda de 15\%, aproximadamente igual ao valor máximo obtido nos casos amostrados nesta pesquisa. 


\section{B.2 Alvenaria}

\section{B.2.1 Blocos e tijolos}

A Tabela B.10 reúne os valores representativos da amostra estudada, destacando-se as medidas de posição (mediana e média), as medidas de dispersão (diferença entre quartis, desvio padrão e valores mínimo e máximo) e o tamanho da amostra (n).

Tabela B.10 Estatísticas da amostra-blocos e tijolos

\begin{tabular}{ccccccc}
\hline Média (\%) & $\begin{array}{c}\text { Mediana } \\
(\%)\end{array}$ & Desvio P. & Dif. Quartis (\%) & Mínimo (\%) & Máximo (\%) & $\mathbf{n}$ \\
\hline 17 & 13 & 12 & 11 & 3 & 48 & 37 \\
\hline
\end{tabular}

O Gráfico B.5 configura-se numa representação visual da distribuição dos valores de perdas para os casos amostrados. Nele, pode -se perceber a região de concentração preferencial e a forma de dispersão dos resultados.

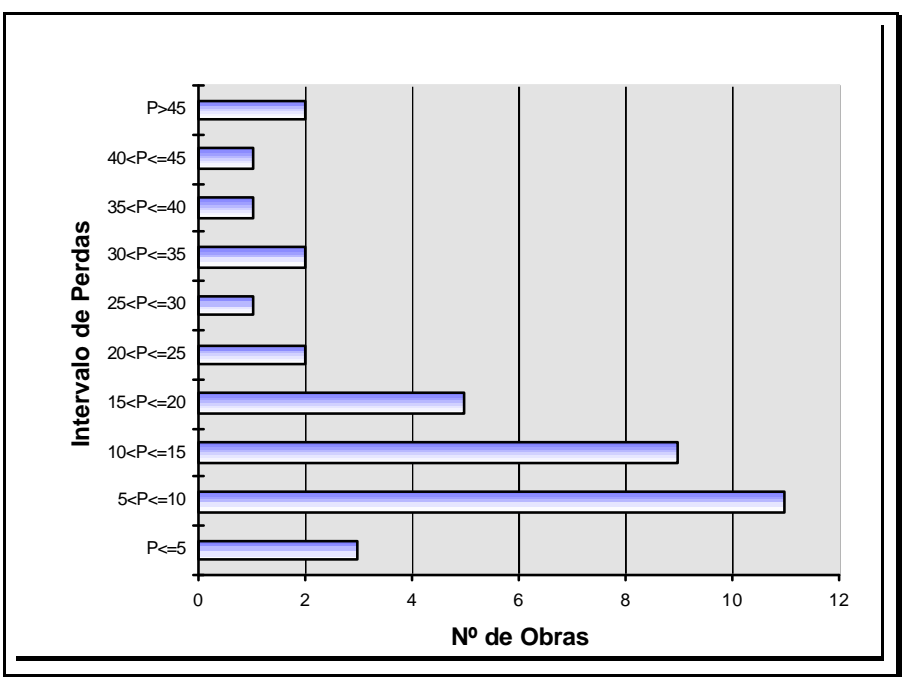

Gráfico B.5 Distribuição amostral dos resultados de perdas: blocos e tijolos

Pode-se tecer alguns comentários adicionais quanto às perdas deste material:

(a) a observação dos dados da Tabela B.11 mostra que a mediana das perdas para os blocos de concreto é ligeiramente menor que a para os blocos cerâmicos e para os tijolos cerâmicos. Tal tendência deve ser assumida com reservas, tanto em 
função da dispersão dos resultados, quanto em função de, no conjunto das obras que usaram blocos de concreto ter-se duas delas em alvenaria estrutural, quando a totalidade dos blocos cerâmicos dizem respeito a alvenaria de vedação somente;

Tabela B.11 Comparação entre estatísticas: material do bloco

\begin{tabular}{l|ccccccc}
\hline \multicolumn{1}{c|}{ Categorias } & $\begin{array}{c}\text { Média } \\
(\%)\end{array}$ & $\begin{array}{c}\text { Mediana } \\
(\%)\end{array}$ & $\begin{array}{c}\text { Desvio } \\
\text { P. }\end{array}$ & $\begin{array}{c}\text { Dif. } \\
\text { Quartis } \\
(\%)\end{array}$ & $\begin{array}{c}\text { Mínimo } \\
(\%)\end{array}$ & $\begin{array}{c}\text { Máximo } \\
(\%)\end{array}$ & $\mathbf{n}$ \\
\hline Bloco cerâmico & 18 & 14 & 12 & 11 & 5 & 48 & 21 \\
Bloco de concreto & 10 & 11 & 5 & 6 & 3 & 20 & 9 \\
Tijolo cerâmico & 21 & 15 & 14 & 15 & 10 & 48 & 7 \\
\hline
\end{tabular}

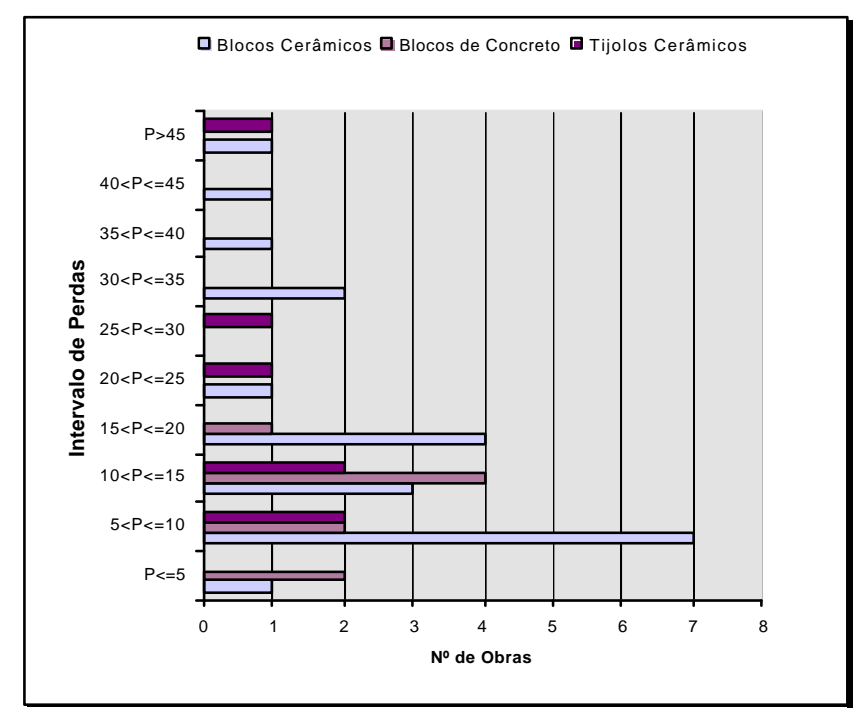

Gráfico B.6 Distribuição amostral dos resultados de perdas: blocos e tijolos

(b) o grupo de obras onde o transporte dos blocos/tijolos era feito com pallets ou carrinhos específicos também apresentou a mediana de perdas inferior ao grupo de obras que usava carrinhos de mão ou similar, conforme ilustra a Tabela B.12. A diferença entre os dois conjuntos não é tão acentuada, acredita-se, em função de, em algumas obras que recebiam os blocos/tijolos em pallets, ter-se pelo menos em parte da movimentação dos componentes o uso de equipamentos inadequados. $O$ Gráfico B.7 traz a distribuição dos intervalos de perdas em função do tipo de equipamento de transporte. 
Tabela B.11 Comparação entre estatísticas: tipo de equipamento de transporte

\begin{tabular}{l|ccccccc}
\hline Categorias & Média (\%) & $\begin{array}{c}\text { Mediana } \\
(\%)\end{array}$ & $\begin{array}{c}\text { Desvio } \\
\text { P. }\end{array}$ & $\begin{array}{c}\text { Dif. } \\
\text { Quartis } \\
(\%)\end{array}$ & $\begin{array}{c}\text { Mínimo } \\
(\%)\end{array}$ & $\begin{array}{c}\text { Máximo } \\
(\%)\end{array}$ & $\mathbf{n}$ \\
\hline $\begin{array}{l}\text { Pallets/carrinho } \\
\text { específico }\end{array}$ & 16 & 12 & 11 & 11 & 3 & 48 & 18 \\
Outros & 18 & 13 & 13 & 8 & 5 & 48 & 19 \\
\hline
\end{tabular}

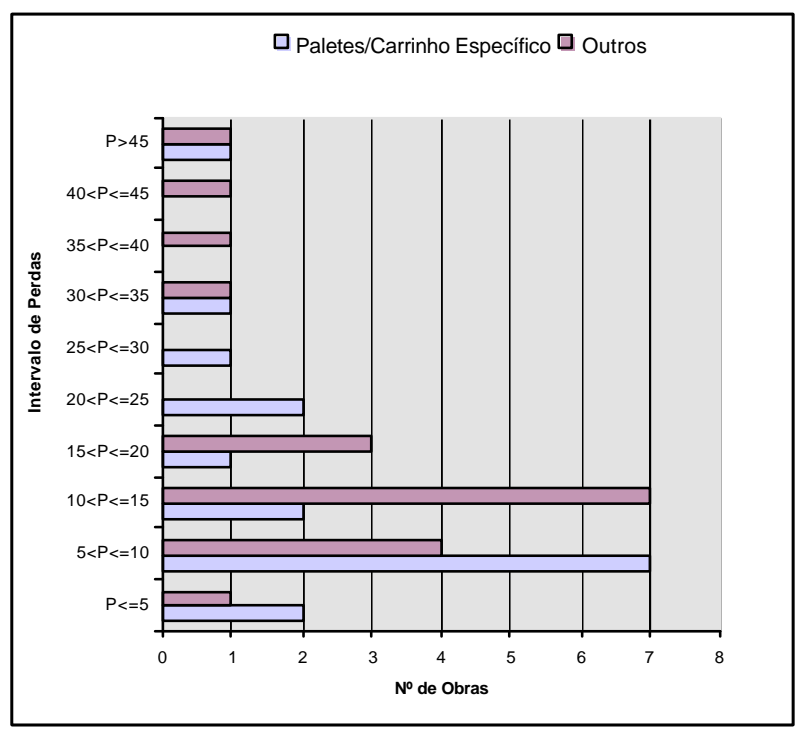

Gráfico B.7 Distribuição amostral dos resultados de perdas: tipo de equipamento de transporte

(c) os valores das estatísticas apresentados na Tabela B.10 são superiores quando comparados aos valores usuais estipulados em composições orçamentárias. O TCPO 10 (1996), por exemplo, aponta uma estimativa de perda entre 3 a 10\%, dependendo do tipo de bloco considerado. Apesar de superior, a mediana se aproxima muito do valor máximo estipulado no TCPO 10 (1996). 


\section{B.2.2 Argamassa de assentamento ${ }^{106}$}

Para o estudo das perdas e/ou consumos de cimento neste serviço em particular, dividiu-se o serviço em duas modalidades: alvenaria cuja argamassa era assentada na forma de filetes e alvenaria cuja forma de assentamento consiste em preencher com argamassa em toda a extensão da largura dos blocos. Tal fato, evidentemente, leva a índices de perdas e consumos diferenciados, pois os referenciais adotados são distintos. Sendo assim, a análise dos índices do estudo deste material ater-se-á apenas à questão do consumo, e não sobre os índices de perdas, pois as discrepâncias são muito significativas.

O Gráfico B.8 configura-se numa representação visual da distribuição dos valores de perdas para os casos amostrados. Nele, pode-se perceber a região de concentração preferencial e a forma de dispersão dos resultados.

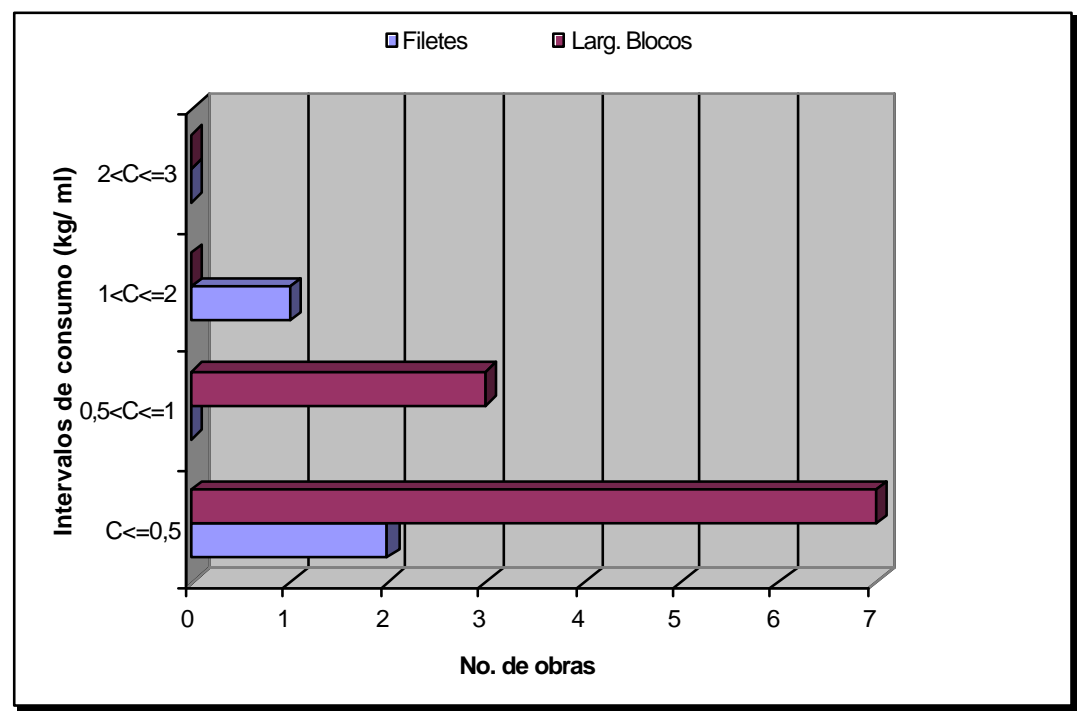

Gráfico B.8 Distribuição amostral dos resultados de consumos: cimento no serviço de Alvenaria

A Tabela B.12 reúne os valores representativos da amostra estudada, destacando-se as medidas de posição (mediana e média), as medidas de dispersão (diferença entre quartis, desvio padrão e valores mínimo e máximo) e o tamanho da amostra (n).

106 As perdas de argamassa nos serviços onde as mesmas são utilizadas (contrapiso, alvenaria, revestimento interno e externo, entre outros) são obtidas indiretamente através do mapeamento da quantidade de cimento destinada a cada serviço. Portanto, utiliza-se o indicador global de perda por serviço pós-estocagem do cimento como sendo o representativo das perdas de argamassa nestes serviços. 
Tabela B.12 Estatísticas da amostra - cimento no serviço de alvenaria - Filete e Largura dos blocos

\begin{tabular}{|c|c|c|c|c|c|c|}
\hline ALVENARIA - FILETES & & & & & & \\
\hline & OBRA & $\begin{array}{l}\mathrm{m} 3 / \mathrm{ml} \\
\text { eórico }\end{array}$ & $\begin{array}{l}\text { kg/m3 } \\
\text { eórico }\end{array}$ & $\begin{array}{c}\mathrm{kg} / \mathrm{ml} \\
\text { eal }\end{array}$ & & \\
\hline & BR 015 & 0,0002 & 296,03 & 1,33 & & \\
\hline & BR 042 & 0,0002 & 267,74 & 0,19 & & \\
\hline & BR 083 & 0,0002 & 172,27 & 0,25 & & \\
\hline ÍNDICES & Média & Mediana & Desvio P. & Dif. Quartil & Mínimo & Máximo \\
\hline CONSUMO TEÓRICO $(\mathrm{kg} / \mathrm{m} 3)$ & 245,35 & 267,74 & 64,85 & 61,88 & 172,27 & 296,03 \\
\hline CONSUMO REAL (kg/ml) & 0,59 & 0,25 & 0,64 & 0,57 & 0,19 & 1,33 \\
\hline $\mathrm{n}=$ & 3 & & & & & \\
\hline \multicolumn{7}{|c|}{ ALVENARIA - LARGURA DOS BLOCOS } \\
\hline & OBRA & $\begin{array}{l}\mathrm{m} 3 / \mathrm{ml} \\
\text { eórico }\end{array}$ & $\begin{array}{l}\mathrm{kg} / \mathrm{m} 3 \\
\text { eórico }\end{array}$ & $\begin{array}{c}\mathrm{kg} / \mathrm{ml} \\
\text { eal }\end{array}$ & & \\
\hline & BR 021 & 0,0009 & 212,48 & 0,47 & & \\
\hline & BR 023 & 0,0015 & 148,81 & 0,22 & & \\
\hline & BR 029 & 0,0009 & 190,55 & 0,41 & & \\
\hline & BR 030 & 0,0010 & 141,34 & 0,50 & & \\
\hline & BR 040 & 0,0010 & 169,63 & 0,54 & & \\
\hline & BR 053 & 0,0012 & 163,74 & 0,62 & & \\
\hline & BR 054 & 0,0016 & 123,00 & 0,221 & & \\
\hline & BR 062 & 0,0020 & 182,00 & 0,39 & & \\
\hline & BR 063 & 0,0014 & 241,50 & 0,56 & & \\
\hline & BR 081 & 0,0015 & 116,00 & 0,20 & & \\
\hline ÍNDICES & Média & Mediana & Desvio P. & Dif. Quartil & Mínimo & Máximo \\
\hline CONSUMO TEÓRICO(kg/m3) & 168,91 & 166,69 & 39,31 & 45,20 & 116,00 & 241,50 \\
\hline CONSUMO REAL (kg/m2) & 0,41 & 0,44 & 0,15 & 0,16 & 0,20 & 0,62 \\
\hline $\mathrm{n}=$ & 10 & & & & & \\
\hline
\end{tabular}

Com relação às perdas e/ou consumos de cimento neste serviço, pode-se tecer os seguintes comentários: 
(a) analisando -se os valores apresentados na Tabela B.12 percebe-se uma grande variação nos traços adotados (116,0 a 296,03 kg/m3), o que se reflete em grandes variações quanto ao consumo teórico de cimento por m3 de argamassa;

(b) em se tratando das espessuras de juntas teóricas adotadas, nota-se também uma grande variação (de 1 a 2,5 cm) (Tabela B.13);

( c) Os consumos $(0,19$ a $1,33 \mathrm{~kg} / \mathrm{ml})$ variaram significativamente, principalmente quando se compara os resultados entre as duas modalidades de alvenaria ou, até mesmo, entre resultados de uma mesma modalidade;

(d) Ao se analisar um dos principais indicadores parciais de perdas na aplicação do material (variação da espessura de junta) através do Gráfico B.9, fica evidente a correlação bem menor $\left(R^{2}=0.4679\right)$ entre as perdas calculadas para este serviço e as sobrespessuras de juntas detectadas. Tal constatação veio corroborar com uma verificação feita em obra, de que a argamassa excedente pode ter sido consumida de diversas outras maneiras (que não elevando a espessura da junta) como por exemplo por inserção nos furos dos blocos. Portanto, o padrão geométrico dos blocos pode ter grande influência no consumo de argamassa de assentamento. Para reforçar, na Tabela B.13 pode-se verificar a representatividade bem menor (em comparação com os outros usos da argamassa) que a sobrespessura das juntas horizontais tem em relação ao indicador global. 
Tabela B.13 Representatividade da variação da espessura das juntas horizontais no índice global de perdas

\begin{tabular}{cccccc}
\hline Obra & Perda (\%) & $\begin{array}{c}\text { Var. Esp. } \\
(\%)\end{array}$ & $\begin{array}{c}\text { Esp. Ref.. } \\
(\mathbf{c m})\end{array}$ & $\begin{array}{c}\text { Esp. Real } \\
(\mathbf{c m})\end{array}$ & $\begin{array}{c}\text { Represent. } \\
(\%)\end{array}$ \\
\hline BR 021 & 136 & 29 & 1,5 & 1,94 & 22 \\
BR 023 & 61 & 70 & 1,5 & 2,50 & 100 \\
BR 029 & 139 & 103 & 1,0 & 2,03 & 74 \\
BR 030 & 247 & 130 & 1,0 & 2,30 & 53 \\
BR 040 & 208 & 53 & 1,0 & 1,53 & 25 \\
BR 053 & 213 & 64 & 1,0 & 1,64 & 30 \\
BR 054 & 12 & 7 & 2,0 & 2,13 & 54 \\
BR 062 & 7 & 3 & 2,0 & 2,06 & 47 \\
BR 063 & 64 & 11 & 1,5 & 1,66 & 17 \\
BR 078( $\left.{ }^{*}\right)$ & 205 & 26 & 1 & 1,26 & 12 \\
BR 081 & 15 & 7 & 1,5 & 1,61 & 49 \\
\hline Média & $\mathbf{1 1 9}$ & & & & 42 \\
global & & & & & \\
\hline
\end{tabular}

$\left({ }^{\star}\right)$ Argamassa parcial ou totalmente produzida fora do canteiro de obras

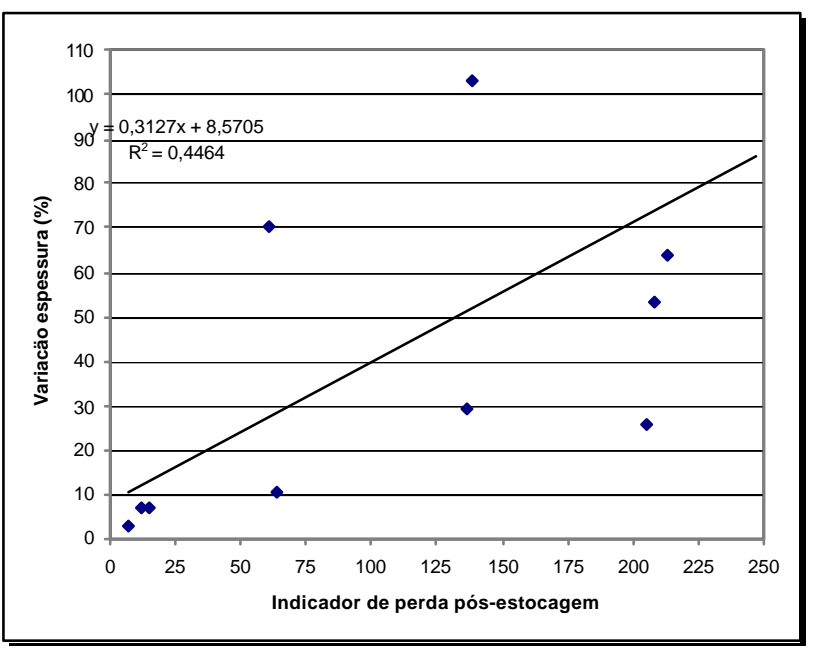

Gráfico B.9 Correlação entre a variação da espessura de juntas e o indicador global de perda pós-estocagem 


\section{B.3 Revestimentos}

\section{B.3.1 Emboço interno}

A Tabela B.14 reúne os valores representativos da amostra estudada, destacando-se as medidas de posição (mediana e média), as medidas de dispersão (diferença entre quartis, desvio padrão e valores mínimo e máximo) e o tamanho da amostra (n).

Tabela B.14 Estatísticas da amostra - cimento no serviço revestimento interno

\begin{tabular}{|c|c|c|c|c|c|c|}
\hline \multicolumn{7}{|c|}{ EMBOÇO OU MASSA ÚNICA - INTERNO } \\
\hline & OBRA & $\begin{array}{l}\text { m3/m2 } \\
\text { eórico }\end{array}$ & $\begin{array}{l}\text { kg/m3 } \\
\text { eórico }\end{array}$ & Perda (\%) & $\begin{array}{c}\mathrm{kg} / \mathrm{m} 2 \\
\text { eal } \\
\end{array}$ & \\
\hline & BR 007 & 0,010 & 147,45 & 141 & 3,56 & \\
\hline & BR 016 & 0,014 & 203,05 & 134 & 6,67 & \\
\hline & BR 021 & 0,020 & 234,63 & 62 & 7,59 & \\
\hline & BR 022 & 0,025 & 115,45 & 139 & 6,91 & \\
\hline & BR 023 & 0,020 & 148,81 & 234 & 9,93 & \\
\hline & BR 034 & 0,015 & 225,23 & 102 & 6,81 & \\
\hline & BR 042 & 0,020 & 267,74 & 21 & 6,47 & \\
\hline & BR 045 & 0,025 & 233,50 & 56 & 9,12 & \\
\hline & BR 053 & 0,010 & 152,61 & 46 & 2,23 & \\
\hline & BR 055 & 0,025 & 194,17 & 196 & 14,38 & \\
\hline & BR 087 & 0,025 & 166,73 & 8 & 5,39 & \\
\hline ÍNDICES & Média & Mediana & Desvio P. & Dif. Quartil & Mínimo & Máximo \\
\hline PERDA (\%) & 104 & 102 & 72 & 89 & 8 & 234 \\
\hline CONSUMO TEÓRICO(kg/m3) & 189,94 & 194,17 & 47,29 & 78,66 & 115,45 & 267,74 \\
\hline CONSUMO REAL (kg/m2) & 7,19 & 6,81 & 3,24 & 2,42 & 2,23 & 14,38 \\
\hline $\mathrm{n}=$ & 11 & & & & & \\
\hline
\end{tabular}

Os gráficos B.10 e B.11 configuram-se numa representação visual da distribuição dos valores de perdas e consumos respectivamente para os casos amostrados. Neles, pode-se perceber a região de concentração preferencial e a forma de dispersão dos resultados. 


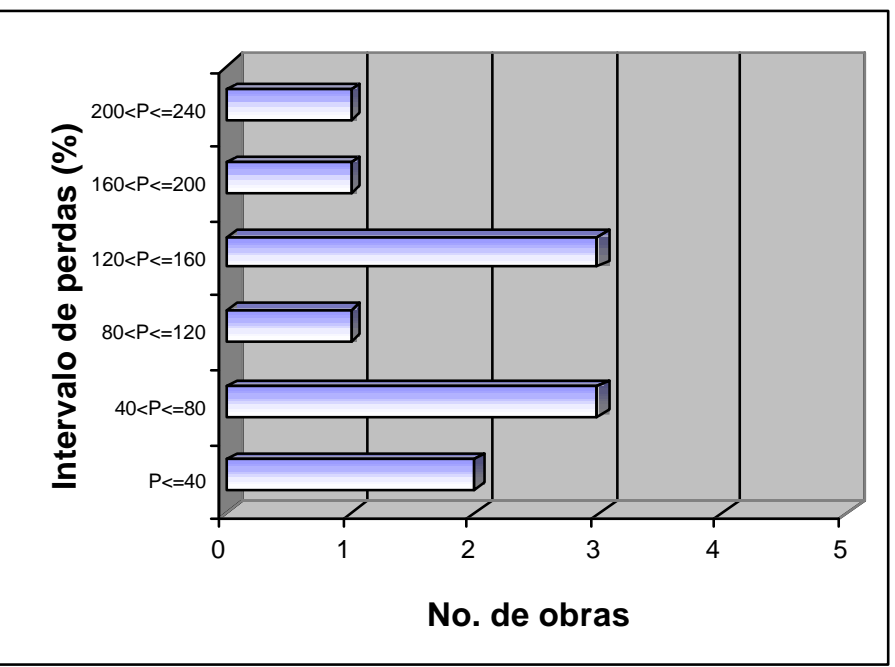

Gráfico B.10 Distribuição amostral dos resultados de perdas: cimento no serviço de revestimento interno

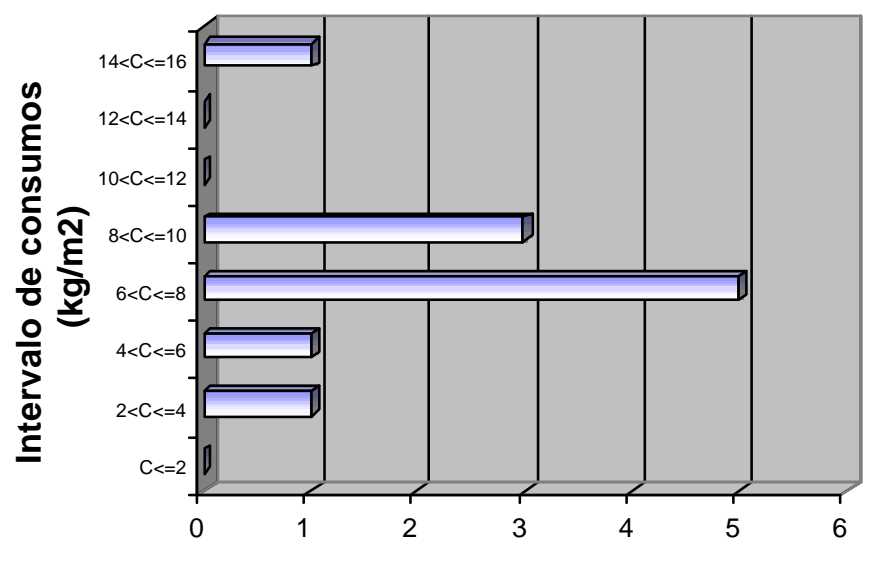

No. de obras

Gráfico B.11 Distribuição amostral dos resultados de consumos: cimento no serviço de revestimento interno

Com relação às perdas e/ou consumos de cimento neste serviço, pode-se tecer os seguintes comentários:

(a) analisando-se os valores apresentados na Tabela B.14 percebe-se uma grande variação nos traços adotados, o que se reflete em grandes variações quanto ao consumo teórico de cimento por m3 de argamassa; 
(b) em se tratando das espessuras teóricas adotadas, nota-se também uma grande variação (de 1 a $2,5 \mathrm{~cm}$ );

(c) as perdas (8 a $234 \%$ e os consumos (2,23 a $14,38 \mathrm{~kg} / \mathrm{m} 2$ ) variaram significativamente. Conforme salientado na s considerações iniciais, a maior perda não necessariamente está associada ao maior consumo;

(d) ao se analisar um dos principais indicadores parciais de perdas na aplicação do material (variação da espessura de revestimento) através do Gráfico B.12, fica evidente a correlação existente entre as perdas calculadas para este serviço e as sobrespessuras detectadas. Tal idéia é reforçada pela Tabela B.15 onde apresenta-se qual a percentagem das perdas calculadas é explicada pela variação da espessura. A sobrespessura da argamassa de revestimento explica $81 \%$ do indicador global de perda para os casos considerados, ou seja, dos $67 \%, 54 \%$ dizem respeito à sobrespessura do revestimento enquanto que $13 \%$ referem-se à perdas de outras naturezas (no caso, provavelmente o entulho). Ressalta-se que para esta análise foram descartados aqueles dados para os quais detectaram-se problemas ou incertezas quanto a coleta, conforme descrito nas fichas de análise de cada obra.

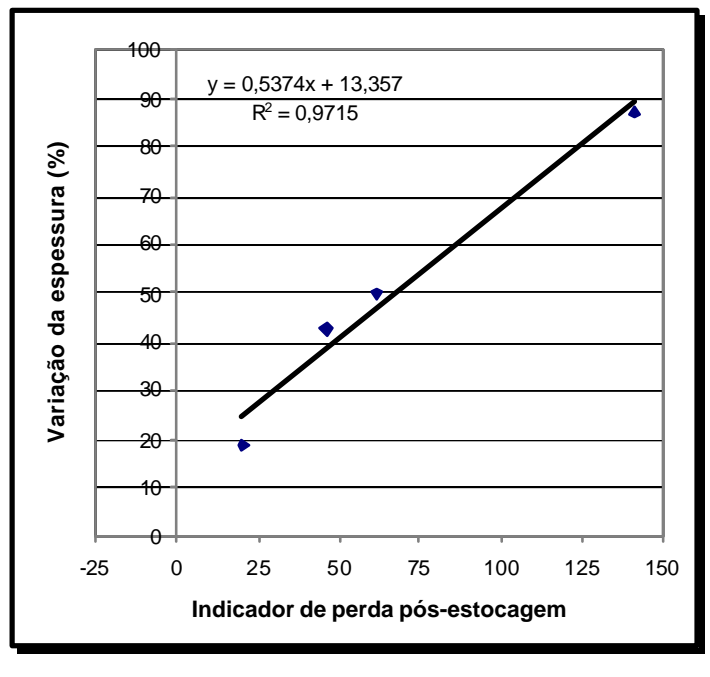

Gráfico B.12 Correlação entre a variação da espessura e o indicador global de perda pós-estocagem 
Tabela B.15 Representatividade da variação da espessura do revestimento no índice global de perdas

\begin{tabular}{cccccc}
\hline Obra & Perda (\%) & $\begin{array}{c}\text { Var. Esp. } \\
(\%)\end{array}$ & $\begin{array}{c}\text { Esp. Ref.. } \\
(\mathbf{c m})\end{array}$ & $\begin{array}{c}\text { Esp. Real } \\
(\mathbf{c m})\end{array}$ & $\begin{array}{c}\text { Represent. } \\
(\%)\end{array}$ \\
\hline BR 007 & 141 & 87 & 1,00 & 1,87 & 62 \\
BR 021 & 62 & 50 & 2,00 & 3,00 & 81 \\
BR 042 & 21 & 19 & 2,00 & 2,38 & 90 \\
BR 053 & 46 & 43 & 1,00 & 1,43 & 92 \\
\hline $\begin{array}{l}\text { Média } \\
\text { global }\end{array}$ & 67 & & & & 81 \\
\hline
\end{tabular}

\section{B.3.2 Emboço externo}

A Tabela B.16 reúne os valores representativos da amostra estudada, destacando-se as medidas de posição (mediana e média), as medidas de dispersão (diferença entre quartis, desvio padrão e valores mínimo e máximo) e o tamanho da amostra (n).

Tabela B.16 Estatísticas da amostra - cimento no serviço revestimento externo

\begin{tabular}{|c|c|c|c|c|c|c|}
\hline \multicolumn{7}{|c|}{ EMBOÇO OU MASSA UNICA - EXTERNO } \\
\hline & OBRA & $\mathrm{m} 3 / \mathrm{m} 2$ & $\mathrm{~kg} / \mathrm{m} 3$ & Perda (\%) & $\mathrm{kg} / \mathrm{m} 2$ & \\
\hline & & eórico & eórico & & eal & \\
\hline & BR 016 & 0,014 & 203,05 & 134 & 6,67 & \\
\hline & BR 021 & 0,015 & 191,51 & 70 & 4,88 & \\
\hline & BR 022 & 0,025 & 171,64 & 164 & 11,33 & \\
\hline & BR 033 & 0,025 & 156,30 & 30 & 5,07 & \\
\hline & BR 042 & 0,025 & 274,32 & 102 & 13,87 & \\
\hline & BR 045 & 0,025 & 233,50 & 36 & 7,96 & \\
\hline & BR 053 & 0,025 & 152,61 & -11 & 3,39 & \\
\hline & BR 065 & 0,025 & 209,47 & 12 & 5,86 & \\
\hline INDICES & Média & Mediana & Desvio P. & Dif. Quartil & Mínimo & Máximo \\
\hline PERDA (\%) & 67 & 53 & 62 & 85 & -11 & 164 \\
\hline CONSUMO TEÓRICO(kg/m3) & 199,05 & 197,28 & 41,00 & 47,67 & 152,61 & 274,32 \\
\hline CONSUMO REAL (kg/m2) & 7,38 & 6,26 & 3,55 & 3,78 & 3,39 & 13,87 \\
\hline $\mathbf{n}=$ & 8 & & & & & \\
\hline
\end{tabular}


Os gráficos B.13 e B.14 configuram-se numa representação visual da distribuição dos valores de perdas e consumos respectivamente para os casos amostrados. Neles, pode-se perceber a região de concentração preferencial e a forma de dispersão dos resultados.

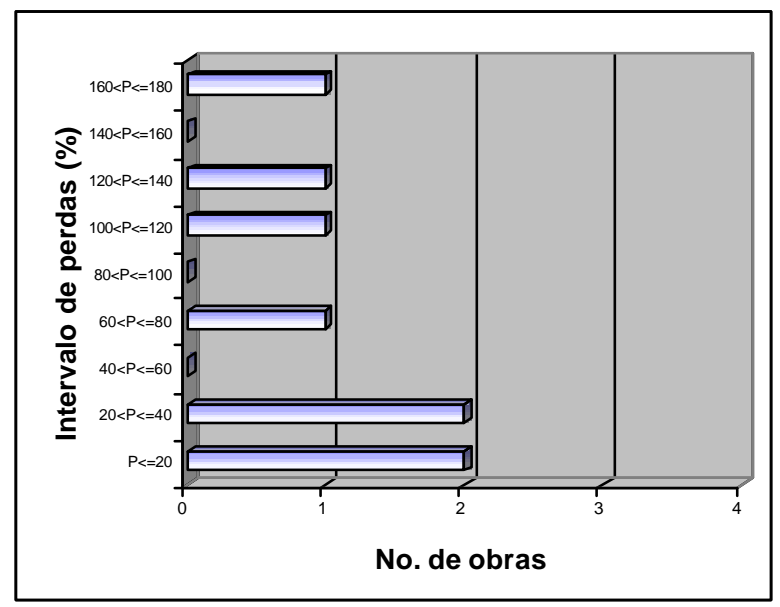

Gráfico B.13 Distribuição amostral dos resultados de perdas: cimento no serviço de revestimento externo

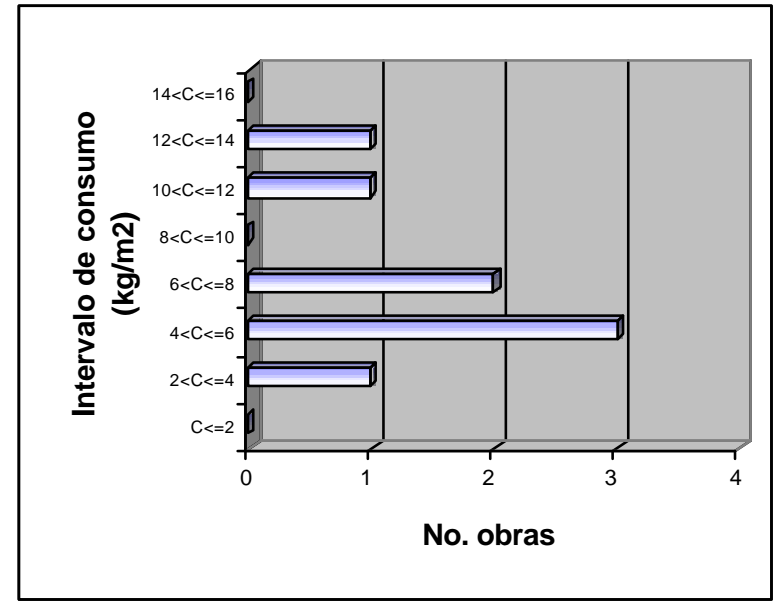

Gráfico B.14 Distribuição amostral dos resultados de consumos: cimento no serviço de revestimento externo

Com relação às perdas e/ou consumos de cimento neste serviço, pode-se tecer os seguintes comentários:

(a) da mesma forma que no serviço de revestimento interno em argamassa, para este serviço observou -se também uma grande variação nos traços adotados (152,61 a $274,32 \mathrm{~kg} / \mathrm{m} 3$ ), o que se reflete em grandes variações quanto ao consumo teórico de cimento por m3 de argamassa (Tabela B.16); 
(b) em se tratando das espessuras teóricas adotadas, nota-se também uma grande variação (de 1,4 a 2,5 cm);

(c) as perdas (-11 a $234 \%)$ e os consumos reais $(3,39$ a $13,87 \mathrm{~kg} / \mathrm{m} 2)$ variaram significativamente. Conforme salientado nas considerações iniciais, a maior perda não necessariamente está associada ao maior consumo;

(d) ao se analisar um dos principais indicadores parciais de perdas na aplicação do material (variação da espessura de revestimento) através do Gráfico B.15, fica evidente a correlação existente entre as perdas calculadas para este serviço e as sobrespessuras detectadas. Tal idéia é reforçada pela Tabela B.17 onde apresenta-se qual a percentagem das perdas calculadas é explicada pela variação da espessura. A sobrespessura da argamassa de revestimento explica $82 \%$ do indicador global de perda para os casos considerados, ou seja, dos $60 \%, 49 \%$ dizem respeito à sobrespessura do revestimento enquanto que $11 \%$ referem-se à perdas de outras naturezas (no caso, provavelmente o entulho). Ressalta-se que para esta análise foram descartados aqueles dados para os quais detectaram-se problemas ou incertezas quanto à coleta, conforme descrito nas fichas de análise de cada obra.

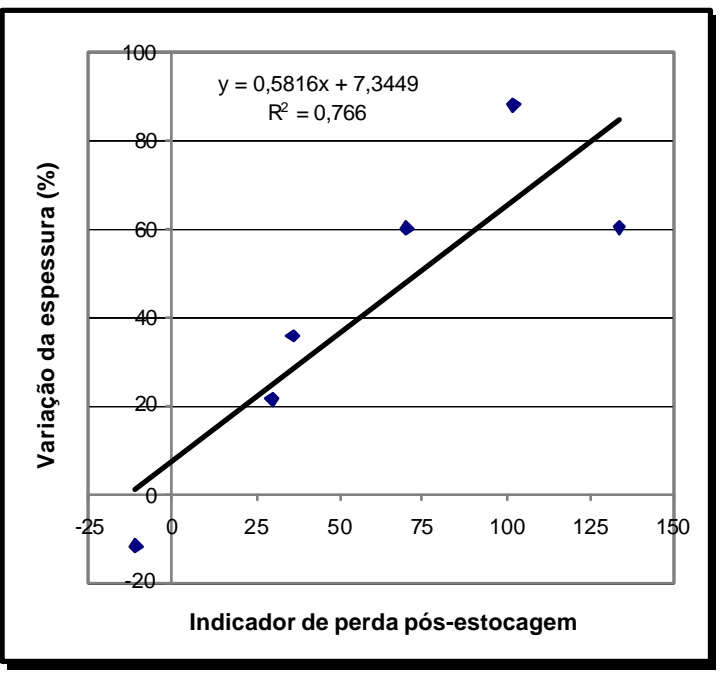

\section{Gráfico B.15 perda pósestocagem}


Tabela B.17 Representatividade da variação da espessura do revestimento no índice global de perdas

\begin{tabular}{|c|c|c|c|c|c|}
\hline Obra & Perda (\%) & $\begin{array}{c}\text { Var. Esp. } \\
(\%)\end{array}$ & $\begin{array}{c}\text { Esp. Ref.. } \\
(\%)\end{array}$ & $\begin{array}{l}\text { Esp. Real } \\
\text { (cm) }\end{array}$ & $\begin{array}{c}\text { Represent. } \\
(\%)\end{array}$ \\
\hline BR 016 & 134 & 60 & 2,5 & 4,0 & 45 \\
\hline BR 021 & 70 & 60 & 1,5 & 2,4 & 86 \\
\hline BR 033 & 30 & 22 & 2,5 & 3,0 & 72 \\
\hline BR 042 & 102 & 88 & 2,5 & 4,7 & 86 \\
\hline BR 045 & 36 & 36 & 2,5 & 3,4 & 99 \\
\hline BR 053 & -11 & -12 & 2,5 & 2,2 & 107 \\
\hline $\begin{array}{l}\text { Média } \\
\text { global }\end{array}$ & 60 & & & & 82 \\
\hline
\end{tabular}

\subsubsection{Contrapiso}

A Tabela B.18 reúne os valores representativos da amostra estudada, destacando-se as medidas de posição (mediana e média), as medidas de dispersão (diferença entre quartis, desvio padrão e valores mínimo e máximo) e o tamanho da amostra (n).

Tabela B.18 Estatísticas da amostra- cimento no serviço de contrapiso

\begin{tabular}{|c|c|c|c|c|c|c|}
\hline CONTRAPISO & & & & & & \\
\hline & OBRA & $\begin{array}{l}\mathrm{m} 3 / \mathrm{m} 2 \\
\text { eórico }\end{array}$ & $\begin{array}{l}\mathrm{kg} / \mathrm{m} 3 \\
\text { eórico }\end{array}$ & Perda (\%) & $\begin{array}{c}\mathrm{kg} / \mathrm{m} 2 \\
\text { eal }\end{array}$ & \\
\hline & BR 022 & 0,020 & 274,40 & 53 & 8,40 & \\
\hline & BR 039 & 0,020 & 287,00 & 288 & 22,25 & \\
\hline & BR 042 & 0,026 & 479,92 & 15 & 14,30 & \\
\hline & BR 045 & 0,060 & 329,55 & 8 & 24,52 & \\
\hline & BR 047 & 0,010 & 200,00 & 18 & 2,36 & \\
\hline & BR 053 & 0,020 & 356,07 & 42 & 10,10 & \\
\hline & BR 073 & 0,020 & 348,27 & 128 & 15,88 & \\
\hline INDICES & Média & Mediana & Desvio P. & Dif. Quartil & Mínimo & Máximo \\
\hline PERDA (\%) & 79 & 42 & 101 & 74 & 8 & 288 \\
\hline CONSUMO TEÓRICO(kg/m3) & 325,03 & 329,55 & 86,75 & 71,47 & 200,00 & 479,92 \\
\hline CONSUMO REAL (kg/m2) & 13,97 & 14,30 & 7,79 & 9,81 & 2,36 & 24,52 \\
\hline $\mathrm{n}=$ & 7 & & & & & \\
\hline
\end{tabular}


Os gráficos B.16 e B.17 configuram-se numa representação visual da distribuição dos valores de perdas e consumos respectivamente para os casos amostrados. Neles, pode-se perceber a região de concentração preferencial e a forma de dispersão dos resultados.

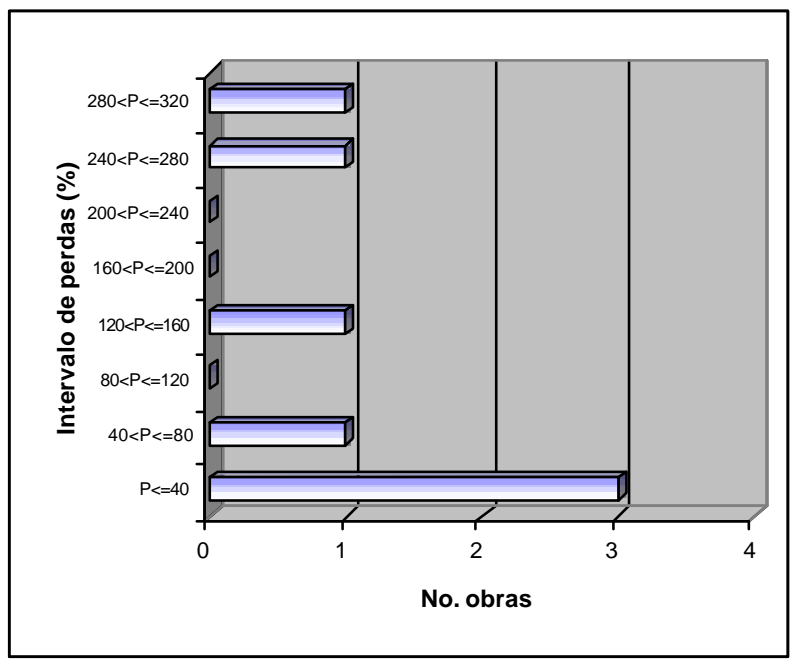

\section{Gráfico B.16 contrapiso}

Distribuição amostral dos resultados de perdas: cimento no serviço de

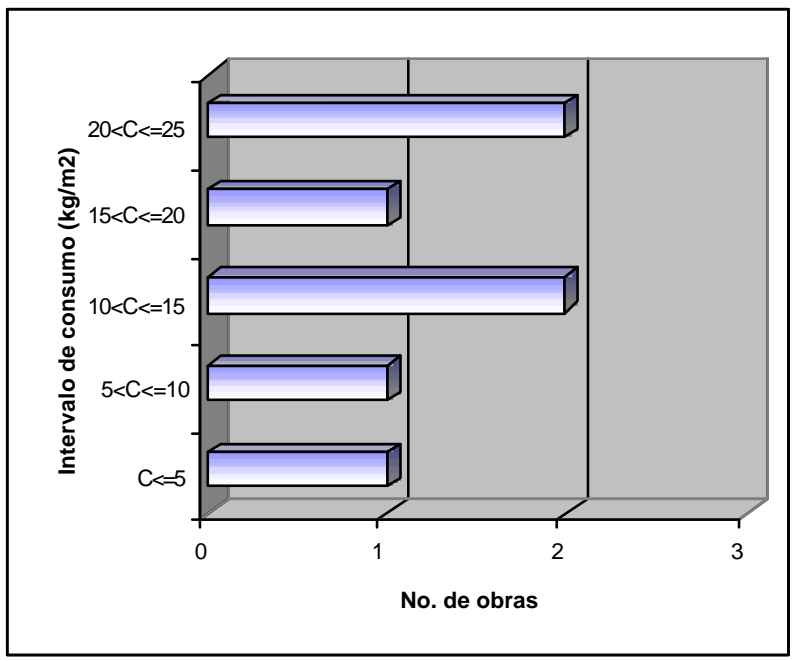

Distribuição amostral dos resultados de consumos: cimento no serviço Gráfico B.17 de contrapiso

Com relação às perdas e/ou consumos de cimento neste serviço, pode -se tecer os seguintes comentários, respeitando-se as considerações iniciais feitas anteriormente: 
(a) analisando-se os valores apresentados na Tabela B.18 percebe-se uma grande variação nos traços adotados (200,00 a 479,9 kg/m3), o que se reflete em grandes variações quanto ao consumo teórico de cimento por m3 de argamassa;

(b) em se tratando das espessuras teóricas adotadas, nota-se também uma grande variação (de 1 a $6 \mathrm{~cm}$ ); (vide planilhas de resultados para este material)

(c) as perdas (8 a 288\%) e os consumos reais $(2,36$ a $24,52 \mathrm{~kg} / \mathrm{m} 2)$ variaram significativamente. Conforme salientado nas considerações iniciais, a maior perda não necessariamente está associada ao maior consumo;

(d) no caso do contrapiso, espera-se que as perda sejam fortemente explicadas através da variação de sobrespessura do revestimento; tal raciocínio se fundamenta na expectativa de que as perdas diretas (entulho) sejam menores que nos casos dos revestimentos de paredes, onde o endurecimento de argamassas que caem no chão podem ser mais representativo. A observação do Gráfico B.18 indica uma alta correlação entre a variação da espessura detectada e a perda calculada. Tal idéia é reforçada pela Tabela B.19 onde apresenta-se qual a percentagem das perdas calculadas é explicada pela variação da espessura. A sobrespessura da argamassa de revestimento explica $79 \%$ do indicador global de perda para os casos considerados, ou seja, dos $90 \%, 71 \%$ dizem respeito à sobrespessura do revestimento enquanto que $8 \%$ referem-se à perdas de outras naturezas (no caso, provavelmente o entulho). Ressalta-se que para esta análise foram descartados aqueles dados para os quais detectaram-se problemas ou incertezas quanto a coleta, conforme descrito nas fichas de análise de cada obra.

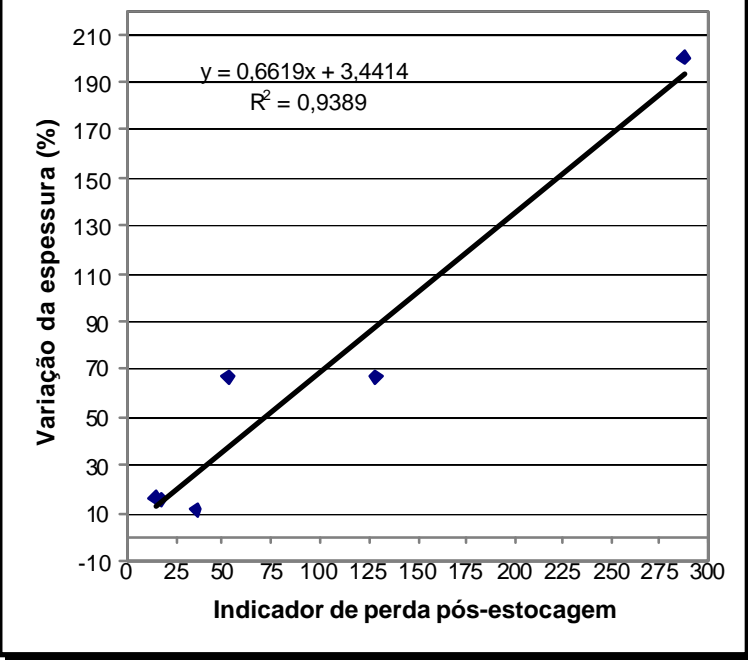
Gráfico B.18 perda pósestocagem

Correlação entre a variação da espessura e o indicador global de 
Tabela B.19 Representatividade da variação da espessura do revestimento no índice global de perdas

\begin{tabular}{cccccc}
\hline Obra & Perda (\%) & $\begin{array}{c}\text { Var. Esp. } \\
(\%)\end{array}$ & $\begin{array}{c}\text { Esp. Ref.. } \\
(\mathbf{c m})\end{array}$ & $\begin{array}{c}\text { Esp. Real } \\
(\mathbf{c m})\end{array}$ & $\begin{array}{c}\text { Represent. } \\
(\%)\end{array}$ \\
\hline BR 022 & 53 & 67 & 2,0 & 3,3 & 126 \\
BR 039 & 288 & 200 & 2,0 & 6,0 & 70 \\
BR 042 & 15 & 16 & 2,6 & 3,0 & 112 \\
BR 047 & 18 & 15 & 1,0 & 1,2 & 84 \\
BR 049 & 36 & 11 & 5,0 & 5,6 & 31 \\
\hline BR 073 & 128 & 67 & 2,0 & 3,3 & 79 \\
\hline $\begin{array}{l}\text { Média } \\
\text { global }\end{array}$ & 90 & & & & \\
\hline
\end{tabular}

(e) Comparando-se os índices de perdas levando-se em consideração a dosagem ou não dos materiais com auxílio de uma padiola dosadora, verifica-se um resultado mais satisfatório para o grupo de obras que utilizaram tal equipamento (Tabela B.20). Apesar desta tendência, há que se fazer reservas para tal afirmação, uma vez que a amostra para do grupo que utilizou outra forma de equipamento de dosagem ser reduzido $(n=2)$.

Tabela B.20 Comparação entre índices de perdas em função da dosagem ser realizada com padiola dosadora ou não

\begin{tabular}{lccccccc}
\hline Categoria & Média & Mediana & Desvio P. & Dif. Quartil & Mínimo & Máximo & n \\
\hline $\begin{array}{l}\text { Com padiola dosadora } \\
\begin{array}{l}\text { Sem o uso de padiola } \\
\text { dosadora }\end{array}\end{array}$ & 151 & 151 & 193 & 137 & 15 & 287 & 2 \\
\hline
\end{tabular}

\section{B.3.4 Gesso}


A Tabela B.21 reúne os valores representativos da amostra estudada, destacando -se as medidas de posição (mediana e média), as medidas de dispersão (diferença entre quartis, desvio padrão e valores mínimo e máximo) e o tamanho da amostra (n).

Tabela B.21 Estatísticas da amostra-gesso

\begin{tabular}{ccccccc}
\hline Média (\%) & $\begin{array}{c}\text { Mediana } \\
(\%)\end{array}$ & Desvio P. & $\begin{array}{c}\text { Dif. Quartis } \\
(\%)\end{array}$ & Mínimo (\%) & Máximo (\%) & $\mathbf{n}$ \\
\hline 45 & 30 & 68 & 67 & $(14)$ & 120 & 3 \\
\hline
\end{tabular}

Apesar de a amostra não ser considerável, pode-se tecer alguns comentários adicionais quanto às perdas deste material:

(a) o consumo de gesso e a mediana das perdas são bastante influenciado pelo tipo de base em que o revestimento de gesso é aplicado. A Tabela B.22 traz a comparação entre duas aplicações diretamente sobre a alvenaria com uma aplicação sobre emboço em argamassa. O valor negativo para o valor da perda para o caso da aplicação sobre a argamassa se deve ao fato de se conseguir menores espessuras, até mesmo inferior ao teoricamente estabelecido (5 mm);

Tabela B.22 Comparação entre estatísticas: tipo de base

\begin{tabular}{l|ccccccc}
\hline \multicolumn{1}{c|}{ Categorias } & $\begin{array}{c}\text { Média } \\
(\%)\end{array}$ & $\begin{array}{c}\text { Mediana } \\
(\%)\end{array}$ & $\begin{array}{c}\text { Desvio } \\
\text { P. }\end{array}$ & $\begin{array}{c}\text { Dif. } \\
\text { Quartis } \\
(\%)\end{array}$ & $\begin{array}{c}\text { Mínimo } \\
(\%)\end{array}$ & $\begin{array}{c}\text { Máximo } \\
(\%)\end{array}$ & $\mathbf{n}$ \\
\hline Alvenaria & 75 & 75 & 64 & 45 & 30 & 120 & 2 \\
Argamassa & $(14)$ & $(14)$ & - & - & $(14)$ & $(14)$ & 1 \\
\hline
\end{tabular}

(b) as estatísticas apresentadas são altas, porém foram consideradas coerentes face ao entulho gerado que, apesar de não quantificado, foi detectado no processo de execução.

\section{B.3.5 Placas cerâmicas}

A Tabela B.23 reúne os valores representativos da amostra estudada, destacando-se as medidas de posição (mediana e média), as medidas de dispersão (diferença entre quartis, desvio padrão e valores mínimo e máximo) e o tamanho da amostra (n).

Tabela B.23 Estatísticas da amostra- placas cerâmicas 


\begin{tabular}{l|ccccccc}
\hline Seção nominal & $\begin{array}{c}\text { Média } \\
(\%)\end{array}$ & $\begin{array}{c}\text { Mediana } \\
(\%)\end{array}$ & $\begin{array}{c}\text { Desvio } \\
\text { P. }\end{array}$ & $\begin{array}{c}\text { Dif. } \\
\text { Quartis } \\
(\%)\end{array}$ & $\begin{array}{c}\text { Mínimo } \\
(\%)\end{array}$ & $\begin{array}{c}\text { Máximo } \\
(\%)\end{array}$ & $\mathbf{n}$ \\
\hline Piso & 22 & 19 & 19 & 12 & 5 & 78 & 13 \\
Parede & 16 & 13 & 14 & 18 & $(1)$ & 50 & 28 \\
Fachada & 12 & 13 & 7 & 7 & 5 & 19 & 3 \\
\hline
\end{tabular}

O Gráfico B.19 configura -se numa representação visual da distribuição dos valores de perdas para os casos amostrados. Nele, pode-se perceber a região de concentração preferencial e a forma de dispersão dos resultados.

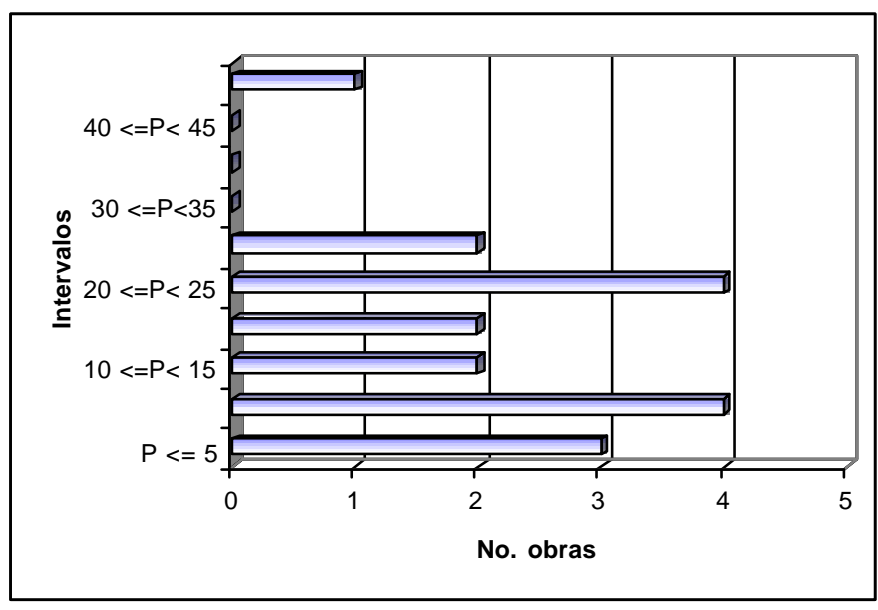

\section{Gráfico B.19}

Distribuição amostral dos resultados de perdas: placas cerâmicas

Pode-se então tecer alguns comentários adicionais, que poderão impulsionar entre outros aspectos, um estudo mais detalhado deste material em futuras pesquisas:

(a) ao se comparar as médias e medianas entre serviços, associa-se valores de perdas menores ao serviço de revestimento cerâmico nas paredes (Tabela B.23). No entanto, a simples subdivisão em piso, parede e fachada parece não conter informações suficientes para o entendimento das perdas detectadas. A Tabela B.24 mostra a distribuição dos casos levantados quanto à incidência de peças cortadas nos revestimentos estudados. Imagina-se que quanto maior a porcentagem de peças cortadas maior probabilidade haverá de se ter perdas maiores. E percebe-se aqui que há uma parcela maior de peças cortadas para revestimento de piso que de parede: o percentual de corte das peças foi menor do que $20 \%$ para o serviço de revestimento de parede quando comparado ao revestimento de piso. A situação se inverte para a faixa de percentual de cortes 
entre 40 e 60\%. A Tabela B.25 mostra a distribuição dos casos levantados quanto ao tamanho das peças. Imagina-se que peças maiores levem a probabilidades maiores de perdas, já que a quebra de uma peça maior represente maior área perdida que a quebra de uma peça menor. Novamente aqui os revestimentos de piso aparecem com predominância de peças maiores com relação aos revestimentos de parede. Portanto, não se pode associar as perdas das placas cerâmicas ao valor único relacionado à posição da face revestida.

Tabela B.24 Comparação entre serviços: percentual de placas cerâmicas cortadas

\begin{tabular}{lcccccc}
\hline \multirow{2}{*}{$\%$ de cortados } & \multicolumn{3}{c}{ Piso } & \multicolumn{2}{c}{ Parede } & \multicolumn{2}{c}{ Fachada } \\
\cline { 2 - 7 } & Abs. & $(\%)$ & Abs. & $(\%)$ & Abs. & $(\%)$ \\
\hline $\mathbf{C} \leq \mathbf{2 0}$ & 2 & 15 & 11 & 34 & 3 & 100 \\
$\mathbf{2 0}<\mathbf{C} \leq \mathbf{4 0}$ & 7 & 54 & 16 & 50 & - & - \\
$\mathbf{4 0}<\mathbf{C} \leq \mathbf{6 0}$ & 4 & 31 & 5 & 16 & - & - \\
\hline Total & 13 & 100 & 32 & 100 & 3 & 100 \\
\hline
\end{tabular}

Tabela B.25 Comparação entre serviços: tamanho das peças

\begin{tabular}{lcccccc}
\hline \multirow{2}{*}{ Tamanho da peça } & \multicolumn{2}{c}{ Piso } & \multicolumn{2}{c}{ Parede } & \multicolumn{2}{c}{ Fachada } \\
\cline { 2 - 7 } & Abs. & $(\%)$ & Abs. & $(\%)$ & Abs. & $(\%)$ \\
\hline$\leq 20 \times 20$ & 7 & 54 & 23 & 72 & 3 & 100 \\
$>20 \times 20$ & 6 & 46 & 9 & 28 & - & 0 \\
\hline Total & 13 & 100 & 32 & 100 & 3 & 100 \\
\hline
\end{tabular}

(b) aprofundando o questionamento levantado no item (a), a Tabela B.26 traz as médias e medianas do indicador global de perdas, discriminadas por dimensões, por porcentagens de peças cortadas e por serviço. Nela observa-se que, 
independentemente do grupo de percentual de placas cortadas, verifica-se a tendência de as placas maiores apresentarem maiores índices de perdas. E, independentemente do grupo de tamanho de placas, há uma tendência de maiores perdas para os casos com maiores porcentagens de peças cortadas.

Tabela B.26 Comparativo entre índices de perdas: tamanho das placas e percentual de placas cortadas

\begin{tabular}{cccccccc}
\hline \multirow{2}{*}{$\begin{array}{c}\text { (\%) } \\
\text { cortadas }\end{array}$} & Tamanho da & \multicolumn{2}{c}{ Piso } & \multicolumn{2}{c}{ Parede } & \multicolumn{2}{c}{ Fachada } \\
\cline { 3 - 8 } & placa & Média & Mediana & Média & Mediana & Média & Mediana \\
\hline $\mathbf{C} \leq \mathbf{2 0}$ & $\leq \mathbf{2 0 \times 2 0}$ & 5 & 5 & 13 & 8 & 12 & 13 \\
& $>\mathbf{2 0 \times 2 0}$ & 8 & 8 & 13 & 13 & - & - \\
\hline $\mathbf{2 0}<\mathbf{C} \leq \mathbf{4 0}$ & $\leq \mathbf{2 0 \times 2 0}$ & 17 & 18 & 14 & 14 & - & - \\
& $>\mathbf{2 0 \times 2 0}$ & 39 & 26 & 24 & 21 & - & - \\
\hline $\mathbf{4 0}<\mathbf{C} \leq \mathbf{6 0}$ & $\leq \mathbf{2 0 \times 2 0}$ & 18 & 18 & 13 & 13 & - & - \\
& $>\mathbf{2 0} \times \mathbf{2 0}$ & 27 & 27 & 29 & 29 & - & - \\
\hline
\end{tabular}


ANEXO C

Natureza das perdas de materiais, suas origens e causas; indic adores 


\section{C1 - MOMENTO DE INCIDÊNCIA DAS PERDAS, PRINCIPAIS CAUSAS, ORIGEM E INDICADORES - areia / brita / saibro}

\begin{tabular}{|c|c|c|c|c|}
\hline $\begin{array}{l}\text { Momento } \\
\text { de } \\
\text { incidência }\end{array}$ & Forma de ocorrência da perda & Causa(s) & Origem(s) & Indicador(es) \\
\hline Recebimento & Quantidade entregue inferior à solicitada ou paga & $\begin{array}{l}\text { - ausência de procedimentos específicos de } \\
\text { avaliação quantitativa; } \\
\text { - inexperiência do responsável pelo } \\
\text { recebimento; }\end{array}$ & $\begin{array}{l}\text { Planejamento } \\
\text { operacional }\end{array}$ & $\begin{array}{l}\text { - Diferença (percentual) entre a quantidade } \\
\text { recebida e a solicitada } \\
\text { - Diferença (percentual) entre a quantidade } \\
\text { recebida e a paga }\end{array}$ \\
\hline Estocagem & $\begin{array}{l}\text { Carreamento das partículas (ação da chuva ou vento); } \\
\text { contaminação por outros materiais ou solo }\end{array}$ & $\begin{array}{l}\text { - } \quad \text { condições inadequadas de estocagem; } \\
\text { ( } \quad \text { duplo manuseio do material; } \\
\text { na falta de um planejamento do layout do canteiro } \\
\text { de obras }\end{array}$ & $\begin{array}{l}\text { Planejamento } \\
\text { operacional }\end{array}$ & - Entulho gerado durante a estocagerm \\
\hline Transporte & Material que cai durante o transporte & $\begin{array}{l}\text { - } \quad \text { equipamento de tr ansporte inadequado; } \\
\text { - condições do trajeto inadequadas } \\
\left(^{\star}\right) \text { na essência, estas causas poderiam ser reunidas } \\
\text { na falta de um planejamento do layout do canteiro } \\
\text { de obras }\end{array}$ & $\begin{array}{l}\text { Planejamento } \\
\text { operacional }\end{array}$ & $\begin{array}{l}\text { - Entulho gerado durante o transporte } \\
\text { interno }\end{array}$ \\
\hline \multirow[t]{3}{*}{ Processamento } & \multirow[t]{2}{*}{$\begin{array}{l}\text { Uso do material em quantidades superiores à } \\
\text { especificada (produção de argamassas e concretos) }\end{array}$} & 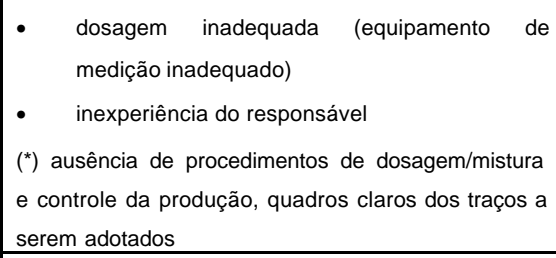 & $\begin{array}{l}\text { Planejamento } \\
\text { operacional }\end{array}$ & \multirow[t]{2}{*}{$\begin{array}{l}\text { - Variação do consumo de areia por m3 de } \\
\text { argamassa ou concreto produzido }\end{array}$} \\
\hline & & qualidade do material (fora das especificações) & $\begin{array}{l}\text { Fornecedor / Projeto / } \\
\text { Suprimentos }\end{array}$ & \\
\hline & $\begin{array}{l}\text { Produção de argamassa ou concreto acima do } \\
\text { necessário (endurecimento do material) }\end{array}$ & $\begin{array}{l}\text { - } \quad \text { ausência de planejamento de produção das } \\
\text { argamassas e concretos }\end{array}$ & $\begin{array}{l}\text { Planejamento } \\
\text { operacional }\end{array}$ & $\begin{array}{l}\text { - Entulho de argamassa e concreto } \\
\text { produzidos em obra gerados durante a } \\
\text { produção }\end{array}$ \\
\hline
\end{tabular}


C1 - MOMENTO DE INCIDÊNCIA DAS PERDAS, PRINCIPAIS CAUSAS, ORIGEM E INDICADORES - areia / brita / saibro (continuação)

\begin{tabular}{l|l|l|l|l}
\hline $\begin{array}{c}\text { Momento } \\
\text { de } \\
\text { incidência }\end{array}$ & Forma de ocorrência da perda & Causa(s) & Origem(s) & Indicador(es) \\
\hline $\begin{array}{l}\text { Transporte/ } \\
\text { Aplicação }\end{array}$ & \multicolumn{3}{|c}{ Vide argamassa produzida em obra } \\
\hline
\end{tabular}




\section{C2 - MOMENTO DE INCIDÊNCIA DAS PERDAS, PRINCIPAIS CAUSAS, ORIGEM E INDICADORES - cimento / cal}

\begin{tabular}{|c|c|c|c|c|}
\hline $\begin{array}{l}\text { Momento } \\
\text { de } \\
\text { incidência }\end{array}$ & Forma de ocorrência da perda & Causa(s) & Origem(s) & Indicador(es) \\
\hline Recebimento & $\begin{array}{l}\text { Quantidade entregue inferior à solicitada ou paga (em } \\
\text { termos de número de sacos ou em termos de massa) }\end{array}$ & $\begin{array}{l}\text { - ausência de procedimentos específicos de } \\
\text { avaliação quantitativa; } \\
\text { - inexperiência do responsável pelo } \\
\text { recebimento; }\end{array}$ & $\begin{array}{l}\text { Planejamento } \\
\text { operacional }\end{array}$ & $\begin{array}{l}\text { - Diferença (percentual) entre a quantidade } \\
\text { recebida e a solicitada } \\
\text { - } \quad \text { Diferença (percentual) entre a quantidade } \\
\text { recebida e a paga } \\
\text { - } \quad \begin{array}{l}\text { Diferença (percentual) entre a massa real } \\
\text { e a nominal }\end{array}\end{array}$ \\
\hline Transporte & Material que cai durante o transporte & $\begin{array}{l}\text { - } \quad \text { equipamento de transporte inadequado; } \\
\text { - condições do trajeto inadequadas } \\
\text { manuseio incorreto dos sacos, ocasionando o } \\
\text { seurasgamento } \\
\left(^{*}\right) \text { na essência, estas causas poderiam ser reunidas } \\
\text { na falta de um planejamento do layout do canteiro } \\
\text { de obras }\end{array}$ & $\begin{array}{l}\text { Planejamento } \\
\text { operacional }\end{array}$ & $\begin{array}{l}\text { - Percentual ou número absoluto de sacos } \\
\text { rasgados durante o transporte do } \\
\text { equipamento de transporte externo e a } \\
\text { área de estocagem }\end{array}$ \\
\hline Esto cagem & "Empedramento" do cimento" & $\begin{array}{l}\text { - ação da umidade em função da condições } \\
\text { inadequadas de estocagem } \\
\text { - } \quad \text { data de validade vencida } \\
\end{array}$ & $\begin{array}{l}\text { Planejamento } \\
\text { operacional }\end{array}$ & - Entulho gerado durante a estocagem \\
\hline Estocagem & Material que cai no chão & $\begin{array}{l}\text { - condições inadequadas de estocagem; } \\
\text { - duplo manuseio do material; } \\
\text { (*) na essência, estas causas poderiam ser reunidas } \\
\text { na falta de um planejamento do layout do canteiro } \\
\text { de obras }\end{array}$ & & \\
\hline
\end{tabular}


C2 - MOMENTO DE INCIDÊNCIA DAS PERDAS, PRINCIPAIS CAUSAS, ORIGEM E INDICADORES - cimento / cal Continuação

\begin{tabular}{|c|c|c|c|c|}
\hline $\begin{array}{c}\text { Momento } \\
\text { de } \\
\text { incidência }\end{array}$ & Forma de ocorrência da perda & Causa(s) & Origem(s) & Indicador(es) \\
\hline \multirow[t]{3}{*}{ Processamento } & \multirow[t]{2}{*}{$\begin{array}{l}\text { Uso do material em quantidades superiores à } \\
\text { especificada (produção de argamassas e concretos) }\end{array}$} & 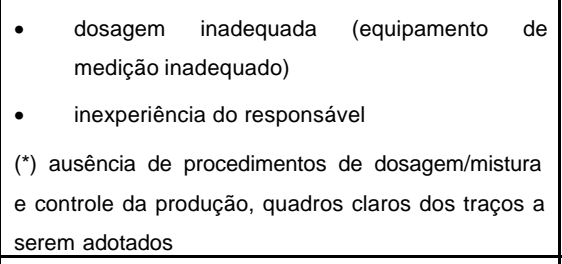 & $\begin{array}{l}\text { Planejamento } \\
\text { operacional }\end{array}$ & \multirow[t]{2}{*}{$\begin{array}{l}\text { - Variação do consumo de cimento por m3 } \\
\text { de argamassa ou concreto produzido }\end{array}$} \\
\hline & & $\begin{array}{llll}\text { - } & \begin{array}{l}\text { qualidade do material (fora das } \\
\text { especificações) }\end{array} \\
\end{array}$ & $\begin{array}{l}\text { Fornecedor / Projeto / } \\
\text { Suprimentos }\end{array}$ & \\
\hline & $\begin{array}{l}\text { Produção concreto acima do necessário } \\
\text { (endurecimento do material) }\end{array}$ & 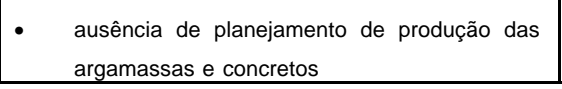 & $\begin{array}{l}\text { Planejamento } \\
\text { operacional }\end{array}$ & $\begin{array}{l}\text { - Entulho gerado durante a produção de } \\
\text { argamassas e concretos }\end{array}$ \\
\hline Transporte/ & \multicolumn{4}{|c|}{ Vide argamassa produzida em obra } \\
\hline Aplicação & & & & \\
\hline
\end{tabular}




\section{C3 - MOMENTO DE INCIDÊNCIA DAS PERDAS, PRINCIPAIS CAUSAS, ORIGEM E INDICADORES - concreto usinado /} concreto produzido em obra

\begin{tabular}{|c|c|c|c|c|}
\hline $\begin{array}{l}\text { Momento } \\
\text { de } \\
\text { incidência }\end{array}$ & Forma de ocorrência da perda & Causa(s) & Origem(s) & Indicador(es) \\
\hline Recebimento & $\begin{array}{l}\text { Quantidade entregue inferior à solicitada ou paga } \\
\text { (somente concreto usinado) }\end{array}$ & $\begin{array}{l}\text { - ausência de procedimentos específicos de } \\
\text { avaliação quantitativa; } \\
\text { - inexperiência do responsável pelo } \\
\text { recebimento; }\end{array}$ & $\begin{array}{l}\text { Planejamento } \\
\text { operacional }\end{array}$ & $\begin{array}{l}\text { - Diferença (percentual) entre a quantidade } \\
\text { recebida e a solicitada } \\
\text { - Diferença (percentual) entre a quantidade } \\
\text { recebida e a paga }\end{array}$ \\
\hline Transporte & Material que cai durante o transporte & $\begin{array}{l}\text { - equipamento de transporte inadequado; } \\
\text { - condições do trajeto inadequadas } \\
\left(^{\star}\right) \text { na essência, estas causas poderiam ser reunidas } \\
\text { na falta de um planejamento do layout do canteiro } \\
\text { de obras }\end{array}$ & $\begin{array}{l}\text { Planejamento } \\
\text { operacional }\end{array}$ & - Entulho gerado durante o transporte \\
\hline \multirow[t]{2}{*}{ Aplicação } & Material que cai & $\begin{array}{l}\text { - } \text { qualidade das fôrmas } \\
\text { - uso de equipamento e ferramentas } \\
\text { inadequadas }\end{array}$ & $\begin{array}{l}\text { Planejamento } \\
\text { operacional / } \\
\text { Execução }\end{array}$ & - Entulho gerado durante a aplicação \\
\hline & $\begin{array}{l}\text { Material que fica incorporado (variação geométrica dos } \\
\text { elementos estruturais) }\end{array}$ & $\begin{array}{l}\text { - } \quad \text { qualidade das fôrmas } \\
\text { - } \quad \text { ausência de controle geométrico }\end{array}$ & Execução & $\begin{array}{l}\text { - Variação percentual entre a espessura da } \\
\text { laje realmente executada e a especificada } \\
\text { - Variação percentual entre a largura da } \\
\text { viga realmente executada e a especificada } \\
\text { - Variação percentual entre a secção do } \\
\text { pilar realmente executada e a especificada }\end{array}$ \\
\hline
\end{tabular}




\section{C4 - MOMENTO DE INCIDÊNCIA DAS PERDAS, PRINCIPAIS CAUSAS, ORIGEM E INDICADORES - argamassa} produzida em obra / argamassa parcial ou totalmente produzida fora do canteiro de obras

\begin{tabular}{|c|c|c|c|c|}
\hline $\begin{array}{l}\text { Momento } \\
\text { de } \\
\text { incidência }\end{array}$ & Forma de ocorrência da perda & Causa(s) & Origem(s) & Indicador(es) \\
\hline Transporte & Material que cai durante o transporte & $\begin{array}{l}\text { - } \quad \text { equipamento de transporte inadequado; } \\
\text { condições do trajeto inadequadas; } \\
\left(^{*}\right) \text { na essência, estas causas poderiam ser reunidas } \\
\text { na falta de um planejamento do layout do canteiro } \\
\text { de obras }\end{array}$ & $\begin{array}{l}\text { Planejamento } \\
\text { operacional }\end{array}$ & $\begin{array}{l}\text { - Entulho gerado durante } 0 \text { transporte } \\
\text { interno }\end{array}$ \\
\hline \multirow{4}{*}{$\begin{array}{l}\text { Aplicação } \\
\text { Revestimentos } \\
\text { argamassados } \\
\text { interno } \\
\text { externo }\end{array}$} & Material que cai & $\begin{array}{l}\text { - uso de equipamento e ferramentas } \\
\text { inadequadas; } \\
\text { - inexperiência do operário; }\end{array}$ & $\begin{array}{l}\text { Planejamento } \\
\text { operacional / } \\
\text { Execução }\end{array}$ & $\begin{array}{l}\text { - Entulho gerado durante a aplicação da } \\
\text { argamassa }\end{array}$ \\
\hline & \multirow[t]{3}{*}{$\begin{array}{l}\text { Material que fica incorporado (variação geométrica dos } \\
\text { elementos estruturais) }\end{array}$} & $\begin{array}{l}\text { - falta de qualidade da base (prumo e } \\
\text { esquadro, para o caso dos revestimentos } \\
\text { verticais; nível, para o caso dos horizontais); }\end{array}$ & Execução & \multirow[t]{3}{*}{$\begin{array}{l}\text { - Variação entre a espessura especificada e } \\
\text { a executada dos revestimentos }\end{array}$} \\
\hline & & $\begin{array}{l}\text { - falta de coordenação modular entre largura da } \\
\text { alvenaria e de vigas/pilares; alvenaria e } \\
\text { caixilhos; }\end{array}$ & Projeto & \\
\hline & & - variações nas dimensões dos componentes; & $\begin{array}{l}\text { Fornecedores / } \\
\text { Suprimentos / } \\
\text { Execução }\end{array}$ & \\
\hline \multirow[t]{2}{*}{$\begin{array}{l}\text { Aplicação } \\
\text { Alvenaria }\end{array}$} & Material que cai & $\begin{array}{l}\text { - uso de equipamento e ferramentas } \\
\text { inadequadas; } \\
\text { - inexperiência do operário; }\end{array}$ & Execução & $\begin{array}{l}\text { - Entulho gerado durante a aplicação da } \\
\text { argamassa }\end{array}$ \\
\hline & $\begin{array}{l}\text { Material que fica incorporado (variação geométrica dos } \\
\text { elementos estruturais) }\end{array}$ & $\begin{array}{l}\text { - tipo de ferramenta para aplicação (bisnaga, } \\
\text { colher de pedreiro); } \\
\text { tipo de componente de vedação utilizado } \\
\text { (presença de furos, dimensões etc) }\end{array}$ & Execução & $\begin{array}{l}\text { - } \text { Variação entre as espessuras verticais e } \\
\text { horizontais especificadas e as executadas } \\
\text { - } \quad \text { Argamassa presente nos furos dos blocos }\end{array}$ \\
\hline
\end{tabular}




\section{C5 - MOMENTO DE INCIDÊNCIA DAS PERDAS, PRINCIPAIS CAUSAS, ORIGEM E INDICADORES - açO}

\begin{tabular}{|c|c|c|c|c|}
\hline $\begin{array}{l}\text { Momento } \\
\text { de } \\
\text { incidência }\end{array}$ & Forma de ocorrência da perda & Causa(s) & Origem(s) & Indicador(es) \\
\hline \multirow[t]{3}{*}{ Recebimento } & Quantidade entregue inferior à solicitada ou paga & $\begin{array}{l}\text { - ausência de procedimentos específicos de } \\
\text { avaliação quantitativa; } \\
\text { - inexperiência do responsável pelo } \\
\text { recebimento; }\end{array}$ & $\begin{array}{l}\text { Planejamento } \\
\text { operacional }\end{array}$ & $\begin{array}{l}\text { - Diferença (percentual) entre a quantidade } \\
\text { recebida e a solicitada } \\
\text { - } \quad \begin{array}{l}\text { Diferença (percentual) entre a quantidade } \\
\text { recebida e a paga }\end{array} \\
\end{array}$ \\
\hline & \multirow[t]{2}{*}{$\begin{array}{l}\text { Massa por metro linear maior do que a especificada } \\
\text { em normas }\end{array}$} & - $\quad$ deficiência dos fornecedores & $\begin{array}{l}\text { Fornecedores / } \\
\text { Suprimentos }\end{array}$ & \multirow[t]{2}{*}{$\begin{array}{l}\text { - Variação percentual entre a massa linear } \\
\text { real e a nominal }\end{array}$} \\
\hline & & $\begin{array}{l}\text { - ausência de procedimentos específicos de } \\
\text { avaliação qualitativa; }\end{array}$ & Execução & \\
\hline $\begin{array}{l}\text { Processamento } \\
\text { (corte) }\end{array}$ & Sobras dos cortes das barras & - inexistência de um plano de corte das barras & $\begin{array}{l}\text { Planejamento } \\
\text { operacional }\end{array}$ & $\begin{array}{l}\text { - Entulho gerado durante a etapa de corte } \\
\text { das barras }\end{array}$ \\
\hline \multirow{3}{*}{$\begin{array}{l}\text { Processamento } \\
\text { (montagem) }\end{array}$} & \multirow{3}{*}{$\begin{array}{l}\text { Incorporação de quantidade superior do material do } \\
\text { que a especificada (substituição de barras por outras } \\
\text { de diâmetros (massa) maior, comprimentos superiores } \\
\text { ao especificados ou ainda, número de barras superior } \\
\text { à especificada) }\end{array}$} & - inexistência de projeto específico & Projeto & \multirow{3}{*}{$\begin{array}{l}\text { - Diferença entre o comprimento de } \\
\text { transpasse previsto e o executado } \\
\text { - Diferença entre o espaçamento das } \\
\text { armaduras longitudinais e transversais }\end{array}$} \\
\hline & & $\begin{array}{ll} & \text { inexistência de procedimentos específicos de } \\
\text { montagem e controle; }\end{array}$ & Execução & \\
\hline & & $\begin{array}{l}\text { - falta de provisão do material especificado no } \\
\text { momento da montagem }\end{array}$ & $\begin{array}{l}\text { Planejamento } \\
\text { operacional }\end{array}$ & \\
\hline \multirow[t]{3}{*}{ Aplicação } & \multirow{3}{*}{$\begin{array}{l}\text { Incorporação de quantidade superior do material do } \\
\text { que a especificada (substituição de barras por outras } \\
\text { de diâmetros (massa) maior, comprimentos superiores } \\
\text { ao especificados ou ainda, número de barras superior } \\
\text { à especificada, comprimento de transpasse maior do } \\
\text { que o especificado) }\end{array}$} & - $\quad$ inexistência de projeto específico & Projeto & \multirow{3}{*}{$\begin{array}{l}\text { - Diferença entre o comprimento de } \\
\text { transpasse previsto e o executado } \\
\text { - Diferença entre o espaçamento das } \\
\text { armaduras longitudinais e transversais }\end{array}$} \\
\hline & & $\begin{array}{l}\text { - inexistência de procedimentos específicos de } \\
\text { montagem e controle; }\end{array}$ & Execução & \\
\hline & & 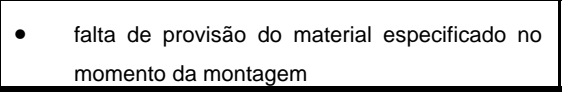 & $\begin{array}{l}\text { Planejamento } \\
\text { operacional }\end{array}$ & \\
\hline
\end{tabular}




\section{C6 - MOMENTO DE INCIDÊNCIA DAS PERDAS, PRINCIPAIS CAUSAS, ORIGEM E INDICADORES - blocos e tijolos}

\begin{tabular}{|c|c|c|c|c|}
\hline $\begin{array}{l}\text { Momento } \\
\text { de } \\
\text { incidência }\end{array}$ & Forma de ocorrência da perda & Causa(s) & Origem(s) & Indicador(es) \\
\hline \multirow[t]{3}{*}{ Recebimento } & \multirow[t]{3}{*}{$\begin{array}{l}\text { Quantidade entregue inferior à solicitada ou paga (em } \\
\text { termos de unidade ou ainda de dimensões) }\end{array}$} & $\begin{array}{l}\text { - ausência de procedimentos específicos de } \\
\text { avaliação quantitativa; } \\
\text { - inexperiência do responsável pelo } \\
\text { recebimento; }\end{array}$ & $\begin{array}{l}\text { Planejamento } \\
\text { operacional }\end{array}$ & $\begin{array}{l}\text { - Diferença (percentual) entre a quantidade } \\
\text { recebida e a solicitada } \\
\text { - Diferença (percentual) entre a quantidade } \\
\text { recebida e a paga }\end{array}$ \\
\hline & & $\begin{array}{l}\text { - quebra de blocos/tijolos no decorrer do } \\
\text { transporte externo (equipamento de transporte } \\
\text { inadequado ou ainda falta de qualidade do } \\
\text { material }\end{array}$ & $\begin{array}{l}\text { Fornecedor / } \\
\text { Suprimentos }\end{array}$ & $\begin{array}{l}\text { - Percentual de blocos/tijolos quebrados no } \\
\text { recebimento }\end{array}$ \\
\hline & & - Variação dimensional dos blocos/tijolos & $\begin{array}{l}\text { Fornecedor / } \\
\text { Suprimentos }\end{array}$ & - Variação dimensional dos blocos/tijolos \\
\hline Estocagem & Material danificado & $\begin{array}{l}\text { - condições inadequadas de estocagem; } \\
\text { - duplo manuseio do material; } \\
\left(^{*}\right) \text { na essência, estas causas poderiam ser reunidas } \\
\text { na falta de um planejamento do layout do canteiro } \\
\text { de obras }\end{array}$ & $\begin{array}{l}\text { Planejamento } \\
\text { operacional }\end{array}$ & - Entulho gerado durante a estocagem \\
\hline Transporte & Material danifi cado durante o transporte & $\begin{array}{l}\text { - } \quad \text { equipamento de transporte inadequado; } \\
\text { - condições do trajeto inadequadas; } \\
\left(^{*}\right) \text { na essência, estas causas poderiam ser reunidas } \\
\text { na falta de um planejamento do layout do canteiro } \\
\text { de obras }\end{array}$ & $\begin{array}{l}\text { Planejamento } \\
\text { operacional }\end{array}$ & $\begin{array}{l}\text { - Entulho gerado durante o transporte } \\
\text { interno }\end{array}$ \\
\hline \multirow[t]{3}{*}{ Aplicação } & \multirow[t]{2}{*}{ Material danificado pela necessidade de corte } & $\begin{array}{l}\text { - falta de coordenação dimensional entre } \\
\text { projetos }\end{array}$ & Projeto & $\begin{array}{l}\text { - Percentual de blocos/tijolos cortados na } \\
\text { parede }\end{array}$ \\
\hline & & - variação das dimensões dos blocos/tijolos & \multirow{2}{*}{$\begin{array}{l}\text { Fornecedores / } \\
\text { Suprimentos }\end{array}$} & \multirow[t]{2}{*}{ - Variação dimensional dos blocos/tijolos } \\
\hline & Material incorporado acima do especificado & - variação das dimensões dos blocos/tijolos & & \\
\hline
\end{tabular}


C7 - MOMENTO DE INCIDÊNCIA DAS PERDAS, PRINCIPAIS CAUSAS, ORIGEM E INDICADORES - tubos para instalações hidrossanitárias

\begin{tabular}{|c|c|c|c|c|}
\hline $\begin{array}{c}\text { Momento } \\
\text { de } \\
\text { incidência }\end{array}$ & Forma de ocorrência da perda & Causa(s) & Origem(s) & Indicador(es) \\
\hline Recebimento & $\begin{array}{l}\text { Quantidade entregue inferior à solicitada ou paga (em } \\
\text { termos de unidade ou ainda de dimensões) }\end{array}$ & $\begin{array}{lll}\text { - } & \text { ausência de procedimentos específicos de } \\
\text { avaliação quantitativa; } & \\
\text { - } & \begin{array}{l}\text { inexperiência do responsável pelo } \\
\text { recebimento; }\end{array} \\
\end{array}$ & $\begin{array}{l}\text { Planejamento } \\
\text { operacional }\end{array}$ & $\begin{array}{l}\text { - Diferença (percentual) entre a quantidade } \\
\text { recebida e a solicitada } \\
\text { - Diferença (percentual) entre a quantidade } \\
\text { recebida e a paga }\end{array}$ \\
\hline Processamento & Sobras devido a cortes & $\begin{array}{l}\text { - ausência de um plano ce corte ou de uma } \\
\text { política de reaproveitamento das sobras }\end{array}$ & $\begin{array}{l}\text { Planejamento } \\
\text { operacional / } \\
\text { Execução }\end{array}$ & $\begin{array}{l}\text { - Entulho gerado durante o corte das barras } \\
\text { / fios }\end{array}$ \\
\hline Aplicação & Material incorporado acima do especificado & - $\quad$ alterações de traçados dos eletrodutos & Projeto / Execução & $\begin{array}{l}\text { - Diferença entre o comprimento do traçado } \\
\text { previsto e o executado }\end{array}$ \\
\hline
\end{tabular}




\section{C8 - MOMENTO DE INCIDÊNCIA DAS PERDAS, PRINCIPAIS CAUSAS, ORIGEM E INDICADORES - placas cerâmicas}

\begin{tabular}{|c|c|c|c|c|}
\hline $\begin{array}{l}\text { Momento } \\
\text { de } \\
\text { incidência }\end{array}$ & Forma de ocorrência da perda & Causa(s) & Origem(s) & Indicador(es) \\
\hline \multirow[t]{2}{*}{ Recebimento } & \multirow[t]{2}{*}{ Quantidade entregue inferior à solicitada ou paga } & $\begin{array}{l}\text { - ausência de procedimentos específicos de } \\
\text { avaliação quantitativa; } \\
\text { - inexperiência do responsável pelo } \\
\text { recebimento; }\end{array}$ & $\begin{array}{l}\text { Planejamento } \\
\text { operacional }\end{array}$ & $\begin{array}{l}\text { - Diferença (percentual) entre a quantidade } \\
\text { recebida e a solicitada } \\
\text { - Diferença (percentual) entre a quantidade } \\
\text { recebida e a paga }\end{array}$ \\
\hline & & $\begin{array}{l}\text { - quebra de placas cerâmicas no decorrer do } \\
\text { transporte externo (equipamento de transporte } \\
\text { inadequado ou ainda falta de qualidade do } \\
\text { material) }\end{array}$ & $\begin{array}{l}\text { Fornecedor / } \\
\text { Suprimentos }\end{array}$ & $\begin{array}{l}\text { - Percentual de placas cerâmicas } \\
\text { quebradas no recebimento }\end{array}$ \\
\hline Estocagem & Material danificado & $\begin{array}{l}\text { - condições inadequadas de estocagem; } \\
\text { - duplo manuseio do material; } \\
\text { (*) na essência, estas causas poderiam ser reunidas } \\
\text { na falta de um planejamento do layout do canteiro } \\
\text { de obras }\end{array}$ & $\begin{array}{l}\text { Planejamento } \\
\text { opera cional }\end{array}$ & - Entulho gerado durante a estocagem \\
\hline Transporte & Material danificado durante o transporte & $\begin{array}{l}\text { - } \quad \text { equipamento de transporte inadequado; } \\
\text { - condições do trajeto inadequadas; } \\
\left(^{*}\right) \text { na essência, estas causas poderiam ser reunidas } \\
\text { na falta de um planejamento do layout do canteiro } \\
\text { de obras }\end{array}$ & $\begin{array}{l}\text { Planejamento } \\
\text { operacional }\end{array}$ & $\begin{array}{l}\text { - Entulho gerado durante o transporte } \\
\text { interno }\end{array}$ \\
\hline Aplicação & Material danificado pela necessidade de corte & $\begin{array}{l}\text { - falta de coordenação dimensional entre } \\
\text { projetos }\end{array}$ & Projeto & $\begin{array}{l}\text { - Percentual de placas cerâmicas cortadas } \\
\text { na parede } \\
\text { - } \quad \text { Entulho gerado durante a aplicação }\end{array}$ \\
\hline
\end{tabular}




\section{C9 - MOMENTO DE INCIDÊNCIA DAS PERDAS, PRINCIPAIS CAUSAS, ORIGEM E INDICADORES - tintas}

\begin{tabular}{|c|c|c|c|c|}
\hline $\begin{array}{l}\text { Momento } \\
\text { de } \\
\text { incidência }\end{array}$ & Forma de ocorrência da perda & Causa(s) & Origem(s) & Indicador(es) \\
\hline \multirow[t]{2}{*}{ Recebimento } & \multirow[t]{2}{*}{$\begin{array}{l}\text { Quantidade entregue inferior à solicitada ou paga (em } \\
\text { termos de unidade ou ainda de dimensões) }\end{array}$} & $\begin{array}{l}\text { - } \begin{array}{l}\text { ausência de procedimentos específicos de } \\
\text { avaliação quantitativa; } \\
\text { - } \\
\text { inexperiência do responsável pelo } \\
\text { recebimento; }\end{array} \\
\end{array}$ & $\begin{array}{l}\text { Planejamento } \\
\text { operacional }\end{array}$ & 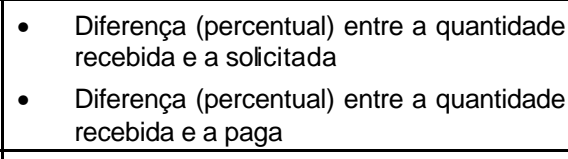 \\
\hline & & $\begin{array}{l}\text { - quebra de placas cerâmicas no decorrer do } \\
\text { transporte externo (equipamento de transporte } \\
\text { inadequado ou ainda falta de qualidade do } \\
\text { material) }\end{array}$ & $\begin{array}{l}\text { Fornecedor / } \\
\text { Suprimentos }\end{array}$ & $\begin{array}{ll}\text { - } & \text { Percentual de placas cerâmicas } \\
\text { quebradas no recebimento }\end{array}$ \\
\hline Estocagem & Material danificado & $\begin{array}{l}\text { - } \quad \text { condições inadequadas de estocagem; } \\
\text { - } \quad \text { tempo de validade vencido; } \\
\text { (*) na essência, estas causas poderiam ser reunidas } \\
\text { na falta de um planejamento do layout do canteiro } \\
\text { de obras }\end{array}$ & $\begin{array}{l}\text { Planejamento } \\
\text { operacional }\end{array}$ & - $\quad$ Entulho gerado durante a estocagem \\
\hline Processamento & Uso acima do especificado (incorporado) & $\begin{array}{l}\text { - dosagem inadequada (equipamento de } \\
\text { medição inadequado) } \\
\text { - inexperiência do responsável } \\
\left(^{\star}\right) \text { ausência de procedimentos de dosagem/mistura } \\
\text { e controle da produção, quadros claros dos traços a } \\
\text { serem adotados }\end{array}$ & $\begin{array}{l}\text { Planejamento } \\
\text { operacional / } \\
\text { Execução }\end{array}$ & $\begin{array}{l}\text { - Diferença entre a dosagem de tinta } \\
\text { especificada e a executada }\end{array}$ \\
\hline \multirow[t]{3}{*}{ Aplicação } & \multirow{2}{*}{$\begin{array}{l}\text { Uso acima do especificado (número de demãos acima } \\
\text { da especificada) }\end{array}$} & - $\quad$ falta de qualidade da base & Execução & \multirow{2}{*}{$\begin{array}{l}\text { - } \begin{array}{l}\text { Diferença entre o número de demãos } \\
\text { previstas e as executadas }\end{array} \\
\text { - } \begin{array}{l}\text { Diferença entre o consumo de tinta } / \mathrm{m}^{2} \text { de } \\
\text { parede previsto e o executado }\end{array} \\
\end{array}$} \\
\hline & & - qualidade do material & $\begin{array}{l}\text { Fornecedor / } \\
\text { Suprimentos }\end{array}$ & \\
\hline & Material que cai & $\begin{array}{l}\text { - equipamento ou ferramenta de aplicação } \\
\text { inadequado }\end{array}$ & $\begin{array}{l}\text { Planejamento } \\
\text { operacional / } \\
\text { Execução }\end{array}$ & - - \\
\hline
\end{tabular}




\section{C - 10 MOMENTO DE INCIDÊNCIA DAS PERDAS, PRINCIPAIS CAUSAS, ORIGEM E INDICADORES - gesSO}

\begin{tabular}{|c|c|c|c|c|}
\hline $\begin{array}{l}\text { Momento } \\
\text { de } \\
\text { incidência }\end{array}$ & Forma de ocorrência da perda & Causa(s) & Origem(s) & Indicador(es) \\
\hline Recebimento & $\begin{array}{l}\text { Quantidade entregue inferior à solicitada ou paga (em } \\
\text { termos de número de sacos ou em termos de massa) }\end{array}$ & $\begin{array}{l}\text { - ausência de procedimentos específicos de } \\
\text { avaliação quantitativa; } \\
\text { - inexperiência do responsável pelo } \\
\text { recebimento; }\end{array}$ & $\begin{array}{l}\text { Planejamento } \\
\text { operacional }\end{array}$ & $\begin{array}{l}\text { - Diferença (percentual) entre a quantidade } \\
\text { recebida e a solicitada } \\
\text { - } \\
\text { Diferença (percentual) entre a quantidade } \\
\text { recebida e a paga } \\
\text { - Diferença (percentual) entre a massa real } \\
\text { e a nominal }\end{array}$ \\
\hline Transporte & Material que cai durante o transporte & $\begin{array}{l}\text { - equipamento de transporte inadequado; } \\
\text { - } \quad \text { condições do trajeto inadequadas } \\
\text { manuseio incorreto dos sacos, ocasionando o } \\
\left(^{*}\right) \text { na essência, estas causas poderiam ser reunidas } \\
\text { na falta de um planejamento do layout do canteiro } \\
\text { de obras }\end{array}$ & $\begin{array}{l}\text { Planejamento } \\
\text { operacional }\end{array}$ & $\begin{array}{l}\text { - Percentual ou número absoluto de sacos } \\
\text { rasgados durante o transporte do } \\
\text { equipamento de transporte externo e a } \\
\text { área de estocagem }\end{array}$ \\
\hline Estocagem & "Empedramento" do gesso" & $\begin{array}{l}\text { - ação da umidade em função da condições } \\
\text { inadequadas de estocagem } \\
\text { - data de validade vencida } \\
\end{array}$ & $\begin{array}{l}\text { Planejamento } \\
\text { operacional }\end{array}$ & - Entulho gerado durante a estocagem \\
\hline Estocagem & Material que cai no chão & $\begin{array}{l}\text { - condições inadequadas de estocagem; } \\
\text { - duplo manuseio do material; } \\
\text { (*) na essência, estas causas poderiam ser reunidas }_{\text {na falta de um planejamento do layout do canteiro }} \\
\text { de obras }\end{array}$ & & \\
\hline
\end{tabular}




\section{C10 - MOMENTO DE INCIDÊNCIA DAS PERDAS, PRINCIPAIS CAUSAS, ORIGEM E INDICADORES - gesso} (continuação)

\begin{tabular}{|c|c|c|c|c|}
\hline $\begin{array}{l}\text { Momento } \\
\text { de } \\
\text { incidência }\end{array}$ & Forma de ocorrência da perda & Causa(s) & Origem(s) & Indicador(es) \\
\hline Transporte & Material que cai durante o transporte & $\begin{array}{l}\text { - } \quad \text { equipamento de transporte inadequado; } \\
\text { - condições do trajeto inadequadas; } \\
\text { (*) na essência, estas causas poderiam ser reunidas }^{\text {na falta de um planejamento do layout do canteiro }} \\
\text { de obras }\end{array}$ & $\begin{array}{l}\text { Planejamento } \\
\text { operacional }\end{array}$ & $\begin{array}{l}\text { - Entulho gerado durante o transporte } \\
\text { interno }\end{array}$ \\
\hline \multirow[t]{4}{*}{ Aplicação } & Material que cai & $\begin{array}{l}\text { - uso de equipamento e ferramentas } \\
\text { inadequadas; } \\
\text { - inexperiência do operário; }\end{array}$ & $\begin{array}{l}\text { Planejamento } \\
\text { operacional / } \\
\text { Execução }\end{array}$ & $\begin{array}{l}\text { - Entulho gerado durante a aplicação do } \\
\text { gesso }\end{array}$ \\
\hline & \multirow[t]{3}{*}{$\begin{array}{l}\text { Material que fica incorporado (variação geométrica dos } \\
\text { elementos estruturais) }\end{array}$} & $\begin{array}{l}\text { - } \quad \begin{array}{l}\text { falta de qualidade da base (prumo e } \\
\text { esquadro, para o caso dos revestimentos } \\
\text { verticais; nível, para o caso dos horizontais); }\end{array} \\
\end{array}$ & Execução & \multirow[t]{3}{*}{$\begin{array}{l}\text { - Variação entre a espessura especificada e } \\
\text { a executada dos revestimentos }\end{array}$} \\
\hline & & $\begin{array}{l}\text { - falta de coordenação modular entre largura da } \\
\text { alvenaria e de vigas/pilares; alvenaria e } \\
\text { caixilhos; }\end{array}$ & Projeto & \\
\hline & & - variações nas dimensões dos componentes; & $\begin{array}{l}\text { Fornecedores / } \\
\text { Suprimentos / } \\
\text { Execução }\end{array}$ & \\
\hline
\end{tabular}




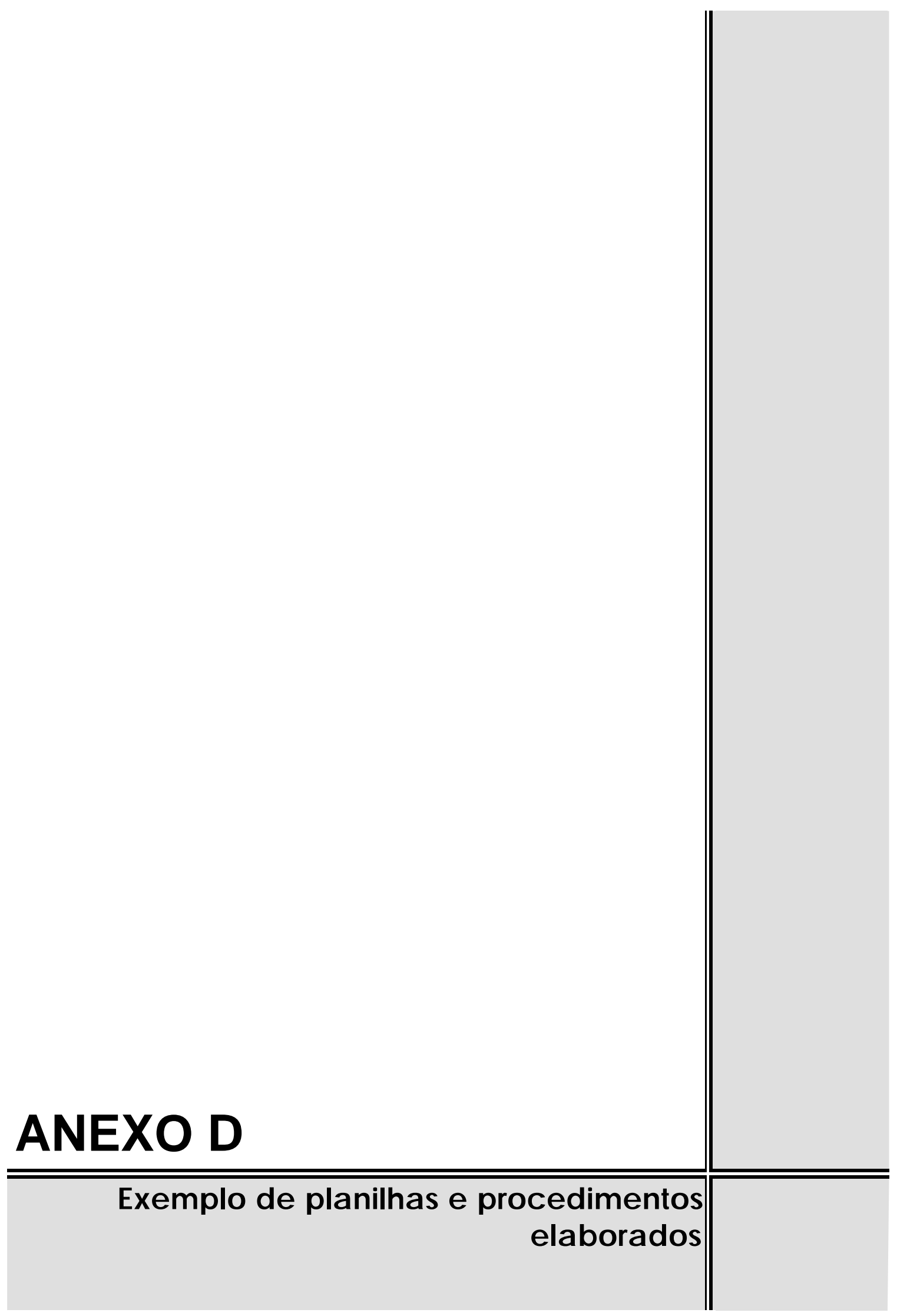




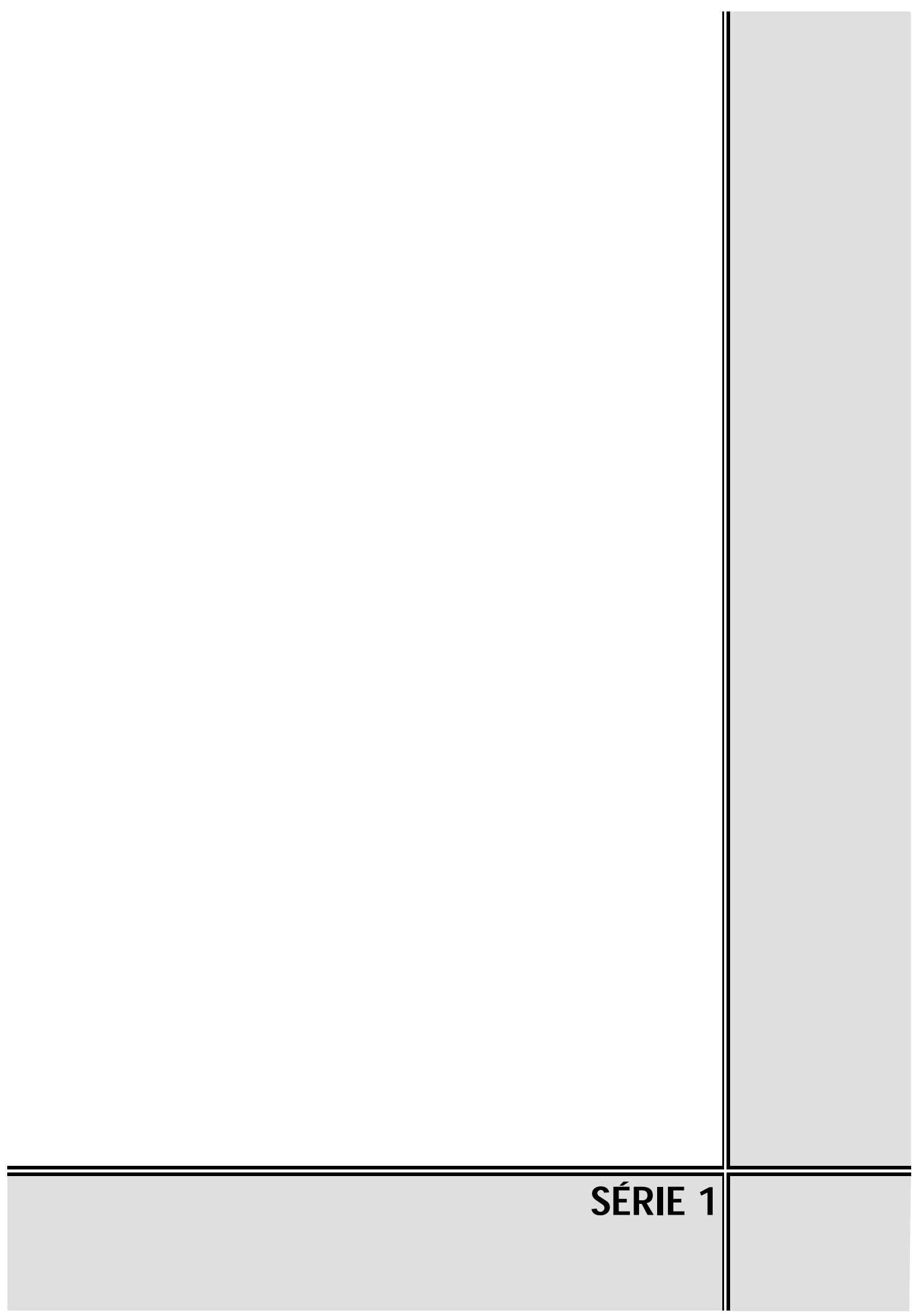




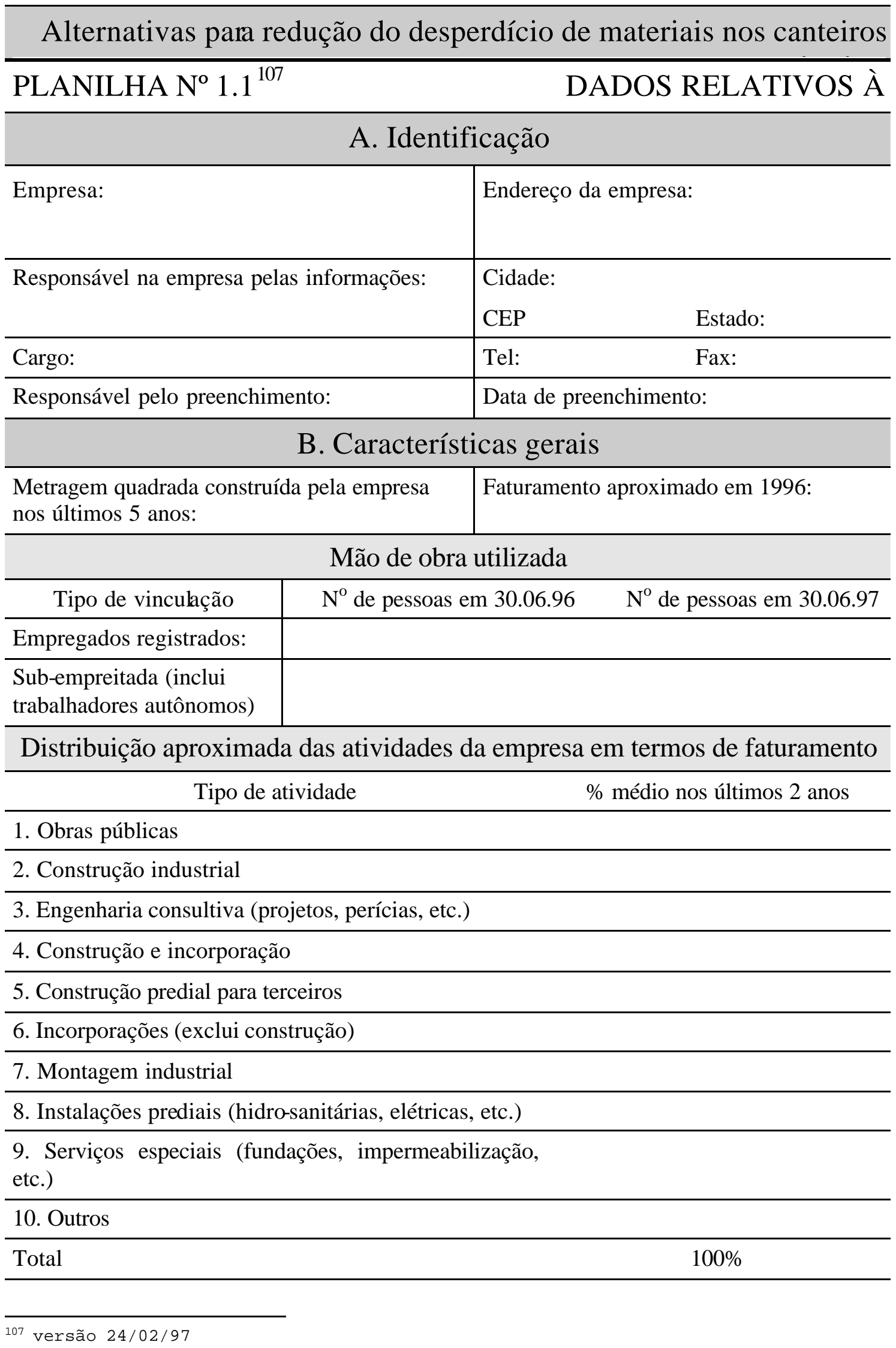




\begin{tabular}{|l|l|l|}
\hline P 1.1 & Dados relativos à empresa & Data: $17 / 10 / 96$ \\
Revisão: 2
\end{tabular}

\section{1 ) PROCEDIMENTO DE COLETA}

A coleta das informações deve ser realizada através de uma entrevista com o Gerente ou Diretor Técnico da empresa ou ainda, uma pessoa designada pelo(s) mesmo(s).
Antes de se efetuar a entrevista, o responsável pela mesma deve contactar com antecedência o entrevistado, indicando-lhe quas as informações que deverão ser fornecidas, para que o mesmo possa providenciá-las com antecedência.

\section{OBSERVAÇÕES}

Fazer observações que considere necessárias para o melhor entendimento dos dados fornecidos na entrevista

\begin{tabular}{l|l}
\hline Data & Observaçôes \\
\hline & \\
\hline & \\
\hline & \\
\hline & \\
\hline & \\
\hline & \\
\hline
\end{tabular}

Projeto de pesquisa: Alternativas para a redução do desperdício de materiais nos canteiros de obra 


\section{Nível de mobilização para qualidade}

\section{Programas institucionais de treinamento para a qualidade}

\begin{tabular}{|c|c|c|c|}
\hline \multicolumn{4}{|c|}{$\begin{array}{l}\text { A empresa já participou de algum programa } \\
\text { institucional de treinamento para a qualidade? }\end{array}$} \\
\hline 口 Não & $\begin{array}{l}\square S \\
\text { qua }\end{array}$ & $\begin{array}{l}\text { aso pos } \\
\text { lado) }\end{array}$ & responda \\
\hline Há & quanto & tempo & iniciou? \\
\hline
\end{tabular}

Quais?

口 PEGQ $^{108}$

口 Convênio

SEBRAE Qualidade Total

$\square$

\section{Empresa de consultoria:}

$\square$ Outros:

\section{Projetos de melhoria já desenvolvidos na empresa ${ }^{109}$}

\begin{tabular}{l}
\hline Programa 5S \\
$\square$ Segurança do trabalho \\
$\square$ Alfabetização \\
$\square$ Padronização de processos
\end{tabular}

\section{Código das obras estudadas}

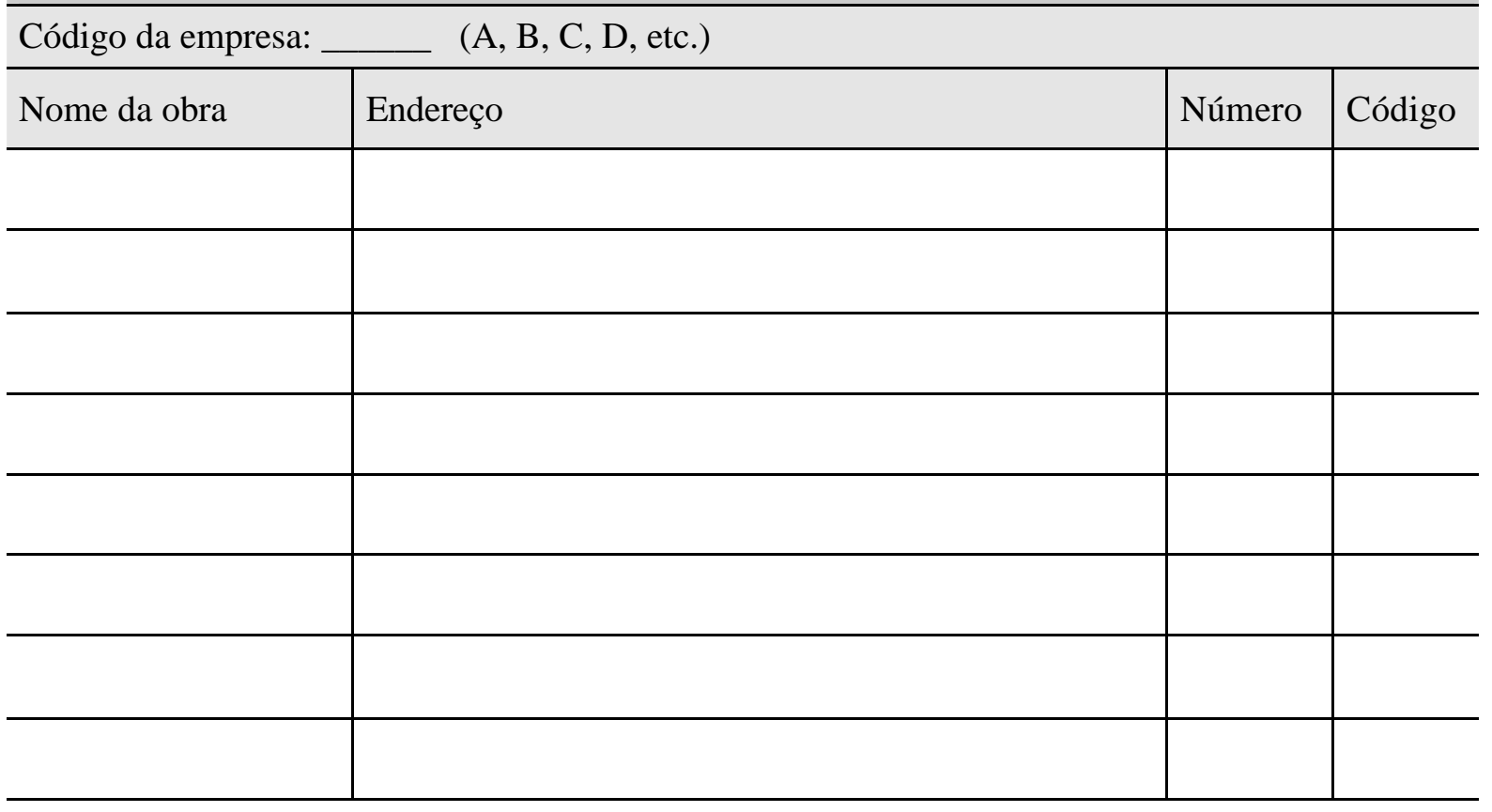

\footnotetext{
108 Programa de Especialização em Gestão da Qualidade, promovido pelo Ministério da Ciência e Tecnologia.

109 Identificar também aqueles que estão em andamento.
} 


\begin{tabular}{|c|c|c|}
\hline \multicolumn{3}{|c|}{$\begin{array}{r}\text { Alternativas para redução do desperdício de materiais nos canteiros } \\
\text { de obra }\end{array}$} \\
\hline \multicolumn{2}{|c|}{ PLANILHA No $1.2^{110}$} & DADOS RELATIVOS À OBRA \\
\hline \multicolumn{3}{|c|}{ A. Identificação } \\
\hline \multicolumn{2}{|l|}{ Empresa: } & Endereço da obra: \\
\hline \multicolumn{2}{|l|}{ Eng ${ }^{\circ}$ responsável: } & Telefone: \\
\hline \multicolumn{2}{|c|}{ Responsável pelo preenchimento: } & Data de preenchimento: \\
\hline \multirow{5}{*}{$\begin{array}{l}\text { Código da obra: } \\
\text { SM } \square \mathrm{n}^{\circ} \\
\text { PA } \square \mathrm{n}^{\circ} \\
\text { SP } \square \mathrm{n}^{\circ} \\
\text { SC } \square \mathrm{n}^{\circ}\end{array}$} & \multirow{5}{*}{$\begin{array}{l}\text { RJ } \square \mathrm{n}^{\circ} \\
\text { BH } \square \mathrm{n}_{-}^{\circ} \\
\text { FO } \square \mathrm{n}_{-}^{\circ} \\
\text { FS } \square \mathrm{n}_{-}^{\circ}\end{array}$} & Tipo de edificação: \\
\hline & & 口esidencial \\
\hline & & Comercial \\
\hline & & Misto \\
\hline & & Outro: \\
\hline \multicolumn{3}{|c|}{ B. Caracterização da edificação } \\
\hline \multicolumn{2}{|c|}{$\begin{array}{l}\text { Área construída real (definida pela } \\
\text { prefeitura): }\end{array}$} & $\begin{array}{l}\mathrm{N}^{\mathrm{o}} \text { de pavimentos (especificando subsolos, } \\
\text { coberturas, etc): }\end{array}$ \\
\hline \multicolumn{3}{|c|}{ Caracterização da estrutura da edificação: } \\
\hline Alvenaria & \multicolumn{2}{|c|}{$\begin{array}{l}\text { vedação (prédio é estruturado e as paredes só tem função de } \\
\text { vedação) } \\
\square \text { resistente tradicional (as paredes são portantes, mas as mesmas não } \\
\text { são dimensionadas ou são construídas com blocos não estruturais) } \\
\square \text { estrutural (existe dimensionamento e os blocos são estruturais) } \\
\text { [ não armada } \\
\square \text { armada, parcialmente armada ou protendida }\end{array}$} \\
\hline Pilares & \multicolumn{2}{|c|}{$\begin{array}{l}\text { concreto armado moldado no local } \\
\text { concreto pré-moldado } \\
\text { outro: }\end{array}$} \\
\hline Vigas & \multicolumn{2}{|c|}{$\begin{array}{l}\text { concreto armado moldado no local } \\
\text { concreto pré-moldado } \\
\text { outro: }\end{array}$} \\
\hline Lajes & \multicolumn{2}{|c|}{$\begin{array}{l}\text { concreto armado moldado no local } \\
\text { concreto pré-moldado } \\
\text { outro: }\end{array}$} \\
\hline
\end{tabular}




\section{1) PROCEDIMENTO DE COLETA DE} DADOS

O observador deverá coletar os dados mediante análise de projeto, visita à obra e entrevista com o engenheiro responsável pela obra em questão.

1.1) Compatibilização dimensional entre subsistemas

Neste item, deve-se observar em projeto ou na própria obra a coerência entre os subsistemas relacionados na planilha.

\section{2 ) Tipo de contrato}

- Administração com Percentual: a empresa será reembolsada por todos os gastos da execução da obra recebendo, sobre este valor, um percentual fixado anteriormente, relativo ao seu lucro e despesas indiretas;
- Administração com Montante Fixo: a empresa será reembolsada por todos os gastos da execução da obra, recebendo um valor fixo ( ou seja, não dependente das despesas) relativo ao seu lucro;

- Empreitada por Preço Global: o preço total da obra é fixado previamente;

- Empreitada por Preço Unitário: o preço das diversas unidades que compõe a obra é fixado no contrato, sendo o custo final a somatória destes valores;

- Incorporação:

\section{OBSERVAÇÕES}

Fazer observações que considere necessárias

para o melhor entendimento dos dados fornecidos na entrevista

\begin{tabular}{l|l}
\hline Data & Observações \\
\hline & \\
\hline & \\
\hline & \\
\hline & \\
\hline & \\
\hline
\end{tabular}

Projeto de Pesquisa: Alternativas para a redução do desperdício de materiais nos canteiros de obra 


\section{Outras características relevantes}

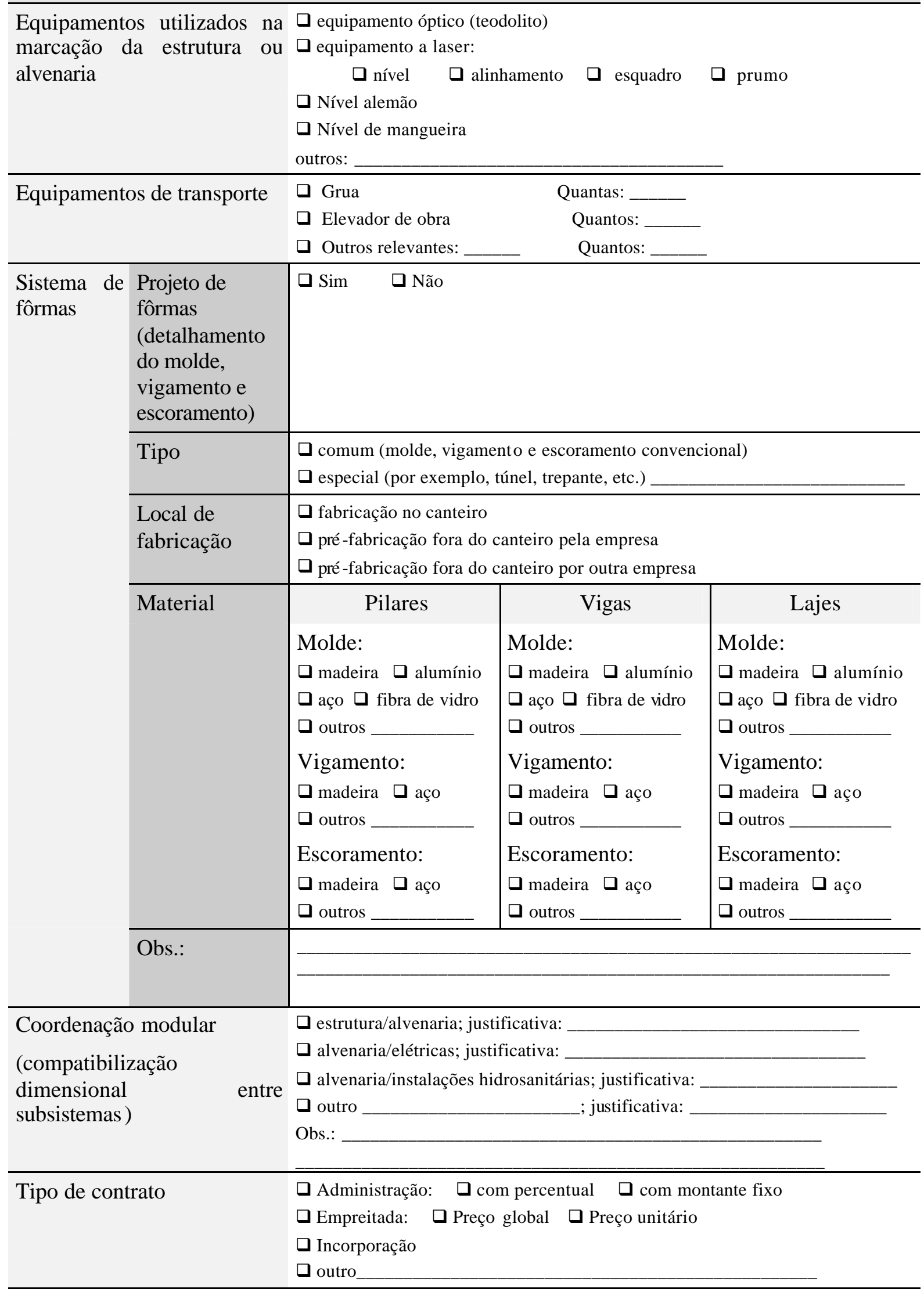




\begin{tabular}{|c|c|}
\hline \multicolumn{2}{|c|}{ C. Serviços e materiais a serem estudados na obra } \\
\hline SERVIÇOS & MATERIAIS \\
\hline \multirow[t]{3}{*}{$\square$ Produção de concreto } & Areia \\
\hline & $\square$ Pedra britada \\
\hline & $\square$ Cimento Portland \\
\hline \multirow[t]{2}{*}{ L Lançamento de concreto } & $\square$ concreto produzido em obra \\
\hline & $\square$ Concreto usinado \\
\hline \multirow[t]{2}{*}{ Produção de Armadura } & Aço em vergalhões \\
\hline & $\square$ Aço cortado e dobrado \\
\hline Fabricação Fôrmas & $\square$ Chapas de madeira compensada \\
\hline Montagem e desmontagem das Fôrmas & $\square$ Chapas de madeira compensada \\
\hline \multirow[t]{3}{*}{ Produção de argamassa (alvenaria) } & $\square$ Areia \\
\hline & $\square \mathrm{Cal}$ \\
\hline & $\square$ Cimento Portland \\
\hline \multirow[t]{5}{*}{ Alvenaria } & Blocos de concreto \\
\hline & Blocos cerâmicos \\
\hline & $\square$ Tijolos maciços \\
\hline & Argamassa produzida em obra \\
\hline & Argamassa iindustrializada \\
\hline \multirow[t]{3}{*}{ Produção de argamassa (contrapiso) } & Areia \\
\hline & $\square \mathrm{Cal}$ \\
\hline & $\square$ Cimento Portland \\
\hline \multirow[t]{2}{*}{$\square$ Contrapiso } & $\square$ Argamassa produzida em obra \\
\hline & $\square$ Argamassa iindustrializada \\
\hline D Colocação dos eletrodutos na laje & $\square$ Eletrodutos flexíveis \\
\hline \multirow[t]{2}{*}{$\square$ Colocação dos eletrodutos (parede) } & $\square$ Eletrodutos flexíveis \\
\hline & $\square$ Eletrodutos rígidos \\
\hline [ Enfiação & $\square$ Condutores elétricos (fios) \\
\hline Instalação água fria & $\square$ Tubos de PVC para instalação água fria \\
\hline Instalação esgoto & $\begin{array}{l}\text { Tubos de PVC para instalação esgoto /águas } \\
\text { pluviais }\end{array}$ \\
\hline \multirow[t]{2}{*}{$\square$ Cobertura (telhado) ${ }^{3}$} & Telhas cerâmicas ${ }^{3}$ \\
\hline & $\square$ Telhas em fibrocimento ${ }^{3}$ \\
\hline
\end{tabular}

${ }^{3}$ Estes itens só serão monitorados em obras de pequena altura ( $\leq 4$ pavimentos). 


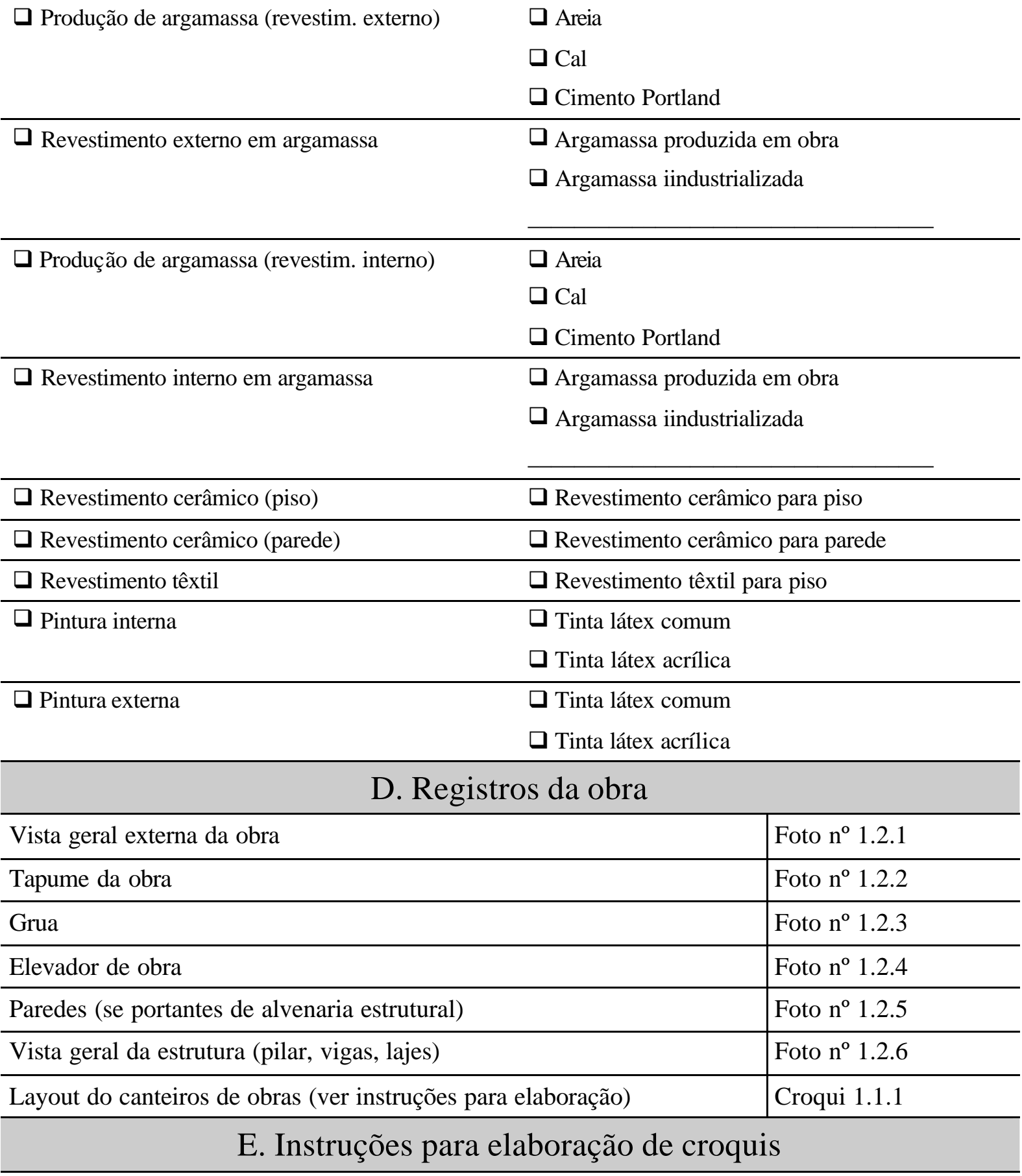

Devem ser desenhados croquis de todos os pavimentos necessários à perfeita compreensão do layout. Sugere-se utilizar folha A4 milimetrada e consultar o projeto arquitetônico, disponível no próprio escritório da obra. Nos canteiros de dimensões usuais uma aproximação da 1:200 será suficiente, porém não é necessário rigidez na transferência de escala. Nestes croquis devem constar os ítens que seguem:

1. Definição aproximada do perímetro dos pavimentos, diferenciando áreas fechadas e abertas;

2. Localização de pilares e outras estruturas que interfiram na circulação de materiais ou pessoas; 
3. Portões de entrada no canteiro (pessoas, veículos) e acesso coberto para clientes, se existir;

4. Localização de árvores que restrinjam ou interfiram na circulação de materiais ou pessoas, inclusive nas calçadas;

5. Localização das instalações provisórias (banheiros, escritório, refeitório, etc.), inclusive plantão de vendas, se existir;

6. Todos os locais de armazenamento de materiais, inclusive depósito de entulho;

7. Localização da calha ou tubo para remoção de entulho, se existir;

8. Localização da betoneira, guincho (elevador de obras) e guincheiro, ou grua;

9. Localização das centrais de carpintaria e aço;

10. Pontos de içamento de fôrmas e armaduras;

11. Localização de passarelas, rampas e/ou escadas provisórias com indicação aproximada do desnível;

12. Linhas de Fluxo principais (produção de argamassa, remoção de entulho, movimentações até o guincho (elevador de obras), entrada de clientes, deslocamentos de operários das instalações provisórias até os postos de trabalho e descargas de materiais, indicando duplos manuseios), utilizando a seguinte convenção:

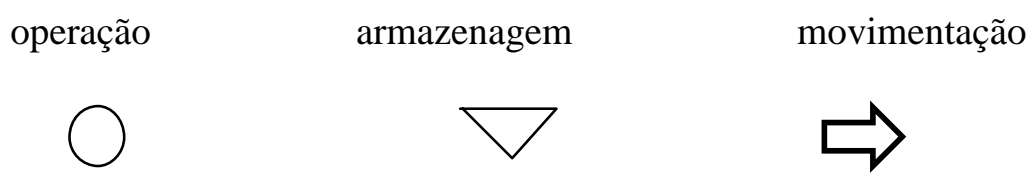

13. Se as instalações estiverem distribuídas em vários pavimentos, desenhá-las em um corte da edificação. 


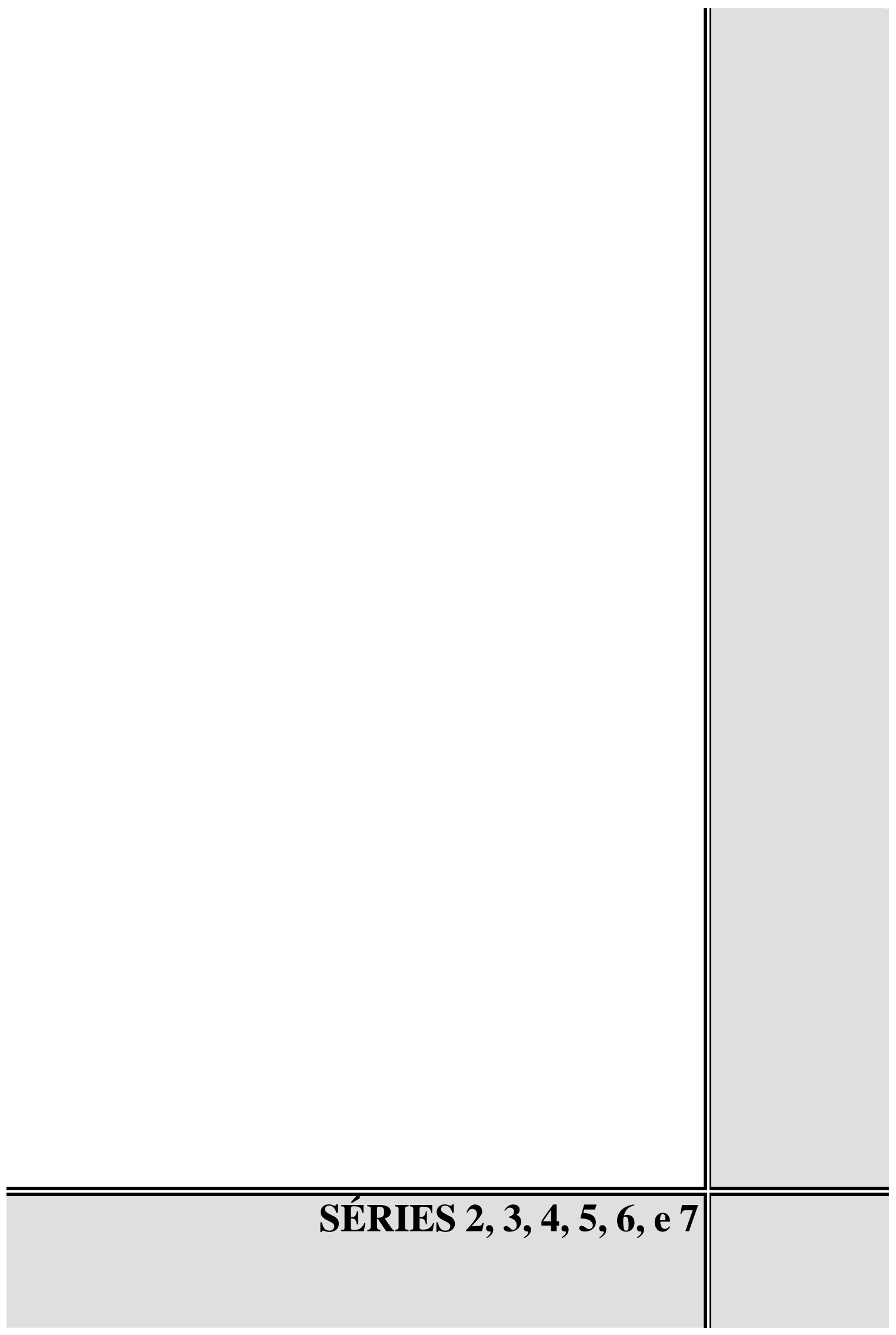


Alternativas para redução dos desperdícios de materiais nos canteiros de obra PLANILHA N ${ }^{0} 2.2$ MEDIÇÃO DOS ESTOQUES DE MATERIAIS (VI E VF): CIMENTO PORTLAND

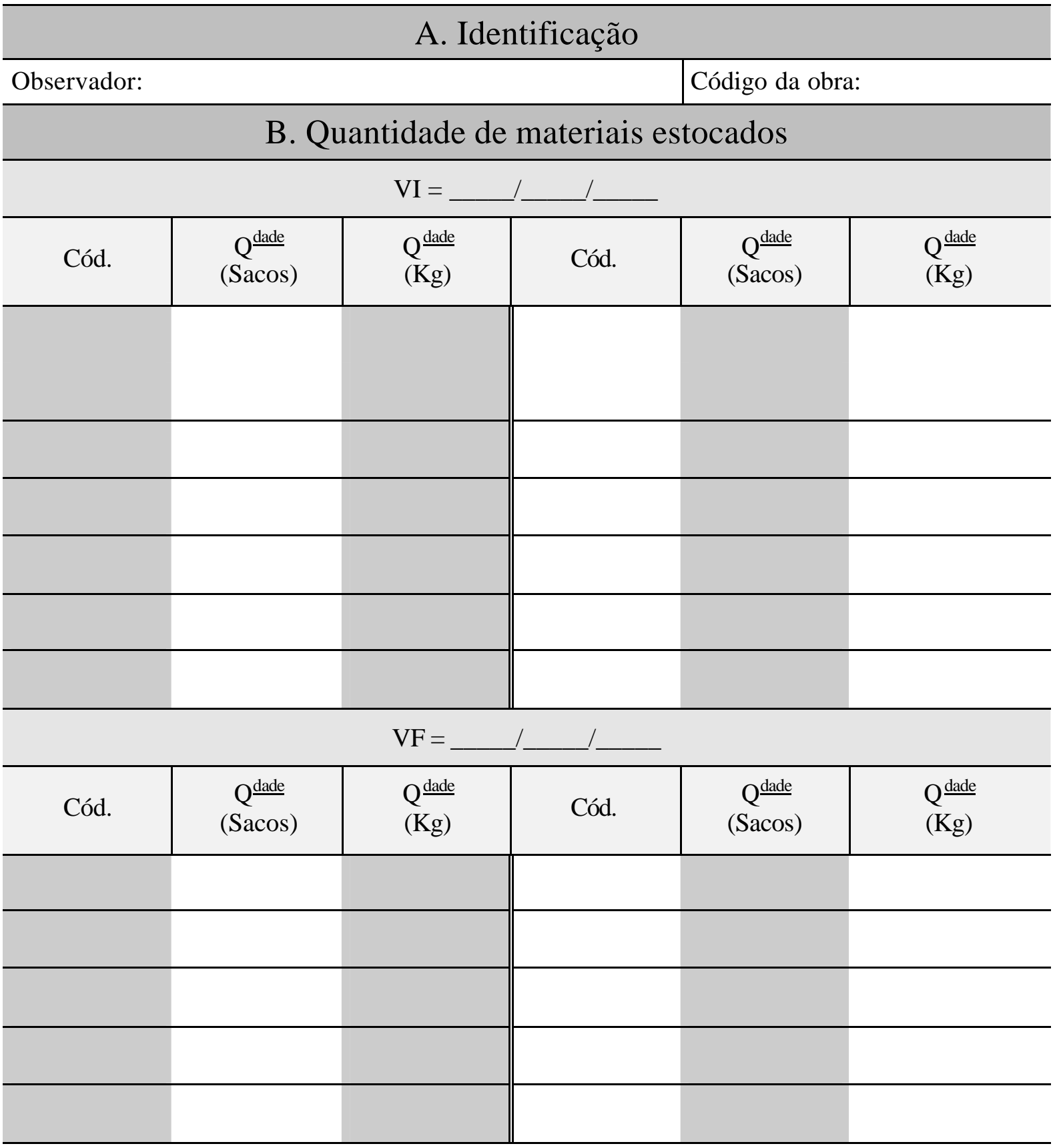




\section{P 2.2 Medição dos estoques de cimento}

Data: $\quad$ 06/03/97

Revisão: 3

\section{1 ) PROCEDIMENTOS DE MEDIÇÃO DOS ESTOQUES}

Os estoques de cimento em obra podem estar dispostos em forma de silo ou acondicionados em sacos.

\section{1) ESTOQUES DISPOSTOS EM SILOS}

No caso do cimento acondicionado em silos, deve-se verificar o volume no silo no qual este material estiver estocado.

De posse do volume estocado, pode-se quantificar a massa total de cimento estocado através do produto deste volume pela sua massa unitária. $\mathrm{Na}$ falta de dados mais precisos, adotar $3120 \mathrm{~kg} / \mathrm{m} 3$.

\section{2) ESTOQUES ACONDICIONADOS EM SACOS}

Contabiliza-se a quantidade de material, multiplicando-se o número de sacos constituintes de um plano horizontal pelo número de faixas que compõe o eixo vertical da pilha.

\section{2 ) OBSERVAÇÕES}

- Deve-se atentar para a presença de estoques intermediários em obra (situados em pavimentos etc.). Ambos os casos devem ser computados no processo de quantificação dos estoques da obra.

- É importante ressaltar que há a possibilidade de encontrar-se sacos em uso (abertos). Neste caso, é necessário contabilizá-los como meio saco inteiro.

\section{Observações}

(Devem ser registradas quaisquer simplificações ou critérios adotados na quantificação dos estoques do material.)

- Projeto de Pesquisa: Alternativas para a redução do desperdício de materiais nos canteiros de obra 
Alternativas para redução do desperdício de materiais nos canteiros de obra

PLANILHA N MEDIÇÃO DA QUANTIDADE $^{\circ} .6 .8$ DE SERVIÇO
DE CONTRAPISO:
ARG. PRODUZIDA EM OBRA

\section{A. Identificação}

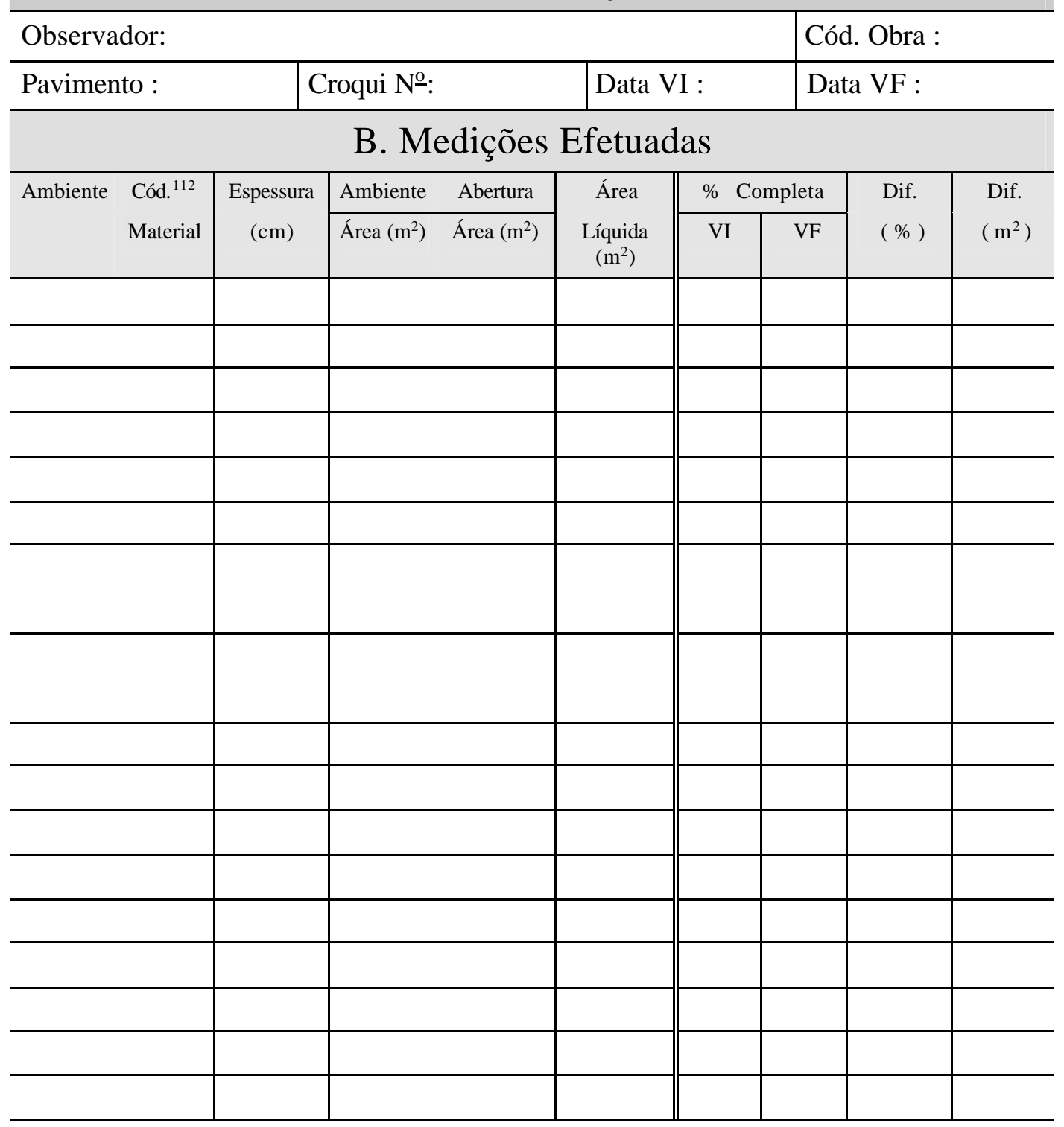

${ }^{111}$ versão 23/12/96

ver tabela no verso da folha 


\begin{tabular}{|cc|ll|}
\hline P 3.6.8 & Medição dos Serviços : Contrapiso & Data: & $27 / 02 / 97$ \\
& Argamassa Produzida em Obra & Versão: & $2^{\underline{a}}$ \\
\hline
\end{tabular}

\section{PROCEDIMENTOS E CRITÉRIOS DE MEDIÇÃO}

De posse do projeto arquitetônico ou do projeto específico de contrapiso, o observador deverá calcular a área de contrapiso de acordo com os seguintes critérios/procedimentos :

a) Fazer um croqui representativo, em folha A4 identificando os ambientes que receberão o contrapiso. b) A área do contrapiso será delimitada pela face da alvenaria do ambiente.

c) Caso haja diferença de espessura no mesmo ambiente, considerá-la dividindo-se o ambiente em duas ou mais áreas se necessário.

d) Considerar o limite de dois ambientes através das portas como sendo a diferença de espessura do contrapiso entre os mesmos .

e) Caso não haja diferença, fica a critério do observador.

\section{DESENHO EXPLICATIVO}

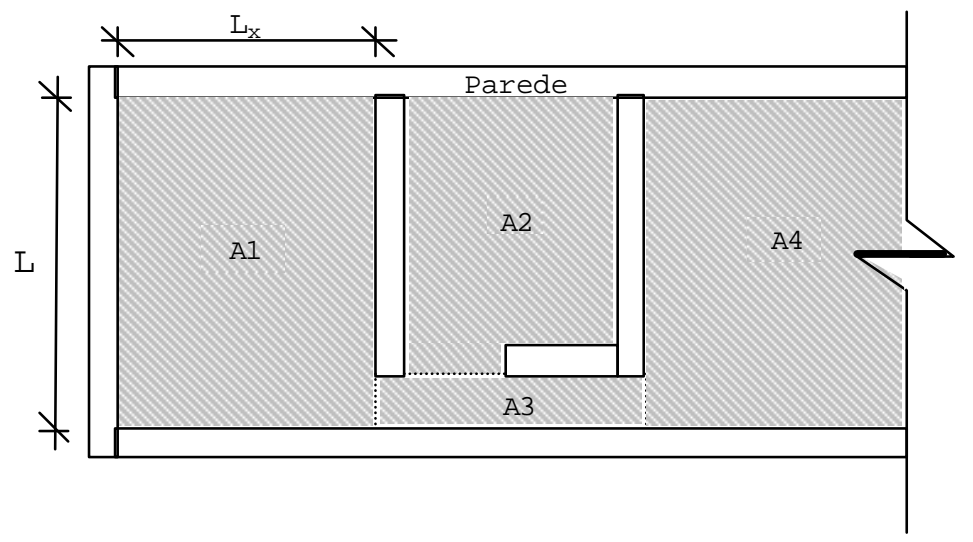

Preencher os dados da tabela de acordo com a especificação de projeto em padrão da empresa. Trata-se do traço teórico previsto.

\begin{tabular}{l|l|l|l|l|l}
\hline Código & & & & & \\
\hline Traço em Volume & & & & & \\
\hline Traço em Massa & & & & & \\
\hline $\mathrm{Kg} \mathrm{Cim} / \mathrm{m}^{3}$ & & & & & \\
\hline $\mathrm{kg} \mathrm{Cal} / \mathrm{m}^{3}$ & & & & & \\
\hline $\mathrm{kg} \mathrm{Areia} / \mathrm{m}^{3}$ & & & & & \\
\hline & & & & & \\
\hline
\end{tabular}

Total $\left(\mathrm{m}^{2}\right)$

\footnotetext{
- Projeto de Pesquisa: Alternativas para a redução do desperdício de materiais nos canteiros de obra
} 


\begin{tabular}{rr}
\hline $\begin{array}{r}\text { Alternativas para redução do desperdício de materiais nos canteiros } \\
\text { de obra }\end{array}$ \\
\hline PLANILHA No $4.2^{113}$ & CONTROLE DE \\
RECEBIMENTO E ESTOQUE \\
DE MATERIAIS: \\
CIMENTO PORTLAND
\end{tabular}

A. Identificação da obra

Observador:

Código obra:

Data de início da coleta (VI):

Data de término da coleta $(\mathrm{VF})$ :

\begin{tabular}{|c|c|c|c|c|c|c|c|}
\hline \multicolumn{8}{|c|}{ B. Quantidade de material recebida de fornecedores } \\
\hline \multirow[t]{2}{*}{ Data } & \multirow[t]{2}{*}{ Código $^{114}$} & \multicolumn{3}{|c|}{ Quantidade $(\mathrm{kg})$} & \multirow{2}{*}{$\begin{array}{l}\mathrm{N}^{\mathrm{o}} \text { sacos } \\
\text { rasgados } \\
\end{array}$} & \multirow{2}{*}{$\begin{array}{l}\text { Ordem de } \\
\text { pagamento }\end{array}$} & \multirow[t]{2}{*}{ Fabricante } \\
\hline & & Solicitada & Recebida & Paga & & & \\
\hline & & & & & & & \\
\hline & & & & & & & \\
\hline & & & & & & & \\
\hline & & & & & & & \\
\hline & & & & & & & \\
\hline & & & & & & & \\
\hline & & & & & & & \\
\hline & & & & & & & \\
\hline & & & & & & & \\
\hline & & & & & & & \\
\hline & & & & & & & \\
\hline & & & & & & & \\
\hline \multicolumn{8}{|c|}{ C. Transferência de material entre canteiros } \\
\hline \multicolumn{2}{|c|}{ Data } & Código & \multicolumn{2}{|c|}{ Quantidade $^{115}$} & Data & Código & $\begin{array}{l}\text { Quanti } \\
\text { dade }\end{array}$ \\
\hline & & & & & & & \\
\hline & & & & & & & \\
\hline & & & & & & & \\
\hline
\end{tabular}

113 Versão de 06/03/97

114 Ver tabela de códigos no verso

115 A quantidade é positiva quando o material chega à obra e negativa quando o material sai 


\begin{tabular}{|c|c|l|}
\hline P 4.2 & $\begin{array}{c}\text { Dados relativos à conferência } \\
\text { quantitativa do recebimento da Cimento } \\
\text { Portland }\end{array}$ & $\begin{array}{l}\text { Data: } 06 / 03 / 97 \\
\text { Versão: } 2\end{array}$ \\
\hline
\end{tabular}

\section{Apresentação}

$\mathrm{O}$ preenchimento dessa planilha tem como objetivo o controle do material recebido na obra entre as datas de início e fim de coleta (VI e VF), inclusive de materiais transfer idos de outros ou para outros canteiros de obra. Em se tratando dos materiais comprados, verifica-se também a quantidade de sacos rasgados durante o recebimento, subsidiando o cálculo ao final da coleta do seguinte indicador de perdas de materiais: "7.2.2 Percentual de sacos rasgados no recebimento".

O item D desta planilha só deve ser preenchido caso seja possível a implantação de um controle de saída da quantidade de material do almoxarifado identificando o serviço no qual o mesmo será utilizado.

\section{Definições e critérios}

solicitada: quantidade de material solicitada (via requisição, se existir, ou através do valor especificado na nota fiscal);

recebida: quantidade de material recebida na obra, incluindo a parcela de material danificada (sacos rasgados desde que eles não sejam devolvidos) medida de acordo com o seguinte procedimento:

- para o material entregue em sacos, basta contá-los;
OBS. Tomar o máximo cuidado com os vazios na pilha de sacos de cimento no caminhão ao simplificar a contagem através da multiplicação dos sacos constituintes no plano horizontal pelo número de faixas que compões o plano vertical.

paga: quantidade efetivamente paga mediante ordem de pagamento emitida pela empresa;

sacos rasgados: número de sacos rasgados de acordo com o seguinte critério:

- serão considerados sacos rasgados apenas aqueles que apresentarem real possibilidade de perda de material (rasgos que exponham o conteúdo);

- a operação de recebimento de material consiste no descarregamento do caminhão, transporte do material até o local de estoque (seja ele definitivo ou não) e a colocação do material nesse local. $\mathrm{O}$ rompimento do saco pode ocorrer em qualquer parte desse ciclo.

\section{Momento e periodicidade de coleta}

A coleta de dados deve se dar a cada recebimento do material durante o período de coleta (entre VI e VF) e a cada saída de material do estoque, desde que seja possível. 
D. Controle de saída de materiais de acordo com o serviços

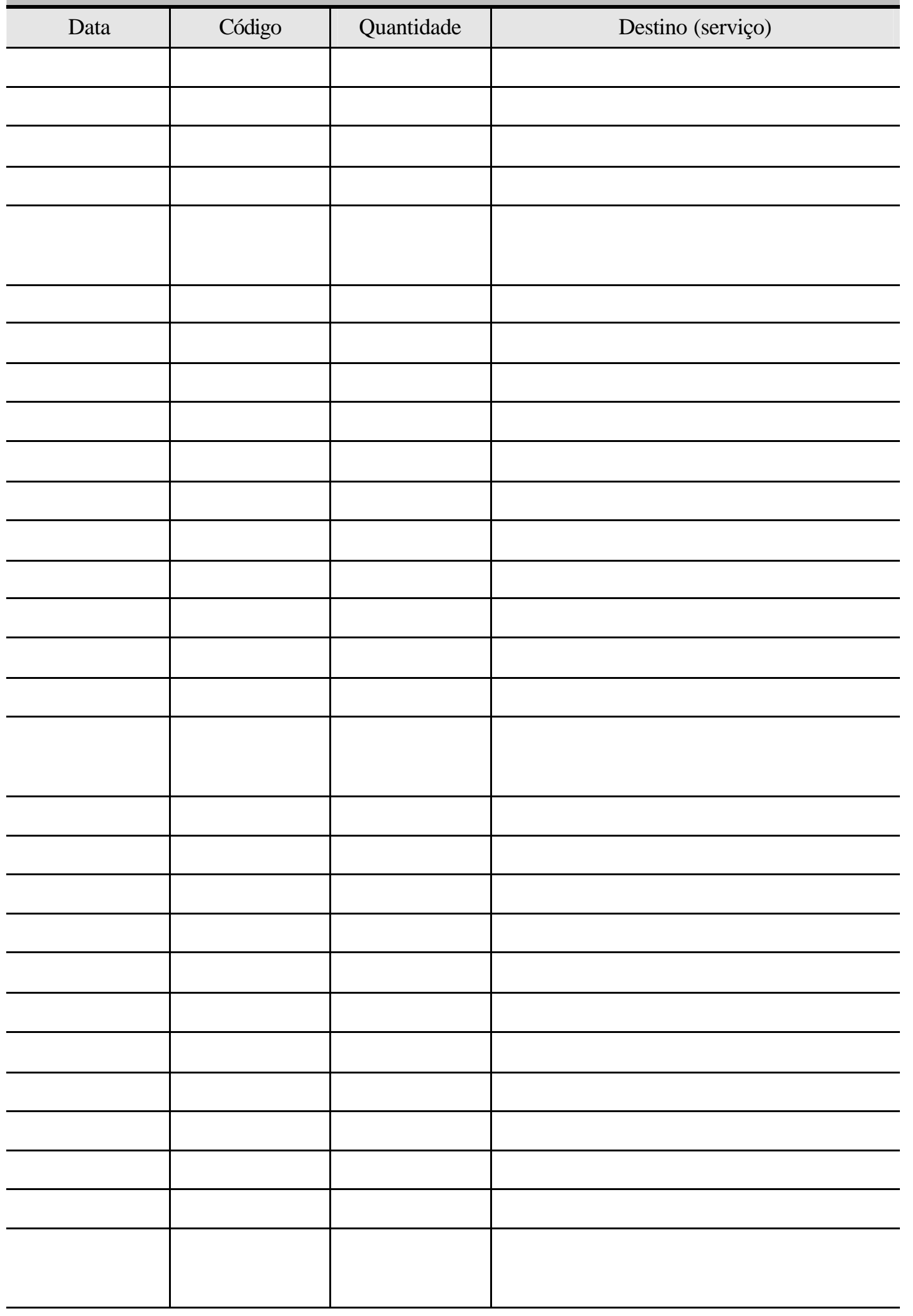




\section{E. Caracterização do recebimento}

Caracterizar o recebimento do material, anotando o procedimento da empresa quanto a falta ou excesso de material entregue. (Por exemplo: a empresa só paga a quantidade realmente recebida em cada entrega; a empresa paga a quantidade na nota fiscal mesmo recebendo quantidade inferior a especificada porém, acumula as faltantes até completar uma carga; o fornecedor entrega uma certa quantidade a mais do que a solicitada ou prevista na nota fiscal devido a ocorrência de perdas no transporte; a empresa devolve os sacos de cimento rasgados e não os paga ou não os paga e o fornecedor não os leva embora etc) 


\section{Alternativas para redução do desperdício de materiais nos canteiros PLANILHA $\mathrm{N}^{\circ} 5.2$ \\ DADOS RELATIVOS AO RECEBIMENTO E À ESTOCAGEM: CIMENTO PORTLAND}

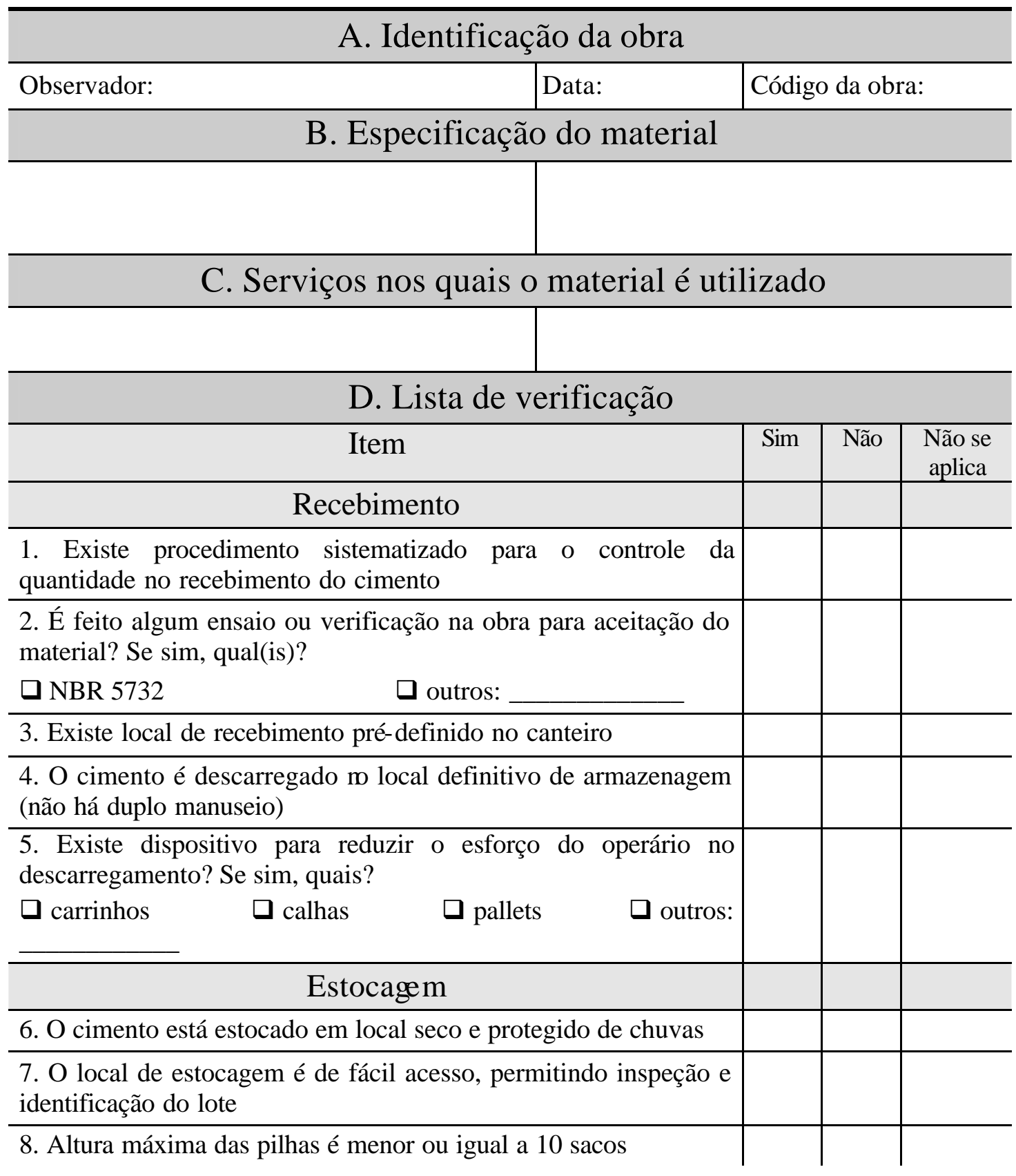




\begin{tabular}{|c|c|c|c|}
\hline Item & $\operatorname{Sim}$ & Não & $\begin{array}{c}\text { Não se } \\
\text { aplica }\end{array}$ \\
\hline \multicolumn{4}{|l|}{ 9. A área de estocagem 'é cimentada (impermeável). } \\
\hline \multicolumn{4}{|l|}{$\begin{array}{l}\text { 10. Há proteção contra umidade na base (por exemplo, estrado de } \\
\text { madeira,) }\end{array}$} \\
\hline \multicolumn{4}{|l|}{ 11. Há espaçamento lateral entre os sacos e as paredes } \\
\hline \multicolumn{4}{|l|}{$\begin{array}{l}\text { 12. Há a política de usar primeiramente o material estocado há } \\
\text { mais tempo em relação aos estocados mais recentemente (PEPS) }\end{array}$} \\
\hline \multicolumn{4}{|l|}{$\begin{array}{l}\text { 13. O local de estocagem é fechado e com acesso restrito } \\
\text { (prevenção quanto a roubos) }\end{array}$} \\
\hline \multicolumn{4}{|l|}{ E. Registros do canteiro de obras } \\
\hline \multicolumn{3}{|l|}{ Local de descarregamento (se for diferente do local da estocagem) } & $\begin{array}{l}\text { Foto } \mathrm{n}^{\mathrm{o}} \\
5.2 .1\end{array}$ \\
\hline \multicolumn{3}{|l|}{ Descarregamento do cimento (no momento da descarga) } & $\begin{array}{l}\text { Foto } \mathrm{n}^{\mathrm{o}} \\
5.2 .2\end{array}$ \\
\hline \multicolumn{3}{|c|}{$\begin{array}{l}\text { Transporte do local de recebimento para o local da estocagem (se forem } \\
\text { diferentes) }\end{array}$} & $\begin{array}{l}\text { Foto } \mathrm{n}^{\mathrm{o}} \\
5.2 .3\end{array}$ \\
\hline \multicolumn{3}{|l|}{ Local de estocagem do cimento } & $\begin{array}{l}\text { Foto } \mathrm{n}^{\mathrm{o}} \\
5.2 .4\end{array}$ \\
\hline egistro de ocorrências anom & & & \\
\hline
\end{tabular}

Descreva qualquer tipo de ocorrência relacionada à utilização inadequada dos materiais, como acidentes, consumo em serviços não previstos. Faça uma estimativa aproximada da perda. Justifique as resposta dos itens de verificação assim como, anote qualquer alteração ocorrida durante o período de coleta de dados.

\begin{tabular}{l|l}
\hline Data & Observações \\
\hline & \\
\hline & \\
\hline & \\
\hline & \\
\hline & \\
\hline & \\
\hline
\end{tabular}




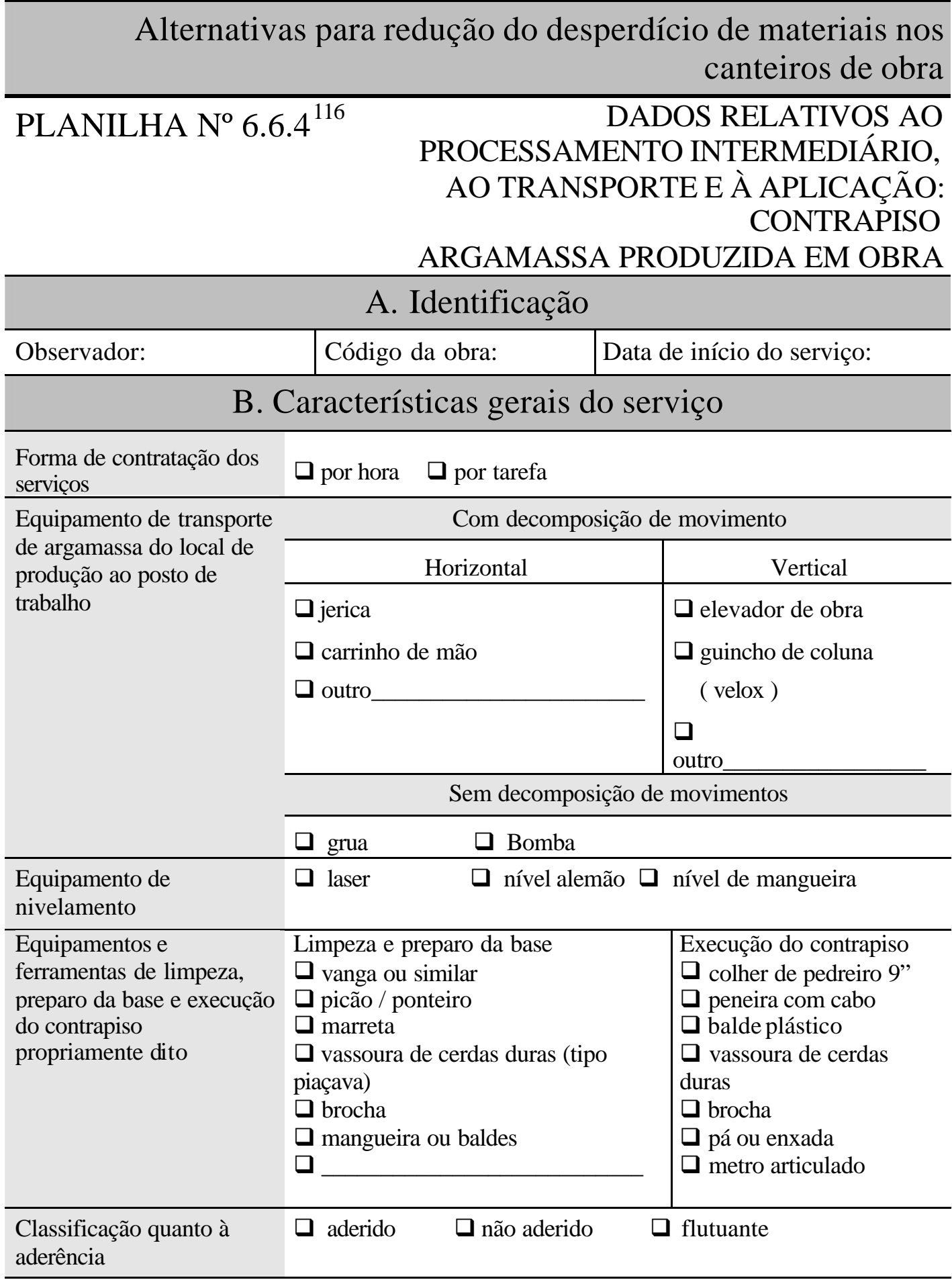

116versão 06/01/97 


\begin{tabular}{|c|c|c|c|}
\hline \multicolumn{4}{|l|}{ C. Projeto } \\
\hline ITENS DE VERIFICAÇÃO & $\mathbf{S}$ & $\mathbf{N}$ & N.S.A. \\
\hline \multicolumn{4}{|l|}{ 1. Há projeto de contrapiso. } \\
\hline \multicolumn{4}{|l|}{ 2. Caso afirmativo, anotar os itens que o compõe: } \\
\hline \multicolumn{4}{|l|}{$\begin{array}{l}\text { - especificação do nível de referência da laje, bem como os } \\
\text { pontos cujos níveis devem ser verificados; }\end{array}$} \\
\hline \multicolumn{4}{|l|}{ - posicionamento das taliscas, perfeitamente identificadas; } \\
\hline \multicolumn{4}{|l|}{ - declividade das áreas molháveis; } \\
\hline \multicolumn{4}{|l|}{$\begin{array}{l}\text { - tipo de acabamento superficial; } \\
\text { - desníveis entre ambientes; }\end{array}$} \\
\hline \multicolumn{4}{|l|}{ - espessura do contrapiso; } \\
\hline \multicolumn{4}{|l|}{ - legenda contendo os tipos de revestimentos de piso; } \\
\hline \multicolumn{4}{|l|}{ - procedimentos de execução. } \\
\hline \multicolumn{4}{|l|}{ - especificação de argamassa } \\
\hline \multicolumn{4}{|c|}{ D. Planejamento e organização da execução } \\
\hline \multicolumn{4}{|c|}{ ITENS DE VERIFICAÇÃO } \\
\hline Logística & $\mathbf{S}$ & $\mathbf{N}$ & N.S.A. \\
\hline \multicolumn{4}{|l|}{$\begin{array}{l}\text { 1. Realiza-se o planejamento do transporte da argamassa do local } \\
\text { de produção ao local de aplicação, ou seja, existem caminhos } \\
\text { previamente definidos para o transporte horizontal de argamassa } \\
\text { do local de produção ao local de aplicação. }\end{array}$} \\
\hline \multicolumn{4}{|l|}{$\begin{array}{l}\text { 2. O sequenciamento de execução do contrapiso no pavimento é } \\
\text { de tal forma que evita o tráfego de pessoas e equipamentos nos } \\
\text { ambientes executados. }\end{array}$} \\
\hline Organização do posto de trabalho & $\mathbf{S}$ & $\mathbf{N}$ & N.S.A. \\
\hline \multicolumn{4}{|l|}{$\begin{array}{l}\text { 1. Há um sistema de solicitação de argamassa ao local de } \\
\text { produção que evite as sobras no local de aplicação. }\end{array}$} \\
\hline \multicolumn{4}{|l|}{$\begin{array}{l}\text { 2. O taliscamento das lajes é realizado de acordo com o } \\
\text { comprimento da régua de sarrafeamento. }\end{array}$} \\
\hline Transporte dos materiais & $\mathbf{S}$ & $\mathbf{N}$ & N.S.A. \\
\hline \multicolumn{4}{|l|}{$\begin{array}{l}\text { 1. As rampas existentes no trajeto (produção-aplicação) tem } \\
\text { inclinação inferior a } 10 \% \text {. }\end{array}$} \\
\hline $\begin{array}{l}\text { 2. As condições do trajeto são isentas de saliências ou depressões, } \\
\text { ou seja, a base está regularizada. }\end{array}$ & & & \\
\hline
\end{tabular}

117 N.S.A. = não se aplica 


\section{Procedimentos de execução e controle}

\begin{tabular}{l|l|l|l}
\hline \multicolumn{1}{c|}{ ITENS DE VERIFICAÇÃO } & S & N & N.S.A. \\
\hline $\begin{array}{l}\text { 1. Dentro do projeto de contrapiso ou fora dele, há procedimentos } \\
\text { documentados de execução do contrapiso. }\end{array}$ & & & \\
\hline $\begin{array}{l}\text { 2. Dentro do projeto de contrapiso ou fora dele, há procedimentos } \\
\text { documentados de verificação e controle da execução do } \\
\text { contrapiso. }\end{array}$ & & & \\
\hline & & & \\
\hline
\end{tabular}

\section{E. Processo de execução}

ITENS DE VERIFICAÇÃO

\begin{tabular}{l|l|l|l}
\hline \multicolumn{1}{c|}{ Condições para início do serviço } & S & N & N.S.A. \\
\hline 1. A elevação das alvenarias está concluída. & & & \\
\hline $\begin{array}{l}\text { 1. Caso a elevação da alvenaria seja feita posteriormente ao } \\
\text { contrapiso, a dosagem da argamassa empregada no contrapiso é } \\
\text { coerente com um nível maios de solicitação. (trânsito de pessoas e } \\
\text { equipamentos etc) }\end{array}$ & & & \\
\hline 2. As instalações elétricas e hidráulicas do piso estão concluídas. & & & \\
\hline 3. As instalações elétricas e hidráulicas do piso estão testadas. & & & \\
\hline \multicolumn{1}{c}{ Limpeza da base e verificação dos níveis } & & & \\
\hline $\begin{array}{l}\text { 1. Tomase os níveis em vários pontos do ambiente para a } \\
\text { determinação da espessura do contrapiso. }\end{array}$ & S & N & N.S.A. \\
$\begin{array}{l}\text { 2. Antes da tomada dos níveis de referência e do taliscamento, os } \\
\text { ambientes são limpos, ou seja, são retirados restos de argamassas } \\
\text { e removidos óleos, graxas etc. }\end{array}$ & & & \\
\hline $\begin{array}{l}\text { 4. Polvilha-se cimento após a limpeza e umedecimento dos pontos } \\
\text { a fim de se garantir a aderência da argamassa de assentamento das } \\
\text { taliscas à base, evitando-se que as taliscas sejam acidentalmente } \\
\text { deslocadas de sua posição original. }\end{array}$ & & & \\
\hline $\begin{array}{l}\text { 1. É realizado o taliscamento prévio da laje para a execução do } \\
\text { contrapiso propriamente dito. }\end{array}$ & & & \\
\hline $\begin{array}{l}\text { 2. No caso de realizar o taliscamento, as taliscas são localizadas } \\
\text { de acordo com os pontos de verificação de nível especificados no } \\
\text { projeto. }\end{array}$ & & & N.S.A. \\
\hline $\begin{array}{l}\text { 3. Os pontos de assentamento das taliscas são devidamente limpos } \\
\text { previamente umedecidos. }\end{array}$ & & & \\
\hline
\end{tabular}




\begin{tabular}{|c|c|c|c|}
\hline Assentamento de taliscas (Continuação) & $\mathbf{S}$ & $\mathbf{N}$ & N.S.A. \\
\hline \multicolumn{4}{|l|}{$\begin{array}{l}\text { 5. Junto aos ralos de áreas molháveis, executa-se uma talisca em } \\
\text { anel, de forma a garantir o caimento mínimo em sua direção. }\end{array}$} \\
\hline \multicolumn{4}{|l|}{$\begin{array}{l}\text { 6. A argamassa de assentamento das taliscas tem características } \\
\text { idênticas à que será empregada no contrapiso. }\end{array}$} \\
\hline Execução de mestras & $\mathbf{S}$ & $\mathbf{N}$ & N.S.A. \\
\hline \multicolumn{4}{|l|}{ 1. Executam-se mestras entre as taliscas. } \\
\hline \multicolumn{4}{|l|}{ 2. Compactam-se as mestras. } \\
\hline $\begin{array}{c}\text { Lançamento, sarrafeamento da argamassa e acabamento da } \\
\text { superfície }\end{array}$ & $\mathbf{S}$ & $\mathbf{N}$ & N.S.A. \\
\hline \multicolumn{4}{|l|}{$\begin{array}{l}\text { 1. Para ambientes cujas espessuras de contrapiso forem maiores } \\
\text { que } 50 \mathrm{~mm} \text {, executa-se o contrapiso em duas camadas. }\end{array}$} \\
\hline \multicolumn{4}{|l|}{$\begin{array}{l}\text { 2. Molha-se a laje com água em abundância antes do lançamento } \\
\text { da argamassa. }\end{array}$} \\
\hline \multicolumn{4}{|l|}{ 3. Remove-se o excesso de água lançada na laje. } \\
\hline \multicolumn{4}{|l|}{$\begin{array}{l}\text { 4. Independentemente do número de camadas, a argamassa } \\
\text { lançada é compactada a fim de diminuir os vazios proporcionando } \\
\text { maior resistência. }\end{array}$} \\
\hline \multicolumn{4}{|l|}{$\begin{array}{l}\text { 5. Após o sarrafeamento, o deslocamento das pessoas sobre a } \\
\text { argamassa é feito sobre pranchas. }\end{array}$} \\
\hline \multicolumn{4}{|l|}{$\begin{array}{l}\text { 6. Para os contrapisos aderidos, executa-se a camada de aderência } \\
\text { polvilhando-se a laje com cimento. (geralmente utiliza-se uma } \\
\text { peneira e aplica-se uma quantidade aproximada de } 0,5 \mathrm{~kg} / \mathrm{m}^{2} \text { ). }\end{array}$} \\
\hline \multicolumn{4}{|l|}{$\begin{array}{l}\text { 7. Para contrapisos aderidos, o polvilhamento com cimento inicia- } \\
\text { se pelos pontos da laje que receberão a argamassa primeiramente, } \\
\text { evitando que a nata que se forma devido ao polvilhamento } \\
\text { endureça antes do lançamento da argamassa (geralmente polvilha- } \\
\text { se inicialmente a região onde serão executadas as mestras para em } \\
\text { seguida polvilhar o restante do ambiente, após as mesmas estarem } \\
\text { prontas). }\end{array}$} \\
\hline \multicolumn{4}{|l|}{$\begin{array}{l}\text { 8. Para o caso dos contrapisos não aderidos, não é realizado } \\
\text { nenhum preparo especial da base, uma vez que não há necessidade } \\
\text { de aderência do contrapiso à mesma. (lavagem, retirada de graxas } \\
\text { e óleos etc.). }\end{array}$} \\
\hline $\begin{array}{l}\text { 9. No caso de contrapiso flutuante, a compactação da camada de } \\
\text { argamassa colocada sobre uma camada intermediária } \\
\text { compressível é realizada com um vibrador de superfície, evitando } \\
\text { que a camada intermediária se deforme diferencialmente. }\end{array}$ & & & \\
\hline
\end{tabular}




\begin{tabular}{|c|c|c|c|}
\hline $\begin{array}{c}\text { Lançamento, sarrafeamento da argamassa e acabamento da } \\
\text { superfície (Continuação) }\end{array}$ & $\mathbf{S}$ & $\mathbf{N}$ & N.S.A. \\
\hline $\begin{array}{l}\text { 10. Ainda para os contrapisos flutuantes, a execução da camada de } \\
\text { contrapiso é feita em duas etapas, ou seja: a primeira camada é } \\
\text { lançada com espessura de } 25 \mathrm{~mm} \text {, sendo compactada e nivelada } \\
\text { apenas com régua e, decorrido o intervalo de } 24 \text { horas, é lançada a } \\
\text { segunda camada, também adequadamente compactada. }\end{array}$ & & & \\
\hline $\begin{array}{l}\text { 11. Em se tratando ainda de contrapiso flutuante, entre as duas } \\
\text { camadas é colocada uma malha metálica, a fim de se reduzir o } \\
\text { risco de fissuração. }\end{array}$ & & & \\
\hline $\begin{array}{l}\text { 12. Contrapisos que receberão acabamentos finos colados (por } \\
\text { exemplo vinílicos) são desempenados com desempenadeiras } \\
\text { metálicas, proporcionando um acabamento mais liso. }\end{array}$ & & & \\
\hline $\begin{array}{l}\text { 13. O acabamento de contrapisos que receberão revestimentos } \\
\text { fixados com dispositivos ou argamassa adesiva (revestimento } \\
\text { cerâmico, por exemplo), é feito com desempenadeira de madeira } \\
\text { (contrapiso desempenado). }\end{array}$ & & & \\
\hline $\begin{array}{l}\text { 14. Para o caso dos contrapisos reforçados, logo após o } \\
\text { sarrafeamento da superfície com régua metálica, polvilha-se } \\
\text { cimento sobre a argamassa sarrafeada. }\end{array}$ & & & \\
\hline 15. O contrapiso é umedecido durante seu período de cura. & & & \\
\hline $\begin{array}{l}\text { 16. O contrapiso é isolado do trânsito de pessoas e equipamentos } \\
\text { durante um período mínimo de } 3 \text { dias. }\end{array}$ & & & \\
\hline \multicolumn{4}{|l|}{ F. Registro do serviço } \\
\hline Sequenciamento da execução do contrapiso. & & \multicolumn{2}{|c|}{ Croqui $\mathrm{n}^{\circ} .6 .6 .5 .1$} \\
\hline $\begin{array}{l}\text { Equipamento de transporte vertical da argamassa (caso não seja o } \\
\text { mesmo fotografado através da aplicação da planilha 1.2). }\end{array}$ & & \multicolumn{2}{|c|}{ Foto $n^{\mathrm{o}} .6 .6 .5 .1$} \\
\hline Equipamento de transporte horizontal da argamassa. & & \multicolumn{2}{|c|}{ Foto $\mathrm{n}^{\mathrm{o}} .6 .6 .5 .2$} \\
\hline $\begin{array}{l}\text { Equipamentos e ferramentas de limpeza e preparo da base (vanga, } \\
\text { ponteiro, picão etc). }\end{array}$ & & \multicolumn{2}{|c|}{ Foto $\mathrm{n}^{\mathrm{o}} \cdot$ 6.6.5.3 } \\
\hline Equipamentos e ferramentas para execução contrapiso. & & \multicolumn{2}{|c|}{ Foto $n^{0} .6 .6 .5 .4$} \\
\hline Equipamento de marcação do nível. & & \multicolumn{2}{|c|}{ Foto ño 6.6 .5 .5} \\
\hline Masseiras utilizadas pelos pedreiros. & & \multicolumn{2}{|c|}{ Foto ñ. 6.6.5.6 } \\
\hline
\end{tabular}




\section{G. Registro de ocorrências anormais}

Descreva qualquer tipo de ocorrência relacionada à utilização inadequada dos materiais, como acidentes, consumo em serviços não previstos. Faça uma estimativa aproximada da perda. Da mesma forma, relacione qualquer alteração das respostas dos itens de verificação em função do andamento do serviço e até mesmo, justificativas/critérios utilizados nas respostas dos itens de verificação.

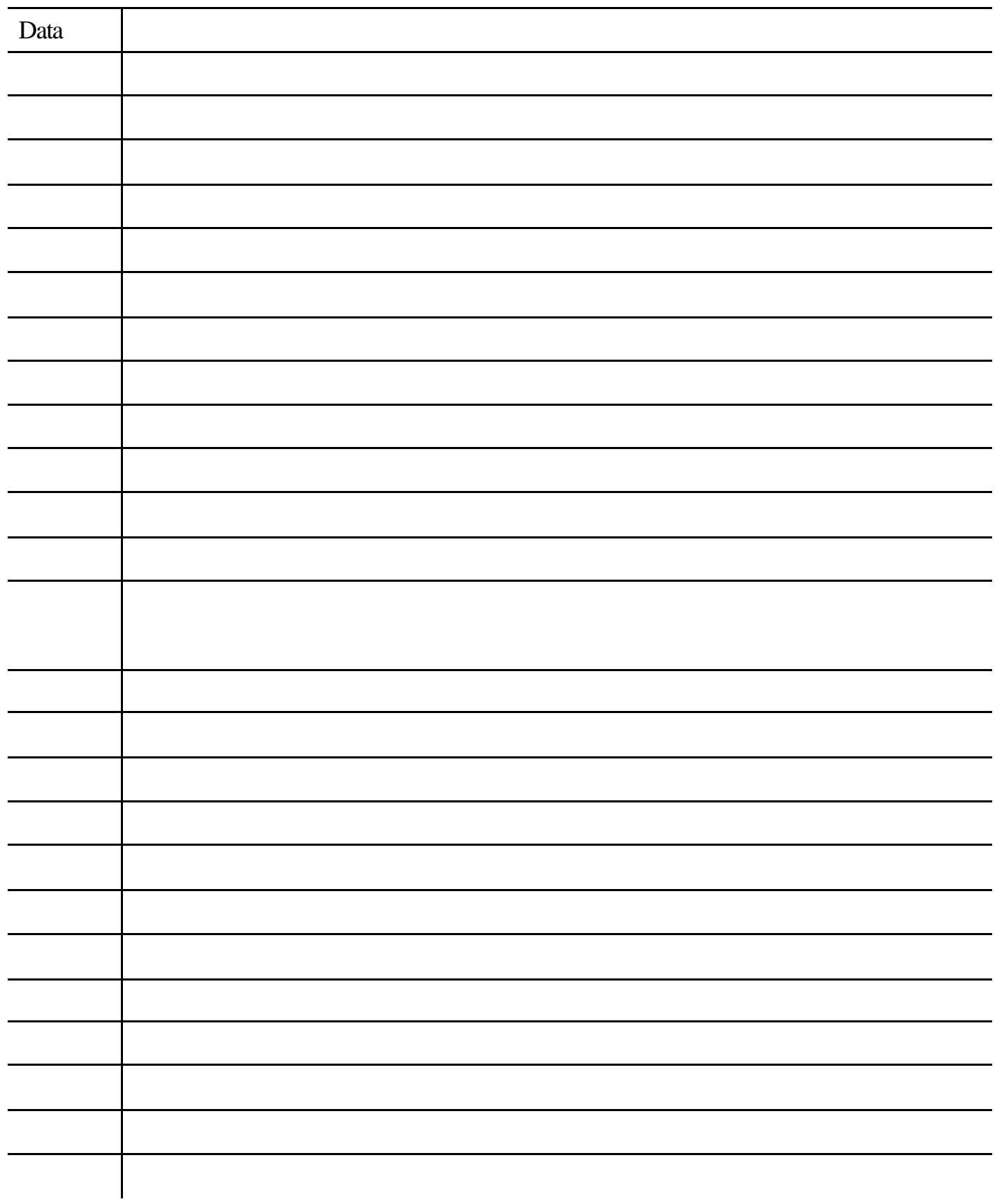


INDICADOR GLOBAL DE PERDAS DE MATERIAIS: $7.2 \cdot$ - ÍNDICE CONTÁBIL: CIMENTO PORTLAND

\section{OBJETIVO}

Esse indicador tem por objetivo conhecer a variação percentual do consumo real do cimento em relação ao seu consumo teórico nos serviços executados entre as datas VI e VF, mostrando as ineficiências do processo construtivo como um todo quanto ao uso desse material.

\section{ROTEIRO PARA CÁLCULO}

\subsection{FÓRMULA}

$$
I_{\text {contabil }}(\%)=\left[\frac{E S T(V I)+\sum_{j=1}^{k} M_{\text {paga }_{j}}(V I, V F) \pm \sum_{m=1}^{p} M^{n} T_{\text {trans }_{m}}(V I, V F)-E S T(V F)}{\sum_{i=1}^{n} \operatorname{SERVICOS}_{i}(V I, V F) x C O M P_{\text {uniti }_{i}}}-1\right] x 100
$$

\begin{tabular}{|c|c|}
\hline VARIÁVEIS & DESCRIÇÃO/CRITÉRIOS \\
\hline$E S T(V I)$ & de de material estocado na data VI (Planilho \\
\hline$E S T(V F)$ & cado na data VF (Planilha 2.2) \\
\hline$M A T_{\text {pagd }}(V I, V F)$ & $\begin{array}{l}\text { Quantidade de material paga entre as datas VI e VF, via ordem } \\
\text { de pagamento (Planilha } 4.2 \text { ) }\end{array}$ \\
\hline$M A T_{\text {transf }}(V I, V F)$ & Quantidade de material transferida entre canteiros entre as datas \\
\hline & $\begin{array}{l}\text { VI e VF, (Planilha 4.2); positivo: material que entra no canteiro; } \\
\text { negativo: material que sai }\end{array}$ \\
\hline $\operatorname{SERVIÇOS(VI,VF)}$ & $\begin{array}{l}\text { Quantidade de serviços que fazem uso desse material, executados } \\
\text { entre VI e VF (Série } 3 \text { de planilhas) }\end{array}$ \\
\hline $\mathrm{COMP}_{U}$ & o do material por unidade de serviço (a ser definido) \\
\hline$V I$ & Inicial) \\
\hline$V F$ & anteiro (Vistoria Final) \\
\hline$k$ & Número de recebimentos entre as datas VI e VF \\
\hline$p$ & $\begin{array}{l}\text { Número de transferências de materiais para fora do canteiro } \\
\text { entre VI e VF }\end{array}$ \\
\hline$n$ & $\begin{array}{l}\text { Número de serviços que consumiram o material entre as datas VI } \\
\text { e VF }\end{array}$ \\
\hline
\end{tabular}

\section{PERIODICIDADE}

$$
\text { Por edificação }
$$




\subsection{CONTR - INDICADOR GLOBAL DE PERDAS DE MATERIAIS POR SERVIÇO: CIMENTO;CONTRAPISO}

\section{OBJETIVO}

Além do conhecimento do índice global de perda do cimento no conjunto de serviços que fazem uso do mesmo entre as datas VI e VF, torna-se imprescindível o conhecimento do índice de perda deste material em cada serviço, objetivo direto deste indicador, especificamente para o serviço de contrapiso.

\section{ROTEIRO PARA CÁLCULO}

\subsection{FÓRMULA}

$$
I_{\text {contrapiso }}(\%)=\left[\frac{\text { cimento }_{\text {contrapiso }}(V I, V F)}{\text { Servico }_{\text {contrapiso }}(V I, V F) x \operatorname{Comp} \cdot_{\text {unit. }}}-1\right] x 100
$$

\begin{tabular}{|c|c|}
\hline VARIÁVEIS & DESCRIÇÃO/CRITÉRIOS \\
\hline cimento $_{\text {contrapiso }}$ & $\begin{array}{l}\text { Quantidade de real de cimento utilizada na produção de argamassa para a execução do } \\
\text { contrapiso (planilha 4.2); } \\
\Rightarrow \text { para que se tenha a quantidade de cimento destinada ao serviço de contrapiso, deve- } \\
\text { se controlar a saída do mesmo do estoque. Existem várias formas de se fazer isso, desde } \\
\text { a mais eficaz a menos eficaz, desde aquela que interfere pouco na organização da } \\
\text { produção até aquela que interfere significativamente nesta organização. Apresenta-se } \\
\text { resumidamente algumas opções: } \\
\text { - trancar o estoque de cimento e concentrar a liberação do material no almoxarife } \\
\text { mediante solicitação prévia; } \\
\text { introduzir um sistema de fichas coloridas, onde as mesmas são depositadas numa } \\
\text { urna de acordo com o número de sacos utilizados na produção de argamassa para } \\
\text { determinado serviço; } \\
\text { estipular uma cor para cada serviço, demarcar os sacos estocados em função dos } \\
\text { serviços que estão sendo executados e determinar que os mesmos sejam utilizados } \\
\text { nos respectivos serviços. Após o uso, pode-se guardá-los em tambores ou até mesmo } \\
\text { elaborar um cabide e pendurá-los. } \\
\Rightarrow \text { a adoção de cada um desses procedimentos dependerá do auxílio dos betoneiros e do } \\
\text { almoxarife e para o sucesso desta operação, eles devem estar cientes da importância de } \\
\text { tal controle. }\end{array}$ \\
\hline Serviço ${ }_{\text {contrapiso }}$ & Quantidade do serviço de contrapiso executada entre VI e VF (planilha 3.6.8) \\
\hline Comp. unitária & Consumo do material por unidade de serviço \\
\hline VI & Data de início da coleta de dados em canteiro. (Vistoria Inicial) \\
\hline$V F$ & Data de término da coleta de dados em canteiro. (Vistoria Final) \\
\hline
\end{tabular}

\section{PERIODICIDADE E MOMENTO DE COLETA DE DADOS}

\section{Por edificação}


INDICADOR PARCIAL DE PERDAS DE MATERIAIS:

7.6.3 - VARIAÇÃO PERCENTUAL DA ESPESSURA MÉDIA DO CONTRAPISO EM RELAÇÃO À ESPECIFICADA EM

PROJETO

ARGAMASSA PRODUZIDA EM OBRA

\section{OBJETIVO}

O contrapiso muitas vezes acaba cumprindo, entre outras, as funções de corrigir as

imperfeições da laje quanto ao acabamento superficial e nível. Com a adoção dos conceitos de racionalização construtiva a espessura do contrapiso tende a diminuir. Esse indicador tem por objetivo medir a perda de argamassa devida ao excesso de espessura

do contrapiso.

\section{ROTEIRO PARA CÁLCULO}

\subsection{FÓRMULAS}

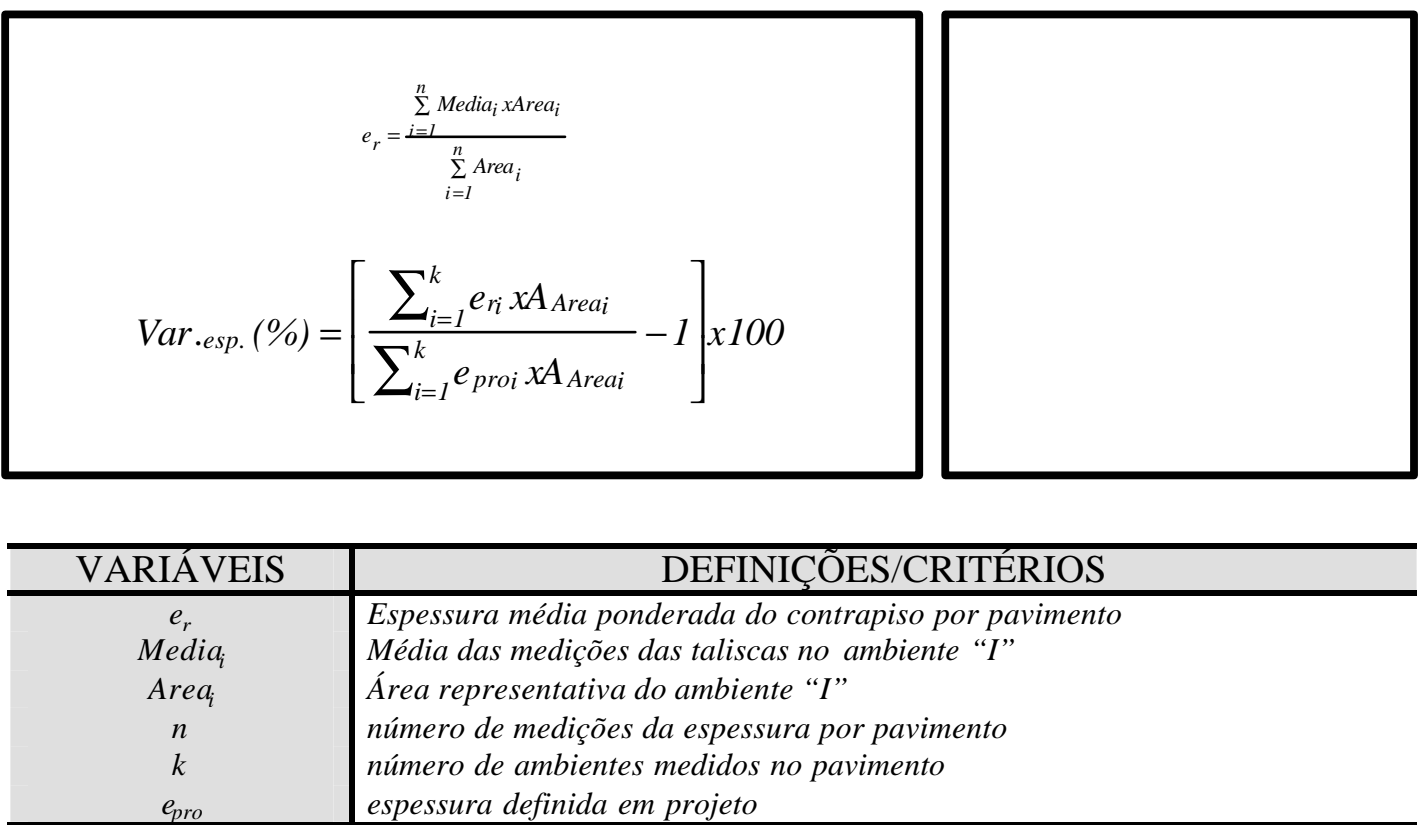

\section{MOMENTO DE COLETA DE DADOS E PERIODICIDADE}

A coleta de dados deve ser realizada antes do "enchimento" dos ambientes, ou seja, logo após o taliscamento da laje. Devese medir pelo menos 1/3 do número total de pavimentos a serem executados entre as datas VI e VF, respeitando-se o número mínimo de 3 pavimentos. Para o cálculo do número total de pavimentos, considera-se somente aqueles onde o serviço em referência será realizado. Em cada pavimento, devese medir 1/3 do número total de ambientes para cada tipo de contrapiso, respeitando-se também o número mínimo de 3 ambientes. Entre cada pavimento, deve-se alternálos afim de se conseguir maior representatividade da amostra.

4. OBSERVAÇÕES

Atentar para o caso de se ter "caimento" do contrapiso. Em tendo-se esse caso, adotase o seguinte procedimento; mede-se quatro espessuras, uma em cada canto do ambiente (pontos mais altos ou de espessuras maiores) e tira-se a média; mede -se a espessura do contrapiso no local mais baixo ou de menor espessura (ralo); realiza -se a média entre os dois valores obtidos nos dois itens anteriores. 


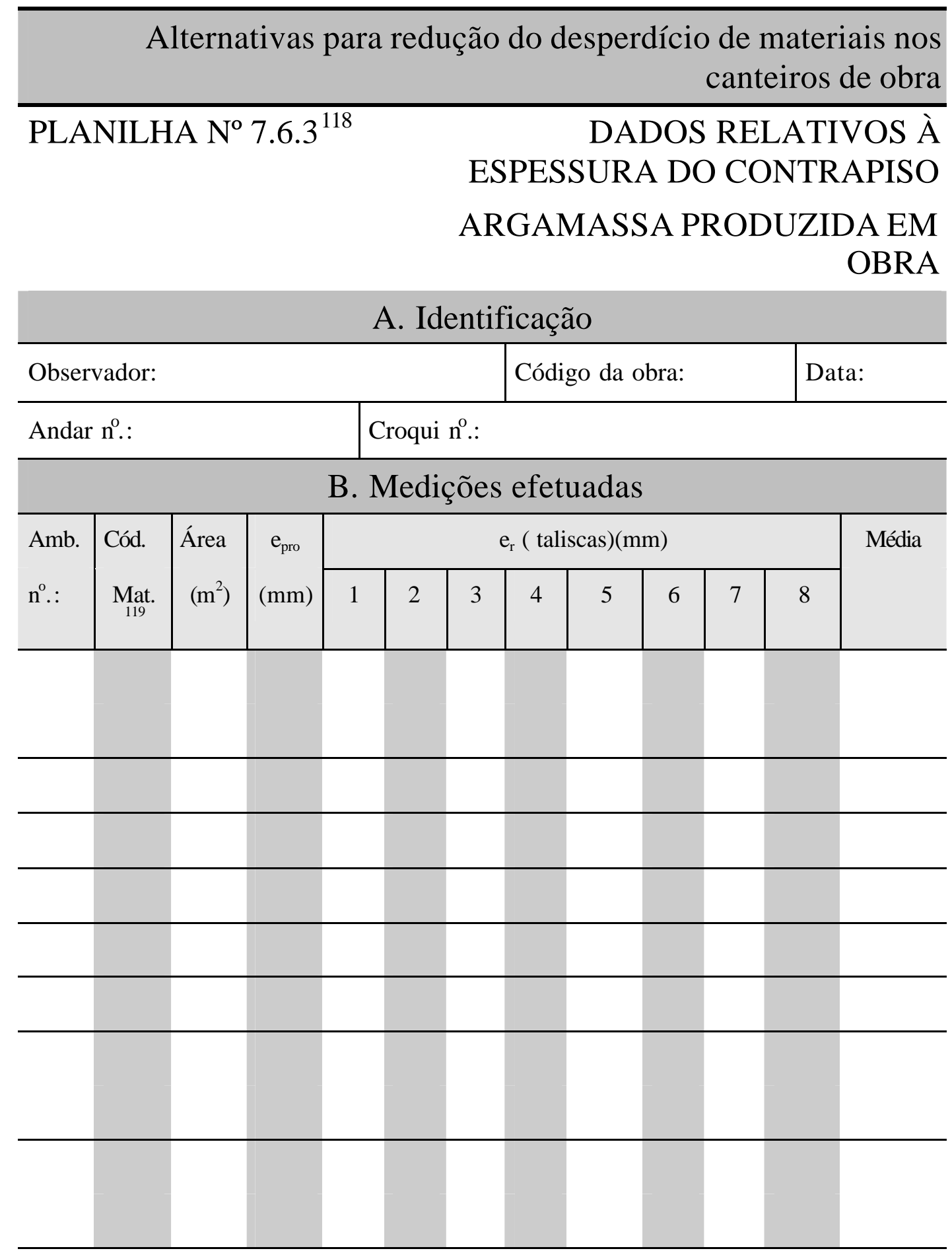

\footnotetext{
118 3a.. versão - 20/06/97

${ }^{119}$ vide tabela no verso da planilha
} 


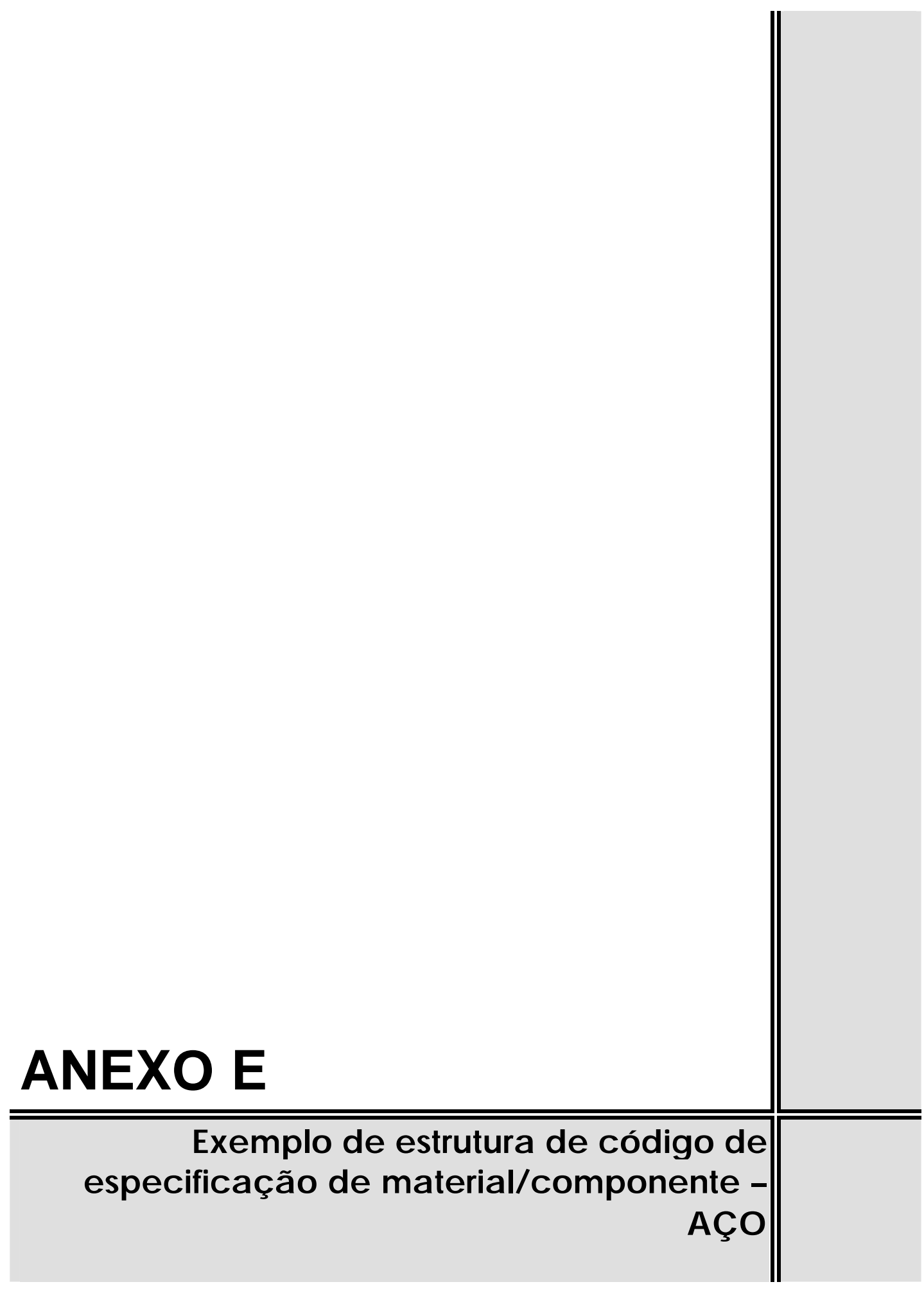




\begin{tabular}{|c|c|c|c|c|c|c|c|c|c|}
\hline Cód. & MATERIAL & Cód. & Forma de entrega & Cód. & $\begin{array}{l}\text { Barras/fios; resistência } \\
\text { característica de } \\
\text { escoamento }\end{array}$ & Cód. & Bitola $(\mathrm{mm})$ & Cód. & --- \\
\hline 07 & Aço & $\begin{array}{l}01 \\
02\end{array}$ & $\begin{array}{l}\text { Vergalhões } \\
\text { Cortado/dobrado }\end{array}$ & $\begin{array}{l}01 \\
02 \\
03\end{array}$ & $\begin{array}{l}\text { Barra CA25 } \\
\text { Barra CA50 } \\
\text { Fio CA60 }\end{array}$ & $\begin{array}{l}01 \\
02 \\
03 \\
04 \\
05 \\
06 \\
07 \\
08 \\
09 \\
10 \\
11 \\
20 \\
21 \\
22 \\
23 \\
24 \\
25 \\
28\end{array}$ & \begin{tabular}{|l}
5.0 \\
6.3 \\
8.0 \\
10.0 \\
12.5 \\
16.0 \\
20.0 \\
22.0 \\
25.0 \\
32.0 \\
40.0 \\
2.4 \\
3.4 \\
3.8 \\
4.2 \\
4.6 \\
5.0 \\
6.4
\end{tabular} & $\mathbf{0 0}$ & -- \\
\hline
\end{tabular}




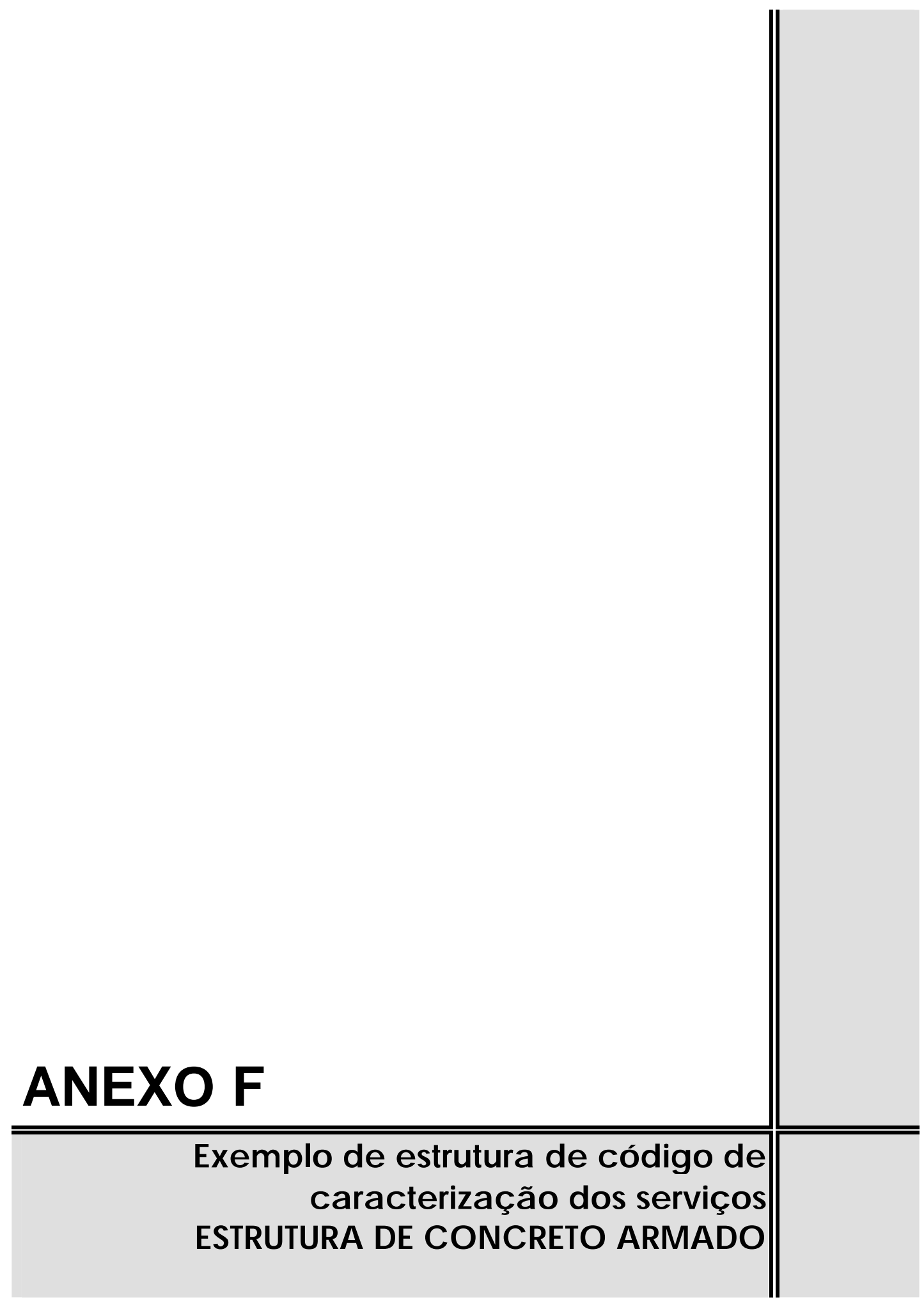




\begin{tabular}{|c|c|c|c|c|c|c|c|}
\hline \multicolumn{2}{|r|}{ Sub-código principal } & \multicolumn{2}{|r|}{ Material } & \multicolumn{2}{|r|}{ Projeto } & \multicolumn{2}{|r|}{ Transporte } \\
\hline Cód & Serviço & Cód & Material & Cód & $\begin{array}{l}\text { Existe projeto específico de } \\
\text { fôrmas ou projeto para } \\
\text { produção? }\end{array}$ & Cód & Equipamento de transporte \\
\hline 08 & $\begin{array}{l}\text { Estrutura de concreto - } \\
\text { lançamento }\end{array}$ & 05 & Concreto Usinado & $\begin{array}{l}1 \\
2\end{array}$ & $\begin{array}{l}\text { Com projeto específico } \\
\text { Sem projeto específico }\end{array}$ & $\begin{array}{l}1 \\
2 \\
3\end{array}$ & $\begin{array}{l}\text { Bombeado } \\
\text { Caçamba - Grua } \\
\text { Outro } \\
\end{array}$ \\
\hline & Serviço Precedente & & Serviço Precedente & & Serviço Precedente & & Aplicação \\
\hline Cód & Tipo de molde de fôrma: & Cód & Tipo de cimbramento: & Cód & Uso Médio do molde & Cód & $\begin{array}{l}\text { Equipamento utilizado para } \\
\text { locação de taliscas e/ou } \\
\text { mestras e/ou para } \\
\text { nivelamento da laje } \\
\text { durante a concretagem: }\end{array}$ \\
\hline $\begin{array}{l}1 \\
2 \\
3 \\
4\end{array}$ & $\begin{array}{l}\text { Metálico } \\
\text { Madeira plastificada } \\
\text { Madeira resinada } \\
\text { Madeira serrada }\end{array}$ & $\begin{array}{l}1 \\
2 \\
3\end{array}$ & $\begin{array}{l}\text { Metálico } \\
\text { Madeira } \\
\text { Misto }\end{array}$ & $\begin{array}{l}0 \\
1 \\
2 \\
3 \\
4 \\
5 \\
6\end{array}$ & $\begin{array}{l}\text { Não determinado } \\
2 \leq \text { Uso Médio }<3 \\
3 \leq \text { Uso Médio }<4 \\
4 \leq \text { Uso Médio }<5 \\
5 \leq \text { Uso Médio }<6 \\
6 \leq \text { Uso Médio }<7 \\
8 \leq \text { Uso Médio }<8\end{array}$ & $\begin{array}{l}1 \\
2\end{array}$ & $\begin{array}{l}\text { nível laser, alemão } \\
\text { outros }\end{array}$ \\
\hline
\end{tabular}

Exemplo:

\begin{tabular}{|l|l|l|l|l|l|l|l|l|}
\hline 08 & 05 & 1 & 2 & 2 & 2 & 6 & 1 & $\begin{array}{l}\text { Estrutura de concreto, concreto usinado; com projeto específico; } \\
\text { sem transporte com caçamba-grua; molde em madeira } \\
\text { plastificada; cimbramento de madeira; uso médio entre 7 e 8; nível } \\
\text { laser/alemão }\end{array}$ \\
\hline
\end{tabular}




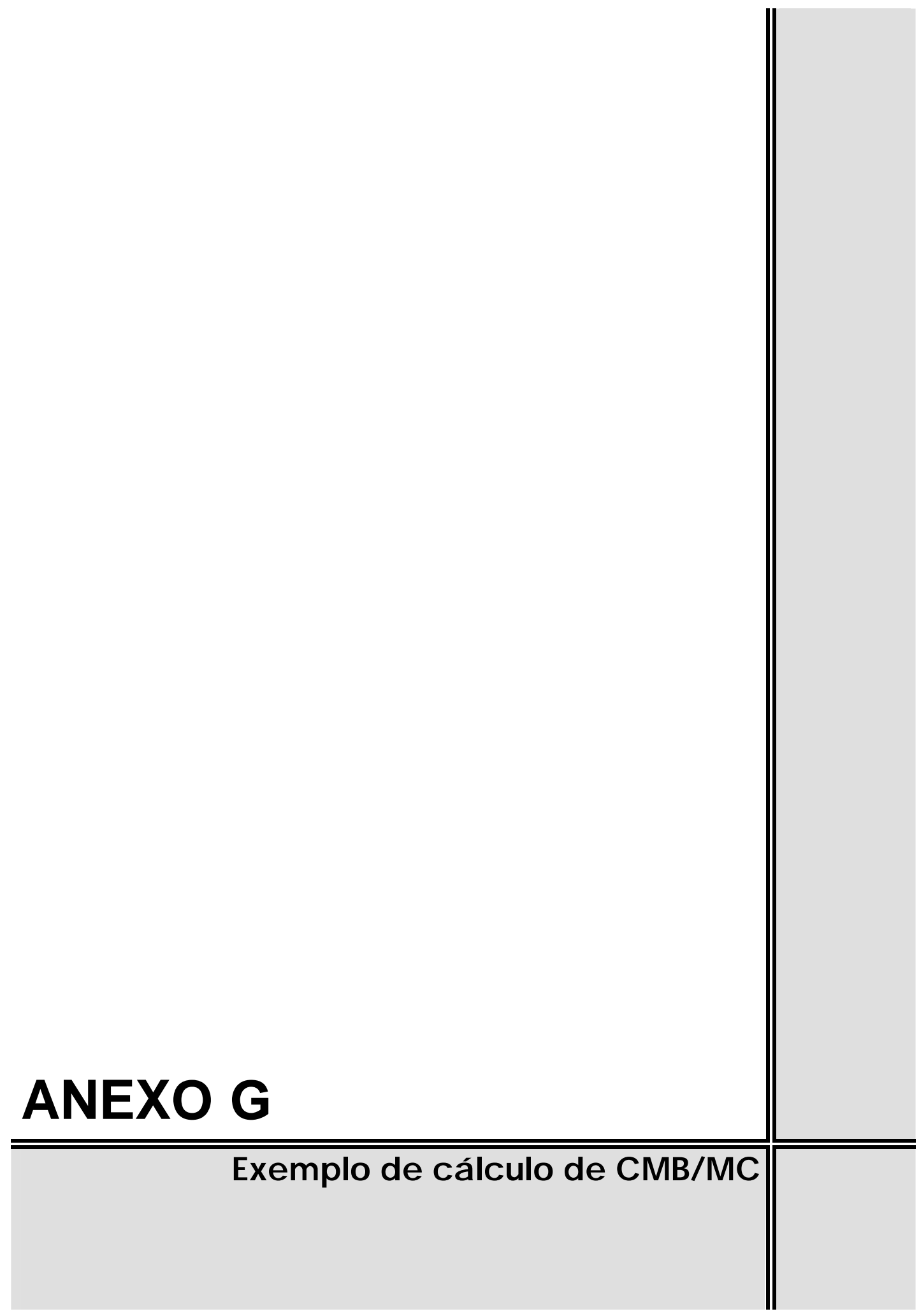




\begin{tabular}{|c|c|c|}
\hline $\begin{array}{l}\text { Serviço } \\
\text { Descriçã } \\
0 \\
\text { Material } \\
\text { Descriçã } \\
0\end{array}$ & \multicolumn{2}{|c|}{$\begin{array}{l}\text { 11.06.1.1.2.1.1.0 } \\
\text { Alvenaria-juntas (ml)(6 MPa) } \\
\text { 06.02.06.03.04 } \\
\text { Argamassa mista sem argamassa Intermediária }\end{array}$} \\
\hline \multirow{3}{*}{$\mathrm{C}_{\mathrm{cim}}$} & Traço: & $1: 0,08: 0: 3.34: 0: 0: 0$ \\
\hline & \multicolumn{2}{|r|}{2000} \\
\hline & \multicolumn{2}{|r|}{$\left(1+0,08+\frac{3,34}{1,25} \cdot 1,30\right.$} \\
\hline $\mathrm{C}_{\text {cal }}$ & \multicolumn{2}{|r|}{$0,08 \times 360,01=28,80 \mathrm{~kg} / \mathrm{m}^{3}$} \\
\hline $\mathrm{C}_{\text {areia média }}$ & \multicolumn{2}{|r|}{$\frac{3,34 \times 360,01}{1000}=1,202 \mathrm{~m}^{3} / \mathrm{m}^{3}$} \\
\hline
\end{tabular}

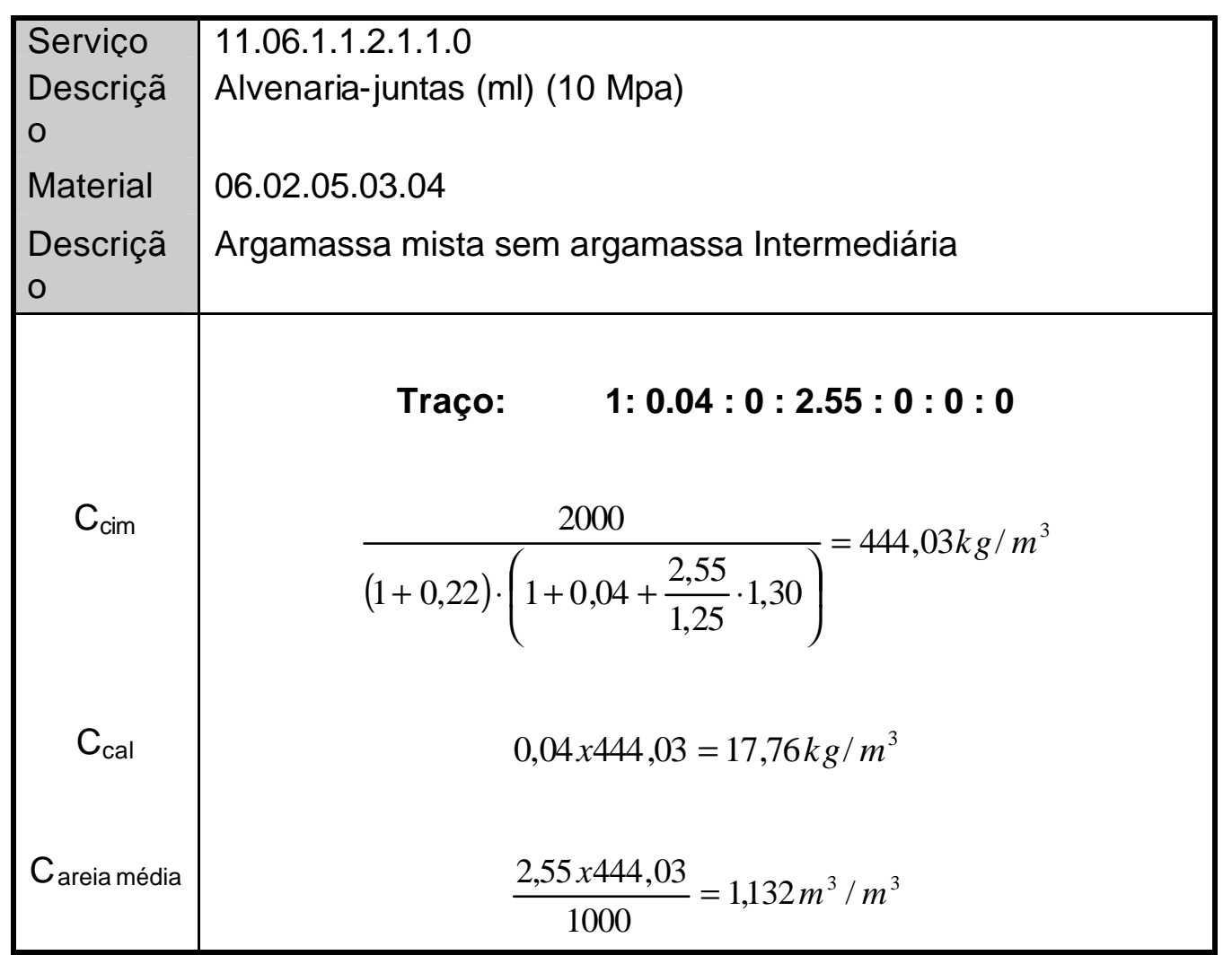




\begin{tabular}{|c|c|c|}
\hline $\begin{array}{l}\text { Serviço } \\
\text { Descriçã } \\
0 \\
\text { Material } \\
\text { Descriçã } \\
0\end{array}$ & \multicolumn{2}{|c|}{$\begin{array}{l}\text { 11.06.2.1.2.1.2.0 } \\
\text { Alvenaria-juntas (ml)- vedação } \\
\text { 06.02.07.03.04 } \\
\text { Arg. mista s/ arg. intermediária }\end{array}$} \\
\hline \multirow{3}{*}{$\mathrm{C}_{\text {cim }}$} & Traço: & $1: 0.04: 0: 6.8: 0: 0: 0$ \\
\hline & \multicolumn{2}{|r|}{2000} \\
\hline & \multicolumn{2}{|r|}{$1+0,04+\frac{6,8}{1,25} \cdot 1,30$} \\
\hline $\mathrm{C}_{\mathrm{cal}}$ & \multicolumn{2}{|r|}{$0,04 \times 197,24=7,89 \mathrm{~kg} / \mathrm{m}^{3}$} \\
\hline $\mathrm{C}_{\text {areia média }}$ & \multicolumn{2}{|r|}{$\frac{6,8 \times 197,24}{1000}=1,341 \mathrm{~m}^{3} / \mathrm{m}^{3}$} \\
\hline
\end{tabular}

\begin{tabular}{|c|c|c|}
\hline $\begin{array}{l}\text { Serviço } \\
\text { Descriçã } \\
0 \\
\text { Material } \\
\text { Descriçã } \\
0\end{array}$ & $\begin{array}{l}\text { 11.06.1.2.1.1.2.0 } \\
\text { Alvenaria-juntas (ml) } \\
\text { 06.02.17.06.01 } \\
\text { Argamassa mista sel }\end{array}$ & n argamassa . intermediária \\
\hline \multirow{3}{*}{$\mathrm{C}_{\mathrm{cim}}$} & Traço: & $1: 0,40: 0: 4.4: 0: 0: 0$ \\
\hline & \multicolumn{2}{|r|}{2000} \\
\hline & $(1+0,25)$ & $\left(1+0,4+\frac{4,4}{1,25} \cdot 1,30\right)=26 / .14 k g$ \\
\hline $\mathrm{C}_{\text {cal }}$ & \multicolumn{2}{|r|}{$0,40 \times 267,74=107,10 \mathrm{~kg}$} \\
\hline $\mathrm{C}_{\text {areia média }}$ & \multicolumn{2}{|r|}{$\frac{267,74 \times 4.4}{1000}=1.18 m^{3}$} \\
\hline
\end{tabular}




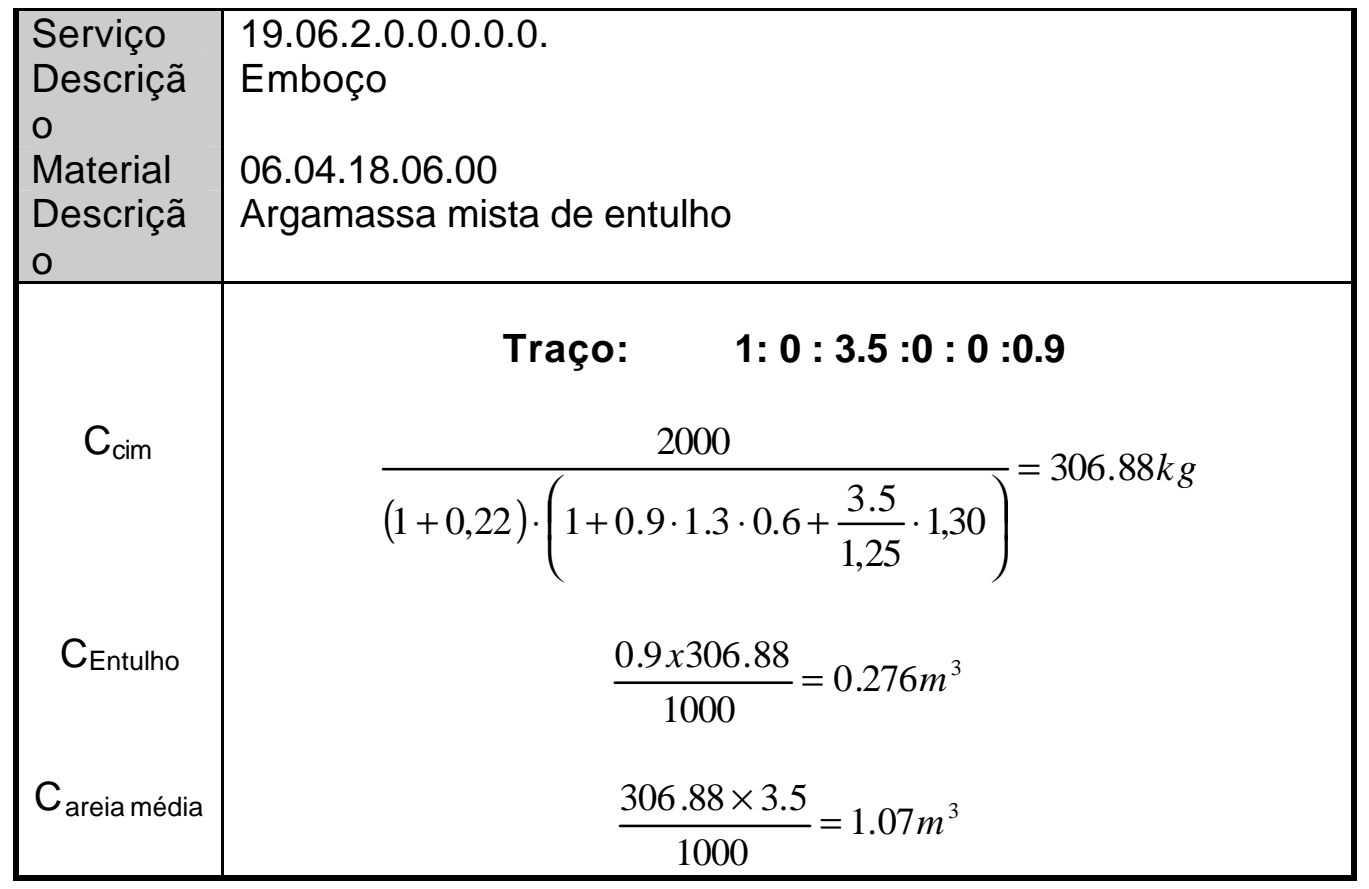

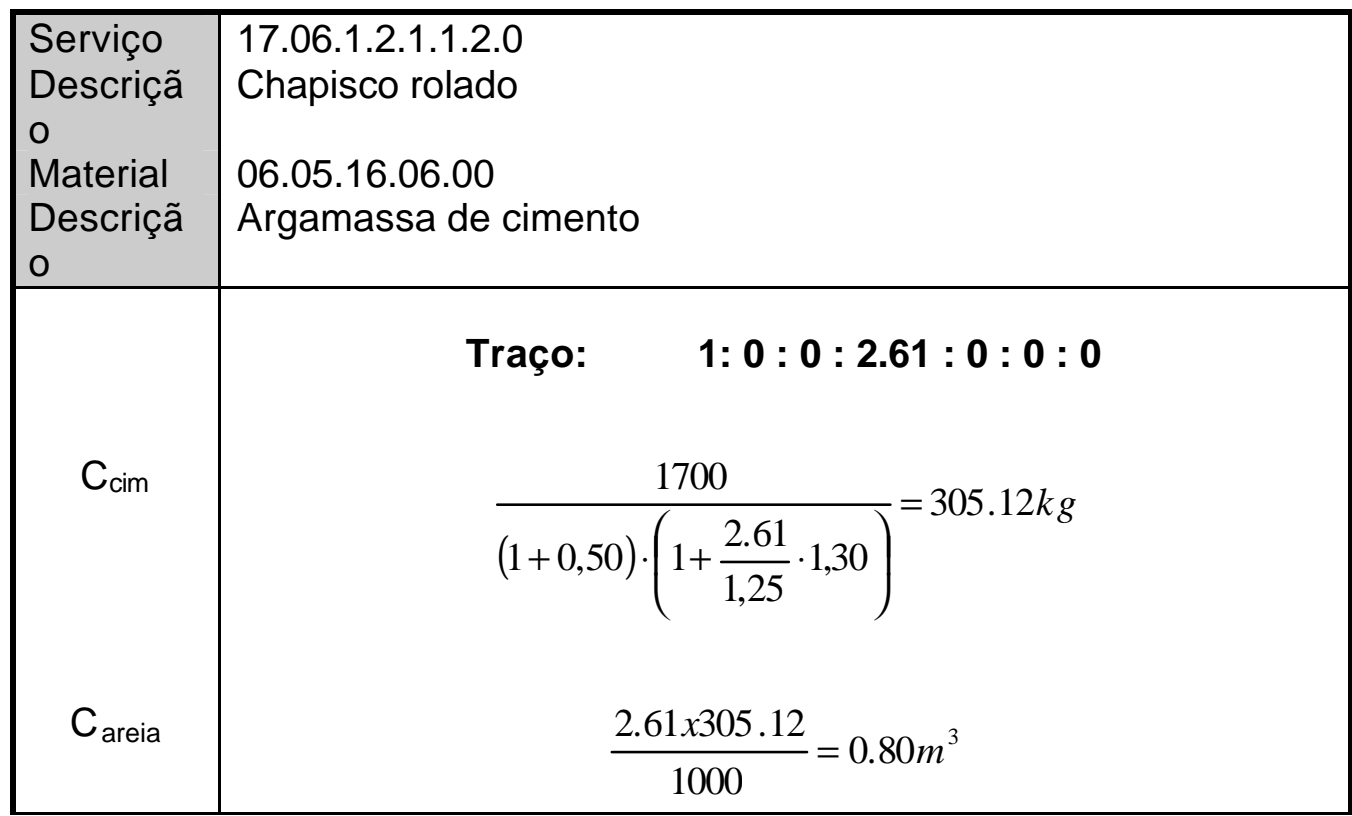




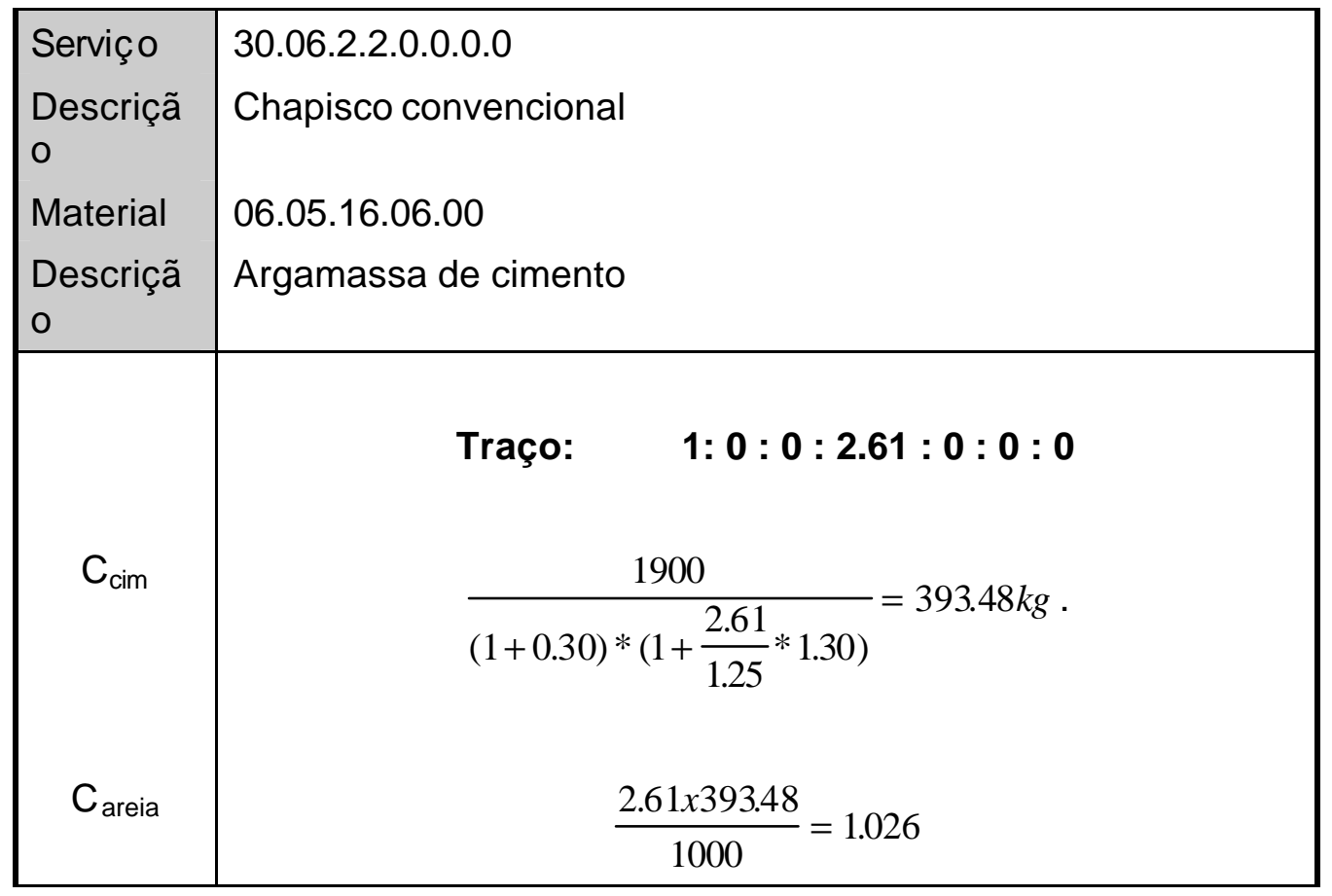

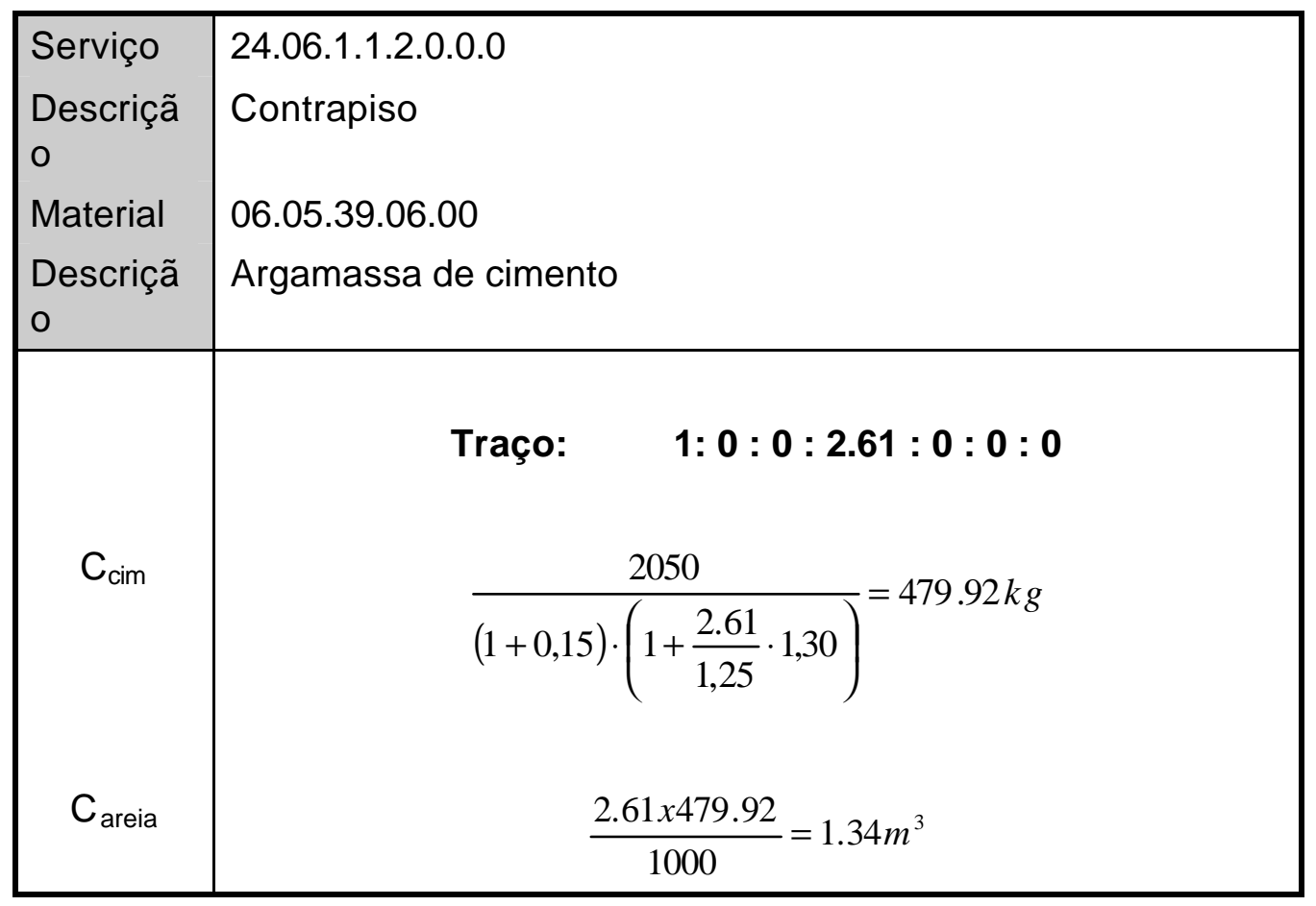




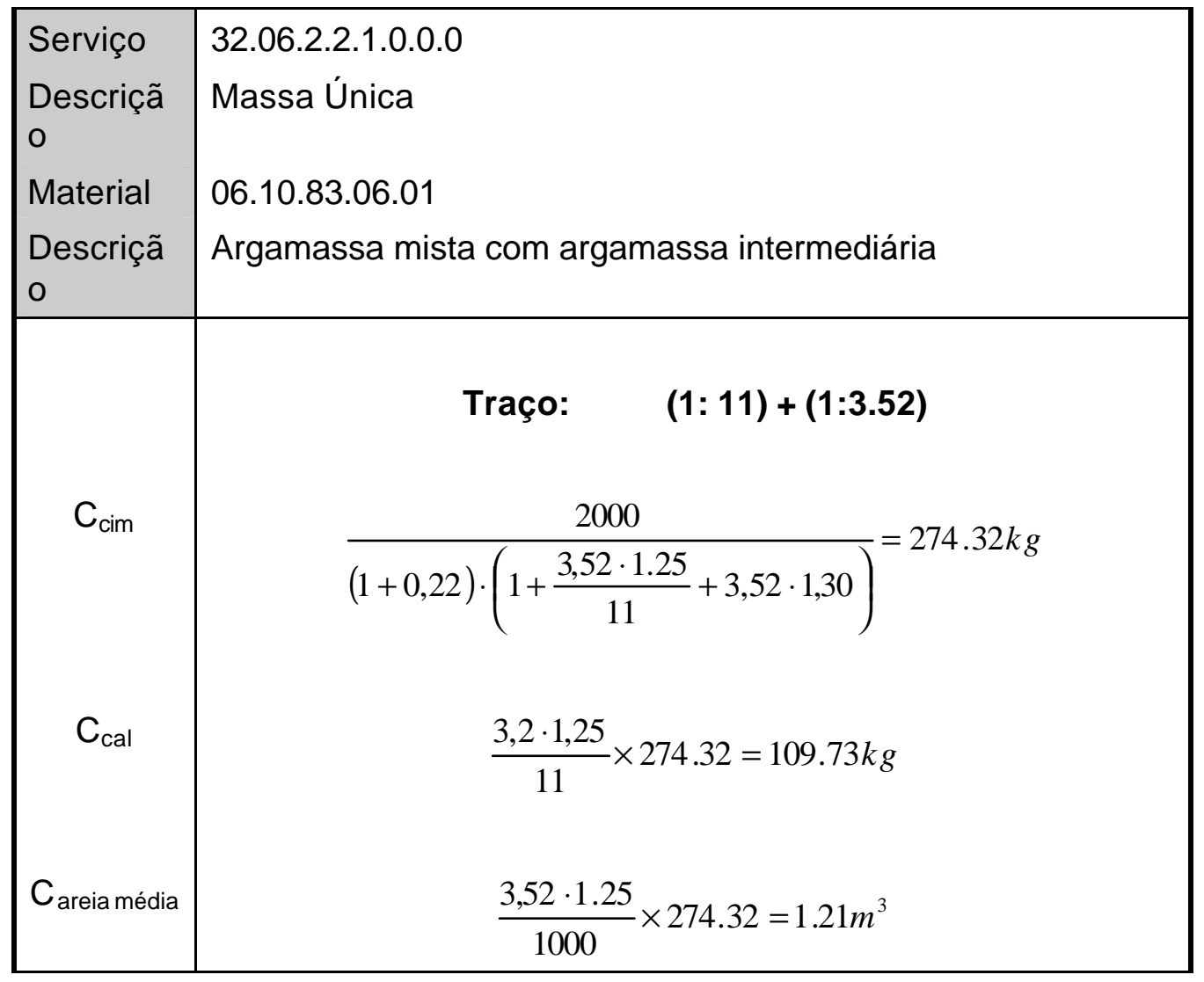




\section{REFERÊNCIAS BIBUOGRÁFCAS}

AGOPYAN, V. et al. (a) Alternativas para a redução do desperdício de materiais nos canteiros de obras: Introdução. São Paulo, PCC/EPUSP, 1998 (Relatório Final: volume 1. Departamento de Engenharia de Construção Civil - PCC-EPUSP)

AGOPYAN, V. et al. (b) Alternativas para a redução do desperdício de materiais nos canteiros de obras: Metodologia. São Paulo, PCC/EPUSP, 1998 (Relatório Final: volume 2. Departamento de Engenharia de Construção Civil - PCC-EPUSP)

AGOPYAN, V. et al. (c) Alternativas para a redução do desperdício de materiais nos canteiros de obras: Resultados. São Paulo, PCC/EPUSP, 1998 (Relatório Final: volume 3. Departamento de Engenharia de Construção Civil - PCC-EPUSP)

AGOPYAN, V. et al. (d) Alternativas para a redução do desperdício de materiais nos canteiros de obras: Resultados. São Paulo, PCC/EPUSP, 1998 (Relatório Final: volume 4. Departamento de Engenharia de Construção Civil - PCC-EPUSP)

AGOPYAN, V. et al. (e) Alternativas para a redução do desperdício de materiais nos canteiros de obras: Resultados. São Paulo, PCC/EPUSP, 1998 (Relatório Final: volume 5. Departamento de Engenharia de Construção Civil - PCC-EPUSP)

ANDRADE, T.W.C.O. et al. Compatibilização e racionalização de projetos na construção civil. In: CONGRESSO IBEROAMERICANO DE PATOLOGIAS 
DAS CONSTRUÇÕES, 4., Porto Alegre, 1997. Anais. Porto Alegre, LEME/CPGEC-UFRGS, 1997. p.301-08.

ANDRADE, A.C. Metodologia para quantificação do consumo de materiais em empresas construtoras de edifícios: execução da estrutura e da alvenaria de vedação. São Paulo, 1999. /Texto apresentado para exame de qualificação - Escola Politécnica - Universidade de São Paulo/

ANTUNES, R.P.N.; OLIVEIRA, C.T.A.; JOHN, V.M. Trabalhabilidade em obra, consistência e calor de hidratação das pastas de gesso. In: SIMPÓSIO BRASILEIRO DE TECNOLOGIA DE ARGAMASSAS, 3., Vitória, 1999. Anais. Vitória, UFES,1999. p.95-106.

ANTUNES JÚNIOR, J.A.V. Mecanismo função produção: a análise dos sistemas produtivos do ponto de vista de uma rede de processos e operações. Produção, v.4, n.1,. p.33-46, jul., 1994.

ARAÚJO, N.M.C.; MEIRA, G.R. Processo de padronização na construção civil: aplicação de revestimentos internos (azulejos). In: CONGRESSO NACIONAL DE ENGENHARIA DE PRODUÇÃO, Piracicaba, 16., 1996. Anais. Piracicaba, UNIMEP, 1996. Anais em CD-ROM.

ASSOCIAÇÃO BRASILEIRA DE NORMAS TÉCNICAS. Projeto e execução de obras em concreto armado; procedimentos-NBR 6118. Rio de Janeiro, 1980.

. Bloco cerâmico para alvenaria; especificação-NBR 7171. Rio de Janeiro, 1992.

Cal hidratada para argamassas; especificação-NBR 7175. Rio de Janeiro, 1992.

Revestimentos de paredes e tetos em argamassas inorgânicas;

procedimentos para execução-NBR 7200. Rio de Janeiro, 1998. 
- Barras e fios de aço destinados a armaduras para concreto armado; especificação-NBR 7480. Rio de Janeiro, 1996.

. Execução e controle de obras em alvenaria estrutural de blocos vazados de concreto; procedimento-NBR 8798. Rio de Janeiro, 1985.

- Gestão da qualidade e garantia da qualidade: terminologiaNBR/ISO 8402. Rio de Janeiro, 1994.

- Gestão da qualidade e elementos do sistema da qualidade Parte 1: diretrizes -NBR/ISO 9004-1. Rio de Janeiro, 1994.

. Tintas para edificações não industriais; terminologia-NBR 12554. Rio de Janeiro, 1991.

. Concreto - Preparo, controle e recebimento; procedimento-NBR 12655. Rio de Janeiro, 1996.

. Gesso para construção civil; especificação-NBR 13207. Rio de Janeiro, 1994.

- Argamassa industrializada para assentamento de paredes e revestimento de paredes e tetos; especificação-NBR 13281. Rio de Janeiro, 1995.

. Revestimentos de paredes e tetos em argamassas inorgânicas; classificação-NBR 13530. Rio de Janeiro, 1995.

ASSUMPÇÃO, J.F.P. Programação de obras: uma abordagem sobre técnicas de programação e uso de softwares. São Carlos, 1988. 143p. Dissertação (Mestrado) - Escola de Engenharia de São Carlos, Universidade de São Paulo.

BARROS, M.M.S.B. Tecnologia de produção de contrapisos para edifícios habitacionais e comerciais. São Paulo, 1991. 316p. Dissertação (Mestrado) - Escola Politécnica, Universidade de São Paulo. 
BASSO, J.L. Engenharia e analise do valor. São Paulo. IMAN, 1991.

BOGADO, J.G.M. Aumento da produtividade e diminuição de desperdícios na construção civil: um estudo de caso - Paraguai. Florianópolis, 1998. 122p. Dissertação (Mestrado) - Curso de Pós-graduação em Engenharia Civil, Universidade Federal de Santa Catarina.

BORNIA, A.C. Mensuração das perdas dos processos produtivos: uma abordagem metodológica de controle interno. Florianópolis, 1995. 125p. Tese (Doutorado) - Curso de Pós-graduação em Engenharia Civil, Universidade Federal de Santa Catarina.

BOSSINCK, A.,G.; BROUWERS, H.J.H. Construction waste: quantification and source evaluation. Journal of Construction Engineering and Management, v.122, n.1, p.55-60, Mar, 1996.

CARRARO, F. Produtividade da mão-de-obra no serviço de alvenaria. São Paulo, 1998. 226p. Dissertação (Mestrado) - Escola Politécnica, Universidade de São Paulo.

CAZET, A.F. et al. Aplicação de técnicas de diagnóstico em canteiros de obras: fôrmas. In: CONGRESSO NACIONAL DE ENGENHARIA DE PRODUÇÃO, 16., Piracicaba, 1996. Anais. Piracicaba, UNIMEP, 1996. Anais em CDROM.

CEOTTO, L.H. O desperdício na construção civil. Construção, v.48, n. 2480, p.26-27, ago, 1995.

CINCOTTO, M.A. Patologia das argamassas de revestimento: análise e recomendações. São Paulo, IPT/PINI, 1989. (Publicação n. 1801)

CONWAY QUALITY. Caçadores de desperdício. São Paulo, Qualitymark, 1998.

CUNHA A. Tecnologias aplicadas à construção popular: 44 fatores de erros e desperdícios de recursos nas obras populares no Brasil. In: JORNADAS DE 
ENGENHARIA DOS PAÍSES DE LÍNGUA OFICIAL PORTUGUESA, Rio de Janeiro, 1987.

DESPERDÍCIOS NO BRASIL - CAUSAS E SOLUÇÕES. Brasília, 1993. s.n.t.

DIAS, F.F. Raio X da alvenaria. Téchne, v. 3, n.18. p.26-28, set./out, 1995.

ENSHASSI, A. Materials control and waste on building sites. Building Research and Information, v.24, n.1, p.31-4, Jan, 1996.

ESTEVES, L.G.N. Impactos ambientais gerados pelos resíduos da Construção em São José do Rio Preto. São Carlos, UFSCar, 1997 (Trabalho de Graduação Integrado. Departamento de Engenharia Civil UFSCar)

FERGUSON J.; KERMODE, N.; NASH, C.L.; SKETCH, W.A.J.; HUXFORD, R.P. Managing and minimizing construction waste: a practical guide. London. Institution of Civil Engineers, 1995.

FILHO, A.C. et al. Avaliação do impacto ao meio ambiente causados pelos produtos e materiais da construção civil a base de cimento. In: IV CONGRESSO IBEROAMERICANO DE PATOLOGIAS DAS CONSTRUÇÕES, 4., Porto Alegre, 1997. Anais. Porto Alegre, LEME/CPGEC-UFRGS, 1997. p.499-506.

FORMOSO, C.T. As perdas na construção civil: conceitos, classificações e seu papel na melhoria do Setor. /Apresentado ao Seminário Desperdício na Construção realizado no SINDUS CON/SP, São Paulo, 1996/

FRANCHI, C.C.; SOIBELMAN, L.; FORMOSO, C.T. As perdas de materiais na industria da construção civil. In: SEMINÁRIO DA QUALIDADE NA CONSTRUÇÃO CIVIL, 2., Porto Alegre, 1993. Gestão e Tecnologia: anais. Porto Alegre, s.ed., 1993. p.133-98.

FRANCISCHINI, P.G. Indicadores de produtividade. AOTS/SP Magazine, v.1, n.1, p.22-4, 1998. 
FRANCO, L.S. Aplicação de diretrizes de racionalização construtiva para a evolução tecnológica dos processos construtivos em alvenaria estrutural não armada. São Paulo, 1992. 319p. Tese (Doutorado) - Escola Politécnica, Universidade de São Paulo.

FREITAS, E.N.G.O. O desperdício na construção civil: caminhos para sua redução. In: ENCONTRO NACIONAL DE TECNOLOGIA DO AMBIENTE CONSTRUÍDO, 6., Rio de Janeiro, 1995. Anais. Rio de Janeiro, UFRJ, 1995. v1, p. 167-72.

FRIEDMAN, A.; CAMMALLERI, V. Reducing energy, resources and construction waste through effective residential unit design. Building Research and Information, v.3, n.2, p.103-08, Mar, 1995.

GALVÃO, J.A.; SALGADO, M. Contribuição ao estudo do recebimento e aceitação de obras de edificações. In: CONGRESSO IBEROAMERICANO DE PATOLOGIAS DAS CONSTRUÇÕES, 4., Porto Alegre, 1997. Anais. Porto Alegre, LEME/CPGEC-UFRGS, 1997. p.337-44.

GUEDERT, L.O. Programa de melhoria de qualidade das alvenarias: o caso do convênio Frechal/UFSC. In: ENCONTRO NACIONAL DE TECNOLOGIA DO AMBIENTE CONSTRUÍDO, 5., São Paulo, 1993. Anais. São Paulo, 1993. v.2, p.681-90 .

HAMMARLUND, Y.; JOSEPHSON, P.E. Qualidade: cada erro tem seu preço. Trad. de Vera M. C. Fernandes Hachich. Téchne, v1, n. 1. p. 32-4, nov./dez., 1992.

HONG KONG POLYTECHNIC (Department of Building and Real Estate); THE HONG KONG CONSTRUCTION ASSOCIATION LTD. Reduction of Construction Waste, Final Report. Hong Kong, march, 199393 p.

INTERNATIONAL COUNCIL FOR BUILDING RESEARCH, STUDIES AND DOCUMENTATION (CIB). The performance Concept and its Terminology. Rotterdam, 1974. (CIB-REPORT 32) 
IOSHIMOTO, E. Incidência de manifestações patológicas em edificações habitacionais. In: Tecnologia de edificações. São Paulo, Pini/IPT, 1988. P. $545-48$.

KOSKELA, L. Application of new production philosophy to construction. University of Salford. Technical Report n 72, August, 1992.

LANTELME, E.M.V. Proposta de um sistema de indicadores de qualidade e produtividade para a construção civil. Porto Alegre, 1994. 111p. Dissertação (Mestrado) - Curso de Pós-graduação em Engenharia Civil, Universidade Federal do Rio Grande do Sul.

LEÃO, S.M.C. Medição de indicadores para o serviço de alvenaria. In: ENCONTRO NACIONAL DE ENGENHARIA DE PRODUÇÃO, 17., ENEGEP 97. Gramado, 1997. Anais. Porto Alegre, UFRGS, 1997. v.2. Anais em CD-ROM.

LICHTENSTEIN, N.B. Patologia das construções: procedimento para formulação do diagnóstico de falhas e definição de conduta adequada à recuperação de edificações. São Paulo, 1985. 191p. Dissertação (Mestrado) - Escola Politécnica, Universidade de São Paulo.

LICHTENSTEIN, N.B. Formulação de modelo para o dimensionamento do sistema de transporte em canteiro de obras de edifícios de múltiplos andares. São Paulo, 1987. 268p. Tese (Doutorado) - Escola Politécnica, Universidade de São Paulo.

LIRA, E.Q. Perdas de materiais em alvenaria, sub-setor edificações em João Pessoa. João Pessoa, 1997. 182p. Dissertação (Mestrado) Universidade Federal da Paraíba.

MACIEL, L.L.; MELHADO, S.B. Qualidade na Construção Civil: fundamentos. São Paulo, PCC-USP, 1995. (Texto Técnico TT/PCC/15) 
MACIEL, L.L. O projeto e a tecnologia construtiva na produção dos revestimentos de argamassa de fachada. São Paulo, 1997. 327p. Dissertação (Mestrado) - Escola Politécnica, Universidade de São Paulo.

MCDONALD, B.; SMITHERS, M. Implementing a waste management plan during the construction phase of a project: a case study. Construction Management and Economics In formation, v.16, n.4, p.71-8, 1998.

MELINGHENDLER, M. Desperdício na construção civil. In: ENCONTRO NACIONAL DA CONSTRUÇÃO, 3., Porto Alegre, 1976. Anais. Porto Alegre, 1976, v.2, 12p.

MERGULHÃO, R.A.C.; IDROGO, A.A.A.; TAIGY, A.C. Avaliação da qualidade dos blocos cerâmicos comuns: estudo de caso. In: CONGRESSO NACIONAL DE ENGENHARIA DE PRODUÇÃO, 15., São Carlos, 1995. Anais. São Carlos, UFSCar, 1995. v.1, p.418-20.

MESEGUER, A.G. Controle e garantia da qualidade na construção. Trad. de Roberto José Falcão Bauer, Antonio Carmona Filho e Paulo Roberto do Lago Helene, São Paulo, Sinduscon-SP/Projeto/PW, 1991.

MILLER, A.J. Energy implications of the transportation of building materials. In: CIB WORLD BUILDING CONGRESS. Gävle - Sweden, june 1998. Proceeding. Gävle, 1998. v.2, p.803-10.

MINISTÉRIO DO TRABALHO. Condições e meio ambiente do trabalho na indústria da construção - NR 18. São Paulo, 1995.

MUTLER, R. Planejamento do layout: sistema SLP. São Paulo, Edgard Blücher, 1978.

NEVES, C. Que bloco é esse? Téchne, v.2, n.8, p.18-20, jan./fev, 1994.

OLIVEIRA, M.; LANTELME, E.M.V.; FORMOSO, C.T. Sistema de indicadores de qualidade e produtividade na construção civil: manual de utilização. Porto Alegre: NORIE/UFRGS, 1993, 79p. 
OLIVEIRA et al. A busca da qualidade do processo construtivo através de um programa de medição de perdas. In: VII ENCONTRO NACIONAL DE TECNOLOGIA DO AMBIENTE CONSTRUÍDO, 7., Florianópolis, 1998. Anais. Florianópolis, UFSC, 1998. v.2, p.515-523.

PICCHI, F.A. Sistema de Qualidade: uso em empresas de construção de edifícios. São Paulo, 1993. 462p. Tese (Doutorado) - Escola Politécnica, Universidade de São Paulo.

PICCHI, F.A. Gestão da qualidade: impacto na redução de desperdícios. In: SEMINÁRIO GERENCIAMENTO VERSUS DESPERDíCIO. São Paub, 1995. Anais. São Paulo, Édile, 1995. p. 59-68.

PINTO, T.P. Perdas de materiais em processos construtivos tradicionais São Carlos, 1989. Departamento de Engenharia Civil, Universidade Federal de São Carlos - UFSCar. /Datilografado/

PINTO, T.P. Entulho de construção: problema urbano que pode gerar soluções. Revista Construção São Paulo, v.9, n. 2325, p.23-26, ago., 1992.

PINTO, T.P. (a) Reciclagem. Téchne, v. 2, n.15, p.15-9, mar./abr., 1995.

PINTO, T.P. (b) De volta à questão do desperdício. Construção, v.48, n. 2491, p. 18-9, nov., 1995.

PINTO, T.P. Reciclagem de resíduos da construção urbana no Brasil: situação atual. In: WORKSHOP RECICLAGEM E REUTILIZAÇÃO DE RESÍDUOS COMO MATERIAIS DE CONSTRUÇÃO CIVIL. São Paulo, 1996, PCCUSP/NPC-UFSC. Anais. São Paulo, PCC-USP, 1996. p.159-70.

PINTO, T.P.; PINTO, C.A.P. Qualidade com pequenas soluções. Construção, v.48, n.2453, p. 12-14, fev., 1995.

PROGRAMA BRASILEIRO DA QUALIDADE E PRODUTIVIDADE. Critérios para a geração de indicadores de qualidade e produtividade no serviço público. Brasília: IPEA/MEFP, 1991. 
SANTOS, A. Método de intervenção em obras de edificações enfocando o sistema de movimentação e armazenamento de materiais: um estudo de caso. Porto Alegre, 1995. 140p. Dissertação (Mestrado) - Curso de Pós graduação em Engenharia Civil, Universidade Federal do Rio Grande do Sul.

SANTOS, A. et al. Método de intervenção para redução das perdas na construção civil: Manual de utilização. Porto Alegre, s.ed., 1996.

SCARDOELLI L.S. et al. Melhorias de qualidade e produtividade:iniciativas das empresas de construção civil. Porto Alegre, s.ed., 1994.

SCARDOELLI L.S. Iniciativas de melhorias voltadas à qualidade e à produtividade desenvolvidas por empresas de construção de edificações. Porto Alegre, 1995. 148p. Dissertação (Mestrado) - Curso de Pós-graduação em Engenharia Civil, Universidade Federal do Rio Grande do Sul.

SECOVI-SP. Qualidade e o custo das não-conformidades em obras de construção civil. São Paulo, 1998.

SILVA, M.A.C. Desperdício: medir para transformar. Obra: Planejamento \& Construção. v. 4, n. 47, p.33, 1993.

SILVEIRA, G.T.R. Metodologia de caracterização dos resíduos sólidos, como base para uma gestão ambiental. Estudo de caso: entulhos da construção civil em Campinas - SP. Campinas, 1993. 130p. Dissertação (Mestrado), Universidade Estadual de Campinas.

SINDUSCON. Sumário Econômico. Revista Mensal. São Paulo. Sindicato da Indústria da Construção Civil do Estado de São Paulo. Julho, 1997.

SINK, D.S.; TUTTLE, T.C. Planejamento e medição para performance. Rio de janeiro, Qualitymark, 1993. 
SKOYLES, E.R. Materials wastage - a misuse of resources. Building Research and Practice, July/August 1976.

SKOYLES, E.R. Site accounting for waste of materials. Building Research Establishment, CP 5/78, 1978.

SKOYLES, E.R., SKOYLES, J. Waste prevention on site. London: Mitchell, 1987.

SOIBELMAN, L. As perdas de materiais na construção de edificações: Sua incidência e controle. Porto Alegre, 1993. 127p. Dissertação (Mestrado) Curso de Pós-graduação em Engenharia Civil, Universidade Federal do Rio Grande do Sul.

SOUZA, M.C.A.F; BACIC, M.J. Importância do planejamento estratégico para a redução do desperdício potencial. In: SEMINÁRIO GERENCIAMENTO VERSUS DESPERDícIO. São Paulo, 1995. Anais. São Paulo, Édile, 1995. p. 34-44.

SOUZA, R. et al. Sistema de gestão da qualidade para empresas construtoras. São Paulo, Pini, 1995.

SOUZA, A.L.R. (a) 0 projeto para produção de lajes racionalizadas de concreto armado de edifícios. São Paulo, 1996. 367p. Dissertação (Mestrado) - Escola Politécnica, Universidade de São Paulo.

SOUZA, U.E.L. (b) Metodologia para o estudo da produtividade da mão-deobra no serviço de formas para estruturas de concreto armado. São Paulo, 1996. 280p. Tese (Doutorado) - Escola Politécnica, Universidade de São Paulo.

SOUZA, R.; MEKBEKIAN, G. Qualidade na aquisição de materiais e execução de obras. São Paulo, Pini, 1996. 
SOUZA, U.E.L. Redução do desperdício de argamassa através do controle do consumo em obra. In: SIMPÓSIO BRASILEIRO DE TECNOLOGIA DE ARGAMASSAS, 2., Salvador, 1997. Anais. Salvador,1997. p. 459-68.

SOUZA, U.E.L. et al. Recomendações gerais quanto à localização e tamanho dos elementos do canteiro de obras. São Paulo, PCC-USP, 1997. (Boletim Técnico BT/PCC/178)

SOUZA, U.E.L. Produtividade e custos dos sistemas de vedação vertical. In: SEMINÁRIO TECNOLOGIA E GESTÃO NA PRODUÇÃO DE EDIFÍCIOS: VEDAÇÕES VERTICAIS. São Paulo, 1998, PCC/EPUSP - Departamento de Engenharia de Construção Civil da EPUSP. Anais. São Paulo, 1998. p. 237-48.

SOUZA, U.E.L. et al. (a) Perdas de materiais nos canteiros de obras: a quebra do mito. Qualidade na Construção, v.2, n.13, p.10-5, 1998.

SOUZA, U.E.L. et al. (b) Os valores das perdas de materiais nos canteiros de obras do Brasil. In: CONGRESSO LATINO-AMERICANO TECNOLOGIA E GESTÃO NA PRODUÇÃO DE EDIFÍCIOS: SOLUÇÕES PARA O TERCEIRO MILÊNIO. São Paulo, 1998. Anais. PCC/EPUSP Departamento de Engenharia de Construção Civil da EPUSP. São Paulo, 1998. v1, p.355-61.

SOUZA, P.S.L. et al. (c) Indicadores da qualidade, no revestimento interno, na construção civil da Belém - PA. In: ENCONTRO NACIONAL DE TECNOLOGIA DO AMBIENTE CONSTRUÍDO, 7., Florianópolis, 1998. Anais. Florianópolis, UFSC,1998. v2, p. 595-601.

TCPO 10: tabelas de composições de preço para orçamento. 10ed. São Paulo. PINI, 1996.

TAKASHINA, N.T; FLORES, M.C.X. Indicadores da qualidade e do desempenho: como estabelecer metas e medir resultados. Rio de Janeiro, Qualitymark, 1996. 
TIRONI, L.F. et al. Critérios para a geração de indicadores de qualidade e produtividade no setor público. Brasília: IPEA/MEFP, 1991, 16 p. (texto para discussão $n^{\circ}$ 238)

UNIVERSIDADE DE SÃO PAULO. Escola Politécnica. Departamento de Engenharia de Construção Civil. Desenvolvimento Tecnológico de Métodos Construtivos de Revestimentos de Piso e de Paredes de Vedação em Alvenaria. São Paulo, EPUSP/PCC/CPqDCC, 1990. (Convênio EPUSP/CPqDCC-ENCOL, Projeto EPUSP-EP/EN-6 /Não publicado/

VARGAS, N. Tendências de mudança na indústria da construção. Obra Planejamento e Construção, v4, n. 44, p.25-9, fev., 1993.

VARGAS, C.L.S. et al. Avaliação de perdas em obras: aplicação de metodologia expedita. In: ENCONTRO NACIONAL DE ENGENHARIA DE PRODUÇÃO, 17., Gramado, 1997. Anais. Porto Alegre, UFRGS, 1997. v.2. Anais em CD-ROM. 